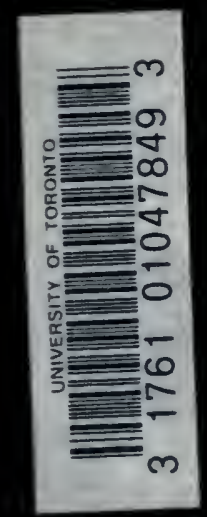

Jipy of

TORONTO IRRARY 
(8) 

Digitized by the Internet Archive in 2008 with funding from Microsoft Corporation 


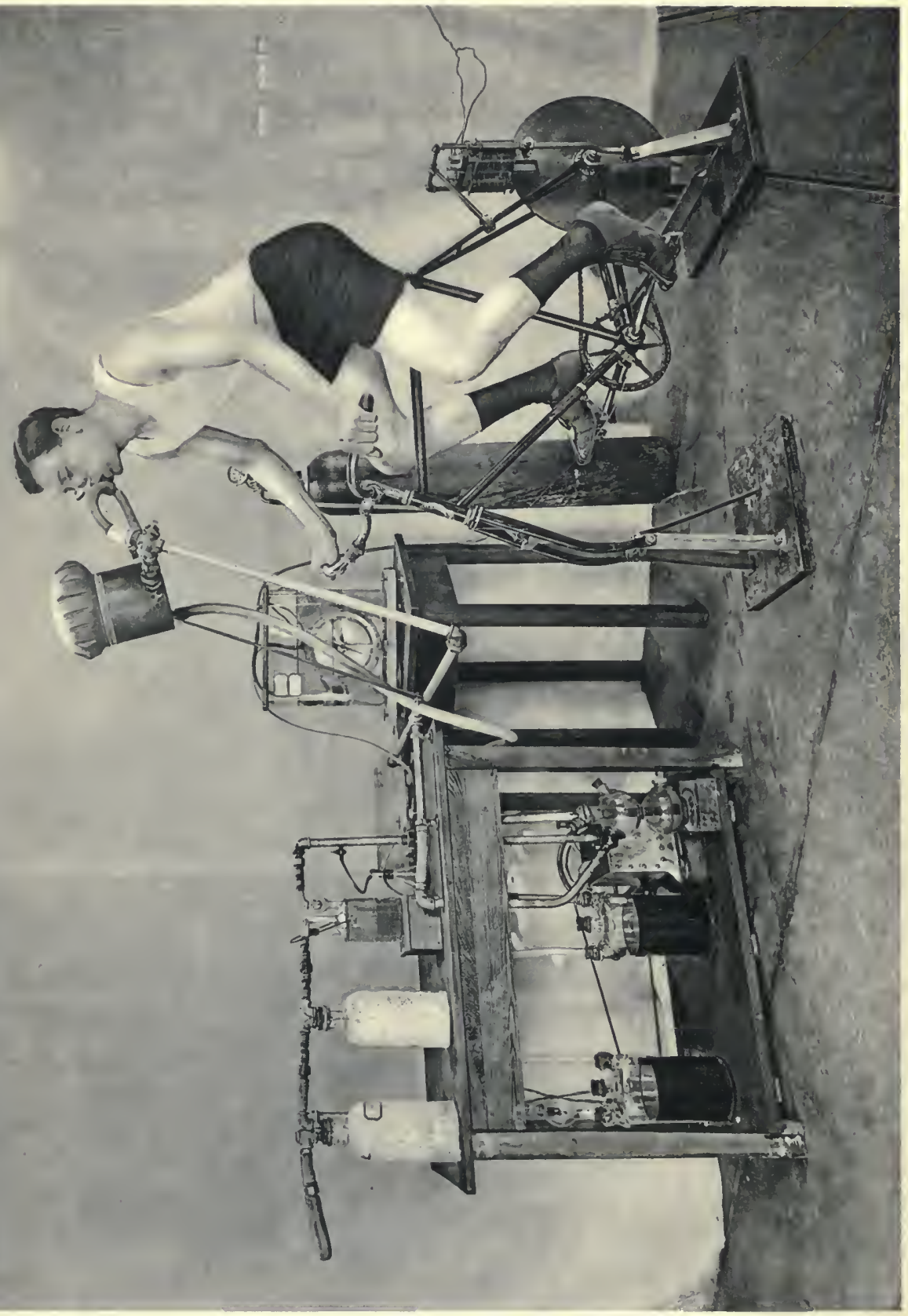

密

总

का

政娄

专 뭉

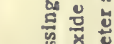

क

步

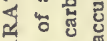

范

द

万的

요연

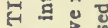

过

훙

列 范

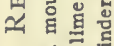

붕

की बै

진 믈

항 뭏

5 约

옹

乙

造

田 0

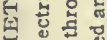

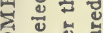

을 츰

ह

项

(1)

论

ते

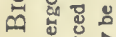

는 훕

으

긍 망

af

궁

苍递

言

号 


\section{MUSCULAR WORK}

\section{A METABOLIC STUDY WITH SPECIAL REFERENCE TO THE EFFICIENCY OF THE HUMAN BODY AS A MACHINE}

BY

FRANCIS G. BENEDICT AND EDIVARD P. CATHCART
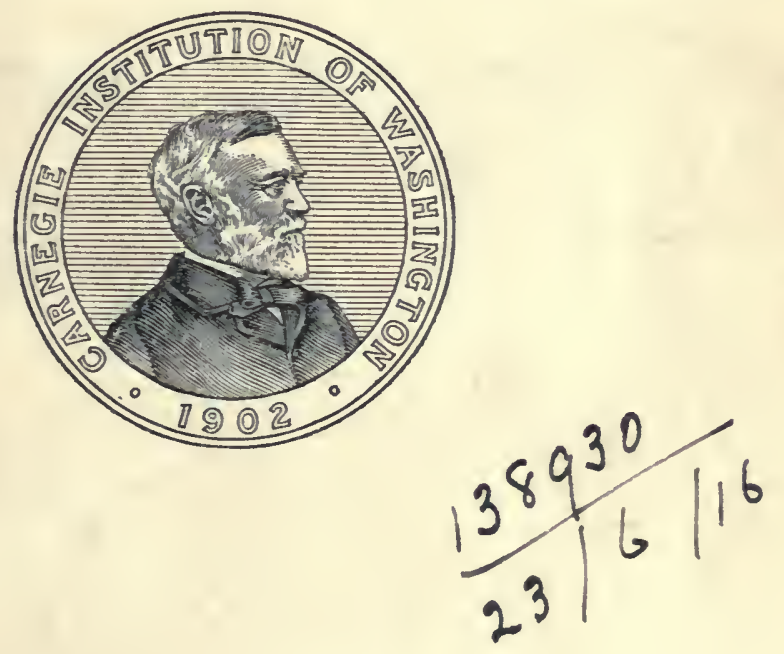

WASHINGTON, D. C.

Published by the Carnegie Institution of Washington 


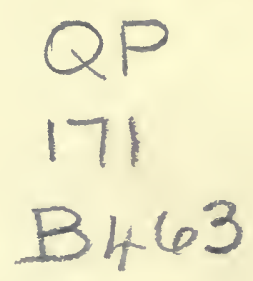

CARNEGIE INSTITUTION OF WASHINGTON

Publication No. 187

THE UNIVERSTTY PRESS, CAMBRIDGE, ర. s. A. 


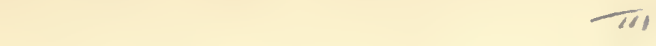

PREFACE.

The experimental evidence secured in connection with this research was raade possible only through the active co-operation and personal interest of the gentlemen who acted as subjects. Our thanks are due to Mr. Kurt H. Arndt, Mr. J. J. Currie, and especially to Mr. H. L. Higgins and Mr. J. E. Fitzgerald, all of the laboratory staff. Mr. Fitzgerald furthermore assisted in practically all of the experiments on others than himself.

We are indebted to Dr. W. G. Anderson, Director of the Yale University Gymnasium, not only for the physical measurements on some of our subjects, but likewise for his co-operation in certain of the tests.

The extraordinary interest and fidelity to the routine exhibited on the part of the professional subject, Mr. Melvin A. Mode, should not pass without special comment. It would have been impossible to conduct a series of experiments of this type without the intelligent co-operation of the subject.

The complicated tables in the report have received the careful preparation of Mr. W. H. Leslie, and the entire manuscript has had the editorial supervision of Miss A. N. Darling. To all of these co-workers we wish to express our thanks.

Nutrition laboratory, Carvegie Institution of Washington, Boston, Mass., A pril 12, 1913. 



\section{CONTENTS.}

PART I.

Introduction

Pioneer investigations on metabolism in its relation to muscular work and animal heat Gaseous exchange during muscular work

Heat output of the animal body

Later investigations on metabolism in its relation to muscular work and animal heat . Investigations by Zuntz and his associates

Investigations in the French laboratories

Investigations by the chamber method $\ldots$

Methods and apparatus used in this research . . . . . . . . . . . . .

General plan of the research fo . . . . . . . . .

Determination of the basal metabolism ${ }_{\text {Determination of the nitrogen exeretion }}$

Pulse observations . . . . . . . . . . . . . . .

Determination of the alveolar air . . . . . . . . . . . .

Observations on the influence of diet . . . . . . . . . .

Experiments with untrained subjects . . . . . . . . . . . . . . .

Apparatus for muscular work determining the gaseous exchange $\ldots$

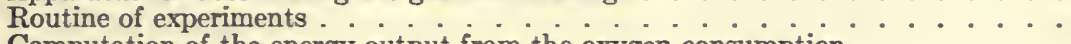

Computation of the energy output from the oxygen consumption $\ldots . . . \quad 32$

Lying vs. sitting experiments

No-load experiments . . . . . .

Work experiments . . . . . . . . . . . . . . . . 43

The character of the katabolism as affected by muscular work $\ldots \ldots$

Determination of the respiratory quotient

Errors incidental to the determination of the carbon-dioxide production . . $\quad 73$

Physiological sources of error in gas measurements .

- The basal metabolism

The normal resting metabolism as determined in this research $\therefore 77$

The character of the katabolism during muscular work as indicated by the respiratory quotient

Theories of Chauveau and Zuntz as to the character of the katabolism during muscular work

The respiratory quotients of the bicycle ergometer experiments and their significance

General comparison of the respiratory quotients

Influence upon the respiratory quotient of increasing amounts of work

- Influence upon the respiratory quotient of variations in the amount of carbohydrates in the diet

- Subsidiary evidence with regard to the effect of muscular work on the character of the katabolism .

Influence upon the respiratory quotient of variations in the amount of work done

- Conclusions regarding the influence of muscular work upon the character of the katabolism

Estimates of the amount of carbohydrates in the body $\ldots$

Urine excretion in experiments with museula

Mechanical efficiency of the human body

Previous studies on the mechanical efficiency of the human body $\ldots$ 
The unit of efficiency

Gross and net efficiency . . . . . . . . . . . . . . 112

Methods of computing the net efficiency . . . . . . . . . . . . . . . 113

Comparison of basal metabolism in bicycle ergometer experiments $\ldots 115$

Increment in metabolism due to changing from a lying to a sitting position : 115

Increment in metabolism due to a change in position from lying on a couch to sitting on a motor-driven ergometer . . . . . . . . 117

Increment in metabolism due to a change in position from lying on a couch to riding on an ergometer with no load and no motor . . . . . . 118

Increment in metabolism in no-load experiments due to a change from a motordriven ergometer to riding without motor .

Gross and net efficiency of subjects in respiration experiments with the bicycle ergometer

Efficiency in work experiments based on values obtained in experiments with the subject sitting on the bicycle ergometer . . . . . . . . .

Efficiency in work experiments based on values obtained in no-load experiments without motor

Efficiency in work experiments based on values obtained in no-load experiments with a motor-driven ergometer ..............

Efficiency in work experiments based on values obtained with a current of $0 . \dot{5}$ ampere

Efficiency in work experiments based upon values obtained with a current of

General consideration of the experimental data obtained with the professional subject, M. A. M. . . . . . . . . 136

Relationships between speed and efficiency 138

Comparison of the efficiency in the earlier and later experiments with the ergometer .......... . . . . . . . .

Relationship between efficiency and the character of the diet $\ldots . . \cdots 145$

Physiological effects of muscular work . . . . . . . . . . . . 147

Mechanics of respiration . . . . . . . . . 147

Ventilation of the lungs as affected by muscular work . . . . . . . . . . 147

Carbon-dioxide content of the alveolar air after muscular work $. . \quad . \quad . \quad 149$

Collapse from excess of carbon dioxide in the ventilating current $\ldots . .150$

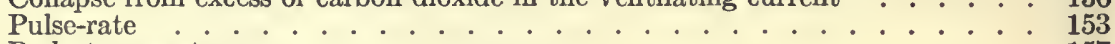

Body-temperature

The maximum working capacity of man $\ldots$

The after-effects of muscular work

An attempted analysis of the components of the total energy transformations incidental to severe muscular work . . . . . . . . 173 


\section{ILLUSTRATIONS.}

Bicycle ergometer and universal respiration apparatus ........ Frontispiece.

Fig. 1. Calibration curves showing heat per revolution of ergometer II . . . . 27

2. Schematic outline of the respiration apparatus . . . . . . . 28

3. Tension equalizer and flexible mouthpiece . . . . . . . . . 29

4. Curves showing oxygen consumption per minute with the subject riding at different speeds and with varying loads . . . . . . . . . 137

5. Curves showing the total heat output per minute and corresponding external muscular work per minute, expressed in calories, for subject riding with constant load - 1.5 amperes - at varying speeds . . . . . . . 138

6. Curves showing the pulse-rate when the external muscular work was equivalent to 1.05 calories per minute . . . . . . . . . . . 153

7. Curves showing the pulse-rate when the external muscular work was equivalent to 1.5 calories per minute . . . . . . . . . . .

8. Curves showing the pulse-rate when the external muscular work was equivalent to 2.0 calories per minute . . . . . . . . . . . .

9. Curves showing the pulse-rate when the external muscular work was equivalent to 2.25 calories per minute . . . . . . . . . . . . .

10. Continuous records of the rectal temperature obtained by thermal element during severe muscular work . . . . . . . . . 158 



\section{MUSCULAR WORK}

A METABOLIC STUDY WITH SPECIAL REFERENCE TO THE EFFICIENCY OF THE HUMAN BODY AS A MACHINE

BY

FRANCIS G. BENEDICT AND EDWARD P. CATHCART 



\section{PART I.}

\section{INTRODUCTION.}

From the days of Count Rumford, who showed that the muscular work of two horses produced sufficient heat to boil water, until the present day, when mechanical efficiency and the study of body-movements in domestic and in manufacturing industries are receiving much attention, the muscular work of the human body, and particularly the efficiency of the body as a machine, have from time to time been experimentally considered. Unfortunately, most of the observations have been of a desultory nature, so that actual knowledge with regard to the extent and character of the chemical processes which are coincidental with muscular movements has but slowly accumulated. This is due primarily to the fact that in but few places are such studies possible.

The practical results of studying body-motions and eliminating the extraneous muscular movements have been strikingly demonstrated on many occasions; ${ }^{a}$ likewise, training has been shown to make possible prolonged and sustained effort by athletes; nevertheless these phenomena have either been considered as due in general to the better training - this broad term covering a multitude of operations - or the causes have been entirely disregarded, the majority of individuals being more interested in the practical results than in the causes. It is not, however, a matter of purely physiological interest, since with the present-day emphasis laid upon mechanical efficiency in the factory and in the home, it is a problem of much practical importance to know more exactly the mechanical efficiency of the human body and the best method of attaining the highest degree of efficiency.

Our knowledge of training at this date is woefully deficient. Why a course of training should result in greater muscular strength, what changes in the body produce this end, and what is the best method to use for the purpose are at present either entirely unknown or our knowledge is based only upon practical experience. The trainer believes that a certain routine is best adapted to bring his athlete to the highest state of efficiency, and it would be a simple matter to follow this provided any number or even any two trainers agreed upon a particular routine. We have, however, on the one hand, the advocates of a high-protein diet and a meat diet, and on the other the advocates of a low-protein diet and a vegetarian diet, and it must be admitted that both have based their beliefs on arguments of great significance, although the asserted increased endurance of vegetarians rests as yet upon scant and fragmentary evidence. What is needed to place these practical observations upon a scientific basis is a most careful study of the total metabolism, both nitrogenous and gaseous, combining with this, if possible, measurements of the muscular activity and the total energy transformations.

a F. B. Gilbreth, Bricklaying system, New York, 1910. 
A study of the mechanical efficiency of a steam-engine, an internalcombustion engine, or an electric motor is relatively simple, since conditions can be arbitrarily controlled and the output measured most accurately. On the other hand, with a mechanism as complicated as that of the human body, the exact measurement of the output of muscular work is very difficult and not readily controlled. Consequently, studies on the efficiency of the human body as a machine are impracticable in most physiological laboratories. Furthermore, the measurement of the income and the actual fuel consumption is greatly complicated by the fact that the human body can draw upon a reserve of its own material, while the supply of potential energy for the steam-engine, the internal-combustion engine, or the electric motor is determined solely by the actual amount delivered to it either through the steampipe, the gasoline or gas pipe, or electrical wires. But if it were possible to study the body-changes induced by a long course of training, to determine what changes take place, and why the body is more capable of extreme muscular activity, it would be logical and possible to lead up to a most rational method for producing this end and to explain the diversity in the training systems; the best features of the different systems could then be combined.

The results of such studies would have a practical value not only for athletes, but for those who are accomplishing large amounts of work. It is of vital importance to the contractor, to the railroad constructor, and to other large employers of labor, that their human machinery as well as their mechanical appliances work to the highest degree of perfection. They spend large sums of money in designing, repairing, and altering the most complicated machinery, but until recently no attempt has been made to increase the efficiency of the large number of workmen that they must necessarily employ. With the advent of scientific management, ${ }^{a}$ we see the dawn of a new era in muscular work and its relationship to large manufacturing and construction enterprises. Scientific management will, however, always fail in its purpose unless it is based upon a scientific foundation, and as yet there is a great paucity of physiological data on which to base such management of the human machine. That any one, or two, or a dozen series of investigations will completely revolutionize the methods of training, the dietary habits, or the hygienic conditions of a group of workmen is hardly to be expected. On the other hand, a carefully worked-out series of experiments for studying the mechanical efficiency of the human body, the relationship between muscular work and the total energy intake and output, the character of metabolism in the body as affected by muscular work, the problem of training as affecting the body-composition, and the relative readiness with which the different stores of material in the body can be drawn upon for fuel, will, if properly made, furnish fundamental data that ultimately should prove of the greatest value in a scientific adjustment of diet, hygienic conditions, and the application of the muscular work of man to levers and other mechanical appliances.

It is the purpose of this book to report a series of experiments conducted throughout the academic year of 1911-12 in the Nutrition Laboratory of the Carnegie Institution of Washington, located in Boston, with a professional athlete as subject. In these experiments the mechanical output was most exactly measured, and the chemical transformations inside the body were

a F. W. Taylor, The principles of acientific management, New York, 1911. 
studied with great accuracy. The relations between the character and the amount of material burned in the body, the total amount of muscular work, and the efficiency of the human body as a machine are all of peculiar and special interest, and considerable emphasis will be laid upon them.

\section{PIONEER INVESTIGATIONS ON METABOLISM IN ITS RELATION TO MUSCULAR WORK AND ANIMAL HEAT.}

\section{GASEOUS EXCHANGE DURING MUSCULAR WORK.}

It is outside the province of this report to enter into a detailed presentation of the experimental evidence which finally led to a knowledge of the source, the cause, and the mechanical equivalent of animal heat, and the development of the law of conservation of energy as applied to the human organism. For the proper understanding of the problems subsequently treated in this report, however, it is necessary to outline certain of the fundamental researches, especially those bearing upon the relationships between the gaseous exchange, the output of mechanical work, and the mechanical efficiency of the human body.

Prior to the time of Lavoisier, the conceptions of the physical and physiological processes as related to the chemistry of the human body were so devoid of scientific foundation that they can have now but little value except as an historic record of the trend of scientific thought at that time. With the advent of Lavoisierand his contemporaries, physiological and chemical research began to take a definite form which gradually led to the unfolding of natural laws and to the explanation of the phenomena of muscular action and of the transformations in the human body and their intimate relationships.

Lavoisier's activity in studying respiration resulted in two remarkable memoirs by himself and Séguin, the first of which was published in $1789 .^{a}$ The results reported in this first memoir have particular significance in connection with the object of this book, in that Lavoisier recognized clearly the relationship between muscular activity and the gaseous metabolism, and not content with the simple determination of the carbon-dioxide excretion, actually attempted the determination of the amount of oxygen consumed.

The apparatus used in this research has been imperfectly described by Séguin, but his description tallies reasonably well with the two drawings attributed to Madame Lavoisier. ${ }^{b}$ A careful study of these drawings shows us, in the most illuminating way, the attitude of Lavoisier and his contemporaries towards respiration experiments. One of the drawings illustrates an experiment in progress with the man resting, and the other the conditions obtaining in an experiment made during muscular work. Evidently a mask was used, which Séguin states was constructed of copper and held in place about the neck by wax or cement. Of particular significance is the fact that in both drawings we see, as evidently an essential part of the experiment, a physician

\footnotetext{
a Seguin and Lavoisier, Mémoires de l'Acad6mie des Sciences, 1789, p. 566. Printed in Paris, 1793.

o Two excellent drawings of Lavoisier's laboratory, both showing studies in the respiration of men, are given by Grimaux (Lavoisier, 1743-94, Paris, 1899, facing pages 119 and 129 respectively). Tigerstedt has reproduced one of these engravings showing the conduct of an experiment during rest (Tigerstedt's Handbuch der physiologischen Methodil. Leipsic, 1911, 1, p. 72).
} 
taking the pulse-rate of the subject. At the present day, when the relationship between the pulse-rate and metabolism is continually being emphasized, it is interesting to note that 130 years ago the importance of this relationship was also recognized by Lavoisier. In the experiments on muscular work a pedal arrangement, which is shown beneath one of the tables and to which the right foot of the subject is attached, was evidently used for performing the work. The amount of work was probably computed from the movements of the pedal. Of further significance is the fact that Lavoisier and Séguin recognized in their experiments that the subjects should be without food in the morning, a prerequisite of all modern respiration experiments. We can do no better than sum up the results in their own words:

Il résulte des expériences auxquelles M. Séguin s'est soumis, qu'un homme à jeun, dans un état de repos et dans une température de $26^{\circ}$ de thermomètre de mercure, divisé en 80 parties, consomme par heure 1210 pouces cubes (24.002 litres ${ }^{a}$ ) d'air vital; que cette consommation augmenté par le froid, et que le même homme, également à ieun et en repos, mais dans une température de $12^{\circ}$ seulement, consommé par heure 1344 pocices (26.660 litres) d'air vital.

Pendant la digestion, cette consommation s'élèvé à 1800 ou 1900 pouces (37.689 litres).

Le mouvement et l'exercice augmentent considérablement toutes ces proportions. M. Séguin étant à jeun et ayant élève pendant un quart d'heure un poids de 15 livres (7.343 kilograms $\left.{ }^{a}\right)$ à une hauteur de 613 pieds (199.776 mètres $\left.{ }^{a}\right)$, sa consommation d'air pendant ce temps a été de 800 pouces, c'est-à-dire de 3200 pouces (63.477 litres) par heure.

Enfin, le même exercice fait pendant la digestion a porté à 4600 pouces (91.248 litres) par heure la quantité d'air vital consommé. Les efforts que M. Séguin avoit faits dans cet intervalle oquivaléient a l'élévation d'un poids de 15 livres (7.343 kilograms) à une hauteur de 650 pieds (211.146 mètres) pendant un quart d'heure.

As a definitely planned series of experiments to study the influence of muscular work on the gaseous metabolism, this investigation is without precedent. That the results obtained are not in accord with those obtained by the use of the modern experimental technique can not dim in any way the brilliancy of the conception of the research.

Aside from these researches of Lavoisier and Séguin, the experimental evidence secured by the earlier investigators dealt almost exclusively with the gaseous excretion while the subject was at rest, the influence of muscular work being investigated but rarely. Owing to a limited technique, the determinations were as a rule confined to the percentages of carbon dioxide in the expired air. As an example of the wide variations found in the percentage of carbon dioxide in air expired in a supposedly normal manner, we may cite a collection of analyses gathered by Valentin. ${ }^{b}$ (See Table 1.)

Of the few researches regarding the influence of muscular work on the gaseous metabolism which followed those of Lavoisier and Séguin, that of Prout is the earliest. Prout, ${ }^{c}$ who used the method then in vogue of determining only the percentage of carbon dioxide in the expired air, states that he found the effects of exercise varied according to the nature and degree of the exercise and also according to its time and duration. Moderate exercise, as walking, seemed always at first to increase the percentage of carbon dioxide in the expired air, but after having been continued for some time, it ceased

$a$ The reduction of pouces to liters, and of pounds and feet to kilograms and meters respectively, has been made

b Valentin, Lehrbuch der Physiologie des Menschen, Braunschweig, 1847-51.

c Prout, Annals of Philosophy, 1813, 2, p. 328. 
to produce this effect; if prolonged so as to induce fatigue, the quantity was diminished. On the contrary, violent exercise seemed to lessen the quantity, even from the first, or if it increased the amount of carbon dioxide excreted, the effect was very trifling. Following violent exercise, the percentage was always much less.

TABLE 1.-Percentages of carbon dioxide in expired air as cited by Valentin.

\begin{tabular}{|c|c|c|c|}
\hline Investigators. & Carbon dioxide. & Investigators. & Carbon dioxide. \\
\hline 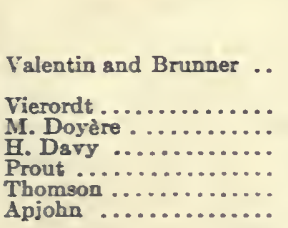 & $\begin{array}{r}\text { p. ct. } \\
4.380 \\
4.160 \\
4.050 \\
4.334 \\
4.400 \\
3.930 \text { to } 4.500 \\
3.300 \text { to } 4.600 \\
3.720 \\
3.600\end{array}$ & 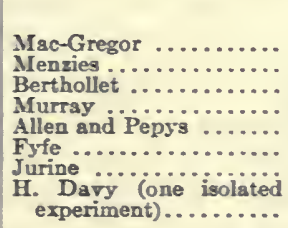 & $\begin{array}{r}\text { p. ct. } \\
3.500 \\
5.000 \\
5.530 \text { to } 13.000 \\
6.200 \text { to } 6.500 \\
8.000 \text { to } 8.500 \\
10.000 \\
10.500\end{array}$ \\
\hline
\end{tabular}

Since, as we now know, the percentage of carbon dioxide in the expired air is greatly influenced by the total ventilation of the lungs, it is obvious that these conclusions of Prout throw very little light upon the actual carbondioxide increment, although the fact that there was not a noticeable decrease in the carbon-dioxide percentage would of itself point to the fact that there must have been in all cases a considerably increased production-a fact that was many times unappreciated by the experimenters.

Later, Valentin ${ }^{a}$ and Vierordt ${ }^{b}$ showed, as did Prout, that movement increased the proportion of carbon dioxide contained in the gases expired. Vierordt was not able to make measurements of the carbon dioxide during work inasmuch as his method of testing required that the subject should be quiet; he emphasized the fact, however, that he could rely upon his pulse and respiration observations during the work, and upon the carbon-dioxide content of the air expired after the work for solving the problems of the effect of activity upon the metabolism. After a brisk walk he found a great increase in the carbon-dioxide excretion, corresponding to 80 c.c. of carbon dioxide per minute. His observations on the after-effect of work are also of interest. He shows that this is considerable, stating: "Es ist folglich die körperliche Bewegung von sehr grossem und nachhaltendem Einflusse auf die Ausscheidung der Kohlensäure." c

Scharling ${ }^{d}$ also studied the influence of muscular work on the carbondioxide output, the work performed being the raising and lowering of a heavy iron bar. A marked increase in the carbon dioxide excreted was observed.

The influence of exercise on respiration was likewise studied by Lassaigne, ${ }^{e}$ who made some very interesting observations on horses. The first horse exhaled per hour before exercise 341.69 grams of carbon dioxide; after exercising 15 minutes, he exhaled 745.90 grams of carbon dioxide. The second horse exhaled per hour before exercise 658.38 grams of carbon dioxide; after exercise, the amount of carbon dioxide exhaled was 754.88 grams. He found, however, that exercise had no effect on the amount of carbon dioxide excreted

\footnotetext{
a Valentin, loc. cit.

V Vierordt, Physiologie des Athmens, Karlsruhe, 1815, p. 98.

c Vierordt, loc. cil., p. 100.

d Scharling, Iiebig's Ann. Chem. u. Pharm., 1843, 45, p. 214.

e Lassaigne, Journ. chim. medicale, 1849, 5, p. 253.
} 
by a pure-blooded Arabian horse which, in the state of repose, exhaled 852.42 grams of carbon dioxide per hour. He states that the intensity of the respiration of this horse was remarkable. Lassaigne's technique was obviously faulty.

\section{HEAT OUTPUT OF THE ANIMAL BODY.}

The earliest attempts to measure the heat given off from the body of a living animal were those made simultaneously by Adair Crawford ${ }^{a}$ in Glasgow and Lavoisier and de la Place ${ }^{b}$ in Paris. Crawford, with a water calorimeter, measured the heat given off from a guinea-pig and likewise made an estimation of the amount of carbon dioxide produced. Lavoisier and de la Place, using the melting of ice for the measure of the heat production, placed in their calorimeter a guinea-pig and weighed the water resulting from the melting of ice; subsequently they placed the guinea-pig under a bell-jar and determined the amount of carbon dioxide produced. Having tested their calorimeters by burning a wax candle or some pure carbon, both Lavoisier and de la Place on the one hand and Crawford on the other attempted to compute the amount of heat that would be required to produce the given amount of carbon dioxide. The results of their computations showed a fairly satisfactory agreement, indicating that the combustion was proportional to the amount of carbon dioxide produced. The interpretation of results is particularly interesting in showing that Crawford still adhered to the phlogiston theory, his explanation of the phenomena being determined chiefly by his experience with specific heats. According to his belief, the heat given off by the body is absolute heat which is abstracted from the pure air in its passage through the lungs, or, to quote him exactly:

That animal heat depends upon the separation of elementary fire from the air in the lungs is moreover supported by the experiments which have been brought in proof of the third and fourth propositions. ${ }^{c}$

In summing up his opinion, he says:

Hence it clearly follows, that, in the respiration of animals, as well as in the combustion of wax, oil, and tallow, the pure air is altered in its properties by its combination with the inflammable principle; and since we know that the union of these elements is universally accompanied with the extrication of heat, and particularly that, by this union, a large quantity of elementary fire is disengaged from the air in the combustion of oleaginous substances, we may conclude that, in the process of respiration, a similar extrication of fire takes place. ${ }^{d}$....

Since, therefore, it has been proved that elementary fire is absorbed from the air in the process of respiration, and since the quantity that is thus absorbed is not only adequate to the effect which we have been endeavoring to explain, but also proportional to it, we may safely conclude that it is the true cause of animal heat.e

Crawford distinctly states:

I do not mean to assert that elementary fire is really capable of being chemically combined with bodies ... . Before this can be admitted it must be proved that heat is a substance; and I do not know that any experiments have hitherto been published which demonstrate the materiality of that principle. ${ }^{f}$

a Crawford, Experiments and observations on animal heat, 2d ed., 1788, J. Johnson, London. According to the preface of this book the experiments were made at Glasgow during the summer of 1777 and were presented to the Royal Medical Society during the winter of 1778 . They were first published in 1779 (J. Murray, London, 1779).

o Lavolsier and dé la Place, Mémoires de l'Académie, 1780, p. 355. See also Lavoisier, Traité élémentaire de Chimie, Paris, 1801, p. 1. The irregularity incidental to the dating of publications issued between 1700 and 1880 has been the subject of comment by J. Rosenthal in a German translation of the two 1700 and 1880 has been the subject of comment by J. Rosentas in a German translation of the two de la Place, 1780 u. 1784. Ostwald's Klassiker der exakten Wissenschaften, No. 40, Leipsic. 1892).

c Crawford, loc. cil., p. 358 . d Ibid., p. 359 . Ibid., p. 361 . f Ibid., p. 363. 
Quite different is the explanation of these phenomena given by Lavoisier and de la Place. ${ }^{a}$ As a result of their experiments on a guinea-pig they conclude:

Ainsi, l'on peut regarder la chaleur qui se dégage dans le changement de l'air pur en air fixe, par la respiration, comme la cause principale de la conservation de la chaleur animale, et si d'autres causes concourent à l'entretenir, leur effet est peu considérable.

$\mathrm{La}$ respiration est donc une combustion, à la vérité fort lente, mais d'ailleurs parfaitement semblable à celle du charbon; elle se fait dans l'intérieur des poumons, sans dégager de lumière sensible, parce que la matière du feu, devenue libre, est aussitôt absorbée par l'humidité de ces organes: la chaleur développée dans cette combustion se communique au sang qui traverse les poumons, et de-là se répand dans tout le système animale. Ainsi, l'air que nous respirons, sert à deux objets également nécessaires à notre conservation; il enlève au sang la base de l'air fixe, dont la surabondance seroit très-nuisible; et la chaleur que cette combinaison dépose dans les poumons, répare la perte continuelle de chaleur que nous éprouvons de la part de l'atmosphère et des corps environnans.

. . . la conservation de la chaleur animale est dûe, au moins en grande partie, à la chaleur que produit la combinaison de l'air pur respiré par les animaux, avec la base de l'air fixe que le sang lui fournit.

While the researches of Crawford and of Lavoisier and de la Place showed that the animal body was capable of giving off heat and that muscular work increased the oxidative processes, the fact that external muscular work could be converted into heat was first brilliantly demonstrated by Count Rumford. This investigator made experiments in which the work of horses was employed to turn a steel cannon-borer pressed against the bottom of a hollow metal cylinder immersed in water. He calculated that the heat produced by friction in such an apparatus was equal to that continuously produced in the combustion of 9 wax candles, each three-fourths of an inch in diameter. At the end of about two hours the water actually boiled. He says:

As the machinery used in this experiment could easily be carried around by the force of one horse (though to render the work lighter two horses were actually employed in doing it) these computations show further how large a quantity of heat might be produced by proper mechanical contrivance merely by the strength of a horse, without either fire, light, combustion, or chemical decomposition; and in a case of necessity the heat thus produced might be used in cooking victuals. But no circumstances can be imagined in which this method of procuring heat would not be disadvantageous; for more heat might be obtained by using the fodder necessary for the support of a horse as fuel. ${ }^{b}$

Beginning with the experiments of Lavoisier, a new impulse was added to the search for the source of animal heat. Lavoisier's personal belief that the lungs are the seat of combustion was contested by Lagrange, ${ }^{c}$ who argued that if the quantity of heat developed in the body in the course of a day was actually produced in the lungs it would necessitate such a high temperature as to cause destruction. The discovery that respiration also took place through the skin ${ }^{d}$ independent of the lungs further complicated the matter. The discussion thus started waged continuously until in 1837 Magnus ${ }^{e}$ concluded that the combustion did not take place exclusively in the lungs, but in the capillaries in general throughout the entire body-a conclusion that has been accepted from that time.

\footnotetext{
a Lavoisier and de la Place, Mémoire sur la chaleur. Mémoires de l'Académie Royale des Sciences, 1780, p. 405 , et seq. Printed in Paris, 1784.

b Rumford's Essays, London, 1798, 2, p. 488.

c Lagrange cited by Hassenfratz. Ann. de Chim., 1791, 9, p. 266.

d Spallanzani, Mémoires sur la respiration, Geneva, 1803.

e Magnus, Ueber die ein Blute enthaltenen Gaze; Sauerstofi, Stickstoff und Kohlensaure, Poggendorff's Ann. der Phys. u. Chem., Leipsic, 1837, 40, p. 583; 1845, 66, p. 177.
} 
The absence of definite proof in Lavoisier's experiments that animal heat was actually a process of combustion led to various explanations as to the cause of production of heat. Brodie, ${ }^{a}$ working with decapitated animals, concluded from his experiments that the brain controlled the production of heat, and that it was due to a nervous action rather than a chemical change. In this he was supported by Chossat, ${ }^{b}$ but Hale in $1813,{ }^{c}$ Legallois in $1817,{ }^{d}$ Wilson Philip in $1817,{ }^{e}$ and Williams in $1835^{f}$ found on the other hand that artificial respiration in decapitated animals was ample to maintain the bodytemperature. All of these experiments, however, dealt only with measurements of body-temperature and not actually with the production of heat.

The first important calorimetric research was that resulting from the offer of a prize by the Academy of Sciences in Paris for the best essay on the origin of animal heat. The prize was awarded to a memoir by Despretz published in $1824 .^{g}$ The essay of his competitor for the prize, Dulong, was read before the Academy in 1822 but not published until 1841, after Dulong's death. ${ }^{h}$ Both investigators employed essentially the same form of apparatus, namely, water calorimeters, and experimented with small animals such as rabbits and cats. According to Despretz, the heat of combustion of carbon and hydrogen accounted for 74 to 90 per cent of the animal heat; according to Dulong from 69 to 80 per cent. ${ }^{i}$

In 1842 appeared the first of two papers by J. R. Mayer, ${ }^{j}$ the second paper appearing three years later in pamphlet form. ${ }^{*}$ In these papers Mayer enunciated and elaborated the fundamental principle now known as the law of the conservation of energy.

While formerly physiologists have been occupied in studying the balance of matter, i.e., the intake and output of the body, stimulated by the active researches of Boussingault ${ }^{l}$ and Barral, ${ }^{m}$ after the enunciation of the principle of the conservation of energy by Mayer, the great problem came to be one of the balance of energy.

As early as Mayer's time we find physiologists considering the question of static work, for Mayer says: "Die Leistung eines Mannes, der mit grosser Anstrengung ein Gewicht frei hält, oder Stundenlang unbeweglich gerade steht u. s. w. ist = Null; ein Gleiches, ja noch viel mehr, kann auch eine hölzerne Figur vollbringen."

In the light of the present tendency toward vitalism, some of Mayer's statements have unusual force, since he dismissed as entirely irrational the idea of the creation of a physical force by means of a vital force. At this time Liebig ${ }^{n}$ advocated the existence of a vital force, and Mayer ${ }^{\circ}$ was particularly emphatic in his polemic against Liebig's theory.

The best statement of the hold that "vitalism" had on the earlier

\footnotetext{
a Brodie, Philosophical Transactions, 1812, 102, p. 378.

b Chossat, Ann. de Chim. et de Phys., 1820, ser. 2, 15, p. 37.

c Hale, Experiments on the production of animal heat by respiration, Boston, 1813.

c Hale, Experiments on the production of animal heat by respir

Wilson Philip. An experimental inquiry into the laws of the vital functions, London, 1817.

Williams, Observations on the changes produced in the blood in the course of the circulation, London, 1835.

9 Despretz, Ann. de Chim, et de Phys., 1824, 26, p. 337.

h Dulong, Ann, de Chim, et de Phys., 1841, 1, p. 440.

I Mayer, Ann. der Chem. u. Pharm., 1842, 42. p. 233.

k Mayer, Die organische Bewegung in ihrem Zusammenhange mit dem Stoffwechsel, Heilbron, 1845.

$l$ Boussingault, Ann. de Chim. et de Phys., ser. 2, 1839, 71, p. 113 . Also ibid, ser. 3, 1844,11, p. 433.

$m$ Barral, Ann. de Chim, et de Phys., 1849, 25, p. 129.

$n$ Liebig, Die organische Chemie in ihrer Anwendung auf Physiologie und Pathologie, Braunschweig, 1842.

- Mayer, loc. cul., p. 57, et seq.
} 
physiologists is found in a paper by Helmholtz ${ }^{a}$ who, independently of Mayer, announced the same fundamental principle of the conservation of energy. In this paper Helmholtz says:

The majority of the physiologists in the last century and in the beginning of this century were of the opinion that the processes in the living bodies were determined by one principal agent which they chose to call the "vital principle." The physical forces in the living body they supposed could be suspended or again set free at any moment by the influence of the vital principle, and that by this means this agent could produce changes in the interior of the body so that the health of the body could be thereby preserved or restored.

The present generation, on the contrary, is hard at work to find out the real causes of the processes which go on in the living body. They do not suppose that there is any other difference between the chemical and the mechanical actions in the living body and out of it than can be explained by the more complicated circumstances and conditions under which these actions take place, and we have seen that the law of conservation of force legitimizes this supposition. This law, moreover, shows the way in which this fundamental question, which has excited so many theoretical speculations, can be really and completely solved by experiment.

Although the calorimetric experiments of Despretz and Dulong, especially after their interpretation by Liebig, aided greatly in verifying experimentally the law of the conservation of energy in the animal body, it was not until the classical experiments of Rubner ${ }^{b}$ in 1893 on dogs, in which the income and outgo were accurately measured, that the law of the conservation of energy in the animal body was demonstrated. Subsequently, Atwater and his associates, working with the respiration calorimeter at Wesleyan University, Middletown, Connecticut, amplified the results obtained by Rubner, and by means of complete balance experiments, demonstrated this uniformity in the income and outgo of energy in the human body, thus proving the law of the conservation of energy. Simultaneously Laulanié in Toulouse made a series of observations with animals in an animal calorimeter which also further substantiated this important deduction.

Shortly after the announcement of the law of the conservation of energy by Mayer, an English engineer, Joule, computed the mechanical efficiency of a horse by comparing the amount of work performed with the energy in the food eaten. The following paragraph is from a paper by Scoresby and Joule: ${ }^{c}$

A horse, when its power is advantageously applied, is able to raise a weight of $24,000,000$ pounds to the height of one foot per day. In the same time ( 24 hours) he will consume 12 pounds of hay and 12 pounds of corn. He is therefore able to raise 143 pounds by the consumption of one grain of the mixed food. From our own experiments on the combustion of a mixture of hay and corn in oxygen gas, we find that each grain of food, consisting of equal parts of undried hay and corn, is able to give $0^{\circ} .682$ to a pound of water, a quantity of heat equivalent to the raising of a weight of 557 pounds to the height of a foot. Whence it appears that one-quarter of the whole amount of vis viva generated by the combustion of food in the animal frame is capable of being applied in producing a useful mechanical effect, - the remaining three-quarters being required in order to keep up the animal heat, etc. If these theoretic views be correct, they would lead to the interesting conclusion (which is the same as that announced by Matteucci from other considerations) that the animal frame, though destined to fulfill so many other ends, is, as an engine, more perfect in the economy of vis viva than the best of human contrivances.

As the problem of the mechanical efficiency of the body came more and more to the front, many estimates with regard to the mechanical output of a

a Helmholtz, Proc. of the Royal Institution, 1861, 3, p. 356.

b Rubner, Zeitschr. f. Biol., 1894, 30, p. 73.

c Scoresby and Joule, Philosophical Magazine, 1816, 28, p. 454. 
man's body during a day of work appeared in the literature. These computations, which are all based upon mathematical considerations entirely dissociated from chemical transformations in the body, present an interesting array of opinions. They are given in abstract in table 2. More recent estimates are not included.

TABLE 2.-Computation of a day's work for a man.

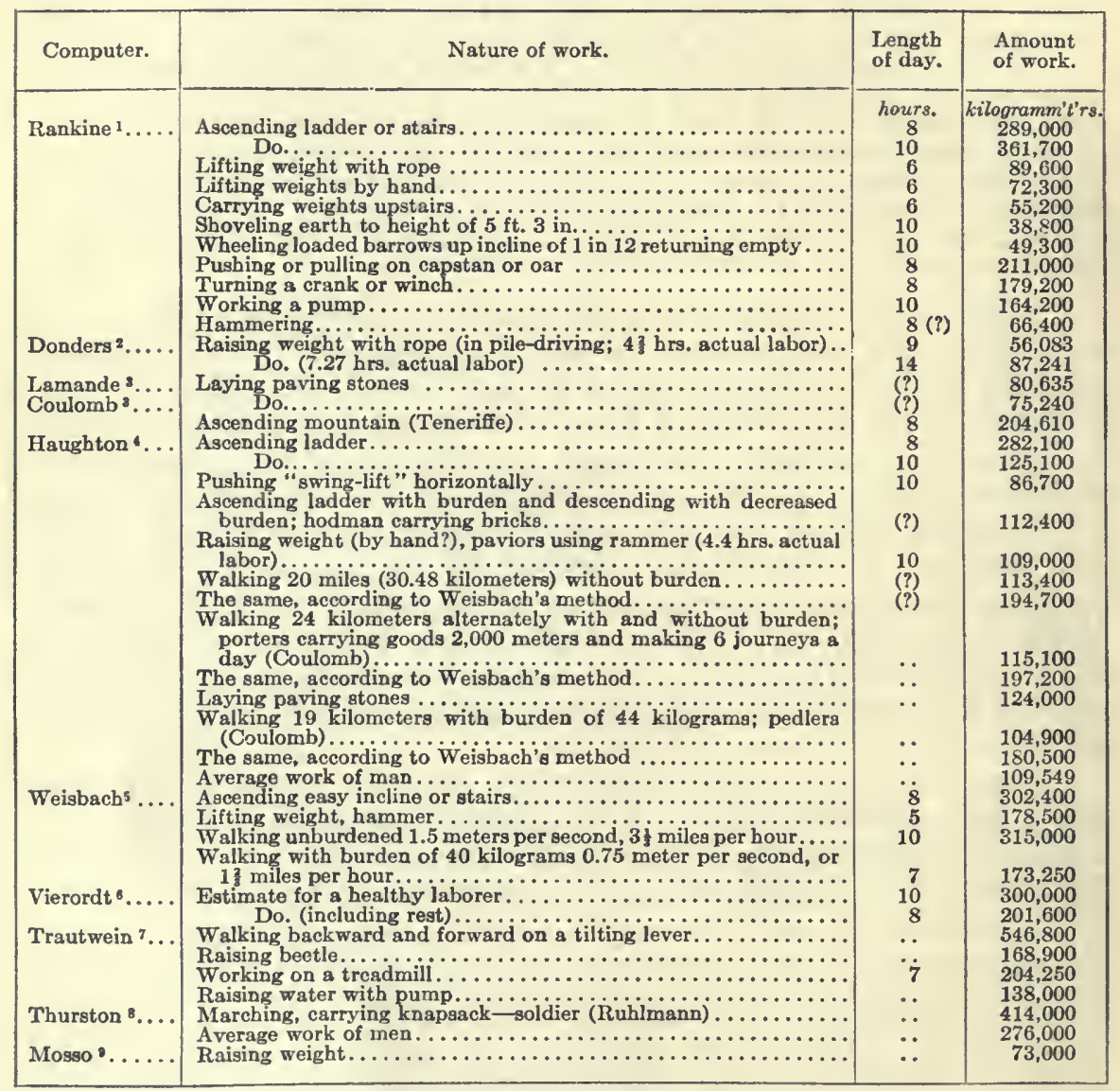

1 Rankine. Manual of applicd mechanics, 2d ed.. Glasgow, 1860, p. 626.

2 Donders, Nederlandsch. Arch. v. Genees. - - en Natuurkunde, 2, p. 210. Also, Journ. Anat. Physiol., 1867,

3 Cited by Donders, Nederlandsch. Arch. v. Genees.-en Natuurkunde, 1864; also, Dublin Quarterly Journal of Science, $1866,41, \mathbf{p} .469$.

4 Haughton, Principles of animal mechanics, London, 1873, pp. 51-62.

5 Weisbach, Lehrbuch d. Ingenieur u. Maschinenmechanik, 2 Theil, 2 Abth., 5 Aufl., 1883-S7, p. 83. Cited by Vierordt, Anat. physiol. u. physik. Daten u. Tabellen, Jena, 1893, p. 293.

6 Vierordt, Anatomische, physiologische und physikalische Daten und Tabellen, Jena, 1893, p. 293.

7 Trautwein, Engineer's Pocket Book. Cited by Carpenter, in The effect of severe and prolonged muscular work and the mechanical work and efficiency of bicyclers, by Atwater, Sherman, and Carpenter, U. S. Dept. Agr., Off. Expt. Stas. Bul. No. 98, 1901.

8 Thurston, The animal as a prime mover, Ann. Rept. Smithsonian Institution, 1896, p. 297.

9 Mosso, La fatigue intellectuelle et physique, Paris, 1894. 


\section{LATER INVESTIGATIONS ON METABOLISM IN ITS RELATION TO MUSCULAR WORK AND ANIMAL HEAT.}

Beginning with 1850 , investigations on the relation between metabolism and muscular work formed a considerable part of the researches of many physiologists. As time passed, the technique was more carefully developed and accuracy increased, since each succeeding investigation improved or attempted to improve upon the earlier ones; rapid progress in this field of research was thus assured. The literature, however, has its greatest value as a record of progress rather than as a series of mathematically exact contributions to the development of the general problem; consequently it is unnecessary to enter into an exhaustive digest of each paper, especially as this has already been admirably done in a number of articles which have appeared in handbooks and encyclopædias. A brief statement of the researches and the methods employed will therefore suffice, but in the subsequent discussion of the results of this investigation, specific reference will frequently be made to such portions of the earlier papers as deal particularly with the points under consideration.

The simultaneous measurement of the products of respiration and the heat outgo in experiments on man was first attempted in 1857 by Hirn. ${ }^{a}$ The study of the mechanical equivalent of heat which was engaged in at this time by many scientists led this investigator to make an attempt to deduce the mechanical equivalent of heat from a comparison of the heat and work simultaneously produced by a man with the calorific equivalent of the amount of oxygen consumed. Although his experiments were wholly unsuccessful, ${ }^{b}$ they marked a step in the attempt to establish the law of the conservation of energy.

The first extensive investigation into the influence of muscular activity upon the carbon-dioxide production was that made by Edward Smith, who early recognized the difficulties of computing the carbon-dioxide output of any individual owing to the unknown factor of muscular exertion. Smith, employing a mask and an absorbent for carbon dioxide, together with a gas-meter, estimated the amount of carbon dioxide excreted per hour under various conditions of muscular activity with and without food.

While walking at the rate of 2 miles per hour during three-quarters of an hour, and carrying a spirometer weighing 7 pounds, the investigator expired 18.1 grains of carbon dioxide per minute and 25.83 grains per minute while walking at the rate of 3 miles per hour. These quantities represent 1.85 and 2.64 times that of rest in the sitting posture. From these experiments Smith computed the quantities of carbon dioxide expired in quietude, by the nonlaboring class, and by laboring individuals. In quietude the results were 26.193 ounces of carbon dioxide per day, this being equal to 7.144 ounces of carbon; with the non-laboring class, 31.824 ounces of carbon dioxide, equal to 8.68 ounces of carbon; and with the laboring class, 43 ounces of carbon dioxide, equal to 11.7 ounces of carbon, with a general average of 33.67 ounces of carbon dioxide and 9.18 ounces of carbon per day.

\footnotetext{
a Hirn, Recherches sur l'equivalent mécanique de la chaleur, Paris, 1858. This paper, subsequently rediscussed by Hirn (La thermodynamique et le travail chez les étres vivants, Paris, 1887), was severely

- See Weiss, Physiologie générale du travail musculaire et de chaleur snimale, Paris, 1909, p. 140, for a critic Smith, Philosophical Transactions, 1859, 149, p. 681.
} 
Smith also studied the carbon dioxide expired during work on a treadmill having 43 steps, ascending 28.65 feet per minute, the carbon dioxide being determined for short periods of a few minutes each. The after-effect of the muscular work is excellently shown by the fact that the pulse-rate during Smith's work experiment of October 9 was 150 , and after 29 minutes of rest it was 102 beats per minute, while his pulse-rate in a period of rest was as a rule considerably under 88 ; furthermore, even after 29 minutes of rest, 9.14 grains of carbon dioxide were given off per minute as compared with approximately 6 grains during rest before work.

Using the large respiration chamber at Munich, Pettenkofer and Voit ${ }^{a}$ made a number of experiments on men at rest and with muscular work. For a subject they employed a man who had been accustomed to using a foot-power lathe, and the resistance of the apparatus was so adjusted as to correspond to his daily work. The man worked 9 hours each day. The workperiods were compared not only with ordinary rest-periods, but with restperiods in which the subject fasted. Thus, in a series of three 24-hour fasting experiments, the subject gave off during the first two days of rest 738 and 695 grams of carbon dioxide respectively, while on the third day, which was a work-day, he gave off 1,187 grams. In another series, in which the work followed rest with food, the results for the first three days of rest were 912 , 943 , and 930 grams of carbon dioxide respectively, while those for the two working-days were 1,285 and 1,134 grams of carbon dioxide respectively. The apparatus used did not permit direct measurements of oxygen, and although the investigators computed the oxygen consumption, their computations were subsequently shown by Voit to contain errors.

In 1881 Voit $^{b}$ reported two other experiments in which the subject worked without food, but no statement as to the method by which the work was performed was given. In the first experiment the work lasted 5 hours, corresponding to 29,529 kilogrammeters per hour. According to Voit, this called for an increase in the metabolism of 9.1 grams of fat per hour. A second man weighing 60 kilograms, likewise without food and working under exactly the same conditions, performed in an hour 19,036 kilogrammeters of work, requiring an increased decomposition of 7.2 grams of fat. Averaging the results of these two experiments, Voit computed that a load or task necessitating 24,282 kilogrammeters of work in an hour resulted in an increased decomposition of 8.2 grams of fat, this being equivalent to a production of 23.0 grams of carbon dioxide.

As early as 1866 Speck, ${ }^{\circ}$ employing a new design of respiration apparatus in which the expired air was collected in a spirometer and then analyzed, made a number of experiments with muscular work. In these experiments, which lasted from 6 to 9 minutes, both the carbon-dioxide production and the oxygen consumption were determined. The muscular work consisted in raising a weight by the bent arm to a given distance, the weight and height being used for the computation of the amount of work performed in kilogrammeters.

In 1871 a second series of experiments was made in which the weight was raised as before, but was lowered by an assistant. The experimental periods averaged about 4 minutes.

\footnotetext{
a Pettenkofer and Voit, Zeitschr. f. Biol., 1866, 2, p. 459.

b Voit, Hermann's Inandbuch der Physiologie, Leipsic, 1881, 6, part I, p. 202.

c Speck, Physiologie des menschlichen Athmens, Leipsic, 1892.
} 
In 1885 Speck made another series of experiments, using a form of ergometer in which a wheel was turned by the hand, the friction being adjusted by means of a screw. In these experiments, which were but 2 to 3 minutes in length, both the carbon-dioxide production and the oxygen consumption were determined.

Speck's results were published in a number of papers, but were later collected by him into one volume. ${ }^{a}$ His results have also been given in abstract by Sondén and Tigerstedt ${ }^{b}$ with special reference to the carbon-dioxide production. Speck noticed distinctly the after-effect of work, and it is obrious that his experiments at work are vitiated by the fact that since they lasted but 2 or 3 minutes, the carbon dioxide excreted during the first part of the experiment was unquestionably not so great as would result from the amount of work carried out during that period.

Employing a unique form of respiration apparatus, Hanriot and Richet made a number of experiments in $1887,{ }^{\circ}$ in which the work was performed either by turning a wheel or raising a weight. Their respiration apparatus, although extraordinarily ingenious, had practical disadvantages which have deterred physiologists as a whole from employing it. In fact, many of the experiments reported by these investigators have been the subject of severe criticism.

The effect on the excretion of carbon dioxide of the muscular activity of climbing was studied in Kronecker's laboratory, in August 1888, by Gruber, ${ }^{d}$ who made experiments in which he climbed a distance of 81.55 meters, the last 31.55 meters being in a tower. Experiments were also made in which a 15-kilogram weight was carried as a load; the effect of practice was likewise studied. The carbon dioxide was determined by absorption with soda-lime, the kilogrammeters of work performed being computed from the bodyweight and the height ascended.

Schnyder, ${ }^{e}$ of Kronecker's laboratory, made further studies on the influence of muscular activity, employing for the purpose a peculiar form of wheel by means of which large blocks of stone could be lifted by the bodyweight of the subject. The carbon dioxide was absorbed by soda-lime as in Gruber's experiments, and the work performed could be computed, due allowance being made for the friction of the wheel and chain. Experiments were also made with an apparatus on the treadmill principle devised by Professor Kronecker.

In addition to the investigations previously cited in which the effect of muscular activity upon metabolism was studied, a considerable number were carried out by means of special forms of apparatus. These may conveniently be classified according to the method employed into three groups, i. e., the investigations of Zuntz and his associates, in which the Zuntz-Geppert apparatus was used; the investigations carried out in the French laboratories with apparatus devised by Chauveau and Tissot; and investigations in which the chamber method was employed, including especially those made by Sondén and Tigerstedt, by Rubner, and by Atwater and his associates.

\footnotetext{
a Speck, loc. cit., pp. 56-95.

b Sondén and Tigerstedt, Skand. Archiv f. Physiol., 1895, 6, p. 1.

c Hanriot and Richet, Comptes rendus, 1887,105, p. 76.

d Gruber, Ztschr. f. Biol., 1891, 28, p. 466. The experiments were reported before the Schweixerischen Naturforscherversammlung in Solothurn; a notice with regard to them was also publisbed in October 1888 in the Correspondenz-Blatte für Schweizer Aerzte.

- Schnyder, Zeitsch. f. Biol., 1896, 33, p. 239.
} 


\section{INVESTIGATIONS BY ZUNTZ AND HIS ASSOCIATES.}

The first extensive investigation on the effect of muscular work upon metabolism carried out by means of the Zuntz-Geppert apparatus was that reported by Katzenstein. ${ }^{a}$ The work consisted of moving a Gaertner ergostat with the arm, and walking on a level and also on an inclined plane by means of a treadmill designed by Lehmann and Zuntz. The experiments were for the most part of very short duration - only 4 to 6 minutes. Katzenstein found no material alteration in the respiratory quotient, notwithstanding the increased metabolism. He also made a series of observations on the aftereffect of work upon metabolism.

In 1898 Leo Zuntz ${ }^{b}$ published a description of a series of experiments made with a Zuntz apparatus for studying the metabolism during bicycle riding. The work performed was sufficient to produce 9 times the amount of carbon dioxide excreted during rest. This series of experiments represents the first careful attempt to study the metabolism during bicycle riding.

The effect of different diets upon muscular work was studied in a long series of experiments, 176 in number, by Frentzel and Reach. ${ }^{c}$ The work was performed on a treadmill in the Zuntz laboratory. ${ }^{d}$ Inasmuch as this is the first time that an extensive investigation was made on the effect of muscular work upon the character of the katabolism, we shall have occasion to refer to it frequently on subsequent pages.

In 1901 Heinemann $^{e}$ reported a series of experiments performed in Zuntz's laboratory, in which the Gaertner ergostat and the Zuntz-Geppert apparatus were likewise used. In these experiments special attention was also given to the effect of different diets upon the amount of muscular work, and upon the quantity and quality of the material burned during muscular activity. The muscular work, which was approximately constant in all the experiments, averaged 360 kilogrammeters per minute.

A practical application of the study of muscular work as influencing the metabolism was made by Reach in the laboratory of Durig in Vienna. $f$ Reach used for the muscular work the turning of a centrifugal milk-separator which had been carefully calibrated by an electrically-driven motor. The gaseous metabolism was determined by the Zuntz-Geppert apparatus and compared with the amount of external muscular work performed. From his results he then computed the calories per kilogrammeter in turning the wheel of the machine, and compared his results with similar body-activity observed by Katzenstein, Sondén and Tigerstedt, Johansson and Koraen, and Hanriot and Richet.

In connection with their study of the fasting metabolism of a subject (Breithaupt) who fasted 6 days, Lehmann and Zuntz ${ }^{\theta}$ made observations on the effect of muscular work, using the Gaertner ergostat and collecting the gas samples in short periods, namely, from 2 to 5 minutes. Their observations also included data with regard to the after-effects of work.

\footnotetext{
a Katzenstein, Pfluger's Archiv f. d. ges. Physiol., 1891, 49, p. 330.

b Leo Zuntz, Pflüger's Archiv f. d. ges. Physiol., 1898, 70, p. 346.

c Frentzel and Reach, Pfüger's Archiv f. d. ges. Physiol., 1901, 83, p. 477.

$d$ The treadmill used is described in the Landw. Jahrb., 1889, 28, p. 7.

e Heinemann, Pfüger's Archiv f. d. ges. Physiol., 1901, 83, p. 441.

$f$ Reach, Landw. Jahrb., 1908, 37, p. 1053. See also Biochem. Zeitschr., 1908, 14, p. 430.

0 Lehmann and Zuntz, Archiv f. path. Anat. u. Physiol., 1893, 131, supp., p. 92.
} 
Among the methods used for measuring the amount of muscular work performed in connection with respiration experiments, mention should be made of a form of ergostat devised by Jaquet and described by H. Christ. ${ }^{a}$ As the subject stepped upon this machine, the height of each step could be measured, and the total height multiplied by the body-weight gave the total amount of muscular work performed. The studies made by Jaquet and Svenson $^{b}$ with this ergostat consisted of experiments with fat individuals in which the Zuntz-Geppert respiration apparatus was used to measure the gaseous metabolism. Jaquet also studied the after-effects upon the respiratory exchange of muscular work incidental to mountain-climbing, using a ZuntzGeppert apparatus. He later repeated these experiments with a Speck apparatus and a spirometer containing 100 liters. $^{\circ}$

Finally, in any résumé of the work done by Zuntz and his associates, mention should be made of the interesting experiments of Kolmer on swimming. ${ }^{d}$ During these experiments he found that the oxygen consumption was increased over that during resting 9 times, nearly 20 per cent greater than the amount required for rapid mountain-climbing, thus showing the enormous metabolism during the operation of swimming.

The active interest of Zuntz and his associates in the metabolism during marching and mountain-climbing has resulted in a large number of contributions on this subject from Zuntz' laboratory and from Durig. ${ }^{e}$ 'The difficulties incidental to computing the amount of external muscular work performed in climbing mountains are obvious, but the observations with the treadmill are of direct mathematical value. The results of the investigations made by Zuntz and other workers who used the Zuntz-Geppert apparatus have been admirably brought together in a number of publications. ${ }^{f}$

\section{INVESTIGATIONS IN THE FRENCH LABORATORIES.}

Investigations in the French laboratories on the question of muscular activity and metabolism have been carried out extensively by Chauveau, Tissot, Laulanié, and, more recently, by Amar. Chauveau ${ }^{\circ}$ in 1899 repeated the experiments of Hirn, using a treadwheel and determining directly the heat radiated from the body. The emission calorimeter was used, and no correction was made for the heat of water vaporized. The air was collected in a Tissot spirometer, the samples being taken in 3 periods of 2 minutes each ${ }^{h}$ at the beginning, middle, and end of the experiment. Since the calorimetric measurements were made during the last part of the experiment, only those results obtained from the analyses of the samples collected in the last period should be used for comparison with the calorimetric measurements. Although dealing exclusively with the respiratory quotient, $i . e .$, the character of the

a Christ, Deutsch. Archiv f. klin. Med., 1894, 53, p. 102.

b Jaquet and Svenson, Zeitschr. f. klin. Med., 1900, 41, p. 17.

c Jaquet, Archiv f. exp. Path. u. Pharm., 1910,62, p. 341.

d Zuntz, Loewy, Mŭller, and Caspari, Höhenklima u. Bergwanderungen, Berlin, 1906, p. 263.

e Zuntz, Loewy, Müller, and Caspari, Ibid. Durig, Physiol. Ergebnisse der im Jahre ig06 Durchgeführten Ionte Rosa Expedition. Besonders Abgedruckt aus dem LXXXVI Bd. Denkschriften der Mathematisch-Naturwissenschaftlichen Klasse der Kaiserlichen Akademie der Wissenschaften, Wien.

$f$ Zuntz, Loewy, Magnus-Levy, and others in Oppenheimer's Handbuch der. Biochemie. Zuntz and Schumberg. Physiologie des Marsches, Berlin, 1901. Magnus-Levy, Physiologie des Stoff wechsels, in von Noorden's Handbuch der Pathologie des Stoffwechsels, Berlin, 1906, 1, p. 379.

- Chauveau, Comptes rendus, 1899, 129, p. 249.

$h$ For a criticism of the length of the experiments see Weiss, Physiologie générale du travail musculaire et de la chaleur animale, Paris, 1909, p. 142. 
katabolism, the experiments on Tissot reported by Chauveau ${ }^{a}$ should be cited. The work was done by going up and down stairs, and the gaseous exchange studied by the Chauveau-Tissot apparatus.

Laulanié's experiments ${ }^{b}$ were made chiefly with animals, but Amar in $1910^{c}$ studied the effect of bicycling upon the metabolism of men. Using a bicycle ergometer, the Chauveau-Tissot valves, and a dry gas-meter, he made experiments on the natives in Algeria, collecting and analyzing samples of the expired air. In his observations special emphasis was laid upon a study of the mechanical efficiency of the body as a machine. These values will be referred to subsequently. Amar's monograph contains an excellent résumé of the earlier literature with particular emphasis upon the work carried out in the French laboratories. The percentage of efficiency is given special treatment. ${ }^{d}$

A later research of $\mathrm{Amar}^{e}$ deals with the muscular work involved in filing a piece of metal. With a most ingenious arrangement of tambours and dynamometer springs Amar made a series of experiments both with an apprentice and a skilled machinist. A study of the gaseous exchange was made in many of the experiments. As was to be expected with this form of work low efficiencies were found.

\section{INVESTIGATIONS BY THE CHAMBER METHOD.}

The principal investigations on muscular work by the chamber method were made by Sondén and Tigerstedt in Stockholm, Rubner in Berlin, and Atwater and his associates in Middletown, Connecticut.

Employing the large Sondén-Tigerstedt respiration chamber in the Karolinska Institute in Stockholm, Sondén and Tigerstedt ${ }^{f}$ carried out a series of investigations studying only the effect of muscular work upon the carbon-dioxide output, their apparatus not being designed for determining the oxygen consumption. Several forms of muscular activity were used, the study including experiments in which the subject walked about the chamber, the distance traveled being measured by means of a pedometer, and experiments in which the subject climbed up and down a ladder placed inside the chamber. The Gaertner ergostat and the Fick dynamometer were also employed. In reporting these researches, Sondén and Tigerstedt computed the results obtained by earlier workers with reference to the relationship between the carbon-dioxide production and muscular activity so as to make them comparable with their own results. This comparison is given in table 3 , which is taken from the report of Sondén and Tigerstedt. ${ }^{\circ}$

Using a special form of ergostat, in which the arms and muscles of the back were employed, Johansson ${ }^{h}$ made a series of experiments in which he raised a weight to a given distance, the amount of work ranging from 600 to 7,000 kilogrammeters. Placing the apparatus inside the Sondén-Tigerstedt respiration chamber, he determined the carbon-dioxide production for each kilogrammeter of external muscular work, concluding from his results that

a Chauveau, Comptes rendus, 1896,122, p. 1163.

b Laulanié, Eléments de physiologie, 2d ed. Paris, 1905.

c Amar, Le rendement de la machine humaine. Recherches sur le travail, Paris, 1910.

d See also Weiss, loc. cit.

e Amar, Journal de Physiologie et de Pathologie generale, 1913, 15, pp. 69 and 102.

$f$ Sondén and Tigerstedt, Skand. Archiv, 1895, 6, p. 1.

- Sondén and Tigerstedt, loc. cit., p. 202.

h Johansson, Skand. Archiv, 1901, 11, p. 273. 
the output of carbon dioxide was proportional to the load. At the end of each experiment the pulse-rate was taken, but in no case was it unusually high, indicating that the work was not excessive. Exactly the same type of apparatus was employed by Johansson and Koraen ${ }^{a}$ to study the effect of static work upon metabolism.

TABLE 3.-Carbon-dioxide production during muscular work.

\begin{tabular}{|c|c|c|c|}
\hline No. & $\begin{array}{l}\text { Carbon-dioxide } \\
\text { production per } \\
\text { kilogrammeter } \\
\text { of work. }\end{array}$ & Nature of work. & Author. \\
\hline $\begin{array}{r}1 \\
2 \\
3 \\
4 \\
5 \\
6 \\
7 \\
8 \\
9 \\
10 \\
11 \\
12 \\
13\end{array}$ & $\begin{array}{r}\text { gram. } \\
0.00086 \\
0.00106 \\
0.00532 \\
0.00719 \\
0.00391-0.00493 \\
0.00473 \\
0.00571 \\
0.00829 \\
0.00317 \\
0.00221 \\
0.00428 \\
0.00214 \\
0.00332 \\
0.00368\end{array}$ & 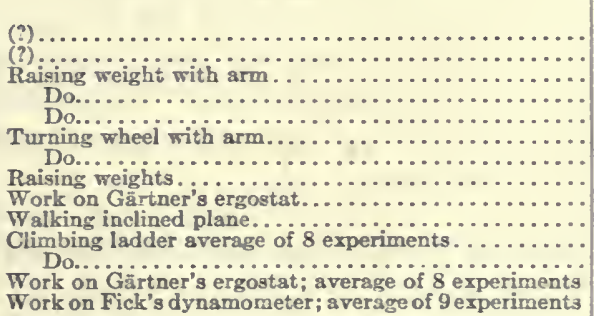 & $\begin{array}{l}\text { Voit.1 } \\
\text { Do. } \\
\text { Speck, } 1866.2 \\
\text { Speck, 1871.: } \\
\text { Speck, 1871." } \\
\text { Speck, 1885.4 } \\
\text { Speck, 1855. } \\
\text { Hanriot and Richet. } \\
\text { Katzenstein.? } \\
\text { Katzenstein. } \\
\text { Sondén and Tigerstedt. } \\
\text { Do. } \\
\text { Do. } \\
\text { Do. }\end{array}$ \\
\hline
\end{tabular}

1 Voit, Handbuch d. Physiol., 1881, 6, 1, p. 202.

2 Speck, Physiologie dey menschlichen Athmens, Leipsic, 1892, p. 63.

Speck, ibid., pp. 66-68.

- Speck, ibit., p. 69 folg.

Speck, ibid., p. 80.

6 Hanriot and Richet, Comptes rend. de l'académie des seiences, 1887, 115, p. 78.

7 Katzenstein. Pfluger's Archiv f. d. ges. Physiol., 1891, 19, p. 359; carbon dioxide computed by Sondén and Tigerstedt.

8 Katzenstein, loc. cit., p. 367 ; carbon dioxide computed by Sondén and Tigerstedt.

A most interesting series of experiments was carried out under Rubner's direction by Wolpert ${ }^{b}$ in the Hygienic Institute in Berlin. Using a large respiration chamber designed by Rubner, Wolpert studied the actual daily work of men and women employed in different occupations, his subjects including a seamstress, a writer, a tailor, a lithographer, a sewing-machine operator, a draftsman, a mechanic, and both a man shoemaker and a woman shoemaker. Only the production of carbon dioxide was observed. In an investigation upon the influence of the temperature of the air on the quantity of carbon dioxide produced by man during severe muscular work, Wolpert, employing an ergostat, found that every gram of carbon dioxide corresponded to approximately 300 kilogrammeters of work, consequently that every kilogrammeter corresponded to $3 \frac{1}{3}$ milligrams of carbon dioxide. Employing this factor in his studies on the work of different laborers, he computed the hourly external muscular work of the different subjects as ranging from 900 kilogrammeters for the seamstress to 8,000 kilogrammeters for the man shoemaker.

Using the Pettenkofer-Voit respiration chamber in Berlin, Rubner ${ }^{\circ}$ made experiments with a subject who took a large quantity of carbohydrate in one period and of protein in another, performing each day 100,000 kilogrammeters of work. By measuring the resting requirement, Rubner found that the increase in energy due to this amount of work when sugar was taken

a Johansson and Koraen, Skand. Archiv, 1902, 13, p. 229.

b Wolpert, Archiv f. Hygiene, 1896, 26, p. 68 .

c Rubner, Sitzber. K. Preuss. Akad. Wiss., 1910, 16, p. 316. 
was 845.3 calories and when protein was ingested, 855.6 calories. Since the heat equivalent of the work performed was 234 calories, the data give opportunity for computing the mechanical efficiency of the body.

The first report of researches carried out by Atwater and his associates ${ }^{a}$ with the respiration chamber at Wesleyan University, Middletown, Connecticut, included three experiments on muscular work in which a block of iron weighing 5.7 kilograms was raised and lowered by means of a rope passing over a pulley attached to the top of the respiration chamber. The movements of raising and lowering the weights brought into play not only the muscles of the arms but also the legs and other parts of the body, the idea being to induce severe muscular activity with no attempt to isolate any group of muscles. With this apparatus the subject did severe work for 8 hours on each experimental day. Throughout the working period he perspired very freely, and at the end he was thoroughly tired. The experiments were made on three successive days, during which time the subject remained in the respiration chamber the entire 24 hours.

Later, by means of a stationary bicycle, the rear wheel of which was connected by a belt with a small dynamo, Atwater and Benedict made an experiment on muscular work with a subject inside the respiration chamber. At that time the chamber had been sufficiently tested as a calorimeter to be used for measuring exactly the heat produced by the body. ${ }^{b}$ As in the earlier experiments, the muscular work period lasted 8 hours, the number of revolutions of the wheel being counted by means of a cyclometer attached to the bicycle. The heat equivalent of the external muscular work was estimated to be not far from 250 calories per day.

This same bicycle ergometer, with its rear wheel belted to a small dynamo, was used by Atwater and Benedict in a work experiment which was published in $1902 .^{\circ}$ The results of four additional experiments were also given in which a modified form of the ergometer was used. ${ }^{d}$ As modified, the rear wheel of the bicycle was applied directly to a pulley fastened to the shaft of the dynamo, which was mounted on a rocking base, the necessary tension being secured by means of a spiral spring which kept the pulley of the dynamo pressed against the tire of the bicycle wheel. The detailed description of the apparatus and the method of calibration were not, however, given until a later publication in which additional work experiments were published. ${ }^{\circ}$ This form of ergometer was calibrated before and after each experiment by running the dynamo as a motor and likewise by connecting another motor with the armature shaft and measuring the energy required to rotate the wheel of the apparatus.

Employing a new form of bicycle ergometer, Benedict and Milner ${ }^{f}$ report a large number of muscular-work experiments, covering several days. These were all carried out inside the respiration calorimeter at Wesleyan University, Middletown, Connecticut, the subject remaining in the chamber the entire 24 hours, the working periods usually being 8 hours in length. Certain of the experiments were designed to study the relative efficiency of fats

a Atwater, Woods, and Benedict, U. S. Dept. Agr., Office Expt. Stas. Bul. 44, 1S97, p. 51.

b Atwater and Rosa, U. S. Dept. Agr., Office Expt. Stas. Bul. 63, 1899. In this description of the respiration calorimeter, Atwater and Rosa cite one of the experiments on muscular work (p. 76). See also Atwater and Benedict, U. S. Dept. Agr., Of.ce Expt. Stas. Bul. 69, 1899, p. 47.

c Atwater and Benedict, U. S. Dept. Agr., Office Expt. Stas. Bul. 109, 1902, p. 21.

d Atwater and Benedict, loc. cit., pp. 94-120.

$e$ Atwater and Benedict, U. S. Dept. Agr., Office Expt. Stas. Bul. 136, 1903, p. 30.

$f$ Benedict and Milner, U. S. Dept. Agr, Office Expt. Stas. Bul. 175, 1907. 
and carbohydrates for muscular work, but the apparatus was chiefly used as a means of securing a large and accurately known amount of muscular work.

A description of this new form of bicycle ergometer was given in a publication by Benedict and Carpenter which appeared in 1909. ${ }^{\circ}$ The experiments reported in the same publication were primarily designed for the study of the efficiency of the body as a machine, and included a series of experiments with a professional bicycle rider in which an enormous amount of external muscular work was performed by means of this ergometer. In the calibration of the apparatus certain abnormal factors were observed which ultimately became the subject of a special investigation ${ }^{b}$ in which the influence on the magnetic field of the rotation of a copper disk was accurately studied. In this research, two ergometers constructed upon the same principle were observed; these instruments were, as a matter of fact, those subsequently employed for the study of the metabolism during muscular work which is reported in this publication.

\section{METHODS AND APPARATUS USED IN THIS RESEARCH.}

\section{GENERAL PLAN OF THE RESEARCH.}

A critical examination of all the literature bearing upon the relationship of muscular work and metabolism brings out two striking facts:

First, that while many investigators have studied the influence of muscular work upon the character of the material katabolized in the body to find whether or not there is a selective combustion incidental to severe muscular activity, it nevertheless remains a fact that there is a wide diversity of opinion on the subject.

Second, that the relationship between the actual amount of external work performed and the energy equivalent of the materials katabolized is by no means established, the results obtained by the various investigators differing within wide limits.

Even in the more recent work, the divergence of opinion on both these points is very noticeable. Thus, Chauveau and the members of the French school are strongly inclined to maintain that there is a selective combustion of carbohydrate material during muscular work. On the other hand, Zuntz and his associates are thoroughly convinced that muscular work does not alter the character of the metabolism. Similarly, in discussing the efficiency of the body as a machine, the values found by the French investigators are noticeably different from those of Zuntz and his associates, and there is likewise a wide difference between the values found with the respiration chamber at Middletown, Connecticut, which have been reported by Benedict and Carpenter, and those of Zuntz and Durig and their associates.

An examination of the experiments made in this laboratory for a number of years past shows that the diversity of results obtained and reported by other investigators has not been observed here, since our values indicate in a general way a uniformity in the effect of muscular work upon metabolism. In view of the development of an extremely accurate bicycle ergometer which

a Benedict and Carpenter, U. S. Dept. Agr., Office Expt. Stas. Bul. 208, 1909, p. 11.

$b$ Benedict and Cady, Carnegie Institution of Washington Publication No. 167, 1912. 
has recently been calibrated with especial care, together with the development of a new form of respiration apparatus capable of measuring accurately the large amounts of carbon dioxide produced and oxygen consumed during severe muscular work, it was considered that this laboratory was peculiarly well fitted for undertaking an investigation on the influence of severe muscular work upon not only the character of the material katabolized, but also upon the amounts of material katabolized. Moreover, the striking disagreement between the results for the mechanical efficiency of man obtained on the one hand by Benedict and Carpenter and on the other by Zuntz and his associates made further experiments on this subject necessary. The study reported here was intended to amplify the results of the earlier investigations.

The research was primarily designed to secure evidence with regard to the influence of severe muscular work upon the character of the metabolism, as well as evidence with regard to the efficiency of the body as a machine. The experiments were for the most part carried out with a professional bicyclist riding a carefully calibrated ergometer with an electric brake. ${ }^{a}$ While no calorimetric measurements were made, the carbon dioxide produced and the oxygen consumed were determined by means of the new form of respiration apparatus, which was especially modified to meet the exacting requirements of experiments with severe muscular work. The experimental periods were all of such length as to overcome the criticism that has previously been made with regard to the short experiments of earlier investigators.

In order to obtain values for use as a base-line, a large number of experiments were made in which the resting metabolism of a subject without food was determined while he lay quietly upon a couch. Studies were also made of the resting metabolism while the subject sat quietly upon the bicycle seat, with his feet in position for riding, but without movement. In the muscularwork experiments, the work varied from very light to extremely severe, $i$.e., the heat equivalent of external muscular work was 2 calories per minute or 850 kilogrammeters per minute; in some experiments the subject rotated the pedals without load; in others, he kept his feet upon the pedals while they were rotated by a motor; in the majority of the work experiments, the subject rode with a load which was varied from light to heavy according to the character of the experiment. All of the experiments were made when the subject had been at least 12 hours without food. The majority of the work experiments were preceded by rest experiments. To carry out successfully a series of experiments of this kind it was necessary to have a well-trained subject capable of severe and prolonged muscular exertion. We were extremely fortunate in securing a subject who coöperated very intelligently with us in the conduct of the experiments, and while the muscular work was frequently very severe, it was at no time beyond or even equal to the endurance or ability of the subject.

\section{DETERMINATION OF THE BASAL METABOLISM.}

The basal metabolism was established by studying the respiratory exchange when the subject lay quietly at rest on a couch and at least 12 hours after the last food. Under these conditions we obtained what may be termed the minimum metabolism of the subject when awake. Inasmuch as this

\footnotetext{
a Benedict and Cady, Carnegie Institution of Washington Publication No. 167, 1912.
} 
resting metabolism was determined on a great many days, the evidence secured supplies a basis for comparison as to the constancy of values obtained under these conditions as well as evidence regarding the normal drafts upon the body-material when the subject was lying quietly without food and awake. From the respiratory quotient the character of the material burned, and therefore the character of the draft upon the body-material can be approximately computed. Furthermore, the base-line with regard to the measurement of the total metabolism under these conditions can be quite definitely established.

Experience in this laboratory has shown that there is a marked difference between the metabolism when the subjects are sound asleep and when they are awake, even though they are well trained and capable of the greatest muscular relaxation. It can be seen, therefore, that our base-line determined in the morning without breakfast is by no means the minimum metabolism of the subject, but represents the minimum metabolism when awake. On purely theoretical grounds it might have been of value to obtain the minimum metabolism of the subject when sound asleep, but this was impracticable. It is perhaps needless to state that during the course of the winter the subject became extremely automatic in his relations to the experiments, and hence if there was any evidence regarding the value of training for an experiment or of training to decrease the incidental muscular activity which might be voluntarily controlled, we should expect to find it here. As a matter of fact, from the very start the subject was not affected in any way, psychologically or otherwise, by the simple routine of the experiments, and we have every reason to believe that the minimum metabolism when the subject was awake was accurately determined.

Since the minimum metabolism under these conditions does not represent the true minimum metabolism of the subject, and since such a base-line is arbitrarily taken for purposes of comparison, it seemed advisable to secure data with regard to base-lines under other conditions. For example, the subject when riding must sit upright on the seat of the bicycle ergometer with the feet on the pedals. Inasmuch as this calls for an increase in the metabolism above that of lying quietly, exactly as lying awake calls for an increased metabolism over lying quietly asleep, it seemed logical likewise to determine the metabolism in the sitting position. This was done in a number of instances. Again, the legs must move in rotating the wheel, and experiments were made in which, by belting a motor to the rear wheel of the ergometer, it was possible to drive the ergometer and thus rotate the legs of the subject at the various speeds employed in the regular work experiments. The values obtained under such circumstances would obviously form still another base-line. Then again, as the subject must in rotating the wheel overcome the ordinary small friction of the machine, a series of experiments was made in which the subject simply rotated the pedals by riding without load. Furthermore, the load was varied so that a series of experiments was carried out with a very low load and increased step by step to the maximum load. Each of these different values can all logically be taken as a series of base-lines for comparison with the highest loads, and thus afford the greatest possibility for variations in the subsequent comparisons.

Finally, since there is much contradictory evidence regarding the aftereffect of muscular work on metabolism, a number of experiments were con- 
tinued after the work-periods ceased. Under these conditions the carbondioxide production and oxygen consumption were both measured, and careful records of the pulse-rate made. In a few experiments a record of the respiration was likewise made by means of the spirometer attached to the ordinary form of respiration apparatus, so as to obtain data regarding the respiratory types before and after work, but for reasons given subsequently it was impracticable to use the spirometer during the muscular-work periods.

\section{DETERMINATION OF THE NITROGEN EXCRETION.}

It was hoped that a reasonably careful study of the urine during severe muscular work could be made, although evidence in the earlier literature with regard to the nitrogen excretion is much more abundant than that with regard to the gaseous exchange. Unfortunately, while the subject was most tractable and coöperated in every way with the investigation while inside the laboratory, it was very difficult to control the diet outside and even more difficult to insure a proper collection of the urine and feces; hence we soon had to give up the plan of securing 24-hour specimens of urine for comparison purposes. When possible, however, the subject emptied the bladder before the experiment began and again after it was over. The data secured have been collected and will be subsequently discussed, but they give only fragmentary evidence with regard to the nitrogen excretion as affected by severe muscular work.

\section{PULSE OBSERVATIONS.}

The intimate relationship between the pulse-rate and the metabolism so regularly noticed in this laboratory led to an attempt to secure the pulserate during these experiments. When the subject was lying quietly upon the couch, the observations were made with the greatest fidelity and regularity and became an integral part of each individual period. When the subject was riding on the ergometer, it was very difficult to secure accurate records of the pulse-rate, although attempts were made to obtain these by means of the stethoscope and occasionally from the radial pulse. While observations were made in practically every experiment, they were by no means so frequent as we should have liked, and obviously some other form of technique will be essential for studying satisfactorily the pulse-rate under these conditions. At the time the experiments were made, we had no string galvanometer or oscillograph at our disposal for securing such records.

\section{DETERMINATION OF THE ALVEOLAR AIR.}

The marked changes in the respiratory quotient noted in many experiments led to observations on the alveolar air, and the influence of muscular work upon its composition. These determinations were made through the assistance of Mr. H. L. Higgins of the laboratory staff, and were carried out by the Haldane ${ }^{a}$ method, the sample being analyzed by means of the small Haldane gas-analysis apparatus. ${ }^{b}$

\section{OBSERVATIONS ON THE INFLUENCE OF DIET.}

The difficulties incidental to an adequate control of the subject while outside the laboratory and his disinclination to follow rigidly a diet, even 
though this was made as liberal as possible, rendered it impracticable to secure much information regarding the effect of diet upon the efficiency of the body as a machine or upon the character of the katabolism. On the other hand in a series of experiments which was carried out with reasonable care, a certain amount of evidence was obtained which can be used with some reserve for discussing this point. Naturally the ideal arrangement would have been to make all of the experiments during a period in which the diet could be carefully controlled for several days previous, but as this was impossible, the plan for a detailed study of the influence of diet upon the character of the metabolism had to be abandoned in order to retain the services of an exceptionally good subject who coopperated in other ways.

\section{EXPERIMENTS WITH UNTRAINED SUBJECTS.}

The majority of the experiments reported were made with a trained athlete, and were conducted over such a long period that differences, if any, which might be due to the influence of season, weather, diet, the alterations in training, the effect of over-training, and psychological condition could be noted. It was considered desirable, however, to make additional observations on a number of untrained individuals. These men, most of whom were members of the laboratory staff, kindly volunteered to subject themselves to these severe tests, even at the risk of becoming very muscle-sore. The evidence secured with the untrained subjects is especially valuable when considered in comparison with the data obtained in the experiments with the trained athlete.

\section{APPARATUS FOR MUSCULAR WORK.}

Of particular interest is the ergometer employed in these experiments. Two instruments were actually used, ergometer I being the identical instrument employed in the previous research by Benedict and Carpenter, ${ }^{a}$ and ergometer II a replica of the same with slight structural modifications but with no alteration in principle. Ergometer I was used in all experiments up to January 19,1912 , inclusive, the experiments subsequent to that date being made with ergometer II. Both instruments have previously been described and the details given of a series of calibrations made with them by Benedict and Cady. ${ }^{b}$

In the latest form of bicycle ergometer (see ergometer II in the frontispiece), a bicycle frame, sprocket, and pedals were used, the rear wheel being replaced by a large copper disk, 405 millimeters in diameter and approximately 6 millimeters thick, securely fastened to a ball-bearing hub. An electromagnet (shown in the frontispiece) was attached to the bicycle frame by means of brass piping, and the disk so adjusted as to rotate exactly in the middle of the electro-magnetic field between the pole faces, with an airspace on each side of the disk of approximately 1 millimeter. The upper edges of the pole-faces form a line that is tangential to the circumference of the copper disk. The large eddy-currents generated as the disk passes through the magnetic field are short-circuited in the disk; thus the whole instrument has the effect of an electric brake, heat being developed in the copper disk

a Benedict and Carpenter, U. S. Dept. Agr., Office Expt. Stas. Bul. 208, 1909.

b Benedict and Cady, Carnegie Institution of Washington Publication No. 167, 1912; also, Cady and Benedict, Physikal. Zeitschr., 1912, 13, p.920. 
and rapidly radiating to the surrounding air. By varying the intensity of the magnetic field, a greater or less brake-effect can be produced. In ergometer II the resistance of the magnet is $10 \mathrm{ohms}$, and a current of 1.5 amperes through the coil produces substantially the same brake-effect as 1.25 amperes on ergometer I. The heat developed in the magnet of ergometer II by magnetization with a current of 1.5 amperes is 17.8 calories per hour.

With the excessively high rates of speed frequently employed by the subject, it was of course impossible to count the ergometer revolutions from minute to minute, and hence a counter of a standard make was attached. Two of these were employed to insure accurate records, one actuated by direct contact with the pedals and the other by a pin on the large sprocketwheel.

The ergometer was calibrated by using one of the respiration calorimeters (the chair calorimeter ${ }^{a}$ ) in the Nutrition Laboratory. The instrument was first divested of the handle-bars and pedals, then placed inside the respiration chamber, and fitted with a flexible shaft which could be driven from the outside by an electric motor. By exciting the magnet and rotating the disk, heat was produced which could be directly measured by the calorimeter as in an ordinary calorimeter experiment. Different strengths of current through the magnetic field and varying speeds were used in calibrating the two instruments, a large number of calibration curves being obtained for both ergometers. With these curves it is necessary to know only the number of revolutions and the intensity of magnetization in order to compute directly and accurately the muscular work which is transformed into heat.

Since the greater number of experiments reported in this book were made with ergometer II, a few characteristic calibration curves of this instrument are given in fig. 1, i.e., those for currents through the magnet of $0.5,0.95$, $1.10,1.25,1.35$, and 1.5 amperes, the six excitations of the magnet used. All of the curves for the calibration of both ergometers I and II, with the exception of that for 0.5 ampere, are given in detail in an earlier publication. ${ }^{b}$

The ergometer is very accurately constructed and runs without much friction. By again employing the respiration calorimeter, friction tests were made with both ergometers I and II. Two tests with ergometer I gave as results 0.000274 and 0.000157 ealorie per revolution respectively; three tests with ergometer II gave $0.000355,0.000182$, and 0.000351 calorie per revolution. While the calorimeter used for the tests was primarily designed to measure the heat production of a man and hence was not as well adapted for the measurement of so small an amount as 1 or 2 calories per hour, the values obtained for the two ergometers agree reasonably well and are doubtless not far from correct. The details have already been published. ${ }^{\circ}$

Inasmuch as the question of the internal friction of the legs came into discussion, it seemed desirable to rotate the ergometer by means of an electric motor so that the legs of the subject would freely move up and down as the pedals revolved. For this purpose a split wooden pulley, with a groove around the periphery, was attached to the hub of the copper disk and connected with a belt brought out to the pulley on the armature shaft of the motor. By measuring the intensity of the field, the current through the armature

$a$ Benedict and Carpenter, Carnegie Institution of Washington Publication No. 123, 1910.

$b$ Benedict and Cady, loc. cit., pp. 18-28.

$c$ Ibid., pp. 21 and $2 g^{\circ}$. 
of the motor, and the voltage between these points, the amount of work required to rotate the machine could be computed. It was hoped by this means to devise some simple and rapid method for calibrating the machine without using the more expensive method of determining the heat produced by the respiration calorimeter. Owing to the great loss by friction and the tension of the belt, the preliminary experimenting by this method was very unsatisfactory, and time did not permit further study along this line. The electric motor was, however, extensively used to drive the ergometer in the so-called "motordriven experiments."

It is important to note that the ergometer, when once calibrated, gives directly the number of calories of external muscular work put upon the machine for each revolution of the pedals, the calories varying somewhat with the rate of speed of revolution. Fortunately for the speeds most commonly used by bicycle riders, namely, between 60 and 80 revolutions of the pedals per minute, when the magnetizing current is constant, the energy output per revolution is practically constant. At speeds lower or higher than this, there is a

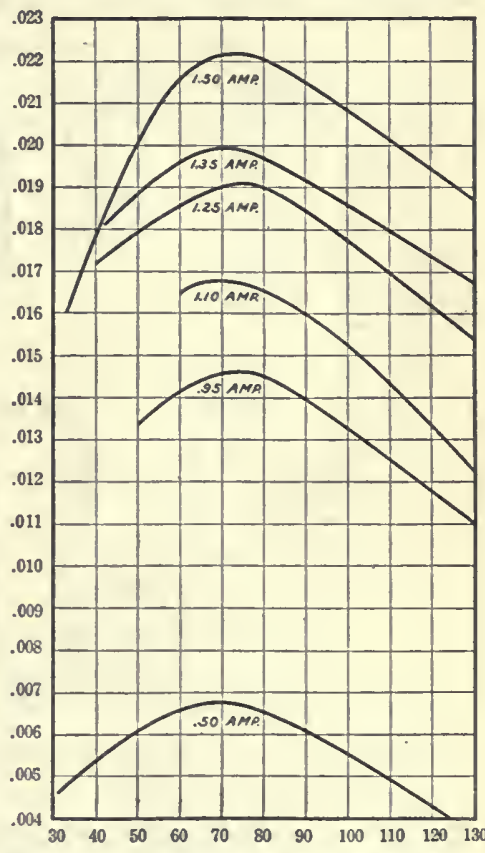

Fig. 1. - Calibration curves showing heat per revolution of ergometer II.

The revolutions per minute are given at the bottom of the figure, and the calories per revolution at the left-hand margin. marked decrease in the heat per revolution. The peculiar anomalies of these calibration curves have been the subject of special discussion elsewhere. ${ }^{a}$

\section{APPARATUS FOR DETERMINING THE GASEOUS EXCHANGE.}

A respiration apparatus that would at one and the same time provide sufficient ventilation for a man working almost to the limit of human endurance and permit both the complete absorption of carbon dioxide and an accurate measurement of oxygen was difficult to obtain, but by slightly modifying the form of respiration apparatus employed in this laboratory for a number of years we were able to meet the requirements for experiments with muscular work. This apparatus has recently been described in detail, including the modifications necessary for experiments with muscular work, ${ }^{b}$ together with a diagram showing the particular adjustment of the apparatus for such experiments. Since the description was published, however, further modifications were found desirable in the progress of this research.

The connections of the respiration apparatus as used for muscular-work experiments are shown in fig. 2. As may be seen in this figure, a rotating ventilator or blower draws air along a pipe and forces it through two Woulff 
bottles containing sulphuric acid. The greater part of the water-vapor in the air-current is absorbed by the acid in the first bottle, but any traces which

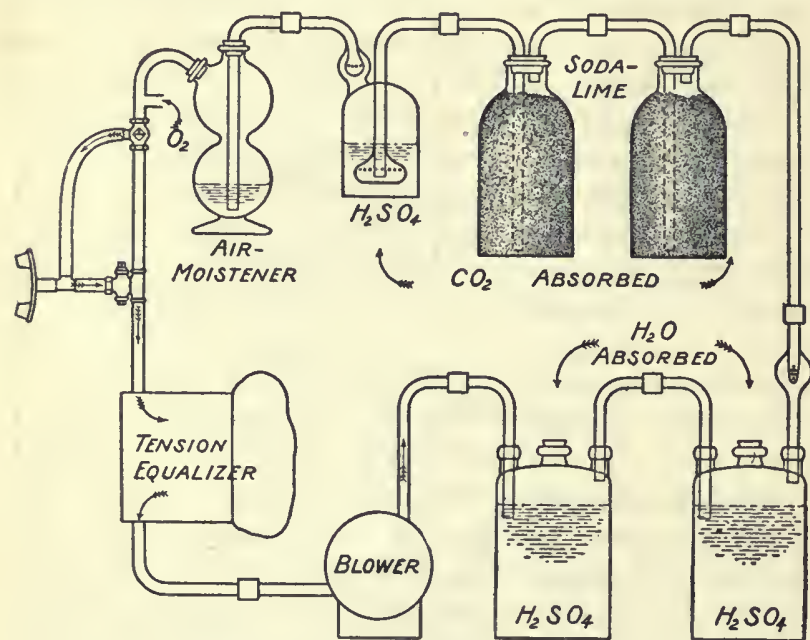

Fig. 2.-Schematic outline of the respiration apparatus. may remain are removed by the acid in the second bottle. The dry air is then passed through the carbon-dioxide absorbers, i. e., two bottles containing sodalime. Since the air absorbs water from the soda-lime it is necessary to remove this moisture by passing the air-current again through sulphuric acid. When the air leaves the drying-bottle it is deficient in oxygen and free from carbon dioxide and water-vapor, but inasmuch as perfectly dry air, if inspired by the subject, would absorb moisture from the respiratory tract and produce discomfort, moisture must be added to the air before it is returned to the subject for breathing. This is done by passing the air-current through the lower part of a Kipp generator partially filled with water. A small amount of sodium carbonate is added to the water in this vessel, which effectually absorbs any acid fumes that may have been carried over. The deficiency ${ }^{a}$ in the oxygen content is made up by the addition of a measured amount of the gas at $\mathrm{O}_{2}$. The air then passes through a 3-way valve and returns, either directly or through the short circuit connected with the subject, to the tension-equalizer and the blower. By weighing the carbondioxide absorbers, and the air-drying vessel before and after the experimental period, and noting the amount of oxygen consumed either by finding the loss in weight of the cylinder of oxygen, or by measuring with a carefully calibrated gas-meter the volume of oxygen added to the air-circuit, the carbon-dioxide production, the oxygen consumption, and the respiratory quotient may be computed.

The absorbing system as here described and used in the muscular-work experiments differs from the usual adjustment of the apparatus in several particulars. When the subject is engaged in severe muscular work, an excessive amount of carbon dioxide is produced, sometimes amounting to as much as 2,500 c.c. per minute. To provide for the absorption of this large amount of carbon dioxide, it was considered safer to use two soda-lime bottles connected in series, instead of one carbon-dioxide absorber as usual.

In the most recent form of the respiration apparatus a spirometer ${ }^{b}$ is used, and much emphasis is placed upon the character of the respiration as

a As a matter of fact, to guard against oxygen-want in the apparatus, the air in the closed systcm was always arbitrarily adjusted somewhat oxygen-rich.

b Benedict, Deutsch. Archiv. f. klin. Med., 1912, 107, p. 172. 
shown by the graphic records obtained. In experiments with severe muscular work, however, when the respiration-rate and the ventilation of the lungs are greatly increased, it was found much more satisfactory to resort to the original form of tension-equalizer. ${ }^{a}$ This tension-equalizer is shown in detail in fig. 3. At each side of the valve $m$ attached to the main

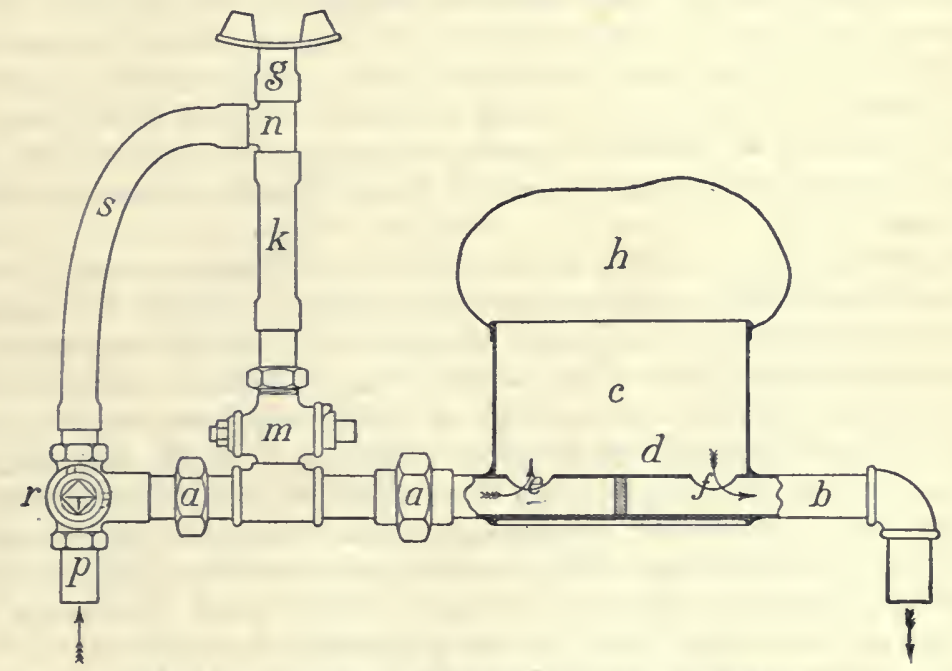

Fig. 3.-Tension-equalizer and flexible mouthpiece.

The air from $p$ passes through the 3-way valve $r$ and continues along the pipe $b$ by the opening of the 3-way valve $m$ until it enters through $e$ the tension-equalizer can $c$ with the rubber diaphragm $h$ over it. It leaves the tension-equalizer through the opening $f$, passing through the pipe $b$ and on to the blower. The mouthpiece $g$ is attached to a tee $n$, which is in turn attached by short lengths of rubber tubing ( $k$ and $s)$ to the two 3-way valves $r$ and $m$. After the experiment has begun and the subject is breathing through the mouthpiece and the pipe $k$, the 3 -way valve $r$ is suddenly turned so as to deflect the air through $s, n$, and $k$ thus diminishing the dead space. The flexibility of $s$ and $k$ permit considerable lateral motion of the head.

ventilating pipe is a brass union $a$, which is easily uncoupled. To one of these is soldered a thin-walled brass tube $b$, which is passed through two holes in the opposite sides of a copper ean $c$, and soldered into place. At a point in the pipe midway across the can is placed a plug of wood, cork, or rubber, $d$, openings into the can being provided by two holes $e$ and $f$. A rubber bathing-cap $h$ is fitted over the top of the can and secured by several rubber bands so as to obtain perfect closure. The air, entering the tensionequalizer from the ventilating pipe at $e$, circulates freely about the confined space in the can and the rubber diaphragm, and passes out the other side at $f$, direct passage through the pipe being prevented by the plug $d$. This can with the rubber diaphragm contains approximately 6.5 liters, so that a large volume of air can be taken from the system without producing any tension. Furthermore, the weight of the rubber diaphragm is so slight as to produce no material amount of pressure or resistance to the respiration, the diaphragm falling with each inspiration and rising with each expiration. The inequalities in the shape preclude the possibility of estimating accurately the height of the diaphragm at any given time, so that it is necessary to resort to a measurement of the inside tension. This is accomplished by connecting 
with the system a delicate petroleum manometer and admitting oxygen before and after the experiment until a certain definite tension upon the rubber diaphragm is indicated.

The rate of ventilation commonly used in resting respiration experiments in this laboratory is about 35 liters per minute, but in this research it was found necessary, owing to the excessive ventilation of the lungs and deep inspiration during severe muscular work, to increase the rate of ventilation to 85 liters per minute. Under these conditions the air-current passed by the mouthpiece so rapidly that at no time could there be any rebreathing of the air, since the rate of flow was always greater than the intake of the lungs. During the rest experiments the rate of ventilation was reduced to 35 liters per minute.

The subject who was used in most of the experiments reported preferred to use the mouthpiece rather than the nosepiece. Indeed, the amount of ventilation permitted with any form of nosepiece would be too small for the intense muscular work done in these experiments. It was found, furthermore, that when riding on the bicycle at high rates of speed, there was an uncontrollable lateral head motion which made it difficult to retain the mouthpiece when fastened directly to the rigid brass tube on the valve providing the opening into the air-circuit; consequently it was necessary to arrange for a somewhat longer and more flexible connection. The device used in the muscular-work experiments is shown in fig. 3 , which gives the details of the connection between the subject and the air-circuit.

With the ordinary form of connection, which was used in some of the rest experiments, the subject breathed into and out of the main air-circuit through the valve $n$, but for the muscular-work experiments and all the later rest experiments a short length of rubber tubing $k$ was attached to the valvepiece $m$, to which was attached a brass tee $n$ and the mouthpiece $g$. The flexible tube $k$ allowed considerable lateral motion of the mouthpiece $g$ when the subject was riding vigorously, which was impossible with the ordinary connection, but on the other hand, the dead air-space was increased. Experiments subsequently made by Mr. T. M. Carpenter of this laboratory have shown that so short a dead air-space as is represented by $n$ and $k$ is absolutely without effect upon the metabolism of resting man. As we did not have the results of Mr. Carpenter's important observations at the time of the research, it was considered necessary to make some provision so that this dead airspace could have no possible effect upon the respiration during severe muscular work. This was done by attaching a supplementary piece of rubber tubing $s$ to the 3 -way valve $r$, and connecting it with the brass tee $n$. During the experimental period, the 3-way valve $r$ was turned so that the air passing through the pipe $p$ was deflected and entered the rubber tube $s$ leading to the mouthpiece $g$. As the air passed through the tube $s$ and directly by the opening of the mouthpiece $g$, it was inspired by the subject and the air expired entered the current which flowed through the tubing $k$ and the valve $m$ to the main air-circuit. In this way the dead air-space between the subject and the ventilating current was reduced to a minimum. Furthermore, this arrangement facilitated easy respiration. 


\section{ROUTINE OF EXPERIMENTS.}

Rest experiments.-The majority of the work experiments were preceded each morning by an experiment in which the respiratory exchange was determined while the subject lay quietly upon a couch. Many work experiments were also followed by similar experiments of several periods each. Since the results of these rest experiments were used as the base-line, particular care was taken to secure uniform conditions. The subject came to the laboratory between $7^{\mathrm{h}} 30^{\mathrm{m}}$ and $7^{\mathrm{h}} 45^{\mathrm{m}}$ a.m., and as no food had been taken for 12 hours, he was in the post-absorptive condition. After putting on his riding clothes he lay down on the couch with a blanket over him and remained quiet for at least half an hour, during which time the pulse-rate continually decreased until a minimum was reached. The subject was instructed to lie very quietly during the period, without moving a muscle but also without rigidity. After he had become thoroughly quieted down and the pulse-rate had reached its normal resting level, the mouthpiece was inserted and the noseclip attached; the subject then breathed room-air for several minutes into and out of the mouthpiece. At the end of a normal expiration the valve was turned, connecting the subject with the main ventilating-current, and the experiment continued in this manner for about 15 minutes. At the end of the experimental period the valve was again turned so that the subject was cut off from the air-current, the valve being so deflected as to connect him with room-air. During the entire experimental period the amount of oxygen admitted was noted on a carefully calibrated gas-meter immersed in water and the temperature of the gas-meter, the barometer, and the pulse-rate were regularly recorded throughout the experiment.

In connection with the respiration experiments carried out in this laboratory, it is a part of the regular routine to secure graphic records of any extraneous muscular activity by means of pneumographs placed around either the chest or the thighs, and sometimes both pneumographs are used. In the first experiments with this bicyclist, graphic records of the degree of muscular rest were obtained in this way. It was soon found, however, that this particular subject was unusually quiet, and as we were convinced of the absence of muscular activity in all rest experiments with this subject, and further, as the application of the apparatus seemed to cause him some annoyance, the use of the pneumograph was abandoned.

Sitting experiments.-In the sitting experiments with the professional bicyclist, the subject sat quietly upon the ergometer as usual, the feet resting on the pedals; there was, however, no rotation of the pedals. In experiments with some of the other subjects, the feet rested lightly upon wooden blocks or upon an iron foot-rest attached to the front fork of the apparatus, the position being otherwise the same as for experiments with the professional athlete. But few of these sitting experiments were made, as the subjects found the position very uncomfortable. The general routine followed was the same as that in the rest experiments.

No-load experiments. - In certain experiments the subject rode the ergometer without load, the pedals being rotated by the feet or by an electric motor. It was found in these experiments that there was considerable lateral motion of the subject's head; consequently it was necessary to use the special 
connection with the mouthpiece designed for the muscular-work experiments, and previously described. The general routine for the no-load experiments was the same as that for the hard-work experiments.

Work experiments. - In these experiments it was necessary to make sure that a continual supply of fresh air passed directly by the mouthpiece, so that the subject would not rebreathe any of the expired air. A slightly different routine was therefore required from that employed in the resting, sitting, and coasting experiments. After throwing the valve $m$ (see fig. 3 ) connecting the subject with the main air-supply, the 3 -way valve $r$ was immediately turned so as to have the air pass by the mouth; if done quickly this valve could be turned without producing a disturbance in the circulation of the air. Toward the end of the working period, which usually did not last more than 11 minutes, the valve $r$ was thrown a moment or two before the valve $m$, and thus when this latter valve was finally thrown the conditions were exactly the same as when the experiment began. Simultaneously with the throwing of the valve $m$ at the beginning and end of the experiment, both counters on the ergometer were read and the observations recorded, and the oxygen-meter likewise read and the data recorded. As the oxygen-meter used during these experiments was not of a self-registering type, an assistant was detailed to watch the meter and record each revolution of the drum. Throughout the entire work experiment a liberal supply of soapsuds was applied to the mouthpiece to insure absence of a leak.

Experiments with controlled diet.-On a few days it was possible to control the diet of the subject by having him take his meals at the laboratory. Since other experiments were being carried out in the laboratory at the same time with essentially the same diet, it was deemed unnecessary to analyze specially the food materials used in the muscular-work experiments. The composition of the foods ingested was obtained, therefore, for the most part, either by using average values computed from previous analyses, or by the direct analysis of simultaneously sampled food products. As there was an uncertainty about the proper collection of the urine, and the collection of feces was absolutely impossible, it was argued that any control of the diet would be at best somewhat tentative, and while an attempt was made at one time to maintain a carbohydrate-rich diet, and at another time a carbohydrate-low diet, the actual data obtained are somewhat questionable. It is believed, however, that the subject honestly adhered to the diet given him in the laboratory.

\section{COMPUTATION OF THE ENERGY OUTPUT FROM THE OXYGEN CONSUMPTION.}

In our experiments, while no direct calorimetric measurements were made, the oxygen consumption was determined with great care, and the data thus secured were used for the computation of the energy output-a method which has been frequently employed by a number of investigators. No one has more painstakingly worked out the theory and principle of such computations than has Zuntz. This method, first elaborated and published by Zuntz ${ }^{a}$ in 1897, has been utilized in several more recent publications. ${ }^{b}$

a Zuntz, Pfäger's Archiv f. d. ges. Physiol., 1897, 68, p. 202.

$b$ Zuntz and Schumburg, Physiologie des Marsches, Berlin, 1901, p. 260; Zuntz, Loewy, Mâller, and Caspari, Höhenklima u. Bergwanderungen, Berlin, 1906, p. 96; and Loewy, Oppenheimer's II andbuch der Biochemie, Jena, 1911, 4 (1), p. 280. 
Using the amount of oxygen absorbed for the combustion in the body of 1 gram of carbohydrates, fat, or protein, and the well-known heats of combustion of these substances, Zuntz has computed that 1 liter of oxygen has a calorific value varying from 4.686 to 5.047 , according to the character of the material burned, the higher values being found for the combustion of carbohydrates and the lower for the combustion of fat. Zuntz has also carefully computed the changes in value of the calorific equivalent of oxygen, depending upon the character of the material burned as indicated by the respiratory quotient.

TABLE 4.-Calorific values of oxygen.

\begin{tabular}{|c|c|c|c|c|c|}
\hline $\begin{array}{l}\text { Respiratory } \\
\text { quotient. }\end{array}$ & $\begin{array}{c}\text { Calorific } \\
\text { value of } \\
1 \text { liter } \\
\text { oxygen. }\end{array}$ & $\begin{array}{l}\text { Respiratory } \\
\text { quotient. }\end{array}$ & $\begin{array}{c}\text { Calorific } \\
\text { value of } \\
1 \text { liter } \\
\text { oxygen. }\end{array}$ & $\begin{array}{l}\text { Respiratory } \\
\text { quotient. }\end{array}$ & $\begin{array}{c}\text { Calorific } \\
\text { value of } \\
1 \text { liter } \\
\text { oxygen. }\end{array}$ \\
\hline $\begin{array}{r}0.70 \\
.71 \\
.72 \\
.73 \\
.74 \\
.75 \\
.76 \\
.77 \\
.78 \\
.79 \\
. . .\end{array}$ & $\begin{array}{c}\text { Calories. } \\
4.686 \\
4.690 \\
4.702 \\
4.714 \\
4.727 \\
4.739 \\
4.752 \\
4.764 \\
4.776 \\
4.789 \\
\ldots . .\end{array}$ & $\begin{array}{r}0.80 \\
.81 \\
.82 \\
.83 \\
.84 \\
.85 \\
.86 \\
.87 \\
.88 \\
.89 \\
. . .\end{array}$ & $\begin{array}{c}\text { Calories. } \\
4.801 \\
4.813 \\
4.825 \\
4.838 \\
4.850 \\
4.863 \\
4.875 \\
4.887 \\
4.900 \\
4.912 \\
\ldots . .\end{array}$ & $\begin{array}{r}0.90 \\
.91 \\
.92 \\
.93 \\
.94 \\
.95 \\
.96 \\
.97 \\
.99 \\
.99 \\
1.00\end{array}$ & $\begin{array}{c}\text { Calories. } \\
4.924 \\
4.936 \\
4.948 \\
4.960 \\
4.973 \\
4.985 \\
4.997 \\
5.010 \\
5.022 \\
5.034 \\
5.047\end{array}$ \\
\hline
\end{tabular}

The Zuntz method of computation assumes that the combustion is entirely of fat, or carbohydrate, or a combination of the two, and no recognition is made of the fact that a certain amount of protein is also burned. As has frequently been pointed out, the amount of protein contributing to the energy production seldom exceeds 15 per cent; according to Magnus-Levy, ${ }^{a}$ if one considers that 15 per cent of protein is simultaneously burned, the calorific value of 1 liter of oxygen would be lowered by 0.031 calorie. Since it is incorrect, however, to consider the nitrogen excretion as simultaneous with the breaking-down of the protein, Loewy argues that it is much more logical in short respiration experiments to use the direct calculations of the energy from the values reported by Zuntz and Schumburg.

Without presuming to pass judgment upon the absolute accuracy ${ }^{b}$ of every point in the Zuntz method, and fully recognizing the difficulties incidental to a comparison of direct and indirect calorimetry in periods of short duration, nevertheless we believe that when the metabolism is measured immediately before, during, and after muscular work, this method of computing the energy transformations is fully applicable for purposes of comparison and hence can be followed implicitly in computing the results of our experiments. We have therefore used as the basis of the computations in this report the values given by Zuntz and Schumburg. ${ }^{c}$ (See table 4.)

a Magnus-Levy, von Noorden's Handbuch der Pathologie des Stoff wechsels, Berlin, 1906, 1, p. 207.

No account is taken of the cutaneous respiration which admittedly may be of considerable size. The influence of the cutaneous respiration would probably affect the respiratory quotient somewhat more than the total katabolism. In the absence of exact knowledge regarding the role played by cutaneous respiration, we do not consider it here though doubtless in the state of profuse perspiration existing in many of our experiments, there must have been a greater cutaneous respiration than normal. When the enormous amount of carbon dioxide produced and oxygen absorbed are taken into consideration, it is not likely that we have greatly erred in neglecting this as yet unsatisfactorily determined factor.

c Zuntz and Schumburg, loc. cie., p. 361 , table 7 . 
, 


\section{PART II.}

\section{STATISTICS OF EXPERIMENTS.}

In this series of experiments, 7 subjects were used. The statistics as to their occupation, age, height, and average weight without clothing are given in table 5. With the single exception of M. A. M., none of the subjects had any special training in bicycle riding or had ever ridden to excess, nor did any of them own bicycles; for many months previous to the experiments, they had ridden only intermittently, if at all.

TABLE 5.-Statistics of age, height, and average weight of subjects.

\begin{tabular}{|c|c|c|c|c|}
\hline Subject. & Occupation. & Age. & Height. & $\begin{array}{l}\text { Body-weight } \\
\text { without } \\
\text { clothing. }\end{array}$ \\
\hline $\begin{array}{l}\text { K. H. A. } \\
\text { W. G. A. } \\
\text { E. P. C. } \\
\text { J. J. C. } \\
\text { J. F. F. } \\
\text { H. L. H. } \\
\text { M. A. M. }\end{array}$ & 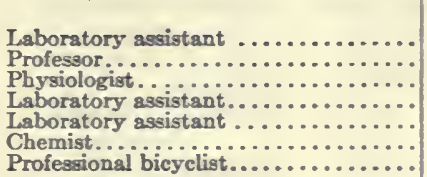 & $\begin{array}{l}y r 8 . \\
26 \\
51 \\
35 \\
28 \\
21 \\
25 \\
32\end{array}$ & $\begin{array}{l}\mathrm{cm} \\
182 \\
175 \\
185 \\
175 \\
172 \\
172 \\
176\end{array}$ & $\begin{array}{l}\text { kilos. } \\
66.7 \\
70.3 \\
63.2 \\
65.0 \\
59.9 \\
60.3 \\
65.9\end{array}$ \\
\hline
\end{tabular}

The subject M. A. M., with whom most of the experiments were made, began riding as an amateur in 1896 and as a professional bicyclist in 1901, continuing until 1910. Between 1901 and 1905 he took part in 5 motor-paced races; in 1905 he rode in a 6-day bicycle race in New York City and in a second in 1907. He also rode in numerous smaller races and kept in general good condition up to the time of the beginning of the experiments. While the subject never took a regular training course, he exercised regularly in a gymnasium between 1896 and 1908, and practiced boxing considerably, although with no special success. As in 1907 his nose was broken, the boxing practice was discontinued. His maximum weight previous to the research was in May 1911, when he weighed 66.7 kilograms. During the research he was twice examined physically by Dr. W. G. Anderson, of Yale University. As a result of the examination on March 4,1912, Dr. Anderson said that the subject was remarkably well developed, particularly in the abdominal and thigh muscles, but drew attention to the somewhat surprising fact that the lower leg-muscles, particularly the gastrocnemii, were not well developed. A second examination was made by Dr. Anderson on April 25, 1912, the results of which are given in table 6 . Information regarding the dietary habits of the subject is given on page 80 .

In presenting the statistics of the experiments, we have grouped them under three heads: (1) lying vs. sitting experiments; (2) no-load experiments both with and without motor; (3) work experiments. The general character of each class of experiments has been described in some detail on pages 31 and 32. In these groups, the experiments have been arranged first according to subject and then for the most part chronologically. Reference to the statistical details of any experiments may thus be readily made. 
The data for the experiments are given in tabular form and include the carbon dioxide eliminated per minute, the oxygen absorbed per minute, the respiratory quotient, and the average pulse and respiration rates, the record for the respiration-rate usually representing the result of but one observation in each period. In the statistics for the no-load experiments, the records of the number of revolutions per minute have been added, and in those for the work experiments, both the revolutions per minute and the current used through the magnetizing field. All necessary details not included in the tabulated material are given in footnotes.

Table 6.-Measurements of M. A. M. Date, April 25, 1912. Age, 32 years.

Height

Girth of -

Neck

Chest, depressed . . . . .

inflated

normal

Waist

$\begin{array}{ll}\text { at ninth rib, full } & 86.9 \\ \text { at ninth rib, depressed } & 77.2\end{array}$

Hips

Right biceps . . . . . . 31.0

Left biceps . . . . . . . . . . 29.7

Right forearm . . . . . . . 26.4

Left forearm cm.

176.0

37.6

86.4

95.3

0.7

74.9

94.5

29.7
26.4

25.7

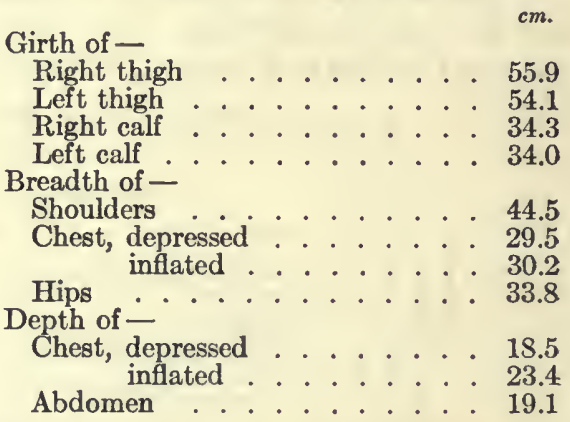

The respiratory exchange was determined with a respiration apparatus which has already been fully described in the previous section of the report. The work was done on a bicycle ergometer; two ergometers were used, designated respectively as ergometer I and ergometer II, both of which are described on pages 25 to 27. Ergometer I was used in the experiments up to January 23, 1912, all subsequent experiments being made with ergometer II.

The general routine of the experiments is given on pages 31 and 32 , together with special details as to methods. The subject was without food in practically every case, the observations being made in the post-absorptive state, i.e., at least 12 hours after the last meal.

\section{LYING VS. SITTING EXPERIMENTS.}

These experiments were made for the special purpose of obtaining the basal metabolism; the statistical details are given in tables 7 to 15 inclusive. In the lying experiments, the subject lay as quietly as possible upon a couch, no observations being made until the conditions were absolutely normal for a rest period. The experiment usually covered three 15-minute periods, with intermissions of varying lengths. Lying experiments were made almost every day as a part of the regular routine; the statistics for those made in comparison with the no-load and work experiments are given with the statistics under these particular heads.

In the sitting experiments, the subject sat motionless upon the bicycle ergometer in position for riding. The general routine as to preliminary periods and length was the same as for the lying experiments. As will be seen in many of the notes appended to the tables, the subjects found the enforced quiet of this position somewhat irksome. An attempt was made with some of the subjects to relieve the constraint by supporting the pedals with a block of wood, or otherwise, but the experiments with the subject M. A. M. were all made without such support. 
TABLE 7.-Results with subject J.E.F. (without food). (Ergometer I.)

\begin{tabular}{|c|c|c|c|c|c|c|}
\hline Date and time. & Duration. & $\begin{array}{l}\text { Carbon } \\
\text { dioxide } \\
\text { eliminated } \\
\text { per minute. }\end{array}$ & $\begin{array}{l}\text { Orgigen } \\
\text { absorbed } \\
\text { per minute. }\end{array}$ & $\begin{array}{l}\text { Respiratory } \\
\text { quotient. }\end{array}$ & $\begin{array}{l}\text { Average } \\
\text { pulse- } \\
\text { rate. }\end{array}$ & $\begin{array}{l}\text { Average } \\
\text { respirstion- } \\
\text { rate. }\end{array}$ \\
\hline 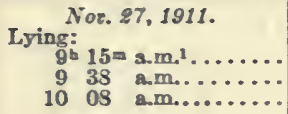 & $\begin{array}{ll}\min & \text { sec. } \\
13 & 30 \\
14 & 29 \\
11 & 30\end{array}$ & $\begin{array}{l}\text { c.c. } \\
202 \\
215 \\
217\end{array}$ & $\begin{array}{l}\text { c.c. } \\
255 \\
218 \\
227\end{array}$ & $\begin{array}{r}0.79 \\
.99 \\
.96\end{array}$ & $\begin{array}{l}59 \\
60 \\
58\end{array}$ & $\begin{array}{l}10 \\
10 \\
08\end{array}$ \\
\hline Average........... & $\ldots \ldots \ldots$ & 211 & 234 & 0.91 & 59 & 09 \\
\hline 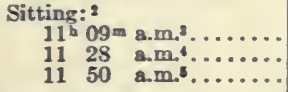 & $\begin{array}{ll}10 & 49 \\
10 & 47 \\
10 & 52\end{array}$ & $\begin{array}{l}223 \\
224 \\
251\end{array}$ & $\begin{array}{l}296 \\
291 \\
290\end{array}$ & $\begin{array}{r}0.75 \\
.77 \\
.87\end{array}$ & $\begin{array}{l}78 \\
78 \\
78\end{array}$ & $\begin{array}{l}09 \\
10 \\
11\end{array}$ \\
\hline Average........... & $\ldots \ldots \ldots$ & 233 & 292 & 0.50 & 78 & 10 \\
\hline
\end{tabular}

1 The subject had walked 12 miles in the course of the preceding 24 hours. His dinner the night before was an ordinary meal, varied in character.

2 The subject sat on the ordinary seat of the ergometer with his feet resting on blocks placed on the floor.

3 The subject sat on the ergometer for half an hour before the period began.

1 The subject complained that the position was very tiring.

5 The subject said that he felt extremely stiff and that he was tired.

TABLE 8.-Results with subject E.P.C. (without food). (Ergometer I.)

\begin{tabular}{|c|c|c|c|c|c|c|}
\hline Date and time. & Duration. & $\begin{array}{c}\text { Carbon } \\
\text { dioxide } \\
\text { eliminated } \\
\text { per minute. }\end{array}$ & $\begin{array}{l}\text { Orygen } \\
\text { sbsorbed } \\
\text { per minute. }\end{array}$ & $\begin{array}{l}\text { Respiratory } \\
\text { quotient. }\end{array}$ & $\begin{array}{l}\text { Average } \\
\text { pulse- } \\
\text { rate. }\end{array}$ & $\begin{array}{l}\text { Average } \\
\text { respiration } \\
\text { rate. }\end{array}$ \\
\hline 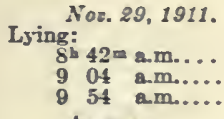 & $\begin{array}{ll}\min & \text { sec. } \\
10 & 49 \\
10 & 55 \\
10 & 48\end{array}$ & $\begin{array}{l}c . c . \\
173 \\
156 \\
167 \\
\end{array}$ & $\begin{array}{l}c . c . \\
223 \\
215 \\
221 \\
\end{array}$ & $\begin{array}{r}0.78 \\
.73 \\
.76 \\
\end{array}$ & $\begin{array}{l}48 \\
46 \\
(1)\end{array}$ & $\begin{array}{l}12 \\
13 \\
14 \\
\end{array}$ \\
\hline Average...... & ........ & 165 & 220 & 0.76 & 47 & 13 \\
\hline 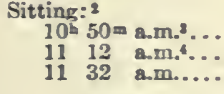 & $\begin{array}{ll}10 & 49 \\
10 & 52 \\
10 & 5 t\end{array}$ & $\begin{array}{l}210 \\
168 \\
176\end{array}$ & $\begin{array}{l}250 \\
239 \\
225\end{array}$ & $\begin{array}{r}0.84 \\
.71 \\
.79\end{array}$ & $\begin{array}{l}\text { (1) } \\
\text { (1) } \\
\text { (1) }\end{array}$ & $\begin{array}{l}11 \\
\because \\
\cdots\end{array}$ \\
\hline Average.... & ........... & 185 & 238 & 0.78 & $\cdots$ & $\cdots$ \\
\hline
\end{tabular}

1 The pulse-rate was not obtained.

2 The subject sat on the ordinary seat of the ergometer with his feet resting on blocks placed on the floor.

3 The subject sat on the ergometer about half an hour before the period began. He was quiet during the period except for removing his hands from the handles and placing them on his knees, and then back again to the handles.

4 The gubject had the position of the handles altered slightly.

TABLE 9.-Results with subject K.H.A. (without food). ${ }^{1}$ (Ergometer I.)

\begin{tabular}{|c|c|c|c|c|c|c|}
\hline Date and time. & Duration. & $\begin{array}{c}\text { Carbon } \\
\text { dioxide } \\
\text { eliminated } \\
\text { per minute. }\end{array}$ & $\begin{array}{c}\text { Oxygen } \\
\text { absorbed } \\
\text { per minute. }\end{array}$ & $\begin{array}{l}\text { Respiratory } \\
\text { quotient. }\end{array}$ & $\begin{array}{c}\text { Average } \\
\text { pulse- } \\
\text { rate. }\end{array}$ & $\begin{array}{c}\text { Average } \\
\text { respiration- } \\
\text { rate. }\end{array}$ \\
\hline \multirow{2}{*}{ 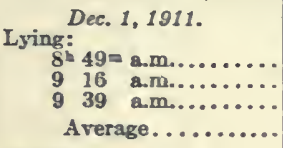 } & $\begin{array}{cc}\min , & \text { sec. } \\
10 & 41 \\
13 & 32 \\
13 & 30\end{array}$ & $\begin{array}{l}\text { c.c. } \\
205 \\
204 \\
197\end{array}$ & $\begin{array}{l}\text { c.c. } \\
249 \\
235 \\
237\end{array}$ & $\begin{array}{r}0.82 \\
.87 \\
.83\end{array}$ & $\begin{array}{l}58 \\
56 \\
56\end{array}$ & $\begin{array}{l}12 \\
14 \\
14\end{array}$ \\
\hline & $\ldots \ldots \ldots$ & 202 & 241 & 0.84 & 57 & 13 \\
\hline \multirow[t]{2}{*}{ 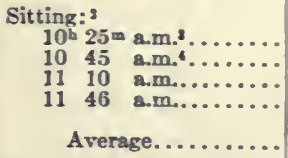 } & $\begin{array}{ll}10 & 40 \\
13 & 55 \\
13 & 55 \\
10 & 32\end{array}$ & $\begin{array}{l}213 \\
215 \\
210 \\
205\end{array}$ & $\begin{array}{l}271 \\
247 \\
286 \\
249\end{array}$ & $\begin{array}{r}0.79 \\
.87 \\
.71 \\
.82\end{array}$ & $\begin{array}{l}60 \\
60 \\
60 \\
59\end{array}$ & $\begin{array}{l}12 \\
14 \\
12 \\
12\end{array}$ \\
\hline & $\ldots \ldots \ldots$ & 211 & 263 & 0.81 & 60 & 13 \\
\hline
\end{tabular}

1 The subject had eaten heavily the day before, as late as $10.00 \mathrm{p} . \mathrm{m}$.

The subject sat on a broad wooden seat with his feet on a rest attached to the front fork of the machine.

3 The subject ast on the ergometer for half an hour before the period. He had the mouthpiece in his mouth 20 minutes before the period and $w a s$ in the usual cramped position. Between the sitting periods the subject was allowed merely to release his mouth a minute or two and then returned to the customary position.

4 The subject was distinctly hungry while sitting up. This feeling was quite lacking while he was lying down. 
TABLE 10.-Results with subject M.A.M. (without food). (Ergometer I.)

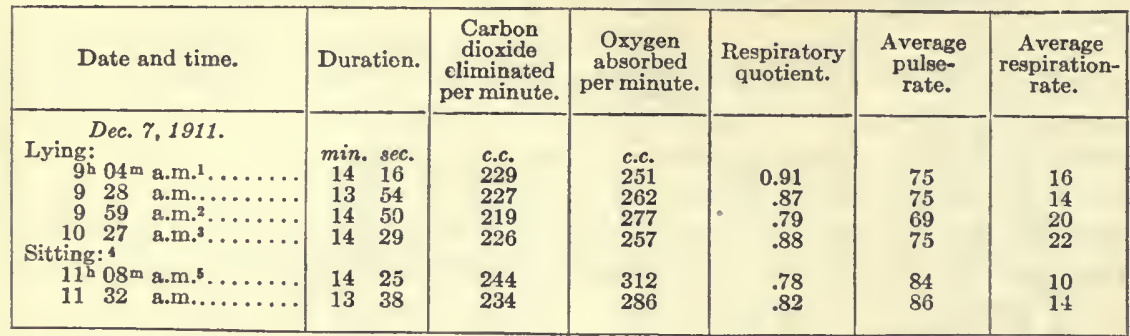

1 A screen was used to shut off the subject's view of the rubber diaphragm.

2 The subject's respiration was rather irregular and shallow throughout the peried. Occasional deep breaths were taken. There was also a curious irregularity in breathing during the preceding period, extremely shallow.

3 The subject desired to urinate and was in some discomfort. He was afraid to breathe deeply, as an abdominal breath was followed by a full movement of the diaphragm with subsequent pressure on the bladder.

4 The subject sat on the ordinary seat with his feet on unsupported pedals, $i$. e. with the disk perfectly free.

6 The subject sat on the ergemeter 20 minutes before the period. He breathed freely and deeply. His feet and logs were remarkably steady throughout.

TABLE 11.-Results with subject M.A.M. (without food). (Ergometer I.)

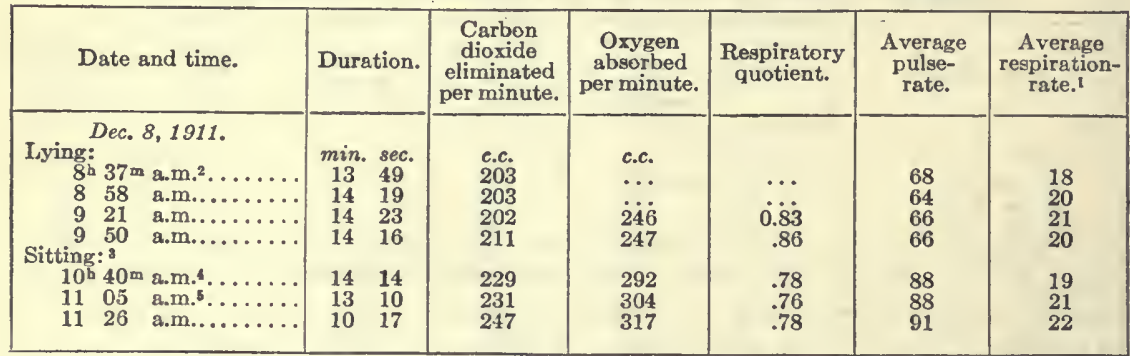

1 The respiration rate was rapid at the start but was more regular than on Dec. 7 . It became shallow in the third period. The subject desired to urinate at the beginning of the third period but did not till the end of the fourth period.

2 The subject lay quietly and was comfortable. He urinated before the experiment. The heart-beat was steady and slow. The pulse-rate at $8^{\mathrm{h}} 15^{\mathrm{m}} \mathrm{a}$. m. was 76 .

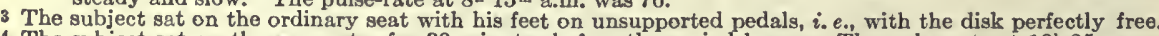

4 The subject sat on the ergometer for 30 minutes before the period began. The pulse-rate at $10^{\mathrm{h}} 25^{\mathrm{m}} \mathrm{a} . \mathrm{m}$ was 76, the subject's feet being on a foot-rest. At $10^{\mathrm{b}} 27 \mathrm{~m}$ a.m. he lowered his feet to the pedals, and put his mouth to the mouthpiece. The pulse-rate at $10^{\mathrm{b}} 29^{\mathrm{m}}$ a.m. was 84 ; at $10^{\mathrm{h}} 32^{\mathrm{m}}$ a.m. $10^{\mathrm{h}} 34^{\mathrm{m}}$ 2.m. and $10^{\mathrm{b}} 36^{\mathrm{m}} \mathrm{a} \mathrm{m}$ it was $86^{\circ}$ a at $10^{\mathrm{h}} 38^{\mathrm{m}} \mathrm{am}$ it $\mathrm{was} 87$.

5 The subject found that sitting perfectly still was very tiring. He complained of dry air. This was found to be due to the fact that the water in the moistener was low.

TABLe 12.-Results with subject M.A.M. (without food). (Ergometer I.)

\begin{tabular}{|c|c|c|c|c|c|c|}
\hline Date and time. & Duration. & $\begin{array}{l}\text { Carbon } \\
\text { dioxide } \\
\text { eliminated } \\
\text { per minute. }\end{array}$ & $\begin{array}{c}\text { Oxygen } \\
\text { absorbed } \\
\text { per minute. }\end{array}$ & $\begin{array}{l}\text { Respiratory } \\
\text { quotient. }\end{array}$ & $\begin{array}{l}\text { Average } \\
\text { pulse- } \\
\text { rate. }\end{array}$ & $\begin{array}{l}\text { Average } \\
\text { respiration- } \\
\text { rate. }\end{array}$ \\
\hline 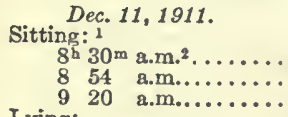 & $\begin{array}{ll}\min . & \text { sec. } \\
14 & 16 \\
14 & 27 \\
14 & 25\end{array}$ & $\begin{array}{l}\text { c.c. } \\
225 \\
231 \\
230\end{array}$ & $\begin{array}{l}\text { c.c. } \\
261 \\
268 \\
273\end{array}$ & $\begin{array}{r}0.86 \\
.86 \\
.84\end{array}$ & $\begin{array}{l}84 \\
83 \\
84\end{array}$ & $\begin{array}{l}23 \\
24 \\
24\end{array}$ \\
\hline 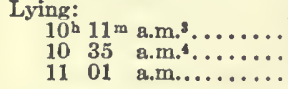 & $\begin{array}{ll}14 & 23 \\
15 & 54 \\
15 & 10\end{array}$ & $\begin{array}{l}194 \\
190 \\
200\end{array}$ & $\begin{array}{l}232 \\
243 \\
238\end{array}$ & $\begin{array}{l}.84 \\
.78 \\
.85\end{array}$ & $\begin{array}{l}60 \\
59 \\
60\end{array}$ & $\begin{array}{l}22 \\
20 \\
22\end{array}$ \\
\hline
\end{tabular}

1 The subject sat on the ordinary seat with his feet on unsupported pedals, $i$. e., with the disk perfectly free.

2 The subject sat on the ergometer at 8 a.m. The pulse-rate at $8^{\mathrm{b}} 15^{\mathrm{mn}}$ a.m., $8^{\mathrm{b}} 22^{\mathrm{m}} \mathrm{a} . \mathrm{m}$., and $8^{\mathrm{b}} 28^{\mathrm{m}} \mathrm{a} \cdot \mathrm{m}$. was 84 . Subject put his mouth to the mouthpiece at $8^{\mathrm{b}} 22^{\mathrm{m}}$ a.m. He sat remarksably steady, and preferred to have his feet on the pedals rather than on the rcst. In the second period the handle bars were uncomfortable, and later the saddle hurt him. He had a cloth covering on the saddle during the
third period.

3 The subject lay down at $9^{\mathrm{b}} 45^{\mathrm{m}}$ a.m. He lay perfectly quiet and was quite comfortable.

4 The timing of the beginning of this period may not have been exactly correct, as it was difficult to follow the subject's breathing. 
TABLE 13.-Results with subject M.A.M. (without food). (Ergometer I.)

\begin{tabular}{|c|c|c|c|c|c|c|}
\hline Date and time. & Duration. & $\begin{array}{l}\text { Carbon } \\
\text { dioxide } \\
\text { eliminsted }\end{array}$ & $\begin{array}{l}\text { Oxygen } \\
\text { absorbed } \\
\text { per minute. }\end{array}$ & $\begin{array}{l}\text { Respiratory } \\
\text { quotient. }\end{array}$ & $\begin{array}{l}\text { Average } \\
\text { pulse- } \\
\text { rate. }\end{array}$ & $\begin{array}{l}\text { Average } \\
\text { respiration- } \\
\text { rate. }\end{array}$ \\
\hline 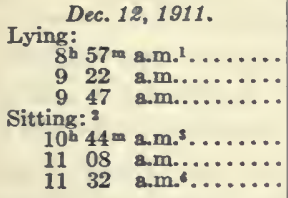 & $\begin{array}{cl}\min . & s e c . \\
14 & 33 \\
14 & 39 \\
14 & 42 \\
& \\
14 & 49 \\
14 & 44 \\
14 & 27\end{array}$ & $\begin{array}{l}\text { c.c. } \\
202 \\
197 \\
195 \\
\\
219 \\
214 \\
212\end{array}$ & $\begin{array}{l}c . c . \\
\ddot{233} \\
226 \\
243 \\
247 \\
240\end{array}$ & $\begin{array}{r}0.85 \\
.86 \\
.90 \\
.87 \\
.89\end{array}$ & $\begin{array}{l}68 \\
70 \\
72\end{array}$ & $\begin{array}{l}24 \\
21 \\
22\end{array}$ \\
\hline
\end{tabular}

1 The subject lay on the couch 57 minutes before the first period, because of change of gas-meters. The pulse-rate at $8^{\text {h }} 20$ ma.m. was 60 .

2 The subject sat on the ordinary seat with his feet on unsupported pedals, i. e., with the disk perfectly free.

8 The subject sat on the ergometer at $10^{\mathrm{b}} 12^{\mathrm{m}} \mathrm{a} . \mathrm{m}$. with feet on the rest. The pulse-rate at $10^{\mathrm{h}} 25^{\mathrm{m}} \mathrm{a} . \mathrm{m}$. was 64 . The subject placed his feet on the pedals at $10^{\mathrm{h}} 25^{\mathrm{m}} \mathrm{a} . \mathrm{m}$. He put his mouth to the mouthpiece at $10^{\mathrm{h}} 34^{\mathrm{m}} \mathrm{am}$. The pulse-rate at $10^{\mathrm{b}} 33^{\mathrm{m}} \mathrm{a} . \mathrm{m}$. was 63 ; at $10^{\mathrm{h}} 35^{\mathrm{m}} \mathrm{a} . \mathrm{m} ., 66 ;$ at $10^{\mathrm{b}} 38^{\mathrm{m}}$ a.m., 68 .

4 The subject always took a very long time to settle down into his so-called resting position, as he was determined to keep his legs absolutely still during the actual period.

TABLE 14.-Results with subject M.A.M. (without food). (Ergometer II.)

\begin{tabular}{|c|c|c|c|c|c|c|}
\hline Date and time. & Durstion. & $\begin{array}{l}\text { Carbon } \\
\text { dioxide } \\
\text { eliminsted }\end{array}$ & $\begin{array}{l}\text { Oxygen } \\
\text { absorbed } \\
\text { per minute. }\end{array}$ & $\begin{array}{l}\text { Respiratory } \\
\text { quotient. }\end{array}$ & $\begin{array}{c}\text { Average } \\
\text { pulse- } \\
\text { rate. }\end{array}$ & $\begin{array}{l}\text { Average } \\
\text { respiration- } \\
\text { rate. }\end{array}$ \\
\hline 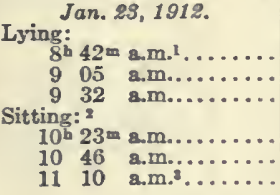 & $\begin{array}{cc}\min . & \text { sec. } \\
14 & 47 \\
15 & 32 \\
15 & 08 \\
& \\
14 & 16 \\
14 & 15 \\
14 & 17\end{array}$ & $\begin{array}{l}\text { c.c. } \\
211 \\
211 \\
209 \\
\\
254 \\
258 \\
303\end{array}$ & $\begin{array}{l}\text { c.c. } \\
252 \\
240 \\
247 \\
\\
327 \\
312 \\
333\end{array}$ & $\begin{array}{r}0.84 \\
.88 \\
.85 \\
.78 \\
.83 \\
.91\end{array}$ & $\begin{array}{l}67 \\
68 \\
67\end{array}$ & $\begin{array}{l}20 \\
20 \\
22\end{array}$ \\
\hline
\end{tabular}

1 The subject Iay down at $8 \mathrm{a} . \mathrm{m}$. The pulse-rate during the preliminary period was as follows: at $8^{\mathrm{h}} 18^{\mathrm{m}}$ a.m. 68 ; at $8^{\text {b }} 27^{\mathrm{m}}$ a.m., 66 ; st $8^{\mathrm{h}} 33^{\mathrm{m}}$ a.m., 68 .

2 The subject sat on the ordinary seat with his feet on unsupported pedals, i. e., with the disk perfectly free.

The aubject complained that the ergometer did not quite suit him. His hands became stiff, and he found it $\mathbf{a}$ great strain to sit absolutely still for 14 to 15 minutes. He did not like the "free-wheel" effect.

TABLE 15.-Results with subject M.A.M. (without food). (Ergometer II.)

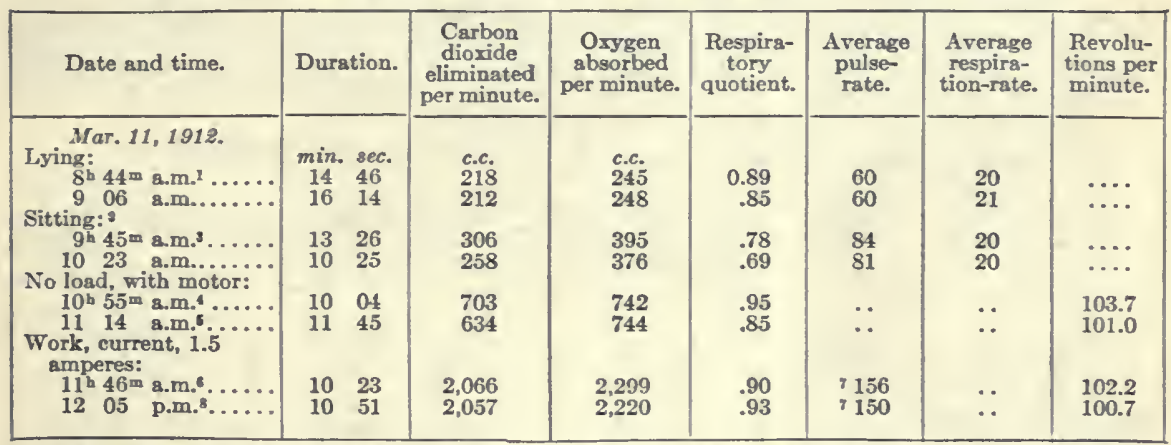

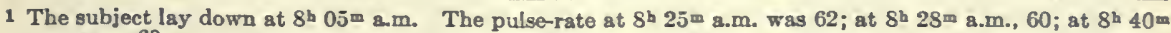

2 The subject sat on the ordinary seat with his feet on unsupported pedals, i. e., with the disk perfectly. free.

From $9^{\mathrm{b}} 27^{\mathrm{m}}$ a.m. to $9^{\mathrm{h}} 39^{\mathrm{m}}$ a.m., the subject sat with feet resting on the forks. He then lowered his feet to the pedals. He found that sitting still in this position was a constant strain.

4 The subject began riding at $10^{\mathrm{b}} 37 \mathrm{~m} \mathrm{a} . \mathrm{m}$., the machine being driven by a motor. The belt slipped at $10^{\mathrm{t}} 52 \mathrm{~m}$ a.m. The pulse-rate 15 seconds after the stopping of work due to the slipping of the belt was only 84 .

Between the two "no-load" periods the average speed was 72 (?) per minute. Soon after the start of the period (75 seconds) the belt slipped off. The machine was stopped completely, the belt was replaced, and the machine restarted.

6 Work was begun at $11^{\mathrm{b}} 32^{\mathrm{m}}$ 8.m. With the current at 1.5 amperes. Between $11^{\mathrm{h}} 32^{\mathrm{m}} \mathrm{am} . \mathrm{m}$. and $11^{\mathrm{b}} 46^{\mathrm{m}} \mathrm{am} . \mathrm{m}$ the average speed was 97 revolutions per minute.

7 Pulse-rate at the end of the period.

8 In the interval before this period, the subject rode at the average rate of 96 revolutions per minute. 


\section{NO-LOAD EXPERIMENTS.}

These experiments (see tables 16 to 22 inclusive) were made to determine the metabolism incidental to revolving the pedals and other extraneous activity in riding the ergometer and the overcoming of the slight friction of the apparatus. The grouping includes both the experiments in which the motor was used to revolve the pedals, and those in which the motor was not used.

In the motor experiments, the subject sat in the usual position for riding, but was supposed to exert no pressure upon the pedals, which were revolved by a small motor. Only ergometer II was used in this series of experiments.

In the experiments without motor, the subject revolved the pedals, but no current was passed through the magnetizing field. Both ergometer I and ergometer II were used for these experiments.

The subjects found these "no-load" experiments irksome, and had considerable difficulty in maintaining an even rate of revolution without involuntarily regulating the motion of the pedals by "back-pedaling" or "racing."

TABle 16.-Results with subject M. A. M. (without food). (Ergometer I.)

\begin{tabular}{|c|c|c|c|c|c|c|c|}
\hline Date and time. & Duration. & $\begin{array}{c}\text { Carbon } \\
\text { dioxide } \\
\text { eliminated } \\
\text { per minute. }\end{array}$ & $\begin{array}{c}\text { Oxygen } \\
\text { absorbed } \\
\text { per minute. }\end{array}$ & $\begin{array}{l}\text { Respira- } \\
\text { tory } \\
\text { quotient. }\end{array}$ & $\begin{array}{l}\text { Average } \\
\text { pulse- } \\
\text { rate. }\end{array}$ & $\begin{array}{c}\text { Average } \\
\text { respira- } \\
\text { tion-rate. }\end{array}$ & $\begin{array}{l}\text { Revolu- } \\
\text { tions per } \\
\text { minute }\end{array}$ \\
\hline 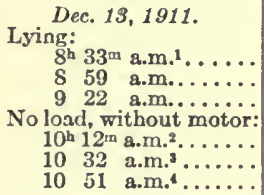 & $\begin{array}{cl}\min & \text { sec. } \\
14 & 34 \\
14 & 38 \\
14 & 51 \\
10 & 30 \\
11 & 03 \\
11 & 55\end{array}$ & $\begin{array}{l}\text { c.c. } \\
200 \\
196 \\
203 \\
\\
533 \\
703 \\
609\end{array}$ & $\begin{array}{l}\text { c.c. } \\
226 \\
222 \\
231 \\
717 \\
783 \\
734\end{array}$ & $\begin{array}{r}0.89 \\
.88 \\
.88 \\
.75 \\
.90 \\
.83\end{array}$ & $\begin{array}{l}64 \\
62 \\
62 \\
\\
85 \\
89 \\
92\end{array}$ & $\begin{array}{l}24 \\
25 \\
24 \\
23 \\
24 \\
28\end{array}$ & $\begin{array}{l}\cdots \\
\cdots \\
83 \\
87 \\
83\end{array}$ \\
\hline
\end{tabular}

1 The subject felt exhausted from the unseasonable heat. He lay down at $8^{\mathrm{b}} 05^{\mathrm{m}}$ a.m. The pulse-rate at $8^{\mathrm{h}} 05^{\mathrm{m}}$ a.m. Was 76 ; at $8^{\mathrm{h}} 10^{\mathrm{m}}$ a.m., 68; at $8^{\mathrm{h}} 15^{\mathrm{m}}$ a.m., 66; at $8^{\mathrm{b}} 22^{\mathrm{m}}$ a.m., $8^{\mathrm{h}} 27^{\mathrm{m}}$ a.m., and $8^{\mathrm{h}} 33^{\mathrm{m}}$ a.m.,

2 The subject began riding "no load" at $9^{\mathrm{h}} 44^{\mathrm{m}}$ a.m. Put mouth to the mouthpiece at $9^{\mathrm{b}} 59^{\mathrm{m}}$ a.m. The pulse-rate between $9^{\mathrm{h}} 46^{\mathrm{m}} \mathrm{a} . \mathrm{m}$. and $10^{\mathrm{h}} 09^{\mathrm{m}} \mathrm{a} . \mathrm{m}$. ranged from 82 to 86 , the average being 84 . The average speed during the preliminary period was about 76 revolutions per minute. The subject was driving the machine without resistance.

3 In the interval before this period the average speed was about 78 per minute. During the period the subject looked cool and not at all distressed. He lost the pedals once or twice. He began to look warm

and perspiring toward the end of the period.
4 In the in terval before this period the average speed was 82 per minute. The subject complained of saddle soreness due to the position. He felt the lack of toe-clips. Respiration was more rapid. Perspiration appeared in beads on his upper lip. There was no flushing, however.

TABLE 17.-Results with subject M. A. M. (without food). (Ergometer I.)

\begin{tabular}{|c|c|c|c|c|c|c|c|c|}
\hline Date and time. & Duration. & $\begin{array}{l}\text { Carbon } \\
\text { dioxide } \\
\text { eliminated } \\
\text { per minute. }\end{array}$ & $\begin{array}{c}\text { Oxygen } \\
\text { absorbed } \\
\text { per } \\
\text { minute. }\end{array}$ & $\begin{array}{l}\text { Respira- } \\
\text { tory } \\
\text { quotient. }\end{array}$ & $\begin{array}{l}\text { Aver- } \\
\text { age } \\
\text { pulse- } \\
\text { rate. }\end{array}$ & $\begin{array}{l}\text { Average } \\
\text { respira- } \\
\text { tion-rate. }\end{array}$ & $\begin{array}{l}\text { Cur- } \\
\text { rent. }\end{array}$ & $\begin{array}{l}\text { Revolu- } \\
\text { tions per } \\
\text { minute. }\end{array}$ \\
\hline 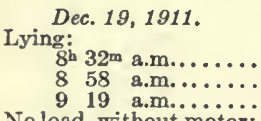 & $\begin{array}{cc}\min & \text { sec. } \\
15 & 36 \\
14 & 29 \\
15 & 03\end{array}$ & $\begin{array}{l}\text { c.c. } \\
204 \\
200 \\
196\end{array}$ & $\begin{array}{l}\text { c.c. } \\
235 \\
250 \\
229\end{array}$ & $\begin{array}{r}0.87 \\
.80 \\
.86\end{array}$ & $\begin{array}{l}63 \\
64 \\
63\end{array}$ & $\begin{array}{l}20 \\
20 \\
20\end{array}$ & $\begin{array}{l}a m p . \\
\because \\
\because \\
\cdots\end{array}$ & $\because$ \\
\hline 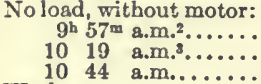 & $\begin{array}{ll}13 & 22 \\
13 & 20 \\
13 & 25\end{array}$ & $\begin{array}{l}420 \\
385 \\
388\end{array}$ & $\begin{array}{l}473 \\
444 \\
443\end{array}$ & $\begin{array}{l}.89 \\
.87 \\
.88\end{array}$ & $\begin{array}{l}86 \\
86 \\
86\end{array}$ & $\begin{array}{l}20 \\
20 \\
20\end{array}$ & $\because$ & $\begin{array}{l}60 \\
60 \\
60\end{array}$ \\
\hline $\begin{array}{l}\text { Work: } \\
\quad 11^{\mathrm{h}} 12^{\mathrm{m}} \text { a.m.4. } \\
\quad 11 \text {. } 34 \text { a.m........ }\end{array}$ & $\begin{array}{ll}10 & 24 \\
10 & 27\end{array}$ & $\begin{array}{l}1,017 \\
1,077\end{array}$ & $\begin{array}{l}1,206 \\
1,246\end{array}$ & $\begin{array}{l}.85 \\
.86\end{array}$ & $\begin{array}{l}118 \\
126\end{array}$ & $\begin{array}{l}23 \\
23\end{array}$ & $\begin{array}{l}0.9 \\
0.9\end{array}$ & $\begin{array}{l}60 \\
60\end{array}$ \\
\hline
\end{tabular}

1 Approximate.

2 The subject sat on the ergometer at $9^{\mathrm{b}} 40^{\mathrm{m}}$ a.m. and began riding. The metronome was used, set at 60 per minute. The counter was not used. The pulse-rate averaged about 84 during the preliminary riding. 3 The subject rode very easily. He said the lack of resistance was rather disagreeable.

4 The metronome was used, set at 60 . Current was on at $10^{\mathrm{b}} 57^{\mathrm{m}} \mathrm{a}$ a.m. The pulse-rate during the preliminary work was 100,104 , and 106 . The mouth was put to the mouthpiece at $11^{\mathrm{b}} 07^{\mathrm{m}} \mathrm{a} . \mathrm{m}$. The work was comparatively easy. No marked perspiration or flushing. The subject, however, found it very hard after coasting. 
TABle 1S.-Results with subject M. A. M. (without food). (Ergometer II.)

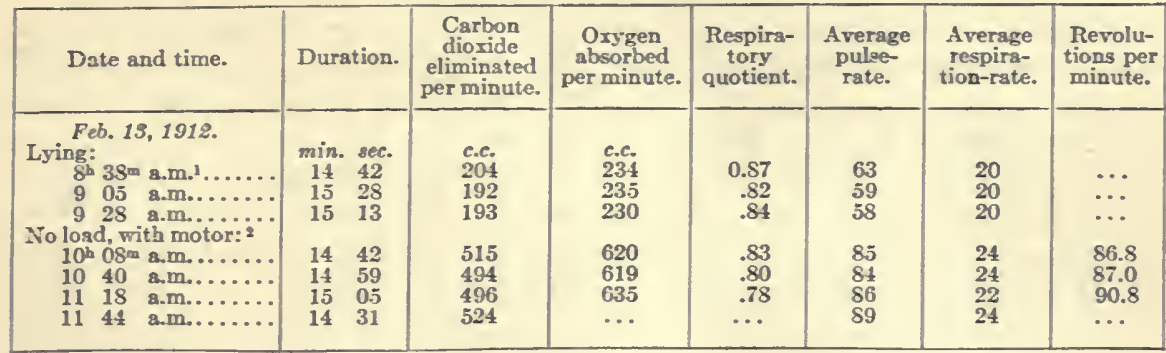

1 The pulse-rate at $8^{\mathrm{s}} 35^{\mathrm{m}} \mathrm{am}$. was 64 .

2 The machine was driven by motor. There was considerable strain on the subject's arms, and he complained at the end of the experiment that his arms were practically useless, particularly his wrists. He rode the motor-driven machine between periods at practically the same speed as during the periods.

TABLe 19.-Results with subject M. A. M. (without food). (Ergometer II.)

\begin{tabular}{|c|c|c|c|c|c|c|c|}
\hline Date and time. & Durstion. & $\begin{array}{c}\text { Carbon } \\
\text { dioxide } \\
\text { eliminsted } \\
\text { per minute. }\end{array}$ & $\begin{array}{l}\text { Oxygen } \\
\text { absorbed } \\
\text { per minute. }\end{array}$ & $\begin{array}{l}\text { Respira- } \\
\text { tory } \\
\text { quotient. }\end{array}$ & $\begin{array}{l}\text { Average } \\
\text { pulse- } \\
\text { rate. }\end{array}$ & $\begin{array}{l}\text { Average } \\
\text { respira- } \\
\text { tion-rate. }\end{array}$ & $\begin{array}{l}\text { Revolu- } \\
\text { tions per } \\
\text { minute. }\end{array}$ \\
\hline 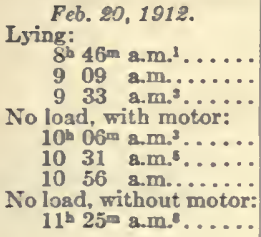 & $\begin{array}{ll}\min . & \text { sec. } \\
14 & 47 \\
14 & 57 \\
16 & 06\end{array}$ & $\begin{array}{l}\text { c.c. } \\
189 \\
209 \\
203\end{array}$ & $\begin{array}{l}c . c . \\
243 \\
250 \\
250\end{array}$ & $\begin{array}{l}0.78 \\
.84 \\
.81\end{array}$ & $\begin{array}{l}186 \\
188 \\
: 88\end{array}$ & $\begin{array}{l}18 \\
20 \\
20\end{array}$ & $\begin{array}{l}\text { S5.8 } \\
91.5 \\
94.5\end{array}$ \\
\hline
\end{tabular}

1 The subject lay down at 8 a.m. The pulse-rate at $\delta^{3} 2 S^{m}$ a.m. was 62 ; at $8^{\text {h }} 35^{\mathrm{m}}$ a.m., and $\delta^{b} 40^{m}$ a.m., 60 .

2 The subject complained that he was very cold. There was question as to whether or not he had a chill, though the pulse did not indicate anything very serious.

3 The riding was like that of Feb. 13, the machine being driven by means of a motor. There was no evidence that the subject used his muscles to rotate the disk. The motor was started at 9.59 a.m. and the subject rode preliminary to the first period. Between the first and second "no-load" periods he rode at the average rate of about 90 revolutions per minute; between the second and third periods at the average rate of about 92 per minute; between the thind and fourth periods at the average rate of about 97 per minute.

4 One record at the wrist.

5 The chain was slack during both the second and the third "no-load" periods.

6 The machine was driven by the subject, not by the motor.

7 Average of records taken at the wrist.

TABLE 20.-Results with subject M. A. M. (without food). (Ergometer II.)

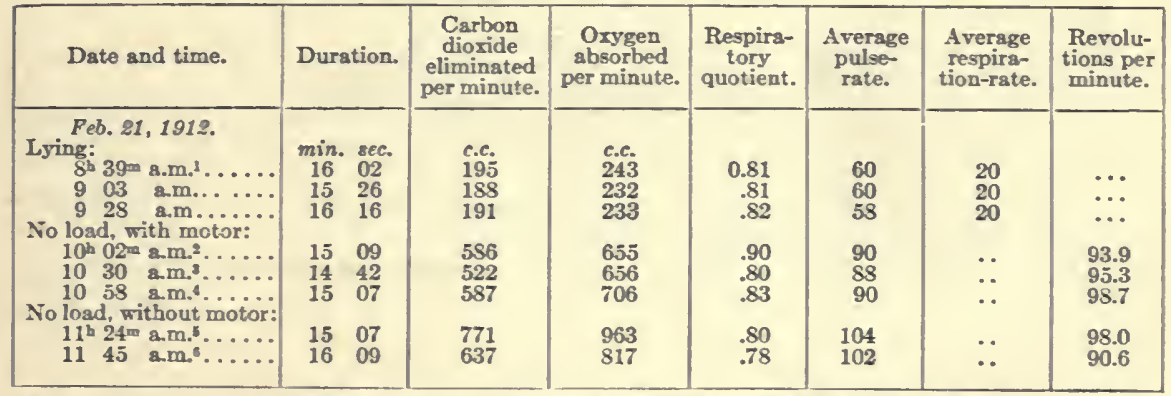

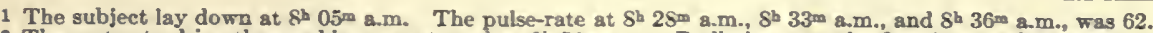

2 The motor to drive the machine was started at $9^{\mathrm{b}} 54^{\mathrm{m}} \mathrm{a.m}$. Preliminary to the first "no-load" period, the subject rode at the average rate of 04 revolutions per minute. The chain was slack during the period.

2 The chain was slack. The subject found this kind of experiment a tremendous strain on his hands and arms. The average speed in the interval before this period was 90 per minute.

4 The chain was slack. The average speed in the interval before the period was 93 revolutions per minute.

5 At $11^{\mathrm{b}} 14^{\mathrm{m}} \mathrm{a} \cdot \mathrm{m}$. the subject began riding without the motor drive. The average speed from $11^{\mathrm{b}} 1 \mathrm{I}^{\mathrm{m}} \mathrm{am}$. to the beginning of the period at $11^{\mathrm{b}} 24_{\mathrm{m}} \mathrm{a}$.m. Was 99 revolutions per minute.

The average speed in the interval before this period was 93 revolutions per minute. 
TABLE 21.-Results with subject $M . A . M$. (without food). (Ergometer II.)

\begin{tabular}{|c|c|c|c|c|c|c|c|c|}
\hline Date and time. & Duration. & $\begin{array}{c}\text { Carbon } \\
\text { dioxide } \\
\text { eliminated } \\
\text { per minute. }\end{array}$ & $\begin{array}{c}\text { Oxygen } \\
\text { absorbed } \\
\text { per } \\
\text { minute. }\end{array}$ & $\begin{array}{l}\text { Respira- } \\
\text { tory } \\
\text { quotient. }\end{array}$ & $\begin{array}{c}\text { Aver- } \\
\text { age } \\
\text { pulse- } \\
\text { rate. }\end{array}$ & $\begin{array}{l}\text { Average } \\
\text { respira- } \\
\text { tion-rate. }\end{array}$ & $\begin{array}{l}\text { Cur- } \\
\text { rent. }\end{array}$ & $\begin{array}{l}\text { Revolu- } \\
\text { tions per } \\
\text { minute. }\end{array}$ \\
\hline 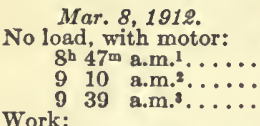 & $\begin{array}{cl}\min . & \text { sec. } \\
14 & 35 \\
14 & 54 \\
15 & 05\end{array}$ & $\begin{array}{l}\text { c.c. } \\
642 \\
618 \\
573\end{array}$ & $\begin{array}{l}\text { c.c. } \\
789 \\
719 \\
724\end{array}$ & $\begin{array}{r}0.82 \\
.86 \\
.79\end{array}$ & $\begin{array}{l}96 \\
95 \\
95\end{array}$ & $\begin{array}{l}18 \\
20 \\
18\end{array}$ & $\begin{array}{c}\text { amps. } \\
\ldots \\
\cdots\end{array}$ & $\begin{array}{l}101.8 \\
101.7 \\
100.6\end{array}$ \\
\hline $\begin{array}{lll}10^{\mathrm{h}} & 30^{\mathrm{m}} & \text { a.m.t. } \\
10 & 54 & \text { a.m. } \\
11 & 19 & \text { a.m. } \\
1 & \ldots\end{array}$ & $\begin{array}{ll}10 & 29 \\
10 & 46 \\
10 & 39\end{array}$ & $\begin{array}{l}2,065 \\
2,051 \\
2,218\end{array}$ & $\begin{array}{l}2,339 \\
2,282 \\
2,365\end{array}$ & $\begin{array}{l}.88 \\
.90 \\
.94\end{array}$ & $\begin{array}{l}155 \\
153 \\
159\end{array}$ & $\begin{array}{l}32 \\
34 \\
32\end{array}$ & $\begin{array}{l}1.5 \\
1.5 \\
1.5\end{array}$ & $\begin{array}{r}99.2 \\
99.1 \\
105.5\end{array}$ \\
\hline
\end{tabular}

1 The machine was motor-driven. The subject began riding at $8^{\mathrm{h}} 18^{\mathrm{m}} \mathrm{a} \cdot \mathrm{m}$., and to the beginning of the period rode at the average rate of 99 revolutions per minute. The average pulse-rate during this preliminary

2 In the interval before this period the average speed was 95 per minute. The subject lifted his body off the seat 3 times. (See note 6. .)

3 In the interval before this period the average speed was 106 per minute. During the period the pin holding the handle bars was broken and the handle bars became loose. This seemed to cause the subject considerable trouble and annoyance.

1 At 10 a.m. work was begun with the current at 1.5 amperes. Between 10 a.m. and $10^{\circ} 30^{\mathrm{m}} \mathrm{a} . \mathrm{m}$. the average rate was 93 revolutions per minute. With the change the subject found the work extremely difficult. He could hardly believe he was working against the usual amount of resistance.

5 In the interval before this period the average speed was 78 per minute.

B In the interval before this period the average speed was 89 per minute. The subject said the ergometer was not at all comfortable; the seat was too high. Another subject using the apparatus had failed to return the seat to the original height found comfortable for M. A. M.

TABLE 22.-Results with subject M.A. M. (without food). (Ergometer II.)

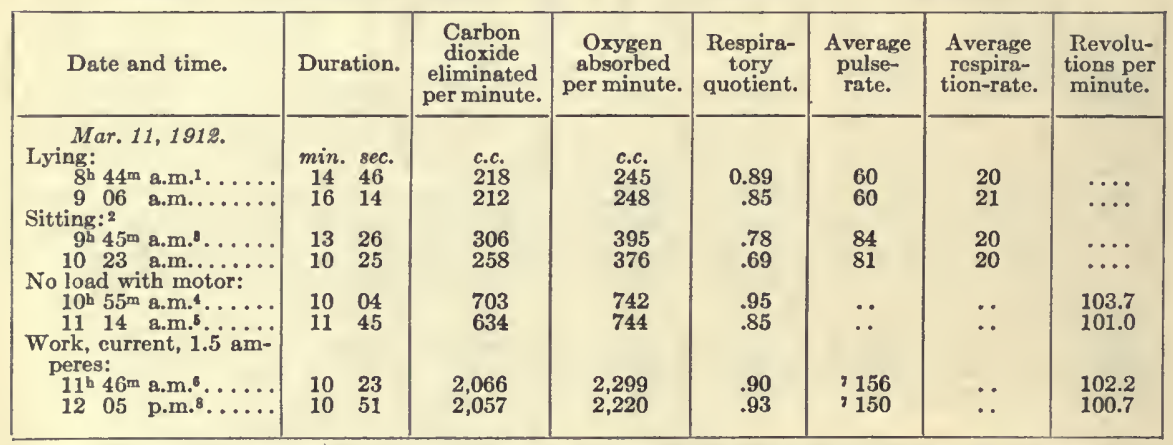
1 The subject lay down at $8^{\mathrm{h}} 05^{\mathrm{m}}$ a.m. The pulse-rate at $8^{\mathrm{h}} 25^{\mathrm{m}}$ a.m. was 62 ; at $8^{\mathrm{h}} 28^{\mathrm{m}}$ a.m., 60 ; at $8^{\mathrm{b}} 40^{\mathrm{m}}$ a.m.,

2 The subject sat on the ordinary seat with his feet on unsupported pedals, $i, e$, with the disk perfectly free. 3 From $9^{\mathrm{b}} 27^{\mathrm{m}} \mathrm{a}$.m. to $9^{\mathrm{b}} 39^{\mathrm{m}}$ a.m. the subject sat with feet resting on the forks. He then lowered his feet to the pedals. He found that sitting still in this position was a constant strain.

4 The subject began riding at $10^{\mathrm{h}} 37^{\mathrm{m}}$ a.m., the machine being driven by a motor. The belt slipped at $10^{\mathrm{b}} 52^{\mathrm{m}}$ a.m. The pulse-rate 15 seconds after the stopping of work due to the slipping of the belt was only 84 .

5 Between the two "no-load" periods the average speed was 72 (?) per minute. Soon after the start of the period ( 75 seconds) the belt slipped off. The machine was stopped completely, the belt was replaced, and the machine restarted.

6 Work was begun at $11^{\mathrm{b}} 32^{\mathrm{m}}$ a.m. with the current at 1.5 amperes. Between $11^{\mathrm{h}} 32^{\mathrm{m}} \mathrm{a}$.m. and $11^{\mathrm{b}} 46^{\mathrm{m}}$ a.m. the average speed was 97 revolutions per minute.

8 Pulse-rate at the end of the period. 


\section{WORK EXPERIMENTS.}

These experiments were made under varying conditions of work, $i . e$, light, moderate, severe, and very severe, one experiment (that of March 15, 1912) being continued almost to the point of exhaustion. The currents through the magnetizing field for these experiments were respectively 0.9 ampere for ergometer $I$ and $0.5,0.95,1.1,1.25$, and 1.5 amperes for ergometer II. The periods in many instances were but 10 minutes in length, but often covered 15 minutes; they were usually two or three in number. The experiments were arranged in series so that a comparison could be made of the working metabolism under different conditions. In some cases the light work preceded the severe work, which was again succeeded by light work. In others, the initial experiments were with severe work. The influence of diet upon the metabolism during muscular work was also studied in a few experiments. (See pages 31 and 88.) In most cases, the resting metabolism was determined for each experimental day before the work experiments began. The statistical data of the experiments are given in tables 23 to 90 inclusive.

TABLE 23.-Resulls with subject J. E. F.

\begin{tabular}{|c|c|c|c|c|c|c|c|c|}
\hline Date and time. & Duration. & $\begin{array}{c}\text { Carbon } \\
\text { dioxide } \\
\text { eliminated } \\
\text { per minute. }\end{array}$ & $\begin{array}{c}\text { Oxygen } \\
\text { absorbed } \\
\text { per } \\
\text { minute. }\end{array}$ & $\begin{array}{l}\text { Respira- } \\
\text { tory } \\
\text { quotient. }\end{array}$ & $\begin{array}{l}\text { Aver- } \\
\text { age } \\
\text { pulse- } \\
\text { rate. }\end{array}$ & $\begin{array}{l}\text { Average } \\
\text { respira- } \\
\text { tion-rate. }\end{array}$ & $\begin{array}{l}\text { Cur- } \\
\text { rent. }\end{array}$ & $\begin{array}{l}\text { Revolu- } \\
\text { tions per } \\
\text { minute. }\end{array}$ \\
\hline $\begin{array}{l}\text { Nov. } 20,1911.1 \\
\text { Lying, without food: } \\
11^{\text {b }} 12^{2} \text { a.m............. }\end{array}$ & $\min _{15} \sec$ & $\begin{array}{l}c . c . \\
225\end{array}$ & $\begin{array}{l}\text { c.c. } \\
280\end{array}$ & 0.81 & $\cdots$ & $\cdots$ & $a m p$. & .. \\
\hline $\begin{array}{l}\text { Work, with food: } \\
1^{\text {th }} 29^{\mathrm{m}} \text { p.m. } \\
25 . \ldots \ldots\end{array}$ & $\begin{array}{ll}12 & 02 \\
10 & 17\end{array}$ & $\begin{array}{l}1,225 \\
1,345\end{array}$ & $\begin{array}{l}1,372 \\
1,320\end{array}$ & $\begin{array}{r}.89 \\
1.02\end{array}$ & 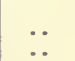 & $\because$ & $\begin{array}{l}0.9 \\
0.9\end{array}$ & $\begin{array}{l}156 \\
58\end{array}$ \\
\hline 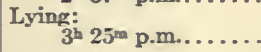 & & 307 & 284 & 1.08 & $\ldots$ & .. & .. & .. \\
\hline
\end{tabular}

1 The experiment on this day was a trial experiment with this subject while working on the ergometer. It should be noted that only the period lying before work was without food.

2 The subject had eaten a comparatively light meal since the conclusion of the first lying period.

It is not recorded how much work was done before or in the interval after this period. Sweat appeared on the brow at $1^{\text {ln }} 34^{\mathrm{m}}$ p.m.

- Approsimate. Only one record of speed was taken in each period.

TABLE 24.-Results with subject J. E. F. (without food).

\begin{tabular}{|c|c|c|c|c|c|c|c|c|}
\hline Date and time. & Duration. & $\begin{array}{c}\text { Carbon } \\
\text { dioxide } \\
\text { eliminated } \\
\text { per minute. }\end{array}$ & $\begin{array}{l}\text { Oxygen } \\
\text { absorbed } \\
\text { per } \\
\text { minute. }\end{array}$ & $\begin{array}{l}\text { Respira- } \\
\text { tory } \\
\text { quotient. }\end{array}$ & $\begin{array}{l}\text { Aver- } \\
\text { age } \\
\text { pulse- } \\
\text { rate. }\end{array}$ & $\begin{array}{l}\text { Average } \\
\text { respira- } \\
\text { tion-rate. }\end{array}$ & $\begin{array}{l}\text { Cur- } \\
\text { rent. }\end{array}$ & $\begin{array}{l}\text { Revolu- } \\
\text { tions per } \\
\text { minute. }\end{array}$ \\
\hline 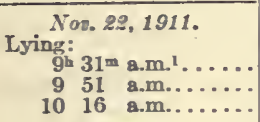 & $\begin{array}{ll}\min . & \text { sec. } \\
10 & 17 \\
13 & 43 \\
13 & 44 \\
\end{array}$ & $\begin{array}{l}\text { c.c. } \\
210 \\
215 \\
213\end{array}$ & $\begin{array}{l}\text { c.c. } \\
236 \\
237 \\
238 \\
\end{array}$ & $\begin{array}{r}0.89 \\
.91 \\
.90 \\
\end{array}$ & $\begin{array}{l}59 \\
59 \\
59 \\
\end{array}$ & $\begin{array}{r}9 \\
10 \\
11 \\
\end{array}$ & $\begin{array}{c}\text { amp. } \\
\because \\
\cdots \\
\end{array}$ & $\begin{array}{l}\cdots \\
\therefore\end{array}$ \\
\hline Average......... & $\ldots \ldots \ldots$ & 213 & 237 & 0.90 & 59 & 10 & * & $\cdots$ \\
\hline $\begin{array}{l}\text { Work: }{ }^{2} \\
10^{\mathrm{h}} 40^{\mathrm{m}} \text { a.m........ } \\
\text { Lying: } \\
11^{\mathrm{k}} 25^{-}=\text {a.m........ }\end{array}$ & $\begin{array}{ll}22 & 00 \\
14 & 10\end{array}$ & $\begin{array}{l}\cdots \\
205\end{array}$ & $\begin{array}{l}\cdots \\
255\end{array}$ & $\begin{array}{l}\cdots \\
0.80\end{array}$ & $\begin{array}{l}\cdots \\
64\end{array}$ & $\begin{array}{l}\cdots \\
\cdots\end{array}$ & $\begin{array}{c}0.9 \\
\ldots\end{array}$ & $\begin{array}{c}368 \\
\ldots\end{array}$ \\
\hline
\end{tabular}

1 The subject had spent the night in the bed calorimeter after a light supper. Before commencing this experiment he said he felt rather hungry and was troubled somewhat with cramps. He lay down at

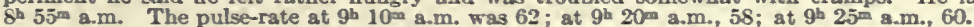

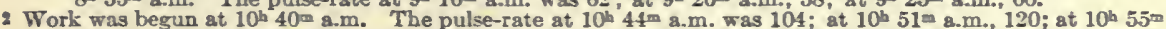
a.m., 122; at $10^{\text {h }} 59^{\mathrm{m}} \mathrm{a} . \mathrm{m} ., 126$. Subject began breathing in the circuit of the respiration apparatus at $11^{\mathrm{h}} 0 \mathrm{~m}^{\mathrm{m}} 15 \mathrm{~s} \mathrm{a} . \mathrm{m}$, and the period was started but within 2 minutes the pulse-rate rose suddenly to 184. The subject collapsed, and could not retain the mouthpiece in his mouth. The pulse-rste at $11^{\mathrm{s}} 08^{\mathrm{m}}$ a.m. was 72 ; at $11^{\mathrm{b}} 20^{\mathrm{m}}$ a.m. 72 .

3 Approximate. Only one record of the speed was taken, and that at $10^{\mathrm{b}} 45^{\mathrm{m}} \mathrm{a} . \mathrm{m}$ 
TABLE 25.-Results with subject J. E. F. (with food).1

\begin{tabular}{|c|c|c|c|c|c|c|c|c|}
\hline Date and time. & Duration. & $\begin{array}{l}\text { Carbon } \\
\text { dioxide } \\
\text { eliminated } \\
\text { per minute. }\end{array}$ & $\begin{array}{c}\text { Oxygen } \\
\text { absorbed } \\
\text { per } \\
\text { minute. }\end{array}$ & $\begin{array}{l}\text { Respira- } \\
\text { tory } \\
\text { quotient. }\end{array}$ & $\begin{array}{l}\text { Aver- } \\
\text { age } \\
\text { pulse- } \\
\text { rate. }\end{array}$ & $\begin{array}{c}\text { Average } \\
\text { respira- } \\
\text { tion-rate. }\end{array}$ & $\begin{array}{l}\text { Cur- } \\
\text { rent. }\end{array}$ & $\begin{array}{l}\text { Revolu- } \\
\text { tions per } \\
\text { minute. }\end{array}$ \\
\hline 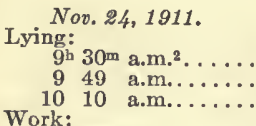 & $\begin{array}{cl}\min . & \text { sec. } \\
10 & 19 \\
13 & 10 \\
12 & 37\end{array}$ & $\begin{array}{l}\text { c.c. } \\
303 \\
279 \\
275\end{array}$ & $\begin{array}{l}\text { c.c. } \\
304 \\
288 \\
276\end{array}$ & $\begin{array}{r}1.00 \\
.97 \\
.99\end{array}$ & $\begin{array}{l}65 \\
65 \\
64\end{array}$ & $\begin{array}{l}12 \\
11 \\
12\end{array}$ & $\begin{array}{l}a m p . \\
\because \\
\because \\
\therefore\end{array}$ & $\begin{array}{l}\cdots \\
\cdots\end{array}$ \\
\hline $\begin{array}{l}10^{\mathrm{h}} 40^{\mathrm{m}} \text { a.m.3 } \\
11 \text {. } \\
\text { Lying }\end{array}$ & $\begin{array}{rr}10 & 33 \\
4 & 00\end{array}$ & $\begin{array}{r}1,303 \\
\ldots\end{array}$ & $\begin{array}{c}1,341 \\
\cdots\end{array}$ & $\begin{array}{l}.97 \\
\cdots\end{array}$ & $\begin{array}{c}137 \\
\cdots\end{array}$ & $\begin{array}{l}21 \\
\cdots\end{array}$ & $\begin{array}{l}0.9 \\
0.9\end{array}$ & $\begin{array}{l}57 \\
58\end{array}$ \\
\hline $\begin{array}{lll}11^{\mathrm{b}} & 18^{\mathrm{m}} & \text { a.m.5. } \\
11 & 50 & \text { a.m. } \ldots \cdots \\
12 & 21 & \text { p.m........ }\end{array}$ & $\begin{array}{ll}14 & 06 \\
13 & 05 \\
13 & 06\end{array}$ & $\begin{array}{l}266 \\
239 \\
233\end{array}$ & $\begin{array}{l}270 \\
246 \\
248\end{array}$ & $\begin{array}{l}0.98 \\
.98 \\
.94\end{array}$ & $\begin{array}{l}74 \\
65 \\
63\end{array}$ & $\begin{array}{l}12 \\
12 \\
10\end{array}$ & $\begin{array}{l}\cdots \\
\cdots\end{array}$ & $\because$ \\
\hline
\end{tabular}

1 The subject had eaten a light breakfast at $6^{\mathrm{h}} 50^{\mathrm{m}}$ a.m., consisting of 2 scrambled eggs, about $125 \mathrm{grams}$ of bread, about 200 c.c. of milk, and an apple. At $8^{\text {h }} 30^{\mathrm{m}}$ a.m. he took 50 grams of cane sugar in water.

2 The subject lay down at $9^{\mathrm{h}} 05^{\mathrm{m}} \mathrm{a} . \mathrm{m}$. The pulse-rate at $9^{\mathrm{b}} 18^{\mathrm{m}} \mathrm{a.m}$. was $64 ;$ at $9^{\mathrm{h}} 22^{\mathrm{m}} \mathrm{a.m} .6^{2} ; \mathrm{at}^{\mathrm{h}} 27^{\mathrm{m}}$ a.m. 64. Respiration at $9^{\mathrm{h}} 19^{\mathrm{m}}$ a.m. was 22 .

3 Work was begun at $10^{\mathrm{h}} 30^{\mathrm{m}}$ a.m. Between $10^{\mathrm{b}} 30^{\mathrm{m}}$ a.m. and $10^{\mathrm{b}} 40^{\mathrm{m}}$ a.m. the average speed was about 59 revolutions per minute. The pulse-rate at $10^{\mathrm{b}} 33^{\mathrm{m}} \mathrm{a} . \mathrm{m}$. was 118 ; at $10^{\mathrm{h}} 35^{\mathrm{m}}$ a.m., $124 ;$ at $10^{\mathrm{h}} 37^{\mathrm{m}}$ a.m.,

4 In the interval between periods the average speed was about 64 per minute. Second period was stopped after 4 minutes of work because of the condition of the subject. There were all the signs of impending collapse. Pulse-rate suddenly became rapid.

5 The subject was transferred from the ergometer to the couch as rapidly as possible, and lay there 11 minutes, i. e., 14 minutes in all from the end of work to the beginning of the first lying period. He was now in good condition. The pulse-rate at $11^{\mathrm{b}} 15^{\mathrm{m}} \mathrm{a} . \mathrm{m}$. was $76 ;$ at $11^{\mathrm{b}} 17^{\mathrm{m}} 30^{\mathrm{s}}$ a.m. it was 72 .

TABLE 26.-Results with subject J. E. F. (without food).

\begin{tabular}{|c|c|c|c|c|c|c|c|c|}
\hline Date and time. & Duration. & $\begin{array}{c}\text { Carbon } \\
\text { dioxide } \\
\text { eliminated } \\
\text { per minute. }\end{array}$ & $\begin{array}{c}\text { Oxygen } \\
\text { absorbed } \\
\text { per } \\
\text { minute. }\end{array}$ & $\begin{array}{l}\text { Respira- } \\
\text { tory- } \\
\text { quotient. }\end{array}$ & $\begin{array}{c}\text { Aver- } \\
\text { age } \\
\text { pulse- } \\
\text { rate. }\end{array}$ & $\begin{array}{l}\text { Average } \\
\text { respirat } \\
\text { tion-rate. }\end{array}$ & $\begin{array}{l}\text { Cur- } \\
\text { rent. }\end{array}$ & $\begin{array}{l}\text { Revolu- } \\
\text { tions per } \\
\text { minute. }\end{array}$ \\
\hline $\begin{array}{l}\text { Mar. } 2,1912 . \\
\text { Severe work: } \\
8^{\mathrm{h}} 54^{\mathrm{m}} \text { a.m.......... } \\
9 \text { 28 a.m. . . } \\
\text { Light work: }\end{array}$ & $\begin{array}{cl}\min . & \text { sec. } \\
11 & 25 \\
10 & 53 \\
& \end{array}$ & $\begin{array}{l}c . c . \\
1,489 \\
1,601\end{array}$ & $\begin{array}{l}\text { c.c. } \\
1,648 \\
1,801\end{array}$ & $\begin{array}{r}0.90 \\
.89\end{array}$ & $\begin{array}{l}140 \\
146\end{array}$ & $\ddot{20}$ & $\begin{array}{c}a m p . \\
1.5 \\
1.5\end{array}$ & $\begin{array}{r}272.0 \\
79.3\end{array}$ \\
\hline $\begin{array}{r}9^{\mathrm{h}} 57^{\mathrm{m}} \text { a.m. } \\
10 \quad 22 \text { a.m.5.... }\end{array}$ & $\begin{array}{ll}12 & 55 \\
12 & 42\end{array}$ & $\begin{array}{l}1,004 \\
1,013\end{array}$ & $\begin{array}{l}1,045 \\
1,044\end{array}$ & $\begin{array}{l}.96 \\
.97\end{array}$ & $\begin{array}{l}124 \\
120\end{array}$ & $\begin{array}{l}20 \\
20\end{array}$ & $\begin{array}{l}0.5 \\
0.5\end{array}$ & $\begin{array}{l}87.1 \\
87.6\end{array}$ \\
\hline
\end{tabular}

1 Work was begun at $8^{\mathrm{h}} 34^{\mathrm{tn}} \mathrm{a} . \mathrm{m}$. Owing to a fault in the counter, it is uncertain how rapidly the riding was done up to the beginning of the period. The probable speed was 54 per minute.

2 Approximate.

3 In the interval before this period the average speed was probably about 54 per minute for the time between $9 \mathrm{~b} 17^{\mathrm{m}} \mathrm{a} . \mathrm{m}$. and $9 \mathrm{~h} 28^{\mathrm{ma}} \mathrm{a} . \mathrm{m}$

4 The current was lowered from 1.5 amperes to 0.5 ampere at $9^{\mathrm{b}} 40^{\mathrm{m}}$ a.m. Between $9^{\mathrm{b}} 40^{\mathrm{m}}$ a.m. and $9^{\mathrm{h}} 57^{\mathrm{m}}$ a.m. the average speed was 76 per minute. The subject was troubled by soreness in his knees, and said it was much easier for him to ride fast than slowly, because his knees pained him less.

5. In the interval before this period the average speed was 78 per minute.

TABLE 27.-Results with subject J. E. F. (without food).

\begin{tabular}{|c|c|c|c|c|c|c|c|c|}
\hline Date and time. & Duration. & $\begin{array}{l}\text { Carbon } \\
\text { dioxide } \\
\text { eliminated } \\
\text { per minute. }\end{array}$ & $\begin{array}{c}\text { Oxygen } \\
\text { absorbed } \\
\text { per } \\
\text { minute. }\end{array}$ & $\begin{array}{c}\text { Respira- } \\
\text { tory } \\
\text { quotient. }\end{array}$ & $\begin{array}{l}\text { Aver- } \\
\text { age } \\
\text { pulse- } \\
\text { rate. }\end{array}$ & $\begin{array}{c}\text { Average } \\
\text { respira- } \\
\text { tion-rate. }\end{array}$ & $\begin{array}{l}\text { Cur- } \\
\text { rent. }\end{array}$ & $\begin{array}{l}\text { Revolu- } \\
\text { tions per } \\
\text { minute. }\end{array}$ \\
\hline $\begin{array}{l}\text { Mar. 16, } 1912 . \\
\text { Light work: } \\
9^{\mathrm{h}} 00^{\mathrm{m}} \text { a.m.1 } \ldots \ldots \\
9 \text { a.m.2. } 24 \text { a.m. } \\
\text { Severe work: }\end{array}$ & $\begin{array}{cl}\min . & \text { sec. } \\
12 & 45 \\
12 & 21\end{array}$ & $\begin{array}{l}\text { c.c. } \\
835 \\
784\end{array}$ & $\begin{array}{l}c . c . \\
902 \\
850\end{array}$ & $\begin{array}{r}0.93 \\
.92\end{array}$ & $\begin{array}{l}94 \\
94\end{array}$ & $\begin{array}{l}16 \\
17\end{array}$ & $\begin{array}{c}a m p . \\
0.5 \\
0.5\end{array}$ & $\begin{array}{l}76.4 \\
73.2\end{array}$ \\
\hline $\begin{array}{l}10^{\mathrm{h}} 06^{\mathrm{m}} \text { a.m. } \\
10 \quad 26 \text { a.m. }{ }^{\mathrm{s}} \ldots \ldots \ldots\end{array}$ & $\begin{array}{ll}10 & 28 \\
10 & 19\end{array}$ & $\begin{array}{l}1,526 \\
1,556\end{array}$ & $\begin{array}{l}1,719 \\
1,824\end{array}$ & $\begin{array}{l}.89 \\
.85\end{array}$ & $\begin{array}{r}133 \\
5140\end{array}$ & $\begin{array}{l}24 \\
26\end{array}$ & $\begin{array}{l}1.5 \\
1.5\end{array}$ & $\begin{array}{l}70.7 \\
71.3\end{array}$ \\
\hline
\end{tabular}

1 Work was begun at $8^{\mathrm{b}} 25^{\mathrm{m}}$ a.m. Between $8^{\mathrm{h}} 25^{\mathrm{m}}$ a.m. and 9 a.m. the average speed was 73 per minute. The pulse-rate at $8^{\mathrm{b}} 56^{\mathrm{m}}$ a.m. Was 88 . The subject was annoyed by saddle soreness during the period.

2 In the interval before this period the average speed was 70 per minute. At $9^{\mathrm{b}} 33^{\mathrm{m}} \mathrm{a} . \mathrm{m}$. the covering which had been placed on the saddle slipped off.

3 The current was raised to 1.5 amperes at $9^{\mathrm{b}} 38^{\mathrm{m}}$ a.m. Between $9^{\mathrm{h}} 38^{\mathrm{m}}$ a.m. and $10^{\mathrm{h}} 06^{\mathrm{m}}$ a.m. the average speed was 62 per minute. The pulse-rate at $9^{\mathrm{b}} 50^{\mathrm{m}} \mathbf{a . m}$. and at $9^{\mathrm{b}} \mathbf{5 7 \mathrm { m }}$ a.m. was 124 . The subject said after the period that he was very tired.

4 In the interval before this period the avcrage speed was 62 per minute. During tho period the work was done without any apparent diffeulty, though the subject said at the end that be was much exhausted and very hungry.

5 Record of pulse-rate at $10^{\mathrm{h}} 31^{\mathrm{m}}$ a.m. Work was finished at the end of the period, and one-half minute later the pulse-rate was 116. 
TABLE 28.-Results with subject H. L. H. (without food).

\begin{tabular}{|c|c|c|c|c|c|c|c|c|}
\hline Date and time. & Duration. & $\begin{array}{c}\text { Carbon } \\
\text { dioxide } \\
\text { eliminated } \\
\text { per minute. }\end{array}$ & $\begin{array}{l}\text { Oxygen } \\
\text { absorbed } \\
\text { per } \\
\text { minute. }\end{array}$ & $\begin{array}{l}\text { Respira- } \\
\text { tory } \\
\text { quotient. }\end{array}$ & $\begin{array}{l}\text { Aver- } \\
\text { age } \\
\text { pulse- } \\
\text { rate. }\end{array}$ & $\begin{array}{l}\text { Average } \\
\text { respira- } \\
\text { tion-rate. }\end{array}$ & $\begin{array}{l}\text { Cur- } \\
\text { rent. }\end{array}$ & $\begin{array}{l}\text { Revolu- } \\
\text { tions per } \\
\text { minute. }\end{array}$ \\
\hline $\begin{array}{l}\text { Nov. } 21,1911 . \\
\text { Lying: } \\
9^{\mathrm{h}} 03^{\mathrm{m}} \text { a.m.1...... } \\
9^{2} 27 \text { a.m........ }\end{array}$ & $\begin{array}{cc}\min . & \text { sec. } \\
13 & 59 \\
13 & 53 \\
\end{array}$ & $\begin{array}{l}\text { c.c. } \\
218 \\
207\end{array}$ & $\begin{array}{l}\text { c.c. } \\
237 \\
243\end{array}$ & $\begin{array}{r}0.92 \\
.86\end{array}$ & $\begin{array}{l}72 \\
70\end{array}$ & $\begin{array}{c}15 \\
\cdots\end{array}$ & $\begin{array}{c}a m p . \\
\cdots \\
\cdots\end{array}$ & $\begin{array}{l}\cdots \\
\cdots\end{array}$ \\
\hline Average.......... & $\ldots \ldots \ldots$ & 213 & 240 & 0.89 & 71 & 15 & $\ldots$ & $\cdots$ \\
\hline 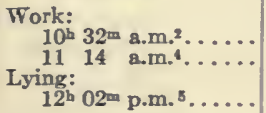 & $\begin{array}{ll}12 & 33 \\
10 & 43 \\
14 & 28\end{array}$ & $\begin{array}{l}1,517 \\
1,741\end{array}$ & $\begin{array}{l}1,461 \\
1,754\end{array}$ & $\begin{array}{r}1.04 \\
.99 \\
.77\end{array}$ & $\begin{array}{l}171 \\
179\end{array}$ & $\begin{array}{l}32 \\
41 \\
16\end{array}$ & $\begin{array}{l}0.9 \\
0.9\end{array}$ & $\begin{array}{l}62 \\
67\end{array}$ \\
\hline
\end{tabular}

1 The pulse-rate at $S^{\mathrm{h}} 40^{\mathrm{m}} \mathrm{am}$. was 72 ; at $8^{\mathrm{h}} 45^{\mathrm{m}}$ a.m., $8^{\mathrm{h}} 48^{\mathrm{m}}$ a.m., and $8^{\mathrm{h}} 51^{\mathrm{m}}$ a.m., 70 .

2 Work was begun at $10^{\mathrm{h}} 20^{\mathrm{m}} \mathrm{am}$. The work was continuous to the beginning of the period and at practically the same speed. The pulse-rate at $10^{\mathrm{h}} 19^{\mathrm{m}}$ a.m. was 72 . The pulse-rate at $10^{\mathrm{h}} 26^{\mathrm{m}} \mathrm{am}$. was $134 ;$ at $10^{\mathrm{h}} 31^{\mathrm{m}}$ a.m., 152 .

3 Approximate.

4 Between the two periods here recorded another work-period was attempted, but it was lost owing to slipping of the noseclip. The pulse-rate at $11^{\mathrm{h}} 13^{\mathrm{m}} \mathrm{a.m}$. was 174 . During the period the subject did not appear to mork quite so readily. The pulse-rate became very rapid.

The subject lay on the couch soon after the work was finished. The pulse-rate fell slowly. At $11^{\mathrm{b}} 44^{\mathrm{m}}$ a.m. it was 100 ; at $11^{\text {h }} 52^{\mathrm{m}}$ a.m., 88 ; at $11^{\text {h }} 56^{\mathrm{m}}$ a.m., 88 ; at 12 noon, 84 .

TABLE 29.-Results with subject H. L. H. (without food). ${ }^{1}$

\begin{tabular}{|c|c|c|c|c|c|c|c|c|}
\hline Date and time. & Duration. & $\begin{array}{c}\text { Carbon } \\
\text { dioxide } \\
\text { eliminated } \\
\text { per minute. }\end{array}$ & $\begin{array}{c}\text { Oxygen } \\
\text { absorbed } \\
\text { per } \\
\text { minute. }\end{array}$ & $\begin{array}{c}\text { Respira- } \\
\text { tory } \\
\text { quotient. }\end{array}$ & $\begin{array}{l}\text { Aver- } \\
\text { age } \\
\text { pulse- } \\
\text { rate. }\end{array}$ & $\begin{array}{l}\text { Average } \\
\text { respira- } \\
\text { tion-rate. }\end{array}$ & $\begin{array}{l}\text { Cur- } \\
\text { rent. }\end{array}$ & $\begin{array}{l}\text { Revolu- } \\
\text { tions per } \\
\text { winute. }\end{array}$ \\
\hline 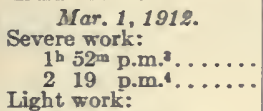 & $\begin{array}{cl}\min . & \text { sec. } \\
10 & 11 \\
10 & 18\end{array}$ & $\begin{array}{c}c . c . \\
1,6.54 \\
1,674\end{array}$ & $\begin{array}{c}c . c . \\
1,643 \\
1,798\end{array}$ & $\begin{array}{r}1.01 \\
.93\end{array}$ & $\begin{array}{l}162 \\
178\end{array}$ & $\begin{array}{l}32 \\
\cdots\end{array}$ & $\begin{array}{c}a m p . \\
1.5 \\
1.5\end{array}$ & $\begin{array}{l}69.2 \\
68.1\end{array}$ \\
\hline $\begin{array}{lll}2^{\mathrm{h}} 49^{\mathrm{m}} & \text { p.m.5 } \\
3 & 15 & \text { p.m. } \ldots \ldots \\
\end{array}$ & $\begin{array}{ll}10 & 21 \\
10 & 59\end{array}$ & $\begin{array}{l}901 \\
900\end{array}$ & $\begin{array}{l}1,211 \\
1,185\end{array}$ & $\begin{array}{l}.75 \\
.76\end{array}$ & $\begin{array}{l}140 \\
144\end{array}$ & $\begin{array}{l}24 \\
24\end{array}$ & $\begin{array}{l}0.5 \\
0.5\end{array}$ & $\begin{array}{l}81.2 \\
80.7\end{array}$ \\
\hline
\end{tabular}

1 The eubject drank a chocolate milk-shake at 8 a.m.

2 One record of pulse and respiration in each period.

3 Work was begun at $1^{\text {b }} 19 \mathrm{~m}$ p.m. The counter was out of order, however, and had to be repaired. Work was begun again at $1^{\mathrm{b}} 34^{\mathrm{m}} \mathrm{p} . \mathrm{m}$. The average speed to the beginning of the first period was approrimately 60 revolutions per minute. During the period the work was done with considerable effort.

4 In the interval before this period the average speed was 64 per minute. During the period the work was done with difficulty.

5 The current was lowered to 0.5 ampere at $2^{\mathrm{b}} 32^{\mathrm{m}}$ p.m. Between $2^{\mathrm{b}} 32^{\mathrm{m}}$ p.m. and $2^{\mathrm{b}} 49^{\mathrm{m}} \mathrm{p} . \mathrm{m}$. the average speed was 88 per minute. During the period the work was done with comparative ease.

6 In the interval before this period the average speed was 69 per minute. During the period the work was on the whole a trifle labored.

TABLE 30.-Results with subject E. P. C. (without food).

\begin{tabular}{|c|c|c|c|c|c|c|c|c|}
\hline Date snd time. & Duration. & $\begin{array}{c}\text { Carbon } \\
\text { dioxide } \\
\text { eliminated } \\
\text { per minute. }\end{array}$ & $\begin{array}{c}\text { Oxygen } \\
\text { absorbed } \\
\text { per } \\
\text { minute. }\end{array}$ & $\begin{array}{c}\text { Respira- } \\
\text { tory } \\
\text { quotient. }\end{array}$ & $\begin{array}{l}\text { Aver- } \\
\text { age } \\
\text { pulse- } \\
\text { rate.1 }\end{array}$ & $\begin{array}{l}\text { Average } \\
\text { respira- } \\
\text { tion-rate. }\end{array}$ & $\begin{array}{l}\text { Cur- } \\
\text { rent. }\end{array}$ & $\begin{array}{l}\text { Revolu- } \\
\text { tions per } \\
\text { minute. }\end{array}$ \\
\hline $\begin{array}{l}\text { Mar. } 5,1912 .{ }^{2} \\
\text { Severe work: } \\
9^{\text {h }} 13^{\mathrm{m}} \text { a.m. } \ldots \ldots \ldots \\
9 \text { a.m. } 38 \text { a.m. } \ldots \ldots\end{array}$ & $\begin{array}{cl}\min . & \sec . \\
10 & 31 \\
10 & 11\end{array}$ & $\begin{array}{c}\text { c.c. } \\
1,379 \\
1,388\end{array}$ & $\begin{array}{c}\text { c.c. } \\
1,498 \\
1,418\end{array}$ & $\begin{array}{r}0.92 \\
.98\end{array}$ & $\begin{array}{l}126 \\
110 ?\end{array}$ & $\begin{array}{l}16 \\
19\end{array}$ & $\begin{array}{c}a m p . \\
1.5 \\
1.5\end{array}$ & $\begin{array}{l}64.8 \\
64.0\end{array}$ \\
\hline $\begin{array}{l}10^{\mathrm{h}} 06^{\mathrm{m}} \mathrm{am} . \\
10 \\
10\end{array}$ & $\begin{array}{ll}10 & 07 \\
10 & 20\end{array}$ & $\begin{array}{l}609 \\
601\end{array}$ & $\begin{array}{l}829 \\
828\end{array}$ & .74 & $\begin{array}{l}112 \\
105\end{array}$ & $\begin{array}{l}16 \\
14\end{array}$ & $\begin{array}{l}0.5 \\
0.5\end{array}$ & $\begin{array}{l}65.0 \\
64.7\end{array}$ \\
\hline
\end{tabular}

1 One record of pulse and respiration in each period.

2 See table 31 for experiment on November 23, 1911.

3 Work was begun at $8^{\mathrm{h}} 57^{\mathrm{m}} \mathrm{a} . \mathrm{m}$. Between $\delta^{\mathrm{h}} 57^{\mathrm{m}} \mathrm{a} . \mathrm{m}$. and $9^{\mathrm{b}} 13^{\mathrm{m}} \mathrm{a} . \mathrm{m}$. the average speed was 65 revolutions per minute.

- During this period the work was easily done. Subject said the work was not very heavy. During the interval before the period the speed was practically at the constant rate maintained throughout the

periods of the day.
5 Immediately at the close of the preceding period the current was lowered from 1.5 amperes to 0.5 ampere. In the interval before the period the average speed was practically at the constant rate for the day.

- In the interval before this period, the average speed was 63 per minute. After this period was completed the subject tried his "capacity to work" at 1.5 amperes. He rode at the rate of 104 per minute for several minutes. 
TABLE 31.-Results with subject E. P. C. (without food).

\begin{tabular}{|c|c|c|c|c|c|c|c|c|}
\hline Date and time. & Duration. & $\begin{array}{l}\text { Carbon } \\
\text { dioxide } \\
\text { eliminated } \\
\text { per minute. }\end{array}$ & $\begin{array}{c}\text { Oxygen } \\
\text { absorbed } \\
\text { per } \\
\text { minute. }\end{array}$ & $\begin{array}{l}\text { Respira- } \\
\text { tory } \\
\text { quotient. }\end{array}$ & $\begin{array}{l}\text { Aver- } \\
\text { age } \\
\text { pulse- } \\
\text { rate. }\end{array}$ & $\begin{array}{l}\text { Average } \\
\text { respira- } \\
\text { tion-rate. }\end{array}$ & $\begin{array}{l}\text { Cur- } \\
\text { rent. }\end{array}$ & $\begin{array}{l}\text { Revolu- } \\
\text { tions per } \\
\text { minute. }\end{array}$ \\
\hline 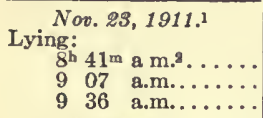 & $\begin{array}{cl}\min . & \text { sec. } \\
14 & 43 \\
14 & 59 \\
10 & 18 \\
\end{array}$ & $\begin{array}{l}\text { c.c. } \\
171 \\
171 \\
165\end{array}$ & $\begin{array}{l}\text { e.c. } \\
199 \\
220 \\
215\end{array}$ & $\begin{array}{r}0.86 \\
.78 \\
.77 \\
\end{array}$ & $\begin{array}{l}55 \\
47 \\
48\end{array}$ & $\begin{array}{l}11 \\
11 \\
11\end{array}$ & $\begin{array}{c}a m p . \\
\cdots \\
\cdots\end{array}$ & $\begin{array}{l}\ddot{ } \\
\ddot{*}\end{array}$ \\
\hline Average......... & $\ldots \ldots \ldots$ & 169 & 211 & 0.80 & 50 & 11 & $\ldots$ & .. \\
\hline 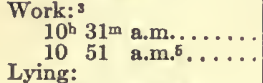 & $\begin{array}{rr}9 & 10 \\
10 & 50\end{array}$ & $\begin{array}{l}1,097 \\
1,095\end{array}$ & $\begin{array}{l}1,167 \\
1,368\end{array}$ & $\begin{array}{r}0.94 \\
.80\end{array}$ & $\begin{array}{l}107 \\
118\end{array}$ & $\begin{array}{l}19 \\
19\end{array}$ & $\begin{array}{l}0.9 \\
0.9\end{array}$ & $\begin{array}{r}454 \\
+58\end{array}$ \\
\hline 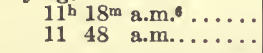 & $\begin{array}{ll}12 & 36 \\
11 & 41\end{array}$ & $\begin{array}{l}190 \\
159\end{array}$ & $\begin{array}{l}249 \\
225\end{array}$ & $\begin{array}{l}.76 \\
.71\end{array}$ & $\begin{array}{l}58 \\
53\end{array}$ & $\begin{array}{l}\cdots \\
\cdots\end{array}$ & $\therefore$ & $\therefore$ \\
\hline
\end{tabular}

1 See table 30 for experiment on Mareh $5,1912$.

2 The pulse-rate at $8^{\mathrm{h}} 39^{\mathrm{n}}$ a.m. Was 52 . The subject was troubled by soreness about the nose due to the use of the noseclip, and by the strong light in his eyes. He was also annoyed by the dryness of the air. It was found that the moistener had become dry.

3 Work was begun at $10^{\mathrm{b}} 16^{\mathrm{m}} \mathrm{a} \cdot \mathrm{m}$. The average speed to the beginning of the period at $10^{\mathrm{b}} 31^{\mathrm{m}} \mathrm{a} . \mathrm{m}$. was about 55 per minute. The pulse-rate at $10^{\mathrm{h}} 16^{\mathrm{m}} \mathrm{a.m}$. Was 70 ; at $10^{\mathrm{h}} 21^{\mathrm{m}}$ a.m., 88 ; at $10^{\mathrm{b}} 25^{\mathrm{m}}$ a.m., $96 ;$ at $10^{\mathrm{h}} 28^{\mathrm{m}}$ a.m., 95 ; at $10^{\mathrm{b}} 30^{\mathrm{m}}$ a.m. 97

Approximate.

5 The rate of the subject's riding between periods was not recorded. The work was continuous.

6 Work was finished at $11^{\mathrm{b}} 03^{\mathrm{m}} \mathrm{a} . \mathrm{m}$. The blood pressure as observed between the seeond and third periods lying before work was maximum 110, minimum 80; soon after work was finished, maximum 115, minimum 80.

TABLE 32.-Results with subject K. H. A. (without food).

\begin{tabular}{|c|c|c|c|c|c|c|c|c|}
\hline Date and time. & Duration. & $\begin{array}{c}\text { Carbon } \\
\text { dioxide } \\
\text { eliminated } \\
\text { per minute. }\end{array}$ & $\begin{array}{c}\text { Oxygen } \\
\text { absorbed } \\
\text { per } \\
\text { minute. }\end{array}$ & $\begin{array}{c}\text { Respira- } \\
\text { tory } \\
\text { quotient. }\end{array}$ & $\begin{array}{c}\text { Aver- } \\
\text { age } \\
\text { pulse- } \\
\text { rate. }\end{array}$ & $\begin{array}{c}\text { Average } \\
\text { respira- } \\
\text { tion-rate. }\end{array}$ & $\begin{array}{l}\text { Cur- } \\
\text { rent. }\end{array}$ & $\begin{array}{l}\text { Revolu- } \\
\text { tions per } \\
\text { minute. }\end{array}$ \\
\hline $\begin{array}{l}\text { Mar. } 7,1912 . \\
\text { Severe work: } \\
8^{\mathrm{h}} 48^{\mathrm{m}} \text { a.m. } \\
9^{1} \text { 07 a.m. } \ldots \ldots \\
\text { Light work: }\end{array}$ & $\begin{array}{cl}\min . & \text { sec. } \\
10 & 20 \\
10 & 15\end{array}$ & $\begin{array}{c}\text { c.c. } \\
1,767 \\
1,824\end{array}$ & $\begin{array}{l}\text { c.c. } \\
2,060 \\
1,949\end{array}$ & $\begin{array}{r}0.86 \\
.94\end{array}$ & $\begin{array}{l}162 \\
174\end{array}$ & $\begin{array}{l}26 \\
32\end{array}$ & $\begin{array}{l}\operatorname{amp} . \\
1.5 \\
1.5\end{array}$ & $\begin{array}{l}79.0 \\
79.7\end{array}$ \\
\hline $\begin{array}{ccc}9^{\mathrm{h}} 43^{\mathrm{m}} & \text { a.m. } & \ldots \ldots \\
10^{3} & 03 & \text { a.m. }\end{array} \ldots$ & $\begin{array}{ll}10 & 53 \\
11 & 52\end{array}$ & $\begin{array}{l}863 \\
902\end{array}$ & $\begin{array}{l}1,070 \\
1,082\end{array}$ & $\begin{array}{l}.81 \\
.84\end{array}$ & $\begin{array}{l}132 \\
136\end{array}$ & 22 & $\begin{array}{l}0.5 \\
0.5\end{array}$ & $\begin{array}{l}78.7 \\
79.4\end{array}$ \\
\hline
\end{tabular}

1 Work was begun at $8^{\text {h }} 18^{\mathrm{m}}$ a.m. Between $8^{\mathrm{h}} 18^{\mathrm{m}}$ a.m. and $8^{\mathrm{h}} 48^{\mathrm{m}}$ a.m. the subjcet rode at the average rate of 79 revolutions per minute. The metronome set at 82 to 84 was used to regulate the speed.

2 In the interval before this period the average speed was 86 per minute.

3 The current was lowered to 0.5 ampere at $9^{\mathrm{b}} 19^{\mathrm{m}} \mathrm{a} . \mathrm{m}$. Between $9^{\mathrm{b}} 19^{\mathrm{m}}$ a.m. and $9^{\mathrm{h}} 43^{\mathrm{m}}$ a.m. the average speed was 78 per minute. During the period the work was done with ease, and the subject restrained himself in order to keep to the rate set for riding.

In the interval before this period, the average speed was 83 per minute.

TABLE 33.-Results with subject K. H. A. (without food).

\begin{tabular}{|c|c|c|c|c|c|c|c|c|}
\hline Date and time. & Duration. & $\begin{array}{l}\text { Carbon } \\
\text { dioxide } \\
\text { eliminated } \\
\text { per minute. }\end{array}$ & $\begin{array}{l}\text { Oxygen } \\
\text { absorbed } \\
\text { per } \\
\text { minute }\end{array}$ & $\begin{array}{l}\text { Respira- } \\
\text { tory } \\
\text { quotient. }\end{array}$ & $\begin{array}{l}\text { Aver- } \\
\text { age } \\
\text { pulse- } \\
\text { rate. }\end{array}$ & $\begin{array}{l}\text { Average } \\
\text { respira- } \\
\text { tion-rate. }\end{array}$ & $\begin{array}{l}\text { Cur- } \\
\text { rent. }\end{array}$ & $\begin{array}{l}\text { Revalu- } \\
\text { tions per } \\
\text { minute. }\end{array}$ \\
\hline 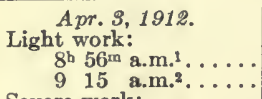 & $\begin{array}{cl}\min & \text { sec. } \\
10 & 20 \\
10 & 20\end{array}$ & $\begin{array}{l}\text { c.c. } \\
921 \\
895\end{array}$ & $\begin{array}{l}\text { c.c. } \\
1,052 \\
1,061\end{array}$ & $\begin{array}{r}0.88 \\
.84\end{array}$ & $\begin{array}{l}120 \\
124\end{array}$ & $\begin{array}{l}20 \\
18\end{array}$ & $\begin{array}{c}a m p . \\
0.5 \\
0.5\end{array}$ & $\begin{array}{l}78.7 \\
78.7\end{array}$ \\
\hline $\begin{array}{l}\text { Severe work: } \\
10^{\mathrm{h}} 04^{\mathrm{m}} \text { a.m. }{ }^{3} \ldots \ldots \\
1025 \text { a.m. } \ldots \ldots\end{array}$ & $\begin{array}{ll}10 & 14 \\
10 & 08\end{array}$ & $\begin{array}{l}1,834 \\
1,825\end{array}$ & $\begin{array}{l}2,015 \\
2,147\end{array}$ & $\begin{array}{l}.91 \\
.85\end{array}$ & $\begin{array}{l}168 \\
170\end{array}$ & $\begin{array}{l}24 \\
24\end{array}$ & $\begin{array}{l}1.5 \\
1.5\end{array}$ & $\begin{array}{l}78.5 \\
78.7\end{array}$ \\
\hline
\end{tabular}

1 Work was begun at $8^{\mathrm{h}} 29^{\mathrm{m}}$ a.m. Between $8^{\mathrm{h}} 29^{\mathrm{m}}$ a.m. and $8^{\mathrm{b}} 56^{\mathrm{m}}$ a.m. the average speed was 79 revolutions per minute.

2 In the interval before this period the average speed was 84 per minute.

3 At $9 \mathrm{~b} 27 \mathrm{~m}$ am. the current was increased to 1.5 amperes. In the interval between the second and third periods the average speed was 77 per minute. The counter was not recorded at $9^{\mathrm{h}} 27^{\mathrm{m}}$ a.m. Perspiration began at $9^{\mathrm{h}} 35^{\mathrm{m}} \mathrm{a} . \mathrm{m}$. The subject's breathing was slow and deep. Perspiration was; somewhat

4 In the interval before this period the average speed was 79 per minute. The subject's breathing was slow and labored during the period, and caused distension of the rubber cap of the tension-equalizer to its full capacity. 
TABLE 34.-Results with subject J. J. C. (without food).

\begin{tabular}{|c|c|c|c|c|c|c|c|c|}
\hline Date and time. & Duration. & $\begin{array}{l}\text { Carbon } \\
\text { dioxide } \\
\text { eliminated } \\
\text { per minute. }\end{array}$ & $\begin{array}{l}\text { Oxygen } \\
\text { absorbed } \\
\text { per } \\
\text { minute. }\end{array}$ & $\begin{array}{l}\text { Respira- } \\
\text { tory } \\
\text { quotient. }\end{array}$ & $\begin{array}{l}\text { Aver- } \\
\text { age } \\
\text { pulse- } \\
\text { rate. }\end{array}$ & $\begin{array}{l}\text { Average } \\
\text { respira- } \\
\text { tion-rate. }\end{array}$ & $\begin{array}{l}\text { Cur- } \\
\text { rent. }\end{array}$ & $\begin{array}{l}\text { Revolu- } \\
\text { tions per } \\
\text { minute. }\end{array}$ \\
\hline $\begin{array}{l}\text { Mar. } 16,1912 . \\
\text { Severe work: } \\
2^{\text {h } 31^{m} \text { p.m. }} \ldots \ldots \ldots \\
251 \text { p.m. } \ldots \ldots \ldots\end{array}$ & $\begin{array}{cc}\min . & \text { sec. } \\
10 & 12 \\
10 & 12\end{array}$ & $\begin{array}{c}c . c . \\
1,690 \\
1,636\end{array}$ & $\begin{array}{r}c . c . \\
1,808 \\
1,886\end{array}$ & 0.94 & $\begin{array}{l}170 \\
166\end{array}$ & $\begin{array}{l}36 \\
36\end{array}$ & $\begin{array}{c}a m p . \\
1.5 \\
1.5\end{array}$ & $\begin{array}{l}72.0 \\
71.8\end{array}$ \\
\hline 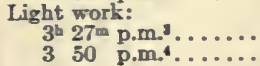 & $\begin{array}{ll}12 & 13 \\
13 & 15\end{array}$ & $\begin{array}{l}861 \\
824\end{array}$ & $\begin{array}{l}1,075 \\
1,035\end{array}$ & $\begin{array}{l}.80 \\
.80\end{array}$ & $\begin{array}{l}139 \\
136\end{array}$ & $\begin{array}{l}36 \\
34\end{array}$ & $\begin{array}{l}0.5 \\
0.5\end{array}$ & $\begin{array}{l}71.3 \\
71.1\end{array}$ \\
\hline
\end{tabular}

1 Work was begun at 2 p.m. Between 2 p.m. and $2^{\text {b }} 31^{\mathrm{m}}$ p.m. the average speed was 74 revolutions per minute. The pulse-rate in the preliminary period before the month was put to the mouthpiece ras $^{\mathrm{at}} 2^{\mathrm{h}} 07 \mathrm{7}=\mathrm{p} \cdot \mathrm{m}$. 148 ; at $2^{\mathrm{h}} 19^{\mathrm{m}} \mathrm{p} . \mathrm{m} ., 168$; st $2^{\mathrm{b}} 26^{\mathrm{m}} \mathrm{p}$. m. 166. The subject's mouth was put to the mouthpiece at $2^{\mathrm{h}} 27 \mathrm{~m}$.m. The pulse-rate at $2^{\mathrm{b}} 2 \mathrm{~S}^{\mathrm{s}} \mathrm{p}$.m. was 166. During the period work was first done rather egily put later with more difficulty. The subject's breathing was labored at the end of the period. The saddle was uncomfortable. The pulse-rate 2 minutes after the close of the period was 146.

2 In the interval before this period the average speed was 63 per minute. During the period work was done with comparative ease. Perspiration was profuse.

3 The current was lowered to 0.5 ampere at $3^{\mathrm{h}} 02^{\mathrm{m}} \mathrm{p} . \mathrm{m}$. In the interval before this period the average speed was 65 per minute. The pulse-rate in this interval was at $3^{\text {h }} 20^{\mathrm{m}}$ p.m., 132 ; at $3^{\text {h }} 26^{m}$ p.m., 130 .

4 In the interval before this period the arerage speed was 56 per minute.

TABLE 35.-Results with subject Dr. W. G. A. (without food).

\begin{tabular}{|c|c|c|c|c|c|c|c|c|}
\hline Date and time. & Duration. & $\begin{array}{c}\text { Carbon } \\
\text { dioxide } \\
\text { eliminated } \\
\text { per minute. }\end{array}$ & $\begin{array}{l}\text { Oxygen } \\
\text { absorbed } \\
\text { per } \\
\text { minute. }\end{array}$ & $\begin{array}{l}\text { Respirs- } \\
\text { tory } \\
\text { quotient. }\end{array}$ & $\begin{array}{l}\text { Aver- } \\
\text { age } \\
\text { pulse- } \\
\text { rate. }\end{array}$ & $\begin{array}{l}\text { Average } \\
\text { respira- } \\
\text { tion-rate. }\end{array}$ & $\begin{array}{l}\text { Cur- } \\
\text { rent. }\end{array}$ & $\begin{array}{l}\text { Revolu- } \\
\text { tions per } \\
\text { minute. }\end{array}$ \\
\hline 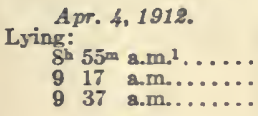 & $\begin{array}{cl}\min , & \text { sec. } \\
10 & 23 \\
14 & 11 \\
12 & 47\end{array}$ & $\begin{array}{l}\text { c.c. } \\
185 \\
182 \\
187\end{array}$ & $\begin{array}{l}\text { c.c. } \\
220 \\
234 \\
222\end{array}$ & $\begin{array}{r}0.84 \\
.78 \\
.85\end{array}$ & $\begin{array}{l}50 \\
50 \\
49 \\
\end{array}$ & $\begin{array}{l}24.8 \\
24.7 \\
34.6 \\
\end{array}$ & $\begin{array}{c}a m p . \\
\ldots \\
\ldots\end{array}$ & $\begin{array}{l}\cdots \\
\cdots \\
\cdots\end{array}$ \\
\hline Average. . . . . . . . & $\ldots \ldots \ldots$ & 185 & 225 & 0.82 & 50 & 24.7 & $\cdots$ & $\ldots$ \\
\hline 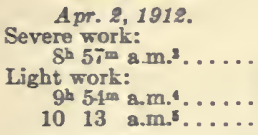 & $\begin{array}{rr}8 & 06 \\
10 & 14 \\
10 & 08\end{array}$ & $\begin{array}{r}1,615 \\
798 \\
765\end{array}$ & $\begin{array}{r}\ldots \\
1,009 \\
958\end{array}$ & $\begin{array}{l}\ldots \\
.79 \\
.80\end{array}$ & $\begin{array}{l}112 \\
108\end{array}$ & $\begin{array}{l}18 \\
\ldots\end{array}$ & $\begin{array}{l}0.5 \\
0.5\end{array}$ & $\begin{array}{l}72.1 \\
76.1 \\
75.5\end{array}$ \\
\hline
\end{tabular}

1 The subject lay down at $8^{\mathrm{h}} 15^{\mathrm{m}} \mathrm{a} . \mathrm{m}$.

2 The respiration-rate while the subject was on the couch was for the full period as recorded by the spirometer.

3 Work was begun at $8^{\mathrm{h}} 26^{\mathrm{m}}$ a.m., the average speed between this time and $\mathrm{S}^{\mathrm{h}} 57^{\mathrm{m}} \mathrm{a} . \mathrm{m}$. being 75 revolutions per minute. The subject started riding all right, beginning to perspire in about 10 minutes, but during the experimental period. he was in grest distress, his lips moving backward and forward on the mouthpiece with each respiration. The period was ended because of the condition of the subject. He complained of saddle soreness and shortage of air. Perspiration was very profuse.

4 In the interval before this period, the current was lowered to 0.5 ampere. The subject rested after the first period. He rode a total of about 2,556 revolutions between the end of the first period and the beginning of the second. During the second period the work was easily and readily done.

5 In the interval before this period the average speed was apparently about 51 revolutions per minute. During the period the work was done with ease. The subject felt rather tired at the end of the experiment.

TABLE 36.-Results with subject M. A. M. (without food). (Ergometer I.)

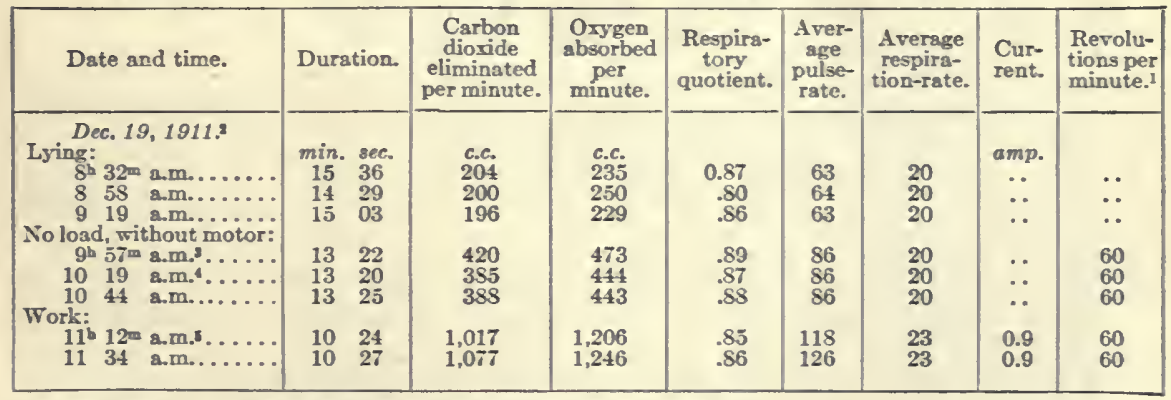

1 Approximate. 2 See table 37 for experiment on December 14, 1911

3 The subject sat on the ergometer at $9^{\mathrm{b}} 40^{\mathrm{m}} \mathrm{a} . \mathrm{m}$. and began riding. The metronome was used, set at 60 per minute. The counter was not used. The pulse averaged about 84 during the preliminary riding.

4 The subject rode very easily. He said the lack of resistance was rather disagreeable.

5 The metronome was used, set at 60 . Current was on at $10^{\mathrm{b}} 5 \mathrm{i}^{\mathrm{m}} \mathrm{a}$.m. Pulse-rate during preliminary work 100,104 and 106 . Mouth put to mouthpiece at $11^{\mathrm{h}} 0 \mathrm{~T}_{\mathrm{m}}^{\mathrm{m}} \mathrm{.m}$. The work was done with comparative ease, with no marked perspiration or flushing, but the subject found it very hard after coasting. 
TABLE 37.-Results with subject M. A. M. (without food).

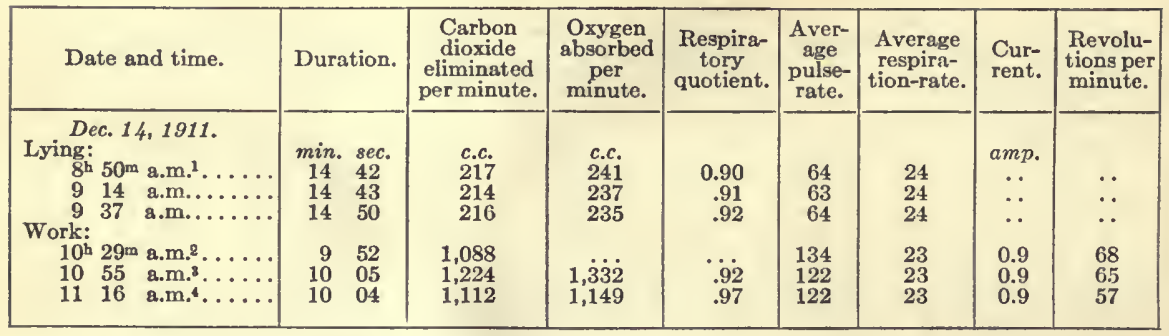

1 The subject lay for $\mathbf{4 0}$ minutes before the period.

2 The metronome was used to keep the speed at about 60 per minute. Work was begun at $10^{\mathrm{h}} 07^{\mathrm{m}}$ a.m. The subject put his mouth to the mouthpiece at $10^{\mathrm{b}} 22^{\mathrm{m}} \mathrm{a}$ a.m. The pulse-rate without the mouthpiece was at $10^{\mathrm{h}} 14^{\mathrm{m}} \mathrm{a} \cdot \mathrm{m} ., 112$; at $10^{\mathrm{h}} 20^{\mathrm{m}}$ a.m. and $10^{\mathrm{h}} 22^{\mathrm{m}} \mathrm{a}$ a.m., 116 . When the subject's mouth was on the mouthpiece, the pulse-rate was at $10^{\mathrm{b}} 24^{\mathrm{m}}$ a.m., 124 ; at $10^{\mathrm{h}} 26^{\mathrm{m}}$ a.m., 120 . During the preliminary 22 minutes the average speed was about 63 revolutions per minute. The level of the mouthpiece was changed to suit subject's convenience. The subject had to stop at the end of 10 minutes. He was crouching in his seat. The oxygen measurement was lost. Perspiration was pouring from the subject during the period. He felt that the stethoscope harness was pressing on him.

3 The subject had changed to a more upright position and was therefore much more comfortable. He was cooler, and feeling better. His face was bathed in perspiration.

4 The subject stopped work for 2 minutes between periods. The average speed for the actual riding in the interval was about 62 revolutions per minute.

TABLE 38.-Results with subject $M . A . M$. (without food).

\begin{tabular}{|c|c|c|c|c|c|c|c|c|}
\hline Date and time. & Duration. & $\begin{array}{c}\text { Carbon } \\
\text { dioxide } \\
\text { eliminated } \\
\text { per minute. }\end{array}$ & $\begin{array}{l}\text { Oxygen } \\
\text { absorbed } \\
\text { per } \\
\text { minute. }\end{array}$ & $\begin{array}{l}\text { Respira- } \\
\text { tory } \\
\text { quotient. }\end{array}$ & $\begin{array}{l}\text { Aver- } \\
\text { age } \\
\text { pulse- } \\
\text { rate. }\end{array}$ & $\begin{array}{l}\text { Average } \\
\text { respira- } \\
\text { tion-rate. }\end{array}$ & $\begin{array}{l}\text { Cur- } \\
\text { rent. }\end{array}$ & $\begin{array}{l}\text { Revolu- } \\
\text { tions per } \\
\text { minute. }\end{array}$ \\
\hline 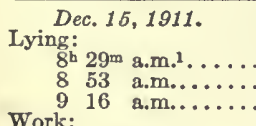 & $\begin{array}{cl}\min . & \text { sec. } \\
14 & 30 \\
14 & 37 \\
14 & 57\end{array}$ & $\begin{array}{l}\text { c.c. } \\
202 \\
205 \\
194\end{array}$ & $\begin{array}{l}c . c . \\
254 \\
252 \\
245\end{array}$ & $\begin{array}{r}0.80 \\
.81 \\
.80\end{array}$ & $\begin{array}{l}64 \\
64 \\
64\end{array}$ & $\begin{array}{l}22 \\
24 \\
22\end{array}$ & $\begin{array}{c}a m p . \\
\cdots \\
\cdots\end{array}$ & $\because$ \\
\hline $\begin{array}{rll}\text { Work: } & \\
10^{\mathrm{h}} & 10^{\mathrm{m}} & \text { a.m. } \\
10 & 29 & \text { a.m. } \\
10 & 47 & \text { a.m. } \\
10 & 4 \ldots\end{array}$ & $\begin{array}{ll}10 & 10 \\
10 & 09 \\
10 & 10\end{array}$ & $\begin{array}{l}1,160 \\
1,163 \\
1,147\end{array}$ & $\begin{array}{l}1,338 \\
1,439 \\
1,444\end{array}$ & $\begin{array}{l}.87 \\
.81 \\
.80\end{array}$ & $\begin{array}{l}122 \\
126 \\
130\end{array}$ & $\begin{array}{l}19 \\
22 \\
27\end{array}$ & $\begin{array}{l}0.9 \\
0.9 \\
0.9\end{array}$ & $\begin{array}{l}362 \\
360 \\
362\end{array}$ \\
\hline $\begin{array}{l}\text { Lying: } \\
\quad 11^{\mathrm{b}} 15^{\mathrm{m}} \text { a.m. } \\
\quad 11 \text { a.m. } \\
\quad 19 \text { a.m. }\end{array}$ & $\begin{array}{ll}14 & 21 \\
14 & 17\end{array}$ & $\begin{array}{l}215 \\
200\end{array}$ & $\begin{array}{l}255 \\
252\end{array}$ & $\begin{array}{l}.84 \\
.80\end{array}$ & $\begin{array}{l}71 \\
64\end{array}$ & $\begin{array}{l}22 \\
19\end{array}$ & $\therefore$ & $\because$ \\
\hline
\end{tabular}

1 The subject said at the beginning of the experiment that he did not feel very well. He had some gastric disturbance. He was lying on the couch 29 minutes before the period began. The pulse-rate at $8^{\mathrm{h}} 05^{\mathrm{m}}$ a.m., $8^{\mathrm{h}} 10^{\mathrm{m}}$ a.m. $8^{\mathrm{h}} 15^{\mathrm{m}}$ a.m., and $8^{\mathrm{h}} 22^{\mathrm{m}}$ a.m. was 64 .

2 The subject was not physically inclined to work. He began work at $9^{\mathrm{h}} 42^{\mathrm{m}}$ a.m. His pulse without the mouthpiece was 116; with the mouthpiece it was 110 and 112 . Perspiration was profuse. Loosening of the subject's clothing gave him relief. Preliminary to the period the average speed was about 59 revolutions per minute.

3 Approximate. The metronome was used to regulate the speed.

4 The subject rode between periods at the average rate of about 59 revolutions per minute, sitting up to ride as is usual between periods. He found that this gave him relief. He volunteered the information that he sometimes found expiration difficult when the rubber cap on the tension-equalizer was too full. Perspiration began at $10^{\mathrm{h}} 35^{\mathrm{m}} \mathrm{a} . \mathrm{m}$.

5 The average speed between periods was about 65 revolutions per minute. The subject's breathing was labored during work, and he looked exhausted when the period ended and breathed badly. Perspiration began at $10^{\mathrm{h}} 53^{\mathrm{m}}$ a.m.

- The subject's change to the couch was made as rapidly as possible. He took in saliva from the mouthpiece when the cock was again turned and made efforts to swallow. Respiration was less shallow than usual. The period began about 12 minutes after the work was finished. The subject was flushed but otherwise was normal in appearance. 
TABLE 39.-Results with subject M. A. M. (without food).

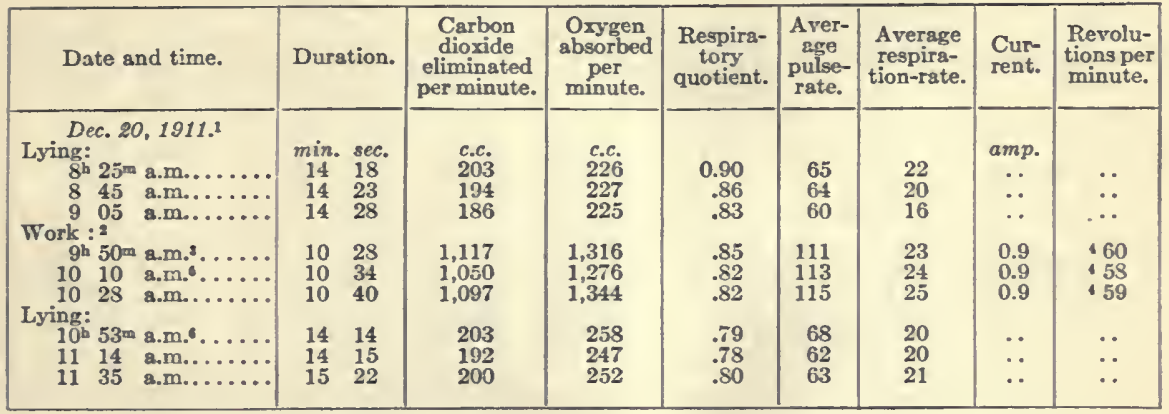

1 See table 36 for experiment on December 19, 1911.

2 The thermal junction rectal thermometer was used during the work periods and during the lying periods following. The body-temperature rose about $1^{\circ} \mathrm{C}$. and after work fell to about the original level. (See Fig. 10, p. 15S.)

3 Work was begun at $9 \mathrm{~h} 30 \mathrm{~m}$ a.m. The metronome was used, set at 60 . The pulse-rate during the preliminary period was at $9^{\mathrm{h}} 35^{\mathrm{m}}$ a.m., 100 ; at $9^{\mathrm{h}} 42^{\mathrm{m}}$ a.m. and $9^{\mathrm{h}} 46^{\mathrm{ma}}$ a.m., 104 ; at $9^{\mathrm{h}} 48^{\mathrm{m}}$ a.m., 102 . The speed of the rotary blower was increased during work. Perspiration appeared on the subject's brow at $9^{\mathrm{h}} 57^{\mathrm{m}}$ a.m.

1 Approximate. The metronome was used to regulate the speed.

5 The metronome was set at 58. At $10^{\mathrm{b}} 18^{\mathrm{m}} \mathrm{m} . \mathrm{m}$. there ras sweat on the subject's lips as well as on his brow. He found the work easy and felt in excellent condition.

- Work was finished at $10^{\mathrm{h}} 40^{\mathrm{m}}$ a.m. The subject then readjusted the rectal thermometer and immediately lay down.

TABLE 40.-Results with subject M. A. M. (without food).

\begin{tabular}{|c|c|c|c|c|c|c|c|c|}
\hline Date and time. & Duration. & $\begin{array}{c}\text { Carbon } \\
\text { dioxide } \\
\text { eliminated } \\
\text { per minute. }\end{array}$ & $\begin{array}{c}\text { Orygen } \\
\text { absorbed } \\
\text { per } \\
\text { minute. }\end{array}$ & $\begin{array}{l}\text { Respira- } \\
\text { tory } \\
\text { quotient. }\end{array}$ & $\begin{array}{l}\text { Aver- } \\
\text { age } \\
\text { pulse- } \\
\text { rate. }\end{array}$ & $\begin{array}{c}\text { Average } \\
\text { respira- } \\
\text { tion-rate. }\end{array}$ & $\begin{array}{l}\text { Cur- } \\
\text { rent. }\end{array}$ & $\begin{array}{l}\text { Revolu- } \\
\text { tions per } \\
\text { minute. }\end{array}$ \\
\hline 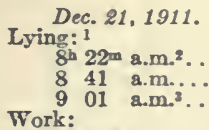 & $\begin{array}{cl}\min . & \text { sec. } \\
14 & 16 \\
14 & 17 \\
14 & 27\end{array}$ & $\begin{array}{l}\text { c.c. } \\
202 \\
199 \\
196\end{array}$ & $\begin{array}{l}\text { c.c. } \\
230 \\
231 \\
231\end{array}$ & $\begin{array}{r}0.88 \\
.86 \\
.85\end{array}$ & $\begin{array}{l}61 \\
60 \\
60\end{array}$ & $\begin{array}{l}18 \\
18 \\
19\end{array}$ & $\begin{array}{c}a m p . \\
\because \\
\because \\
\cdots\end{array}$ & $\because$ \\
\hline $\begin{array}{r}10^{\mathrm{i}} 03^{\mathrm{m}} \text { a.m. } \\
100^{4} \text { a.m. }\end{array}$ & $\begin{array}{ll}10 & 23 \\
10 & 17\end{array}$ & $\begin{array}{r}1,055 \\
971\end{array}$ & $\begin{array}{l}1,245 \\
1,256\end{array}$ & .85 & $\begin{array}{l}125 \\
132\end{array}$ & $\begin{array}{l}25 \\
28\end{array}$ & $\begin{array}{l}0.9 \\
0.9\end{array}$ & $\begin{array}{l}80 \\
60\end{array}$ \\
\hline $\begin{array}{lll}10^{\mathrm{b}} & 43^{\mathrm{m}} & \text { a.m. } \\
11 & 02 & \text { a.m.... } \\
11 & 23 & \text { a.m.... } \\
11 & 44 & \text { a.m. }\end{array}$ & $\begin{array}{ll}14 & 22 \\
14 & 32 \\
14 & 30 \\
14 & 32\end{array}$ & $\begin{array}{l}217 \\
203 \\
196 \\
192\end{array}$ & $\begin{array}{l}259 \\
261 \\
247 \\
246\end{array}$ & $\begin{array}{l}.84 \\
.78 \\
.79 \\
.78\end{array}$ & $\begin{array}{l}75 \\
70 \\
67 \\
65\end{array}$ & $\begin{array}{l}23 \\
23 \\
20 \\
24\end{array}$ & $\begin{array}{l}. \\
\because \\
\cdots\end{array}$ & $\begin{array}{l}\because \\
\because\end{array}$ \\
\hline
\end{tabular}

1 The rectal thermometer was used ou this day but was not inserted during work. The records show that a rise in the body temperature of about $0.9^{\circ} \mathrm{C}$. occurred during work. During the second series of lying periods there was a steady fall totaling about $1.6^{\circ} \mathrm{C}$. (See Fig. 10, p. 158.)

2 The subject lay down at $7^{\mathrm{h}} 55^{\mathrm{m}} \mathrm{a}$ a.m. The pulse-rate at $7^{\mathrm{h}} 57^{\mathrm{m}} \mathrm{a}$.m. was 66 ; at $8^{\mathrm{b}} 02^{\mathrm{m}} \mathrm{a}$.m., 64 ; at $8^{\mathrm{h}} 07^{\mathrm{m}}$ a.m., 58. From $8^{\text {h }} 10^{\mathrm{m}}$ a.m. to \& $^{\mathrm{h}} 17^{\mathrm{m}}$ a.m. the average pulse-rate was 60 .

3 In the third period the position of the mouthpiece was twice altered for the subject because it was not as comfortable for him as usual.

1 The subject rode at the average rate of 107 revolutions per minute from $9^{\mathrm{h}} 22^{\mathrm{m}} \mathrm{a} . \mathrm{m}$. to $9^{\mathrm{h}} 47_{\mathrm{m}}$ a.m. when the speed was lowered to 60 revolutions per minute. The pulse-rate could not be observed during the rapid riding because the subject could not wear the stethoscope harness. It took him till $9^{\mathrm{h}} 38^{\mathrm{m}} \mathrm{a}$.m. to get his second wind. During the preliminary period following $9^{\mathrm{h}} 47^{\mathrm{m}} \mathrm{s} . \mathrm{m}$., the pulse-rate was 132 , $128,124,12 S$. During the rapid riding the speed went as high as 135 revolutions per minute.

5 Approximate. The metronome was used to regulate the speed.

6 The subject complained of saddle soreness. After the rate was lowered to 60 revolutions per minute, the metronome was used to regulate the speed. He said the ergometer was different from the ordinary form of bicycle. While at work he was annoyed at having to keep time with the metronome. The crank of the bicycle was working loose, and that also annoyed him and interfered with the smoothness of his work.

The subject stopped work at $10^{\mathrm{h}} 35^{\mathrm{m}} \mathrm{a}$.m. His respiration was now shallow, though regular. He was tired, and there was tendency, therefore, to loosen the mouth on the mouthpiece. 
TABLE 41.-Results with subject $M . A . M$. (without food).

\begin{tabular}{|c|c|c|c|c|c|c|c|c|}
\hline Date and time. & Duration. & $\begin{array}{l}\text { Carbon } \\
\text { dioxide } \\
\text { eliminated } \\
\text { per minute. }\end{array}$ & $\begin{array}{c}\text { Oxygen } \\
\text { absorbed } \\
\text { per } \\
\text { minute. }\end{array}$ & $\begin{array}{l}\text { Respira- } \\
\text { tory } \\
\text { quotient. }\end{array}$ & $\begin{array}{l}\text { Aver- } \\
\text { age } \\
\text { pulse- } \\
\text { rate. }\end{array}$ & $\begin{array}{l}\text { Average } \\
\text { respira- } \\
\text { tion-rate. }\end{array}$ & $\begin{array}{l}\text { Cur- } \\
\text { rent. }\end{array}$ & $\begin{array}{l}\text { Revolu- } \\
\text { tions per } \\
\text { minute. }\end{array}$ \\
\hline 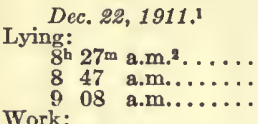 & $\begin{array}{cl}\min . & \text { sec. } \\
14 & 25 \\
14 & 22 \\
14 & 25\end{array}$ & $\begin{array}{l}\text { c.c. } \\
199 \\
195 \\
188\end{array}$ & $\begin{array}{l}\text { c.c. } \\
229 \\
217 \\
229\end{array}$ & $\begin{array}{r}0.87 \\
.90 \\
.82\end{array}$ & $\begin{array}{l}61 \\
60 \\
60\end{array}$ & $\begin{array}{l}20 \\
20 \\
20\end{array}$ & $\begin{array}{c}a m p . \\
\cdots \\
\cdots\end{array}$ & $\ddot{0}$ \\
\hline 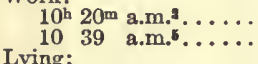 & $\begin{array}{ll}10 & 12 \\
10 & 13\end{array}$ & $\begin{array}{l}1,030 \\
1,077\end{array}$ & $\begin{array}{l}1,326 \\
1,355\end{array}$ & .78 & $\begin{array}{l}116 \\
119\end{array}$ & $\begin{array}{l}22 \\
24\end{array}$ & $\begin{array}{l}0.9 \\
0.9\end{array}$ & $\begin{array}{l}458 \\
158\end{array}$ \\
\hline $\begin{array}{ccc}10^{\mathrm{b}} & 59 \mathrm{~m} & \text { a.m. } \\
11 & 21 & \text { a.m......... } \\
11 & 41 & \text { a.m....... }\end{array}$ & $\begin{array}{ll}14 & 24 \\
14 & 29 \\
14 & 24\end{array}$ & $\begin{array}{l}225 \\
197 \\
198\end{array}$ & $\begin{array}{l}253 \\
238 \\
228\end{array}$ & $\begin{array}{l}.89 \\
.83 \\
.87\end{array}$ & $\begin{array}{l}70 \\
64 \\
62\end{array}$ & $\begin{array}{l}22 \\
20 \\
20\end{array}$ & $\ddot{\cdots}$ & $\ddot{\cdots}$ \\
\hline
\end{tabular}

1 The rectal thermometer was used during this entire experiment. During work there was a maximum rise of about $1.2^{\circ} \mathrm{C}$. in the body-temperature; during the lying periods following the work periods it fell steadily to the temperature at the beginning of the day. (See Fig. 10, p. 158.)

2 The subject lay down at $7^{\mathrm{h}} 57^{\mathrm{m}} \mathrm{a.m}$. The pulse-rate at $8^{\mathrm{h}} 10^{\mathrm{m}} \mathrm{a.m}$. was $66^{\prime} ;$ at $8^{\mathrm{h}} 20^{\mathrm{m}}$ a.m., $61 ;$ at $8^{\mathrm{h}} 22^{\mathrm{m}}$

3 The windows were opened, and the subject rode rapidly from $9^{\mathrm{h}} 28^{\mathrm{m}}$ a.m. to $9^{\mathrm{h}} 53^{\mathrm{m}}$ a.m. The speed during this rapid riding was probably about the same as on Dec. 21 . At $9^{\mathrm{h}} 53^{\mathrm{m}}$ a.m. the speed was reduced to 60 revolutions per minute. The pulse-rate at $9^{\mathrm{h}} 57^{\mathrm{m}} \mathrm{a.m}$. was $120 ;$ at $10^{\mathrm{h}} 04^{\mathrm{m}} \mathrm{a} \cdot \mathrm{m} .1^{2}, 122$ at $10^{\mathrm{h}} 08^{\mathrm{m}}$ a.m., 120. The measurement of the metabolism was attempted at $10^{\mathrm{h}} 10^{\mathrm{m}} \mathrm{a} \cdot \mathrm{m}$. but the subject stopped work after $1 \frac{1}{\mathrm{l}}$ minutes. He said he could not continue because of the great pressure from the rubber cap on the tension-equalizer which affected his expiration. The pulse-rate was $112 \mathrm{at} 10^{\mathrm{h}} 10^{\mathrm{m}} \mathrm{a} . \mathrm{m}$. There was no flushing to speak of. There was considerable perspiration, but this was due to the preThere was no flushing to speak of. There was considerable perspiration, but this was due to the pre-
vious exercise. The subject stopped pedaling for about 3 minutes and said he was much exhausted. He had very labored breathing. During the period which was successfully carried out between $10^{\mathrm{h}} 20^{\mathrm{m}}$ a.m. and $10^{\mathrm{h}} 30^{\mathrm{m}} \mathrm{a}$.m., the test for carbon dioxide in the circuit was positive. The amount of carbon dioxide present was small, but the blower was run for 3 minutes after the period to clear it out.

1 Approximate. The metronome was used in both work periods and during the interval between the two periods to regulate the speed.

5 The subject worked steadily and evenly.

6 The subject lay down at $10^{\mathrm{b}} 50^{\mathrm{ma}}$ a.m.

TABLe 42.-Results with subject M. A. M. (without food).

\begin{tabular}{|c|c|c|c|c|c|c|c|c|}
\hline Date and time. & Duration. & $\begin{array}{c}\text { Carbon } \\
\text { dioxide } \\
\text { eliminated } \\
\text { per minute. }\end{array}$ & $\begin{array}{c}\text { Oxygen } \\
\text { absorbed } \\
\text { per } \\
\text { minute. }\end{array}$ & $\begin{array}{l}\text { Respira- } \\
\text { tory } \\
\text { quotient. }\end{array}$ & $\begin{array}{c}\text { Aver- } \\
\text { age } \\
\text { pulse- } \\
\text { rate. }\end{array}$ & $\begin{array}{l}\text { Average } \\
\text { respira- } \\
\text { tion-rate. }\end{array}$ & $\begin{array}{l}\text { Cur- } \\
\text { rent. }\end{array}$ & $\begin{array}{l}\text { Revolu- } \\
\text { tions per } \\
\text { minute. }\end{array}$ \\
\hline $\begin{array}{c}\text { Jan. } 2,1912.1 \\
\text { Lying: } \\
8^{\mathrm{b}} 49^{\mathrm{m}} \text { a.m.2....... } \\
9.11 \text { a.m....... }\end{array}$ & $\begin{array}{cl}\min . & \text { sec. } \\
14 & 29 \\
14 & 36\end{array}$ & $\begin{array}{l}\text { c.c. } \\
198 \\
200\end{array}$ & $\begin{array}{l}c . c . \\
231 \\
232\end{array}$ & $\begin{array}{r}0.86 \\
.87\end{array}$ & $\begin{array}{l}60 \\
61\end{array}$ & $\begin{array}{l}16 \\
19\end{array}$ & $\begin{array}{c}a m p . \\
\because \\
\therefore\end{array}$ & $\because$ \\
\hline $\begin{array}{c}10^{\mathrm{h}} 14^{\mathrm{m}} \text { a.m.s. } \\
10 \\
34\end{array}$ & $\begin{array}{ll}10 & 29 \\
10 & 08\end{array}$ & $\begin{array}{l}1,033 \\
1,059\end{array}$ & $\begin{array}{l}1,254 \\
1,244\end{array}$ & $\begin{array}{l}.83 \\
.85\end{array}$ & $\begin{array}{l}129 \\
129\end{array}$ & $\begin{array}{l}23 \\
25\end{array}$ & $\begin{array}{l}0.9 \\
0.9\end{array}$ & $\begin{array}{l}40 \\
460\end{array}$ \\
\hline $\begin{array}{lll}10^{\mathrm{b}} & 54 \text { a.m. } & \text { a.m. } \\
11 & 18 & \text { a.m. } \\
11 & 40 & \text { a.m. }\end{array}$ & $\begin{array}{ll}14 & 54 \\
16 & 50 \\
18 & 21\end{array}$ & $\begin{array}{l}223 \\
208 \\
217\end{array}$ & $\begin{array}{l}271 \\
257 \\
270\end{array}$ & $\begin{array}{l}.83 \\
.81 \\
.81\end{array}$ & $\begin{array}{l}81 \\
79 \\
75\end{array}$ & $\begin{array}{l}24 \\
23 \\
21\end{array}$ & $\because$ & $\begin{array}{l}\because \\
\because\end{array}$ \\
\hline
\end{tabular}

1 See table 43 for experiment on Jan. 1, 1912 .

2 Before the experiment the subject complained of a heavy feeling in his stomach. It was possibly due to the fatty supper of the night before. He looked well. The pulse-rate at $8^{\mathrm{h}} 10^{\mathrm{m}} \mathrm{a} . \mathrm{m}$. was $68 ;$ at $8^{\mathrm{h}} 20^{\mathrm{m}}$ a.m., 63 ; at $8 \mathrm{~h} 42^{\mathrm{h}}$ a.m., 62 .

3 Beginning at $9^{\mathrm{h}} 31^{\mathrm{m}} \mathrm{a}$ a.m., the subject rode rapidly for 25 minutes at the average rate of 110 revolutions per minute. At $9 \mathrm{~b} 56^{\mathrm{m}} \mathrm{a} \cdot \mathrm{m}$. the speed was lowered to 60 revolutions per minute. The pulse-rate after the speed was decreased was at $10^{\mathrm{h}} 01^{\mathrm{m}}$ a.m., 134 ; at $10^{\mathrm{h}} 04^{\mathrm{ma}} \mathrm{a} . \mathrm{m}$. and $10^{\mathrm{h}} 07^{\mathrm{m}} \mathrm{a} . \mathrm{m} ., 130 ; \mathrm{at} 10^{\mathrm{h}} 09^{\mathrm{m}}$ a.m., 132. The subject washed his mouth by gargling with water at $10^{\mathrm{h}} 07^{\mathrm{m}}$ a.m. He said then that he could start all over again with ease.

4 Approximate. The metronome set at 60 was used to regulate the speed from $9^{\mathrm{h}} 56^{\mathrm{m}} \mathrm{a}, \mathrm{m}$. to the end of work. 5 The subject was in excellent condition and had no difliculty in doing the work. There was a tendency in both periods for him to fall off from the set rate of 60 revolutions per minute.

6 The subject lay down at $10^{\mathrm{h}} 45^{\mathrm{m}} \mathrm{am}$

7 The subject moved actively for about 10 seconds at $11^{\mathrm{b}} 51^{\mathrm{m}} \mathrm{a.m}$. 
TABLE 43.-Results with subject M. A. M. (without food).

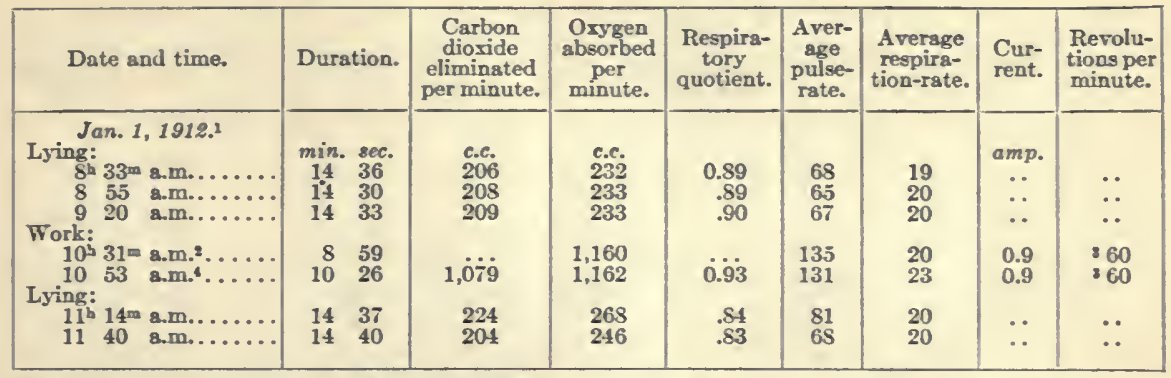

1 See table 42 for experiment on January $2,1912$.

2 During the interval there were $2 S$ minutes of hard work followed by 14 minutes of work at 60 revolutions per minute. The records of speed at $9^{\mathrm{h}} 52^{\mathrm{m}} \mathrm{a.m}$. and $10^{\mathrm{h}} 12^{\mathrm{mm}} \mathrm{a} \cdot \mathrm{m}$. Were 95 and 98 revolutions per minute. Second wind after 16 minutes. Pulse-rate during the preliminary work with the speed at 60 revolutions was $145,124,128$.

3 Approximate.

The subject had 5 minutes' complete rest sitting on the bicycle after the last experiment. He started again at $10^{\mathrm{h}} 45^{\mathrm{m}} \mathrm{a} \cdot \mathrm{m}$, at a speed of 60 revolutions per minute.

TABLE 44.-Results with subject M. A. M. (vithout food).

\begin{tabular}{|c|c|c|c|c|c|c|c|c|}
\hline Date and time. & Duration. & $\begin{array}{l}\text { Carbon } \\
\text { dioxide } \\
\text { eliminated } \\
\text { per minute. }\end{array}$ & $\begin{array}{l}\text { Oxygen } \\
\text { absorbed } \\
\text { per } \\
\text { minute. }\end{array}$ & $\begin{array}{l}\text { Respirs- } \\
\text { tory } \\
\text { quotient. }\end{array}$ & $\begin{array}{l}\text { Aver- } \\
\text { age } \\
\text { pulse- } \\
\text { rate. }\end{array}$ & $\begin{array}{l}\text { Average } \\
\text { respira- } \\
\text { tion-rate. }\end{array}$ & $\begin{array}{l}\text { Cur- } \\
\text { rent. }\end{array}$ & $\begin{array}{l}\text { Revolu- } \\
\text { tions per } \\
\text { minute. }\end{array}$ \\
\hline $\begin{array}{l}\text { Jan. } 3,1912 . \\
\text { Lying: } \\
8^{\mathrm{a}} 26 \mathrm{~m} \text { a.m. } \ldots \ldots \ldots \\
8 \text { 47 } \text { a.m........ } \\
909 \text { a.m...... }\end{array}$ & $\begin{array}{cl}\min . & \text { sec. } \\
14 & 33 \\
14 & 32 \\
14 & 34\end{array}$ & $\begin{array}{l}\text { c.c. } \\
201 \\
199 \\
201\end{array}$ & $\begin{array}{l}\text { c.c. } \\
233 \\
237 \\
229\end{array}$ & $\begin{array}{r}0.86 \\
.84 \\
.88\end{array}$ & $\begin{array}{l}61 \\
60 \\
60\end{array}$ & $\begin{array}{l}18 \\
18 \\
20\end{array}$ & $\begin{array}{c}a m p . \\
\cdots \\
\cdots\end{array}$ & $\begin{array}{l}\cdots \\
\cdots\end{array}$ \\
\hline 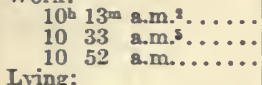 & $\begin{array}{rr}8 & 02 \\
10 & 19 \\
10 & 14\end{array}$ & $\begin{array}{l}972^{3} \\
1,024 \\
1,015\end{array}$ & $\begin{array}{l}1,356 \\
1,258 \\
1,218\end{array}$ & $\begin{array}{l}.72 \\
.80 \\
.81\end{array}$ & $\begin{array}{l}1 \pm 6 \\
129 \\
124\end{array}$ & $\begin{array}{l}20 \\
22 \\
20\end{array}$ & $\begin{array}{l}0.9 \\
0.9 \\
0.9\end{array}$ & $\begin{array}{r}60 \\
+60 \\
.60\end{array}$ \\
\hline $11^{\mathrm{h}} 15^{\mathrm{m}}$ a.m........ & $\begin{array}{ll}14 & 49 \\
15 & 01\end{array}$ & $\begin{array}{l}219 \\
209\end{array}$ & $\begin{array}{l}287 \\
277\end{array}$ & .76 & $\begin{array}{r}79 \\
77\end{array}$ & $\begin{array}{l}22 \\
22\end{array}$ & 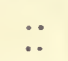 & 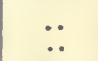 \\
\hline
\end{tabular}

1 The subject lay down at $7^{\mathrm{h}} 55^{\mathrm{m}}$ a.m. The pulse-rate at $8^{\mathrm{h}} 12^{\mathrm{m}}$ a.m. was $68^{\mathrm{m}}$; at $8^{\mathrm{h}} 16^{\mathrm{m}}$ a.m., $66^{2}$; at $8^{\mathrm{h}} 19^{\mathrm{m}}$ a.m., 64 ; at $8^{\text {h }} 22$ a.m., 63.

2 Beginning at $9 \mathrm{~h} 29 \mathrm{~m}$ a.m. the subject rode rapidly for 25 minutes at the average rate of 119 revolutions per minute. At $9 \mathrm{~h} 54 \mathrm{~m} \mathrm{~m} . \mathrm{m}$. the speed was lowered to 60 revolutions per minute. The subject washed his mouth by gargling while riding fast. He perspired freely and felt winded just before he finished the fast riding. He rode fastest at first, i. e., about 136 revolutions per minute. Second wind at $9^{\mathrm{h}} 33^{\mathrm{m}} \mathrm{a} . \mathrm{m}$.

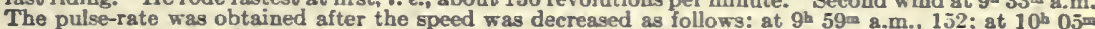
a.m., 144; at $10^{\mathrm{h}} 09_{\mathrm{m}} \mathrm{a.m} . \mathrm{I}^{\mathrm{m}}$. During the period itself there were symptoms of collapse at the end of 7.5 minutes and the period was therefore ended as soon as possible. There was twitching of the subject's lips but no leak.

3here was a possible trace of carbon dioxide in the circuit by test. Approximate. The metronome set at 60 was used to regulate the speed from $9 \mathrm{~h} 54^{\mathrm{m}}$ a.m. to the end of work.
5 The subject looked all right and said he was quite ready to continue the work. The work was easily done.

TABLE 45.-Results with subject M. A. M. (without food).

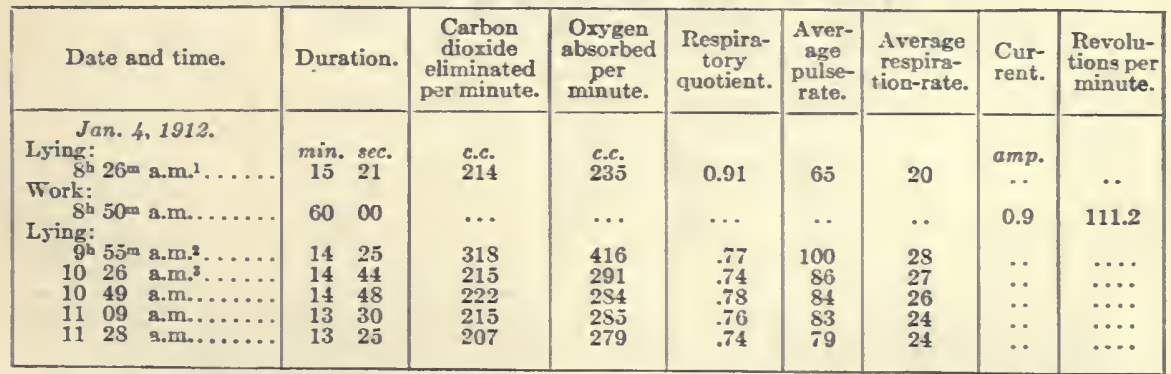

1 The subject lay down at $7^{\mathrm{h}} 55^{\mathrm{m}} \mathrm{a} . \mathrm{m}$. Pulse-rate at 5-minute intervals after $8^{\mathrm{h}} 10^{\mathrm{m}} \mathrm{a.m}$. $\mathrm{was} 66,64,64,64$.

2 The subject rode rapidly for an hour after the first lying period, not breathing in the circuit of the respiration apparatus. At times he rode much more rapidly, as high as 140 revolutions per minute. Work was finished at $9 \mathrm{~h} 50 \mathrm{~m}$ a.m. The subject then lay down pouring with perspiration, and was rubbed down. He had to rest a little and rested with his mouth on the mouthpiece from $9^{\mathrm{b}} 53^{\mathrm{m}} \mathrm{a} . \mathrm{m}$. to $9^{\mathrm{h}} 55^{\mathrm{m}}$ a.m., when the period began. He lay very quietly. At the end of the preceding period the aubject was still thoroughly bathed in perspiration. His arms and
chest were rubbed down and his flannels were removed for comfort. 
TABLE 46.-Results with subject $M$. A. M. (without food).

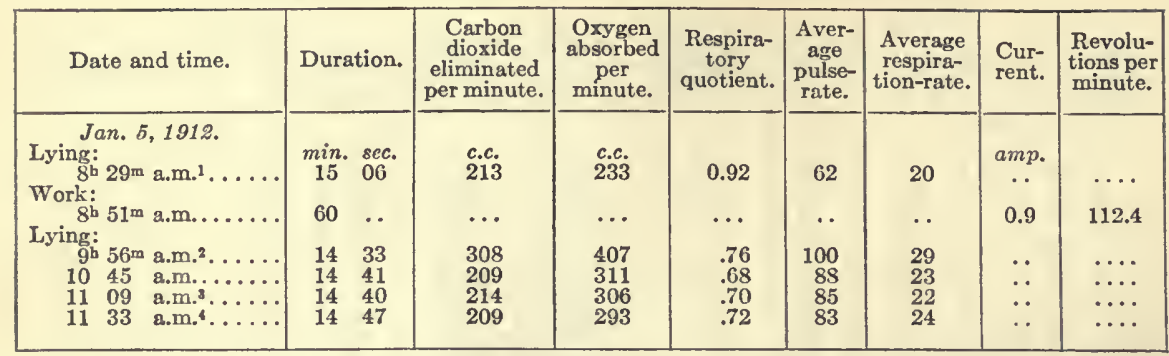

1 The subject lay down at 8 a.m. The pulse-rate at $8^{\mathrm{h}} 11^{\mathrm{m}}$ a.m. was 62 ; at $8^{\mathrm{h}} 15^{\mathrm{m}}$ a.m., 62 ; at $8^{\mathrm{h}} 19^{\mathrm{m}}$ a.m., 62 ; at $8^{\mathrm{h}} 22^{\mathrm{m}}$ a.m., 60 .

2 The subject rode rapidly for an hour after the first lying period, not breathing in the eircuit of the respiration apparatus. He rode more rapidly at times, once at the rate of 153 revolutions per minute. Work was finished at $9^{\mathrm{b}} 51^{\mathrm{m}}$ a.m. There was very great perspiration after the work. Subjeet was rubbed down before be lay upon the couch. He lay very quietly, his respiration being shallow and rapid.

3 The apparatus was carefully tested for tightness before the period was started. There was no evidence that the mouth was not kept elosed.

- The apparatus was again tested carefully. The subject asserted that in both previous periods his lips and his nose (held by noseclip) were absolutely tight. He complained that he was extremely hungry.

TABLE 47.-Results with subject M. A. M. (without food).

\begin{tabular}{|c|c|c|c|c|c|c|c|c|}
\hline Date and time. & Duration. & $\begin{array}{c}\text { Carbon } \\
\text { dioxide } \\
\text { eliminated } \\
\text { per minute. }\end{array}$ & $\begin{array}{l}\text { Oxygen } \\
\text { absorbed } \\
\text { per } \\
\text { minute. }\end{array}$ & $\begin{array}{l}\text { Respira- } \\
\text { tory } \\
\text { quotient. }\end{array}$ & $\begin{array}{l}\text { Aver- } \\
\text { age } \\
\text { pulse- } \\
\text { rate. }\end{array}$ & $\begin{array}{l}\text { Average } \\
\text { respira- } \\
\text { tion-rate. }\end{array}$ & $\begin{array}{l}\text { Cur- } \\
\text { rent. }\end{array}$ & $\begin{array}{l}\text { Revolu- } \\
\text { tions per } \\
\text { minute. }\end{array}$ \\
\hline 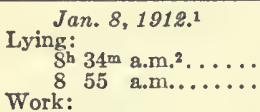 & $\begin{array}{cl}\min . & s e c \\
15 & 26 \\
14 & 42\end{array}$ & $\begin{array}{l}c . c . \\
205 \\
204\end{array}$ & $\begin{array}{l}c . c . \\
228 \\
234\end{array}$ & $\begin{array}{r}0.90 \\
.87\end{array}$ & $\begin{array}{l}59 \\
58\end{array}$ & $\begin{array}{l}20 \\
20\end{array}$ & $\begin{array}{l}a m p . \\
\cdots \\
\therefore\end{array}$ & $\ldots$ \\
\hline 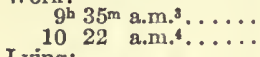 & $\begin{array}{ll}10 & 04 \\
10 & 11\end{array}$ & $\begin{array}{l}1,743 \\
1,902\end{array}$ & $\begin{array}{l}1,959 \\
1,989\end{array}$ & $\begin{array}{l}.89 \\
.96\end{array}$ & $\begin{array}{l}162 \\
180\end{array}$ & $\ddot{3} \dot{2}$ & $\begin{array}{l}0.9 \\
0.9\end{array}$ & $\begin{array}{l}85.8 \\
95.0\end{array}$ \\
\hline 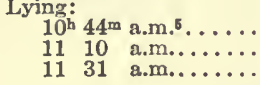 & $\begin{array}{ll}14 & 51 \\
14 & 43 \\
15 & 21\end{array}$ & $\begin{array}{l}241 \\
217 \\
220\end{array}$ & $\begin{array}{l}288 \\
263 \\
263\end{array}$ & $\begin{array}{l}.84 \\
.83 \\
.84\end{array}$ & $\begin{array}{l}89 \\
85 \\
83\end{array}$ & $\begin{array}{l}22 \\
20 \\
20\end{array}$ & $\because$ & $\begin{array}{l}\cdots \\
\cdots\end{array}$ \\
\hline
\end{tabular}

1 A new and larger wooden wheel had been put on the motor and a smaller wheel or rim of the blower was used. The ventilation was increased from about 60 liters per minute to about 82 liters per minute.

2 The subject had a slight cold but otherwise felt and looked to be in good condition.

3 The subject began work at $9^{\mathrm{h}} 24^{\mathrm{m}}$ a.m. and to the beginning of the period he rode at the average rate of 92 revolutions per minute.

1 The subject had no difficulty in breathing. The machine was not running at just the second the subject was brought into the circuit. It was started immediately. The subject rode at the average rate of 100 revolutions per minute between the two periods.

5 Work was finished at $10^{\mathrm{h}} 33^{\mathrm{m}} \mathrm{a} \cdot \mathrm{m}$. The subject was then rubbed down and lay on the couch at $10^{\mathrm{h}} 37^{\mathrm{m}} \mathrm{a} . \mathrm{m}$.

TABLe 48.-Results with subject $M . A . M$. (without food).

\begin{tabular}{|c|c|c|c|c|c|c|c|c|}
\hline Date and time. & Duration. & $\begin{array}{c}\text { Carbon } \\
\text { dioxide } \\
\text { eliminated } \\
\text { per minute. }\end{array}$ & $\begin{array}{l}\text { Oxygen } \\
\text { absorbed } \\
\text { per } \\
\text { minute. }\end{array}$ & $\begin{array}{l}\text { Respira- } \\
\text { tory } \\
\text { quotient. }\end{array}$ & $\begin{array}{l}\text { Aver- } \\
\text { age } \\
\text { pulse- } \\
\text { rate. }\end{array}$ & $\begin{array}{l}\text { Average } \\
\text { respira- } \\
\text { tion-rate. }\end{array}$ & $\begin{array}{l}\text { Cur- } \\
\text { rent. }\end{array}$ & $\begin{array}{l}\text { Revolu- } \\
\text { tions per } \\
\text { minute. }\end{array}$ \\
\hline $\begin{array}{c}\text { Jan. } 9,1912 . \\
\text { Lying: } \\
8^{\mathrm{h}} 30^{\mathrm{m}} \text { a.m.1...... } \\
855 \text { a.m....... }\end{array}$ & $\begin{array}{cl}\min . & \text { sec. } \\
14 & 41 \\
14 & 42\end{array}$ & $\begin{array}{l}\text { c.c. } \\
215 \\
207\end{array}$ & $\begin{array}{l}\text { c.c. } \\
237 \\
246\end{array}$ & $\begin{array}{r}0.91 \\
.85\end{array}$ & $\begin{array}{l}60 \\
60\end{array}$ & $\begin{array}{l}18 \\
20\end{array}$ & $\begin{array}{c}a m p . \\
\ldots \\
\ldots\end{array}$ & $\ldots$ \\
\hline 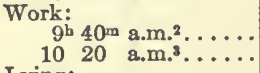 & $\begin{array}{rl}9 & 02 \\
10 & 09\end{array}$ & $\begin{array}{l}1,528 \\
1,727\end{array}$ & $\begin{array}{l}1,877 \\
1,976\end{array}$ & $\begin{array}{l}.82 \\
.87\end{array}$ & $\begin{array}{l}156 \\
162\end{array}$ & $\begin{array}{l}28 \\
26\end{array}$ & $\begin{array}{l}0.9 \\
0.9\end{array}$ & $\begin{array}{l}85.8 \\
89.1\end{array}$ \\
\hline 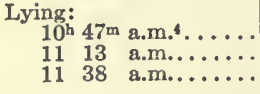 & $\begin{array}{ll}14 & 38 \\
14 & 42 \\
14 & 58\end{array}$ & $\begin{array}{l}229 \\
207 \\
213\end{array}$ & $\begin{array}{l}329 \\
299 \\
285\end{array}$ & $\begin{array}{l}.70 \\
.70 \\
.75\end{array}$ & $\begin{array}{l}87 \\
83 \\
83\end{array}$ & $\begin{array}{l}24 \\
24 \\
24\end{array}$ & $\begin{array}{l}\cdots \\
\cdots\end{array}$ & $\cdots$ \\
\hline
\end{tabular}

1 The subject had great difficulty in walking over to the laboratory and fell twice because of the icy street. He said he was not much inclined to work. He lay down at $8^{\mathrm{h}} 10^{\mathrm{m}} \mathrm{a} . \mathrm{m}$. The pulse-rate at $8^{\mathrm{b}} 19^{\mathrm{m}} \mathrm{a} . \mathrm{m}$. was 64 ; at $8^{\mathrm{b}} 23^{\mathrm{m}}$ a.m., 60 ; at $8^{\mathrm{h}} 27^{\mathrm{m}}$ a.m., 60 .

2 Work was begun at $9^{\mathrm{h}} 17^{\mathrm{m}} \mathrm{a}$ a.m. Between $9^{\mathrm{h}} 17^{\mathrm{m}} \mathrm{a}$.m. and $9^{\mathrm{h}} 40^{\mathrm{m}}$ a.m. the average speed was 109 revolutions per minute. From $9^{\mathrm{h}} 25^{\mathrm{m}} \mathrm{a}$.m. to $9^{\mathrm{h}} 32^{\mathrm{m}}$ a.m. the subjeet was riding at the rate of about 130 revolutions per minute. He was directed to ride more slowly and reduced the speed to about 90 revo-

lutions per minute. During the period itself the subject was not looking well and the period was there-

lutions per minute. During the period itself the subject was not looking well and the period was therethe soda-lime. The subject said he did not feel as well as on Jan. 8 . but could have completed 10 minutes. s The average specd between the two periods was 97 revolutions per minute.

- Work was finished at $10^{\mathrm{h}} 32^{\mathrm{m}} \mathrm{a}$.m. The subject's respiration was shallow during this period. 
TABLe 49.-Results with subject M. A. M. (without food).

\begin{tabular}{|c|c|c|c|c|c|c|c|c|}
\hline Date and time. & Duration. & $\begin{array}{l}\text { Carbon } \\
\text { dioxide } \\
\text { eliminated } \\
\text { per minute. }\end{array}$ & $\begin{array}{l}\text { Oxygen } \\
\text { absorbed } \\
\text { per } \\
\text { minute. }\end{array}$ & $\begin{array}{l}\text { Respira- } \\
\text { tory } \\
\text { quotient. }\end{array}$ & $\begin{array}{l}\text { Aver- } \\
\text { age } \\
\text { pulse- } \\
\text { rate. }\end{array}$ & $\begin{array}{l}\text { Average } \\
\text { respira- } \\
\text { tion-rate. }\end{array}$ & $\begin{array}{l}\text { Cur- } \\
\text { rent. }\end{array}$ & $\begin{array}{l}\text { Revolu- } \\
\text { tions per } \\
\text { minute. }\end{array}$ \\
\hline $\begin{array}{l}\text { Jan. } 16,1912 . \mathrm{l} \\
\text { Lying: } \\
\text { \$ }^{\mathrm{h}} 36^{\mathrm{m}} \text { a.m.2....... } \\
\text { 8 } 59 \text { a.m...... } \\
\text { Work: }\end{array}$ & $\begin{array}{cl}\min . & s e c . \\
14 & 46 \\
14 & 50\end{array}$ & $\begin{array}{l}\text { c.c. } \\
212 \\
210\end{array}$ & $\begin{array}{l}\text { c.c. } \\
250 \\
245\end{array}$ & $\begin{array}{r}0.85 \\
.86\end{array}$ & $\begin{array}{l}81 \\
82\end{array}$ & $\begin{array}{l}24 \\
22\end{array}$ & $\begin{array}{c}a m p . \\
\ldots \\
\cdots\end{array}$ & $\cdots$ \\
\hline 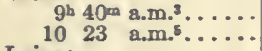 & $\begin{array}{ll}10 & 16 \\
14 & 28\end{array}$ & $\begin{array}{l}2,198 \\
1,776\end{array}$ & $\begin{array}{l}2,671 \\
2,131\end{array}$ & .82 & $\begin{array}{r}168 \\
164\end{array}$ & $\begin{array}{l}34 \\
32\end{array}$ & $\begin{array}{l}0.9 \\
0.9\end{array}$ & $\begin{array}{r}108.4 \\
91.3\end{array}$ \\
\hline 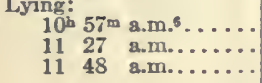 & $\begin{array}{ll}14 & 30 \\
14 & 23 \\
14 & 22\end{array}$ & $\begin{array}{l}226 \\
217 \\
219\end{array}$ & $\begin{array}{l}293 \\
275 \\
277\end{array}$ & $\begin{array}{l}.77 \\
.79 \\
.79\end{array}$ & $\begin{array}{l}86 \\
83 \\
82\end{array}$ & $\begin{array}{l}28 \\
28 \\
24\end{array}$ & $\begin{array}{l}\ddot{ } \\
\cdots\end{array}$ & $\begin{array}{l}\ldots \\
\cdots \cdots \\
\cdots\end{array}$ \\
\hline
\end{tabular}

1 See table 52 for experiment on Jenuary 10, 1912. 2 The subject lay down at 8 a.m.

Work was begun at $9^{\mathrm{b}} 25^{\mathrm{m}}$ a.m. Between $9^{\mathrm{b}} 25^{\mathrm{m}}$ a.m. and $9^{\mathrm{b}} 40^{\mathrm{m}} \mathrm{a} . \mathrm{m}$. the subject rode at the average speed of 97 revolutions per minute, though in the first 6 minutes he rode at the rate of 136 revolutions per minute. During the period evidence of carbon dioxide in the circuit was found after about 6 minutes. The subject's speed was distinctly held down after the carbon dioxide was found to be passing the sodalime. Before that the speed was well above 120 rev. per minute, rather of a strain for the subject. 1 One record, at the wrist.

- Between the two periods (about 32 minutes) the subject rode at the average rate of 95 revolutions per minute. At one time he rode 90 revolutions in one-half minute.

Work was finished at $10^{\mathrm{h}} 38^{\mathrm{m}} \mathrm{am}$.

TABLE 50.-Results with subject M. A. M. (without food).

\begin{tabular}{|c|c|c|c|c|c|c|c|c|}
\hline Date and time. & Duration. & $\begin{array}{l}\text { Carbon } \\
\text { dioxide } \\
\text { eliminated } \\
\text { per minute. }\end{array}$ & $\begin{array}{l}\text { Oxygen } \\
\text { absorbed } \\
\text { per } \\
\text { minute. }\end{array}$ & $\begin{array}{l}\text { Respirs- } \\
\text { tory } \\
\text { quotient. }\end{array}$ & $\begin{array}{l}\text { Aver- } \\
\text { age } \\
\text { pulse- } \\
\text { rate. }\end{array}$ & $\begin{array}{l}\text { Average } \\
\text { respira- } \\
\text { tion-rate. }\end{array}$ & $\begin{array}{l}\text { Cur- } \\
\text { rent. }\end{array}$ & $\begin{array}{l}\text { Revolu- } \\
\text { tions per } \\
\text { minute. }\end{array}$ \\
\hline 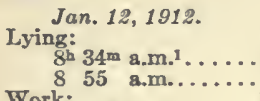 & $\begin{array}{cl}\min & \text { sec. } \\
14 & 23 \\
14 & 43\end{array}$ & $\begin{array}{l}\text { c.c. } \\
228 \\
217\end{array}$ & $\begin{array}{l}c . c . \\
266 \\
259\end{array}$ & $\begin{array}{r}0.86 \\
.84\end{array}$ & $\begin{array}{l}64 \\
62\end{array}$ & $\begin{array}{l}21 \\
21\end{array}$ & $\begin{array}{c}a m p . \\
\cdots \\
\therefore\end{array}$ & $\cdots$ \\
\hline 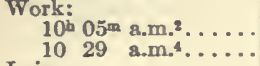 & $\begin{array}{ll}10 & 09 \\
10 & 08\end{array}$ & $\begin{array}{l}2,004 \\
2,011\end{array}$ & $\begin{array}{l}2,210 \\
2,293\end{array}$ & $\begin{array}{l}.91 \\
.88\end{array}$ & ${ }_{162}^{3} 164$ & $\begin{array}{l}30 \\
34\end{array}$ & $\begin{array}{l}0.9 \\
0.9\end{array}$ & $\begin{array}{l}101.8 \\
103.3\end{array}$ \\
\hline 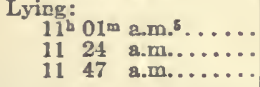 & $\begin{array}{ll}14 & 50 \\
14 & 42 \\
14 & 49\end{array}$ & $\begin{array}{l}228 \\
212 \\
210\end{array}$ & $\begin{array}{l}321 \\
289 \\
288\end{array}$ & $\begin{array}{l}.71 \\
.74 \\
.73\end{array}$ & $\begin{array}{l}82 \\
80 \\
81\end{array}$ & $\begin{array}{l}24 \\
20 \\
24\end{array}$ & $\begin{array}{l}\cdots \\
\cdots\end{array}$ & $\cdots \cdots$ \\
\hline
\end{tabular}

1 The subject lay down at $8^{\mathrm{h}} 02^{\mathrm{m}}$ a.m. The pulse-rate was 64 at $\mathrm{S}^{\mathrm{h}} 10^{\mathrm{m}}, 8^{\mathrm{h}} 15^{\mathrm{m}}$, and $8^{\mathrm{h}} 25^{\mathrm{m}}$ a.m.

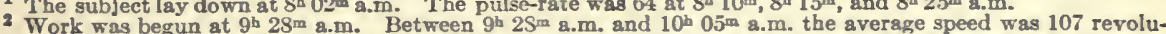
tions per minute; at times it was as high as 126 revolutions per minute. There was no difficulty of any kind during the period, except in keeping the subject down to a low level of work. There was always a tendency to sprint.

2 At the wrist.

1 Between the two periods the subject rode at the average rate of 85 revolutions per minute. It was difficult to prevent the subject from doing too much work during this period.

6 Work ceased at $10^{\mathrm{h}} 40^{\mathrm{m}} \mathrm{8} \cdot \mathrm{m}$. and the subject lay down at $10^{\mathrm{h}} 43^{\mathrm{m}} \mathrm{am}$.

TABLE 51.-Results with subject M. A. M. (without food).

\begin{tabular}{|c|c|c|c|c|c|c|c|c|}
\hline Date and time. & Duration. & $\begin{array}{l}\text { Carbon } \\
\text { dioxide } \\
\text { eliminated } \\
\text { per minute. }\end{array}$ & $\begin{array}{l}\text { Orygen } \\
\text { absorbed } \\
\text { per } \\
\text { minute. }\end{array}$ & $\begin{array}{l}\text { Respirs- } \\
\text { tory } \\
\text { quotient. }\end{array}$ & $\begin{array}{l}\text { Aver- } \\
\text { age } \\
\text { pulse- } \\
\text { rate. }\end{array}$ & $\begin{array}{l}\text { Average } \\
\text { respira- } \\
\text { tion-rate. }\end{array}$ & $\begin{array}{l}\text { Cur- } \\
\text { rent. }\end{array}$ & $\begin{array}{l}\text { Revolu- } \\
\text { tions per } \\
\text { minute. }\end{array}$ \\
\hline $\begin{array}{l}\text { Jan. } 15,1912 . \\
\text { Lying: } \\
8^{\mathrm{h}} 33^{\mathrm{m}} \text { a.m......... } \\
8^{8} 56 \text { a.m........ } \\
\text { Work: }\end{array}$ & $\begin{array}{cl}\min . & \text { sec. } \\
14 & 39 \\
14 & 41\end{array}$ & $\begin{array}{l}\text { c.c. } \\
235 \\
229\end{array}$ & $\begin{array}{l}\text { c.c. } \\
266 \\
249\end{array}$ & $\begin{array}{r}0.88 \\
.92\end{array}$ & $\begin{array}{l}64 \\
65\end{array}$ & $\begin{array}{l}21 \\
24\end{array}$ & $\begin{array}{c}a m p . \\
\quad \cdots \\
\cdots\end{array}$ & $\ldots$ \\
\hline $\begin{array}{ccc}9^{\mathrm{h}} & 35^{\mathrm{m}} & \text { a.m. } \\
10 & 16 & \text { a.m. } \\
3^{3} & \ldots\end{array}$ & $\begin{array}{ll}10 & 23 \\
14 & 51\end{array}$ & $\begin{array}{l}2,428 \\
1,890\end{array}$ & $\begin{array}{l}2,691 \\
2,091\end{array}$ & $\begin{array}{l}.90 \\
.91\end{array}$ & $\begin{array}{r}2162 \\
169\end{array}$ & $\begin{array}{l}36 \\
26\end{array}$ & $\begin{array}{l}0.9 \\
0.9\end{array}$ & $\begin{array}{r}114.9 \\
93.9\end{array}$ \\
\hline 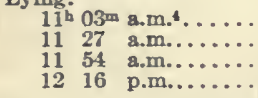 & $\begin{array}{ll}14 & 51 \\
14 & 49 \\
14 & 44 \\
14 & 22\end{array}$ & $\begin{array}{l}224 \\
232 \\
236 \\
220\end{array}$ & $\begin{array}{l}256 \\
280 \\
275 \\
266\end{array}$ & $\begin{array}{l}.79 \\
.83 \\
.86 \\
.83\end{array}$ & $\begin{array}{l}84 \\
85 \\
83 \\
79\end{array}$ & $\begin{array}{l}20 \\
24 \\
24 \\
20\end{array}$ & $\begin{array}{l}\cdots \\
\cdots \\
\cdots\end{array}$ & $\begin{array}{l}\ldots \\
\ldots \\
\cdots \\
\cdots\end{array}$ \\
\hline
\end{tabular}

1 Work wag begun at $9^{\mathrm{h}} 19_{\mathrm{m}} \mathrm{am}$. Between $9^{\mathrm{b}} 10^{\mathrm{m}} \mathrm{a} . \mathrm{m}$. and $9^{\mathrm{h}} 35^{\mathrm{m}} \mathrm{a} . \mathrm{m}$. the subject rode at the average rate of 110 revolutions per minute during the actual time of riding. In the first 5 minutes the average speed was 131 revolutions per minute. He stopped for a minute at $9^{\mathrm{b}} 26^{\mathrm{m}} \mathrm{a} . \mathrm{m}$. to urinate. The subject felt that he was in splendid condition.

2 One record, at the wrist.

3 Between the two periods the subject rode at the aversge rate of 86 revolutions per minute.

4 Work was finished at $10^{\mathrm{b}} 31^{\mathrm{m}} \mathrm{a} . \mathrm{m}$. There was delay in atarting the first rest period because of the time required to rcmedy a leak. The apparatus was finally pronounced tight after repeated testing. 
TABLE 52.-Results with subject M. A. M. (without food).

\begin{tabular}{|c|c|c|c|c|c|c|c|c|}
\hline Date and time. & Duration. & $\begin{array}{c}\text { Carbon } \\
\text { dioxide } \\
\text { eliminated } \\
\text { per minute. }\end{array}$ & $\begin{array}{c}\text { Oxygen } \\
\text { absorbed } \\
\text { per } \\
\text { minute. }\end{array}$ & $\begin{array}{l}\text { Respira- } \\
\text { tory } \\
\text { quotient. }\end{array}$ & $\begin{array}{l}\text { Aver- } \\
\text { age } \\
\text { pulse- } \\
\text { rate. }\end{array}$ & $\begin{array}{c}\text { Average } \\
\text { respira- } \\
\text { tion-rate. }\end{array}$ & $\begin{array}{l}\text { Cur- } \\
\text { rent. }\end{array}$ & $\begin{array}{l}\text { Revolu- } \\
\text { tions per } \\
\text { minute. }\end{array}$ \\
\hline 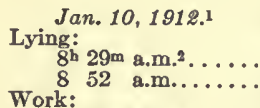 & $\begin{array}{cl}\min . & 8 e c . \\
14 & 53 \\
14 & 49\end{array}$ & $\begin{array}{l}c . c . \\
206 \\
211\end{array}$ & $\begin{array}{l}\text { c.c. } \\
258 \\
259\end{array}$ & $\begin{array}{r}0.80 \\
.81\end{array}$ & $\begin{array}{l}64 \\
66\end{array}$ & $\begin{array}{l}20 \\
20\end{array}$ & $\begin{array}{c}a m p . \\
\quad . \\
.\end{array}$ & $\cdots$ \\
\hline 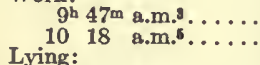 & $\begin{array}{ll}10 & 06 \\
10 & 07\end{array}$ & $\begin{array}{l}1,786 \\
1,872\end{array}$ & $\begin{array}{l}2,092 \\
2,035\end{array}$ & $\begin{array}{l}.86 \\
.92\end{array}$ & $\begin{array}{l}4168 \\
1156\end{array}$ & $\begin{array}{l}28 \\
30\end{array}$ & $\begin{array}{l}0.9 \\
0.9\end{array}$ & $\begin{array}{l}96.1 \\
95.3\end{array}$ \\
\hline 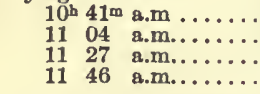 & $\begin{array}{ll}15 & 05 \\
14 & 25 \\
13 & 41 \\
14 & 37\end{array}$ & $\begin{array}{l}247 \\
225 \\
228 \\
219\end{array}$ & $\begin{array}{l}333 \\
308 \\
316 \\
310\end{array}$ & $\begin{array}{l}.75 \\
.73 \\
.73 \\
.71\end{array}$ & $\begin{array}{l}89 \\
89 \\
86 \\
84\end{array}$ & $\begin{array}{l}28 \\
24 \\
22 \\
23\end{array}$ & $\begin{array}{l}\ldots \\
\cdots\end{array}$ & $\begin{array}{l}\cdots \\
\cdots \\
\cdots\end{array}$ \\
\hline
\end{tabular}

1 See table 49 for experiment on January $16,1912$.

2 The subject lay down at $8^{\mathrm{h}} 05^{\mathrm{m}}$ a.m. The pulse-rate at $8^{\mathrm{h}} 14^{\mathrm{m}}$ a.m. was $68^{\text {; }}$ at $8^{\mathrm{h}} 20^{\mathrm{m}}$ a.m., $8^{\mathrm{h}} 23^{\mathrm{m}}$ a.m., and $8^{\mathrm{b}} 25^{\mathrm{m}}$ a.m., 64 .

3 Work was begun at $9^{\mathrm{b}} 16^{\mathrm{m}} \mathrm{a} . \mathrm{m}$. The average speed from $9^{\mathrm{h}} 16^{\mathrm{m}}$ a.m. to $9^{\mathrm{h}} 47^{\mathrm{m}}$ a.m. was 118 revolutions per minute, though the subject rode as rapidly as 136 revolutions per minute. The speed at $9^{\mathrm{h}} 41^{\mathrm{m}} \mathrm{a} . \mathrm{m}$. was about 120 revolutions per minute, when he slowed down. by direction, to about 83 revolutions per minute. The subject said he felt in excellent condition while at work, and he looked as if he were.

4 One record, at the wrist.

5 Between the two periods the subject rode at the average speed of 86 revolutions per minute, though much of the time he rode as rapidly as 95 revolutions per minute. At the beginning of the second period through accident the rotary blower was not started and therefore for about one-half minute the subject rebreathed while hard at work. He showed all the usual symptoms of impending collapse. As soon as the rotary blower was started and a liberal allowance of oxygen was given, the symptoms disappeared very rapidly. After that he continued the work with ease.

TABLE 53.-Results with subject M. A. M. (without food, following 1 day with carbohydratepoor diet).

\begin{tabular}{|c|c|c|c|c|c|c|c|c|}
\hline Date and time. & Duration. & $\begin{array}{c}\text { Carbon } \\
\text { dioxide } \\
\text { eliminated } \\
\text { per minute. }\end{array}$ & $\begin{array}{l}\text { Oxygen } \\
\text { absorbed } \\
\text { per } \\
\text { minute. }\end{array}$ & $\begin{array}{l}\text { Respira- } \\
\text { tory } \\
\text { quotient. }\end{array}$ & $\begin{array}{l}\text { Aver- } \\
\text { age } \\
\text { pulse- } \\
\text { rate. }\end{array}$ & $\begin{array}{l}\text { Average } \\
\text { respira- } \\
\text { tion-rate. }\end{array}$ & $\begin{array}{l}\text { Cur- } \\
\text { rent. }\end{array}$ & $\begin{array}{l}\text { Revolu- } \\
\text { tions per } \\
\text { minute. }\end{array}$ \\
\hline 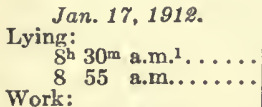 & $\begin{array}{cl}\min . & \text { sec. } \\
14 & 44 \\
15 & 09\end{array}$ & $\begin{array}{l}\text { c.c. } \\
196 \\
187\end{array}$ & $\begin{array}{l}\text { c.c. } \\
253 \\
249\end{array}$ & $\begin{array}{r}0.78 \\
.76\end{array}$ & $\begin{array}{l}61 \\
60\end{array}$ & $\begin{array}{l}20 \\
20\end{array}$ & $\begin{array}{c}a m p . \\
\cdots \\
\cdots\end{array}$ & $\ldots$ \\
\hline $\begin{array}{ccc}9^{\mathrm{h}} & 33^{\mathrm{m}} & \text { a.m. } \\
10^{2} & 08 & \text { a.m. }\end{array} \ldots \ldots$ & $\begin{array}{ll}10 & 34 \\
14 & 12\end{array}$ & $\begin{array}{l}1,893 \\
1,756\end{array}$ & $\begin{array}{l}2,055 \\
2,143\end{array}$ & $\begin{array}{l}.92 \\
.82\end{array}$ & $\begin{array}{l}161 \\
155\end{array}$ & $\begin{array}{l}36 \\
36\end{array}$ & $\begin{array}{l}0.9 \\
0.9\end{array}$ & $\begin{array}{r}101.4 \\
91.2\end{array}$ \\
\hline $\begin{array}{l}\text { Lying: } \\
\begin{array}{rll}10^{\mathrm{h}} & 35^{\mathrm{m}} & \text { a.m. } \\
11 & 04 & \text { a.m. } \ldots \ldots \ldots \\
11 & 28 & \text { a.m...... } \\
11 & 49 & \text { a.m..... }\end{array}\end{array}$ & $\begin{array}{ll}16 & 19 \\
14 & 51 \\
14 & 45 \\
15 & 00\end{array}$ & $\begin{array}{l}233 \\
205 \\
216 \\
220\end{array}$ & $\begin{array}{l}335 \\
296 \\
283 \\
286\end{array}$ & $\begin{array}{l}.70 \\
.70 \\
.76 \\
.77\end{array}$ & $\begin{array}{l}89 \\
84 \\
83 \\
80\end{array}$ & $\begin{array}{l}28 \\
24 \\
24 \\
26\end{array}$ & $\begin{array}{l}\cdots \\
\cdots \\
\cdots\end{array}$ & $\begin{array}{l}\cdots \\
\cdots \\
\cdots \\
\cdots\end{array}$ \\
\hline
\end{tabular}

1 The subject said the muscles of his body were stiff and he felt as if he needed a rubdown. He lay absolutely still during the period.

2 Work was begun at $9^{\mathrm{h}} 18^{\mathrm{m}}$ a.m. Between $9^{\mathrm{b}} 18^{\mathrm{m}}$ a.m. and $9^{\mathrm{h}} 3^{\mathrm{m}} \mathrm{a}$.m. the subject rode at the average rate of about 104 revolutions per minute, though for the first 5 minutes he rode at the average rate of 134 revolutions per minute.

3 Between the two periods the subject rode at the average speed of 87 revolutions per minute. During the period the work was carried out with comparative ease, though the subject looked much fatigued at the

4 Work ceased at $10^{\mathrm{h}} 22^{\mathrm{m}}$ a.m. The subject was then rubbed vigorously with liniment and towels and lay down at $10^{\mathrm{h}} 28^{\mathrm{m}}$ a.m. He lay very quietly. He made the statement that he was very tired and hungry and felt just as if he had ridden 100 miles. 
TABLE 54.-Results with subject M. A. M. (without food, following 2 days with carbohydratepoor diet).

\begin{tabular}{|c|c|c|c|c|c|c|c|c|}
\hline Date and time. & Duration. & $\begin{array}{l}\text { Carbon } \\
\text { dioxide } \\
\text { eliminated } \\
\text { per minute. }\end{array}$ & $\begin{array}{l}\text { Oxygen } \\
\text { absorbed } \\
\text { per } \\
\text { minute. }\end{array}$ & $\begin{array}{l}\text { Respira- } \\
\text { tory } \\
\text { quotient. }\end{array}$ & $\begin{array}{l}\text { Aver- } \\
\text { age } \\
\text { pulse- } \\
\text { rate. }\end{array}$ & $\begin{array}{l}\text { Average } \\
\text { respira- } \\
\text { tion-rate. }\end{array}$ & $\begin{array}{l}\text { Cur- } \\
\text { rent. }\end{array}$ & $\begin{array}{l}\text { Revolu- } \\
\text { tions per } \\
\text { minute. }\end{array}$ \\
\hline $\begin{array}{l}\text { Jan. } 18,1912 . \\
\text { Lying: } \\
\delta^{\text {b }} 30 \mathrm{~m} \text { a.m.1 } \ldots \ldots . \\
8 \text { a.m. } 54 \ldots \ldots\end{array}$ & $\begin{array}{ll}\min . & \text { sec. } \\
15 & 12 \\
15 & 00\end{array}$ & $\begin{array}{l}\text { c.c. } \\
197 \\
205\end{array}$ & $\begin{array}{l}c . c . \\
255 \\
267\end{array}$ & 0.77 & $\begin{array}{l}63 \\
62\end{array}$ & $\begin{array}{l}24 \\
24\end{array}$ & $\begin{array}{c}a m p . \\
\ldots \\
\ldots\end{array}$ & $\ldots$ \\
\hline $\begin{array}{c}9^{\mathrm{h}} 32^{\mathrm{m}} \text { a.m.2. . . . . } \\
10 \text { it am.4 } \ldots \\
\text { Lying: }\end{array}$ & $\begin{array}{rr}8 & 27 \\
10 & 52\end{array}$ & $\begin{array}{l}1,817 \\
1,460\end{array}$ & $\begin{array}{l}2,498 \\
1,977\end{array}$ & $\begin{array}{l}.73 \\
.74\end{array}$ & $\begin{array}{l}172 \\
161\end{array}$ & $\begin{array}{l}40 \\
30\end{array}$ & $\begin{array}{l}0.9 \\
0.9\end{array}$ & $\begin{array}{r}116.2 \\
84.8\end{array}$ \\
\hline 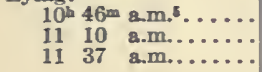 & $\begin{array}{ll}14 & 56 \\
15 & 25 \\
17 & 26\end{array}$ & $\begin{array}{l}211 \\
222 \\
203\end{array}$ & $\begin{array}{l}311 \\
309 \\
297\end{array}$ & $\begin{array}{l}.68 \\
.72 \\
.69\end{array}$ & $\begin{array}{l}87 \\
84 \\
84\end{array}$ & $\begin{array}{l}26 \\
22 \\
24\end{array}$ & $\begin{array}{l}\cdots \\
\cdots\end{array}$ & $\begin{array}{l}\ldots \\
\cdots \\
\cdots\end{array}$ \\
\hline
\end{tabular}

1 The aubject complained that he felt stiff and tired and had no particular inclination to work. He did not feel like "breaking any records." He lay very quietly.

2 He lay very still. There was some disturbance because of sereral people coming into the room toward the end of the period. His attention was also taken up with preparations being made for taking samples of his alveolar air.

3 Work was begun at $9^{\mathrm{b}} 20 \mathrm{~m} \mathrm{a} \mathrm{m}$. Between $9 \mathrm{~h} 20^{\mathrm{m}} \mathrm{a} . \mathrm{m}$. and $9^{\mathrm{h}} 32^{\mathrm{m}} \mathrm{a} . \mathrm{m}$. the subject rode at the arerage speed of 95 revolutions per minute, though for the first 5 minutes he rode at the rate of 114 revolutions per minute. Carbon dioxide was found to be passing the absorbers at $9 \mathrm{~b} 40^{\mathrm{m}} \mathrm{a} . \mathrm{m}$. because of very poor soda-lime. The subject had all the symptoms of impending collapse. He said he could go on, but the period was ended.

- Between the two periods the subject rode at the average rate of 76 revolutions per minute, more rapidly at first. At $10^{\mathrm{m}} 07_{\mathrm{m}}^{\mathrm{m}} \mathrm{am}$. he rode 94 revolutions in one-half minute. At $10^{\mathrm{h}} 24^{\mathrm{m}} \mathrm{g}$.m. carbon dioxide wras detected passing the absorbers. The subject was not looking well, and the period was therefore ended. As in the preceding period the soda-lime was found to be poor.

5 Work ceased at $10^{\mathrm{b}} 25^{\mathrm{m}} \mathrm{am}$. The subject felt very hungry at about $10 \mathrm{p} . \mathrm{m}$. the night before. He felt tired when rising time came, and lacked energy. During the week he felt very tired and was disinclined to exert himself. In the half minute $\left(10^{\circ} 07 \mathrm{~m} \mathrm{am}\right.$. ) in which he did exert himself, the effort was too great. He could not work as hard as usual and felt that he had somehow lost his strength. He was very hungry. Samples of his slveolar air were taken at about $10^{\mathrm{t}} 10^{\mathrm{m}} \mathrm{am}$. during work and at $10^{\mathrm{b}} 26^{\mathrm{m}} \mathrm{am} . \mathrm{m}, 10^{\mathrm{b}} 45^{\mathrm{m}} \mathrm{am}$., $11^{\mathrm{b}} 05^{\mathrm{m}} \mathrm{a} \cdot \mathrm{m}, 11^{\mathrm{b}} 30^{\mathrm{m}} \mathrm{am}$. and $11^{\mathrm{b}} 57^{\mathrm{m}} \mathrm{am}$., after the work was finished.

TABLE 55.-Results with subject M. A. M. (without food, following 3 days with carbohydratepoor diet).

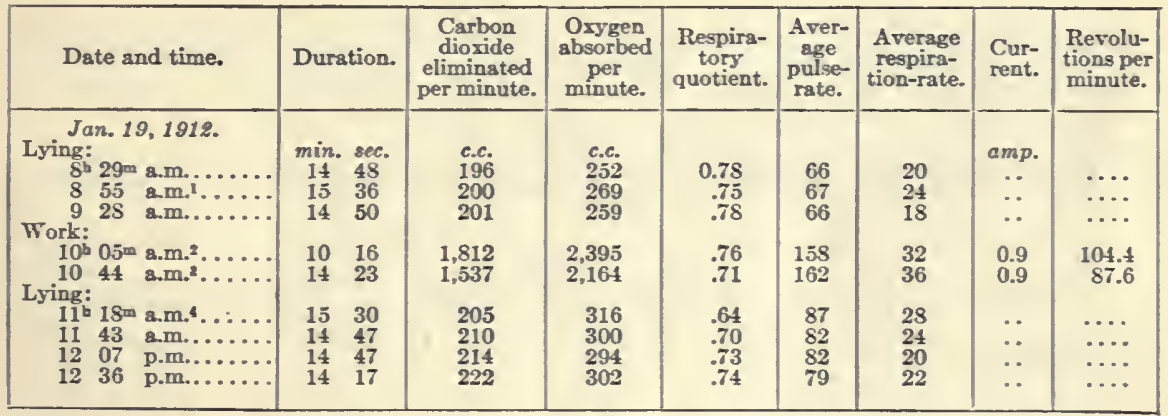

1 Between the first and second periods samples of alveolar air were taken, causing the subject to move his body somewhat on the couch. The same movements of the body occurred on Jan. 18, when the samples were taken.

2 Work was begun at $9^{\mathrm{b}} 52^{\mathrm{m}} \mathrm{am}$. Between $9^{\mathrm{h}} 52^{\mathrm{m}} \mathrm{a} . \mathrm{m}$. and $10^{\mathrm{b}} 05^{\mathrm{m}} \mathrm{a} . \mathrm{m}$. the subject rode at the average speed of 94 revolutions per minute, during the first 5 minutes at the rate of 113 revolutions per minute. He found the work extremely hard and fatiguing and thought he had broken all his previous records.

3 Between the two periods the subject rode at the average speed of 68 revolutions per minute. At about $10^{\mathrm{b}} 30^{\mathrm{m}} \mathrm{am}$. he rode 98 revolutions in 30 seconds. The work was apparently laborious. The subject was positive that he was doing far hander work on this day than on earlier days when his diet was varied in character. He denied that he would not work because he thought the food was not right for him. He said that he was putting forth the best that was in him. The subject felt more tired than ever after work.

4 Work ceased at $10^{\mathrm{h}} 59 \mathrm{~m}$ a.m. Between 5 and 10 minutes later samples of alveolar air were taken. A number of samples of alveolar air were taken during the day while the subject was lying before work, sitting on the ergometer before work, during work, and while lying after work. 
TABLE 56.-Results with subject M. A. M. (without food, following 1 day with carbohydraterich diet).

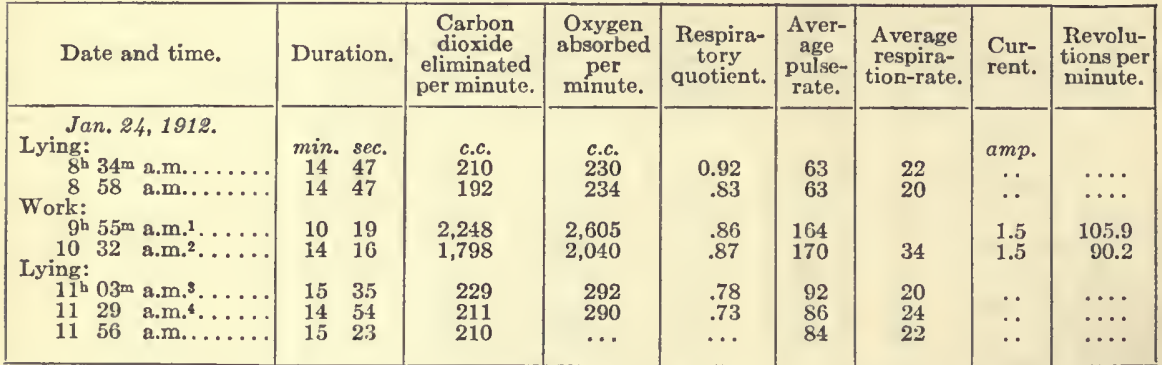

1 Work was begun at $9^{\mathrm{b}} 43^{\mathrm{m}}$ a.m. Between $9^{\mathrm{b}} 43^{\mathrm{m}}$ a.m. and $9^{\mathrm{b}} 55^{\mathrm{m}}$ a.m. the subject rode at the average rate of 106 revolutions per minute; in the first 5 minutes at the rate of 119 revolutions per minute. The work in the period seemed to be readily done. The subject complained that he found the work harder than at the close of the last experiment on Jan. 19. He thought he was out of practice.

2 Between the two periods the subjeet rode at the average rate of 83 revolutions per minute. At $10^{\mathrm{h}} 24^{\mathrm{m}}$ a.m. he rode 91 revolutions in one-half minute.

3 Work ceased at about $10^{\mathrm{b}} 46^{\mathrm{m}} \mathrm{a} . \mathrm{m}$.

- The respiration was extremely irregular and very shallow.

TABLE 57.-Results with subject M. A. M. (without food, following 2 days with carbohydraterich diet).

\begin{tabular}{|c|c|c|c|c|c|c|c|c|}
\hline Date and time. & Duration. & $\begin{array}{l}\text { Carbon } \\
\text { dioxide } \\
\text { eliminated } \\
\text { per minute. }\end{array}$ & $\begin{array}{c}\text { Oxygen } \\
\text { absorbed } \\
\text { per } \\
\text { minute. }\end{array}$ & $\begin{array}{l}\text { Respira- } \\
\text { tory } \\
\text { quotient. }\end{array}$ & $\begin{array}{l}\text { Aver- } \\
\text { age } \\
\text { pulse- } \\
\text { rate. }\end{array}$ & $\begin{array}{l}\text { Average } \\
\text { respira- } \\
\text { tion-rate. }\end{array}$ & $\begin{array}{l}\text { Cur- } \\
\text { rent. }\end{array}$ & $\begin{array}{l}\text { Revolu- } \\
\text { tions per } \\
\text { minute. }\end{array}$ \\
\hline 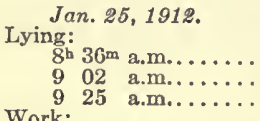 & $\begin{array}{cl}\min . & \text { sec. } \\
14 & 41 \\
15 & 07 \\
15 & 12\end{array}$ & $\begin{array}{l}c . c . \\
202 \\
201 \\
195\end{array}$ & $\begin{array}{l}\text { c.c. } \\
260 \\
236 \\
251\end{array}$ & $\begin{array}{r}0.78 \\
.85 \\
.78\end{array}$ & $\begin{array}{l}63 \\
64 \\
63\end{array}$ & $\begin{array}{l}20 \\
20 \\
20\end{array}$ & $\begin{array}{c}a m p . \\
\because \\
\cdots\end{array}$ & $\cdots$ \\
\hline $\begin{array}{r}9^{\mathrm{b}} 59^{\mathrm{m}} \text { a.m. } \\
10 \\
47\end{array}$ & $\begin{array}{ll}10 & 09 \\
13 & 37\end{array}$ & $\begin{array}{l}2,296 \\
2,040\end{array}$ & $\begin{array}{l}2,452 \\
2,303\end{array}$ & $\begin{array}{l}.94 \\
.89\end{array}$ & $\begin{array}{l}164 \\
168\end{array}$ & $\begin{array}{l}36 \\
40\end{array}$ & $\begin{array}{l}1.5 \\
1.5\end{array}$ & $\begin{array}{l}112.2 \\
102.3\end{array}$ \\
\hline 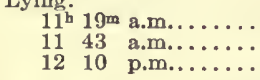 & $\begin{array}{ll}15 & 14 \\
14 & 51 \\
15 & 06\end{array}$ & $\begin{array}{l}218 \\
207 \\
212\end{array}$ & $\begin{array}{l}287 \\
262 \\
272\end{array}$ & $\begin{array}{l}.76 \\
.79 \\
.78\end{array}$ & $\begin{array}{l}89 \\
84 \\
84\end{array}$ & $\begin{array}{l}22 \\
\ddot{2} \dot{4}\end{array}$ & $\begin{array}{l}\cdots \\
\cdots\end{array}$ & $\begin{array}{l}\cdots \\
\cdots\end{array}$ \\
\hline
\end{tabular}

1 Work was begun at $9^{\mathrm{b}} 47^{\mathrm{m}}$ a.m. Between $9^{\mathrm{b}} 47^{\mathrm{m}}$ a.m. and $9^{\mathrm{h}} 59^{\mathrm{m}}$ a.m. the subject rode at an average rate of 96 rcvolutions per minute.

2 Between the two periods the subject rode at the average rate of 88 revolutions per minute. At $10^{\mathrm{h}} 28^{\mathrm{m}}$ a.m. he rode 91 revolutions in one-half minute. Work was finished at $11^{\mathrm{b}} 01^{\mathrm{m}} \mathrm{a} . \mathrm{m}$.

TABLE 58.-Results with subject M. A. M. (without food, following 3 days with carbohydraterich diet).

\begin{tabular}{|c|c|c|c|c|c|c|c|c|}
\hline Date and time. & Duration. & $\begin{array}{c}\text { Carbon } \\
\text { dioxide } \\
\text { eliminated } \\
\text { per minute. }\end{array}$ & $\begin{array}{c}\text { Oxygen } \\
\text { absorbed } \\
\text { per } \\
\text { minute. }\end{array}$ & $\begin{array}{l}\text { Respira- } \\
\text { tory } \\
\text { quotient. }\end{array}$ & $\begin{array}{l}\text { Aver- } \\
\text { age } \\
\text { pulse- } \\
\text { rate. }\end{array}$ & $\begin{array}{l}\text { Average } \\
\text { respira- } \\
\text { tion-rate. }\end{array}$ & $\begin{array}{l}\text { Cur- } \\
\text { rent. }\end{array}$ & $\begin{array}{l}\text { Revolu- } \\
\text { tions per } \\
\text { minute. }\end{array}$ \\
\hline 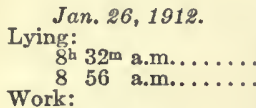 & $\begin{array}{cc}\min & \text { sec. } \\
15 & 23 \\
15 & 15\end{array}$ & $\begin{array}{l}\text { c.c. } \\
204 \\
200\end{array}$ & $\begin{array}{l}\text { c.c. } \\
240 \\
233\end{array}$ & $\begin{array}{r}0.86 \\
.86\end{array}$ & $\begin{array}{l}63 \\
64\end{array}$ & $\begin{array}{l}22 \\
24\end{array}$ & $\begin{array}{l}a m p . \\
\cdots \\
\cdots\end{array}$ & $\cdots \cdot$ \\
\hline 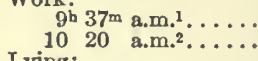 & $\begin{array}{ll}10 & 12 \\
14 & 08\end{array}$ & $\begin{array}{l}2,425 \\
1,767\end{array}$ & $\begin{array}{l}2,906 \\
2,167\end{array}$ & $\begin{array}{l}.84 \\
.82\end{array}$ & 157 & $\dot{34}$ & $\begin{array}{l}1.5 \\
1.5\end{array}$ & $\begin{array}{r}114.0 \\
90.9\end{array}$ \\
\hline 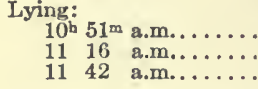 & $\begin{array}{ll}14 & 52 \\
16 & 21 \\
14 & 58\end{array}$ & $\begin{array}{l}211 \\
214 \\
204\end{array}$ & $\begin{array}{l}268 \\
266 \\
266\end{array}$ & $\begin{array}{l}.79 \\
.81 \\
.77\end{array}$ & $\begin{array}{l}85 \\
82 \\
81\end{array}$ & $\begin{array}{l}24 \\
24 \\
24\end{array}$ & $\begin{array}{l}\cdots \\
\cdots\end{array}$ & $\cdots \cdots$ \\
\hline
\end{tabular}

1 Work was begun at $9^{\mathrm{b}} 23^{\mathrm{m}}$ a.m. Between $9^{\mathrm{h}} 23^{\mathrm{ma}}$ a.m. and $9^{\mathrm{h}} 37^{\mathrm{m}} \mathrm{a}$.m. the subject rode at the average rate of 89 revolutions per minute, but at the rate of about 96 revolutions per minute between $9^{\mathrm{k}} 23^{\mathrm{m}} \mathrm{a} . \mathrm{m}$. and $9 \mathrm{~b} 33^{\mathrm{m}}$ a.m.

2 Between the two periods the subject rode at the average rate of 80 revolutions per minute. Once before the period he rode 97 revolutions in one-half minute. Work ended at $10^{\mathrm{b}} 35^{\mathrm{m}}$ a.m. The subject said after the period that he felt very tired and exhausted. 
TABLE 59.-Results with subject M. A. M. (without food).

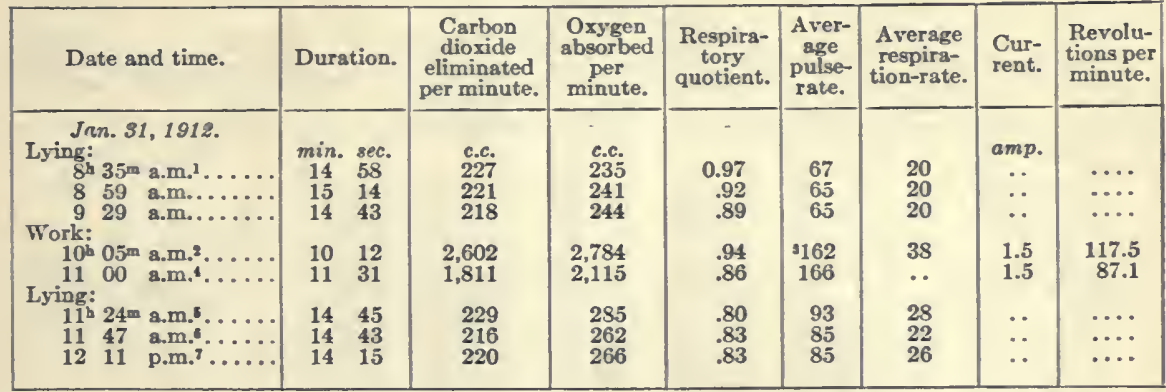

1 The subject lay down at 8 a.m. The pulse-rate at $8^{\mathrm{h}} 20^{\mathrm{m}} \mathrm{a.m}$. Was $72 ;$ at $8^{\mathrm{h}} 24^{\mathrm{m}}, 8^{\mathrm{h}} 27^{\mathrm{m}}, 8^{\mathrm{h}} 32^{\mathrm{m}}$ a.m., it was 68 .

2 Work was begun at $9^{\mathrm{h}} 48^{\mathrm{m}} \mathrm{a} . \mathrm{m}$. and for 5 minutes the subject rode at the rate of 112 revolutions per minute. After that the riding was somewhat interrupted because of blowing of fuses and about 8 minutes was lost from work. Sweating was profuse, but not abnormally so.

3 One record, at wrist.

1 After the preceding period work was stopped for about 21 minutes due to an accident in testing the resistance of the ergometer. During this time the subject sat quite still on the bicycle, without working. Work was resumed at $10^{\mathrm{h}} 36^{\mathrm{m}} \mathrm{a} . \mathrm{m}$. The subject felt cold and physically less fit. He had lost all his eagerness, whereas he had felt in good riding condition before. Between $10^{b} 44^{\mathrm{m}}$ a.m. and 11 a.m. when the second period began, he rode at the average rate of about 85 revolutions per minute.

5 Work was finished at $11^{\mathrm{b}} 12^{\mathrm{m}} \mathrm{am}$. "The subject coughed once or twice in the first "lying" period, and swallowed a little saliva.

6 The subject was very sleepy and there was a tendency for the lips to relax. The lips were plastered up firmly.

7 Mouth was plastered up.

TABLE 60.-Results with subject M. A. M. (without food).

\begin{tabular}{|c|c|c|c|c|c|c|c|c|}
\hline Date and time. & Duration. & $\begin{array}{c}\text { Carbon } \\
\text { dioxide } \\
\text { eliminated } \\
\text { per minute. }\end{array}$ & $\begin{array}{l}\text { Oxygen } \\
\text { absorbed } \\
\text { per } \\
\text { minute. }\end{array}$ & $\begin{array}{l}\text { Respira- } \\
\text { tory } \\
\text { quotient. }\end{array}$ & $\begin{array}{l}\text { Aver- } \\
\text { age } \\
\text { pulse- } \\
\text { rate. }\end{array}$ & $\begin{array}{l}\text { Average } \\
\text { respira- } \\
\text { tion-rate. }\end{array}$ & $\begin{array}{l}\text { Cur- } \\
\text { rent. }\end{array}$ & $\begin{array}{l}\text { Revolu- } \\
\text { tions per } \\
\text { minute. }\end{array}$ \\
\hline 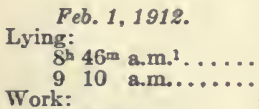 & $\begin{array}{cl}\min . & s e c . \\
17 & 06 \\
16 & 23\end{array}$ & $\begin{array}{l}\text { c.c. } \\
212 \\
216\end{array}$ & $\begin{array}{l}\text { c.c. } \\
239 \\
242\end{array}$ & $\begin{array}{r}0.89 \\
.89\end{array}$ & $\begin{array}{l}68 \\
68\end{array}$ & $\begin{array}{l}20 \\
20\end{array}$ & $\begin{array}{c}a m p . \\
\cdots \\
\cdots\end{array}$ & $\cdots$ \\
\hline 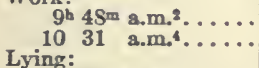 & $\begin{array}{ll}10 & 07 \\
14 & 07\end{array}$ & $\begin{array}{l}2,358 \\
1,785\end{array}$ & $\begin{array}{l}2,604 \\
2,010\end{array}$ & $\begin{array}{l}.91 \\
.89\end{array}$ & $\begin{array}{l}3 \\
3 \\
161\end{array}$ & $\begin{array}{l}36 \\
38\end{array}$ & $\begin{array}{l}1.5 \\
1.5\end{array}$ & $\begin{array}{r}113.1 \\
90.1\end{array}$ \\
\hline 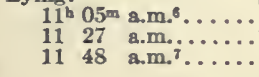 & $\begin{array}{ll}14 & 35 \\
14 & 32 \\
14 & 44\end{array}$ & $\begin{array}{l}217 \\
207 \\
218\end{array}$ & $\begin{array}{l}280 \\
279 \\
280\end{array}$ & $\begin{array}{l}.78 \\
.74 \\
.78\end{array}$ & $\begin{array}{l}91 \\
85 \\
81\end{array}$ & $\begin{array}{l}24 \\
22 \\
20\end{array}$ & $\begin{array}{l}\because \\
\therefore\end{array}$ & $\begin{array}{l}\cdots \\
\cdots\end{array}$ \\
\hline
\end{tabular}

1 The subject put his mouth to the mouthpiece 17 minutes before the first period was begun.

2 Work was started at $9^{\mathrm{b}} 35^{\mathrm{m}} \mathrm{am}$. Between $9^{\mathrm{b}} 35^{\mathrm{m}} \mathrm{a.m}$. and $9^{\mathrm{b}} 48^{\mathrm{m}} \mathrm{a.m}$. the subject rode at the average rate of about 96 revolutions per minute.

3 One record, at the wrist.

4 Between the two work-periods the subject rode at the average rate of about 73 revolutions per minute. At $10^{\mathrm{h}} 13^{\mathrm{m}} \mathrm{a} . \mathrm{m}$. he rode 103 revolutions in one-half minute and was in consequence very much exhausted. The subject said he felt in splendid form for work.

5 At the wrist.

6 Work was finished at $10^{\mathrm{b}} 46^{\mathrm{m}} \mathrm{a} . \mathrm{m}$. The subject lay down at $10^{\mathrm{h}} 50^{\mathrm{m}} \mathrm{a} . \mathrm{m}$.

7 The subject took 3 or 4 very long deep breaths during this period. He said be felt the need of breath. He was absolutely unable to urinate after the experimeat. 
TABLE 61.-Results with subject M. A. M. (without food).

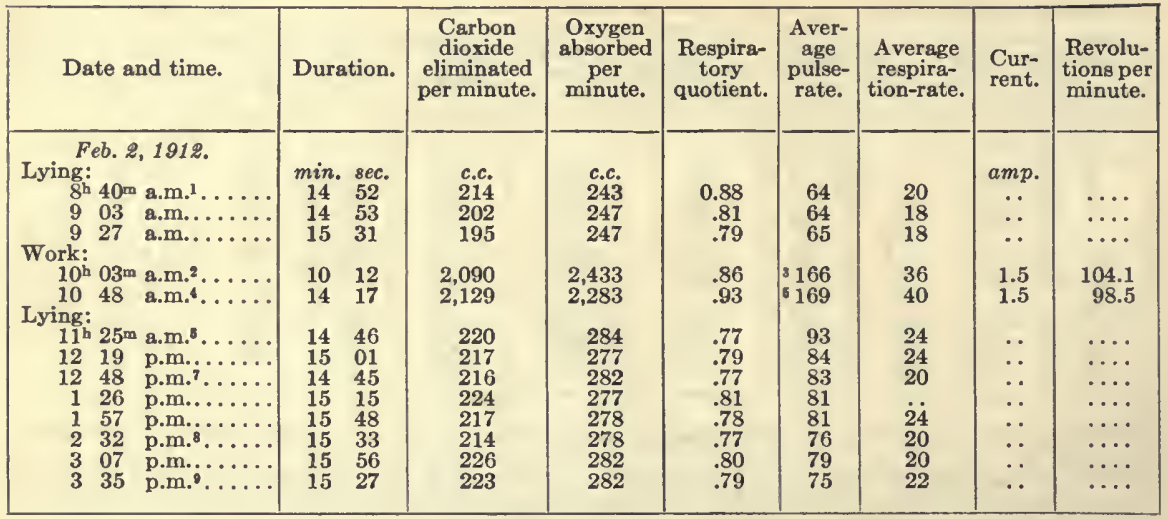

1 The subject lay down at $8^{\mathrm{b}} 05^{\mathrm{m}}$ a.m. The pulse-rate at $8^{\mathrm{b}} 27^{\mathrm{m}}$ a.m. was 68 ; at $8^{\mathrm{b}} 32^{\mathrm{ma}}$ a.m., 66 .

2 Work was begun at $9^{\mathrm{h}} 49 \mathrm{~m} \mathrm{a} . \mathrm{m}$. Between $9 \mathrm{~h} 49 \mathrm{~m} \mathrm{am}$. and $10^{\mathrm{h}} 03^{\mathrm{m}} \mathrm{g} . \mathrm{m}$. the subject rode at the average rate of 109.5 revolutions per minute. A portion of the time he rode as rapidly as 126 revolutions per minute. 3 One record at the wrist.

4 Between the two periods the subject rode at the average rate of 93 revolutions per minute. Part of the time he rode as rapidly as 113 revolutions per minute. During the period the handle-bars were loosened. The subject became restless because of the swinging of the loose bars. He also had trouble with the pedals.

5 At the wrist.

6 Work was finished at $11^{\mathrm{h}} 03^{\mathrm{m}} \mathrm{g} . \mathrm{m}$

7 The subject's respiration was very shallow and irregular.

8 The subject rose from the couch at $2^{\mathrm{b}} 24^{\mathrm{m}} \mathrm{p} . \mathrm{m}$. and walked about slowly, stretched himself, and then lay down. The total time used for these operations was one and one-half minutes. The pulse rate at $2^{\mathrm{b}}$ $30^{\mathrm{m}}$ p.m. was 78

The subject was tired and hungry at the end of the experiment. He was also suffering from cramp of the lips, owing to the fact that he had held bis mouth to the mouthpiece so frequently.

TABLE 62.-Results with subject M. A. M. (without food).

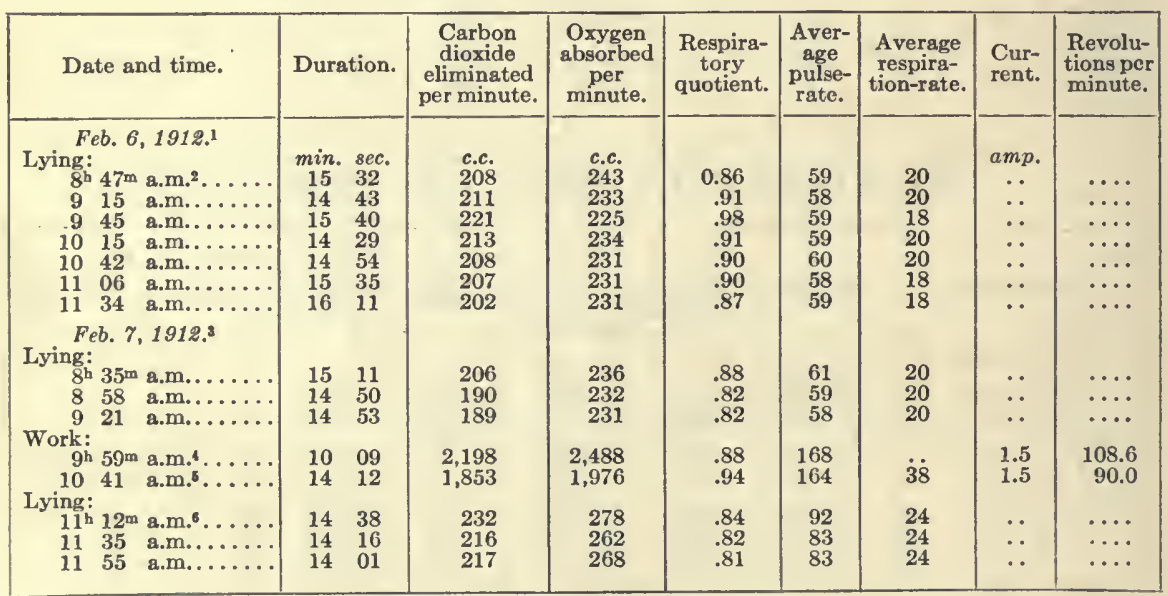

1 The experiment of Feb. 6 was made following several days with ordinary diet, and was a test of the flexible connection for the mouthpiece. This connection was not used in the first four periods; it was uscd in the last three periods.

2 Pulse at $8^{\mathrm{h}} 23^{\mathrm{m}}$ a.m. was 64 ; at $8 \mathrm{~h} 27 \mathrm{~m}$ a.m., 64 .

3 After 1 day with carbohydrate-poor diet.

Work of 105 revolutions per minute. During the first 5 minutes he rode at the rate of 121 revolutions per minute. He did not feel that he was in as good condition as during the preceding week, though he was very fit.

6 Between the two periods the subject rode at the average rate of 89 per minute.

6 Work was finished at $10^{\mathrm{b}} 57^{\mathrm{m}} \mathrm{a} . \mathrm{m}$. Subject lay down at $11^{\mathrm{b}} 03^{\mathrm{m}} \mathrm{a.1n}$. 
TABLE 63.-Results with sutject M. A. M. (without food, following 2 days with carbohydratepoor diet).

\begin{tabular}{|c|c|c|c|c|c|c|c|c|}
\hline Date and time. & Duration. & $\begin{array}{l}\text { Carbon } \\
\text { dioxide } \\
\text { eliminated } \\
\text { per minute. }\end{array}$ & $\begin{array}{l}\text { Oxygen } \\
\text { absorbed } \\
\text { per } \\
\text { minute. }\end{array}$ & $\begin{array}{l}\text { Respira- } \\
\text { tory } \\
\text { quotient. }\end{array}$ & $\begin{array}{l}\text { Aver- } \\
\text { age } \\
\text { pulse- } \\
\text { rate. }\end{array}$ & $\begin{array}{l}\text { Average } \\
\text { respira- } \\
\text { tion-rate. }\end{array}$ & $\begin{array}{l}\text { Cur- } \\
\text { rent. }\end{array}$ & $\begin{array}{l}\text { Revolu- } \\
\text { tions per } \\
\text { minute. }\end{array}$ \\
\hline 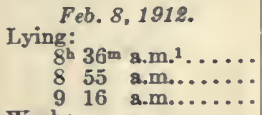 & $\begin{array}{cl}\min & \text { sec. } \\
14 & 33 \\
14 & 24 \\
14 & 48\end{array}$ & $\begin{array}{l}\text { c.c. } \\
208 \\
206 \\
208\end{array}$ & $\begin{array}{l}c . c . \\
260 \\
254 \\
254\end{array}$ & $\begin{array}{r}0.80 \\
.81 \\
.82\end{array}$ & $\begin{array}{l}66 \\
67 \\
66\end{array}$ & $\begin{array}{l}20 \\
20 \\
20\end{array}$ & $\begin{array}{c}a m p . \\
\cdots \\
\cdots\end{array}$ & $\begin{array}{l}\cdots \\
\cdots \\
\cdots\end{array}$ \\
\hline 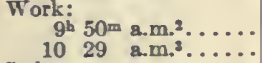 & $\begin{array}{ll}10 & 14 \\
14 & 13\end{array}$ & $\begin{array}{l}2,209 \\
1,825\end{array}$ & $\begin{array}{l}2,56.5 \\
2,146\end{array}$ & $\begin{array}{l}.86 \\
.85\end{array}$ & $\begin{array}{l}160 \\
168\end{array}$ & $\ldots$ & $\begin{array}{l}1.5 \\
1.5\end{array}$ & $\begin{array}{r}111.8 \\
93.6\end{array}$ \\
\hline 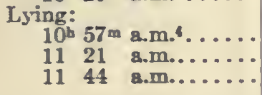 & $\begin{array}{ll}14 & 57 \\
15 & 50 \\
15 & 30\end{array}$ & $\begin{array}{l}238 \\
217 \\
218\end{array}$ & $\begin{array}{l}310 \\
290 \\
293\end{array}$ & $\begin{array}{l}.77 \\
.75 \\
.75\end{array}$ & $\begin{array}{l}96 \\
89 \\
86\end{array}$ & $\begin{array}{l}22 \\
24 \\
22\end{array}$ & $\begin{array}{l}\cdots \\
\therefore\end{array}$ & $\begin{array}{l}\cdots \\
\cdots \\
\cdots\end{array}$ \\
\hline
\end{tabular}

1 The pulse-rate at $8^{\mathrm{h}} 25^{\mathrm{m}} \mathrm{a.m}$. Was 64 ; at $8^{\mathrm{b}} 35^{\mathrm{m}}$ a.m. , 64 .

2 Work was begun at $9^{\mathrm{h}} 37^{\mathrm{m}} \mathrm{am}$. Between $9^{\mathrm{h}} 37^{\mathrm{m}} \mathrm{a.m}$, and $9^{\mathrm{h}} 50^{\mathrm{m}} \mathrm{a.m}$. the subject rode at the average rate of 100 revolutions per minute.

3 Between the two periods the subject rode at the avarage rate of 96 revolutions per minute.

4 Work was finished at $10^{\mathrm{h}} 43^{\mathrm{m}} \mathrm{am}$.

TABLE 64.-Results with subject M. A. M. (without food, following 3 days with carbohydratepoor diet).

\begin{tabular}{|c|c|c|c|c|c|c|c|c|}
\hline Date and time. & Duration. & $\begin{array}{c}\text { Carbon } \\
\text { dioxide } \\
\text { eliminated } \\
\text { per minute. }\end{array}$ & $\begin{array}{c}\text { Oxygen } \\
\text { absorbed } \\
\text { per } \\
\text { minute. }\end{array}$ & \multirow[t]{2}{*}{$\begin{array}{l}\text { Respira- } \\
\text { tory } \\
\text { quotient. }\end{array}$} & \multirow[t]{2}{*}{$\begin{array}{l}\text { Aver- } \\
\text { age } \\
\text { pulse- } \\
\text { rate. }\end{array}$} & \multirow[t]{2}{*}{$\begin{array}{l}\text { Average } \\
\text { respira- } \\
\text { tion-rate. }\end{array}$} & \multirow{3}{*}{$\begin{array}{l}\text { Cur- } \\
\text { rent. } \\
\text { amp. }\end{array}$} & $\begin{array}{l}\text { Revolu- } \\
\text { tions per } \\
\text { minute. }\end{array}$ \\
\hline Feb. 9, 1912. & & & & & & & & \\
\hline Lying: & $\min _{15} \sec$ & c.e. & $\begin{array}{l}\text { c.c. } \\
244\end{array}$ & 0.81 & 64 & 18 & & $\ldots$ \\
\hline 902 a.m.............. & $14 \quad 46$ & 191 & 237 & .81 & 67 & 20 & $\therefore$ & $\cdots$ \\
\hline 924 a.m......... & $14 \quad 56$ & 183 & 246 & .75 & 63 & 20 & $\therefore$ & $\ldots$ \\
\hline Work: $57 \mathrm{~m}$ & 10 & 1.856 & 2,342 & .79 & 162 & 28 & 1.5 & 99.9 \\
\hline $10 \quad 38$ a.m. ${ }^{2} \ldots \ldots$ & $0 \mathrm{~s}$ & 1,744 & 2,073 & .84 & 166 & 36 & 1.5 & 92.3 \\
\hline Lying: & & & & & & & & \\
\hline $11^{\text {h }} 09^{m}$ a.m.3. $\ldots \ldots$ & 15 & 217 & 296 & .74 & 85 & 24 & $\cdots$ & $\cdots$ \\
\hline $11 \quad 54$ g.m.............. & 22 & 215 & $2 S S$ & .75 & 84 & 24 & 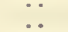 & $\cdots$ \\
\hline 1214 p.m........ & 36 & 213 & 270 & .79 & 82 & & .. & $\cdots$ \\
\hline 1235 p m......... & 14 & 209 & 264 & .79 & 83 & 22 & .. & ... \\
\hline
\end{tabular}

1 Work was begun at $9^{\mathrm{b}} 44^{\mathrm{m}}$ a.m. Between $9^{\mathrm{h}} 44^{\mathrm{m}}$ a.m. and $9 \mathrm{~b} 57^{\mathrm{m}}$ a.m. the subject rode at the average rate of 98 revolutions per minute.

2 Between the two periods the aubject rode at the average rate of 85 revolutions per minute.

Work ceased at $10^{\mathrm{h}} 53^{\mathrm{m}} \mathrm{am}$. The subject felt stiff and somewhat exhausted.

TABLE 65.-Results with subject M. A. M. (without food, following 2 days with carbohydraterich diet).

\begin{tabular}{|c|c|c|c|c|c|c|c|c|}
\hline Date and time. & Duration. & $\begin{array}{c}\text { Carbon } \\
\text { dioxide } \\
\text { eliminated } \\
\text { per minute. }\end{array}$ & $\begin{array}{c}\text { Oxygen } \\
\text { absorbed } \\
\text { per } \\
\text { minute. }\end{array}$ & $\begin{array}{l}\text { Respirs- } \\
\text { tory } \\
\text { quotient. }\end{array}$ & $\begin{array}{l}\text { Aver- } \\
\text { age } \\
\text { pulse- } \\
\text { rate. }\end{array}$ & $\begin{array}{c}\text { Average } \\
\text { respira- } \\
\text { tion-rate. }\end{array}$ & $\begin{array}{l}\text { Cur- } \\
\text { rent. }\end{array}$ & $\begin{array}{l}\text { Revolu- } \\
\text { tions per } \\
\text { minute. }\end{array}$ \\
\hline Feb. 15, 1912.1 & & & & & & & & \\
\hline Lying: & $\min . \sec$. & c.e. & c.c. & & & & amp. & \\
\hline $\mathrm{S}^{\mathrm{b}} 38^{\mathrm{m}}$ a.m.2. $\ldots \ldots$ & $14 \quad 49$ & 191 & 234 & 0.52 & 64 & 20 & . & $\cdots$ \\
\hline 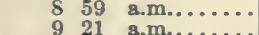 & $14 \quad 53$ & 187 & 228 & .82 & 61 & 20 & $\cdots$ & $\cdots$ \\
\hline Work: 21 a.m...... & 14 & 187 & 240 & .78 & 61 & 20 & $\cdots$ & $\cdots$ \\
\hline $9^{\mathrm{h}} 53^{m} \mathrm{~s} \cdot \mathrm{m} \cdot{ }^{3} \ldots \ldots$ & 10 & 2,237 & 2,319 & .97 & 162 & 36 & 1.5 & 109.8 \\
\hline 1036 a.m. ${ }^{5} \ldots \ldots$ & 14 & 1,870 & 2,004 & .93 & 168 & 36 & 1.5 & S9.8 \\
\hline $11^{\mathrm{b}} 04^{\mathrm{m}}$ a.m. ${ }^{7} \ldots . .$. & 14 & 245 & $2 S 4$ & .86 & 92 & 26 & .. & $\ldots$ \\
\hline 1124 a.m........ & 07 & 207 & 278 & .75 & S8 & 22 & . & $\ldots$ \\
\hline 1151 a.m........ & 13 & 209 & 253 & .83 & S5 & 20 & . & $\ldots$ \\
\hline
\end{tabular}

1 See table 66 for experiment on February 14, 1912.

2 The subject lay down at $S^{\mathrm{h}} 05^{\mathrm{m}}$ a.m. The pulse-rate at $8^{\mathrm{h}} 25^{\mathrm{m}} \mathrm{a.m}$. was 64 ; at $8^{\mathrm{h}} 34^{\mathrm{m}}$ a.m., 64 .

3 Work was begun at $9^{\mathrm{b}} 41^{\mathrm{m}} \mathrm{a.m}$. Between $9^{\mathrm{b}} 4 \mathrm{I}^{\mathrm{m}} \mathrm{a} . \mathrm{m}$. and $9^{\mathrm{h}} 53^{\mathrm{m}} \mathrm{am}$. the subject rode at the average rate of 102 revolutions per minute.

4 One record, at the wrist.

5 Between the two periods the subject rode at the aversge rate of about 90 revolutions per minute.

6 At the wrist.

7 Work ended at $10^{\mathrm{h}} 51^{\mathrm{m}} \mathrm{a}, \mathrm{m}$. The subject lay down at $10^{\mathrm{h}} 57^{\mathrm{m}} \mathrm{a} . \mathrm{m}$. 
TABLE 66.-Results with subject M. A. M. (without food, following 1 day with carbohydraterich diet).

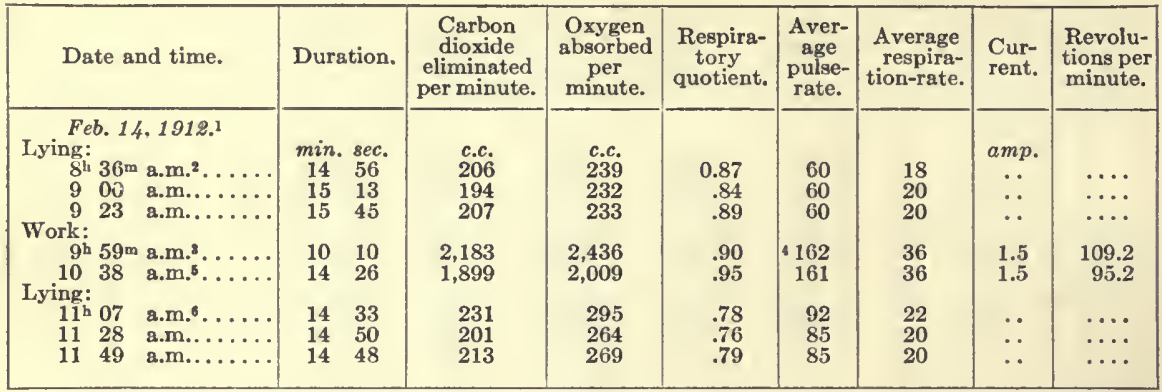

1 Sce table 65 for experiment on February $15,1912$.

2 In all experiments it was customary to have the mouth on the mouthpiece 3 to 5 minutes before the start of a period. Frequently this was done 10 minutes before the first period. The pulse-rate at $8^{\mathrm{h}} 25^{\mathrm{m}} \mathrm{a} . \mathrm{m}$. on Feb. 14 was 60 ; at $8^{\mathrm{h}} 31^{\mathrm{m}}$ a.m., 58; at $8^{\mathrm{h}} 34^{\mathrm{m}}$ a.m., 58 . The food eaten by the subject in connection with this series of experiments (Feb. 14-16) was of the same nature as in the first series with carbohydrate-rich diet (Jan. 24-26, 1912).

3 Work was begun at $9^{\mathrm{h}} 46^{\mathrm{m}}$ a.m. Between $9^{\mathrm{h}} 46^{\mathrm{m}}$ a.m. and $9^{\mathrm{h}} 59^{\mathrm{m}}$ a.m. the subject rode at the average rate of 96 revolutions per minute. He was keen to work and had to be restrained.

4 At the wrist.

5 Between the two periods the subject rode at the average rate of 87 revolutions per minute, though at first he rode as high as 101 revolutions per minute. During the period the work was easily done, with no strain. He said before he started that it was a long time since he felt in such excellent riding mood. He felt that he could ride for hours.

Work ceased at $10^{\mathrm{b}} 53^{\mathrm{m}} \mathrm{a} . \mathrm{m}$.

TABLE 67.-Results with subject $M$. A. M. (without food, following 3 days with carbohydraterich diet).

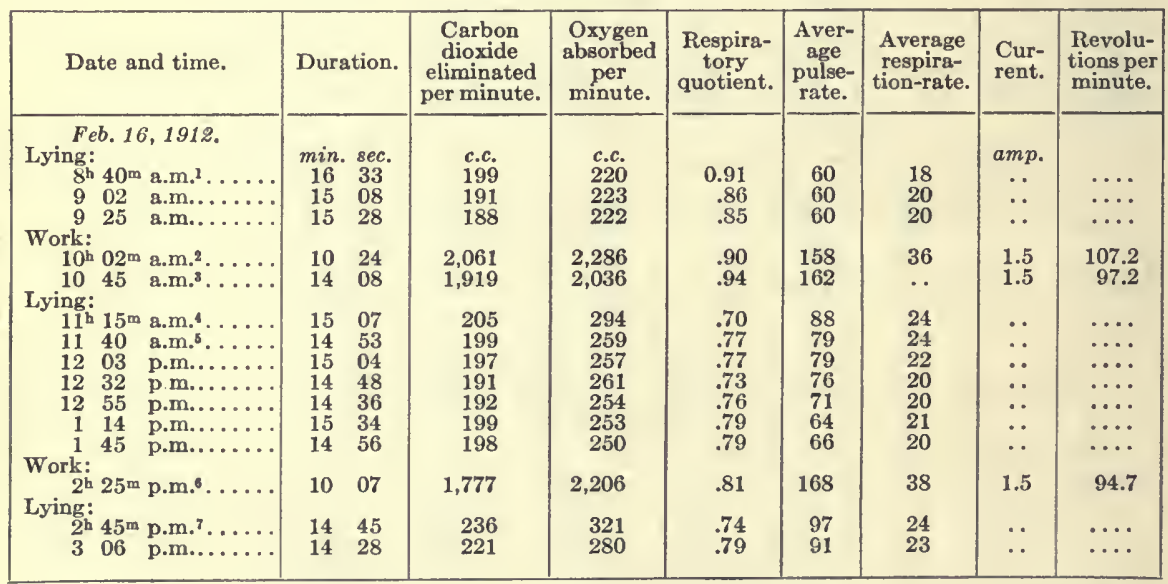

1 The subject lay down at $8^{\mathrm{h}} 10^{\mathrm{m}}$ a.m. The pulse-rate at $8^{\mathrm{h}} 25^{\mathrm{m}}$ a.m. was $64 ;$ at $8^{\mathrm{h}} 30^{\mathrm{m}}$ a.m., $64 ;$ at $8^{\mathrm{h}} 35^{\mathrm{m}}$

2 Work was begun at $9^{\mathrm{h}} 50^{\mathrm{m}}$ a.m. Between $9^{\mathrm{h}} 50^{\mathrm{m}}$ a.m. and $10^{\mathrm{h}} 02^{\mathrm{m}}$ a.m. the subject rode at the average rate of 111 revolutions per minute.

3 Between the two periods the subject rode at the average rate of 89 revolutions per minute. At $10^{\mathrm{h}} 20^{\mathrm{m}}$ a.m. a sample of the alveolar air was taken and this caused a slowing of speed. A sample of the alveolar air was also taken at $10^{\mathrm{h}} 42^{\mathrm{m}}$ a.m.

1 Work was finished at $11 \mathrm{a.m}$. A sample of the alveolar air was taken at $11^{\mathrm{b}} 05^{\mathrm{m}}$ a.m. The subject lay down at $11^{\mathrm{h}} 06^{\mathrm{m}}$ a.m.

6 A sample of the alvcolar air was taken at $11^{\mathrm{b}} 35^{\mathrm{m}}$ a.m.

6 Work was started again at $2^{\mathrm{h}} 05^{\mathrm{m}}$ p.m. Between $2^{\mathrm{h}} 05^{\mathrm{m}}$ p.m. and $2^{\mathrm{h}} 25^{\mathrm{m}}$ p.m. the subject rode at the average rate of 115 revolutions per minute, the highest rate being 145 revolutions in the second 5 minutes and the lowest 76 revolutions in the last 5 minutes.

7 Work was finished at $2^{\mathrm{b}} 36^{\mathrm{m}} \mathrm{p} . \mathrm{m}$. The subject lay down at $2^{\mathrm{h}} 40^{\mathrm{m}} \mathrm{p} . \mathrm{m}$. 
TABLE 68.-Results with subject M. A. M. (without food).

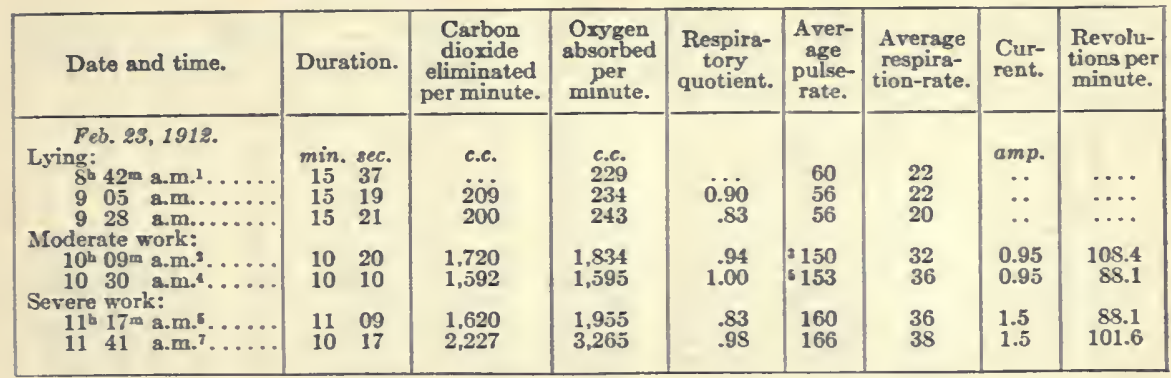

1 The subject lay down at $8^{\mathrm{h}} 05^{\mathrm{m}} \mathrm{a} . \mathrm{m}$. The pulse-rate at $\mathrm{S}^{\mathrm{h}} 30^{\mathrm{m}} \mathrm{a.m}$. was 58 ; at $8^{\mathrm{h}} 40^{\mathrm{m}} \mathrm{a.m} .56$.

2 Work was begun at $9^{\mathrm{b}} 50^{\mathrm{m}} \mathrm{a.m}$. Between $9^{\mathrm{b}} 50^{\mathrm{m}}$ a.m. and $10^{\mathrm{h}} 09^{\mathrm{m}} \mathrm{a}$.m. the subject rode at the average rate of 114 revolutions per minute, the rate for the first 10 minutes being 129 per minute.

3 One record, at wrist.

1 Carbon dioxide sccumulated in the circuit because of the condition of the soda-lime. By mistake soda-lime was being used which had already absorbed 20 grams of carbon dioxide. The subject showed no signs somewhat exhausted for a short time but that the feeling did not last long. The average speed in the interval before this period was 103 revolutions per minute.

6 Average of records taken at the wrist.

B Between the end of the preceding period at $10^{\mathrm{h}} 40^{\mathrm{m}} \mathrm{am}$. and $11^{\mathrm{b}} 02^{\mathrm{m}} \mathrm{a} . \mathrm{m}$., the subject rode at the average rate of about 101 revolutions per minute. At $11^{\mathrm{h}} 02^{\mathrm{m}} \mathrm{a.m}$. the current was increased to 1.5 amperes. From that time till the beginning of the next period at $11^{\mathrm{h}} 1 \mathrm{i}^{\mathrm{m}} \mathrm{a} . \mathrm{m}$., the average speed was 80 per minute. During the period the aubject found that there was now a good deal of labor involved. It was much harder than usual. No carbon dioxide was detected in the circuit.

7 Between the two periods with a current of 1.5 amperes the subject rode at the average rate of 73 revolutions per minute. During this last period the work was done with great difficulty. He was bathed in perspiration and looked strained. He was unsteady on his feet when he came of the machine. He said he did not remember when he had done such hard work.

TABLE 69.-Results with subject $M . A . M$. (without food).

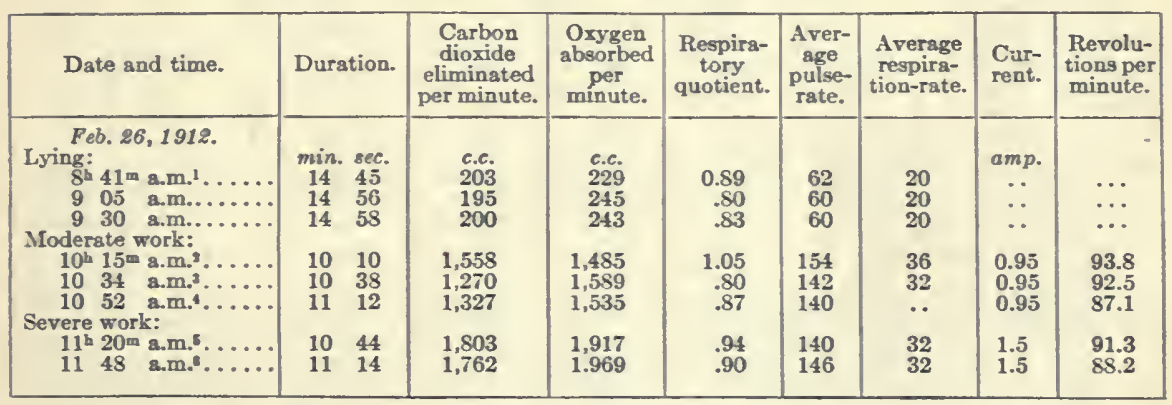

1 The sublect lay down at $\delta^{\mathrm{h}} 05^{\mathrm{m}}$ a.m. The pulse-rate at $\delta^{\mathrm{h}} 30^{\mathrm{m}} \mathrm{am}$. was 62 .

2 Work was begun at $9^{\mathrm{b}} 55^{\mathrm{m}}$ am. Between $9^{\mathrm{b}} 55^{\mathrm{m}} \mathrm{a.m}$. and $10^{\mathrm{h}} 15^{\mathrm{m}} \mathrm{a.m}$. the average rate was 91 revolutions per minute.

3 In the interval before this period the subject rode at the average rate of 94 revolutions per minute. During the period work was done much more easily than during the preceding period. It did not seem labored.

4 In the interval before this period the average speed was 94 revolutions per minute.

6 At $11^{\mathrm{h}} 04^{\mathrm{m}} \mathrm{a} . \mathrm{m}$. the current was increased to $1.5 \mathrm{amperes}$. The subject kept at work at a slow pace, the average speed to the beginning of the period being 76 revolutions per minute. He did not notice the transfer from 0.95 ampere to 1.5 amperes. He began to labor when his attention was called to the change, but afterwards admitted it was not so very hard. During the period work was easily and steadily done, though perspiration was more marked.

- Between the last two periods the average speed was 70 revolutions per minute. During the last period the work was done with comparative ease, though the subject's breathing was perhaps a little labored. 
TABLE 70.-Results with subject M. A. M. (without food).

\begin{tabular}{|c|c|c|c|c|c|c|c|c|}
\hline Date and time. & Duration. & $\begin{array}{l}\text { Carbon } \\
\text { dioxide } \\
\text { eliminated } \\
\text { per minute. }\end{array}$ & $\begin{array}{l}\text { Oxygen } \\
\text { absorbed } \\
\text { per } \\
\text { minute. }\end{array}$ & $\begin{array}{l}\text { Respira- } \\
\text { tory } \\
\text { quotient. }\end{array}$ & $\begin{array}{l}\text { Aver- } \\
\text { age } \\
\text { pulse- } \\
\text { rate. }\end{array}$ & $\begin{array}{l}\text { Average } \\
\text { respira- } \\
\text { tion-rate. }\end{array}$ & $\begin{array}{l}\text { Cur- } \\
\text { rent. }\end{array}$ & $\begin{array}{l}\text { Revolu- } \\
\text { tions per } \\
\text { minute. }\end{array}$ \\
\hline 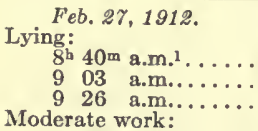 & $\begin{array}{ll}\min . & \text { sec. } \\
14 & 50 \\
15 & 13 \\
15 & 56\end{array}$ & $\begin{array}{l}c . c . \\
218 \\
202 \\
208\end{array}$ & $\begin{array}{l}\text { c.c. } \\
242 \\
241 \\
235\end{array}$ & $\begin{array}{r}0.90 \\
.84 \\
.89\end{array}$ & $\begin{array}{l}56 \\
56 \\
56\end{array}$ & $\begin{array}{l}20 \\
20 \\
18\end{array}$ & $\begin{array}{c}a m p . \\
\cdots \\
\cdots\end{array}$ & $\ddot{\cdots}$ \\
\hline 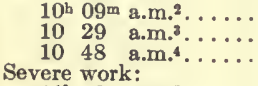 & $\begin{array}{ll}12 & 17 \\
11 & 38 \\
10 & 44\end{array}$ & $\begin{array}{l}1,224 \\
1,185 \\
1,280\end{array}$ & $\begin{array}{l}1,490 \\
1,418 \\
1,444\end{array}$ & $\begin{array}{l}.82 \\
.84 \\
.89\end{array}$ & $\begin{array}{l}126 \\
126 \\
125\end{array}$ & $\begin{array}{l}26 \\
28 \\
28\end{array}$ & $\begin{array}{l}0.95 \\
0.95 \\
0.95\end{array}$ & $\begin{array}{l}83.3 \\
81.8 \\
86.0\end{array}$ \\
\hline $\begin{array}{lll}11^{\mathrm{h}} & 16^{\mathrm{m}} & \text { a.m. } \\
11 & 36 & \text { a.m. } \\
11 & 59 & \text { a.m. } \\
11 & \ldots\end{array}$ & $\begin{array}{ll}10 & 24 \\
10 & 16 \\
10 & 18\end{array}$ & $\begin{array}{l}1,773 \\
1,722 \\
1,789\end{array}$ & $\begin{array}{l}1,828 \\
1,858 \\
1,850\end{array}$ & $\begin{array}{l}.97 \\
.93 \\
.97\end{array}$ & $\begin{array}{l}146 \\
146 \\
154\end{array}$ & $\begin{array}{l}32 \\
36 \\
34\end{array}$ & $\begin{array}{l}1.5 \\
1.5 \\
1.5\end{array}$ & $\begin{array}{l}88.2 \\
86.8 \\
88.7\end{array}$ \\
\hline
\end{tabular}

1 The subject lay down at $8^{\mathrm{b}} 07^{\mathrm{m}}$ a.m. The pulse-rate at $8^{\mathrm{b}} 30^{\mathrm{m}}$ a.m. was 56 .

2 Work was begun at $9^{\mathrm{h}} 49^{\mathrm{m}}$ a.m. Between $9^{\mathrm{h}} 49^{\mathrm{m}}$ a.m. and $10^{\mathrm{b}} 09^{\mathrm{m}}$ a.m. the average rate was 91 revolutions per minute. Mouth was put to the mouthpiece 5 minutes before the first period.

3 In the interval before this period the average rate was 76 revolutions per minute.

4 Between the second and third work-periods the average rate of work was 75 per minute.

5 At $10^{\mathrm{h}} 59^{\mathrm{m}}$ a.m. the current was increased to 1.5 amperes. He noticed the change in the current, which was made very rapidly, though it was believed that he had a suspicion the change was to be made. On testing this subject as to whether he were really sensitive to amall changes in resistance, it was found that he could easily tell when the resistance was at 1.5 amperes. It was immaterial whether the test were made starting from below at 0.25 ampere, or coming down from 3.0 amperes, as in each case the subject stated almost exactly when the 1.5 amperes was reached. Between $10^{\mathrm{b}} 59^{\mathrm{m}} \mathrm{a} . \mathrm{m}$. and $11^{\mathrm{b}}$ $16^{\text {m }}$ a.m. the subject rode at the average rate of 74 revolutions per minute: He perspired quite freely during the period, though the work was easily done. Once during the period he lost his toe-clip.

6 The average speed in the interval before this period was 74 revolutions per minute. During.the period the work was done without any difficulty.

7 The average speed in the interval before this period was about 57 (?) per minute. During the period work was done easily, but the subject's breathing was rather labored. He did not feel exhausted or that he had worked excessively hard. He thought he was "pushing" a little harder.

TABLE 71.-Results with subject M. A. M. (without food).

\begin{tabular}{|c|c|c|c|c|c|c|c|c|}
\hline Date and time. & Duration. & $\begin{array}{l}\text { Carbon } \\
\text { dioxide } \\
\text { eliminated } \\
\text { per minute. }\end{array}$ & $\begin{array}{l}\text { Oxygen } \\
\text { absorbed } \\
\text { per } \\
\text { minute. }\end{array}$ & $\begin{array}{l}\text { Respira- } \\
\text { tory } \\
\text { quotient. }\end{array}$ & $\begin{array}{l}\text { Aver- } \\
\text { age } \\
\text { pulse- } \\
\text { rate. }\end{array}$ & $\begin{array}{l}\text { Average } \\
\text { respira- } \\
\text { tion-rate. }\end{array}$ & $\begin{array}{l}\text { Cur- } \\
\text { rent. }\end{array}$ & $\begin{array}{l}\text { Revolu- } \\
\text { tions per } \\
\text { minute. }\end{array}$ \\
\hline $\begin{array}{l}\text { Feb. } 28,1912 . \\
\text { Light work: } \\
8^{\text {h }} 51^{\mathrm{m}} \text { a.m.1 } \ldots \ldots \\
9 \text { a.m. } 15 \text { a.m. } \ldots \ldots \ldots \\
948 \text { a.m. } \ldots \ldots \ldots \\
\text { Severe work: }\end{array}$ & $\begin{array}{ll}\min & \text { sec. } \\
15 & 03 \\
11 & 36 \\
11 & 23\end{array}$ & $\begin{array}{l}\text { c.c. } \\
871 \\
970 \\
999\end{array}$ & $\begin{array}{l}\text { c.c. } \\
1,070 \\
1,170 \\
1,254\end{array}$ & $\begin{array}{r}0.82 \\
.83 \\
.80\end{array}$ & $\begin{array}{l}100 \\
126 \\
124\end{array}$ & $\begin{array}{l}20 \\
24 \\
24\end{array}$ & $\begin{array}{l}a m p . \\
0.5 \\
0.5 \\
0.5\end{array}$ & $\begin{array}{r}95.7 \\
102.0 \\
103.5\end{array}$ \\
\hline 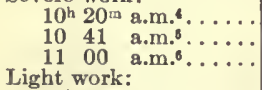 & $\begin{array}{ll}10 & 25 \\
10 & 14 \\
10 & 08\end{array}$ & $\begin{array}{l}2,284 \\
2,030 \\
2,212\end{array}$ & $\begin{array}{l}2,356 \\
2,101 \\
2,144\end{array}$ & $\begin{array}{r}.97 \\
.97 \\
1.03\end{array}$ & $\begin{array}{l}163 \\
160 \\
\cdots\end{array}$ & $\begin{array}{c}36 \\
38 \\
\ldots\end{array}$ & $\begin{array}{l}1.5 \\
1.5 \\
1.5\end{array}$ & $\begin{array}{r}107.5 \\
96.7 \\
99.5\end{array}$ \\
\hline 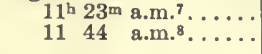 & $\begin{array}{ll}10 & 14 \\
14 & 11\end{array}$ & $\begin{array}{l}1,056 \\
1,141\end{array}$ & $\begin{array}{l}1,134 \\
1,215\end{array}$ & $\begin{array}{l}.93 \\
.94\end{array}$ & $\begin{array}{l}127 \\
130\end{array}$ & $\begin{array}{l}30 \\
28\end{array}$ & $\begin{array}{l}0.5 \\
0.5\end{array}$ & $\begin{array}{r}100.0 \\
99.1\end{array}$ \\
\hline
\end{tabular}

1 Work was begun at $8^{\text {h }} 22^{\mathrm{m}}$ a.m. without preliminary lying periods. Betwcen $8^{\mathrm{h}} 22^{\mathrm{m}}$ a.m. and $8^{\mathrm{h}} 51^{\mathrm{m}}$ a.m. the subject rode at the average rate of 94 revolutions per minute. During the period the work was done easily and well, though it was somewhat difficult to keep him up to the 100 mark, the atandard speed for the day.

2 In the interval between the first two periods the subject rode at the average rate of 110 revolutions per minute.

3 Bctween the second and third periods the subject rode at the average rate of 92 revolutions per minute. Throughout the first three periods with current at 0.5 ampere there was no free perspiration.

4 At $10^{\mathrm{h}} 01^{\mathrm{m}} \mathrm{a} . \mathrm{m}$. the current was increased to 1.5 amperes. From $10^{\mathrm{h}} 01^{\mathrm{m}} \mathrm{a} . \mathrm{m}$. to $10^{\mathrm{h}} 20^{\mathrm{m}} \mathrm{a} . \mathrm{m}$. the subject rode at the average rate of 91 revolutions per minute. During the period he found the work very hard and almost gave up at about the end of seven minutes. He looked tired, but otherwise was all right. He thought a mistake had been made with the current.

5 In the interval before this period the average speed was 78 revolutions per minute. During the period the work was done with great difficulty and the speed fell off steadily toward the end. The work became very labored.

6 In the interval before this period the average speed was 84 revolutions per minute. At the end of the fourth minute of the period he looked very tired. His breathing became more labored. He was completely exhausted at the end of the period and admitted that he had reached his limit.

7 At $11^{\mathrm{h}} 11^{\mathrm{m}} \mathrm{a} . \mathrm{m}$. the current was lowered to $0.5 \mathrm{ampere}$. From the end of the preceding period to $11^{\mathrm{h}} 23^{\mathrm{m}} \mathrm{a} . \mathrm{m}$. the subject rode at the average rate of about 70 revolutions per minute. During the period the work was very easily done. The subject had a good color. The speed began to fall off just at the close. The subject said he was very tired and that his arms and wrists were sore from holding the handle bars.

8 In the interval before this period the average speed was 86 revolutions per minute. The subject complained that his wrists, hands, and arms were very sore and stiff. During the period his feet slipped from the pedals several times. (He was not usiug toe-clips.) When he stopped pedaling at the end, his legs showed a good deal of tremor. 
TABLE 72.-Results with subject M. A. M. (without food).

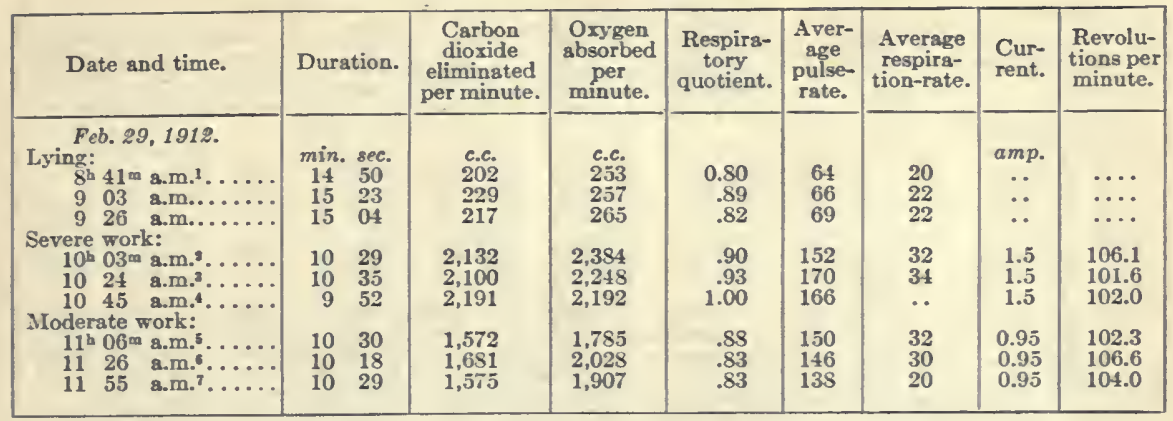

1 The subject lay down at $8^{\mathrm{h}} 07^{\mathrm{m}}$ a.m. The pulse-rate at $8^{\mathrm{h}} 25^{\mathrm{m}}$ a.m. was $64 ;$ at $8^{\mathrm{h}} 35^{\mathrm{m}}$ a.m., 61 .

Work was begun at $9^{\mathrm{h}} 47^{\mathrm{m}} \mathrm{a} . \mathrm{m}$. Between $9^{\mathrm{h}} 47^{\mathrm{m}} \mathrm{am}$. and $10^{\mathrm{h}} 03^{\mathrm{m}} \mathrm{am}$. the subject rode at the average rate of 109 revolutions per minute.

3 In the interval before this period the average speed was 84 revolutions per minute.

4 In the interval before this period the sverage speed was 81 revolutions per minute. The full 10 minutes for the period were not completed as the subject was manifestly fatigued. He admitted at the end of the period that he was much exhausted.

5 At $10^{\mathrm{h}} 56^{\mathrm{m}} \mathrm{a} . \mathrm{m}$. the current was lowered to 0.95 ampere. Between $10^{\mathrm{h}} 56^{\mathrm{m}}$ a.m. and $11^{\mathrm{h}} 06^{\mathrm{m}}$ a.m. the average speed was 76 revolutions per minute.

6 In the interval before this period the average speed was 83 revolutions per minute.

7 In the interval before this period the average speed was 77 revolutions per minute. The subject had now fully recovered from his hard work. During the two preceding periods at 0.95 ampere, however, he was still feeling the effect of the previous hard work.

TABLE 73.-Results with subject M. A. M. (without food).

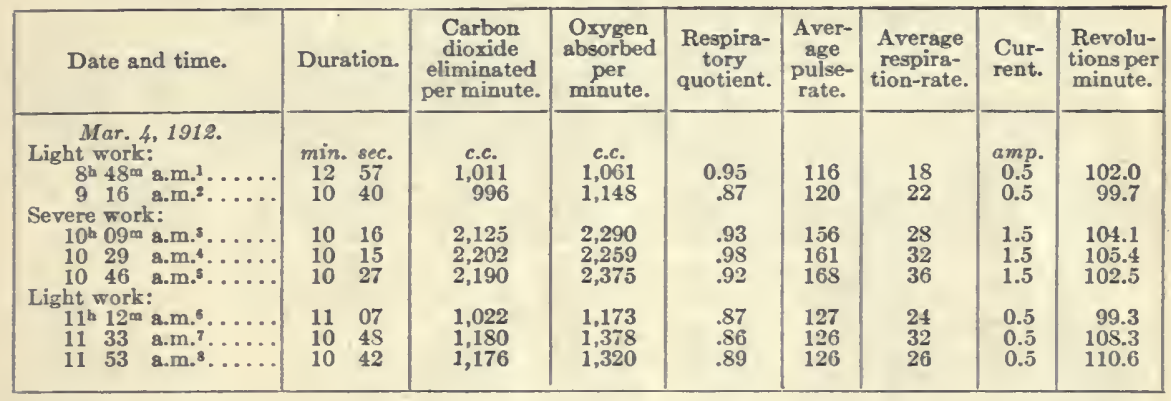

1 Work was begun at $8^{\mathrm{b}} 15^{\mathrm{m}} \mathrm{a} . \mathrm{m}$. without preliminary lying periods. Between $8^{\mathrm{h}} 15^{\mathrm{m}} \mathrm{a} . \mathrm{m}$. and $8^{\mathrm{h}} 4 \mathrm{~S}^{\mathrm{ma}}$ a.m. the subject rode at the average rate of 120 revolutions per minute. It was difficult to keep hirn from racing. The plan was to keep the speed practically constant throughout the day.

2 In the interval before this period the average speed was 95 revolutions per minute.

3 From the end of the preceding period to $9^{\mathrm{b}} 49^{\mathrm{an}} \mathrm{a} . \mathrm{m}$. the subject rode at the average rate of about 99 revolutions per minute. At $9^{\mathrm{h}} 49^{\mathrm{m}}$ a.m. the current was increased to 1.5 amperes and the handle bars were raised. The raising of the handle bars helped his wrists and arms. Between $9^{\mathrm{h}} 49 \mathrm{~m} \mathrm{a} . \mathrm{m} . \mathrm{and} 10^{\mathrm{h}} 09_{\mathrm{m}}$ a.m. the subject rode at the average speed of 94 revolutions per minute. There was again a tendency to race. Sweating was somewhat profuse.

4 In the interval before this period the average speed was 82 revolutions per minute.

6 In the interval before this period the average speed was 120 revolutions per minute. There was still a tendency to race.

6 At $10^{\mathrm{b}} 57_{\mathrm{m}} \mathrm{am}$. the current was lowered to 0.5 ampere. Between $10^{\mathrm{h}} 57_{\mathrm{m}} \mathrm{am}$. and $11^{\mathrm{b}} 12^{\mathrm{m}}$ a.m. the average speed was 96 revolutions per minute. It was constantly necessary to restrain the subject in order to prevent overspeeding.

7 In the interval before this period the average speed was 87 revolutions per minute.

8 In the interval before this period the average speed was 89 revolutions per minute. Dr. W. G. Anderson was present during the period and the subject's speed could not be checked so readily. He was inclined to ride fast and "show off." Dr. Anderson examined the subject. 
TABLE 74.-Results with subject M. A. M. (without food).

\begin{tabular}{|c|c|c|c|c|c|c|c|c|}
\hline Date and time . & Duration. & $\begin{array}{l}\text { Carbon } \\
\text { dioxide } \\
\text { eliminated } \\
\text { per minute. }\end{array}$ & $\begin{array}{c}\text { Oxygen } \\
\text { absorbed } \\
\text { per } \\
\text { minute. }\end{array}$ & $\begin{array}{l}\text { Respira- } \\
\text { tory } \\
\text { quotient. }\end{array}$ & $\begin{array}{l}\text { Aver- } \\
\text { age } \\
\text { pulse- } \\
\text { rate. }\end{array}$ & $\begin{array}{c}\text { Average } \\
\text { respira- } \\
\text { tion-rate. }\end{array}$ & $\begin{array}{l}\text { Cur- } \\
\text { rent. }\end{array}$ & $\begin{array}{l}\text { Revolu- } \\
\text { tions per } \\
\text { minute. }\end{array}$ \\
\hline$\underset{M a r}{\operatorname{Mar}} 6,1912$. & & & & & & & & \\
\hline $8^{\mathrm{h}} 47^{\mathrm{m}}$ a.m.... & 1305 & 235 & $26 \mathrm{i}$ & 0.90 & 64 & 221 &.. & \\
\hline 925 a.m.......... & 1342 & 229 & 257 & .89 & 64 & 221 & $\ldots$ & $\ldots$ \\
\hline 947 a.m....... & 1348 & 225 & 258 & .87 & 62 & 222 & .. & $\cdots$ \\
\hline $10^{\mathrm{h}} 14^{\mathrm{m}}$ a.m. ${ }^{2} \ldots \ldots$ & 22 & 2,751 & 2,976 & .93 & 160 & 36 & 1.5 & 127.8 \\
\hline $\begin{array}{c}10 \\
54\end{array}$ a.m.4. & 10 & 2,537 & 2,685 & .95 & 177 & 40 & 1.5 & 113.3 \\
\hline $11^{\mathrm{b}} 15^{\mathrm{m}}$ a.m.5 & 14 & 251 & 333 & .76 & 95 & 228 & .. & $\ldots$ \\
\hline 1137 a.m........ & 14 & 225 & 316 & .71 & 88 & 224 & .. & $\ldots$ \\
\hline 1158 a.m........ & 45 & 220 & 298 & .74 & 88 & 224 & . & $\cdots \cdot$ \\
\hline 1220 p.m.... & 46 & 224 & 293 & .77 & 81 & ${ }^{2} 22$ & .. & $\ldots$ \\
\hline
\end{tabular}

1 The "lying" periods were run on another respiration apparatus located on the third floor of the laboratory. The ventilation of the lungs was measured in these periods. After the first three periods the subject went downstairs to the first floor for the work experiment. He returned to the third floor at the completion of the work periods.

2 The respiration rate while the subject was on the couch was for the full period, as recorded by the spirometer.

3 Work was begun at $10^{\mathrm{h}} 04^{\mathrm{m}}$ a.m. Between $10^{\mathrm{h}} 04^{\mathrm{m}} \mathrm{a} . \mathrm{m}$. and $10^{\mathrm{h}} 14^{\mathrm{m}} \mathrm{a} . \mathrm{m}$. the average speed was 105 revolutions per minute. There was very much perspiration and Bushing. The plan was for the subject to work as rapidly and as hard as be could.

4 Between the two work-periods the average speed was 115 revolutions per minute. During the second period the work went well. At the end of 7.5 minutes, however, the subject was somewhat exhausted and had to ride more slowly. He increased his speed again later, however. He was very much flushed and perspired profusely.

5 Work was finished at $11^{\mathrm{b}} 05^{\mathrm{m}}$ a.m. He immediately changed to the apparatus on the third floor. He was later reported as having a "jump" in his leg, i. e., a "tonio spasm.".

TABLE 75.-Results with subject M. A. M. (without food). (Ergometer II.)

\begin{tabular}{|c|c|c|c|c|c|c|c|c|}
\hline Date and time. & Duration. & $\begin{array}{l}\text { Carbon } \\
\text { dioxide } \\
\text { eliminated } \\
\text { per minute. }\end{array}$ & $\begin{array}{c}\text { Oxygen } \\
\text { absorbed } \\
\text { per } \\
\text { minute. }\end{array}$ & $\begin{array}{l}\text { Respira- } \\
\text { tory } \\
\text { quotient. }\end{array}$ & $\begin{array}{l}\text { Aver- } \\
\text { age } \\
\text { pulse- } \\
\text { rate. }\end{array}$ & $\begin{array}{l}\text { Average } \\
\text { respira- } \\
\text { tion-rate. }\end{array}$ & $\begin{array}{l}\text { Cur- } \\
\text { rent. }\end{array}$ & $\begin{array}{l}\text { Revolu- } \\
\text { tions per } \\
\text { minute. }\end{array}$ \\
\hline 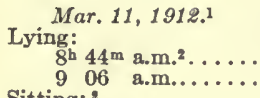 & $\begin{array}{cl}\min . & \text { sec. } \\
14 & 46 \\
16 & 14\end{array}$ & $\begin{array}{l}c . c . \\
218 \\
212\end{array}$ & $\begin{array}{l}\text { c.c. } \\
245 \\
248\end{array}$ & $\begin{array}{r}0.89 \\
.85\end{array}$ & $\begin{array}{l}60 \\
60\end{array}$ & $\begin{array}{l}20 \\
21\end{array}$ & $\begin{array}{c}a m p . \\
\cdots \\
\cdots\end{array}$ & $\cdots \cdots$ \\
\hline $\begin{array}{l}\text { Sitting: } \\
9^{\mathrm{h}}{ }^{2} \\
105^{\mathrm{m}} \text { a.m.4. } \ldots \ldots \\
23 \text { a.m........ } \\
\text { No load with motor: }\end{array}$ & $\begin{array}{ll}13 & 26 \\
10 & 25\end{array}$ & $\begin{array}{l}306 \\
258\end{array}$ & $\begin{array}{l}395 \\
376\end{array}$ & $\begin{array}{l}.78 \\
.69\end{array}$ & $\begin{array}{l}84 \\
81\end{array}$ & $\begin{array}{l}20 \\
20\end{array}$ & $\because$ & $\cdots$ \\
\hline $\begin{array}{r}10^{\mathrm{h}} 55^{\mathrm{m}} \text { a.m. } \\
11 \\
\text { Work: }\end{array}$ & $\begin{array}{ll}10 & 04 \\
11 & 45\end{array}$ & $\begin{array}{l}703 \\
634\end{array}$ & $\begin{array}{l}742 \\
744\end{array}$ & $\begin{array}{l}.95 \\
.85\end{array}$ & $\because$ & $\because$ & $\because$ & $\begin{array}{l}103.7 \\
101.0\end{array}$ \\
\hline 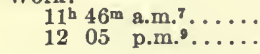 & $\begin{array}{ll}10 & 23 \\
10 & 51\end{array}$ & $\begin{array}{l}2,066 \\
2,057\end{array}$ & $\begin{array}{l}2,299 \\
2,220\end{array}$ & $\begin{array}{l}.90 \\
.93\end{array}$ & $\begin{array}{l}8156 \\
8150\end{array}$ & $\because$ & $\begin{array}{l}1.5 \\
1.5\end{array}$ & $\begin{array}{l}102.2 \\
100.7\end{array}$ \\
\hline
\end{tabular}

1 See table 77 for experiment on March 8, 1912.

2 The subject lay down at $8^{\mathrm{h}} 05^{\mathrm{m}} \mathrm{a} . \mathrm{m}$. The pulse-rate at $8^{\mathrm{h}} 25^{\mathrm{m}}$ a.m. was 62 ; at $8^{\mathrm{b}} 28^{\mathrm{m}}$ a.m., 60 ; at $8^{\mathrm{h}} 40^{\mathrm{m}}$

a.m., 60 .
3 The subject sat on the ordinary seat with his feet on unsupported pedals, $i$. $e$., with the disk perfectly free.

The subject sat on the ordinary seat with his feet on unsupported pedals, i. e., with the disk perfectly free.
4 From $9^{\mathrm{h}} 27^{\mathrm{m}} \mathrm{a} . \mathrm{m}$. to $9^{\mathrm{h}} 39^{\mathrm{m}} \mathrm{a}$. the subject sat with feet resting on the forks. He then lowered his feet to the pedals. He found that sitting still in this position was a constant strain.

6 The subject began riding at $10^{\mathrm{h}} 37_{\mathrm{m}} \mathrm{a.m}$., the machine being driven by a motor. The belt slipped at $10^{\mathrm{h}}$ $52^{\mathrm{m}}$ a.m. The pulse-rate 15 seconds after the stopping of work due to the slipping of the belt was only 84.

B Between the two "no-load" periods the average speed was 72 (?) revolutions per minute. Soon after the start of the period ( 75 seconds) the belt slipped off. The machine was stopped completely, the belt was replaced and the machine restarted.

7 Work was begun at $11^{\mathrm{h}} 32^{\mathrm{m}}$ a.m. with the current at 1.5 amperes. Between $11^{\mathrm{h}} 32^{\mathrm{m}}$ a.m. and $11^{\mathrm{h}} 46^{\mathrm{m}}$ a.m. the average speed was 97 revolutions per minute.

8 Pulse-rate at the end of the period.

- In the interval before this period the subject rode at the average rate of 96 revolutions per minute. 
TABLE 76.-Results with subject M.A. M. (without food).

\begin{tabular}{|c|c|c|c|c|c|c|c|c|}
\hline Date and time. & Duration. & $\begin{array}{l}\text { Carbon } \\
\text { dioxide } \\
\text { eliminated } \\
\text { per minute. }\end{array}$ & $\begin{array}{c}\text { Oxygen } \\
\text { absorbed } \\
\text { per } \\
\text { minute. }\end{array}$ & $\begin{array}{l}\text { Respirs- } \\
\text { tory } \\
\text { quotient. }\end{array}$ & $\begin{array}{l}\text { Aver- } \\
\text { age } \\
\text { pulse- } \\
\text { rate. }\end{array}$ & $\begin{array}{l}\text { Average } \\
\text { respira- } \\
\text { tion-rate. }\end{array}$ & $\begin{array}{l}\text { Cur- } \\
\text { rent. }\end{array}$ & $\begin{array}{l}\text { Revolu- } \\
\text { tions per } \\
\text { minute. }\end{array}$ \\
\hline 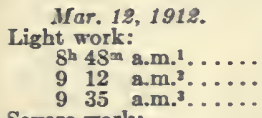 & $\begin{array}{ll}\min . & \text { sec. } \\
12 & 44 \\
12 & 41 \\
12 & 40\end{array}$ & $\begin{array}{l}\text { c.c. } \\
675 \\
658 \\
684\end{array}$ & $\begin{array}{l}\text { c.c. } \\
797 \\
807 \\
814\end{array}$ & $\begin{array}{r}0.85 \\
.82 \\
.81\end{array}$ & $\begin{array}{l}90 \\
88 \\
90\end{array}$ & $\begin{array}{l}20 \\
20 \\
22\end{array}$ & $\begin{array}{l}a m p . \\
0.5 \\
0.5 \\
0.5\end{array}$ & $\begin{array}{l}70.7 \\
71.5 \\
72.4\end{array}$ \\
\hline 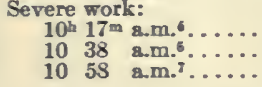 & $\begin{array}{ll}11 & 26 \\
11 & 33 \\
11 & 28\end{array}$ & $\begin{array}{l}1,310 \\
1,319 \\
1,369\end{array}$ & $\begin{array}{l}1,564 \\
1,520 \\
1,534\end{array}$ & $\begin{array}{l}.84 \\
.87 \\
.89\end{array}$ & $\begin{array}{l}112 \\
112 \\
116\end{array}$ & $\begin{array}{l}28 \\
32 \\
28\end{array}$ & $\begin{array}{l}1.5 \\
1.5 \\
1.5\end{array}$ & $\begin{array}{l}71.5 \\
70.5 \\
70.9\end{array}$ \\
\hline
\end{tabular}

The subject started riding at $8^{\mathrm{h}} 24^{\mathrm{m}} \mathrm{a.m}$., timed by the metronome set at 70 .

2 In the interval before this period the subject rode at the average rate of 74 revolutions per minute.

In the interval before this period the average speed was 69 revolutions per minute. At the end of the period the subject said he felt in excellent condition, but that his hands, wrists and arms were sore from strain.

4 The current was increased to 1.5 amperes at $9^{\mathrm{b}} 49^{\mathrm{m}} \mathrm{a} . \mathrm{m}$. Between $9^{\mathrm{b}} 49^{\mathrm{m}} \mathrm{a} . \mathrm{m}$. and $10^{\mathrm{b}} 17^{\mathrm{m}} \mathrm{a} . \mathrm{m}$. the average speed was 70 revolutions per minute. The subject began to perspire during this period.

5 Pulse-rate at the end of the period.

6 In interval before period the av. speed was 71 revs. per min. The subject perspired freely during the period.

7 In the interval before this period the subject rode at the average rate of 54 (?) revolutions per minute. During the period the perspiration was profuse.

TABLE 77.-Results with subject M.A. M. (without food). (Ergometer II.)

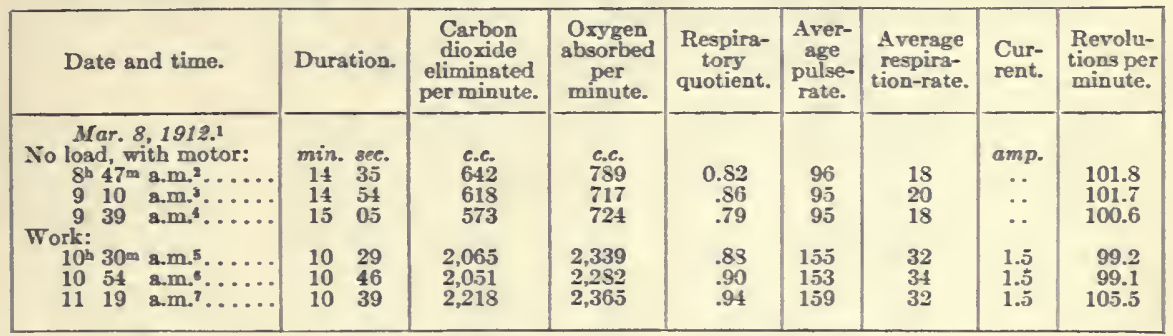

1 See table 78 for experiment on March $13,1912$.

2 The machine was motor-driven. The subject began riding at $8^{\mathrm{b}} 18^{\mathrm{m}} \mathrm{a} . \mathrm{m}$., and to the beginning of the period rode at the average rate of 99 revolutions per minute. A verage pulse during preliminary period, 96.

3 In interval before period, av. speed 95 revs. per min. Subject lifted his body off seat 3 times. (See note 6.)

- In the interval before this period the average speed was 106 revolutions per minute. During the period the pin holding the handle bars was broken and the handle bars became loose. This seemed to cause the subject considerable trouble and annoyance.

- At $10 \mathrm{am}$. work was begun with the current at 1.5 amperes. Between $10 \mathrm{a} . \mathrm{m}$. and $10^{\mathrm{b}} 30^{\mathrm{ma}} \mathrm{a} . \mathrm{m}$. the average rate was 93 revolutions per minute. With the change the subject found the work extremely difficult. He could hardly believe he was working against the usual smount of resistance.

6 In the interval before this period the average speed was 78 revolutions per minute.

7 In the interval before this period the average speed was 89 revolutions per minute. The subject said the ergometer was not at all comfortable; the seat was too high. Another subject using the appsratus had failed to return the seat to the original height found comfortable for M. A. M.

TABLE 78.-Results with subject M. A. M. (without food).

\begin{tabular}{|c|c|c|c|c|c|c|c|c|}
\hline Date and time. & Duration. & $\begin{array}{l}\text { Carbon } \\
\text { dioxide } \\
\text { eliminated } \\
\text { per minute. }\end{array}$ & $\begin{array}{l}\text { Oxygen } \\
\text { absorbed } \\
\text { per } \\
\text { minute. }\end{array}$ & $\begin{array}{l}\text { Respira- } \\
\text { tory } \\
\text { quotient. }\end{array}$ & $\begin{array}{l}\text { Aver- } \\
\text { age } \\
\text { pulse- } \\
\text { rate. }\end{array}$ & $\begin{array}{l}\text { Average } \\
\text { respira- } \\
\text { tion-rate. }\end{array}$ & $\begin{array}{l}\text { Cur- } \\
\text { rent. }\end{array}$ & $\begin{array}{l}\text { Revolu- } \\
\text { tions per } \\
\text { minute. }\end{array}$ \\
\hline 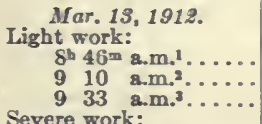 & $\begin{array}{ll}\min & \text { sec. } \\
12 & 40 \\
12 & 41 \\
12 & 48\end{array}$ & $\begin{array}{l}\text { c.c. } \\
768 \\
785 \\
748\end{array}$ & $\begin{array}{l}c . c . \\
837 \\
895 \\
848\end{array}$ & $\begin{array}{r}0.92 \\
.88 \\
.85\end{array}$ & $\begin{array}{l}92 \\
96 \\
94\end{array}$ & $\begin{array}{l}20 \\
24 \\
24\end{array}$ & $\begin{array}{l}a m p . \\
0.5 \\
0.5 \\
0.5\end{array}$ & $\begin{array}{l}71.5 \\
75.5 \\
72.1\end{array}$ \\
\hline 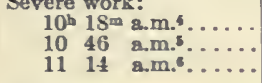 & $\begin{array}{ll}11 & 30 \\
10 & 16 \\
11 & 27\end{array}$ & $\begin{array}{l}1,375 \\
1,342 \\
1,421\end{array}$ & $\begin{array}{l}1,513 \\
1,631 \\
1,556\end{array}$ & $\begin{array}{l}.91 \\
.83 \\
.91\end{array}$ & $\begin{array}{l}112 \\
110 \\
116\end{array}$ & $\begin{array}{l}28 \\
28 \\
28\end{array}$ & $\begin{array}{l}1.5 \\
1.5 \\
1.5\end{array}$ & $\begin{array}{l}70.2 \\
70.4 \\
70.3\end{array}$ \\
\hline
\end{tabular}

1 Work was begun at $\delta^{\mathrm{b}} 16^{\mathrm{m}} \mathrm{am}$. Between $8^{\mathrm{h}} 16^{\mathrm{m}} \mathrm{am}$. and $\delta^{\mathrm{b}} 46^{\mathrm{m}} \mathrm{am}$. av. 8 peed 72 revs. per min.

3 In the interval before this period the average spced was 73 revolutions per minute. The subject found it difficult to keep pace with the metronome; it was too slow for him.

3 In the interval before this period the average speed was $6 \pm$ revolutions per minute.

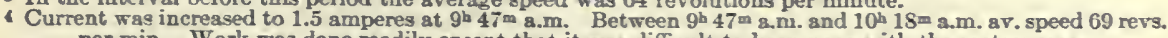
per min. Work was done readily except that it was difficult to keep pace with the metronome.

5 The average speed in the interval before the period was 60 revolutions per minute.

I In the interval before this period the average speed was 65 revolutions per minute. 
TABLE 79.-Results with subject M. A. M. (without food).

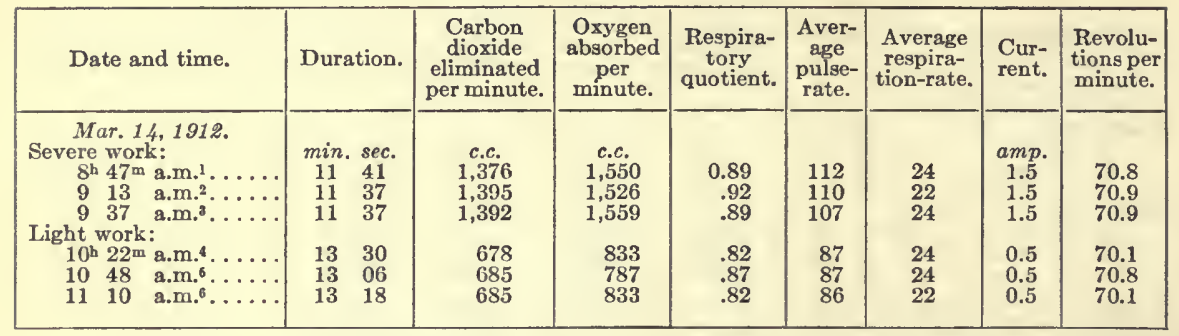

1 The starting records were lost. There was the usual preliminary period, however, and it is probable that the speed was about 70 revolutions per minute. During the period sweating was marked though not profuse.

2 In the interval before this period the average speed was 71 revolutions per minute.

3 In the interval before this period the average speed was 74 revolutions per minute.

4 In the interval between this period and the preceding period the average speed was 69 revolutions per minute. The current was decreased to 0.5 ampere at $10^{\mathrm{h}} 10^{\mathrm{m}} \mathrm{a} . \mathrm{m}$. Some oxygen was lost by leak during the period. The loss was estimated.

5 In the interval before this period the average speed was 59 revolutions per minute.

6 In the interval before this period the average speed was 68 revolutions per minute. The subfect on this day had his usual trouble in changing from high to low resistance. He complained that it was extremely difficult to work as efficiently.

TABLE 80.-Results with subject M. A. M. (without food). Continuous work-fatigue experiment.

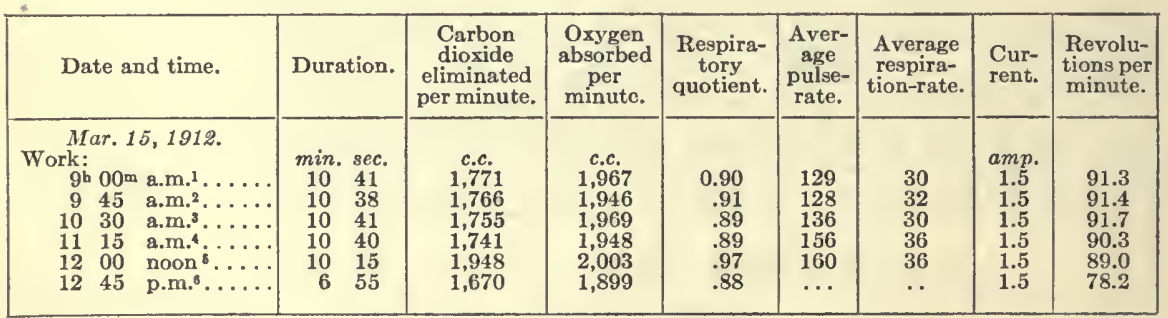

1 Work was begun at $8^{\mathrm{h}} 30^{\mathrm{m}}$ a.m. the average speed from $8^{\mathrm{h}} 30^{\mathrm{m}} \mathrm{a} . \mathrm{m}$. to $9^{\mathrm{h}} \mathrm{a} . \mathrm{m}$. being 86 revolutions per minute. During the period the work was easily done. Perspiration was marked though not very

2 The average speed in the interval before this period was 87 revolutions per minute. During the period the work was done very easily. Perspiration was not very profuse.

3 The average speed in the interval before this period was 91 revolutions per minute. During the period the work was still done easily. Perspiration was perhaps a little more profuse.

4 The average speed in the interval before this period was 84 revolutions per minute. During the period the work was not done so easily. It seemed to require a littlo more effort to keep up to the rate of 90 revolutions per minute.

5 The average speed in the interval before this period was 82 revolutions per minute. During the period the subject was much distressed. The observer thought he was about to give up several times, but each time he seemed to make a fresh effort. Perspiration was profuse.

6 The average speed in the interval before this period was 79 revolutions per minute. The subject did not look well at the beginning of this last period, but insisted he was all right. He kept his lips tightly on look well at the beginning of this last period, but insisted he was all right. He kept his lips tightly on the mouthpiece. The rate of riding fell off steadily. At the end the subject looked exhausted and ad-
mitted that he was. He swayed when he released his mouth from the mouthpiece. He spoke of a constant struggle for breath, but that he was unable to help himself. An analysis of the air in the system at the end of the whole series of periods showed that the oxygen present was 22.5 per cent. The subject drank 30 c.c. of water after the end of each period except the first. The entire duration of work was from $8^{\mathrm{h}} 30^{\mathrm{m}}$ a.m. to $12^{\mathrm{h}} 52^{\mathrm{m}}$ p.m., or 4 hours and 22 minutes. The total number of revolutions was 22,482 , the average speed per minute being 85.8 revolutions. 
TABLE 81.-Results with subject M. A. M. (without food).

\begin{tabular}{|c|c|c|c|c|c|c|c|c|}
\hline Date and time. & Duration. & $\begin{array}{l}\text { Carbon } \\
\text { dioxide } \\
\text { eliminated } \\
\text { per minute. }\end{array}$ & $\begin{array}{c}\text { Oxygen } \\
\text { absorbed } \\
\text { per } \\
\text { minute. }\end{array}$ & $\begin{array}{l}\text { Respira- } \\
\text { tory } \\
\text { quotient. }\end{array}$ & $\begin{array}{c}\text { Aver- } \\
\text { age } \\
\text { pulse- } \\
\text { rate. }\end{array}$ & $\begin{array}{l}\text { Average } \\
\text { respira- } \\
\text { tion-rate. }\end{array}$ & $\begin{array}{l}\text { Cur- } \\
\text { rent. }\end{array}$ & $\begin{array}{l}\text { Revolu- } \\
\text { tions per } \\
\text { minute. }\end{array}$ \\
\hline $\begin{array}{l}\text { Mar. 1S, } 1912 . \\
\text { Serere work: } \\
\text { S }^{\mathrm{h}} 49 \mathrm{~m} \text { a.m.1. } \\
9 \ldots \ldots \\
920 \text { a.m. } \\
940 \text { a.m. } \\
9\end{array}$ & $\begin{array}{ll}\min . & \text { sec. } \\
11 & 11 \\
10 & 18 \\
10 & 11\end{array}$ & $\begin{array}{l}c . c . \\
1,374 \\
2,065 \\
2,076\end{array}$ & $\begin{array}{l}\text { c.c. } \\
1,341 \\
2,315 \\
2,320\end{array}$ & $\begin{array}{r}0.89 \\
.89 \\
.90\end{array}$ & $\begin{array}{l}103 \\
132 \\
135\end{array}$ & $\begin{array}{l}24 \\
32 \\
32\end{array}$ & $\begin{array}{l}a m p . \\
1.5 \\
1.5 \\
1.5\end{array}$ & $\begin{array}{r}70.9 \\
102.1 \\
101.8\end{array}$ \\
\hline $\begin{array}{ccc}10^{\mathrm{h}} & 17^{2} & \text { a.m. } \\
10 & 56 & \text { a.m. } \\
11 & 18 & \text { a.m. } \\
1 & \ldots\end{array}$ & $\begin{array}{ll}12 & 15 \\
10 & 30 \\
10 & 21\end{array}$ & $\begin{array}{r}671 \\
1,025 \\
1,052\end{array}$ & $\begin{array}{c}\$ 23 \\
\cdots\end{array}$ & $\begin{array}{l}.82 \\
\cdots \\
\cdots\end{array}$ & $\begin{array}{r}96 \\
103 \\
108\end{array}$ & $\begin{array}{l}22 \\
28 \\
28\end{array}$ & $\begin{array}{l}0.5 \\
0.5 \\
0.5\end{array}$ & $\begin{array}{r}70.8 \\
101.9 \\
102.1\end{array}$ \\
\hline
\end{tabular}

1 Work was begun at $8^{\mathrm{b}} 19 \mathrm{~m}$ a.m. Between $8^{\mathrm{h}} 19 \mathrm{~m} \mathrm{am}$. and $8^{\mathrm{b}} 49_{\mathrm{m}} \mathrm{am}$. the average speed was 71 rerolutions per minute. The work was done without strain and the perspiration was slight.

2 At $9^{\mathrm{h}} \mathrm{C}^{\mathrm{m}} \mathrm{a} . \mathrm{m}$. the pace was changed to 100 revolutions per minute. Between $9^{\mathrm{h}} 02 \mathrm{~m}$ a.m. and $9^{\mathrm{h}} 20^{\mathrm{a}} \mathrm{am}$. the average speed was approximately 95 revolutions per minute. Perspiration was profuse.

3 In the interval before this period the sverage speed was 104 revolutions per minute. During the period the work was easily done. The subject perspined freely.

1. At 9t 51 a.m. the current was decreased to 0.5 ampere and the speed to 70 revolutions per minute. Between $9 \mathrm{~b} 51 \mathrm{~m} \mathrm{a} . \mathrm{m}$. and $10^{\mathrm{h}} 17 \mathrm{~m} \mathrm{am}$. the average speed was 70 revolutions per minute. During the fourth period the work was done without effort of any kind. There was no perspiration. The pulse-rate before this period was at $10^{\mathrm{b}} 10^{\mathrm{m}} \mathrm{\&} . \mathrm{m}, 92$; at $10^{\mathrm{h}} 16^{\mathrm{m}} \mathrm{a} . \mathrm{m} ., 94$.

5 At $10^{\mathrm{m}} 30^{\mathrm{m}} \mathrm{a} . \mathrm{m}$. the speed was increased to 100 revolutions per minute. The average speed from $10^{\mathrm{h}} 30^{\mathrm{m}}$ a.m. to the beginning of the fifth period was 82 (?) revolutions per minute.

- The average speed in interval before the period was 90 revs. per min. During period the work was done with comparative ease, but subject was glad when it was finished. No perspiration.

TABLE 82.-Results with subject M. A. M. (without food).

\begin{tabular}{|c|c|c|c|c|c|c|c|c|}
\hline Date and time. & Duration. & $\begin{array}{c}\text { Carbon } \\
\text { dioxide } \\
\text { eliminsted } \\
\text { per minute. }\end{array}$ & $\begin{array}{c}\text { Oxygen } \\
\text { absorbed } \\
\text { per } \\
\text { minute. }\end{array}$ & $\begin{array}{l}\text { Respirs- } \\
\text { tory } \\
\text { quotient. }\end{array}$ & $\begin{array}{l}\text { Aver- } \\
\text { age } \\
\text { pulse- } \\
\text { rate. }\end{array}$ & $\begin{array}{l}\text { Average } \\
\text { respira- } \\
\text { tion-rate. }\end{array}$ & $\begin{array}{l}\text { Cur- } \\
\text { rent. }\end{array}$ & $\begin{array}{l}\text { Revolu- } \\
\text { tions per } \\
\text { minute. }\end{array}$ \\
\hline $\begin{array}{l}\text { Mar. } 19,1912 . \\
\text { Work: } \\
9^{\text {h }} 10^{m} \text { a.m. }{ }^{1} \ldots \ldots \\
\text { Lying: }\end{array}$ & $\begin{array}{c}\min _{10} \text { sec. } \\
19\end{array}$ & $\begin{array}{c}\text { c.c. } \\
2,049\end{array}$ & $\begin{array}{c}c_{. c .} \\
2,263\end{array}$ & 0.91 & 140 & 32 & $\begin{array}{c}\text { amp. } \\
1.5\end{array}$ & 101.6 \\
\hline 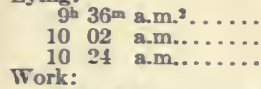 & $\begin{array}{rr}16 & 7 \\
15 & 17 \\
15 & 19\end{array}$ & $\begin{array}{l}240 \\
221 \\
220\end{array}$ & $\begin{array}{l}260 \\
251 \\
254\end{array}$ & $\begin{array}{l}.92 \\
.88 \\
.87\end{array}$ & $\begin{array}{l}72 \\
63 \\
64\end{array}$ & $\begin{array}{l}24 \\
24 \\
20\end{array}$ & $\begin{array}{l}\cdots \\
\therefore\end{array}$ & $\cdots$ \\
\hline 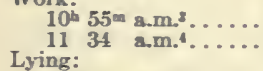 & $\begin{array}{ll}10 & 14 \\
10 & 11\end{array}$ & $\begin{array}{l}2,124 \\
1,892\end{array}$ & $\begin{array}{l}2,346 \\
2,146\end{array}$ & $\begin{array}{l}.91 \\
.85\end{array}$ & $\begin{array}{l}14 S \\
1 \pm 6\end{array}$ & $\begin{array}{l}29 \\
32\end{array}$ & $\begin{array}{l}1.5 \\
1.5\end{array}$ & $\begin{array}{r}102.5 \\
96.2\end{array}$ \\
\hline $12 \mathrm{~h} 01=$ p.m. & 15 & 222 & 276 & .81 & 70 & 20 & .. & $\ldots$ \\
\hline
\end{tabular}

1 Work began at $\delta^{b} 13^{m}$ a.m. From $S^{h} 13^{m a} \mathrm{am}$. to $9^{\mathrm{h}} 10^{\mathrm{m}} \mathrm{a} \cdot \mathrm{m}$. av. speed 97 revs. per min. Perspiration profuse.

2 The first work period was finished at about $9^{\mathrm{h}} 20=\mathrm{a}$ a.m. Subject lay down at $9^{\mathrm{h}} 23^{\mathrm{m}} \mathrm{am}$.

3 Work way begun agsin at $10^{\mathrm{k}} 46^{\mathrm{m}} \mathrm{am}$. Between $10^{\mathrm{b}} 46^{\mathrm{m}} \mathrm{\textrm {am }}$. and $10^{\mathrm{h}} 55^{\mathrm{m}} \mathrm{am}$. the average speed was 89 revolutions per minate. Work was started with difficulty. The subject said his muscles were exceedingly stif. He rode mor.

4. In the interval before this period the average speed was $\$ 3$ revolutions per minute.

5 Work was finished at $11^{\mathrm{h}} 44^{\mathrm{m}} \mathrm{am}$. The subject lay down st $11^{\mathrm{b}} 48^{\mathrm{m}} \mathrm{a} . \mathrm{m}$.

TABLE 83.-Results with subject $M . A . M$. (without food).

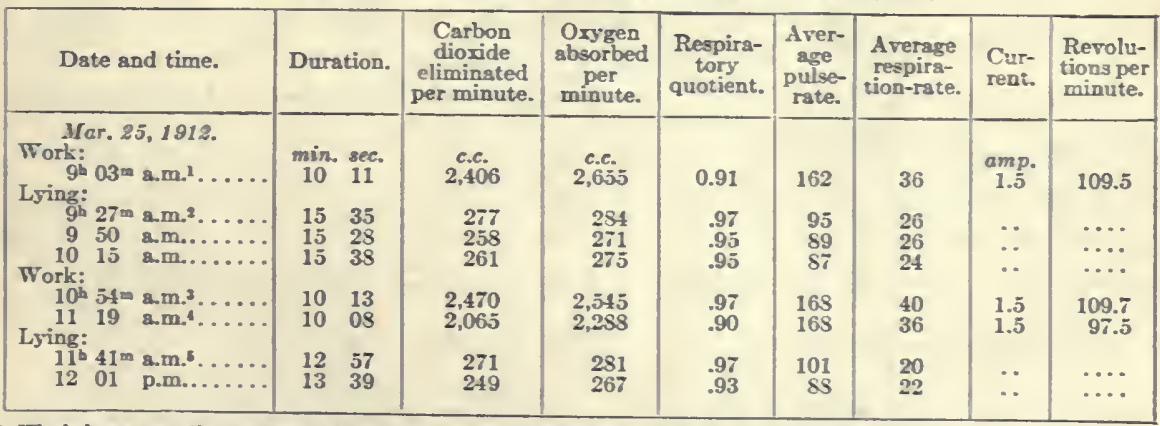

1 Work began at $\delta^{b} 19=a m$. From $\delta^{b} 19 \mathrm{am}$. to $9^{\mathrm{b}} 03 \mathrm{a}$ a.m. av. speed 104 revs. per min.

2 The frst work period was finished at $9^{\mathrm{b}} 17^{\mathrm{m}} \mathrm{am} . \mathrm{m}$. During the first lying period the subject's breathing was somewhat rapid and shallow.

3 Work began again at $10^{\mathrm{h}} 41 \mathrm{~m} \mathrm{am}$. From $10^{\mathrm{b}} 41 \mathrm{~m} \mathrm{am}$, to $10^{\mathrm{b}} 54^{\mathrm{m}} \mathrm{am}$. av. speed 9 ) rev8. per min. Throughout the period the rate of work was gradually and steadily increased. Perspiration profuse.

4 In the interval before this period the average speed was 93 revolutions per minute.

s Work was finished at $11^{\mathrm{b}} 30^{\mathrm{m}} \mathrm{am}$. The subject lay down at $11^{\mathrm{b}} 31^{\mathrm{m}} \mathrm{am}$. 
TABLE 84.-Results with subject M. A. M. (without food).

\begin{tabular}{|c|c|c|c|c|c|c|c|c|}
\hline Date and time. & Duration. & $\begin{array}{c}\text { Carbon } \\
\text { dioxide } \\
\text { eliminated } \\
\text { per minute. }\end{array}$ & $\begin{array}{c}\text { Oxygen } \\
\text { absorbed } \\
\text { per } \\
\text { minute. }\end{array}$ & $\begin{array}{l}\text { Respira- } \\
\text { tory } \\
\text { quotient. }\end{array}$ & $\begin{array}{l}\text { Aver- } \\
\text { age } \\
\text { pulse- } \\
\text { rate. }\end{array}$ & $\begin{array}{l}\text { Average } \\
\text { respira- } \\
\text { tion-rate. }\end{array}$ & $\begin{array}{l}\text { Cur- } \\
\text { rent. }\end{array}$ & $\begin{array}{l}\text { Revolu- } \\
\text { tions per } \\
\text { minute. }\end{array}$ \\
\hline 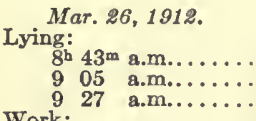 & $\begin{array}{ll}\min . & \text { sec. } \\
14 & 21 \\
14 & 43 \\
14 & 41\end{array}$ & $\begin{array}{l}c . c . \\
210 \\
202 \\
\cdots\end{array}$ & $\begin{array}{l}c . c . \\
232 \\
235 \\
232\end{array}$ & $\begin{array}{l}0.91 \\
.86 \\
\cdots\end{array}$ & $\begin{array}{l}60 \\
55 \\
56\end{array}$ & $\begin{array}{l}20 \\
19 \\
20\end{array}$ & $\begin{array}{c}a m p . \\
\because \\
\cdots \\
\cdots\end{array}$ & $\cdots$ \\
\hline $\begin{array}{l}\text { Work: } \\
10^{\mathrm{h}} 01 \mathrm{~m} \text { a.m.1 } \ldots \ldots \\
10 \quad 40 \text { a.m. }{ }^{2} \ldots \ldots\end{array}$ & $\begin{array}{ll}10 & 10 \\
10 & 34\end{array}$ & $\begin{array}{l}2,057 \\
2,223\end{array}$ & $\begin{array}{l}2,206 \\
2,368\end{array}$ & $\begin{array}{l}.93 \\
.94\end{array}$ & $\begin{array}{l}156 \\
162\end{array}$ & $\begin{array}{l}30 \\
32\end{array}$ & $\begin{array}{l}1.5 \\
1.5\end{array}$ & $\begin{array}{r}98.3 \\
100.5\end{array}$ \\
\hline 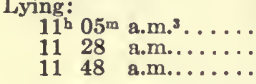 & $\begin{array}{ll}15 & 07 \\
14 & 47 \\
14 & 45\end{array}$ & $\begin{array}{l}234 \\
215 \\
220\end{array}$ & $\begin{array}{l}264 \\
250 \\
249\end{array}$ & $\begin{array}{l}.89 \\
.86 \\
.88\end{array}$ & $\begin{array}{l}86 \\
76 \\
76\end{array}$ & $\begin{array}{l}28 \\
22 \\
20\end{array}$ & $\because$ & $\cdots \cdots$ \\
\hline
\end{tabular}

1 Work was begun at $9^{\mathrm{b}} 46^{\mathrm{m}}$ a.m. Between $9^{\mathrm{b}} 46^{\mathrm{m}}$ a.m. and $10^{\mathrm{h}} 01^{\mathrm{m}} \mathrm{a} . \mathrm{m}$. the subject rode at the average rate of 81 revolutions per minute.

2 Between the two work-periods the average speed was 87 revolutions per minute. The subject's breathing was perhaps rather labored toward the end.

$s$ Work was finished at $10^{\mathrm{h}} 52^{\mathrm{m}} \mathrm{a}$ a.m. The subject lay down at $10^{\mathrm{b}} 55^{\mathrm{m}} \mathrm{a} . \mathrm{m}$.

TABLE 85.-Results with subject M. A. M. (without food).

\begin{tabular}{|c|c|c|c|c|c|c|c|c|}
\hline Date and time. & Duration. & $\begin{array}{c}\text { Carbon } \\
\text { dioxide } \\
\text { eliminated } \\
\text { per minute. }\end{array}$ & $\begin{array}{c}\text { Oxygen } \\
\text { absorbed } \\
\text { per } \\
\text { minute. }\end{array}$ & $\begin{array}{l}\text { Respira- } \\
\text { tory } \\
\text { quotient. }\end{array}$ & $\begin{array}{l}\text { Aver- } \\
\text { age } \\
\text { pulse- } \\
\text { rate. }\end{array}$ & $\begin{array}{l}\text { Average } \\
\text { respira- } \\
\text { tion-rate. }\end{array}$ & $\begin{array}{l}\text { Cur- } \\
\text { rent. }\end{array}$ & $\begin{array}{l}\text { Revolu- } \\
\text { tions per } \\
\text { minute. }\end{array}$ \\
\hline $\begin{array}{l}\text { Mar. } 27,1912 . \\
\text { Work: } \\
9^{\text {h }} 11^{\text {m }} \text { a.m.l...... }\end{array}$ & $\begin{array}{l}\min . \\
10 \\
13\end{array}$ & 2,166 & $\begin{array}{l}\text { c.c. } \\
2,257\end{array}$ & 0.96 & 160 & 36 & $\begin{array}{c}a m p . \\
1.5\end{array}$ & 101.6 \\
\hline 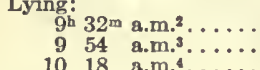 & $\begin{array}{ll}16 & 04 \\
16 & 03\end{array}$ & 261 & $\begin{array}{l}255 \\
256\end{array}$ & $\begin{array}{r}1.02 \\
.87\end{array}$ & $\begin{array}{l}88 \\
75 \\
78\end{array}$ & $\begin{array}{l}24 \\
20\end{array}$ & $\because$ & $\cdots$ \\
\hline $\begin{array}{l}10 \\
\text { Work: }\end{array}$ & & & 247 & & 78 & 20 & . & $\cdots$ \\
\hline 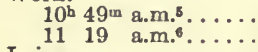 & $\begin{array}{ll}10 & 08 \\
10 & 08\end{array}$ & $\begin{array}{l}2,246 \\
2,066\end{array}$ & $\begin{array}{l}2,327 \\
2,333\end{array}$ & $\begin{array}{l}.97 \\
.89\end{array}$ & $\begin{array}{l}160 \\
168\end{array}$ & $\begin{array}{l}34 \\
40\end{array}$ & $\begin{array}{l}1.5 \\
1.5\end{array}$ & $\begin{array}{r}102.5 \\
95.2\end{array}$ \\
\hline $\begin{array}{l}\text { Lying: } \\
\quad 11^{\mathrm{b}} 40^{\mathrm{m}} \text { a.m. } \\
12 \text {. } \\
12\end{array}$ & $\begin{array}{ll}14 & 24 \\
14 & 51\end{array}$ & $\begin{array}{l}255 \\
221\end{array}$ & $\begin{array}{l}310 \\
238\end{array}$ & $\begin{array}{l}.82 \\
.93\end{array}$ & $\begin{array}{l}94 \\
92\end{array}$ & 18 & $\because$ & $\cdots$ \\
\hline
\end{tabular}

1 Work was begun at $8^{\mathrm{b}} 19^{\mathrm{m}}$ a.m. Between $8^{\mathrm{b}} 19^{\mathrm{m}} \mathrm{a}$.m. and $9^{\mathrm{h}} 11^{\mathrm{m}}$ a.m. the subject rode at the average rate of 93 revolutions per minute.

2 The first work-period was finished at about $9^{\mathrm{h}} 21^{\mathrm{m}}$ a.m. The subject immediately lay down.

3 The breathing was extremely irregular, even for this subject. Periods of almost complete apnœa occurred which were of 15 to 20 seconds' duration.

4 Breathing was still irregular, though the apnca was not so marked.

5 Work was resumed at $10^{\mathrm{h}} 38^{\mathrm{m}}$ a.m. Between $10^{\mathrm{h}} 38^{\mathrm{m}}$ a.m. and $10^{\mathrm{b}} 49^{\mathrm{m}}$ a.m. the average speed was 87 revs. per minute. Subject said he never felt keen to work now and feared he was getting a little stale.

- Between periods the average speed was 99 revolutions per minute. During this period the work was well enough done, but the speed fell off after about 6 minutes. He became very tired.

7 Work was finished at $11^{\mathrm{b}} 30^{\mathrm{m}}$ a.m. The subject lay down immediately.

TABLe 86.-Results with subject M. A. M. (without food).

\begin{tabular}{|c|c|c|c|c|c|c|c|c|}
\hline Date and time. & Duration. & $\begin{array}{c}\text { Carbon } \\
\text { dioxide } \\
\text { eliminated } \\
\text { per minute. }\end{array}$ & $\begin{array}{c}\text { Oxygen } \\
\text { absorbed } \\
\text { per } \\
\text { minute. }\end{array}$ & $\begin{array}{l}\text { Respira- } \\
\text { tory } \\
\text { quotient. }\end{array}$ & $\begin{array}{l}\text { Aver- } \\
\text { age } \\
\text { pulse- } \\
\text { ratc. }\end{array}$ & $\begin{array}{l}\text { Average } \\
\text { respira- } \\
\text { tion-rate. }\end{array}$ & $\begin{array}{l}\text { Cur- } \\
\text { rent. }\end{array}$ & $\begin{array}{l}\text { Revolu- } \\
\text { tions per } \\
\text { minute. }\end{array}$ \\
\hline $\begin{array}{l}\text { Mar. } 28,1912 . \\
\text { Work: } \\
8^{\mathrm{b}} 58^{\mathrm{m}} \text { a.m.1 } \ldots\end{array}$ & $\begin{array}{cl}\min . & s e c . \\
10 & 24\end{array}$ & $\begin{array}{r}c . c . \\
1,505\end{array}$ & $\begin{array}{r}\text { c.c. } \\
1,861\end{array}$ & 0.81 & 132 & 28 & $\underset{1.5}{a m p .}$ & 79.7 \\
\hline 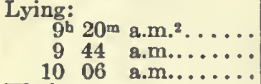 & $\begin{array}{ll}15 & 45 \\
15 & 15 \\
14 & 59\end{array}$ & $\begin{array}{l}209 \\
201 \\
209\end{array}$ & $\begin{array}{l}298 \\
262 \\
261\end{array}$ & $\begin{array}{l}.71 \\
.77 \\
.80\end{array}$ & $\begin{array}{l}69 \\
63 \\
63\end{array}$ & $\begin{array}{l}24 \\
20 \\
22\end{array}$ & $\because$ & $\ldots$ \\
\hline 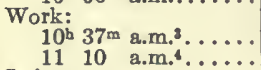 & $\begin{array}{ll}10 & 30 \\
10 & 12\end{array}$ & $\begin{array}{l}1,806 \\
1,658\end{array}$ & $\begin{array}{l}2,110 \\
1,909\end{array}$ & $\begin{array}{l}.86 \\
.87\end{array}$ & $\begin{array}{l}150 \\
168\end{array}$ & $\begin{array}{l}32 \\
32\end{array}$ & $\begin{array}{l}1.5 \\
1.5\end{array}$ & $\begin{array}{l}91.5 \\
83.6\end{array}$ \\
\hline $\begin{array}{l}\text { Lying: } \\
\quad 11^{\mathrm{h}} 28^{\mathrm{m}} \text { a.m.5. . . . . } \\
1147 \text { a.m...... }\end{array}$ & $\begin{array}{ll}14 & 15 \\
14 & 14\end{array}$ & $\begin{array}{l}241 \\
223\end{array}$ & $\begin{array}{l}323 \\
313\end{array}$ & $\begin{array}{l}.75 \\
.72\end{array}$ & $\begin{array}{l}83 \\
79\end{array}$ & $\begin{array}{l}28 \\
24\end{array}$ & $\therefore$ & $\cdots$ \\
\hline
\end{tabular}

1 Work was begun at $8^{\mathrm{h}} 07^{\mathrm{m}}$ a.m. Between $8^{\mathrm{b}} 07^{\mathrm{m}}$ a.m. and $8^{\mathrm{h}} 58^{\mathrm{m}}$ a.m. the average speed was 79 revolutions per minute. During the period the work was always done with effort, and the subject looked sullen and exhausted. He complained that he was extremely stiff and tired and could not work. He did the work steadily, when once he was started.

2 The first work-period was finished at $9^{\mathrm{h}} 09^{\mathrm{m}} \mathrm{a} \cdot \mathrm{m}$. The subject lay down at $9^{\mathrm{h}} 12^{\mathrm{m}}$ a.m.

8 Work was resumed at $10^{\mathrm{h}} 27^{\mathrm{m}} \mathrm{a} . \mathrm{m}$. Betwoen $10^{\mathrm{h}} 27^{\mathrm{m}}$ a.m. and $10^{\mathrm{h}} 37^{\mathrm{m}}$, a.m. the average speed was 89 revs. per minute. During the period work was done with comparative easc. Perspiration very profuse.

4 In the interval before this period the average speed was 70 revolutions per minute. Perspiration was profuse.

5 Work was finished at about $11^{\mathrm{b}} 20^{\mathrm{m}} \mathrm{a} \cdot \mathrm{m}$. The subject lay down at $11^{\mathrm{b}} 24^{\mathrm{m}} \mathrm{a} . \mathrm{m}$. 
TABLE 87.-Results with subject M. A. M. (without food).

\begin{tabular}{|c|c|c|c|c|c|c|c|c|}
\hline Date and time. & Duration. & $\begin{array}{l}\text { Carbon } \\
\text { dioxide } \\
\text { eliminated } \\
\text { per minute. }\end{array}$ & $\begin{array}{l}\text { Oxygen } \\
\text { sbsorbed } \\
\text { per } \\
\text { minute. }\end{array}$ & $\begin{array}{l}\text { Respira- } \\
\text { tory } \\
\text { quotient. }\end{array}$ & $\begin{array}{l}\text { Aver- } \\
\text { age } \\
\text { pulise- } \\
\text { rate. }\end{array}$ & $\begin{array}{l}\text { Average } \\
\text { respira- } \\
\text { tion-rate. }\end{array}$ & $\begin{array}{l}\text { Cur- } \\
\text { rent. }\end{array}$ & $\begin{array}{l}\text { Revolu- } \\
\text { tions per } \\
\text { minute. }\end{array}$ \\
\hline 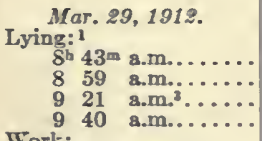 & $\begin{array}{ll}\min & \text { sec. } \\
10 & 46 \\
14 & 27 \\
14 & 26 \\
10 & 01\end{array}$ & $\begin{array}{l}\text { c.c. } \\
214 \\
236 \\
206 \\
212\end{array}$ & $\begin{array}{l}c . c . \\
277 \\
283 \\
269 \\
282\end{array}$ & $\begin{array}{r}0.78 \\
.83 \\
.77 \\
.76\end{array}$ & $\begin{array}{l}65 \\
71 \\
63 \\
68\end{array}$ & $\begin{array}{l}219 \\
222 \\
221 \\
221\end{array}$ & $\begin{array}{l}a m p . \\
\ldots \\
\cdots \\
\cdots\end{array}$ & $\begin{array}{l}\cdots \cdots \\
\cdots \\
\cdots\end{array}$ \\
\hline $\begin{array}{l}\text { Work: } \\
10^{\text {b }} 11=\text { a.m.4. } \ldots \ldots \\
10^{45} \text { a.m. } \ldots \ldots .\end{array}$ & $\begin{array}{ll}10 & 36 \\
10 & 18\end{array}$ & $\begin{array}{l}2,116 \\
1,961\end{array}$ & $\begin{array}{l}2,378 \\
2,227\end{array}$ & $\begin{array}{l}.89 \\
.88\end{array}$ & $\begin{array}{l}168 \\
168\end{array}$ & $\begin{array}{l}32 \\
40\end{array}$ & $\begin{array}{l}1.5 \\
1.5\end{array}$ & $\begin{array}{r}100.2 \\
94.5\end{array}$ \\
\hline 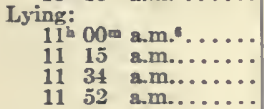 & $\begin{array}{ll}10 & 15 \\
14 & 41 \\
14 & 05 \\
14 & 25\end{array}$ & $\begin{array}{l}305 \\
230 \\
221 \\
232\end{array}$ & $\begin{array}{l}360 \\
307 \\
292 \\
298\end{array}$ & $\begin{array}{l}.85 \\
.75 \\
.76 \\
.78\end{array}$ & $\begin{array}{l}95 \\
87 \\
86 \\
85\end{array}$ & $\begin{array}{l}227 \\
225 \\
222 \\
222\end{array}$ & $\begin{array}{l}\cdots \\
\cdots \\
\cdots\end{array}$ & $\begin{array}{l}\ldots \\
\ldots \\
\ldots \\
\ldots\end{array}$ \\
\hline
\end{tabular}

1 The "lying" periods were a!l run on another respiration apparatus located on the third floor of the laboratory. The subject went downstairs to the first floor for the work periods and then returned to the third floor. The ventilation of the lungs was measured while the subject was on the couch.

2 The respiration rate while the subject was on the couch was for the full period, as recorded by the spirometer. 3 The subject said at the close of this period that he had a headache. His forehead was bathed in perspiration. 4 Work was started at $9^{\mathrm{h}} 5^{\mathrm{m}} \mathrm{m}$ a.m. Between $9^{\mathrm{h}} 57^{\mathrm{m}} \mathrm{am}$. and $10^{\mathrm{b}} 11^{\mathrm{m}} \mathrm{am}$. the average speed was 104 revolutions per minute.

5 Between the periods the average speed was 82 revolutions per minute.

- Work was finished at $10^{\mathrm{b}} 55^{\mathrm{m}}$ a.m. The subject immediately left the ergometer, hurried upstairs, and lay down on the couch.

TABLE 85.-Results with subject M. A. M. (without food).

\begin{tabular}{|c|c|c|c|c|c|c|c|c|}
\hline Date and time. & Duration. & $\begin{array}{l}\text { Carbon } \\
\text { dioxide } \\
\text { eliminated } \\
\text { per minute. }\end{array}$ & $\begin{array}{c}\text { Oxygen } \\
\text { absorbed } \\
\text { per } \\
\text { minute. }\end{array}$ & $\begin{array}{l}\text { Pespirs- } \\
\text { tory } \\
\text { quotient. }\end{array}$ & $\begin{array}{l}\text { Aver- } \\
\text { age } \\
\text { pulse- } \\
\text { rate. }\end{array}$ & $\begin{array}{l}\text { Average } \\
\text { respira- } \\
\text { tion-rate. }\end{array}$ & $\begin{array}{l}\text { Cur- } \\
\text { rent. }\end{array}$ & $\begin{array}{l}\text { Revolu- } \\
\text { tions per } \\
\text { minute. }\end{array}$ \\
\hline 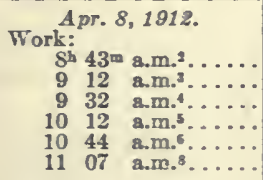 & $\begin{array}{ll}\min & \text { sec. } \\
11 & 40 \\
11 & 13 \\
11 & 26 \\
10 & 07 \\
10 & 09 \\
10 & 22\end{array}$ & $\begin{array}{c}\text { c.c. } \\
1,270 \\
1,243 \\
1,254 \\
2,729 \\
2,712 \\
2,134\end{array}$ & $\begin{array}{c}c . c . \\
1,422 \\
1,425 \\
1,451 \\
2,719 \\
2,712 \\
2,343\end{array}$ & $\begin{array}{r}0.89 \\
.87 \\
.87 \\
1.00 \\
1.00 \\
.91\end{array}$ & $\begin{array}{r}116 \\
116 \\
112 \\
175 \\
7158\end{array}$ & $\begin{array}{l}18 \\
20 \\
22 \\
36 \\
40 \\
34\end{array}$ & $\begin{array}{l}a m p . \\
1.25 \\
1.25 \\
1.25 \\
1.25 \\
1.25 \\
1.25\end{array}$ & $\begin{array}{r}70.8 \\
69.8 \\
71.2 \\
126.1 \\
121.6 \\
105.4\end{array}$ \\
\hline
\end{tabular}

1 The metronome was used in each period to regulate the speed.

2 Work was begun at $\delta^{\mathrm{h}} 06^{\mathrm{m}}$ a.m. Between $\mathcal{S}^{\mathrm{h}} 06^{\mathrm{m}}$ a.m. and $\mathcal{S}^{\mathrm{h}} 43^{\mathrm{m}}$ a.m. the average speed was 70 revolutions per minute. During the period the work was done with perfect ease. There was no strain whatever. The subject said he scarcely felt the pork. He said he bad been at Revere Beach on Apr. 7 and had ridden 10 miles on the track at the rate of 1 min. 36 sec. to the mile. He had done this with absolutely no difficulty. His opinion was that one hour's work on the ergometer was equivalent to about 50 miles on the track.

3 In the interval before this period the average speed was 66 revolutions per minute. During the period the work was done without difficulty.

4 In the interval before this period the average speed was 70 revolutions per minute. During the period the work was done with ease.

6 At $9^{\mathrm{b}} 45^{\mathrm{m}} \mathrm{g} . \mathrm{m}$. the speed was increased to 120 revolutions per minute. Between $9^{\mathrm{h}} 45 \mathrm{~m} \mathrm{a} . \mathrm{m}$. and $10^{\mathrm{h}} 12^{\mathrm{m}}$ a.m. the average speed was 90 revolutions per minute. During the period itself the work was done at tremendous speed toward the end. At the end of 7.5 minutes the subject lost a pedal and picked it up again. Perspiration was not very profuse.

6 In the interval before this period the average speed was 76 revolutions per minute. During the period the work was done with greater difficulty. The subject found it harder. Perspiration was very profuse.

7 The pulse was very rapid in this period, no satisfactory count being possible.

8 In the interval before this period the average speed was 70 revolutions per minute. During the period the work was done with comparative ease. It was much less trying than in the preceding period.

Pulse-rate at the end of the period. 
TABLE 89.-Results with subject $M . A . M$. (without food).

\begin{tabular}{|c|c|c|c|c|c|c|c|c|}
\hline Date and time. & Duration. & $\begin{array}{l}\text { Carbon } \\
\text { dioxide } \\
\text { eliminated } \\
\text { per minute. }\end{array}$ & $\begin{array}{c}\text { Oxygen } \\
\text { absorbed } \\
\text { per } \\
\text { minute. }\end{array}$ & $\begin{array}{l}\text { Respira- } \\
\text { tory } \\
\text { quotient. }\end{array}$ & $\begin{array}{l}\text { Aver- } \\
\text { age } \\
\text { pulse- } \\
\text { rate. }\end{array}$ & $\begin{array}{c}\text { Average } \\
\text { respira- } \\
\text { tion-rate. }\end{array}$ & $\begin{array}{l}\text { Cur- } \\
\text { rent. }\end{array}$ & $\begin{array}{l}\text { Revolu- } \\
\text { tions per } \\
\text { minute. }\end{array}$ \\
\hline 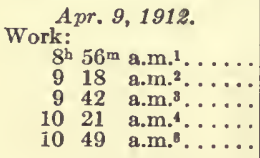 & $\begin{array}{cc}\min & \text { sec. } \\
11 & 35 \\
11 & 29 \\
11 & 43 \\
10 & 06 \\
10 & 07\end{array}$ & $\begin{array}{l}c . c . \\
1,198 \\
1,216 \\
1,241 \\
2,774 \\
2,200\end{array}$ & 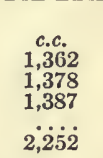 & $\begin{array}{r}0.88 \\
.88 \\
.90 \\
\because .98\end{array}$ & $\begin{array}{r}110 \\
112 \\
116 \\
\cdot 170 \\
176\end{array}$ & $\begin{array}{l}20 \\
24 \\
24 \\
48 \\
36\end{array}$ & $\begin{array}{c}a m p . \\
1.1 \\
1.1 \\
1.1 \\
1.1 \\
1.1\end{array}$ & $\begin{array}{r}71.4 \\
71.4 \\
71.8 \\
128.9 \\
108.4\end{array}$ \\
\hline
\end{tabular}

1 Work was begun at $8^{\mathrm{h}} 18^{\mathrm{m}}$ a.m. Between $8^{\mathrm{h}} 18^{\mathrm{m}}$ a.m. and $8^{\mathrm{h}} 56^{\mathrm{m}}$ a.m. the subject rode at the average rate of 70 revolutions per minute. During the period the work was very easily done, in fact it could hardly be considered work. There was no perspiration. 2 In the interval before this period the average speed was 71 revolutions per minute. There was slight perspira-

3 In the interval before this period the average speed was 71 revolutions per minute. The perspiration was some what increased.

4 At $9^{\mathrm{h}} 55^{\mathrm{m}}$ a.m. the speed was increased so that between $9^{\mathrm{h}} 55^{\mathrm{m}}$ a.m. and $10^{\mathrm{h}} 21^{\mathrm{m}} \mathrm{a}$.m. the average rate was 97 revolutions per minute. At the beginning of the period itself the subject lost the pedals, otherwise the speed during the period would have been greater. The work was hard and perspiration was profuse. 5 Pulse-rate at the end of the period.

6 In the interval before this period the average speed was 74 revolutions per minute. During the period perspiration was very profuse. The subject was practically "all in" at the end of 8 minutes, but kept at work. He looked very tired and exhausted. He was so tired that for about the first time since he had worked here he could not go on and asked to be relieved from doing a third period at this resistance. He said that the rapid pace of the first high speed period had killed him.

TABLe 90.-Results with subject M. A. M. (without food).

\begin{tabular}{|c|c|c|c|c|c|c|c|c|}
\hline Date and time. & Duration. & $\begin{array}{c}\text { Carbon } \\
\text { dioxide } \\
\text { eliminated } \\
\text { per minute. }\end{array}$ & $\begin{array}{l}\text { Oxygen } \\
\text { absorbed } \\
\text { per } \\
\text { minute. }\end{array}$ & $\begin{array}{l}\text { Respira- } \\
\text { tory } \\
\text { quotient. }\end{array}$ & $\begin{array}{l}\text { Aver- } \\
\text { age } \\
\text { pulse- } \\
\text { rate. }\end{array}$ & $\begin{array}{c}\text { Average } \\
\text { respira- } \\
\text { tion-rate. }\end{array}$ & $\begin{array}{l}\text { Cur- } \\
\text { rent. }\end{array}$ & $\begin{array}{l}\text { Revolu- } \\
\text { tions per } \\
\text { minute. }\end{array}$ \\
\hline 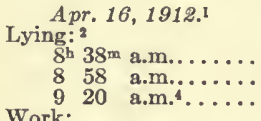 & $\begin{array}{cl}\min & \text { sec. } \\
10 & 38 \\
13 & 43 \\
14 & 27\end{array}$ & $\begin{array}{l}\text { c.c. } \\
234 \\
207 \\
212\end{array}$ & $\begin{array}{l}\text { c.c. } \\
249 \\
238 \\
250\end{array}$ & $\begin{array}{r}0.94 \\
.87 \\
.85\end{array}$ & $\begin{array}{l}66 \\
63 \\
64\end{array}$ & $\begin{array}{l}820 \\
320 \\
321\end{array}$ & $\begin{array}{c}a m p . \\
\because \\
\because\end{array}$ & $\ldots$ \\
\hline $\begin{array}{c}10^{\mathrm{h}} 08^{\mathrm{m}} \text { a.m. } \\
1045 \text { a.m. } \ldots \ldots\end{array}$ & $\begin{array}{ll}10 & 12 \\
10 & 11\end{array}$ & $\begin{array}{l}2,382 \\
2,748\end{array}$ & $\begin{array}{l}2,650 \\
2,857\end{array}$ & $\begin{array}{l}.90 \\
.96\end{array}$ & $\begin{array}{l}160 \\
162\end{array}$ & $\begin{array}{r}36 \\
38\end{array}$ & $\begin{array}{l}1.5 \\
1.5\end{array}$ & $\begin{array}{l}108.4 \\
116.6\end{array}$ \\
\hline 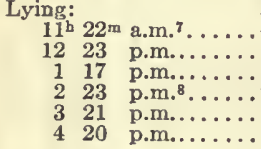 & $\begin{array}{ll}14 & 58 \\
15 & 59 \\
16 & 42 \\
16 & 52 \\
17 & 06 \\
16 & 20\end{array}$ & $\begin{array}{l}213 \\
203 \\
203 \\
201 \\
208 \\
218\end{array}$ & $\begin{array}{l}296 \\
248 \\
247 \\
255 \\
278 \\
268\end{array}$ & $\begin{array}{l}.72 \\
.82 \\
.82 \\
.79 \\
.75 \\
.81\end{array}$ & $\begin{array}{l}88 \\
76 \\
79 \\
70 \\
68 \\
70\end{array}$ & $\begin{array}{l}822 \\
820 \\
819 \\
818 \\
821 \\
323\end{array}$ & $\begin{array}{l}\because \\
\because \\
\because\end{array}$ & $\begin{array}{l}\cdots \\
\cdots \\
\cdots \\
\cdots \\
\cdots\end{array}$ \\
\hline
\end{tabular}

1 This experiment was to a certain extent an attempt to learn the after-effect of work on the respiratory

2 The "lying" periods were carried out on another respiration apparatus located on the third floor of the laboratory. The work periods were as usual with the apparatus on the first floor.

3 The respiration rate while the subject was on the couch was for the full period, as recorded by the spirometer.

4 The subject had considerable trouble just at the end of this period. He said that he had pain in his throat and difficulty in breathing. The kymograph record shows disturbance, the respiration becoming very irregular.

5 Work was begun at $9^{\mathrm{h}} 48^{\mathrm{m}}$ a.m. Between $9^{\mathrm{h}} 48^{\mathrm{m}}$ a.m. and $10^{\mathrm{h}} 08^{\mathrm{m}} \mathrm{a}$.m. the average speed was 99 revolutions per minute. During the period the work was easily done, except that the subject was troubled by a tendency for his feet to slip from the pedals, as just after starting he broke his toe-clips. He looked very well.

6 Between the periods the average speed was 84 revolutions per minute. During the second period the work was still readily done.

7 Work was finished at $11^{\mathrm{b}} 03^{\mathrm{m}}$ a.m. and the subject immediately went upstairs to the third floor and lay down on the couch.

8 The subject said he was becoming very tired and stiff with lying. He was also very hungry. He moved his legs freely before the period started. 


\section{PART III.}

\section{DISCUSSION OF RESULTS.}

The mass of experimental data accumulated in connection with this research permits of the adequate discussion of several major and innumerable minor problems in the relationship between muscular work and metabolism. We shall lay our greatest stress upon a consideration of the character of the katabolism and the mechanical efficiency of the body, and finally devote a portion of the discussion to a presentation of our evidence bearing upon a number of the physiological effects of muscular work.

\section{THE CHARACTER OF THE KATABOLISM AS AFFECTED BY MUSCULAR WORK.}

When muscular work is performed by the human body, the consumption of fuel either from food or from body-material is greatly increased. When food is not given, the energy must be supplied from body-material. If we consider to what extent, under these conditions, the constituents of the bodymaterial are available for the production of energy, we find that the amount of protein present in the normal human body is amply sufficient to provide for all drains upon nitrogenous material during rest or a short period of work. Similarly, with a well-nourished man there is a practically unlimited supply of fat. On the other hand the supply of carbohydrates is found to be very limited; thus, with dogs and with other animals, it is possible to rid the body of all but traces of glycogen by starvation, by strychnine convulsions, and by the shivering induced by prolonged exposure to severe cold, while under the same conditions there is no material draft upon the body-protein and but a small part of the large amount of body-fat is used. Apparently the storage of carbohydrates is also somewhat easily depleted by excessive muscular work. It is believed, therefore, that the ideal conditions for a study of the question as to whether or not there is a selective combustion of carbohydrate material during severe muscular work would obtain after the subject had abstained from food for twelve to fifteen hours, i.e., when there was a relatively large supply of body-protein, and a relatively small supply of bodyglycogen. If, under these conditions, a selective combustion took place, the supply of body-glycogen would be rapidly depleted and this would be indicated by the respiratory quotient. Nearly all of our experiments, therefore, including both the rest and the work experiments, were made in the morning, the subject having taken no food since the previous evening.

We have found it difficult to select a word to express this condition of abstinence from food for 12 hours. As is well known, the stimulating action of the substances absorbed from recently-introduced foodstuffs produces an increase in total katabolism which frequently obscures the effect to be studied. A German word, "nüchtern," has been freely used in the past but in our opinion it is not explanatory. English words, such as fasting, breakfastless, etc., have been considered but owing to difficulties in connection 
with the common use of these words, they are unsuitable. We prefer the far-reaching term post-absorptive.

We were fortunate in being able to secure a subject who was not made unduly uncomfortable by performing a large amount of muscular work on an empty stomach, so that in neither the rest nor the work experiments were the measurements of the metabolism complicated by the influence of food. While it cannot properly be said that during the experiments the entire alimentary tract was free from absorbable material, nevertheless, it was to a very large extent thus free, so that for all practical purposes we may say that the subject was living upon body-material.

By previous experimenting in this laboratory, it has been shown that the character of the post-absorptive katabolism might be considerably modified by normal alterations in the diet. It was therefore necessary to obtain a baseline both for the character of the katabolism as shown by the respiratory quotient and for the amount of the katabolism as determined by the measurement of the carbon dioxide produced and the oxygen consumed. This baseline was determined by making a series of rest experiments each morning previous to the experiment with muscular work.

In order that the picture of the resting katabolism might be more complete, an attempt was made to secure regularly the urine voided during the experimental period. In a research of this kind it is of course necessary to assume that the nitrogenous products of the urine collected during an experimental period represent the protein disintegration for that period. This assumption is liable to many gross errors, particularly in experiments with severe muscular work as an after-effect of the work upon protein katabolism, or at least the nitrogenous excretion in the urine, has frequently been noticed. Analyses have been made of these urines, however, and the results of the determinations are reported.

\section{DETERMINATION OF THE RESPIRATORY QUOTIENT.}

In a study of the character of the katabolism as influenced by muscular work, the significance of the respiratory quotient makes it necessary that this value should be determined with the greatest accuracy. This is doubly difficult inasmuch as the determination of the respiratory quotient is affected by errors in the values obtained for both the carbon dioxide and the oxygen. The determination of the carbon dioxide produced by man is relatively a simple matter, there being a number of excellent methods for this purpose. The determination of the oxygen absorption is, on the other hand, very difficult, and while several methods are in good repute among physiologists, it still remains a fact that extraordinary skill is required on the part of the observer to secure reliable results. All of our energies, therefore, were concentrated in an effort to obtain the most exact measurements of these two factors. The determinations of the carbon dioxide and the oxygen were always verified, the respiration apparatus and the connections with the subject were continually tested for tightness, precautions were taken to insure the full efficiency of the absorbers, and the calibrations of the meter were often checked. Furthermore, the inherent difficulties involved in an altered respiratory type and the possible effect of a pumping out of carbon dioxide by excessive ventilation were taken into consideration. 
Errors Incidental to the Determination of the Carbox-dioxide Prodectiox.

In the type of apparatus here used the carbon-dioxide production is determined by absorbing the gas in suitable containers filled with soda-lime. No volumetric gas-analyses, no aliquoting of samples, and no records of the variations in the barometer and the pressure are required. The determination of the carbon dioxide in the air-current thus becomes a method of gravimetric analysis. There are, however, several possible sources of error.

The first to be considered is an incomplete absorption of the carbon dioxide due to the inefficiency of the soda-lime. To provide for the absorption of any excess of carbon dioxide the air was swept through the system for several minutes at the end of each experimental period, the air-current passing through the soda-lime two, three or even four times. Furthermore, a test of the air leaving the soda-lime bottles was frequently made by passing a small sample of it through barium hydroxide, the complete absorption of the carbon dioxide being shown by the absence of turbidity. We have also found an annoying source of error in the fact that when the absorbers are weighed, the rubber gaskets used to secure tight closure between the different receptacles are occasionally left in the couplings. Each weighing of the soda-lime bottles was therefore checked by a second person and the absence of the gasket noted on the record sheet when the record of the weight was made, thus eliminating the possibility of error from this cause.

Another way in which the determinations of the carbon dioxide may be affected is by the inefficiency of the sulphuric acid in the air-drying bottle. If, through carelessness, the sulphuric acid in this bottle is allowed to absorb more than 10 grams of the water taken up in the passage of the air through the soda-lime, the absorption will not be quantitative and the determined amount of carbon dioxide will be lower than that actually produced. To provide against this error, it was the custom to have the two soda-lime bottles and the air-drying bottle removed at the end of each day's experiment, repeated tests having shown that the limit of absorption, namely, 10 grams, was never reached under these conditions. In view of these precautions, we have every confidence in the measurements of the carbon-dioxide production. ${ }^{a}$

\section{Errors Incidental to the Determanation of the Oxygen Consumption.}

The determination of the oxygen consumption can be made either gravimetrically, as was originally designed for this apparatus, by weighing the oxygen cylinder before and after the experiment and noting the amount of oxygen added to the air-current, or by the more convenient and recently adopted method of measuring the amount of oxygen by means of a carefully calibrated Bohr gas-meter immersed in water. This method of measuring the oxygen consumption depends upon the fact that the subject uses out of the air in the system a certain amount of oxygen which must be replaced by pure oxygen or by a known volume of some other gas. If the oxygen in the system is not allowed to fall below 10 or 11 per cent, even pure nitrogen might be used to replace the oxygen absorbed and bring the air to the original volume, since it has been shown that the metabolism is normal above this oxygen percentage. For this replacement, however, we ordinarily use oxygen

a More recent tests kindly carried out by Mr. T. M. Carpenter have shown conclusirely that no apprecisble amount of water escaped absorption. 
of a high grade, namely, of about 98 per cent purity, and measure the volume of gas passing through the Bohr gas-meter, assuming that no air escapes from the system through the mouth or nose of the subject, or through defective connections. Since every liter of air leaking out of the system through the mouth, the nose, or defective connections must be replaced by a liter of oxygen in order to bring the air again to the normal volume, such loss of air affects only the oxygen determination.

To provide against any such loss of air through defects in the absorbing system the apparatus was tested every morning by running the motor for several minutes before connecting the subject with it, the volume of air in the system being carefully noted at the beginning and end of the test. If a leak was found no experiments were made until the apparatus was proved to be tight. Practically the only other source of leaks possible, therefore, was about the nose and mouth of the subject. Since there was especial danger of such leaks in the muscular-work experiments, the utmost precautions were taken to prevent them. The nose of the subject was closed with a clip supplied by Siebe, Gorman \& Co.; as a further check upon the complete closure of the nose and mouth, it was an invariable rule to cover the face around the noseclip and mouthpiece with soapsuds so that the slightest leakage of air through the nose or the mouth would be instantly indicated by bubbles.

In determining the oxygen consumed by the subject, all of the values are referred to the same basis, namely, the weight of a liter of the gas issuing from the cylinder when the valve is open. This is true irrespective of whether the determination is made by noting the loss in weight of a cylinder of the highly compressed gas or by using the Bohr gas-meter immersed in water, since the method of calibrating the gas-meter involves the use of the weighed cylinder of oxygen. In a recent description of the method of calibration and of computing the oxygen consumption, attention was called to the fact that but rarely is pure oxygen available, the residual gas unabsorbed by potassium pyrogallate being usually about 3 per cent. ${ }^{a}$ This residual gas has commonly been considered as nitrogen, and the difference in weight per liter of the oxygen and nitrogen has been taken into consideration in the computations.

Recently an interesting paper has appeared by Morey, ${ }^{b}$ who examined the impurities in the commercial oxygen made from liquid air. Inasmuch as practically all of the oxygen used in this laboratory is obtained from the Linde Air Products Company and is derived from liquid air, the interesting observations of Morey hold true with the use of this gas. Morey finds that the residual gas is not wholly nitrogen, but is in large part argon, a sample of oxygen analyzed by him showing 96.9 per cent of oxygen, 2.8 per cent of argon, and 0.3 per cent of nitrogen. He points out that this confirms the work of Claude, ${ }^{c}$ who has noted that argon to the extent of about 3 per cent is the chief impurity in oxygen prepared by the Claude process.

After the manuscript and computations for this report were practically completed, our attention was called by Mr. H. L. Higgins of the laboratory staff to the possible influence on our results of the presence in the oxygen of argon. Mr. Higgins maintained correctly that if gas were used containing 97 per cent oxygen and 3 per cent nitrogen, the weight of a liter would be

a Benedict, Deutsch. Archiv f. klin. Med., 1912, 107, p. 181.

b Morey, Journ. Am. Chem. Soc., 1912, 34, p. 491. c Claude, Comptes rendus, 1909,151, p. 752. 
1.423 grams. On the other hand if 90 per cent of the residual gas is argon, the weight of a liter of the gas would be 1.4375 grams, an increase of over 1 per cent. It has formerly been our custom to apply a correction of +0.4 per cent to the weight of oxygen, but if the impurity is argon, the correction should have been -0.6 per cent. The values for the oxygen consumption as originally calculated, therefore, were all 1 per cent too high, and they have consequently been reduced by this percentage which represents a definitely established error. Since a decrease of 1 per cent in the values for the oxygen affects the respiratory quotient by 1 per cent, all of the respiratory quotients as originally calculated were too low, and accordingly throughout the whole report they have been raised by 0.01 .

In all experiments in which oxygen made from liquid air is used, the correction for argon must be of significance and necessary, this being one of the relatively few instances where the actual difference between argon and nitrogen has entered extensively into the computations of chemical or physiological routine technique. In all future publications of this laboratory, the correction will be made without further comment.

\section{Physiological Sotrces of Error in Gas Measurements.}

The carbon-dioxide output of the body may be equal to that expired in a given time, it may exceed the amount eliminated, or, under certain conditions, it may be much less. If the subject artificially or unintentionally ventilates the lungs excessively by labored respiration, the composition of the alveolar air may be considerably changed, and carbon dioxide may leave the blood so that a large amount of carbon dioxide may be "pumped out" of the body that was not simultaneously produced. Under these conditions there would be an excessive elimination of carbon dioxide with a consequent abnormal respiratory quotient-the respiratory quotient being much too large. After a period of excessive ventilation, with a large "pumping out" of carbon dioxide, the equilibrium between the alveolar air and the blood may be again established by the retention of carbon dioxide. Under these conditions the amount of carbon dioxide expired would be less than that produced, and consequently the respiratory quotient would again be abnormal in that it would be too low. Recognizing the great influence that an abnormal ventilation of the lungs, or an abnormal elimination or retention of carbon dioxide would have upon the respiratory quotient, and hence upon the interpretation of the character of the metabolism, every precaution was taken with these subjects to secure a normal respiration during the work experiments. This was done by having the subject ride on the bicycle ergometer for a preliminary period of not less than 15 minutes before the experiment began, the conditions being the same as during the actual experimental period. As a general rule, the work continued for approximately an hour, and sometimes longer, the measurements being made at intervals throughout the working period, so that the subject previous to the different periods of the experiment had been working for a length of time varying from $15 \mathrm{~min}-$ utes to an hour or more.

Only in the experiments following work was there a possibility of the retention of carbon dioxide playing any great rôle. This was studied in observations made of the respiratory exchange immediately after the work ex- 
periments, the subject lying quietly upon a couch and the measurements being made as rapidly as possible in periods of 15 minutes each. The composition of the alveolar air was also determined in this study of the aftereffect of muscular work. The negative results of these observations will be discussed in a subsequent section of the report.

\section{THE BASAL METABOLISM.}

In many investigations on the influence of muscular work upon the metabolism, as, for instance, in experiments in which mountain-climbing, marching, or other work outside of the laboratory was performed, it was frequently impossible to secure a value for the normal resting metabolism of the subject under conditions obtaining at the time that the muscular activity began or ended; it was therefore necessary to assume this value. There are, however, many factors which tend to alter the relative proportions of materials in the body,-the protein, the fat, and the carbohydrates, - and which thus obviously alter the basal metabolism. This is especially true in a research covering a long period.

It is difficult to conceive of any factor which would alter in a short time the relative proportion of either the stored body-protein or the body-fat. Consequently we consider first the factors affecting the body composition which require considerable periods of time. These would include prolonged inanition, which would deplete carbohydrates and fat, rather than protein; training in any form of muscular activity, during which there would be a loss of subcutaneous fat with a hypertrophy of the muscles; fever, which would cause a great depletion of fat and also of protein; and obesity, in which there would be the addition of large amounts of subcutaneous fat. With the possible exception of very severe training, none of these would result in any material alteration in the storage of protein and fat in a period of less than a week.

While the storage of protein and fat in the body is not readily altered, the storage of carbohydrates, on the other hand, being comparatively small, may be quickly depleted in 24 hours or perhaps in even less time. Of the factors known to affect rapidly the glycogen storage, none has been more definitely demonstrated than complete inanition, experiments made with fasting men showing a very rapid and extensive depletion of the carbohydrate storage. Thus it has been established that a fasting man may draw from the storage of carbohydrates in the body, chiefly glycogen, as much as 180 grams on the first day of fasting, while experiments made at Wesleyan University, Middletown, Connecticut, with 7 fasting men showed that on the first day of fasting there was an average katabolism of 110 grams of glycogen. ${ }^{a}$ Since it is commonly supposed that the total storage of glycogen or carbohydrates in the body is not far from 400 grams, $^{b}$ it can be seen that this is a relatively enormous depletion of the stored material.

The preceding diet also has a great influence upon the storage of carbohydrates in the body, as indicated by the respiratory quotient. In experiments carried out in this laboratory ${ }^{c}$ with diets containing in one period a large preponderance of carbohydrates and in another period a large prepon-

a Benedict, Carnegie Institution of Washington Publication No. 77, 1907, p. 464.

$b$ For a discussion of this estimate see p. 96 , this report.

$c$ Benedict and Higgins, Am. Journ. Physiol., 1912, 30, p. 217. 
derance of fat, it has been found that there was a material alteration in the respiratory quotient indicating a difference in the character of the material burned under the varying conditions of diet. The respiratory quotients with a carbohydrate-rich diet, even 12 hours after the last meal, were invariably higher than those after a carbohydrate-poor diet, while with a carbohydratefree diet the respiratory quotient quickly reached 0.7 or even below, indicating a combustion almost exclusively of fat. The marked and immediate influence on the respiratory quotient of the absence of carbohydrates from the food accentuates the fundamental importance of determining the post-absorptive value of the respiratory quotient in the normal resting position before every experiment in which the influence of a superimposed factor, such as muscular work, is to be studied.

\section{The Normal Resting Metabolism as Determined in this Research.}

As has already been explained, it has not been necessary to assume a basal metabolism in this research, since the normal resting metabolism for each individual day was established by a preliminary rest experiment each morning. While this of course largely increased the number of experiments, the resting values thus obtained had an added interest in that they showed what degree of constancy may be expected from day to day and throughout 5 months in the gaseous exchange of a normal resting man in the post-absorptive state.

Naturally, the greatest number of rest experiments were made with the professional bicyclist, M. A. M. In table 91 are given in abstract the results for the series of experiments made with this man beginning December 7, 1911, and ending with April 16,1912, each experiment usually consisting of three periods of 15 minutes each. During the winter there was a slight progressive change in body-weight from 64.5 to 68 kilograms, hence the results have been computed per kilogram of body-weight per minute. The data given represent the fluctuations that may be fairly expected to occur in the course of a season of experimenting with a subject of this type. As has been previously stated, the man was an ideal subject and became thoroughly used to the apparatus, adjusting himself in every way to the experiments without the least hesitancy or disinclination.

The carbon-dioxide production per kilogram per minute varied from 2.86 to 3.49 c.c. with an average of 3.12 c.c. per kilogram of body-weight per minute. Since we know that the amount of carbon dioxide produced fluctuates considerably with the character of the preceding diet and with the storage of body-material, these fluctuations are no greater than one would normally expect to find.

The oxygen consumption varied from 3.38 to 4.09 c.c., averaging 3.67 c.c. per kilogram of body-weight. The measurement of the oxygen consumption represents much more nearly the calorific production than does the carbon-dioxide excretion, and hence we have in the oxygen consumption a more accurate index of the total heat production. This, it is seen, amounts to an extreme variation of 7 parts in 34 , or essentially 20 per cent, so that without attempting to analyze the results for each individual day, it can be seen that the resting metabolism, even when obtained under ideal conditions, may vary 20 per cent in the course of a winter. A close examination of the 
TABLE 91.-Post-absorptive katabolism in respiration experiments with subject $M . A . M$. lying on couch before work.

\begin{tabular}{|c|c|c|c|c|c|c|c|c|}
\hline \multirow{2}{*}{ Date. } & \multirow{2}{*}{$\begin{array}{l}\text { Weight } \\
\text { without } \\
\text { clothing. }\end{array}$} & \multicolumn{2}{|c|}{ Total per minute. } & \multicolumn{2}{|c|}{$\begin{array}{c}\text { Per kilogram per } \\
\text { minute. }\end{array}$} & \multirow{2}{*}{$\begin{array}{l}\text { Respira- } \\
\text { tory } \\
\text { quotient. }\end{array}$} & \multirow{2}{*}{$\begin{array}{l}\text { Pulse- } \\
\text { rate. }\end{array}$} & \multirow{2}{*}{$\begin{array}{c}\text { Respira- } \\
\text { tion- } \\
\text { ratc. }\end{array}$} \\
\hline & & $\begin{array}{l}\text { Carbon } \\
\text { dioxide. }\end{array}$ & Oxygen. & $\begin{array}{l}\text { Carbon } \\
\text { dioxide. }\end{array}$ & Oxygen. & & & \\
\hline 1911. & kilos. & c.c. & c.c. & c.c. & c.c. & & & \\
\hline Dec. 7 & 64.5 & 225 & 262 & 3.49 & 4.07 & 0.86 & 74 & 18 \\
\hline 11 & $\begin{array}{l}04.5 \\
64.5\end{array}$ & $\begin{array}{l}205 \\
195\end{array}$ & $\begin{array}{l}247 \\
238\end{array}$ & $\begin{array}{l}3.18 \\
3.02\end{array}$ & $\begin{array}{l}3.82 \\
3.68\end{array}$ & $\begin{array}{l}.85 \\
.82\end{array}$ & $\begin{array}{l}66 \\
60\end{array}$ & $\begin{array}{l}20 \\
21\end{array}$ \\
\hline 12 & 64.5 & 198 & 230 & $\begin{array}{l}3.02 \\
3.07\end{array}$ & $\begin{array}{l}3.00 \\
3.56\end{array}$ & .82 & 60 & 22 \\
\hline 13 & 64.5 & 200 & 226 & 3.10 & 3.49 & .88 & 63 & 24 \\
\hline 14 & 64.5 & 216 & 238 & 3.35 & 3.68 & .91 & 64 & 24 \\
\hline 15 & 64.5 & 200 & 250 & 3.10 & 3.88 & .80 & 64 & 23 \\
\hline 19 & 65.0 & 200 & 238 & 3.08 & 3.65 & .84 & 63 & 20 \\
\hline 20 & 65.0 & 194 & 226 & 2.98 & 3.47 & .86 & 63 & 19 \\
\hline 21 & 65.0 & 199 & 231 & 3.06 & 3.54 & .86 & 60 & 18 \\
\hline $\begin{array}{r}22 \\
1912\end{array}$ & 65.0 & 194 & $\overline{225}$ & 2.98 & 3.46 & .86 & 60 & 20 \\
\hline Jan. 1 & 65.5 & 208 & 233 & 3.18 & 3.55 & .89 & 67 & \\
\hline$\overline{2}$ & 65.5 & 199 & 232 & 3.04 & 3.53 & .87 & 61 & 17 \\
\hline$\overline{3}$ & 65.5 & 200 & 233 & 3.05 & 3.55 & .86 & 60 & 19 \\
\hline 4 & 65.5 & 214 & 235 & 3.27 & 3.58 & .91 & 65 & 20 \\
\hline 5 & 65.5 & 213 & 233 & 3.25 & 3.55 & .92 & 62 & 20 \\
\hline 8 & 66.0 & 204 & 231 & 3.09 & 3.49 & .88 & 59 & 20 \\
\hline 9 & 66.0 & 211 & 241 & 3.20 & 3.64 & .88 & 60 & 19 \\
\hline 10 & 66.0 & 208 & 258 & 3.15 & 3.91 & .80 & 65 & 20 \\
\hline 12 & 66.2 & 222 & 262 & 3.35 & 3.96 & .85 & 63 & 21 \\
\hline 15 & 66.6 & 232 & 258 & 3.48 & 3.88 & .90 & 65 & 23 \\
\hline 16 & 66.2 & 211 & 247 & 3.19 & 3.74 & .85 & 82 & 23 \\
\hline 171 & 65.9 & 191 & 251 & 2.90 & 3.81 & .77 & 61 & 20 \\
\hline 181 & 65.5 & 201 & 261 & 3.07 & 3.99 & .77 & 63 & 24 \\
\hline 191 & 65.5 & 199 & 260 & 3.04 & 3.98 & .77 & 66 & 21 \\
\hline 23 & 65.9 & 210 & 247 & 3.19 & 3.74 & .86 & 67 & 21 \\
\hline $24^{2}$ & 65.9 & 201 & 232 & 3.05 & 3.51 & .87 & 63 & 21 \\
\hline 252 & 65.9 & 199 & 249 & 3.02 & 3.78 & .80 & 63 & 20 \\
\hline $26^{2}$ & 65.2 & 202 & 237 & 3.10 & 3.63 & .86 & 64 & 23 \\
\hline 31 & 66.5 & 222 & 240 & $\mathbf{3 . 3 4}$ & 3.60 & .93 & 66 & 20 \\
\hline Feb. 1 & 66.5 & 214 & 241 & 3.22 & 3.61 & .89 & 68 & 20 \\
\hline 2 & 66.5 & 204 & 246 & 3.07 & 3.69 & .83 & 64 & 19 \\
\hline 6 & 65.9 & 210 & 233 & 3.19 & 3.53 & .90 & 59 & 19 \\
\hline $7:$ & 65.9 & 195 & 233 & 2.96 & 3.53 & .84 & 59 & 20 \\
\hline $8:$ & 64.9 & 207 & 256 & 3.19 & 3.95 & .81 & 66 & 20 \\
\hline $9^{3}$ & 64.8 & 190 & 242 & 2.93 & 3.73 & .79 & 65 & 19 \\
\hline 13 & 65.7 & 196 & 233 & 2.98 & 3.54 & .84 & 60 & 20 \\
\hline 144 & 65.7 & 202 & 235 & 3.07 & 3.57 & .87 & 60 & 19 \\
\hline 154 & 65.7 & 188 & 234 & 2.86 & 3.55 & .81 & 62 & 20 \\
\hline 164 & 65.7 & 193 & 222 & 2.94 & 3.38 & .87 & 60 & 19 \\
\hline 20 & 66.0 & 200 & 247 & 3.03 & 3.75 & .81 & 61 & 19 \\
\hline 21 & 66.1 & 191 & 236 & 2.89 & 3.56 & .81 & 59 & 20 \\
\hline 23 & 66.4 & 205 & 235 & 3.09 & 3.53 & .87 & 57 & 21 \\
\hline 26 & 66.8 & 199 & 239 & 2.98 & 3.57 & .84 & 61 & 20 \\
\hline 27 & 66.9 & 209 & 239 & 3.12 & 3.56 & .88 & 56 & 19 \\
\hline 29 & 67.2 & 216 & 258 & & 3.84 & .84 & 66 & 21 \\
\hline Mar. $6^{5}$ & 68.0 & 230 & 259 & 3.38 & 3.81 & .89 & 63 & .21 \\
\hline 11 & 68.0 & 215 & 247 & 3.16 & 3.62 & .87 & 60 & 21 \\
\hline 26 & 68.0 & 206 & 233 & 3.03 & 3.42 & .89 & 57 & 20 \\
\hline $29^{5}$ & 68.0 & 217 & 7278 & 3.19 & 74.09 & 7.79 & 68 & 21 \\
\hline Apr. $16^{6}$ & 68.0 & 218 & 246 & 3.21 & 3.61 & .89 & 64 & 20 \\
\hline Average & 65.9 & 205 & 242 & 3.12 & 3.67 & .85 & 63 & 20 \\
\hline
\end{tabular}

1 The experiments of $\mathrm{Jan} .17,18$, and 19 were made following 1,2 , and 3 days, respectively, with carbohydratepoor diet (100 grams carbohydrates per day).

2 The experiments of Jan. 24,25 , and 26 were made following 1, 2, and 3 days, respectively, with carbohydraterich diet (ca. 400 grams carbohydrates per day).

3 The experiments of Feb. 7, 8, and 9 were made following 1, 2, and 3 days, respectively, with carbohydratepoor diet (100 grams per day).

1 The experiments of Feb. 14, 15, and 16 were made following 1,2, and 3 days, respectively, with carbohydraterich diet (ca, 400 grams carbohydrates per day).

5 The lying periods for Mar, 6, Mar, 29, and Apr. 16 were made with a somewhat modified apparatus.

6 These respiration records are for the full period, from kymograph records. Records of the ventilation wcre also taken.

7 The tightness of the system was tested. At the end of the third period the subject said he had a headachc.

figures shows, however, that these extreme variations are but rarely met with. Thus, values higher than 4 c.c. are recorded but twice and values less than 3.49 c.c. are recorded but three times. To the writers it appears obvious, however, that it is practically impossible to obtain an average base-line in 
any series of metabolism experiments to be subsequently applied to researches during muscular work. When the increment in the gaseous metabolism is as great as in experiments with severe muscular work, the method of employing an average base-line is open to the least objection. But in many researches in which an average base-line has been employed, the increment due to the superimposed factor does not amount to more than 20 per cent of the total metabolism; it can therefore readily be seen that the basal metabolism obtained as the average of a large number of figures cannot logically be used. It should be stated that in but relatively few experiments in this report was such an average base-line employed.

An examination of the values for the respiratory quotient shows likewise a considerable fluctuation, ranging from 0.77 to 0.93 , with an average value of 0.85. As will be pointed out subsequently, the values for 0.77 were found on days following the ingestion of a diet poor in carbohydrates.

The values of the pulse-rate have likewise been of interest inasmuch as they indicate the normal fluctuations that may be expected under the conditions of experimentation, ranging from 56 to 82 per minute, with an average of 63 . On the other hand, values higher than 70 are recorded but twice, while values lower than 59 are recorded but three times. The respiration-rate apparently stayed remarkably constant throughout the whole period, fluctuating only from 17 to 24 , and remaining almost constantly at 20 throughout the greater number of experiments.

Having pointed out the futility of using a constant average base-line for metabolism experiments, particularly when relatively small increases in metabolism accompany the superimposed factor to be studied, it should be stated that many of the fluctuations here occurring may be easily interpreted by a reference to the statistical data accompanying the individual experiments. Noticeable alterations were observed in the carbon-dioxide production, the oxygen consumption, and the respiratory quotient. Each of these factors may readily be affected by extraneous conditions prior to the experiment, such as the general character of the diet, the degree of muscular activity on the day before, the storage of body-material, or the psychical stimulus which obviously was present in the first experiment. Furthermore, in a series of observations such as this, it is not unreasonable to look for the influence of other less determined factors, such as cold weather, and the condition of training.

In several instances a high metabolism was believed to have resulted from the greater muscular activity of the subject on his way to the laboratory, when he walked over a somewhat rough pathway, ran, or found it difficult to keep his balance owing to the icy pavements. The abnormality in the oxygen consumption during the early part of January may almost certainly be explained in large part by the condition of the streets at that time.

The influence of training upon the metabolism is not easily estimated. The oxygen intake per minute per kilogram of body-weight remained remarkably constant throughout the series of experiments, notwithstanding the fact that the subject gained 3.5 kilograms during the progress of the research. As this increase in weight took place while work was being constantly and steadily done, it was doubtless due in part to increased muscular development. On the other hand, the average intake of oxygen during the first 
10 experiments was 3.68 c.c. per minute per kilogram of body-weight, while the last experiment on April 16 gave an oxygen consumption of 3.61 c.c. per minute per kilogram of body-weight. The general inference from these data would thus be that training influenced the metabolism but little in this series of experiments. It should be taken into consideration, however, that the subject was a trained bicyclist, and in good condition when he began the work.

In general, this subject was inclined to eat heartily, having a decided preference for meat. He several times suggested that he would have been able to do considerably more work if he could have had a hearty meal before the experiment, instead of coming to the laboratory without breakfast. In fact, the subject found it somewhat difficult to adjust himself to this feature of the routine, although towards the end of the experimenting he became accustomed to it. Usually he ate a full meal about noon and a second about $7^{\mathrm{h}} 30^{\mathrm{m}}$ p.m., occasionally but not often taking food later in the evening. He drank no alcoholic liquors, and while he smoked cigars and cigarettes considerably in the first part of the study, later he practically ceased, because the mucous membrane was somewhat irritated by the frequent use of soapsuds over the mouth. While it was found impracticable to control the diet of the subject when he was outside of the laboratory, the special study previously referred to of the influence on the metabolism of varying amounts of carbohydrate in the diet supplied sufficient data for intelligent discussion. This phase of the subject is given treatment elsewhere. ${ }^{a}$

THE CHARACTER OF THE KATABOLISM DURING MUSCULAR WORK AS INDICATED BY THE RESPIRATORY QUOTIENT.

A critical analysis of the respiratory quotients secured in this research permits an estimate as to the character of the katabolism before, during, and after work, this being one of the main objects of the study. Chauveau was one of the earliest to recognize the significance of the respiratory quotient as an index of the character of the katabolism, and as the foremost advocate of the belief that all muscular work is accomplished at the expense of carbohydrate combustion, his views should be presented somewhat extensively.

\section{Theories of Chauveau and Zuntz as to the Character of the Katabclism} DURING Muscular Work.

One of the most striking pieces of evidence that Chauveau has presented in favor of his theory of a selective carbohydrate combustion during muscular work is an experiment made on M. Tissot. ${ }^{b}$ In this experiment the subject was without food, the last meal having been taken 16 hours before. The work, which was continuous, consisted of going up and down a long staircase in the laboratory, the time for the ascent and descent being always the same. At the end of 70 minutes the subject had done about 29,000 kilogrammetcrs of positive work, the amount of negative work, according to Chauveau's computations, being similar. At the end of this time the subject was completely fatigued. During the experiment the expired air was collected 6 times in a Chauveau-Tissot apparatus, each sample requiring precisely 5 minutes. The respiratory quotients, which were determined at different periods during the work, were as follows: 
R 0

Immediately before work . . . . . . . . . . . 0.75

During the first 5 minutes of work . . . . . . . . 0.84

Between the 10th and 15th minute . . . . . . . . . . 0.87

Between the 40th and 45th minute . . . . . . . . 0.95

At the end of work, between the 65th and 70th minute . . . 0.84

After 1 hour of rest . . . . . . . . . . . . 0.74

Unfortunately Chauveau gives this merely as a sample experiment, and states that it is neither the best experiment nor the most conclusive. The only evidence with regard to the intensity of the work and the gaseous exchange is the statement that it is four times that during rest; on this basis Chauveau computes the theoretical respiratory quotient as follows: If the subject burned exclusively fat, using a respiratory quotient for fat katabolism of 0.70 , the computation would be $\frac{0.70 \times 3+0.75 \times 1}{4}$, thus giving a respiratory quotient of 0.71 . He argues from this that if the subject burned only fat during muscular work, the tendency would be to lower the respiratory quotient. On the other hand, if the combustion were exclusively of carbohydrates, using a respiratory quotient for carbohydrate katabolism of 1 , the computation would be $\frac{1 \times 3+0.75 \times 1}{4}$, or a respiratory quotient of 0.94 . This was essentially the value found at the end of 40 to 45 minutes of work. Chauveau argues from this that the work during the experiment with Tissot was done exclusively at the expense of carbohydrates. He points out, however, that the quotient does not stay at this high value but gradually falls as the work progresses. While he considers that the data indicate without doubt that the muscular work cannot be done simply by the combustion of fat, he brings up the question as to why the quotient is lowered if the work is done exclusively by the combustion of glycogen. These lower values he explains by the statement that there is a draft upon the store of carbohydrates which is immediately compensated by the conversion of fat into carbohydrate and this partial combustion of fat results in a lowering of the respiratory quotient.

As is too frequently the case, the details of this important experiment are not given, and its shortness has been frequently criticized. Whether or not there was a cessation of work during the collection of samples or whether the samples were collected by means of a portable apparatus is not known, but the possible alterations in the character of the respiration at the cessation or the beginning of work may all play an important rôle in determining the measurements of the character of the katabolism.

The experiments as a whole have been severely criticized by Zuntz, ${ }^{a}$ who points out that while Chauveau attempts to explain the low respiratory quotient toward the end of work, he does not explain why the respiratory quotient was low at the beginning of the work-period when the store of carbohydrates was abundant. Zuntz argues that the quotient obtained during the first 15 minutes agrees with the theory of himself and his associates that during work the nutrients oxidized are essentially the same as during rest, but that there is some increase in the utilization of the carbohydrates because, 
as the most mobile of the nutrients circulating with the blood, they can be more quickly brought to the place where they are to be used. He further states that he and his co-workers have never observed so high a respiratory quotient as Chauveau found between the 40th and 45th minute of the experiment except when, on account of fatigue, the circulation and respiration failed to furnish an adequate supply of oxygen to the active tissues; he therefore infers that under those conditions the high quotient is due to a kind of anærobic action of the muscles similar to that observed in dogs by Pflüger.

The clearest expression of the views of the Zuntz school on the character of the katabolism during muscular work may be obtained from a recent article by Zuntz. ${ }^{a}$ Here Zuntz points out the fact that the best evidence of the nature of the material burned in the muscles during muscular work is secured in experiments in which the work, which should not be too great, is carried out over a long period of time without excessive fatigue. Such experiments were made, he claims, by himself and Hagemann on horses and by Katzenstein and others of the Zuntz school on men. In these experiments the respiratory quotient in the work-period was in many cases exactly equal to that during rest, and in others a few units lower, namely, in long-continued experimenting. In one of Katzenstein's experiments, for example, the resting quotient was 0.80 ; when the subject walked about on horizontal ground and even walked up an incline, the quotient remained the same, although the oxygen consumption was increased to more than 5 times that of normal. In experiments with soldiers, in which marching followed a rest-period, Zuntz and Schum$\operatorname{burg}^{b}$ also found equal respiratory quotients for rest and work. If the march was very fatiguing, they always found a respiratory quotient 6 units lower than at the beginning of the marching. To explain the lower quotients after excessive work, Zuntz cites some experiments by himself and Hagemann on a horse in which the respiratory quotient during rest, shortly after feeding with carbohydrate-rich food, was always near 1 , while with work there was a tendency toward a lower respiratory quotient.

While Chauveau's experiments are comparable with those reported in our research since they were made in the post-absorptive condition, the experiments of Zuntz and Hagemann with a horse were always made with food, and consequently the situation was complicated by the continual absorption of the nutritive materials out of the alimentary tract. Zuntz, in computing the consumption of material by the horse, in at least one experiment indicates that the material used for the muscular work was in very large part fat, although the horse certainly had not drawn upon more than one-fourth of its glycogen supply. In one experiment, in which the animal worked for 95 minutes, the energy was in large part derived from the combustion of glycogen, the respiratory quotient being 0.91 . During subsequent work of 27 minutes the quotient found was 0.81 , indicating that the energy was in large part derived from the combustion of fat. In the first period, therefore, four times as much glycogen was used as fat, while in the last period only one-seventeenth of the total energy came from glycogen. Zuntz maintains that the experiments on men made by his students lead to the same conclusion, citing especially the experiments of Heinemann. ${ }^{c}$

a Zuntz, in Oppenheimer's Handbuch der Biochemie, Jena, 1911, 4, (1), pp. 849-850.

b Zuntz and Schumburg, Physiologie des Marsehes, Berlin, 1901.

c Heinemann, Pflüger's Archiv f. d. ges. Physiologie, 1901, 83, p. 441. 
Chauveau also argues that in the conversion of fat into carbohydrates there is a waste energy which is not utilizable for muscular work, since a part of the oxygen consumed must be used in first converting fat into carbohydrates, during which process there is no energy liberated which is available for external muscular work; hence for the same amount of muscular work on a carbohydrate diet there will be a considerably smaller heat production than when the muscular work results from fat disintegration. In opposition to this theory, Zuntz cites experiments made by his various students, especially those of Frentzel and Reach ${ }^{a}$ and also the experiments of Atwater, Sherman, and Carpenter, ${ }^{b}$ which showed that the absorption of oxygen per unit of work is essentially the same whether fat or carbohydrate is burned. According to Zuntz, therefore, there is no selective combustion of carbohydrate material during muscular activity; furthermore, since Chauveau's theory would require for a unit of external muscular work 30 per cent more energy with fat than with carbohydrates, Zuntz argues that all nutrients can furnish muscular energy without previous transformation into sugar. ${ }^{c}$

Respiratory QUotients of Bicycle Ergoneter Experiments aNd their Significance.

A comparison of the character of the katabolism before, during, and after work may be made either directly by comparing the respiratory quotients, or by comparing the amounts of protein, fat, and carbohydrates katabolized per minute, as computed by the Zuntz formula from the measurements of the nitrogen and carbon-dioxide output and the oxygen consumption. Since the character of the katabolism has a direct influence upon the relation between the carbon-dioxide excretion and the oxygen consumption, we have considered it unnecessary to make the elaborate computation of the amounts of glycogen and fat katabolized per minute, and have based all our comparisons upon the respiratory quotient. In doing this we have assumed that low respiratory quotients indicate a katabolism chiefly of fat and protein, and that the higher the quotient the greater the proportion of carbohydrates burned. It has, furthermore, been assumed that throughout the rest and work periods there is a relative constancy in the katabolism of protein, with no excessive immediate disintegration of protein as a result of the muscular activity.

GENERAL COMPARISON OF THE RESPIRATORY QUOTIENTS.

From an inspection of the data obtained in the bicycle ergometer experiments, it is seen that there were variations in the character of the respiratory quotients obtained before, during, and after work, with no complete uniformity. The difficulty in considering individual experiments is clear when not only the variations in the amount of work done but the well-known influence of the preceding diet upon the character of the respiratory exchange are borne in mind. Furthermore, it must be remembered that in the first period during muscular work, the true value of the respiratory quotient may be affected by the formation of lactic acid, i.e., imperfect oxidation. As, however, the so-called lactic-acid period appears to be very transitory, its effect on our results has been practically ignored.

a Frentzel and Resch, Pfüger's Archiv. 1901, 83, p. 477

o Atwater, Sherman, and Carpenter, U. S. Dept. Agr., Office Expt. Stas. Bul. 98, 1901.

c Zuntr, loc. cit. 
It seems evident, therefore, that it will be more desirable to present the data as a whole first and then draw from the average figures such deductions as are permissible. Accordingly, in table 92, are presented the average quotients found before, during, and after work. Such quotients as were obtained in later periods will be found in the footnotes. No indication is given in the table as to how many periods are included in the averages nor of the actual amount of work done, since the data are intended to present only a general picture of the results. ${ }^{a}$

TABLE 92.-Respiratory quotients in respiration experiments without food before, during, and after work.

\begin{tabular}{|c|c|c|c|c|c|c|c|c|c|c|c|}
\hline \multirow[b]{2}{*}{ Subject. } & \multirow[b]{2}{*}{ Date. } & \multirow[b]{2}{*}{$\begin{array}{l}\text { Lying } \\
\text { before } \\
\text { work. }\end{array}$} & \multirow[b]{2}{*}{$\begin{array}{c}\text { Dur- } \\
\text { ing } \\
\text { work. }\end{array}$} & \multicolumn{2}{|c|}{ Lying. } & \multirow[b]{2}{*}{ Subject. } & \multirow[b]{2}{*}{ Date. } & \multirow[b]{2}{*}{$\begin{array}{l}\text { Lying } \\
\text { before } \\
\text { work. }\end{array}$} & \multirow[b]{2}{*}{$\begin{array}{c}\text { Dur- } \\
\text { ing } \\
\text { work. }\end{array}$} & \multicolumn{2}{|c|}{ Lying. } \\
\hline & & & & $\begin{array}{l}\text { During } \\
\text { first } \\
\text { hour } \\
\text { after } \\
\text { work. }\end{array}$ & $\begin{array}{c}\text { During } \\
\text { gecond } \\
\text { hour } \\
\text { after } \\
\text { work. }\end{array}$ & & & & & $\begin{array}{l}\text { During } \\
\text { first } \\
\text { hour } \\
\text { after } \\
\text { work. }\end{array}$ & $\begin{array}{l}\text { During } \\
\text { second } \\
\text { hour } \\
\text { after } \\
\text { work. }\end{array}$ \\
\hline \multirow{21}{*}{$\begin{array}{l}\text { H. L. H. } \\
\text { E. P. C. } \\
\text { M. A. M. }\end{array}$} & \multirow{20}{*}{$\begin{array}{r}1911 . \\
\text { Nov. } 21 \\
23 \\
\text { Dec. } 14 \\
15 \\
19 \\
20 \\
21 \\
22 \\
1912 . \\
\text { Jan. } 1 \\
2 \\
3 \\
4 \\
5 \\
8 \\
9 \\
10 \\
12 \\
15 \\
16 \\
17 \\
18 \\
19 \\
24 \\
25 \\
26\end{array}$} & \multirow{20}{*}{$\begin{array}{r}0.89 \\
.80 \\
.91 \\
.80 \\
.84 \\
.86 \\
.86 \\
.86 \\
.89 \\
.87 \\
.86 \\
.91 \\
.92 \\
.88 \\
.88 \\
.80 \\
.85 \\
.90 \\
.85 \\
.77 \\
.77 \\
.77 \\
.87 \\
.80 \\
\end{array}$} & & & & \multirow{18}{*}{ M. A. M. } & \multirow{18}{*}{$\begin{array}{rr}1912 . \\
\text { Jan. } 31 \\
\text { Feb. } \\
1 \\
2 \\
7 \\
8 \\
9 \\
9 \\
14 \\
15 \\
16 \\
23 \\
26 \\
27 \\
29 \\
\text { Mar. } 6 \\
11 \\
19 \\
25 \\
26 \\
27 \\
28 \\
29 \\
\text { Apr. } 16\end{array}$} & & & & \\
\hline & & & $\begin{array}{r}1.01 \\
.87\end{array}$ & $\begin{array}{r}0.77 \\
.74\end{array}$ & $\cdots$ & & & $\begin{array}{r}093 \\
89\end{array}$ & $\begin{array}{r}0.90 \\
.90\end{array}$ & $\begin{array}{l}0.82 \\
77\end{array}$ & . \\
\hline & & & .94 & $\cdots$ & $\cdots$ & & & .83 & .90 & .77 & 0.78 \\
\hline & & & .83 & .82 & $\cdots$ & & & .84 & .91 & .82 & $\ldots$ \\
\hline & & & $\begin{array}{l}1.86 \\
.83\end{array}$ & 79 & $\cdots$ & & & $\begin{array}{r}.81 \\
.79\end{array}$ & $\begin{array}{l}.86 \\
.82\end{array}$ & .76 & $\ddot{78}$ \\
\hline & & & .81 & .80 & 0.78 & & & .87 & .93 & .78 & $\ldots$ \\
\hline & & & .79 & .86 & $\ldots$ & & & .81 & .95 & .81 & . \\
\hline & & & .93 & .84 & $\ldots$ & & & 8 & .94 & .74 & .75 \\
\hline & & & .84 & .82 & $\ldots$ & & & .84 & .91 & $\ldots$ & $\cdots$ \\
\hline & & & .78 & .76 & 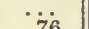 & & & .88 & .90 & $\cdots$ & $\ldots$ \\
\hline & & & $\cdots$ & $\begin{array}{l}.76 \\
.72\end{array}$ & $\begin{array}{l}.76 \\
.71\end{array}$ & & & $\begin{array}{l}.84 \\
.89\end{array}$ & $\begin{array}{l}.90 \\
.94\end{array}$ & .74 & 76 \\
\hline & & & .93 & .84 & & & & .87 & 5.92 & & \\
\hline & & & .85 & .70 & .75 & & & $\ldots$ & .91 & .90 & 8.87 \\
\hline & & & .89 & .74 & .72 & & & $\cdots$ & .91 & ${ }^{7} .96$ & 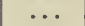 \\
\hline & & & .90 & .73 & .73 & & & .89 & .94 & .88 & $\ldots$ \\
\hline & & & .91 & .81 & .85 & & & $\cdots$ & .96 & 8.92 & $\cdots$ \\
\hline & & & .87 & .70 & .77 & & & 79 & $\begin{array}{l}.81 \\
.89\end{array}$ & .70 & $\ldots$ \\
\hline & & & .74 & .70 & .69 & & & .89 & .93 & .72 & 10.82 \\
\hline & & & .87 & .76 & & \multirow{3}{*}{$\begin{array}{l}\text { Avg.,34 d. } \\
\text { Avg.,16 d. }\end{array}$} & & .85 & .88 & .78 & \\
\hline & & & .92 & $\begin{array}{l}.78 \\
80\end{array}$ & .78 & & & .84 & .86 & .75 & .77 \\
\hline & & & & & & & & & & & \\
\hline
\end{tabular}

1 The work-periods on this day were begun about $1 \frac{3}{4}$ hours after the conclusion of the periods lying before work. The subject rode without load and without motor for 11 hours in the interval.

2 Only one period lying before work was run on this day.

3 The respiratory quotient during the third hour lying after work was 0.80 ; during the fourth hour, 0.77 ; and during the fifth hour, 0.80 .

4 The respiratory quotient during the third hour lying after work was 0.79. Another work-period followed for which the respiratory quotient was 0.81 . In the three-quarters of an hour subsequent to this last for which the respiratory quotient was 0.81 . In the three-quarters of an hour subsequent to
work-period, the average respiratory quotient was 0.77 with the subject lying on the couch.

5 The work-periods on this day were begun about $2 \frac{1}{2}$ hours after the conclusion of the periods lying before work. During the interval the subject sat inactive on the ergometer for two periods; he then rode for about 1 hour without load on the motor-driven ergometer.

- Other work-periods were then run for which the average respiratory quotient was 0.90 . In the half-hour following the latter work-periods, the respiratory quotient was 0.81 with the subject lying on the couch.

7 Other work-periods were then run for which the average respiratory quotient was 0.94 . In the threequarters of an hour following the latter work-periods, the average respiratory quotient was 0.95 with the subject lying on the couch.

8 Other work-periods were then run for which the average respiratory quotient was 0.93 . In the three-quarters of an hour following the latter work-periods, the average respiratory quotient was 0.88 with the subject lying on the couch.

9 Other work-periods were then run for which the average respiratory quotient was 0.87 . In the 45 minutes following the latter work-periods, the average respiratory quotient was 0.74 with the subject lying on the couch.

10 The respiratory quotient during the third hour lying after work was 0.82 ; during the fourth hour, 0.79 ; during the fifth hour, 0.75 ; and during the sixth hour, 0.81 .

In order to bring out in the sharpest contrast the relationships of the periods before work, during work, and after work, two separate averages 
have been drawn, first, for the 34 days on which such values were obtained, and second, for the 16 days on which the after-periods were of such length that a subdivision could be made of the values obtained for the first and second hours after work, respectively, this last average necessarily including only data secured in the experiments with the subject M. A. M. In the grand average for 34 days, it will be seen that the respiratory quotient of 0.85 was raised during work to 0.88 , falling after work to 0.78 . An inspection of the data shows that this rise and fall was present in the majority of the experiments, although in several of the earlier experiments there was a fall in the respiratory quotient during work, with a further lowering-very rarely a rise -during the period after work. The greater number of the experiments included in the average for the 16 days were made in the latter part of the experimental year, for, with the exception of the experiment of December 21, there were none prior to January 9. This average also shows a slight, though definite, rise in the quotient during the work, with a subsequent marked fall in both periods after work.

From the research as a whole, therefore, the significant conclusions can be drawn that there was a distinct, though numerically small, increase in the respiratory quotient during work, with a very appreciable decrease in the quotient following work, especially in the first hour of rest. This rise and fall may be interpreted in various ways. The rise in the quotient during work would distinctly imply that a larger proportion of carbohydrates was burned during this period than before or after work, especially as the rise in the quotient could not have been produced by an excessive disintegration of protein, since practically all of the quotients obtained in the period before work were above 0.8 . It also seems probable that the marked fall and general continued lower level of the respiratory quotient after work indicates the combustion of a larger proportion of fat than was the case in the period before work, the lower quotients showing that the supply of carbohydrates in the body had been materially depleted. The increases in the respiratory quotient during the work-period as compared with the period before work was but small, namely, from 0.85 to 0.88 and from 0.84 to $0.86-$ an increment that might almost be considered within the limit of experimental error when the great differences in the physiological condition of the man are taken into account. Of themselves, therefore, these increases do not indicate a selective combustion of carbohydrates during muscular work, since it is possible that the combustion of carbohydrates in the period after work was proportionally the same as in the period preceding work, and that the low quotients in the last rest-periods were simply due to a natural depletion of the storage of carbohydrates during muscular work.

Furthermore, a close inspection of the data in table 92 shows that there are variations in the respiratory quotients obtained with the professional bicycle rider, M. A. M., between the earlier and the later experiments. To bring this out more clearly, the quotients may be averaged in the following way: For the 20 comparable days from December 15 to January 31 the average quotients for this subject were 0.85 before work, 0.85 during work, and 0.78 after work, while for the 12 comparable days from February 1 to April 16 the average quotients were 0.85 before work, 0.91 during work, and 0.78 after work. Dividing the experimental year with this subject 
into halves, we found that the average respiratory quotients for the 16 comparable days from December 15 to January 19 were 0.84 before work, 0.84 during work, and 0.77 after work, while for the 16 comparable days from January 24 to April 16 the quotients were 0.85 before work, 0.90 during work, and 0.78 after work. Apparently in the later experiments there was an increase in the respiratory quotient during the working period which was not observed in the earlier experiments, this probably being due to the fact that the excessive muscular work was performed in the last part of the research.

\section{INFLUENCE UPON THE RESPIRATORY QUOTIENT OF INCREASING AMOUNTS OF WORK.}

It is obvious from the foregoing that for a better understanding of these respiratory quotients, it is necessary to analyze the results obtained for the periods before work, during work, and after work. In some experiments external muscular work to the extent of over 150 calories was performed. Obviously during these experiments there must have been heavier and more prolonged drafts upon the storage of body-material than in experiments in

TABLE 93.-Respiratory quotients in respiration experiments without food, with accumulated amounts of work on the bicycle ergometer.

\begin{tabular}{|c|c|c|c|c|c|c|c|c|c|}
\hline \multirow[b]{2}{*}{ Subject and date. } & \multirow{2}{*}{$\begin{array}{l}\text { Lying } \\
\text { before } \\
\text { work. }\end{array}$} & \multicolumn{6}{|c|}{ During work accumulated to- 1} & \multicolumn{2}{|c|}{ Lying after work. } \\
\hline & & $\begin{array}{c}35 \\
\text { cals. }\end{array}$ & $\begin{array}{c}50 \\
\text { cals. }\end{array}$ & $\begin{array}{c}75 \\
\text { cals. }\end{array}$ & $\begin{array}{l}100 \\
\text { cals. }\end{array}$ & $\begin{array}{l}125 \\
\text { cals. }\end{array}$ & $\begin{array}{l}150 \\
\text { cals. }\end{array}$ & $\begin{array}{c}\text { During } \\
\text { first } \\
\text { hour. }\end{array}$ & $\begin{array}{l}\text { During } \\
\text { second } \\
\text { hour. }\end{array}$ \\
\hline 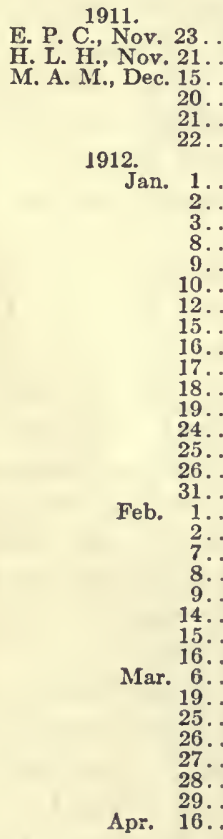 & $\begin{array}{l}.89 \\
.87 \\
.86 \\
.88 \\
.80 \\
.85 \\
.90 \\
.85 \\
.77 \\
.77 \\
.87 \\
.80 \\
.86 \\
.89 \\
.83 \\
.84 \\
.81 \\
.79 \\
.87 \\
.87 \\
.89 \\
. .8 \\
.89 \\
. .8 \\
.79 \\
.89\end{array}$ & 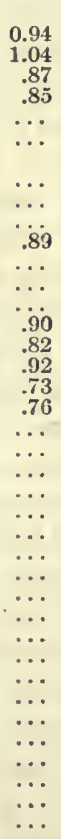 & $\begin{array}{l}0.80 \\
.81 \\
.82 \\
\ldots . \\
\ldots . \\
\ldots . \\
\ldots . \\
.82 \\
\ldots \\
\ldots . \\
\ldots \\
\ldots \\
\because . \\
.86 \\
.94 \\
.84 \\
.94 \\
.91 \\
.86 \\
.88 \\
.89 \\
.90 \\
.97 \\
.90 \\
.93 \\
\ldots \\
.93 \\
\ldots \\
.89 \\
\ldots\end{array}$ & 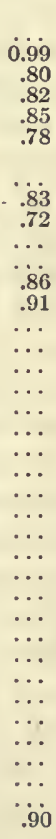 & $\begin{array}{c}.93 \\
.85 \\
.80 \\
.96 \\
\ldots \\
\ldots \\
.91 \\
.82 \\
.74 \\
.71 \\
\ldots \\
\ldots \\
\ldots \\
\ldots \\
\ldots \\
\ldots \\
\ldots \\
\ldots \\
\ldots \\
\ldots \\
\ldots \\
\ldots \\
\ldots \\
\ldots\end{array}$ & $\begin{array}{l}\ldots \\
\ldots \\
\ldots \\
\ldots \\
\ldots \\
0.81 \\
.87 \\
.92 \\
.88 \\
.84 \\
\ldots \\
\ldots \\
.88 \\
\because 82 \\
.86 \\
.89 \\
\ldots \\
.85 \\
.84 \\
.95 \\
\ldots \\
.95 \\
.95 \\
.94 \\
.96 \\
.88 \\
.96\end{array}$ & 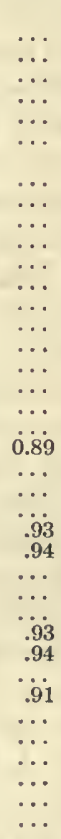 & $\begin{array}{l}.84 \\
.82 \\
.76 \\
.84 \\
.70 \\
.74 \\
.73 \\
.81 \\
.78 \\
.70 \\
.70 \\
.68 \\
.76 \\
.78 \\
.80 \\
.82 \\
.77 \\
.77 \\
.82 \\
.76 \\
.78 \\
.81 \\
.74 \\
.74 \\
.90 \\
.96 \\
.88 \\
.92 \\
.76 \\
.79 \\
.72\end{array}$ & $\begin{array}{c}\ldots \\
\ldots \\
\ldots .7 \\
0.78 \\
\ldots \\
\ldots \\
\ldots \\
\ldots \\
.75 \\
.72 \\
.73 \\
.85 \\
.79 \\
.77 \\
.74 \\
.78 \\
.77 \\
\ldots \\
2.78 \\
\ldots \\
.78 \\
\ldots \\
.75 \\
.75 \\
.76 \\
.87 \\
\ldots \\
\ldots \\
\ldots \\
\ldots 82 \\
.85\end{array}$ \\
\hline
\end{tabular}

1 The respiratory quotients were determined during the last part of the period in which the work specified was done.

2 The respiratory quotient during the third hour lying after work was 0.80 ; during the fourth hour, 0.77 ; during the fifth hour, 0.80 .

8 The respiratory quotient during the third hour lying after work was 0.79 .

4 The respiratory quotient during the third hour lying after work was 0.82; during the fourth hour, 0.79 ; during the fifth hour, 0.75 ; during the sixth hour, 0.81 . 
which the external muscular work was but 35 calories. Consequently, in table 93 the respiratory quotients determined during muscular activity are classified according to the accumulated amount of work done, the values secured before and after the work-period also being included. The work each morning was practically continuous; the table therefore shows the quotients obtained at various times during the morning as the amount of external muscular work gradually accumulated.

The quotients given for the periods before work are usually the average of those obtained for two or three periods, and probably represent the true values, but those for the work-periods are individual determinations and hence are liable to the errors which may creep into the determination of both the carbon dioxide and the oxygen. While every precaution was taken to prevent error, it is pointed out that these individual values should be used with extreme caution, and deductions can only be drawn from the tabulated results as a whole.

The respiratory quotients before work demand no particular discussion at this point, but the quotients obtained during work, and particularly the relationship to the amount of work done, indicate that as the experimental year progressed the amount of work increased until in the latter part of the year practically all of the experiments were made with excessive amounts of muscular activity. An examination of the data shows that in the majority of the experiments the quotients tend to increase as the total amount of work increases on any particular day. This is not invariably the case, as in several of the experiments there is a marked fall in the quotient during the second work-period. Considering only the experiments with M. A. M., we find that on 13 days the quotients decreased in value while on 18 days they increased.

This tendency for the quotients to increase with the increased work has an important bearing upon the interpretation of the results. If, for example, the metabolism were of exactly the same character during muscular work as it was during the preceding rest-period, there would be a certain draft upon body-glycogen which, under the conditions of these experiments, namely, no food in the morning, would cause a rapid reduction in the storage of carbohydrates. Under these conditions we should normally expect to find an invariable decrease in the respiratory quotient as the work progressed, assuming that the character of the metabolism remains exactly that prior to the experiment. Since on the whole the results show an increase in the respiratory quotient rather than a decrease, this evidence would point strongly to the fact that the character of the katabolism during the muscular work does not remain the same as that prior to the work, but that there was an increased combustion of carbohydrate. This is furthermore accentuated by the fact that in all but a very few experiments there was a marked drop in the respiratory quotient during the period after the work was finished. This finding during the first hour after work is usually substantiated by observations made during the second hour, as well as in the relatively few instances in which the respiratory quotient was followed for several hours after work.

These figures then, taken as a whole, indicate strongly that during the period of severe muscular activity the character of the katabolism is altered by an increase in the amount of carbohydrates burned, the storage of carbo- 
hydrates in the body being drawn upon for the purpose. At the completion of the work-period the specific katabolism incidental to muscular work ceases, and the picture of a body subsisting upon a depleted storage of carbohydrate material is then indicated by the lower respiratory quotient.

\section{INFLUENCE UPON THE RESPIRATORY QUOTIENT OF VARIATIONS IN THE AMOUNT OF CARBOHYDRATES IN THE DIET.}

The analysis of the figures with the subject M. A. M. can be carried somewhat farther by isolating a few experiments which were made with a semi-controlled diet. On certain days the subject was fed in the laboratory and given a diet which was approximately controlled. During 6 days his diet contained 400 or more grams of carbohydrate a day, while on 6 other days it was noticeably deficient in carbohydrate material, although by no means carbohydrate-free. The results for these particular experiments are given with some detail in table 94 .

TABLE 94.-Respiratory quotients in experiments without food following special diets. (Subject M.A.M.)

\begin{tabular}{|c|c|c|c|c|}
\hline Preceding diet. & Date. & $\begin{array}{c}\text { Lying } \\
\text { before } \\
\text { work. }\end{array}$ & $\begin{array}{l}\text { During } \\
\text { work. }\end{array}$ & $\begin{array}{l}\text { Lying } \\
\text { after } \\
\text { work. }\end{array}$ \\
\hline Carbohydrate-rich. . . . . . . . . . . & $\begin{array}{l}1912 . \\
\text { Jan. } 24 \\
\text { Jan. } 25 \\
\text { Jan. } 26 \\
\text { Feb. } 14 \\
\text { Feb. } 15 \\
\text { Feb. } 16\end{array}$ & $\begin{array}{r}0.87 \\
.80 \\
.86 \\
.87 \\
.81 \\
.87\end{array}$ & $\begin{array}{r}0.87 \\
.92 \\
.83 \\
.93 \\
.95 \\
.88\end{array}$ & $\begin{array}{r}0.76 \\
.78 \\
.79 \\
.78 \\
.81 \\
.76\end{array}$ \\
\hline Average...$\ldots \ldots \ldots \ldots \ldots$ & ........ & .85 & .90 & .78 \\
\hline 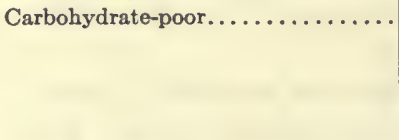 & $\begin{array}{lr}\text { Jan. } 17 \\
\text { Jan. } 18 \\
\text { Jan. } 19 \\
\text { Feb. } 7 \\
\text { Feb. } 8 \\
\text { Feb. } 9\end{array}$ & $\begin{array}{l}.77 \\
.77 \\
.77 \\
.84 \\
.81 \\
.79\end{array}$ & $\begin{array}{l}.87 \\
.74 \\
.74 \\
.91 \\
.86 \\
.82\end{array}$ & $\begin{array}{l}.73 \\
.70 \\
.71 \\
.82 \\
.76 \\
.77\end{array}$ \\
\hline Average................ & $\ldots \ldots \ldots$ & .79 & .82 & .75 \\
\hline
\end{tabular}

The average respiratory quotient during the preliminary rest-period with the carbohydrate-rich diet was considerably higher than that for the same period with the carbohydrate-low diet, $i$. e., 0.85 as against 0.79 . During the periods with muscular work, there was a marked increase in the respiratory quotient with both diets which was somewhat greater with the carbohydrate-rich diet. The low quotient after work was also observed in both series of experiments, the lowest quotients being found with the diet poor in carbohydrates. This is fully in conformity with the view previously expressed that during muscular work there is an excessive combustion of carbohydrates so that in the subsequent period the katabolism is that of a body deficient in glycogen.

It is clear, therefore, that during the winter's experimentation there were variations in the storage of carbohydrates in the body, the relatively few days on which the diet was controlled giving a reasonably accurate picture of the conditions that would be expected to exist. It is interesting to note that even with the carbohydrate-poor diet, when the respiratory quotients indicated low amounts of glycogen in the body, there was nevertheless on the average a slight increase in the respiratory quotient during work, 
and a marked fall in the subsequent rest-period. It might be argued that the results for January 18 and 19 appear to show that there were no alterations in the character of the metabolism during work, since the quotient of 0.77 before work was followed by a quotient of 0.74 during work, and 0.70 to 0.71 after work. It should be pointed out, however, that the work performed on those days (see table 93) was relatively smaller than it was on February 7,8 , and 9 . It is obvious that here we deal with the nutritive plane of the body. To be ideal, therefore, a series of experiments should include the dietetic control of the subject over a considerable period of time.

SUBSIDIARY EVTDENCE WITH REGARD TO THE EFFECT CF MUSCULAR WORK ON THE CHARACTER OF THE KATABOLISM.

The experiments included in tables 92,93 , and 94 were made primarily in order to study the effect of severe muscular work on the respiratory quotient, but we have a considerable amount of fragmentary evidence which bears upon this point that was secured in connection with experiments made for a different purpose, namely, to study the efficiency of the body as a machine. So far as this discussion is concerned, these experiments were incomplete in that one or both of the rest-periods were lacking, but we deem the results of sufficient importance to discuss in this connection.

In 7 of these experiments the respiratory quotient was not determined after the muscular work was performed, although it was secured prior to the work-period. The results of these experiments are given in table 95. Since

TABLE 95.-Respiratory quotients in experiments without food with subject M. A. M., before work (lying on couch) and during work.

[Figures in light-face type represent accumulated work to end of period expressed in calories.]

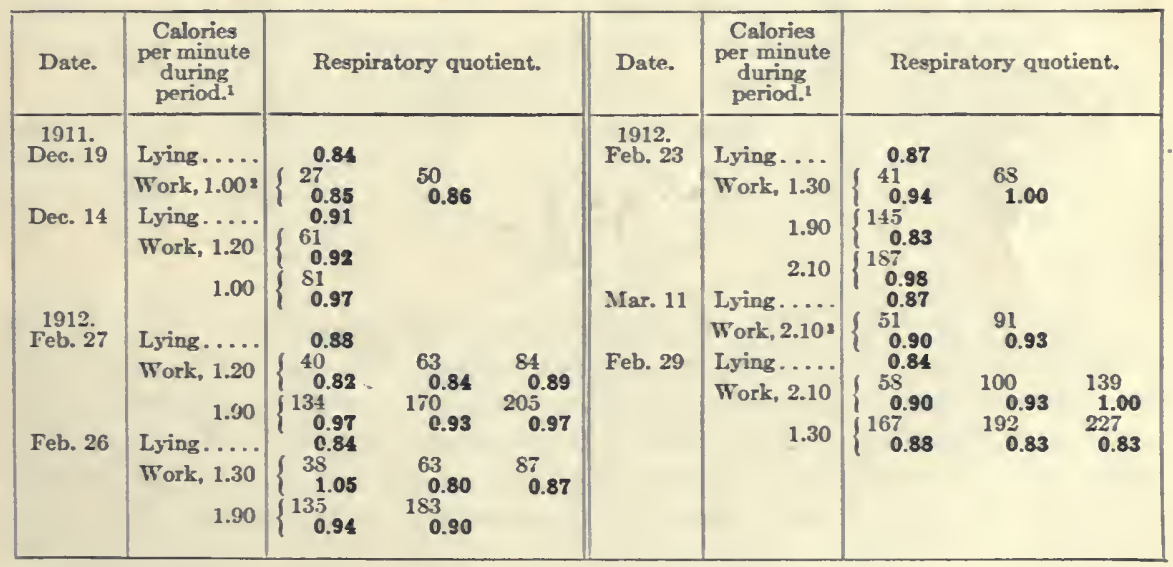

1 Approximate.

2 In the interval between the periods Iying before and the first work-period, the subject rode without load and without motor for $1 \frac{1}{4}$ hours.

8 In the interval between the periods lying before work and the first work-period, the subject sat inactive on the ergometer an hour and then rode without load for an hour on the motor-driven ergometer.

there was a suggestion in some of the earlier tables that the intensity of the work, as well as the total amount performed, played an important rôle in the character of the katabolism, in this and in subsequent tables the intensity of 
the work expressed in calories of external muscular work per minute will be given. The accumulated work to the end of the period is also given in small type in the respiratory quotient column. In practically every experiment except that on February 27 there was an increase of the respiratory quotient in work over the rest-period. On this date during the first periods of work, with 1.20 calories of external work per minute, the quotient averaged somewhat less than during rest, but in the subsequent periods when the intensity of work was much greater, the respiratory quotient rose nearly to unity. The abnormal quotients of 1.05 and 0.80 on February 26 and the low quotient of 0.83 when 1.90 calories per minute were being evolved in the experiment of February 23 are not easily explained save on the ground of physiological errors or mechanical errors in the technique, the difficulties incidental to securing absolutely correct values for the respiratory quotient for each individual period having already been frequently emphasized in this report. The picture presented by these experiments is, however, fully in conformity with the general impressions obtained from the results previously given, namely, that with severe muscular work the respiratory quotient increases materially above that of rest.

TABLE 96.-Respiratory quotients in experiments without food with subject $M$. A. M. in alternating conditions of work and lying on couch.

[Figures in light-face type represent accumulated work to end of period expressed in calories.]

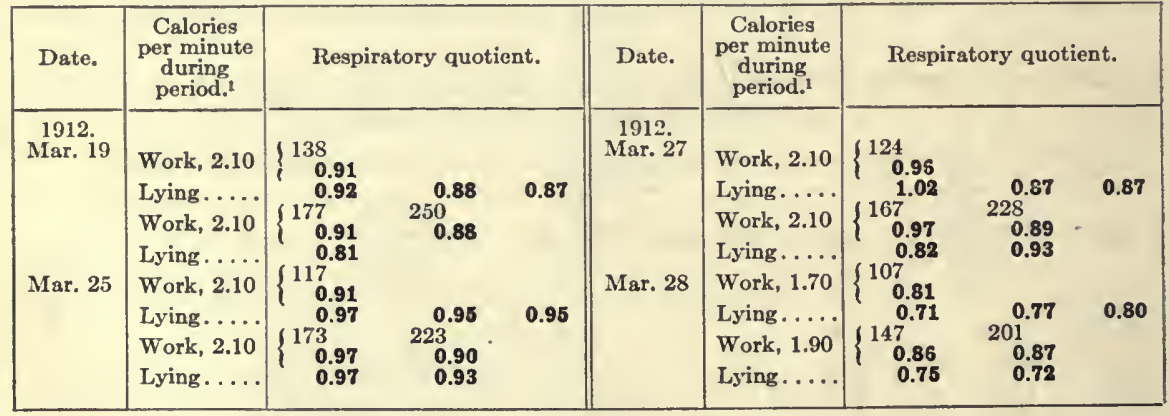

1 Approximate.

In still another series of incomplete experiments, 4 in number, the quotients were not obtained before the work began, but were determined after the work was over. Furthermore, the rest-periods were frequently alternated with the work-periods. The results of these experiments are given in table 96 . With the exception of the experiment on March 28, the intensity of work in all cases was very great, namely, 2.10 calories of external muscular work per minute. The respiratory quotients obtained in the experiment of March 25 and in the first rest-period after work in the experiment of March 27 are striking exceptions to the general rule that the respiratory quotients after work are lower than those during work. Taking the table as a whole, however, the results given are in accord with those previously presented in that they show a marked fall in the respiratory quotient after severe muscular activity. Indeed, in certain of the experiments the resumption of muscular work was accompanied by another increase in the respiratory quotient, this being shown 
in all of the experiments if the last quotient in the preceding rest-period is taken as a base-line. Thus the quotient changes on March 19 from 0.87 to 0.91 , on March 25 from 0.95 to 0.97 , on March 27 from 0.87 to 0.97 , and on March 28 from 0.80 to 0.86 .

An experiment with M. A. M., not included in this table, that of February 16,1912 , differs somewhat from the others inasmuch as there were two consecutive periods of rest, with respiratory quotients of 0.86 and 0.85 respectively, then two periods of work with quotients indicating the usual rise after rest, namely, 0.90 and 0.94 respectively, next seven periods of rest with quotients of $0.70,0.77,0.77,0.73,0.76,0.79,0.79$, followed by one period of work with a quotient of 0.81 , and finally two periods of rest with quotients of 0.74 and 0.79 . Although the mathematical differences between the quotients are not as great as in some of the experiments already cited, these results likewise substantiate the general impression that the respiratory quotient increases with work and subsequently decreases after the work is over, again increases slightly when the work is resumed, and in turn decreases during the following rest-period.

INFLUENCE UPON RESPIRATORY QUOTIENT OF VARIATIONS IN AMOUNT OF WORK DONE.

For the specific purpose of studying the influence of an alteration in the load upon the muscular activity and the efficiency of the body as a machine, a lengthy series of experiments was carried out in which the subject began with a very light resistance which was subsequently increased materially. Certain experiments reversed this routine, the periods with the heavy load preceding those with the light load; finally two experiments were made in which the light load was first used, then the heavy load, and subsequently the light load was again used. The respiratory quotients for these experiments have been computed and presented in tables 97,98 , and 99 .

The results of the experiments in which a small or moderate amount of work preceded the severe work are given in table 97 . The striking feature of these results is the fact that the quotients for all the individual periods in which severe muscular work was done are high with the exception of one period in the experiments of April 3, March 16, March 12, and March 13, respectively. All the other quotients were 0.87 or higher, with an average of over 0.91. Only four of the experiments permit a comparison of the results obtained with 0.5 calorie per minute and 1.65 calories per minute, and these show no definite relationships one way or the other, the average quotients in both series remaining about the same. Obviously, since the resting value was not obtained with these experiments, the first respiratory quotients on individual days may be considerably affected by the character of the preceding diet, and the evidence does not justify any definite conclusions. The only deduction warranted by the data, therefore, is that in general in all periods with excessive muscular work the respiratory quotient is high.

In discussing the data given in table 97, the experiment of March 15 demands special consideration. On this date the subject rode with a high intensity, namely, 1.95 calories of external muscular work per minute, for a long period, the object of the experiment being to produce fatigue and complete exhaustion. From the accumulated muscular work, which is given in the light-face figures, it will be seen that the subject on this day did 489 
calories of external muscular work in $4^{\mathrm{h}} 22^{\mathrm{m}}$ of actual riding, this being equivalent to 208,000 kilogrammeters. Despite this enormous amount of muscular work, the respiratory quotient remained in the vicinity of 0.90 throughout the experiment, while if there had been a material combustion of fat or a conversion of fat into carbohydrate, a considerably lower quotient than this would have been expected. Although the average quotient of 0.90 does not indicate by any means a combustion exclusively of carbohydrates, it does indicate a combustion of material containing a considerable proportion of carbohydrates, since Magnus-Levy ${ }^{a}$ has shown that a respiratory quotient of 0.90 corresponds to a metabolism of 15 per cent of protein, 61 per cent of carbohydrates, and 24 per cent of fat, and that a respiratory quotient of 0.85 corresponds to a metabolism of 15 per cent of protein, 44 per cent of carbohydrates, and 41 per cent of fat. (See p. 96.)

TABLE 97.-Respiratory quotients in experiments without food, light or moderate work preceding severe work.

[Figures in light-face type represent accumulated work to end of period expressed in calories.]

\begin{tabular}{|c|c|c|c|c|c|c|c|c|}
\hline \multirow{3}{*}{$\begin{array}{c}\text { Date. } \\
\begin{array}{c}1912 . \\
\text { Apr. } 3\end{array}\end{array}$} & \multirow{3}{*}{$\begin{array}{l}\text { Subject. } \\
\text { K. H. A. }\end{array}$} & \multirow{2}{*}{$\begin{array}{c}\text { Calories of } \\
\text { work per } \\
\text { minute } \\
\text { during } \\
\text { period. }\end{array}$} & \multicolumn{6}{|c|}{ Respiratory quotient. } \\
\hline & & & $\{19$ & & & & & \\
\hline & & 1.65 & 111 & 148 & & & & \\
\hline Mar. 16 & J. E. F. & $\begin{array}{r}.50 \\
1.65\end{array}$ & $\left\{\begin{array}{c}24 \\
0.93 \\
89 \\
0.89\end{array}\right.$ & $\begin{array}{r}35 \\
0.92 \\
119 \\
0.85\end{array}$ & & & & \\
\hline Mar. 12 & M. A. M. & $\begin{array}{r}.50 \\
1.65\end{array}$ & $\left\{\begin{array}{c}17 \\
0.85 \\
102 \\
0.84\end{array}\right.$ & $\begin{array}{c}29 \\
0.82 \\
135 \\
0.87\end{array}$ & $\begin{array}{r}40 \\
0.84 \\
162 \\
0.89\end{array}$ & & & \\
\hline Mar. 13 & M. A. M. & $\begin{array}{r}.50 \\
1.65\end{array}$ & $\left\{\begin{array}{c}21 \\
0.92 \\
109 \\
0.91\end{array}\right.$ & $\begin{array}{r}33 \\
0.88 \\
147 \\
0.83\end{array}$ & $\begin{array}{c}43 \\
0.88 \\
190 \\
0.91\end{array}$ & & & \\
\hline Mar. 15 & M. A. M. & 1.95 & $\begin{array}{r}77 \\
0.90\end{array}$ & $\begin{array}{r}163 \\
0.91\end{array}$ & $\begin{array}{r}251 \\
0.89\end{array}$ & $\begin{array}{r}334 \\
0.89\end{array}$ & $\begin{array}{l}416 \\
0.97\end{array}$ & $\begin{array}{l}489 \\
0.882\end{array}$ \\
\hline Apr. 8 & M. A. M. & 1.30 & $\begin{array}{r}65 \\
0.89\end{array}$ & $\begin{array}{l}102 \\
0.87\end{array}$ & $\begin{array}{l}129 \\
0.87\end{array}$ & & & \\
\hline Apr. 9 & M. A. M. & $\begin{array}{l}1.30 \\
1.65\end{array}$ & $\left\{\begin{array}{r}195 \\
1.00 \\
59 \\
0.88 \\
207 \\
0.98\end{array}\right.$ & $\begin{array}{r}246 \\
1.00 \\
85 \\
0.88\end{array}$ & $\begin{array}{c}283 \\
0.91 \\
114 \\
0.90\end{array}$ & & & \\
\hline
\end{tabular}

1 Approximate.

2 During this period the external work per minute amounted to 1.734 calories.

A special experiment made with M. A. M. on March 8, though not included in the table, may likewise be cited here as confirmatory evidence of the conclusions already drawn from these data. In this experiment the subject rode for $1^{\mathrm{h}} 45^{\mathrm{m}}$ without load and with the ergometer driven by the motor. The respiratory quotient determined during this time was 0.82 . There were then three periods of work in which on the average 2.10 calories of external muscular work per minute were performed. With 81 calories of accumulated external work, the respiratory quotient was 0.88 , with 127 calories of accumulated work the respiratory quotient was 0.90 , and with 177 calories of accumu-

a Magnus-Levy in von Noorden's Handbuch der Pathologie des Stoffwechsels, Berlin, 1906, 1, p. 207. 
lated wors the respiratory quotient was 0.94 . Of significance are the increase in the respiratory quotient after the beginning of severe work and the characteristic high quotients found throughout all of the three work-periods.

While the transition from low intensity to high intensity did not lead to any definite conclusions as to the character of the katabolism, when the conditions were reversed and the period of light muscular work followed the severe work, the picture presented is quite different. The results for the experiments with this routine are given in table 98.

TABLE 98.-Respiratory quotients in experiments without food, severe work preceding light work.

[Figures in light-face type represent accumulated work to end of period expressed in calories.]

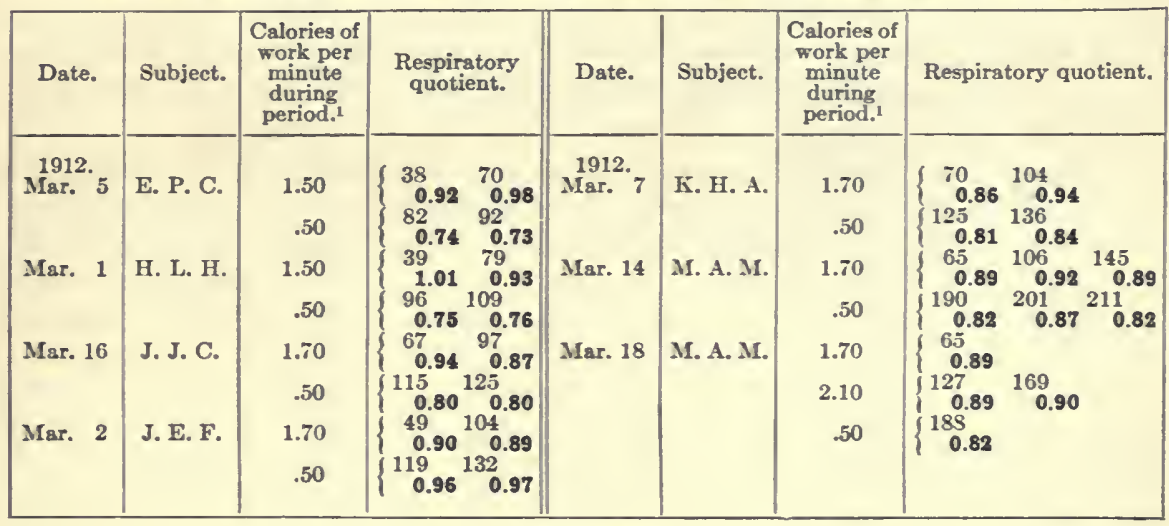

Approximate.

The data given in this table agree perfectly with the results found in table 97 in that with a high intensity of work, such as 1.50 calories or over per minute, the respiratory quotients are high, the lowest value for such periods being 0.86 on March 7. On the other hand the values obtained in periods with light work present a striking contrast to the results given in table 97 , as the values with a light load are almost invariably small. The single exception to this is the experiment of March 2 with J. E. F., in which the highest values were found with 0.50 calorie per minute, an explanation of which is by no means clear. The natural inference from the results given in this table would be that after severe muscular work the light work of 0.50 calorie per minute can be considered as having approximated resting katabolism, so that the "specific muscular katabolism" called into play by excessive muscular work was no longer in action, and the body was then nearing the condition of normal repose.

Finally, in table 99 are given the results of two experiments with the professional bicyclist M. A. M., in which the subject rode first with a light load, next with a heavy load, and then again with a lighter load. On February 28 there was a marked rise in the respiratory quotient with the severe muscular work which was followed by a slight fall on resuming the light load; on March 4, however, the katabolism during the first two periods with a light load evidently consisted in large part of carbohydrates, since the respiratory 
quotient was relatively high. As would be expected, these high quotients were not materially altered by the severe muscular work, but the characteristic fall ${ }^{a}$ after the severe muscular work is observed on the resumption of the light work of 0.56 calorie per minute. The experiment of March 4 and, to a slight extent, the experiment of February 28, substantiate the conclusions drawn from the values shown in table 98, namely, that after severe muscular work the same tendency for the respiratory quotient to drop is shown with the resumption of slight muscular activity as in a period of rest, and that in all probability the average degree of work here performed, namely, 0.50 calorie per minute, was so light that the specific katabolism incidental to severe muscular work was not called into play and the body was essentially in a condition of repose.

TABLE 99.-Respiratory quotients without food during work with severe work preceded and followed by light work. (Subject M.A.M.)

\begin{tabular}{|c|c|c|c|c|c|c|c|}
\hline \multirow{2}{*}{$\begin{array}{l}\text { Date and } \\
\text { condition. }\end{array}$} & \multicolumn{2}{|c|}{$\begin{array}{c}\text { External } \\
\text { muscular work. }\end{array}$} & \multirow{2}{*}{$\begin{array}{l}\text { Respira- } \\
\text { tory } \\
\text { quotient. }\end{array}$} & \multirow[b]{2}{*}{$\begin{array}{l}\text { Date and } \\
\text { condition. }\end{array}$} & \multicolumn{2}{|c|}{$\begin{array}{c}\text { External } \\
\text { muscular work }\end{array}$} & \multirow{2}{*}{$\begin{array}{l}\text { Respira- } \\
\text { tory } \\
\text { quotient. }\end{array}$} \\
\hline & $\begin{array}{l}\text { Accumu- } \\
\text { lated amt. } \\
\text { to end of } \\
\text { period. }\end{array}$ & $\begin{array}{l}\text { Amt. per } \\
\text { minute } \\
\text { during } \\
\text { period. }\end{array}$ & & & $\begin{array}{l}\text { Accumu- } \\
\text { lated amt. } \\
\text { to end of } \\
\text { period. }\end{array}$ & $\begin{array}{l}\text { Amt. per } \\
\text { minute } \\
\text { during } \\
\text { period. }\end{array}$ & \\
\hline $\begin{array}{c}\text { Feb. } 28,1912 . \\
\text { Light work. . . . }\end{array}$ & $\begin{array}{r}\text { cals. } \\
24 \\
36 \\
54\end{array}$ & $\begin{array}{l}\text { cals. } \\
0.55 \\
.55 \\
.55\end{array}$ & $\begin{array}{r}0.82 \\
.83 \\
.80\end{array}$ & $\begin{array}{c}\text { Mar. 4, 1912. } \\
\text { Light work...... }\end{array}$ & $\begin{array}{r}\text { cals. } \\
24 \\
39\end{array}$ & $\begin{array}{l}c a l s . \\
0.55 \\
.55\end{array}$ & $\begin{array}{r}0.95 \\
.87\end{array}$ \\
\hline $\begin{array}{l}\text { Severe work..... } \\
\text { Light work. . . . . }\end{array}$ & $\begin{array}{l}114 \\
153 \\
190 \\
202 \\
216\end{array}$ & $\begin{array}{r}2.18 \\
2.04 \\
2.07 \\
.55 \\
.55\end{array}$ & $\begin{array}{r}.97 \\
.97 \\
1.03 \\
.93 \\
.94\end{array}$ & Severe work. ... . & $\begin{array}{l}113 \\
153 \\
191 \\
207 \\
218 \\
229\end{array}$ & $\begin{array}{r}2.15 \\
2.16 \\
2.12 \\
.56 \\
.55 \\
.54\end{array}$ & $\begin{array}{l}.93 \\
.98 \\
.92 \\
.87 \\
.86 \\
.89\end{array}$ \\
\hline
\end{tabular}

Conclusions Regarding the Influence of Muscular Work upon the Character of the Katabolism.

Although the evidence in all of the experiments cited is strikingly in favor of the view that during periods of muscular work there is an increased draft upon carbohydrate material in the body, the data by no means indicate that the muscular work is performed exclusively by the combustion of carbohydrate. In Chauveau's experiments the total metabolism during work was but four times that of rest, but in the majority of our experiments the total metabolism during work was from eight to ten times that of rest; hence, employing the formula used by Chauveau, we would expect with a normal postabsorptive metabolism during rest, in which there was a respiratory quotient of 0.84 , that the corresponding respiratory quotient during work would be 0.98 , the computation being:

$$
\frac{0.84 \times 1+1 \times 8}{9}=\frac{8.84}{9}=0.98
$$

As a matter of fact, in our results we rarely find quotients of unity or above. It is furthermore apparent from an inspection of our tables, particularly table 94 , that the height of the respiratory quotient during work is usually dependent upon the supply of glycogen in the body, this being indi-

a Jaquet (Archiv f. exp. Pathol. u. Pharm., 1910, 62, p. 341) found similar low quotients after severe muscular work. 
cated in the majority of experiments by the respiratory quotient before work. If the combustion during severe muscular work were exclusively of carbohydrates, with the amount of katabolism here involved very high respiratory quotients would be expected; yet, on reference to table 92 , it is seen that the respiratory quotients during severe muscular work average only 0.88 for 34 days, with a respiratory quotient for the initial base-line of resting metabolism of 0.85 . Porges,${ }^{a}$ by cutting the liver out of the circulation, found that a respiratory quotient which was essentially that of fat katabolism before the experiment, rose immediately afterwards, his results pointing strongly torvard an exclusive combustion of carbohydrates, and the experiment made by Verzár in Tangl's laboratory ${ }^{b}$ gave somewhat the same results. We are, however, disinclined to cite these researches in support of the belief that muscular work is done exclusively by the combustion of carbohydrates, for we agree fully with $\mathrm{Zuntz}^{c}$ that respiration experiments made under these abnormal conditions do not warrant such sweeping deductions.

Our final conclusion must be, therefore, that the more severe the muscular activity, the heavier is the draft upon the carbohydrate material in the body, with a consequent persistent alteration in the character of the katabolism, the proportion of carbohydrate burned being increased during the muscular-work period. As the work progresses, and the subject is still without food, the drafts upon the carbohydrate storage in the body become so extensive that, after the cessation of the work and the "specific working katabolism" disappears, the katabolism of the body is such that a much lower proportion of carbohydrates is burned for the total energy output of the resting period. The average results of the experiments in this research, although they suggest such a conclusion, do not demonstrate absolutely that muscular work is done exclusively at the expense of carbohydrate combustion.

While basing the interpretation of our results upon the depletion of carbohydrate storage and the changing of the character of the katabolism from carbohydrate-rich to carbohydrate-poor after work, an alternative explanation is possible. If we assume, what as yet unfortunately lacks conclusive experimental demonstration, that fat is converted in the body to carbohydrate, certain of our values, particularly those in the first periods after work and below 0.7 , strongly suggest this explanation.

Similarly a further assumption might be made that the respiratory quotient after work is really compounded of two or more metabolic phases, so that to assess properly the values which we obtained we should subtract the basal output of carbon dioxide and intake of oxygen, i.e., the output and intake obtaining before work is started, from the output and intake which are found after work has ceased. This would give us what might be termed the normal basal metabolism obtaining in the periods both before and after work. The respiratory quotient computed from the excess of oxygen intake and carbon-dioxide output over the basal metabolism might be considered as representing the changes which take place as the direct result of the work done. If such calculations be made extraordinarily low respiratory quotients are found. 
While such an explanation as the conversion of fat to carbohydrate is a possible one, it must not be forgotten that the conditions under which these low "after-work" quotients are obtained are far from ideal, as the subject is somewhat restless, and his temperature, pulse, and respirations are all above normal and rapidly falling, - experimental conditions we believe not suitable for obtaining data which are to be compared with the normal.

\section{Estimates of the Amodnt of Carbohydrate in the Body.}

This exhaustive study of the respiratory quotient in connection with an excessive amount of external muscular work leads to interesting conclusions as to the probable amount of carbohydrates stored in the body. The amount of glycogen in the different muscles and organs of animals has been frequently determined. An attempt has also been made to compute the carbohydrate content of the body from the amputated limbs of adults and the bodies of infants. From the results of such investigations, it has been commonly reported that the body of a human adult contains normally not far from 400 grams of glycogen, but, as already shown in this report, ${ }^{a}$ the relative amount of glycogen may vary considerably according to the muscular activity and the previous diet-a point also emphasized by Benedict and Higgins. ${ }^{b}$

One of the experiments in this present series of work experiments offers evidence which seems to us the best thus far procurable as to the probable minimum amount of carbohydrate in the body of an active, well-nourished athlete. It should be borne in mind that these were all post-absorptive experiments, $i$. e., at least 12 hours after the last meal, and they deal, therefore, not with the carbohydrates unabsorbed in the intestinal tract but with carbohydrates in the body, chiefly glycogen. On March 15, 1912, the professional subject M. A. M. began work at $8^{\mathrm{h}} 30^{\mathrm{m}}$ a.m. and continued without cessation until $12^{\mathrm{h}} 52^{\mathrm{m}}$ p.m., the severe muscular work corresponding to a total calorie output of 9.75 calories per minute. Inasmuch as the work covered a period of 262 minutes, or $4^{\mathrm{h}} 22^{\mathrm{m}}$, at the rate of 9.75 calories per minute, the total energy output during this period was 2,554 calories, or approximately 600 calories an hour. During this period of severe work six respiratory quotients were obtained, $0.90,0.91,0.89,0.89,0.97$, and 0.88 , the average quotient throughout the period being 0.91 .

Magnus-Levy ${ }^{c}$ has computed that with a respiratory quotient of 0.90 , assuming that 15 per cent of the total energy is derived from katabolized protein, 61 per cent would be derived from the combustion of carbohydrates and 24 per cent from that of fat. As a matter of fact, in these experiments the subject probably derived much less than 15 per cent of the total energy from protein, and we could accordingly use Magnus-Levy's figures for a combustion consisting wholly of carbohydrates and fat, with a negligible amount of energy resulting from protein combustion. In this case Magnus-Levy computes for a respiratory quotient of 0.90 , that 66 per cent of the energy is derived from carbohydrates instead of the 61 per cent mentioned above. Using the lower value of 61 per cent, however, we find that of the total energy produced during the 262 minutes of work, namely, 2,554 calories, 1,558 calories would be ascribable to carbohydrates. Using 4.23 calories as the heat of combustion

a See pp. 88 and 89.

b Benedict and Higgins, Am. Journ. Physiol., 1912, 30, p. 217.

c Magnus-Levy, in von Noorden's Handbuch der Pathologie des Stoffwechsels, Berlin, 1906, 1, p. 207. 
of 1 gram of glycogen, ${ }^{a}$ the heat of combustion of 1,558 calories would correspond to 368 grams of glycogen. Inasmuch as the respiratory quotient does not show a marked falling off as the work progressed, it is reasonable to suppose that at the cessation of work there was still a considerable supply of glycogen in the body and that the above calculated amount (368 grams) represents the minimum rather than the maximum.

It is greatly to be regretted that the resting value in the post-absorptive condition was not determined on this man both before the experiment began and after the experiment ended. As a matter of fact the proper determination of the post-absorptive resting value usually requires about 2 hours, namely, onehalf hour period of lying before the experiment begins, and approximately one-half hour for each experimental period. Inasmuch as in this experiment it was especially designed to have the subject ride to his maximum capacity, it was obviously important that the experiment should begin as early as possible in the morning. When it is considered that this enormous amount of muscular work was carried on without any food in the stomach, it can be seen that the subject was capable of very great muscular exertion. The protocols of the experiment ${ }^{b}$ show that the work was very easily done by the subject for the first 2 hours of the period, but he then began to show slight and increasing signs of fatigue and at the end of the experimental period was thoroughly exhausted. The perspiration was very profuse during the whole experiment. The last period in which the respiratory exchange was determined was but 6 minutes and 55 seconds in length instead of 10 or 11 minutes, like the other periods of work. During this period the subject was distinctly unable to keep the pace with which he had begun. When the subject finished work and his mouth was removed from the mouthpiece, it was noted that he was in a state of absolute collapse. When questioned, the subject reported that he felt completely exhausted, with a constant struggle for breath at the end of the experiment. As it was thought that the labored respiration might possibly be due to the fact that the air in the circuit contained too small a percentage of oxygen, analyses were immediately made and the air was found to contain 22.5 per cent of oxygen. Tests for unabsorbed carbon dioxide were negative in all periods. We have in this experiment, therefore, a case of simple exhaustion from excessive muscular work. It has been computed elsewhere ${ }^{c}$ that the muscular work accumulated to 208,000 kilogrammeters.

It is of interest to compute the distance that would have been covered by this man provided he had ridden an ordinary bicycle. During the entire period of work he made 22,482 revolutions of the pedal. The ratio of the number of teeth on the large sprocket to those on the smaller sprocket being $3.25: 1$, the copper disk was therefore rotated 73,066 times. The brake-effect with which the subject was riding, i.e., 1.5 amperes through the magnet, was in his judgment somewhat greater than that experienced in riding in a 6-day bicycle race. Repeated tests have shown that this brake-effect or resistance would be secured for this subject by considerably less current, namely, 1.25 amperes. It is reasonable to suppose that the resistance would therefore be equal to that riding over a fairly good country road on a still day. Assuming that the wheel had a standard diameter of 28 inches ( 71 centimeters), a simple calculation shows that the work done was equivalent

a Benedict and Emery, Am. Journ. Physiol., 1911, 29, p. 301. b See table 80, p. 66. 
to over 100 miles (161 kilometers) of riding. In other words, this man took what might be called a "century run" before breakfast, an evidence of his staying power that, to say the least, is rather remarkable.

It is furthermore of interest to cite the heroic experiments of Lusk ${ }^{a}$ and his associates in which an effort was made to remove the glycogen from the body. Having shown that experiments in which phlorizinized dogs were exposed to cold indicated the removal of the residual glycogen, they attempted to exhaust the human body of glycogen by the same means, using cold baths. Although Lusk's report of these experiments with men indicated that cold per se was the predominating factor in producing this effect, personal discussion with him leads to the belief that he considered the cold of moment chiefly for the stimulation of shivering, this intense muscular activity using the muscles all over the body. It was hoped by this means to deprive all the muscles of glycogen. The abnormally high post-absorptive values obtained for the respiratory quotient with both person $A$ and person $B$ after a rather rigid carbohydrate-free régime lead one to suspect errors in these determinations. The greatest increase in the heat production brought about by the cold baths was 188 per cent above the normal with person B, or 645 c.c. of oxygen per minute as compared with 224 c.c. of oxygen consumed while resting. Applying these figures to person A, although as a matter of fact the measured heat production after shivering was but 63 per cent higher than normal, we find from the protocols of the experiment that this subject shivered 18 minutes during the first bath and 19 minutes during the second, or a total of 37 minutes of shivering. Assuming that the metabolism was not 188 per cent, but 3 times that of normal, and that the resting metabolism for a man of this weight would be 76 calories per hour, under conditions of shivering the metabolism would be 228 calories per hour, or 141 calories in 37 minutes. If the total combustion during this time were exclusively of glycogen, this would correspond to about 33 grams of glycogen.

With our professional subject M. A. M., the initial respiratory quotient during work was not far from 0.90 and remained constant throughout the experiment. With person A in Lusk's experiments the initial quotient of 0.99 would lead one to believe that there was a surplus of glycogen at the beginning of the experiment, and yet according to the computations it appears that only 33 grams could possibly have been removed during the experimental period. It would seem highly improbable, therefore, that the body could be deprived of glycogen by shivering which continued not more than 37 minutes when the metabolism was no greater than three times that of normal; for while unquestionably shivering brings into play a larger number of muscles throughout the whole body than does bicycle riding, it is clear from the results obtained in our research that the severe muscular work incidental to prolonged bicycle riding removes a very much larger amount of glycogen from the body.

Urine Excretion in Experiments with Muscular Work.

The difficulties incidental to securing the proper collection of urine during experiments with severe muscular work have already been pointed out. The profuse perspiration, the nervous excitement incidental to the bi- 
cycle riding, and with some of the subjects the inability to urinate at the proper time made a sharply cut separation practically impossible. It was hoped that the collection of the urine could be divided into two periods, the first beginning when the subject rose in the morning and ending when the work experiment began, and the second covering the period of work. This separation was obtained in only two experiments, those of November 21 with H. L. H. and of March 27 with M. A. M. On the other hand, with M. A. M. specimens of urine were obtained at some time during practically every day of work, and determinations made of the total nitrogen. The results of these determinations are given in table 100, which shows that the nitrogen excretion per hour ranges from 0.06 to 0.77 gram, averaging not far from 0.4 gram per hour. Since the body-weight of this subject was approximately 65 kilograms, it can be seen that under the conditions of the experiments, which were usually part resting and part severe muscular work, the nitrogen excretion per kilogram of body-weight per minute was approximately 6 milligrams per hour per kilogram of body-weight. This is, if anything,

TABLE 100.-Nitrogen in urine during experiments without food, with rest and muscular work.

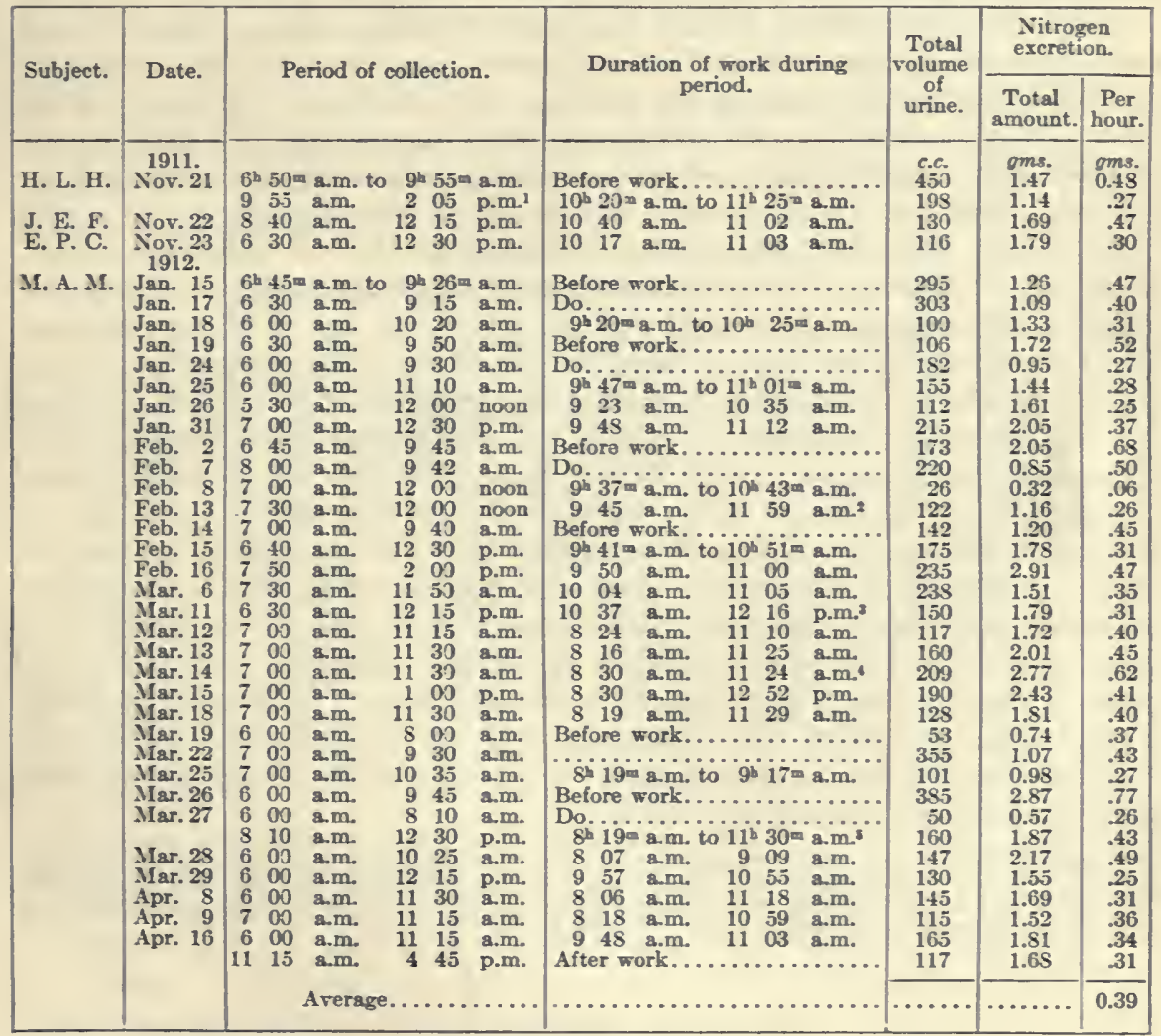

1 Probably ate a light meal shortly before the collection of the urine.

2 Without load, with pedals rotated by motor. Times for beginning and ending approximate.

Without load, with pedals rotated by motor, $10^{\mathrm{b}} 37^{\mathrm{m}}$ to $11^{\mathrm{b}} 32^{\mathrm{m}} \mathrm{am}$.; work with resistance $11^{\mathrm{b}} 32^{\mathrm{m}} \mathrm{a} \cdot \mathrm{m}$, to $12^{\mathrm{h}} 16^{\mathrm{m}} \mathrm{p}$.m.

4 Probably began work before $8 \mathrm{~b} 30 \mathrm{~m}$ a.m.

5 Work done in two periods, $8^{\mathrm{h}} 19^{\mathrm{m}}$ to $9^{\mathrm{th}} 21^{\mathrm{m}} \mathrm{am}$, and $10^{\mathrm{h}} 33^{\mathrm{m}}$ to $11^{\mathrm{b}} 30^{\mathrm{m}} \mathrm{am}$. 
somewhat less than that found by Benedict and Carpenter in resting experiments with a large number of normal subjects. ${ }^{a}$ It is thus obvious that during the actual time of work there was not an excessive excretion of nitrogen per hour. This is further shown by the data for March 18 and April 8 with M. A. M., when the subject worked nearly the whole period of collection, the nitrogen excretion being about the same as in periods covering rest and work. On the other hand the figures throw absolutely no light upon the lag in the excretion of nitrogen following severe muscular work which has been observed by many investigators.

So much experimental evidence has already been accumulated to prove that protein cannot be the sole source of muscular work that no further attempt was made with our professional subject to collect the urine throughout the day, especially as this was difficult inasmuch as after the work was over each day he left the laboratory and the greater part of the time was uncontrolled as to diet. The data given in this table are interesting only in showing that even after the excessively severe work frequently done by the subject M. A. M. there was, on the whole, no great increase in the excretion of nitrogen from the body. ${ }^{b}$

On the other hand it should be stated that the volumes of urine were for the most part very small. There was very free perspiration and hence the fluid excreted by the kidneys was reduced to a minimum. In one case but 50 c.c. of urine could be collected, while from 7 o'clock until 12 o'clock noon of another experimental day but 26 c.c. of urine were secured; in at least one instance (February 1) the subject was unable to pass any urine. It is thus obvious that with such fragmentary evidence as this no sweeping conclusions can be drawn, but that experiments planned primarily to study this problem are necessary in order to secure data that can be of material use. The values for nitrogen were secured primarily for the purpose of supplying data to be used in conjunction with the measurements of the gaseous exchange for computing the amounts of protein, fat, and carbohydrate katabolizeda computation frequently employed by many writers. On the other hand it should be stated that in all probability it is entirely erroneous to assume that the nitrogen excretion is coincidental with the metabolism of protein, as the excretion of abnormally large amounts of nitrogen are frequently observed after severe muscular work, showing that there is a distinct delay in the excretion of the decomposition products of protein. Although it has been pointed out that if any increase in nitrogen output takes place following work it usually appears two to three days afterwards, this is in the present series of experiments of little moment as the majority of the actual tests were carried out on consecutive days.

\footnotetext{
a Reported by Benedict and Joslin, Carnegie Institution of Washington Publication No. 176, 1912, p. 103.

$b$ Fragmentary evidence bearing on this point has been secured in this laboratory on Marathon runners which shows that the total nitrogen output per hour during the severe work of running was small. See Higgins and Benedict, Am. Journ. Physiol., 1911, 28, p. 291.
} 


\section{MECHANICAL EFFICIENCY OF THE HUMAN BODY.}

The relationship between the energy consumption and the output of work, which has been extensively studied with different machines, is a relationship which is likewise of great interest in the study of the mechanical efficiency of the human body. The experiments reported in this publication were primarily designed to furnish evidence with regard to the relationship between the total energy transformation and the external muscular work performed, and it is the purpose of this section of the report to discuss the experiments from this particular standpoint.

It may be desirable first to define what is meant by efficiency. Two terms are used by writers in this connection, but unfortunately often without sharp distinction. In this review of the literature on the subject; the term "gross efficiency" is used to designate the value obtained as a result of dividing the actual heat equivalent of the external effective muscular work by the total energy output of the man. This has frequently been designated by writers as "gross efficiency," "industrial efficiency," and "crude efficiency." When from the total output of the day is deducted the output for a period of corresponding length without external muscular work, the result gives the increase in the energy output which is caused by the work. Dividing the heat equivalent of the external muscular work done by the increase in the energy due to the work gives a value which may be designated as the "net efficiency." These two base-lines are those most commonly used by writers. In this publication other base-lines are considered and designations for these will appear in their regular places.

PREVIOUS STUdIES ON MECHANICAL EFFICIENCY OF THE HUMAN BODY.

Even the early literature gives evidence which can be used for the computation of the efficiency of the body as a machine, for in the experiments of Lavoisier and Séguin, which we have already cited, we find that for the performance of work equivalent to the lifting of 7.343 kilograms to 799 meters, i.e., 5,867 kilogrammeters, Lavoisier's subject required an increase in the oxygen consumption over and above resting ${ }^{a}$ of 36.8 liters. Assuming a respiratory quotient of approximately 0.87 (the average of the respiratory quotients obtained in over 100 experiments with our subject), the calorific equivalent of oxygen would be 4.887 calories, ${ }^{b}$ so that 36.8 liters of oxygen would correspond to 179.8 calories. The heat equivalent ${ }^{c}$ of 5,867 kilogrammeters would equal 13.8 calories; hence it appears that at the most about 7.7 per cent of the oxygen consumed over and above the amount consumed during rest was used for mechanical work, and about 4.4 per cent of the total amount of oxygen consumed. Lavoisier and Séguin also made observations on a man during digestion, and although the experiments are not well adapted for computing the efficiency, they are of interest in this connection. The total amount of oxygen consumed in an hour during work was 91.2 liters, an increase over resting of 53.6 liters. The subject performed 6,202 kilogrammeters of work, the calorific equivalent of which would be 14.6

\footnotetext{
a The oxygen consumption per hour, resting, equalled 26.66 liters.

bee p. 33 of this report.

c In this report 1 calorie is considered as equal to 425 kilogrammeters, the value most used by the various
} investigators. 
calories. Assuming a respiratory quotient of 0.90 , the calorific equivalent of 91.2 liters of oxygen would be 449.1 calories and of 53.6 liters, 263.9 calories, so that it can be seen that of the excess of oxygen consumed, approximately 5.5 per cent was used for mechanical work, and of the total consumption of oxygen less than 3.3 per cent.

Following the experiments of Lavoisier and Séguin, no data from which the efficiency of the body can be computed were obtained until the experiments of Edward Smith. ${ }^{a}$ From the results obtained by Smith and by Despretz and Dulong, ${ }^{b}$ Helmholtz ${ }^{c}$ computed that of the total heat incidental to the performance of muscular work, one-fifth is used for mechanical work and four-fifths are given off in the form of heat, thus showing a gross efficiency of the body of 20 per cent.

Haughton, in an address before the British Medical Association at Oxford ${ }^{d}$ calculated the average daily labor of a man to be 109,549 kilogrammeters, or the work necessary to raise a man of 150 pounds of weight to the height of 1 mile, and that the heat produced in 24 hours would be the equivalent of six times the average mechanical work performed by a laboring man. Thus he considers that the gross mechanical efficiency would be equal to 17 per cent.

Basing their computations upon the utilization by the body of 300 grams of carbon in the ascent of Mont Blanc, Dumas and Boussingault computed the efficiency of the body as 33 per cent.e

TABLE 101.-Mechanical efficiency of the human body as computed by Hirn.

\begin{tabular}{|c|c|c|c|c|c|}
\hline Subject. & $\begin{array}{l}\text { Work in } \\
1 \text { hour.1 }\end{array}$ & $\begin{array}{c}\text { Oxygen } \\
\text { consumed. }\end{array}$ & $\begin{array}{c}\text { Carbon } \\
\text { dioxide } \\
\text { excreted. }\end{array}$ & $Q$ & $r^{2}$ \\
\hline $\begin{array}{l}42 \text { years........... } \\
47 \text { years, laborer... }\end{array}$ & $\begin{array}{c}\text { kgm. } \\
+27,581 \\
+27,448 \\
+23,257 \\
-26,972 \\
+32,550 \\
-30,275 \\
+25,912 \\
+22,987 \\
+19,586 \\
-24,175\end{array}$ & $\begin{array}{r}g m 8 . \\
126.80 \\
130.95 \\
115.72 \\
63.71 \\
123.68 \\
59.86 \\
99.12 \\
88.63 \\
85.55 \\
49.57\end{array}$ & $\begin{array}{r}\text { gms. } \\
174.35 \\
180.06 \\
159.12 \\
87.60 \\
170.06 \\
81.90 \\
136.29 \\
121.87 \\
117.63 \\
68.16\end{array}$ & $\begin{array}{c}\text { cals. } \\
233.10 \\
251.60 \\
203.50 \\
351.50 \\
229.40 \\
251.60 \\
192.30 \\
268.30 \\
214.60 \\
251.60\end{array}$ & $\begin{array}{l}0.217 \\
0.204 \\
0.212 \\
0.220 \\
0.250 \\
0.394 \\
0.172 \\
0.167 \\
0.176 \\
0.292\end{array}$ \\
\hline
\end{tabular}

$1+=$ positive work; - = negative work.

2 Hirn designates by $r$ the gross efficiency, i. e., $\frac{\mathrm{Kgm} \text {. work }}{425} \div\left(Q+\frac{\mathrm{Kgm} \text {. work }}{425}\right)$.

In 1857 a French physician in Colmar, Hirn, ${ }^{f}$ attacked the problem of the mechanical efficiency of the body from the experimental standpoint. Considering $Q$ as all the heat losses of the body, such as radiation, the warming of the expired gases, perspiration evaporated, etc., and $T$ the work, he calculated that the total heat production of the body would be equal to $Q+(T \div 425)$. Hirn's results are given in abstract in table 101. There is obviously a great discrepancy between the calorific values of the oxygen

a Smith, Edward, Philosophical Transactions, 1859, 149, p. 681.

b Despretz, Ann. de Chim. et de Phys., ser. 2, 1824, 26, p. 337:.Dulong, Ann. de Chim. et de Phy's., ser. 3, 1841, $1, p .440$.

c Helmholtz, Proc. Royal Institution, 1861, 3, p. 347.

d Haughton, Relation of food to work, Dublin, 1868 .

$e$ Dumas and Boussingault, Essai de statique chimique des êtres organisés, 1844 . Cited by Amar, Le rendement de la machine humaine, Paris, 1910, p. 21.

$f$ The first work of Hirn on the buman motor was published in the Comptes rendus de la Soe. de physique de Colmar, 1857. See, also, Hirn, Théorie mécanique de la chaleur, Paris, 1857, 1. 
consumed and the values of $Q$. Amar ${ }^{a}$ shows that if we are to consider the values of $Q$ as correctly measured calorimetrically, the efficiency agrees reasonably well with that of Helmholtz, who computes it as 20 per cent.

Although the classical experiment of Fick and Wislicenus ${ }^{b}$ in their ascent of the Faulhorn has frequently been cited as an indication of the fact that the work was not done by the disintegration of protein, it is a matter of special interest in this connection to note that these authors computed their mechanical efficiency as equivalent to 50 per cent.

Hirn ${ }^{c}$ argues that the effective work represents one-fourth of the chemical action in the muscles, namely, an efficiency of 25 per cent. Joule ${ }^{d}$ also contends that the efficiency is one-fourth, or 25 per cent, while in 1867 and 1868 Paul Bert ${ }^{e}$ computed that the values for English prisoners producing 260,000 kilogrammeters per day would be 34 per cent for the net efficiency and 21 per cent for the gross efficiency.

In 1887 Hanriot and Richet, ${ }^{\prime}$ working with their newly developed methods of studying the respiratory exchange and with a subject raising weights, assumed that muscular work is done by the consumption of glucose. As the net efficiency of their subject they found one-seventh, or 14.3 per cent, and concluded that the net efficiency of the body lies between 11.1 and 14.3 per cent.

In repeating some of Hirn's work on a wheel similar to the one used by him, Chauveau obtained results that were quite different. Computing the values from the amount of oxygen absorbed in excess of that absorbed during rest, the subject being without food in the stomach, Chauveau found a net efficiency averaging 14 per cent. ${ }^{\circ}$ Amar calls attention to the fact that there are marked differences in the calculated net efficiencies in two classes of experiments; thus, for going upstairs he found an efficiency as great as 15 to 30 per cent, but when the work was done exclusively with the muscles of the arm he found but 3 to 5 per cent. The criticisms regarding the length

TABLE 102.-Results of experiments made by Laulanié with a constant amount of work.

\begin{tabular}{|c|c|c|c|c|}
\hline $\begin{array}{c}\text { Duration of } \\
\text { work. }\end{array}$ & $\begin{array}{c}\text { Effective } \\
\text { work. }\end{array}$ & $\begin{array}{l}\text { Oxygen } \\
\text { increase } \\
\text { due to } \\
\text { work. }\end{array}$ & $\begin{array}{l}\text { Energy } \\
\text { required } \\
\text { for effec- } \\
\text { tive work. }\end{array}$ & $\begin{array}{c}\text { Net } \\
\text { efficiency. }\end{array}$ \\
\hline $\begin{array}{r}5 \text { minutes. . . . . } \\
10 \text { minutes. . . } \\
15 \text { minutes. . . }\end{array}$ & $\begin{array}{r}\text { kgm. } \\
560 \\
1,206 \\
1,664\end{array}$ & $\begin{array}{l}\text { lilers. } \\
1.333 \\
2.861 \\
3.900\end{array}$ & $\begin{array}{l}\text { kgm. } \\
2,666 \\
5,722 \\
7,800\end{array}$ & $\begin{array}{l}p . c t . \\
21.0 \\
21.0 \\
21.3\end{array}$ \\
\hline
\end{tabular}

of the experiments and the methods used in carrying out his researches have already been cited. A mathematical treatment of Chauveau's results as to the efficiency under different conditions is admirably presented by Lefévre. $^{h}$

amar, loc. cit., p. 23.

b Fick and Wislicenus, Ann. des sei. nat., 1853, 10, p. 273.

c Hirn, Revue scientifique, 1S57, 39, p. 673 .

d Joule, cited by Hanriot and Richet, Comptes rendus, 1857, 105, p. 76, who, in turn, cite from Fick, Mechanische Arbeit und Wärmeentwicklung bei der Muskelthātigkeit, Leipsic, 1881, p. 231.

e Bert, La machine humaine, 1867-68, 2, p. 50. Cited by Amar, loc. cit., p. 24.

Hanriot and Richet, Comptes rendus, 1857,105, p. 76

- Cited by Amar, loc. cil., p. 25.

h Lefévre (Chaleur animale et bioenergetique, Paris, 1911, p. 749). It should here be stated that a sharp distinction as to the effect of the various factors on efficiency has rarely been recognized by writers, hence Lefévre's abstract of Chauveau's work is of unusual interest. The variations in the percentage ascribed to the etficiencies by different writers is in large part explained by the lack of agreement on the basis of computation, a point that is clearly brought out by Lefére. 
A most interesting series of experiments was carried out by Laulanié ${ }^{a}$ on himself in which a wheel with a brake upon it was used. In one series the brake was adjusted so as to have a resistance of 4 kilograms, the experiments lasting 5, 10, and 15 minutes respectively. The results are collected in table 102. These experiments showed a constancy in the efficiency with a constant amount of work per unit of time.

Still more important, however, was the series of experiments made by Laulanie ${ }^{b}$, on the same apparatus in which the rapidity of work was voluntarily altered. The values of the resistance ranged from 1 to 15 kilograms, and the speed altered from 1.49 to 0.13 meters per second. The results are presented in table 103 .

TABLE 103.- Results of work experiments made by Laulanie with varying speed and resistance.

\begin{tabular}{|c|c|c|c|c|c|}
\hline $\begin{array}{c}\text { Resist- } \\
\text { ance. }\end{array}$ & $\begin{array}{c}\text { Speed per } \\
\text { second. }\end{array}$ & $\begin{array}{c}\text { Work pro- } \\
\text { duced in 5 } \\
\text { minutes. }\end{array}$ & $\begin{array}{c}\text { Oxygen } \\
\text { increase } \\
\text { due to } \\
\text { work. }\end{array}$ & $\begin{array}{c}\text { Oxygen } \\
\text { consumed } \\
\text { per kilo- } \\
\text { grammeter. }\end{array}$ & $\begin{array}{c}\text { Net } \\
\text { efficiency. }\end{array}$ \\
\cline { 1 - 1 } kilos. & meters. & kgms. & liters. & c.c. & p.ct. \\
1 & 1.49 & 448 & 1,596 & 3.5 & 14.1 \\
2 & 1.07 & 642 & 1,568 & 2.44 & 20.4 \\
3 & 0.80 & 726 & 1,581 & 2.17 & 22.9 \\
4 & 0.61 & 778 & 1,683 & 2.14 & 23.3 \\
5 & 0.54 & 812 & 1,797 & 2.23 & 22.3 \\
6 & 0.44 & 853 & 1,928 & 2.25 & 22.1 \\
8 & 0.37 & 896 & 2,188 & 2.43 & 20.4 \\
10 & 0.29 & 905 & 2,590 & 2.53 & 19.7 \\
12 & 0.24 & 906 & 2,829 & 3.12 & 17.0 \\
15 & 0.13 & 570 & 3,030 & 5.31 & 9.4 \\
\hline
\end{tabular}

This interesting table brings out the fact that the highest efficiency was obtained with a resistance of 4 kilograms, and with a rapidity of 0.61 meter per second, thus showing that there appears to be an optimum condition of mechanical work under these circumstances. Laulanié indicates two "optimum conditions," the "optimum mécanique" corresponding to resistances between 8 and 12 kilograms, and the "optimum économique" to a resistance of 4 kilograms.

A series of computations of the mechanical efficiency of isolated muscles when stimulated should be cited here. Fick ${ }^{c}$ found on isolated muscle under the most favorable conditions an efficiency of 25 per cent. Danilewsky, ${ }^{d}$ employing similar methods, found an efficiency of 50 per cent, but Fick observed that these figures were improbable.

Gautier $^{e}$ concludes that a man produces 250,700 kilogrammeters of gross work per day, which would be equivalent to 588 calories, and consumes a working diet, $i$. e., a diet in excess of the resting diet, of 1779 calories. He assumes that the efficiency is therefore one-third, but that of these 250,700 kilogrammeters, 100,000 kilogrammeters and above are lost in the different movements of the body and the friction of the machine, so that the useful work corresponds to but 150,000 kilogrammeters, the equivalent energy of which would be 352 calories. The net efficiency, therefore, of the human motor would be approximately one-fifth.

The two forms of muscular work most commonly employed by Zuntz

a Laulanié, Éléments de physiologie, 2d ed., Paris, 1905, p. 801.

b Laulanie, loc, cit., p. 802 .

c Fick, Pflüger's Archiv, 1878,16, p. 58

d Danilewsky, in Fick's Myothermische Untersuchungen, Wiesbaden, 1889, pp. 173-194.

e Gautier, Cours de chimie, Paris, 1892, 3, p. 800. 
and his associates were those of turning a brake ergometer or of moving the body through a given distance, as in using a treadmill or climbing a mountain. The most complete collection of the results obtained in the various experiments carried out by the Zuntz school in which the forward and upward progression of the body was studied has been brought together by Durig. Durig's data include the experiments of Zuntz and Schumburg ${ }^{b}$ on the treadmill, the extensive series reported by Zuntz, Loewy, Müller, and Caspari, ${ }^{c}$ the experiments of Frentzel and Reach, ${ }^{d}$ and those of Leo Zuntz. These, as well as Durig's own experiments, were all carried out by the Zuntz method. The results obtained by Bürgi ${ }^{f}$ under Kronecker's direction and by an entirely different method, in which only sthe carbon dioxide was determined, have also been painstakingly recalculated by Durig." The efficiency, which was in all cases obtained by deducting the metabolism incidental to forward progression from that during climbing, ranged from as low as 19 per cent in one or two experiments with Bürgi to as high as 46.5 per cent with Kolmer in the treadmill experiments. ${ }^{h}$

The experiments made by Durig ${ }^{i}$ and his co-workers showed efficiencies on the treadmill as high as 37 per cent. In practically all experiments the effect of velocity on the speed was noticeable, but Durig considers that an average value for the efficiency is 31 per cent. Of special interest is the noticeable influence of training apparent in these experiments. The several groups of experiments in which Durig himself was the subject are worthy of special note. The average net efficiencies in these ranged from 34.9 per cent shown when he was walking on a treadmill in Vienna with an inclination of 21.6 per cent, to 21.2 per cent when walking along a path on Monte Rosa with an inclination of 15.5 per cent. In these computations the work of forward progression was deducted, so that the efficiency is based solely upon the equivalent of lifting the body through a given height. During the experiments made at Neuwaldegg in summer, in which the path had an inclination of 16.4 per cent, Durig showed 31.1 per cent efficiency. Of his three collaborators, all traveling on the same path, Kolmer showed 30.3 per cent, Rainer 31.7 , and Reichel 30.1 per cent efficiency.

Several series of experiments in Zuntz's laboratory, in which the brake ergometer or the Gärtner ergostat was used, were those of Katzenstein, ${ }^{j}$ Loewy, ${ }^{k}$ Heinemann, ${ }^{l}$ and Frentzel and Reach. ${ }^{m}$ Later, in reporting an interesting series of experiments on the energy ${ }^{n}$ required to rotate a centrifugal machine (a cream separator), Reach ${ }^{\circ}$ summarized the earlier work and showed that Katzenstein's results indicated a gross efficiency of from 13 to 19 per cent, and a net efficiency of 25.4 per cent. Heinemann's results show a net efficiency of 20.6 to 25 per cent. Reach found in his experiments that

a Durig, Physiologische Ergebnisse Monte Ross-Expedition, Ueber den Gaswechsel beim Gehen, Denkschrift

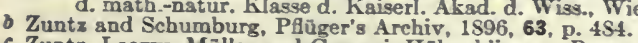

c Zuntz, Loewy, Müller and Caspari, Hōhenklima u. Bergwanderungen, Berlin, 1906.

d Frentzel and Reach, PAüger's Archiv, 1901, 83, p. 477.

c A. Loewy, J. Loewy, and L. Zuntz, Pfiuger's Archiv, 1S97, 66, p. 497.

$f$ Bürgi, Archiv f. Physiologie, 1900, p. 509.

- Durig, loc. cit., p. 301.

h Durig, loc. cit., pp. 299 and 301.

Durig, loc. cil., pp. 299 and 301.

J Katzenstein, Pfüger's Archiv, 1891, 49, p. 330.

Loewy, Pfluger's Archiv, 189i, 49, p. 405.

Heinemann, PAüger's Archiv, 1901, 83, p. 441.

m Frentzel and Reach, Pflüger's Archiv, 1901, 83, p. 477.

$n$ Erroneously reported as "rohe Wirkungsgrad" by Reach, Biochem. Ztschr., 1908, 14, p. 445.

- Reach, Landw. Jahrb., 190S, 37, p. 1053; also Biochem. Ztschr., 1908, 14, p. 430. 
when turning the wheel of the centrifugal machine the gross efficiency was 14.5 to 16.6 per cent ${ }^{a}$ and the net efficiency, 24.1 to 27.9 per cent. ${ }^{b}$ Reach also noticed an alteration in the net efficiency incidental to increased velocity, the net efficiency having a tendency to decrease as the velocity increased.

Another summary of the results of the Zuntz school has been made by Loewy, ${ }^{c}$ who finds that the energy consumption for 1 kilogrammeter of work in lifting the body when walking up an inclined plane was from 2.190 to 3.770 kilogrammeters with a dog, and with a horse 2.912 kilogrammeters. With a man, when the inclination of the path was 6.5 per cent, the energy consumption was 3.165 kilogrammeters; with an inclination of from 23 to 30.5 per cent, it was 2.831 kilogrammeters, and from 30.7 to 62 per cent, 3.559 kilogrammeters. He states that the values varied inversely with the body-weight, changing considerably according to the size of the individual, but contends that for every kilogrammeter of work in the elevation of the body there is required on the average 3 kilogrammeters of energy output. In computing the work done in turning the wheel of an ergostat, he takes as an average value 4 to 4.3 kilogrammeters of energy after a long training in the experiments of Heinemann, while the experiments of Katzenstein, in which the subjects had less experience, show 5.5 to 7.1 kilogrammeters of energy. Loewy, like other writers of the Zuntz school, indicates that for walking up an inclined plane the net efficiency would be on the average 33.33 per cent, while for turning a brake ergometer, the net efficiency would be 24 to 25 per cent for welltrained men, and considerably less than 20 per cent for untrained men.

In connection with the studies on mountain-climbing or raising the body to a given distance, the interesting experiments of Jaquet and Svenson on fat persons should be cited. ${ }^{d}$ Employing the special pedal apparatus of Jaquet described by $\mathrm{H}$. Christ, ${ }^{e}$ Jaquet and Svenson made experiments on two fat individuals, one weighing 118 kilograms and the other 93.7 kilograms. The increased oxygen consumption per kilogrammeter during work was with the first subject, 4.67 c.c. per minute; with the second, three different experiments gave $1.722,2.1$, and 1.79 c.c. per minute, respectively. These values are considerably above those found by Katzenstein, ${ }^{f}$ who found on four different individuals, 1.187, 1.244, 1.435, and 1.504 c.c.

In their extensive researches upon the influence of muscular work on metabolism, Sondén and Tigerstedt, ${ }^{g}$ using the large Stockholm respiration chamber, determined the carbon-dioxide output of individuals while turning the Gärtner ergostat. For purposes of comparison they computed the carbon dioxide per kilogrammeter of work done from the data of preceding experiments. The results have been tabulated and given on page 19 of this report.

Reach ${ }^{h}$ computed from the carbon-dioxide values found by Sondén and Tigerstedt that the gross efficiency of the body would be 17.3 per cent, and the net efficiency, 27.4 per cent.

Using a Gärtner ergostat inside the large respiration chamber in the Hygienic Institute in Berlin, Rubner ${ }^{i}$ made an experiment on a man who

a Reach, loc. cit., p. 1074. b Reach, loc. cit., p. 1082.

c Loewy, Oppenheimer's Handbuch der Biochemie, Jena, 1911, 4, (1), p. 274.

d Jaquet and Svenson, Zeitschr. f. klin. Med., 1900, 11, p. 1.

$e$ Christ, Deutsch. Archiv f. klin. Med., 1894, 53, p. 102.

$f$ Katzenstein, Pfinger's Archiv, 1891, 49, p. 368.

o Sondén and Tigerstedt, Skand. Archiv f. Physiol., 1895, 6, p. 187.

$h$ Reach, loc. cit., p. 1053.

1 Rubner, Sitzungsber. k. Preuss. Akad. Wissensch., 1910, 16, p. 316. 
pcrformed 100,000 kilogrammeters of work during the day, this being equivalent to 234 calories. Deducting the energy requirement during rest, Rubner found that for the 234 calories of external muscular work, the increase in energy was 845.3 calories with a sugar diet and 855.6 calories with a protein diet. The average net efficiency may readily be computed as follows: $\frac{234 \times 100}{850}=27.5$ per cent. In this experiment Rubner's computations of the energy requirement were based upon the carbon-dioxide determinations alone, no oxygen determinations being made.

The Gärtner ergostat and other forms of ergometer permit a study of the work done by the arms only. The work of the legs in walking and climbing has been shown by the experiments of the Zuntz school to be more economically done than is the work of the arms, and hence it is particularly fortunate that the bicycle ergometer has been rapidly developed as an instrument of precision.

The experiments of Leo Zuntz, ${ }^{a}$ in which the metabolism incidental to bicycle riding was first studied and an efficiency of 33.33 per cent computed, have been more illuminated by the subsequent study of the resistance to be overcome by riding a bicycle. ${ }^{b}$ In the light of this last study Berg, du Bois-Reymond, and Zuntz computed that Zuntz in his first experiments showed a net efficiency of 28 per cent.

TABLE 104.-Relation of external muscular work to energy katabolized per day, as reported by Atwater and Benedict.

\begin{tabular}{|c|c|c|c|c|c|c|}
\hline \multirow[b]{2}{*}{ Subject and lind of experiment. } & \multirow[b]{2}{*}{$\begin{array}{l}\text { Dura- } \\
\text { tion. }\end{array}$} & \multicolumn{2}{|c|}{ Energy katabolized. } & \multirow{2}{*}{$\begin{array}{l}\text { Heat equiv- } \\
\text { alent of } \\
\text { muscular } \\
\text { work. }\end{array}$} & \multicolumn{2}{|c|}{ Efficiency. } \\
\hline & & Total. & $\begin{array}{l}\text { Excess in } \\
\text { work over } \\
\text { rest ex- } \\
\text { periments. }\end{array}$ & & Net. & Gross. \\
\hline $\begin{array}{l}\text { Subject, E. O.: } \\
\text { Average of } 13 \text { rest experiments.... } \\
\text { Average of } 3 \text { work experiments... }\end{array}$ & $\begin{array}{l}\text { days. } \\
42 \\
12\end{array}$ & $\begin{array}{l}\text { cals. } \\
2,279 \\
3,892\end{array}$ & $\begin{array}{l}\text { cals. } \\
i, 613\end{array}$ & $\begin{array}{l}\text { cals. } \\
\dot{2 i i}\end{array}$ & $\begin{array}{l}\text { p. et. } \\
\text { i3.3 }\end{array}$ & $\begin{array}{l}\text { p. ct. } \\
\ddot{5} . \overline{5}\end{array}$ \\
\hline $\begin{array}{l}\text { Subject, J. F. S.: } \\
\text { Average of } 4 \text { rest experiments........ }\end{array}$ & 18 & 2,119 & & 212 & & \\
\hline $\begin{array}{l}\text { Average of } 6 \text { work experiments...... } \\
\text { Subject, J. C. W.: }\end{array}$ & 18 & 3,559 & 1,440 & $\ddot{2} \dot{3} \dot{3}$ & 16.2 & 6.6 \\
\hline $\begin{array}{l}\text { Average of } 1 \text { rest experiment......... } \\
\text { Minimum of } 14 \text { work experiments... } \\
\text { Maximum of } 14 \text { work experiments... } \\
\text { Average of } 14 \text { work experiments.... }\end{array}$ & $\begin{array}{r}4 \\
46 \\
45 \\
46\end{array}$ & $\begin{array}{l}2,357 \\
5,056 \\
5,332 \\
5,143\end{array}$ & $\begin{array}{l}2,699 \\
2,975 \\
2,786\end{array}$ & $\begin{array}{l}529 \\
601 \\
546\end{array}$ & $\begin{array}{l}19.6 \\
20.2 \\
19.6\end{array}$ & $\begin{array}{l}10.5 \\
11.3 \\
10.6\end{array}$ \\
\hline
\end{tabular}

The stationary form of bicycle, $i$. e., a bicycle with resistance, or a bicycle ergometer, was first employed by Atwater and his associates in connection with the studies on muscular work conducted at Wesleyan University. In the earlier experiments, while the oxygen was not measured, a measurement was made of the total heat production by placing both ergometer and subject inside a large respiration calorimeter. The data secured in these experiments thus permit the computation of the efficiency. Unfortunately the estimates of the actual amount of external muscular work performed on this earlier machine will always be somewhat questionable; on the other hand the values for the total heat production as measured by the calorimeter can be considered as accurately established.

a Leo Zuntz, Untersuchungen ūber den Gaswechsel und Energieumsatz des Radfahrers, Berlin, 1899

- Berz, du Bois-Reymond, and Leo Zuntz, Archiv f. Anat. u. Physiol., Physiol. Abth., Suppl., 1904, p. 20. 
The earlier experiments with the form of bicycle ergometer in which an electric motor was attached to the rear wheel of the bicycle have been collected and summarized in a table by Atwater and Benedict. ${ }^{a}$ (See table 104.) In this table are given the average resting katabolism, the average working katabolism, the increased katabolism due to work, and the heat equivalent of the external muscular work, together with the net efficiency. To the original table we have added a column showing the gross efficiency.

The disadvantages in the first ergometers used were very quickly recognized by these investigators, and plans for a new form of ergometer were immediately made. The later apparatus, which was as a matter of fact the "ergometer I" used in our study on muscular work, was employed by Benedict and Carpenter in an extensive series of investigations with several subjects. ${ }^{b}$ A series of six experiments during work was made with a well-trained college athlete, J. C. W., of which an abstract is given in table 105 .

TABLE 105.-Heat equivalent of muscular work and corrected amount of heat produced in experiments with J. C. W., as reported by Benedict and Carpenter. ( 7 a.m.to 7 p.m.)

\begin{tabular}{|c|c|c|c|c|c|}
\hline Experiment. & Date. & $\begin{array}{l}\text { Heat equiv- } \\
\text { alent of } \\
\text { muscular } \\
\text { work. }\end{array}$ & $\begin{array}{l}\text { Heat } \\
\text { pro- } \\
\text { duced. }\end{array}$ & $\begin{array}{l}\text { Heat pro- } \\
\text { duced over } \\
\text { resting } \\
\text { metabolism. }\end{array}$ & $\begin{array}{c}\text { Net } \\
\text { effi- } \\
\text { ciency. }\end{array}$ \\
\hline No. $56 . .$. & 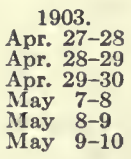 & $\begin{array}{l}\text { cals. } \\
569 \\
601 \\
538 \\
657 \\
563 \\
587\end{array}$ & $\begin{array}{c}\text { cals. } \\
3,959 \\
4,139 \\
3,834 \\
4,309 \\
4,056 \\
4,131\end{array}$ & $\begin{array}{l}\text { cals. } \\
2,619 \\
2,799 \\
2,494 \\
2,969 \\
2,716 \\
2,791\end{array}$ & $\begin{array}{l}p . c t . \\
21.7 \\
21.5 \\
21.6 \\
22.1 \\
20.7 \\
21.0\end{array}$ \\
\hline
\end{tabular}

As will be seen, the average net efficiency for this subject was 21.5 per cent. The computations in this table are based upon the fact that the work was all done between 7 a.m. to 7 p.m., and hence the energy required for rest experiments during the same period is deducted from the energy produced during the severe muscular work. The average of four rest experiments showed that from 7 a.m. to 7 p.m. this subject gave off on the average 1,340 calories, the range being from 1,320 to 1,383 calories.

The comparison as made is subject to a correction for the extra heat production incidental to the ingestion of food. Larger diets were taken on the work days than on the rest days, and as Oppenheimer ${ }^{c}$ correctly points out, this fact should be taken into consideration in this type of comparison.

With another subject, B. F. D., an average of three rest experiments with food gave a heat production of 1,244 calories for the 12 hours from 7 a.m. to 7 p.m. On one day's work in which he did 419 calories of external muscular work, the total heat production from 7 a.m. to 7 p.m. was 3,421 calories; thus, the excess due to work was 2,177 calories, corresponding to an efficiency of 19.2 per cent.

A somewhat extensive series of experiments was also carried out with the subject A. L. L., an abstract of which is given in table 106. Although the base-line for computing the resting metabolism was not so satisfactory as could be desired, work experiments were likewise made with two other subjects, B. F. D. and E. F.S. The results of these experiments are abstracted in table 107.

a Atwater and Benedict, U. S. Dept. Agr., Office Exot. Stas. Bul. No. 136, 1903, p. 190.

$b$ Benedict and Carpenter, U. S. Dept. Agr., Office Expt. Stas. Bul. No. 208, 1909.

c See editor's note to article by.Tigerstedt in Oppenheimer's Handbuch der Biochemie, Jena, 1908,4 (2), p. 45. 
TABLE 106.- Heat equivalent of muscular work and corrected amount of heat produced in experiments with A.L. L., as reported by Benedict and Carpenter. (7 a.m. to 7 p. m.)

\begin{tabular}{|c|c|c|c|c|c|}
\hline Experiment. & Date. & $\begin{array}{c}(a) \\
\text { Heat equi- } \\
\text { valent of } \\
\text { muscular } \\
\text { work. }\end{array}$ & $\begin{array}{c}\text { (b) } \\
\text { Heat } \\
\text { pro- } \\
\text { duced. }\end{array}$ & $\begin{array}{c}(c) \\
\text { Heat pro- } \\
\text { duced over } \\
\text { resting } \\
\text { metabolism. }\end{array}$ & $\begin{array}{c}(d) \\
\text { Net } \\
\text { efficiency. } \\
(a \times 100) \div c\end{array}$ \\
\hline $\begin{array}{l}\text { Work: } \\
\text { No. } 62 \ldots \ldots \ldots \ldots \ldots \ldots \ldots \\
\text { No. } 63 \ldots \ldots \ldots \ldots \ldots \ldots \\
\text { No. } 64 \ldots \ldots \ldots \ldots \ldots \ldots\end{array}$ & $\begin{array}{l}1904 \\
\text { Apr. 16-17 } \\
\text { Apr. 17-18 } \\
\text { Apr. 18-19 } \\
\text { Apr. 19-20 } \\
\text { Apr. 20-21 } \\
\text { Apr. 21-22 } \\
\text { Apr. 22-23 }\end{array}$ & $\begin{array}{l}\text { cals. } \\
459 \\
458 \\
460 \\
460 \\
460 \\
458 \\
957\end{array}$ & $\begin{array}{l}\text { cals. } \\
3,599 \\
3,578 \\
3,602 \\
3,657 \\
3,573 \\
3,518 \\
6,843\end{array}$ & $\begin{array}{l}\text { cals. } \\
2,322 \\
2,301 \\
2,325 \\
2,380 \\
2,296 \\
2,241 \\
4,638\end{array}$ & $\begin{array}{l}\text { p. } c t . \\
19.8 \\
19.9 \\
19.8 \\
19.3 \\
20.0 \\
20.4 \\
20.6\end{array}$ \\
\hline $\begin{array}{l}\text { Rest with food: } \\
\text { No. } 65 \ldots \ldots \ldots \ldots \ldots \\
\text { No. } 66 \ldots \ldots \ldots \ldots \ldots\end{array}$ & $\begin{array}{l}\text { Apr. } 23-24 \\
\text { Apr. 24-25 }\end{array}$ & $\ldots$ & $\begin{array}{l}1,203 \\
1,351\end{array}$ & $\ldots$ & $\ldots$ \\
\hline Average of Nos. 65 and 66. . & & ... & 1,277 & .... & $\ldots$ \\
\hline
\end{tabular}

1 In deducting the heat production of resting metabolisn from that in the work experiments, the averages of Nos. 65 and 66 were used. For the severe work experiment (No. 64), the heat production during the period from $7 \mathrm{a} . \mathrm{m}$. to $4 \mathrm{a} . \mathrm{m}$. of experiment No. 65 was used as the resting metabolism. This was found to be 2,205 calories. Deducting this from the total heat production of experiment No. $64(6,843$ calories) lesves 4,638 calories as the heat production necessary to produce mechanical work, the heat equivalent of which is 957 calories.

TABLE 107.-Heat produced in experiments with B. F. D. and E. F. S., as reported by Benedict and Carpenter.

\begin{tabular}{|c|c|c|c|c|c|c|c|c|}
\hline $\begin{array}{l}\text { Subject and } \\
\text { date. }\end{array}$ & Period. & $\begin{array}{c}\text { (a) } \\
\text { Heat } \\
\text { pro- } \\
\text { duced. }\end{array}$ & $\begin{array}{l}\text { (b) } \\
\text { No. of } \\
\text { revolu- } \\
\text { tions. }\end{array}$ & $\begin{array}{l}\text { (c) } \\
\text { No. of } \\
\text { revolu- } \\
\text { tions } \\
\text { per } \\
\text { minute. }\end{array}$ & $\begin{array}{l}\text { (d) } \\
\text { Cur- } \\
\text { rent. }\end{array}$ & $\begin{array}{c}\text { (e) } \\
\text { Heat } \\
\text { equivalent } \\
\text { of muscu- } \\
\text { lar work. }\end{array}$ & $\begin{array}{c}(0) \\
\text { Heat pro- } \\
\text { duced over } \\
\text { resting } \\
\text { metsbolism. }\end{array}$ & $\begin{array}{c}(g) \\
\text { Net } \\
\text { efficiency. } \\
(e \times 100) \div f\end{array}$ \\
\hline W. F. D. & & cals. & & & $a m p$. & cals. & cals. & p. ct. \\
\hline Mar. 1, 1904 & $\begin{array}{l}7 \text { a.m. to } 7 \text { p.m. } \\
7 \text { a.m. to } 1 \text { p.m. }\end{array}$ & $\begin{array}{l}4,085 \\
1,963\end{array}$ & $\begin{array}{l}25,959 \\
12,645\end{array}$ & $\begin{array}{l}60 \\
56\end{array}$ & $\begin{array}{l}1.25 \\
1.25\end{array}$ & $\begin{array}{l}600 \\
292\end{array}$ & $\begin{array}{l}2,747 \\
1,280\end{array}$ & $\begin{array}{l}21.8 \\
22.8\end{array}$ \\
\hline $\begin{array}{l}\text { Rest with food: } \\
\text { Mar. 3, } 1904\end{array}$ & 7 a.m. to 7 p.m. & 1,339 & & .. & & & & \\
\hline $\begin{array}{l}\text { E. F. S. } \\
\text { Work: } \\
\text { Mar. 5, } 1904\end{array}$ & 7 a.m. to 7 p.m. & 4,782 & 26,495 & 61 & 1.25 & 612 & 3,382 & 18.1 \\
\hline
\end{tabular}

1 No resting experiment with E. F. S. was made, as the subject left the city shortly after the conclusion of the work experiment. His body-weight was 80 kilos., and from a large amount of data obtained with other subjects, it is highly probable that his resting metabolism would have been not far from 1,400 calories for the period from $7 \mathrm{a} . \mathrm{m}$. to $7 \mathrm{p.m}$. Accordingly, this resting metabolism has been assumed in the computations.

Finally, a series of experiments was made with a professional athlete, N. B., in which the metabolism was studied during short periods, usually $11 / 2$ to 3 hours in length. The subject, who was 35 years old, weighed 66 kilograms, and was 172 centimeters in height, was one of the best-known professional bicycle riders in America. He was in excellent condition and an ideal subject for the experiment. The results, calculated on a one-hour basis, are abstracted in table 108. No data for oxygen consumption are given for the experiments made in October 1904, as the methods for the measurement of this factor had not then been perfected. Of special note is the net efficiency exhibited by this professional subject, the average being 21 per cent. 
TABLE 108.-Results of experiments with N. B., as reported by Benedict and Carpenter.

[Amounts per hour].

\begin{tabular}{|c|c|c|c|c|c|c|c|c|}
\hline Date. & Period. & $\begin{array}{c}(a) \\
\text { Current. }\end{array}$ & $\begin{array}{c}\text { (b) } \\
\text { Carbon } \\
\text { dioxide } \\
\text { eliminated. }\end{array}$ & $\begin{array}{c}(c) \\
\text { Oxygen } \\
\text { ab- } \\
\text { sorbed. }\end{array}$ & $\begin{array}{c}(d) \\
\text { Heat } \\
\text { pro- } \\
\text { duced. }\end{array}$ & $\begin{array}{c}(e) \\
\text { Heat equiv- } \\
\text { alent of } \\
\text { work done. }\end{array}$ & $\begin{array}{c}(f) \\
\text { Heat above } \\
\text { resting } \\
\text { metabolism. }\end{array}$ & $\begin{array}{c}(g) \\
\text { Net } \\
\text { efficiency. } \\
(e \times 100) \div \ell\end{array}$ \\
\hline \multirow{10}{*}{$\begin{array}{r}1904 . \\
\text { Oct. } 21 \\
22 \\
22 \\
24 \\
1905 . \\
\text { Jan. } 23 \\
23 \\
23 \\
24 \\
24 \\
25 \\
25 \\
26 \\
26 \\
26\end{array}$} & \multirow{3}{*}{$\begin{array}{l}\text { First...... } \\
\text { First...... } \\
\text { Second } . . . \\
\text { First..... }\end{array}$} & \multirow{3}{*}{$\begin{array}{c}a m p . \\
1.25 \\
\text { Rest. } \\
1.25 \\
\text { No load. }\end{array}$} & \multirow{3}{*}{$\begin{array}{c}\text { grams. } \\
215.3 \\
28.6 \\
208.1 \\
62.2\end{array}$} & grams. & \multirow{3}{*}{\begin{tabular}{r|} 
cals. \\
625.4 \\
94.2 \\
616.2 \\
182.5
\end{tabular}} & $\begin{array}{c}\text { cals. } \\
104.5\end{array}$ & $\begin{array}{c}\text { cals. } \\
531.2\end{array}$ & $\begin{array}{l}\text { p. ct. } \\
19.7\end{array}$ \\
\hline & & & & & & \multirow{2}{*}{ iis.7 } & \multirow{2}{*}{522.0} & $\ddot{22.2}$ \\
\hline & & & & ..... & & & & 22.2 \\
\hline & First..... & Rest. & $\begin{array}{r}29.4 \\
2310\end{array}$ & $\begin{array}{r}22.8 \\
183.4\end{array}$ & 89.7 & & & \\
\hline & & $\begin{array}{l}1.25 \\
1.25\end{array}$ & $\begin{array}{l}231.0 \\
210.4\end{array}$ & $\begin{array}{l}183.4 \\
174.0\end{array}$ & $\begin{array}{l}608.0 \\
625.8\end{array}$ & $\begin{array}{l}113.8 \\
114.7\end{array}$ & $\begin{array}{l}518.3 \\
536.2\end{array}$ & $\begin{array}{l}22.0 \\
21.4\end{array}$ \\
\hline & & .90 & 153.5 & 142.8 & 473.3 & 79.8 & 383.7 & \\
\hline & & .90 & 159.6 & 140.2 & 468 & 77. & 378.6 & 20 \\
\hline & First.... & .80 & 124.8 & 114.6 & 392 & & 302 & \\
\hline & $\begin{array}{l}\text { S } \\
\text { First.... }\end{array}$ & No load. & $\begin{array}{r}139.8 \\
63.5\end{array}$ & $\begin{array}{r}125.7 \\
57.4\end{array}$ & $\begin{array}{l}405 \\
181\end{array}$ & & & \\
\hline & & & 138.2 & 111.1 & 382.4 & 59.9 & 292.7 & 20.5 \\
\hline
\end{tabular}

A summary of the results obtained with all of the work experiments with these subjects is given in table 109, which shows the gross and net efficiency for each man.

\begin{tabular}{|c|c|c|c|c|}
\hline & \multicolumn{4}{|c|}{ [Amounts per hour.] } \\
\hline & \multirow{2}{*}{ Subject. } & \multirow{2}{*}{$\begin{array}{l}\text { Heat } \\
\text { equiva- } \\
\text { lent of } \\
\text { muscular } \\
\text { work. }\end{array}$} & \multicolumn{2}{|c|}{$\begin{array}{l}\text { Mechanical } \\
\text { efficiency. }\end{array}$} \\
\hline & & & Gross. & Net. \\
\hline . & 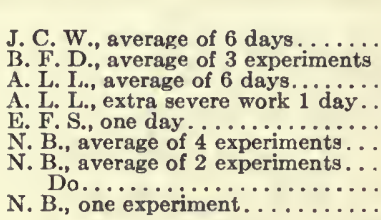 & $\begin{array}{r}\text { cals. } \\
49 \\
45 \\
38 \\
46 \\
51 \\
112 \\
79 \\
65 \\
60\end{array}$ & $\begin{array}{l}p . c t . \\
14.5 \\
14.2 \\
12.7 \\
14.1 \\
12.8 \\
18.1 \\
16.8 \\
16.2 \\
15.7\end{array}$ & $\begin{array}{l}p . c t . \\
21.6 \\
21.2 \\
19.7 \\
20.8 \\
18.1 \\
21.3 \\
20.8 \\
21.0 \\
20.7\end{array}$ \\
\hline
\end{tabular}

The authors also computed the mechanical efficiency based on the coasting or "no-load" values of these men; the results are abstracted in table 110 . These values are wrong, owing to an erroneous assumption for the friction of the ergometer. ${ }^{a}$ Finally, the effect on the efficiency of increasing the ex-

TABLE 110.-Mechanical efficiency based on coasting as reported by Benedict and Carpenter.

[Amounts per hour.]

\begin{tabular}{|c|c|c|c|c|c|c|c|}
\hline Subject. & $\begin{array}{c}\text { (a) } \\
\text { Current. }\end{array}$ & $\begin{array}{c}(b) \\
\text { Revolu- } \\
\text { tions } \\
\text { per } \\
\text { minute. }\end{array}$ & $\begin{array}{l}\text { (c) } \\
\text { Heat pro- } \\
\text { duced dur- } \\
\text { ing work. }\end{array}$ & $\begin{array}{c}(d) \\
\text { Heat pro- } \\
\text { duced dur- } \\
\text { ing coasting. }\end{array}$ & $\begin{array}{l}\text { (e) } \\
\text { Estimated } \\
\text { heat re- } \\
\text { quired for } \\
\text { work. } \\
(c-d)\end{array}$ & $\begin{array}{l}\quad(D) \\
\text { Heat equi- } \\
\text { valent of } \\
\text { work (less } \\
\text { friction).1 }\end{array}$ & $\begin{array}{c}(\theta) \\
\text { Net } \\
\text { efficiency. } \\
(f \times 100) \div e\end{array}$ \\
\hline $\begin{array}{l}\text { N. B. } \\
\text { N. B. } \\
\text { N. B. } \\
\text { N. B. } \\
\text { A. L. L. }\end{array}$ & $\begin{array}{r}a m p . \\
1.25 \\
.90 \\
.80 \\
.70 \\
1.25\end{array}$ & $\begin{array}{l}83 \\
76 \\
70 \\
78 \\
.\end{array}$ & $\begin{array}{l}\text { cals. } \\
617 \\
471 \\
401 \\
382 \\
299\end{array}$ & $\begin{array}{l}\text { cals. } \\
182 \\
167 \\
153 \\
171 \\
135\end{array}$ & $\begin{array}{l}c a l s . \\
435 \\
304 \\
248 \\
211 \\
164\end{array}$ & $\begin{array}{c}\text { cals. } \\
107 \\
72 \\
58 \\
52 \\
35.5\end{array}$ & $\begin{array}{l}\text { p. ct. } \\
24.6 \\
23.7 \\
23.4 \\
24.6 \\
21.6\end{array}$ \\
\hline
\end{tabular}

1 Later researches with the apparatus show that the values in this column are erroneous. (See Benedict and Cady, Carnegie Institution of Washington Publication No. 167, 1912, p. 22.)

a For discussion of this point see p. 143 of this report. 
ternal work or load was computed as shown in table 111. The authors point out that there was a disturbing factor in that the speed per minute was not uniform with all degrees of magnetization of the field, and state that the experiments must be looked upon as more or less tentative.

TABLE 111.-Effect on mechanical efficiency of increasing external work as reported by Benedict and Carpenter.

\begin{tabular}{|c|c|c|c|}
\hline $\begin{array}{l}\text { Increase in } \\
\text { magnetization } \\
\text { from - }\end{array}$ & $\begin{array}{l}\text { Increase } \\
\text { of total } \\
\text { heat. }\end{array}$ & $\begin{array}{l}\text { Increase } \\
\text { of heat of } \\
\text { external } \\
\text { work. }\end{array}$ & Efficiency. \\
\hline $\begin{array}{l}\quad a m p . \\
0.7 \text { to } 0.8 \ldots \ldots \ldots \\
0.7 \text { to } 0.9 \ldots \ldots \ldots \\
0.7 \text { to } 1.25 \ldots \ldots \\
0.8 \text { to } 0.9 \ldots \ldots \ldots \\
0.8 \text { to } 1.25 \ldots \ldots \ldots \\
0.9 \text { to } 1.25 \ldots \ldots \ldots\end{array}$ & $\begin{array}{r}\text { cals. } \\
19 \\
89 \\
237 \\
70 \\
218 \\
148\end{array}$ & $\begin{array}{c}\text { cals. } \\
5 \\
19 \\
52 \\
14 \\
47 \\
33\end{array}$ & $\begin{array}{l}\text { p. ct. } \\
26.0 \\
21.3 \\
22.0 \\
20.0 \\
21.5 \\
22.3\end{array}$ \\
\hline
\end{tabular}

As an indication of the great difficulties that may be experienced in computing the heat efficiency of the bicycle rider from the energy intake and the mechanical measurements, we must cite the discussion of R. C. Carpenter, ${ }^{\text {" }}$ who computed the efficiency of two professional riders in a 6-day bicycle race, obtaining the apparent gross efficiencies of over 60 per cent in one case and nearly 45 per cent in the other. Computations of the effective muscular work in complicated muscular processes must always be of uncertain value.

One of the great difficulties incidental to computing the amount of external muscular work performed by going up and down stairs or walking along a horizontal or an inclined plane is strikingly indicated in certain experiments of Chauveau. ${ }^{b}$ This investigator computed that Tissot in his experiments on the respiratory exchange performed in 70 minutes 29,000 kilogrammeters of positive work and an equal amount of negative work. The total amount of work would thus be 58,000 kilogrammeters, or 136 calories, approximately 2 calories per minute. And yet Chauveau, in his computation of the respiratory quotients, maintains that the metabolism during work was but 4 times that of rest. In this laboratory in order to secure an effective output of 2 calories per minute on a bicycle ergometer, it was necessary for the subject to increase his metabolism over rest more than 10 times. It is thus obvious that either Chauveau's estimate of the amount of external muscular work performed must be erroneous or the analyses for the gaseous exchange are open to severe criticism. The technique of the ChauveauTissot apparatus has been carefully gone over in this laboratory by Mr. T. M. Carpenter, and when carried out according to the specific instructions of Chauveau and Tissot, the apparatus and method give admirable results. We are thus disinclined to consider the measurements of the gaseous exchange at fault, although the lengths of periods are short and the technique of sampling has not been adequately given. It is probable that the estimates of the work performed are erroneous.

Amar, ${ }^{c}$ using a bicycle ergometer in which the rear wheel was supplied with a steel ribbon as a brake, the amount of friction on the ribbon being

Atwater, Sherman, and Carpenter, U. S. Dept. Agr., Office Expt. Stas. Bul. No. 98, 1901, pp. 64 and 65.
Chaureau, Comptes rendus, 1896, 122, p. 1163. Previously cited on p. 80 of this report.

c Amar, Jules, Le rendement de la machine humaine. Recherches sur le travail, Paris, 191a. 
continuously measured by a combination of weights and springs, determined the efficiency of a number of Arabs in Algeria. The net efficiency varied from 27 to 38 per cent, with an average of not far from 32.5 per cent, while the gross efficiency varied from 3.2 to 5.1 per cent, with an average of 4.5 per cent, these values being calculated from the ration eaten by the subjects. Amar also computed the net efficiency from the consumption of oxygen as measured by means of the Tissot apparatus, finding an average net efficiency of 27 per cent instead of the 32.5 per cent found when computed from the food intake. When the subject performed 13,748 kilogrammeters per hour for 4 consecutive hours, Amar computed the net efficiency from the oxygen consumption to be 29.33 per cent for the first hour, 31.23 per cent for the second, 33.81 for the third, and 35.03 for the fourth hour. Other experiments gave a similar increase in the efficiency as the work progressed. Of particular interest in connection with our research is his study of the effect upon the efficiency of the rate of speed. With 70 revolutions of the pedal he found with one subject 25.1 per cent, with 80 revolutions 26.7 per cent, with 90 revolutions 28.4 per cent, while with another subject with 90 revolutions he found 30.6 per cent, and with 100 revolutions 25.8 per cent, indicating approximately an optimum speed of about 90 revolutions of the pedal per minute. Considering the conditions under which Amar worked and the difficulties incidental to an inadequately equipped laboratory, these results are of special interest; yet, as pointed out by Lefèvre, ${ }^{a}$ the values must be taken with considerable reserve.

\section{THE UNIT OF EFFICIENCY.}

\section{Gross and Net Efriciency.}

An examination of the earlier literature on the efficiency of the body shows that a large number of units of efficiency have been used by various writers. If the total energy output for the day is made the base-line, and the actual amount of energy transformed into external muscular work taken as the numerator, the percentage of efficiency can be obtained by the formula $\frac{a \times 100}{b}$, in which $a$ represents the external work performed in calories and $b$ the total energy output in calories. This unit, which may be called the "gross efficiency," the "crude efficiency," or the "industrial efficiency," is naturally largely affected by the amount of work performed during the day and the number of hours in which work is done, since at least half of the day is usually spent in rest, during which time there is energy output but unaccompanied by effective external work. For computation of the energy output of a gang of laborers or artisans in a mill and for the provisioning of an army or navy under severe stress of muscular work, the gross efficiency is of particular value, but in physiological experiments per se it indicates but little of the potentialities of the human body for severe muscular work, and gives no conception of the possible efficiency of the human body as a machine.

To find this latter, it is obvious, to say the least, that the energy given off when the subject is at rest and not performing muscular work should be deducted from the total daily quota. Further than that, it can readily be assumed that a deduction should likewise be made of the energy required for 
the maintenance of the body of a subject lying quietly during a period of time equal in length to the working period. A value, which may be termed the "net efficiency" or "pure efficiency," would thus be obtained by the formula $\frac{a \times 100}{b-c}$, in which $a$ is the external amount of muscular work performed, $b$ the total calorie output for the period during which work was performed, and $c$ the resting requirement in calories during a similar period. Under these conditions, therefore, the value $b-c$ represents the increment in oxygen or calories required to produce $a$ calories of external muscular work.

\section{METHODS OF COMPUTING THE NET EFFICIENCY.}

This relationship has been used by many writers in their computations, but we find that there are many methods for computing this net efficiency. For instance, Durig ${ }^{a}$ has emphasized the fact that when computing the net efficiency for a person walking along level ground, it is a question whether the resting lying metabolism should be deducted, or the metabolism while the person is standing. Similarly, for walking up an incline or climbing mountains it is difficult to select the exact base-line for comparison. In the work of mountain climbing, which has been studied so extensively by Zuntz, Durig, and their collaborators, it is legitimate to deduct not only the metabolism when the subject is lying quietly awake, but also logical to deduct the metabolism incidental to movement along a horizontal plane for a distance equivalent to that traveled on an ascent less the height; the actual amount of work involved in raising the body to a vertical height will then be shown by the increase in the oxygen consumption during the ascent over that required to move the body forward on the horizontal plane. This method of computation has been employed quite extensively. In the computations of the results of his mountain-climbing experiments, Durig has first deducted from the total katabolism the metabolism of the subject while lying quietly and then from the value remaining he has computed that for the "horizontal component;" deducting this, he obtains the value for the katabolism due to raising the body to a given height, i.e., the "vertical component." The difficulties incidental to this form of computation need not be pointed out.

Although somewhat extraneous to this discussion, it is not without interest to note that Durig states in his conclusions ${ }^{b}$ that experiments of this kind should be made in a respiration chamber since the Zuntz method does not take account of the cutaneous respiration and makes no provision for eliminating the influence of the resistance to the work of respiration. While the form of respiration apparatus used in the present series of experiments does not measure the cutaneous respiration, which is unquestionably considerable, yet, on the other hand, it does eliminate all resistance to the respiration since there are no valves to be actuated and no meter to be turned. A special calorimeter for severe muscular work is in process of construction in this laboatory which will give an opportunity for measuring the cutaneous respiration, but the results of this research may be taken as representing an intermediate step between results obtained by the Zuntz method and by the respiration chamber.

a Durig, Physiologische Ergebnisse Monte Rosa Erpedition, Ueber den Gaswechsel beim Gehen, Denkschrift d. math.-natur. Klasse d. Kaiserl. Akad. d. Wiss., Wien. 1909, 86, p. 294.

- Durig, loc, cui., p. 338 . 
In computing the results obtained with a brake ergometer, such as the Gärtner ergostat, still another method has been used for finding the net efficiency as it is customary to deduct from the total energy output during work the energy output required to turn the ergostat the same number of revolutions without external friction. Various other methods of computation have suggested themselves to different writers, with a consequent lack of uniformity in the base-lines used. The difficulties incidental to the computation of the results obtained during mountain-climbing and marching are also found in connection with our bicycle ergometer experiments, but, as has previously been pointed out, an attempt has been made to secure as many base lines as possible. Unquestionably some of these base-lines are wholly fictitious and their use in the computations is not justifiable. On the other hand, with all the possible combinations and conditions, it is more than probable that certain of these calculations do indicate truly the increased metabolism incidental to a measured amount of external muscular work. It is our purpose to recognize these various base-lines, and use them, so far as possible, in computing the results of our experiments.

Confining ourselves for the moment exclusively to the question of the method to be used in computing the results obtained in experiments with the bicycle ergometer, it can be seen that not only may we deduct the metabolism for the equivalent period when the subject is lying quietly in bed, but we may also deduct the metabolism incidental to sitting quietly upon the bicycle without rotating the pedals. This is an upright position that must be assumed by the subject before work can be begun and which calls for an increased metabolism over the lying position. The work incidental to this can not be measured on the ergometer; indeed, it is doubtful if there is any measurable external muscular work performed, although sustaining the body in an upright position does call for a considerable increase in internal muscular work.

Furthermore, in rotating the pedals, there is a movement of the legs with consequent muscular work which, for the want of better phraseology, may be termed the internal friction of the legs. A value may be obtained for this activity and used as a base-line by rotating the wheel of the bicycle by means of an electric motor, so that the legs are made to move up and down as in riding while no actual work is done upon the ergometer itself. Although the ergometer has but little friction, considerable internal work of the legmuscles is required in rotating the wheel of the ergometer, even when no current is passed through the magnet; hence in computing one of the various grades of efficiency the energy output incidental to rotating the ergometer under these conditions may properly be deducted from the total energy output, thus forming a third base-line.

Even though measurable, the friction of the ergometer is so small in amount that it would not justify a computation based upon the ground that overcoming the friction of the bicycle requires a given amount of external muscular work. The efficiency of the body in performing a very small amount of work may be studied, however, by using a slight measurable brake-effect upon the wheel. The amount of work thus done is so small in comparison with the total metabolism of the body that it may be classed with such minor muscular movements as the moving of a fan back and forth or rocking 
in a rocking-chair. Such work does, however, bring the body-muscles into play, and theoretically, at least, forms an excellent base-line for the superimposition of more severe loads; by increasing the resistance of the ergometer step by step, various loads may be superimposed upon this base-line and very satisfactory computations made from the increments in work.

Finally, since many investigators have found that the efficiency varies with variations in the speed, the work may be done both at slow and at high speeds, all with the same resistance on the wheel. As a matter of fact, inasmuch as for comparison experiments wide variations in speed should be employed, with this particular form of ergometer there exists an inherent diffculty in carrying out such a study, for, as will be seen by the calibration curves, with wide differences in speed, there is a marked difference in the brakeeffect at any part of the curve. Nevertheless, experiments have been made on this basis and the results will be subsequently discussed.

COMPARISON OF BASAL METABOLISM IN BICYCLE ERGOMETER EXPERIMENTS.

Increment in Metabolisis Doe to Changing from a Lring to a Sitting Position.

The influence of minor muscular movements and of changes in bodyposition on metabolism have received especial attention in the last few years. In a long series of experiments carried out in the laboratory of Wesleyan University, alterations in the body-position were studied by Benedict and Carpenter. ${ }^{G}$ Later a series of observations was carried out in the Nutrition Laboratory by Emmes and Riche, ${ }^{b}$ who noted a definite increase in metabolism on changing the subject from a lying to a sitting position, the increase being less marked when the sitting body was supported by pillows or otherwise. In one experiment made in this laboratory and still unpublished, there was no measurable increase in metabolism following a change to the sitting position, this result being probably due to the fact that the body, shoulders, arms, neck, and head were thoroughly supported by pillows. Nevertheless, in changing the position of the subject from lying on a couch to sitting on the bicycle seat, it is reasonable to expect considerable increases in metabolism, and as the values obtained in the latter position were likely to be used as a base-line for the computation of the net efficiency, it seemed desirable to secure evidence as to the increase in metabolism incidental to the change in position. Accordingly, such studies were made with four of our subjects including one experiment with each of three subjects and several experiments with the fourth subject. Nearly all of the observations were made with ergometer I. The results have been collected and presented in abstract in table 112, the carbon-dioxide production, oxygen consumption, and the pulse and respiration rates being recorded, as well as the increments in these factors in the form of per cent. Turning our attention particularly to the oxygen consumption per minute, it will be seen that in the experiments made with ergometer I the increments for all the subjects ranged from 6.1 per cent to 24.8 per cent, and, indeed, with the subject M. A. M., the ranges are nearly as great, i.e., from 6.1 to 23.1 per cent. On the other hand, with the two subjects E. P. C. and K. H. A., the increments are essentially the same, 8.2 and 9.1 .

a Benedict and Carpenter, Carnegie Institution of Washington Publication No. 126, 1910, p. 243.

o Ernines and Riche, Am. Journ. Physiol., 1911, 27, p. 406. 
TABLE 112.-Metabolism in experiments without food with subject lying on couch compared with metabolism in experiments with subject sitting inactive on ergometer. (Average results.)

\begin{tabular}{|c|c|c|c|c|c|c|c|c|c|c|c|c|c|c|}
\hline \multirow{4}{*}{ Subject and date. } & \multicolumn{4}{|c|}{$\begin{array}{l}\text { Carbon dioxide per } \\
\text { minute. }\end{array}$} & \multicolumn{4}{|c|}{ Oxygen per minute. } & \multicolumn{4}{|c|}{$\begin{array}{l}\text { Pulse-rate per } \\
\text { minute. }\end{array}$} & \multirow{2}{*}{\multicolumn{2}{|c|}{$\begin{array}{c}\text { Respira- } \\
\text { tion-rate } \\
\text { per minute. }\end{array}$}} \\
\hline & \multirow{3}{*}{$\begin{array}{l}\text { Ly- } \\
\text { ing. }\end{array}$} & \multirow{3}{*}{$\begin{array}{l}\text { Sit- } \\
\text { ting. }\end{array}$} & \multirow{2}{*}{\multicolumn{2}{|c|}{$\begin{array}{l}\text { Increase } \\
\text { over lying. }\end{array}$}} & \multirow{3}{*}{$\begin{array}{l}\text { Ly- } \\
\text { ing. }\end{array}$} & \multirow{3}{*}{$\begin{array}{l}\text { Sit- } \\
\text { ting. }\end{array}$} & \multirow{2}{*}{\multicolumn{2}{|c|}{$\begin{array}{l}\text { Increase } \\
\text { over lying. }\end{array}$}} & \multirow{3}{*}{$\begin{array}{l}\text { Ly- } \\
\text { ing. }\end{array}$} & \multirow{3}{*}{$\begin{array}{l}\text { Sit- } \\
\text { ting. }\end{array}$} & \multirow{2}{*}{\multicolumn{2}{|c|}{$\begin{array}{l}\text { Increase } \\
\text { over lying. }\end{array}$}} & \multirow{3}{*}{$\begin{array}{l}\text { Ly- } \\
\text { ing. }\end{array}$} & \\
\hline & & & & & & & & & & & & & & \multirow{2}{*}{$\begin{array}{l}\text { Sit- } \\
\text { ting. }\end{array}$} \\
\hline & & & Amt. & P. ct. & & & Amt. & P. ct. & & & Amt. & P. et. & & \\
\hline Eroometer $I$. & c.c. & c.c. & c.c. & & c.c. & c.c. & c.c. & & & & & & & \\
\hline $\begin{array}{l}\text { J. E. F.: } \\
\text { Nov. } 27,1911 \ldots\end{array}$ & 211 & 233 & 22 & 10.4 & 234 & 292 & 58 & 24.8 & 59 & 78 & 19 & 32 & 9 & 10 \\
\hline Nov. $29,1911$. & 165 & 185 & 20 & 12.1 & 220 & 238 & 18 & 8.2 & 47 & . & .. & .. & 13 & .. \\
\hline $\begin{array}{l}\text { K. H. A.: } \\
\text { Dec. 1, } 1911 \ldots\end{array}$ & 202 & 211 & 9 & 4.5 & 241 & 263 & 22 & 9.1 & 57 & 60 & 3 & 5 & 13 & 13 \\
\hline $\begin{array}{l}\text { M. A. M.: } \\
\text { Dec. } 7,19112 \text {. }\end{array}$ & 225 & 239 & 14 & 6.2 & 262 & 299 & 37 & 14.1 & 74 & 85 & 11 & 15 & 18 & 12 \\
\hline Dec. $8,1911$. & 205 & 236 & 31 & 15.1 & $\begin{array}{l}3247 \\
3247\end{array}$ & 304 & 57 & 23.1 & 66 & 89 & 23 & 35 & 20 & 21 \\
\hline Dec. 11, 1911.. & 195 & 4229 & 34 & 17.4 & 238 & 1267 & 29 & 412.2 & 60 & 484 & 24 & 440 & 21 & 124 \\
\hline Dec. $12,1911$. & 198 & 215 & 17 & 8.6 & 5230 & 244 & 14 & 6.1 & 60 & 70 & 10 & 17 & 22 & 22 \\
\hline Ergometer II. & & & & & & & & & & & & & & \\
\hline $\begin{array}{l}\text { M. A. M.: } \\
\text { Jan. 23, } 1912 .\end{array}$ & & 272 & 62 & 29.5 & 247 & 32 & & & 67 & 82 & 15 & 22 & 21 & 23 \\
\hline Mar. 11, 1912.: & 215 & 282 & 67 & $\begin{array}{l}29.3 \\
31.2\end{array}$ & 247 & $\begin{array}{l}024 \\
386\end{array}$ & 139 & 56.3 & 60 & 83 & 23 & 38 & 21 & 20 \\
\hline
\end{tabular}

1 Average pulse-rate for first two periods.

2 Aside from a preliminary experiment on Deo. 6, this was the first experiment with this subject.

3 In averaging, the oxygen consumption during the first two periods was omitted.

4 Sitting periods were run before lying periods on this day.

It is important to note here that the increased oxygen consumption incidental to sitting was accompanied by an increased pulse-rate. The increments in these two factors, it is true, were not invariably parallel, especially in the experiment with M. A. M. on December 11, in which the oxygen increment was but 12.2 per cent, while the increase in the pulse-rate was 40 per cent. Generally, however, the increment in the pulse-rate was roughly proportional to the increased oxygen consumption. The respirationrate, on the other hand, was not materially altered by changing from a lying to a sitting position. The record obtained on December 7 with M. A. M. is worthy of especial note; the low value for this subject of 12 respirations per minute, while sitting, is unquestionably due to an altered type of respiration, since the average value for a large number of experiments made with this subject throughout the experimental year was 20 respirations per minute. It should be said, however, that this was one of the earlier experiments; the subject was therefore unused to the apparatus and the routine, and consequently somewhat apprehensive. In general it may be inferred that there are practically no alterations in the respiration-rate due to changing from lying on a couch to the position of sitting on a bicycle seat.

Our attention was chiefly given to the subject M. A. M., and his personal observations on these tests are of unusual interest. This subject invariably complained that the experiments were long and tedious and that he found it irksome to sit still for so long a period. Although he was allowed to select the form of bicycle seat he preferred, as well as to adjust the angle, height, and position of both seat and handle bars, and every effort was made to secure for him the most comfortable position, yet reference to the protocols of the experiments shows that apparently sitting quietly on the ergometer was for him a great strain. As any position he might assume on the ergometer ul- 
timately became strained and uncomfortable, it was obvious that this subject was in a wholly abnormal condition throughout practically all of this class of experiments. With the subject M. A. M. no foot-rests were used, the feet being placed upon the pedals and allowed to remain there. With the other subjects, J. E. F., K. H. A., and E. P. C., a foot-rest was usually placed on the front of the machine or else a wooden block was placed upon the floor on which the feet could rest. J. E. F. also found the sitting position very tiresome and accompanied by strain.

It will be seen, therefore, that there is a complete lack of harmony in the results obtained from experiments in which the subject changed from a lying to a sitting position. It was particularly unfortunate that with ergometer II, with which the largest number of work experiments was made, the values for sitting indicate clearly that the discomfort experienced by the professional subject unquestionably increased his metabolism, a fact which must be taken into consideration when this abnormally high base-line is used in any way.

\section{Increment in Metabolism Dee to a Change in Position from Lyivg on a Couch to Sittivg on a Motor-Drives Ergometer.}

In certain experiments, when the subject was sitting on the bicycle ergometer with the feet on the pedals and the body in a riding position, the pedals were rotated by means of an electric motor belted to the rear wheel. Under these conditions the legs moved up and down in the usual manner, but no external muscular work was performed, ${ }^{a}$ the legs being raised and lowered by means of the electric motor; the work done, therefore, was essentially that of the internal friction of the leg-muscles. Five of these experiments were made with slightly varying rates of speed; the results are given in table 113 , together with the results for the comparison experiments made on the same days in which the subject lay quietly upon a couch. In one instance, namely, March 8, the average value for the whole experimental year was used for comparison, as no couch experiment preceded the motor-driven ergometer experiment for that day. By deducting the metabolism of the subject when lying upon the couch from that during the ergometer experiment, the increment due to the muscular activity could be easily obtained. The increases found for the carbon dioxide and the oxygen are essentially alike, the increases in the oxygen consumption ranging from 162 to 207 per cent according to the speed. The pulse-rate increments were likewise considerable, ranging from 42 per cent to 51 per cent. As in the series of experiments given in table 112, the respiration-rate showed but slight alteration. From the results of these experiments it will be seen that when the subject rode on an ergometer with the wheel rotated by a motor, the metabolism was practically 3 times that obtained when he lay on a couch.

In connection with these motor-driven ergometer experiments many interesting observations were made regarding the muscular control of the subject. Throughout the entire series he objected to them, stating that it was hard for him to relax completely and allow his legs to swing idly and be rotated by the motor. From a consideration of the construction of the apparatus it can be seen that there should always be a tension on the sprocketa See Berg, du Bois-Reymond and L. Zuntz for a discussion of this motion. Archiv f. Anat. u. Physiol., Physiol. Abth. Suppl., 1904, p. 42. 
chain, with the lower part taut. With a steady load or steady resistance on the pedals, the pull on the lower part of the chain would be constant. It was noticed, however, that the lower part was frequently slack and that the upper part was taut, showing that the subject at times involuntarily overcame the inertia of the machine and perhaps contributed slightly to the

TABLE 113.-Metabolism experiments without food with subject lying on a couch compared with the metabolism in no-load experiments with motor-driven ergometer. (Subject M. A. M.; ergometer $I I$.

\begin{tabular}{|c|c|c|c|c|c|c|c|c|c|c|c|c|c|c|c|c|}
\hline \multirow{4}{*}{ Date. } & \multirow{4}{*}{$\begin{array}{l}\text { Rev- } \\
\text { olu- } \\
\text { tions } \\
\text { per } \\
\text { min- } \\
\text { ute. }\end{array}$} & \multirow{4}{*}{$\begin{array}{l}\text { No. } \\
\text { of no- } \\
\text { load } \\
\text { peri- } \\
\text { ods. }\end{array}$} & \multicolumn{4}{|c|}{$\begin{array}{l}\text { Carbon dioxide per } \\
\text { minute. }\end{array}$} & \multicolumn{4}{|c|}{ Oxygen per minute. } & \multicolumn{4}{|c|}{$\begin{array}{l}\text { Pulse-rate per } \\
\text { minute. }\end{array}$} & \multirow{2}{*}{\multicolumn{2}{|c|}{$\begin{array}{c}\text { Respira- } \\
\text { tion-rate } \\
\text { per } \\
\text { minute. }\end{array}$}} \\
\hline & & & \multirow{3}{*}{$\begin{array}{l}\text { Ly- } \\
\text { ing. }\end{array}$} & \multirow{3}{*}{$\begin{array}{l}\text { No } \\
\text { load } \\
\text { with } \\
\text { mo- } \\
\text { tor. }\end{array}$} & \multirow{2}{*}{\multicolumn{2}{|c|}{$\begin{array}{l}\text { Increase } \\
\text { over lying. }\end{array}$}} & \multirow{3}{*}{$\begin{array}{l}\text { Ly- } \\
\text { ing. }\end{array}$} & \multirow{3}{*}{$\begin{array}{l}\text { No } \\
\text { load } \\
\text { with } \\
\text { mo- } \\
\text { tor. }\end{array}$} & \multirow{2}{*}{\multicolumn{2}{|c|}{$\begin{array}{l}\text { Increase } \\
\text { over lying. }\end{array}$}} & \multirow{3}{*}{$\begin{array}{l}\text { Ly- } \\
\text { ing. }\end{array}$} & \multirow{3}{*}{$\begin{array}{l}\text { No } \\
\text { load } \\
\text { with } \\
\text { mo- } \\
\text { tor. }\end{array}$} & \multirow{2}{*}{\multicolumn{2}{|c|}{$\begin{array}{l}\text { Increase } \\
\text { over lying. }\end{array}$}} & & \\
\hline & & & & & & & & & & & & & & & \multirow{2}{*}{$\begin{array}{l}\text { Ly- } \\
\text { ing. }\end{array}$} & \multirow{2}{*}{$\begin{array}{l}\text { No } \\
\text { load } \\
\text { with } \\
\text { mo- } \\
\text { tor. }\end{array}$} \\
\hline & & & & & Amt. & P. ct. & & & Amt. & P. ct. & & & Amt. & P. ct. & & \\
\hline $\begin{array}{l}1912 \text {. } \\
\text { Feb. } 13\end{array}$ & 88 & 3 & $\begin{array}{l}\text { c.c. } \\
196\end{array}$ & $\begin{array}{l}\text { c.c. } \\
502\end{array}$ & $\begin{array}{l}\text { c.c.c. } \\
306\end{array}$ & 156 & $\begin{array}{l}\text { c.c.c. } \\
233\end{array}$ & $\begin{array}{l}\text { c.c. } \\
625\end{array}$ & $\begin{array}{l}\text { c.c. } \\
392\end{array}$ & 168 & 60 & 85 & 25 & 42 & 20 & 23 \\
\hline Feb. 20 & 92 & 3 & 200 & 503 & 303 & 152 & 247 & 647 & 400 & 162 & 61 & 187 & 26 & 43 & 19 & .. \\
\hline Feb. 21 & 96 & 3 & 191 & 565 & 374 & 195 & 236 & 672 & 436 & 185 & 59 & 89 & 30 & 51 & 20 & \\
\hline Mar. 8 & 101 & 3 & 2205 & 611 & 406 & 198 & 2242 & 743 & 501 & 207 & 263 & 95 & 32 & 51 & 220 & 19 \\
\hline Mar. 11 & 102 & 2 & 215 & 669 & 454 & 211 & 247 & 743 & 496 & 201 & 60 & .. & .. & . & 21 & $\ldots$ \\
\hline
\end{tabular}

1 There was but one record of pulse in each no-load period on this day.

2 This figure is a general average of results with this subject while lying on couch before work in respiration experiments without food. (See table 91.)

movement of the pedals. While the results are reasonably uniform, the five experiments being made inside of a month, they doubtless represent a larger amount of energy output than would normally be expected from the simple friction of the leg. Unquestionably there were slight involuntary compensatory movements of the legs, tending to oppose the work of the motor at one time and again tending to assist it, and this interplay of muscles may have caused a not inconsiderable proportion of the total increase in the metabolism. While at first sight it would appear as if in such experiments equilibrium was obtained by the balancing of one leg against the other as it went down, the fact that the legs are not in equilibrium has been interestingly brought out by Berg, du Bois-Reymond, and L. Zuntz. ${ }^{a}$

Unfortunately, the difficulties incidental to the calibration of the ergometer by means of an electric motor belted to the rear wheel ${ }^{b}$ made it likewise impossible to measure exactly the amount of energy required to drive the motor when the legs of the subject were moved freely by the motion of the pedals. We believe it especially significant that the professional subject M. A. M. found these experiments difficult; consequently, while the resuits obtained with the motor-driven ergometer have been computed and used as a base-line, we seriously question whether these values are not considerably higher than they should be. If they are too high, the use of them as a baseline in computing the increment due to severe work would obviously lead to erroneous results.

Increment in Metabolism Due to a Change in Position from lying on a Couch to Riding on an Ergometer with No Load and No Motor.

In these experiments the subject sat upon the ergometer in the usual riding position, and rotated the pedals by the feet at varying speeds, the only 
resistance to be overcome being that of the ergometer itself. Under these conditions the work would be simply the internal friction of the legs. The unequal balancing of the legs discussed by Berg, du Bois-Reymond, and Zuntz, with consequent muscular work in raising the legs when rotating the pedals, should be taken into account in these experiments also.

Measurements were made only with subject M. A. M., ergometer I being used in two experiments and ergometer II in three experiments. The results are brought together in table 114. The speed varied from 60 to 98 revolutions per minute, but the results obtained with the two machines are singularly concordant. The increase in the oxygen consumption during the muscular activity ranged from 90 per cent to 308 per cent, increasing regularly with the speed. The marked influence of changes in speed is noted when it is seen that the increase in the oxygen consumption is more than doubled in the change from 60 to 84 revolutions per minute, while at 98 revolutions per minute the metabolism was practically four times that of rest. All of the values for the lying metabolism were secured on the day of the riding experiment, and hence it was not necessary to use an average value as in some of the other tables.

TABLE 114.-Melabolism in experiments without food with subject lying on couch compared with the melabolism of the subject in no-load experiments on ergometer without motor. (Subject M.A.M.)

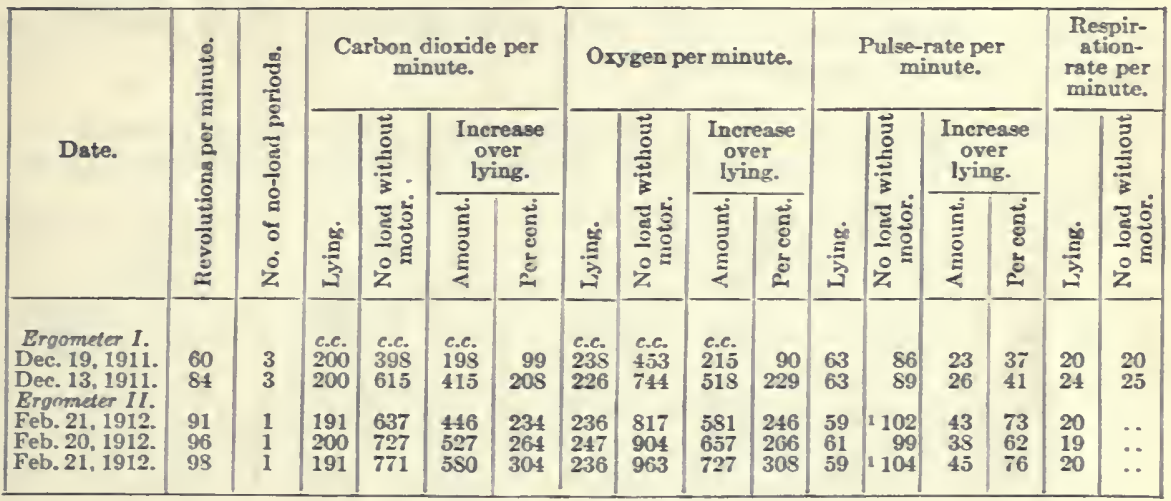

1 One record of pulse.

Accompanying the increased metabolism we find a similar increase in the pulse-rate which usually proceeds more or less regularly with the increment in the speed; the one exception is the unusually high pulse-rate found in the first period of February 21. It should, however, be stated that this record is the result of but a single observation. The few records of the respiration-rate again show slight, if any, change in the rate.

It is obvious, therefore, that riding on an ergometer with no resistance is accompanied by a considerable increase in the muscular work, an increase very much greater than would be expected from the small amount of muscular activity incidental to overcoming the very slight friction of the machine. Here again it should be stated that in all of these experiments the subject found it extremely trying to ride without load, and continually complained of inability to hold himself at any given speed, his tendency being to "spurt," 
followed by an effort to restrain himself. A superficial inspection of the tension on the sprocket-chain bore out his assertion that there were varying pressures put upon the pedals during the tests. In view of the unquestionable inhibition on the part of the subject and the abnormal amount of internal muscular work, the same difficulty is found in using these values as a baseline as was found with the values obtained in experiments when the subject rode without load on a motor-driven ergometer. These abnormalities should be continually borne in mind in making subsequent comparisons.

Increment in Metabolism in No-load Experiments Due to a Change from a Motor-DRIVEN ERgometer to RIDING Without Motor.

As has already been pointed out, when the subject is riding on the ergometer without load, the legs are not in equilibrium and the actual work of rotation produces a considerable increase in metabolism. Furthermore, when the ergometer is driven by a motor, while theoretically, at least, the subject remains inert on the seat of the apparatus and does no work, there is without doubt a tendency to resist the work of the motor in driving the machine. Four experiments were made with the motor-driven ergometer, and these have been compared in table 115 with two experiments in which the motor was not used, the results being given on the basis of the rate of speed. As would be expected, when the subject rode without motor there was a greater metabolism than when he rode with motor, the average increase in the oxygen consumption being not far from 30 per cent. There was likewise a small increase in the pulse-rate.

TABLE 115.-Metabolism in no-load experiments without food with ergometer driven by motor compared with metabolism in no-load experiments without motor. (Subject M. A. M.; ergometer $I I$.)

\begin{tabular}{|c|c|c|c|c|c|c|c|c|c|c|c|c|c|c|c|}
\hline \multicolumn{4}{|c|}{$\begin{array}{l}\text { Revolutions per minute } \\
\text { with no load. }\end{array}$} & \multicolumn{4}{|c|}{$\begin{array}{l}\text { Carbon dioxide per } \\
\text { minute. }\end{array}$} & \multicolumn{4}{|c|}{ Oxygen per minute. } & \multicolumn{4}{|c|}{$\begin{array}{l}\text { Pulse-rate per } \\
\text { minute. }\end{array}$} \\
\hline \multicolumn{2}{|c|}{$\begin{array}{l}\text { With } \\
\text { motor. }\end{array}$} & \multicolumn{2}{|c|}{$\begin{array}{l}\text { Without } \\
\text { motor. }\end{array}$} & \multicolumn{2}{|c|}{ No load. } & \multicolumn{2}{|c|}{$\begin{array}{l}\text { Increase } \\
\text { without } \\
\text { motor. }\end{array}$} & \multicolumn{2}{|c|}{ No load. } & \multicolumn{2}{|c|}{$\begin{array}{l}\text { Increase } \\
\text { without } \\
\text { motor. }\end{array}$} & \multicolumn{2}{|c|}{ No load. } & \multicolumn{2}{|c|}{$\begin{array}{c}\text { Increase } \\
\text { without } \\
\text { motor. }\end{array}$} \\
\hline Date. & 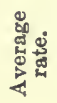 & Date. & 通 & 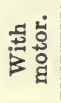 & 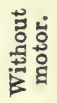 & 泀 & 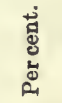 & 岳兘 & 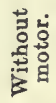 & $\begin{array}{l}\text { 苞 } \\
\text { छั }\end{array}$ & 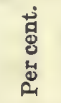 & 象宽 & 泀客 & 总 & 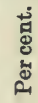 \\
\hline $\begin{array}{l}\text { 1912. } \\
\text { Feb. } 20 \\
\text { Feb. } 21 \\
\text { Mar. } 8 \\
\text { Mar. } 11\end{array}$ & $\begin{array}{r}92 \\
96 \\
101 \\
102\end{array}$ & $\begin{array}{l}\text { 1912. } \\
\text { Feb. } 21 \\
\text { Feb. } 20 \\
\text { Feb. } 21 \\
\text { Feb. } 21\end{array}$ & $\begin{array}{l}91 \\
96 \\
98 \\
98\end{array}$ & $\begin{array}{l}\text { c.c. } \\
503 \\
565 \\
611 \\
669\end{array}$ & $\begin{array}{l}\text { c.c. } \\
637 \\
727 \\
771 \\
771\end{array}$ & $\begin{array}{l}\text { c.c. } \\
134 \\
162 \\
160 \\
102\end{array}$ & $\begin{array}{l}26.6 \\
28.7 \\
26.2 \\
15.2\end{array}$ & $\begin{array}{l}c . c . \\
647 \\
672 \\
743 \\
743\end{array}$ & $\begin{array}{l}\text { c.c. } \\
817 \\
904 \\
963 \\
963\end{array}$ & $\begin{array}{l}c . c . \\
170 \\
232 \\
220 \\
220\end{array}$ & $\begin{array}{l}26.3 \\
34.5 \\
29.6 \\
29.6\end{array}$ & $\begin{array}{r}187 \\
89 \\
95 \\
.\end{array}$ & $\begin{array}{r}2102 \\
99 \\
2104 \\
2104\end{array}$ & $\begin{array}{r}15 \\
10 \\
9 \\
\cdots\end{array}$ & $\begin{array}{l}17 \\
11 \\
10 \\
. .\end{array}$ \\
\hline
\end{tabular}

1 There was but one record of pulse in each no-load period on this day.

2 One record of pulse.

That the increase in the metabolism incidental to riding without motor when compared to riding with motor was not greater is astonishing, to say the least, and bears out the conviction of all the observers that with this subject, riding without a reasonable load was a very complicated muscular process. In fact, it may seriously be questioned whether the values obtained for riding without load, both with and without motor, can properly be taken for a base-line in computing the efficiency. On the other hand, the increase in the metabolism without the motor as compared with that with the motor was approximately uniform, which implies a regularity in the muscular action 
that is quite inconsistent with the theory that there were large compensatory movements. To anyone who watched the sprocket-chain during all of these tests it was, however, very obvious that it was impossible for this subject to sit quietly upon the motor-driven machine and allow his legs to rotate freely without attempting to stop them or to increase the speed of the machine. Likewise, in the no-load experiments without the motor, it was impossible for him to maintain an even rate, and there was unquestionably a tendency to "back-pedal" at times.

GROSS AND NET EFFICIENCY OF SUBJECTS IN RESPIRATION EXPERIMENTS WITH THE BICYCLE ERGOMETER.

In conformity with the custom of practically all of the earlier writers, we have computed the gross efficiency of our subjects, using simply the relationship between the heat equivalent of external muscular work and the total heat output; the results are given in table 116. The values for the net efficiency are likewise given, together with the data for the oxygen intake and heat output per minute during both the work and the rest periods, with the heat equivalent of muscular work.

The values for the different factors have been arranged, first, in the order of subjects, and second, on the basis of ascending values for the heat equivalent of external muscular work. The reason for this particular arrangement will appear in examining the figures in the table, since the gross efficiency percentages as here shown indicate invariably an increasing gross efficiency with an increased load. Thus, in the experiment with E. P. C., in which the load was very light and the effective work equivalent to but 0.44 calorie per minute, the gross efficiency was 11.3 per cent. When the load was approximately double, and the effective work 0.93 calorie, the efficiency was increased to 16.1 per cent, while with a load approximately triple, and the effective work 1.41 calories, the efficiency was 19.9 per cent.

The reason for this increase in the gross efficiency with an increasing load is easily seen when we consider the fact that a considerable amount of heat is required to maintain the body over and above that used for effective muscular work. When the subject lies quietly upon a couch, the heat output is only that required for body maintenance, this being an approximately constant value in all experiments. With a light load the maintenance requirement forms a large proportion of the total energy output, so that the deduction of the resting metabolism has a pronounced effect. As the load is increased, however, there is no increase in the maintenance requirement, since it is an approximately constant value; consequently, with increasing loads, the extra heat output is due solely to the external muscular activity, and the percentage for the gross efficiency is accordingly increased. As an illustration, a comparison may be made with a boiler in a boiler-house where sufficient steam must be maintained to keep the boiler and the boiler-room warm. If in addition a small draft is made upon the supply of steam for running a small engine, the output of mechanical energy from the engine bears a relatively small proportion to the total heat output from the boiler, and the efficiency of the plant as a whole is very low. With increasing drafts upon the supply of steam, the percentage of the basal requirement for keeping the boilers and the engine-room warm becomes less and less, and the percentage of gross efficiency is correspondingly increased. 
TABLE 116.-Gross and net efficiency in respiration experiments with the bicycle ergometer.?

[Basal values obtained with subject lying on couch.]

\begin{tabular}{|c|c|c|c|c|c|c|c|c|c|}
\hline \multirow[b]{2}{*}{$\begin{array}{l}\text { Subject, date, } \\
\text { and current. }\end{array}$} & \multicolumn{2}{|c|}{$\begin{array}{l}\text { Oxygen intake } \\
\text { per minute. }\end{array}$} & \multicolumn{3}{|c|}{ Heat output per minute. } & \multirow{2}{*}{$\begin{array}{l}(f) \\
\text { Revolu- } \\
\text { tions } \\
\text { per } \\
\text { minute. }\end{array}$} & \multirow{2}{*}{$\begin{array}{c}(g) \\
\text { Heat equiv- } \\
\text { alent of } \\
\text { extcrnal } \\
\text { work per } \\
\text { minute. }\end{array}$} & \multicolumn{2}{|c|}{ Efficiency. } \\
\hline & $\begin{array}{c}\text { (a) } \\
\text { Work. }\end{array}$ & $\begin{array}{c}(b) \\
\text { Lying. }\end{array}$ & $\begin{array}{c}(c) \\
\text { Work. }\end{array}$ & $\begin{array}{c}(d) \\
\text { Lying. }\end{array}$ & $\begin{array}{c}(e) \\
\text { Increase } \\
\text { over } \\
\text { lying. } \\
c-d\end{array}$ & & & $\begin{array}{c}\begin{array}{c}(h) \\
\text { Gross. } \\
g \times 100\end{array} \\
c\end{array}$ & $\frac{\begin{array}{c}\text { (i) } \\
\text { Net. } \\
g \times 100\end{array}}{e}$ \\
\hline Subject E.P.C. & c.c. & c.c. & cals. & cals. & cals. & & cals. & p. ct. & p. ct. \\
\hline Mar. $5,1912 \ldots$. & $\begin{array}{l}829 \\
828\end{array}$ & 208 & $\begin{array}{l}3.91 \\
3.89\end{array}$ & 1.00 & 2.91 & 65 & 0.44 & 11.3 & 15.1 \\
\hline Nov. $23,1911 . .$. & 1,167 & $\ddot{2 i i}$ & 5.79 & i.01 & $\begin{array}{l}2.89 \\
4.78\end{array}$ & $\begin{array}{l}65 \\
54\end{array}$ & $\begin{array}{l}.43 \\
.93\end{array}$ & $\begin{array}{l}11.1 \\
16.1\end{array}$ & $\begin{array}{l}14.9 \\
19.5\end{array}$ \\
\hline 0.9 amp........ & 1,368 & & 6.55 & & 5.54 & 58 & 1.02 & 15.6 & 18.4 \\
\hline Mar. $5,1912 \ldots \ldots$ & 1,498 & $=208$ & 7.40 & 1.00 & 6.40 & 65 & 1.43 & 19.3 & 22.3 \\
\hline $1.5 \mathrm{amp} . \ldots$ & 1,418 & $\cdots$ & 7.10 & $\cdots$ & 6.10 & 64 & 1.41 & 19.9 & 23.1 \\
\hline $\begin{array}{l}\text { Subject J. J. C. } \\
\text { Mar. 16, } 1912 \ldots \ldots\end{array}$ & 1,075 & 230 & 5.15 & 1.11 & 4.04 & 71 & .48 & 9.3 & 11.9 \\
\hline 0.5 amp....... & 1,035 & $\ddot{3}$ & 4.95 & & 3.84 & 71 & .48 & 9.7 & 12.5 \\
\hline 1.5 amp...... & $\begin{array}{l}1,808 \\
1,886\end{array}$ & $\begin{array}{l}230 \\
\ldots\end{array}$ & $\begin{array}{l}8.97 \\
9.20\end{array}$ & $\begin{array}{l}1.11 \\
\cdots\end{array}$ & $\begin{array}{l}7.86 \\
8.09\end{array}$ & $\begin{array}{l}72 \\
72\end{array}$ & $\begin{array}{l}1.60 \\
1.60\end{array}$ & $\begin{array}{l}17.8 \\
17.4\end{array}$ & $\begin{array}{l}20.4 \\
19.8\end{array}$ \\
\hline $\begin{array}{c}\text { Subject Dr. A. } \\
\text { Apr. } 2,1912 . \ldots\end{array}$ & 1,009 & 4225 & 4.82 & 1.08 & 3.74 & 76 & .51 & & 13.6 \\
\hline 0.5 amp........ & 958 & ... & 4.59 & $\ldots$ & 3.51 & 76 & .50 & $\begin{array}{l}10.6 \\
10.9\end{array}$ & $\begin{array}{l}13.6 \\
14.2\end{array}$ \\
\hline $\begin{array}{l}\text { Subject } H . L . H . \\
\text { Mar. } 1,1912 .\end{array}$ & 1,211 & 242 & 5.72 & 1.18 & 4.54 & 81 & .53 & 93 & 117 \\
\hline $\begin{array}{r}\text { Mar. } 1,1912 . . . \\
0.5 \text { amp...... }\end{array}$ & $\begin{array}{l}1,211 \\
1,185\end{array}$ & 242 & 5.61 & 1.18 & $\begin{array}{l}4.24 \\
4.43\end{array}$ & 81 & .03 & 9.4 & $\begin{array}{l}11.7 \\
12.0\end{array}$ \\
\hline Nov. $21,1911 \ldots$. & 1,461 & 240 & 7.38 & 1.18 & 6.20 & 62 & 1.09 & 14.8 & 17.6 \\
\hline 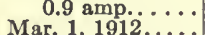 & $\begin{array}{l}1,754 \\
1,643\end{array}$ & $3 \dot{24}$ & $\begin{array}{l}8.81 \\
8.30\end{array}$ & $i 18$ & $\begin{array}{l}7.63 \\
7.63\end{array}$ & 67 & 1.18 & 13.4 & 15.5 \\
\hline 1.5 amp........ & 1,798 & $2 \pi 0$ & 8.89 & 1.10 & $\begin{array}{l}7.12 \\
7.71\end{array}$ & $\begin{array}{l}69 \\
68\end{array}$ & $\begin{array}{l}1.54 \\
1.50\end{array}$ & $\begin{array}{l}18.6 \\
16.9\end{array}$ & $\begin{array}{l}21.6 \\
19.5\end{array}$ \\
\hline Subject J.E. F. & & & & & & & & & \\
\hline Mar. $16,1912 \ldots$ & 902 & ${ }^{6} 227$ & 4.46 & 1.10 & 3.36 & 76 & 0.51 & 11.4 & 15.2 \\
\hline $\begin{array}{r}0.5 \text { amp. } \ldots \\
\text { Mar. } 2,1912 . \ldots\end{array}$ & $\begin{array}{r}850 \\
1.044\end{array}$ & - $\ddot{2} \ddot{2} \dot{7}$ & $\begin{array}{l}4.20 \\
5.21\end{array}$ & i.io & 3.10 & $\begin{array}{l}73 \\
87\end{array}$ & .49 & 11.7 & 15.8 \\
\hline 0.5 amp......... & 1,043 & & 5.22 & & 4.12 & 88 & .54 & 10.3 & $\begin{array}{l}13.1 \\
13.1\end{array}$ \\
\hline Mar. $16,1912 \ldots$. & 1,719 & 1227 & 8.42 & 1.10 & 7.32 & 71 & 1.57 & 18.6 & 21.4 \\
\hline 1.5 amp...... & 1,824 & & 8.84 & & 7.74 & 71 & 1.58 & 17.9 & 20.4 \\
\hline Mar. 2, $1912 . \ldots$. & 1,648 & - 227 & 8.10 & 1.10 & 7.00 & 72 & 1.59 & 19.6 & 22.7 \\
\hline 1.5 amp...... & 1,801 & $\cdots$ & 8.82 & $\cdots$ & 7.72 & 79 & 1.75 & 19.8 & 22.7 \\
\hline $\begin{array}{l}\text { Subject K. H. A. } \\
\text { Apr. } 3,1912 . \ldots\end{array}$ & 1,052 & 7246 & 5.15 & 1.19 & 3.96 & 79 & 0.52 & 101 & \\
\hline $\begin{array}{r}\text { Apr. } 3,1912 . \ldots \ldots \\
0.5 \text { amp...... }\end{array}$ & 1,061 & 240 & 5.14 & & $\begin{array}{l}3.96 \\
3.95\end{array}$ & 79 & $\begin{array}{l}0.52 \\
.52\end{array}$ & 10.1 & 13.1 \\
\hline Mar. $7,1912 \ldots \ldots$ & 1,070 & $7 \ddot{2} \dot{4} \dot{6}$ & 5.14 & i.i9 & 3.95 & 79 & .52 & 10.1 & 13.2 \\
\hline 0.5 amp...... & 1,082 & & 5.24 & & 4.05 & 79 & .52 & 9.9 & 12.8 \\
\hline Apr. $3,1912, \ldots$. & 2,015 & 7246 & 9.92 & 1.19 & 8.73 & 79 & 1.73 & 17.4 & 19.8 \\
\hline 1.5 amp....... & 2,147 & & 10.41 & & 9.22 & 79 & 1.74 & 16.7 & 18.9 \\
\hline Mar. $7,1912 \ldots \ldots$ & 2,060 & ${ }^{7} 246$ & 10.02 & 1.19 & 8.83 & 79 & 1.74 & 17.4 & 19.7 \\
\hline Subject $M . A . M$. & 1,949 & & 9.67 & $\cdots$ & 8.48 & 80 & 1.76 & 18.2 & 20.8 \\
\hline Mar. $12,1912 \ldots$ & 797 & 8242 & 3.86 & 1.17 & 2.69 & 71 & .48 & 12.4 & 17.8 \\
\hline 0.5 amp...... & 807 & $\cdots$ & 3.88 & $\cdots$ & 2.71 & 72 & .48 & 12.4 & 17.7 \\
\hline Mar. $14,1912 \ldots$. & 833 & $8 \dot{2} \dot{4} \dot{2}$ & $\begin{array}{l}3.94 \\
4.01\end{array}$ & i.iz & $\begin{array}{l}2.77 \\
2.84\end{array}$ & $\begin{array}{l}72 \\
70\end{array}$ & $\begin{array}{l}.49 \\
.47\end{array}$ & $\begin{array}{l}12.4 \\
11.7\end{array}$ & $\begin{array}{l}17.7 \\
16.5\end{array}$ \\
\hline $0.5 \mathrm{amp}$. & 787 & $\ldots$ & 3.83 & $\ldots$ & 2.66 & 71 & .48 & 12.5 & 18.0 \\
\hline & 833 & סiن & 4.01 & $\therefore$ & 2.84 & 70 & .47 & 11.7 & 16.5 \\
\hline $\begin{array}{r}\text { Mar. } 13,1912 \ldots \ldots \\
0.5 \text { amp...... }\end{array}$ & $\begin{array}{l}837 \\
895\end{array}$ & $\begin{array}{r}8242 \\
\ldots\end{array}$ & $\begin{array}{l}4.13 \\
4.38\end{array}$ & 1.17 & $\begin{array}{l}2.96 \\
3.21\end{array}$ & $\begin{array}{l}72 \\
76\end{array}$ & $\begin{array}{l}.48 \\
.50\end{array}$ & $\begin{array}{l}11.6 \\
11.4\end{array}$ & $\begin{array}{l}16.2 \\
15.6\end{array}$ \\
\hline & 848 & & 4.15 & & 2.98 & 72 & .49 & 11.8 & 16.4 \\
\hline $\begin{array}{r}\text { Mar. } 18,1912 \ldots \ldots \\
0.5 \text { amp...... }\end{array}$ & 823 & ${ }^{3} 242$ & 3.96 & 1.17 & 2.79 & 71 & .48 & 12.1 & 17.2 \\
\hline Feb. $28,1912 \ldots$ & 1,070 & $8 \ddot{2} \dot{4}$ & 5.15 & i.i. & $\ddot{3} \ddot{9} 8$ & $\ddot{9} 6$ & $\because .55$ & 10.7 & 13.8 \\
\hline 0.5 amp......... & 1,170 & $\ldots$ & 5.64 & $\ldots$ & 4.47 & 102 & .55 & 9.8 & 12.3 \\
\hline & 1,254 & $\cdots$ & 6.01 & $\cdots$ & 4.8 & 104 & .55 & 9.2 & 11.4 \\
\hline & 1,134 & $\ldots$ & 5.60 & $\cdots$ & 4.43 & 100 & .55 & 9.8 & 12.4 \\
\hline & 1,215 & 8242 & 6.03 & iiiz & 4.86 & 99 & .55 & 9.1 & 11.3 \\
\hline $\begin{array}{r}\text { Mar. } 4,1912 . . . \\
0.5 \text { amp..... }\end{array}$ & $\begin{array}{l}1,061 \\
1,148\end{array}$ & ... & $\begin{array}{l}5.28 \\
5.59\end{array}$ & $\begin{array}{l}1.17 \\
\ldots\end{array}$ & $\begin{array}{l}4.11 \\
4.42\end{array}$ & $\begin{array}{l}102 \\
100\end{array}$ & $\begin{array}{l}.55 \\
.55\end{array}$ & $\begin{array}{r}10.4 \\
9.8\end{array}$ & $\begin{array}{l}13.4 \\
12.4\end{array}$ \\
\hline & 1,173 & $\ldots$ & 5.72 & $\cdots$ & 4.55 & 99 & .56 & 9.8 & 12.3 \\
\hline & 1,378 & $\ldots$ & 6.70 & $\ldots$ & 5.53 & 108 & .55 & 8.2 & 9.9 \\
\hline & 1,320 & $\ldots$ & 6.46 & $\ldots$ & 5.29 & 111 & .54 & 8.4 & 10.2 \\
\hline
\end{tabular}

1 Ergometer. I was used for all experiments to January 19, 1912, inclusive; ergometer II was used in all experiments subsequent to that date.

2 Determined in respiration experiment of April 6, 1912. The corresponding respiratory quotient was 0.81 .

3 Assumed from results obtained with this oubject in respiration experiments made Jan. 4, to April 25, 1911. The corresponding respiratory quotient was 0.84 .

4 Determined in respiration experiment of April 4, 1912. (See table 35.)

5 Determined in a series of respiration experiments made Jan. 9 to 13,1912 . The corresponding respiratory quotient was 0.86 .

- Determined in respiration experiments of Feb. 12 and April 6, 1912. Corresponding respiratory quotient 0.86.

7 Determined in respiration experiment of March 14, 1912. The corresponding respiratory quotient was 0.84 .

8 This figure is a general average of results obtained with this subject while lying on the couch before work. (See table 91.) 
TABLE 116. - Continued.

[Basal values obtained with subject lying on couch.]

\begin{tabular}{|c|c|c|c|c|c|c|c|c|c|}
\hline \multirow[b]{2}{*}{$\begin{array}{l}\text { Subject, date, } \\
\text { and current. }\end{array}$} & \multicolumn{2}{|c|}{$\begin{array}{l}\text { Oxygen intake } \\
\text { per minute. }\end{array}$} & \multicolumn{3}{|c|}{ Heat output per minute. } & \multirow{2}{*}{$\begin{array}{c}(f) \\
\text { Revolu- } \\
\text { tions } \\
\text { per } \\
\text { minute. }\end{array}$} & \multirow{2}{*}{$\begin{array}{c}(\theta) \\
\text { Heat equir- } \\
\text { alent of } \\
\text { externsl } \\
\text { work per } \\
\text { minute. }\end{array}$} & \multicolumn{2}{|c|}{ Efficiency. } \\
\hline & $\begin{array}{c}(a) \\
\text { Work. }\end{array}$ & $\begin{array}{c}\text { (b) } \\
\text { Lying. }\end{array}$ & $\begin{array}{c}\text { (c) } \\
\text { Work. }\end{array}$ & $\begin{array}{c}\text { (d) } \\
\text { Lying. }\end{array}$ & $\begin{array}{c}(e) \\
\text { Increase } \\
\text { over } \\
\text { lying. } \\
c-d\end{array}$ & & & $\begin{array}{c}(h) \\
\text { Gross. } \\
\frac{o \times 100}{c}\end{array}$ & $\frac{\begin{array}{c}\text { (i) } \\
\text { Net. } \\
g \times 100\end{array}}{e}$ \\
\hline & c.c. & c.c. & cals. & cals. & cals. & & cals. & p.ct. & p. ct. \\
\hline $\begin{array}{r}\text { Dec. } 22,1911 \ldots \\
0.9 \text { amp...... }\end{array}$ & 1,326 & 225 & 6.32 & 1.09 & 5.23 & 58 & 1.02 & 16.1 & 19.5 \\
\hline Dec. $20,1911 . .$. & & $\ddot{0}$ & & & 5.40 & 58 & 1.02 & 15.7 & 18.9 \\
\hline 0.9 amp...... & $\begin{array}{l}1,316 \\
1,276\end{array}$ & $\begin{array}{l}226 \\
\ldots\end{array}$ & $\begin{array}{l}6.39 \\
6.14\end{array}$ & $\begin{array}{l}1.10 \\
\ldots .\end{array}$ & 5.29 & 60 & 1.06 & 16.6 & 20.0 \\
\hline & 1,344 & & $\begin{array}{l}6.14 \\
6.48\end{array}$ & $\cdots$ & $\begin{array}{l}5.04 \\
5.38\end{array}$ & $\begin{array}{l}58 \\
59\end{array}$ & 1.02 & 16.6 & 20.2 \\
\hline $\begin{array}{r}\text { Dec. } 19,1911 \ldots \\
0.9 \text { amp. . . . }\end{array}$ & 1,206 & 238 & 5.85 & 1.15 & $\begin{array}{l}5.38 \\
4.70\end{array}$ & $\begin{array}{l}59 \\
60\end{array}$ & $\begin{array}{l}1.04 \\
1.06\end{array}$ & $\begin{array}{l}16.1 \\
18.1\end{array}$ & $\begin{array}{l}19.3 \\
22.6\end{array}$ \\
\hline & 1,246 & & 6.06 & & 4.91 & 60 & 1.06 & 17.5 & 21.6 \\
\hline $\begin{array}{r}\text { Dec. } 21,1911 \ldots . \\
0.9 \text { amp..... }\end{array}$ & 1,245 & 231 & 6.04 & 1.12 & 4.92 & 60 & 1.06 & 17.6 & 21.5 \\
\hline Jan. 1,1912 . & $\begin{array}{l}1,256 \\
1,160\end{array}$ & $\ddot{2} 3 \dot{3}$ & $\begin{array}{l}5.97 \\
5.71\end{array}$ & i.i4 & $\begin{array}{l}4.85 \\
4.57\end{array}$ & $\begin{array}{l}60 \\
60\end{array}$ & $\begin{array}{l}1.06 \\
1.06\end{array}$ & $\begin{array}{l}17.8 \\
18.6\end{array}$ & $\begin{array}{l}21.9 \\
23.2\end{array}$ \\
\hline 0.9 amp. . . . & 1,162 & & 5.75 & 1.02 & 4.61 & 60 & 1.06 & 18.4 & 23.0 \\
\hline Jan. $2,1912 \ldots$. & 1,254 & 232 & 6.05 & 1.13 & 4.92 & 60 & 1.06 & 17.5 & 21.5 \\
\hline 0.9 amp........ & 1,244 & & 6.04 & & 4.91 & 60 & 1.06 & 17.6 & 21.6 \\
\hline Jan. $3,1912 \ldots \ldots$ & 1,356 & 233 & 6.37 & 1.13 & 5.24 & 60 & 1.06 & 16.6 & 20.2 \\
\hline 0.9 amp...... & 1,288 & $\cdots$ & 6.17 & $\cdots$ & 5.04 & 60 & 1.06 & 17.2 & 21.0 \\
\hline Dec. $15,1911 \ldots$ & $\begin{array}{l}1,248 \\
1,338\end{array}$ & $\ddot{2} \dot{50}$ & $\begin{array}{l}5.99 \\
6.52\end{array}$ & 1.20 & $\begin{array}{l}4.86 \\
5.32\end{array}$ & 60 & 1.06 & 17.7 & 21.8 \\
\hline 0.9 amp...... & 1,439 & $\cdots$ & 6.91 & $\ldots$ & $\begin{array}{l}5.32 \\
5.71\end{array}$ & $\begin{array}{l}62 \\
60\end{array}$ & $\begin{array}{l}1.08 \\
1.06\end{array}$ & $\begin{array}{l}16.6 \\
15.3\end{array}$ & $\begin{array}{l}20.3 \\
18.6\end{array}$ \\
\hline Dec. $14,1911 \ldots$ & 1,444 & & 6.92 & & 5.72 & 62 & 1.10 & 15.9 & 19.2 \\
\hline $\begin{array}{r}\text { Dec. } 14,1911 \ldots . . \\
0.9 \text { amp..... }\end{array}$ & 1,332 & 238 & 6.57 & 1.17 & 5.40 & 65 & 1.16 & 17.7 & 21.5 \\
\hline Feb. 27, $1912 \ldots$ & $\begin{array}{l}1,150 \\
1,490\end{array}$ & $\ddot{2} 3 \dot{9}$ & 5.74 & i.i. & 4.57 & 57 & .99 & 17.2 & 21.7 \\
\hline 0.95 amp...... & $\begin{array}{l}1,490 \\
1,418\end{array}$ & $\begin{array}{l}239 \\
\ldots\end{array}$ & $\begin{array}{l}7.17 \\
6.86\end{array}$ & $\begin{array}{l}1.17 \\
\ldots .\end{array}$ & $\begin{array}{l}6.00 \\
5.69\end{array}$ & $\begin{array}{l}83 \\
82\end{array}$ & $\begin{array}{l}1.20 \\
1.18\end{array}$ & $\begin{array}{l}16.7 \\
17.2\end{array}$ & 20.0 \\
\hline Apr. 9, $1912 \ldots \ldots$ & 1,444 & & 7.08 & $\because$ & 5.91 & 86 & 1.22 & 17.2 & 20.6 \\
\hline $\begin{array}{r}\text { Apr. 9, } 1912 \ldots \ldots \\
1.1 \text { amp...... }\end{array}$ & $\begin{array}{l}1,362 \\
1,378\end{array}$ & 1242 & 6.65 & 1.17 & 5.48 & 71 & 1.20 & 18.0 & 21.9 \\
\hline 1.1 sinp...... & $\begin{array}{l}1,378 \\
1,387\end{array}$ & $\cdots$ & $\begin{array}{l}6.73 \\
6.81\end{array}$ & $\cdots$ & $\begin{array}{l}5.56 \\
5.64\end{array}$ & $\begin{array}{l}71 \\
72\end{array}$ & $\begin{array}{l}1.19 \\
1.20\end{array}$ & $\begin{array}{l}17.7 \\
17.6\end{array}$ & 21.4 \\
\hline & 2,252 & $\ldots$ & 11.29 & $\cdots$ & 10.12 & 108 & 1.58 & 14.0 & 15.6 \\
\hline $\begin{array}{r}\text { Feb. } 26,1912 \ldots \\
0.95 \text { amp. . . }\end{array}$ & 1,485 & 239 & 7.49 & 1.16 & 6.33 & 94 & 1.29 & 17.2 & 20.4 \\
\hline 0.95 amp..... & 1,589 & $\cdots$ & 7.61 & $\ldots$ & 6.45 & 93 & 1.28 & 16.8 & 19.8 \\
\hline Apr. 8, 1912 . & $\begin{array}{l}1,535 \\
1,422\end{array}$ & $1 \ddot{2} \dot{2}$ & $\begin{array}{l}7.48 \\
6.97\end{array}$ & $i .17$ & $\begin{array}{l}6.32 \\
5.80\end{array}$ & 87 & 1.24 & 16.6 & 19.6 \\
\hline 1.25 smp. & 1,425 & $\ldots$ & 6.95 & 1.18 & 5.78 & 70 & $\begin{array}{l}1.35 \\
1.33\end{array}$ & $\begin{array}{l}19.4 \\
19.1\end{array}$ & $\begin{array}{l}23.3 \\
23.0\end{array}$ \\
\hline & 1,451 & $\ldots$ & 7.08 & ... & 5.91 & 71 & 1.36 & 19.2 & 23.0 \\
\hline & 2,719 & $\cdots$ & 13.68 & $\cdots$ & 12.51 & 126 & 1.98 & 14.5 & 15.8 \\
\hline & 2,712 & $\cdots$ & 13.65 & $\cdots$ & 12.48 & 122 & 1.94 & 14.2 & 15.5 \\
\hline Feb, 29, 1912 . & 2,343 & & 11.53 & $\therefore$ & 10.36 & 105 & 1.83 & 15.9 & 17.7 \\
\hline Feb. 29,1912 . & 1,785 & 258 & 8.72 & 1.25 & 7.47 & 102 & 1.35 & 15.5 & 18.1 \\
\hline 0.95 amp.. & 2,028 & $\cdots$ & 9.78 & $\cdots$ & 8.53 & 107 & 1.35 & 13.8 & 15.8 \\
\hline & 1,907 & & 9.20 & $\because \because$ & 7.95 & 104 & 1.35 & 14.7 & 17.0 \\
\hline Feb. $23,1912 \ldots$ & 1,834 & 235 & 9.10 & 1.15 & 7.95 & 108 & 1.37 & 15.1 & 17.2 \\
\hline 0.95 amp.... . & 1,595 & $\ddot{2} \dot{i}$ & 8.03 & & 6.88 & 88 & 1.24 & 15.4 & 18.0 \\
\hline Jan. 8, 1912 . . & 1,959 & 231 & 9.60 & 1.13 & 8.47 & 86 & 1.44 & 15.0 & 17.0 \\
\hline 0.9 amp... & 1,989 & & 9.91 & & 8.78 & 95 & 1.55 & 15.6 & 17.7 \\
\hline Jan. 9, 1912. . & 1,877 & 241 & 9.04 & 1.18 & 7.86 & 86 & 1.45 & 16.0 & 18.4 \\
\hline $0.9 \mathrm{amp} . . .$. & 1,976 & 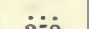 & 9.63 & & 8.45 & 89 & 1.50 & 15.6 & 17.8 \\
\hline Jan. 10, $1912 \ldots$ & 2,092 & 258 & 10.18 & 1.24 & 8.94 & 96 & 1.56 & 15.3 & 17.5 \\
\hline 0.9 smp....... & 2,034 & & 10.04 & & 8.80 & 95 & 1.56 & 15.5 & 17.7 \\
\hline Mar. 13, $1912 \ldots$ & 1,513 & 1242 & 7.44 & 1.17 & 6.27 & 70 & 1.56 & 21.0 & 24.9 \\
\hline 1.5 smp ........ & 1,631 & $\cdots$ & 7.87 & $\ldots$ & 6.70 & 70 & 1.57 & 20.0 & 23.4 \\
\hline Mar 14, 1912 & $\begin{array}{l}1,556 \\
1,551\end{array}$ & $\ddot{2} \dot{42}$ & $\begin{array}{l}7.66 \\
7.59\end{array}$ & iii & 6.49 & 70 & 1.56 & 20.4 & 24.0 \\
\hline $\begin{array}{r}M a r .14,1912 . . . \\
1.5 \text { amps...... }\end{array}$ & $\begin{array}{l}1,551 \\
1,526\end{array}$ & $\ldots$ & $\begin{array}{l}7.59 \\
7.53\end{array}$ & 1.18 & $\begin{array}{l}6.42 \\
6.36\end{array}$ & 71 & 1.57 & 20.7 & 24.5 \\
\hline & 1,559 & $\cdots$ & 7.64 & $\cdots$ & $\begin{array}{l}0.36 \\
6.47\end{array}$ & 71 & $\begin{array}{l}1.57 \\
1.57\end{array}$ & $\begin{array}{l}20.9 \\
20.6\end{array}$ & $\begin{array}{l}24.7 \\
24.3\end{array}$ \\
\hline Mar. $12,1912 \ldots$. & 1,564 & 1242 & 7.56 & 1.17 & 6.39 & 72 & 1.59 & 21.0 & 24.9 \\
\hline 1.5 amp..... & 1,520 & $\cdots$ & 7.41 & $\cdots$ & 6.24 & 71 & 1.57 & 21.2 & 25.2 \\
\hline Jan. 17, $1912 \ldots$ & $\begin{array}{l}1,534 \\
2,055\end{array}$ & 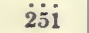 & $\begin{array}{r}7.51 \\
10.15\end{array}$ & 1.20 & $\begin{array}{l}6.34 \\
8.95\end{array}$ & $\begin{array}{r}71 \\
101\end{array}$ & $\begin{array}{l}1.57 \\
1.62\end{array}$ & 20.9 & 24.8 \\
\hline 0.9 amp........ & 2,143 & & 10.32 & & 9.12 & 91 & $\begin{array}{l}1.62 \\
1.52\end{array}$ & $\begin{array}{l}16.0 \\
14.7\end{array}$ & $\begin{array}{l}18.1 \\
16.7\end{array}$ \\
\hline Jan. $12,1912 \ldots \ldots$ & 2,210 & 262 & 10.88 & 1.28 & 9.60 & 102 & 1.63 & 15.0 & 17.0 \\
\hline 0.9 amp....... & 2,293 & & 11.21 & & 9.93 & 103 & 1.64 & 14.6 & 16.5 \\
\hline Jan. $19,1912 \ldots$ & 2,395 & 260 & 11.35 & 1.24 & 10.11 & 104 & 1.65 & 14.5 & 16.3 \\
\hline 0.9. & 2,164 & & 10.14 & & 8.90 & 88 & 1.47 & 14.5 & 16.5 \\
\hline Jan. $16,1912 \ldots$ & 2,671 & 247 & 12.85 & 1.20 & 11.65 & 108 & 1.68 & 13.1 & 14.4 \\
\hline 0.9 amp. $_{10} .$. & 2,131 & & 10.32 & & 9.12 & 91 & 1.52 & 14.7 & 16.7 \\
\hline Jan. $15,1912 \ldots$ & 2,691 & 258 & 13.22 & 1.27 & 11.95 & 115 & 1.73 & 13.1 & 14.5 \\
\hline $0.9 \mathrm{amp} \ldots \ldots$ & 2,091 & & 10.30 & & 9.03 & 94 & 1.54 & 15.0 & 17.1 \\
\hline Jan. $18,1912 \ldots$ & 2,498 & 261 & 11.74 & 1.24 & 10.50 & 116 & 1.74 & 14.8 & 16.6 \\
\hline 0.9 amp...... & 1,977 & & 9.32 & & 8.08 & 85 & 1.44 & 15.5 & 17.8 \\
\hline Mar. 2S, $1912 \ldots$ & 1,861 & 1242 & 8.94 & 1.17 & 7.77 & 80 & 1.75 & 19.6 & 22.5 \\
\hline 1.5 amp...... & 2,110 & $\cdots$ & 10.26 & & 9.09 & 92 & 1.96 & 19.1 & 21.6 \\
\hline & 1,909 & ... & 9.31 & $\cdots$ & 8.14 & 84 & 1.83 & 19.7 & 22.5 \\
\hline
\end{tabular}

1 This figure is a general average of results obtained with this subject while lying on the couch before work. (See table 91.) 
TABLE 116.-Continued.

[Basal values obtained with subject lying on couch.]

\begin{tabular}{|c|c|c|c|c|c|c|c|c|c|}
\hline \multirow[b]{2}{*}{$\begin{array}{l}\text { Subject, date, } \\
\text { and current. }\end{array}$} & \multicolumn{2}{|c|}{$\begin{array}{l}\text { Oxygen intake } \\
\text { per minute. }\end{array}$} & \multicolumn{3}{|c|}{ Heat output per minute. } & \multirow{2}{*}{$\begin{array}{c}(f) \\
\text { Revolu- } \\
\text { tions } \\
\text { per } \\
\text { minute. }\end{array}$} & \multirow{2}{*}{$\begin{array}{l}(g) \\
\text { Heat equiv- } \\
\text { alent of } \\
\text { external } \\
\text { work per } \\
\text { minute. }\end{array}$} & \multicolumn{2}{|c|}{ Efficiency. } \\
\hline & $\begin{array}{c}(a) \\
\text { Work. }\end{array}$ & $\begin{array}{c}\text { (b) } \\
\text { Lying. }\end{array}$ & $\begin{array}{c}\text { (c) } \\
\text { Work. }\end{array}$ & $\begin{array}{c}(d) \\
\text { Lying. }\end{array}$ & $\begin{array}{c}(e) \\
\text { Increase } \\
\text { over } \\
\text { lying. } \\
c-d\end{array}$ & & & $\begin{array}{c}(h) \\
\text { Gross. } \\
\frac{g \times 100}{c}\end{array}$ & $\begin{array}{c}\begin{array}{c}(i) \\
\text { Net. } \\
g \times 100\end{array} \\
e\end{array}$ \\
\hline 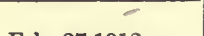 & c.c. & c.c. & cals. & cals. & cals. & & cals. & p. ct. & \\
\hline Feb. $27,1912 \ldots \ldots$ & 1,828 & 239 & 9.13 & 1.17 & 7.96 & 88 & 1.91 & 20.9 & 24,0 \\
\hline 1.5 amp...... & 1,858 & $\cdots$ & 9.20 & $\cdots$ & 8.03 & 87 & 1.89 & 20.5 & 23.5 \\
\hline Feb. $23,1912, \ldots$ & 1,850 & $\ddot{235}$ & 9.25 & $i i 5$ & 8.08 & 89 & 1.91 & 20.6 & 23.6 \\
\hline $\begin{array}{r}\text { Feb } 23,1912 \ldots \\
1.5 \text { amp..... }\end{array}$ & $\begin{array}{l}1,955 \\
2,265\end{array}$ & 230 & 9.43 & 1.15 & 8.28 & 88 & 1.91 & 20.3 & 23.1 \\
\hline Feb. 26, 1912 . & $\begin{array}{l}2,200 \\
1,917\end{array}$ & $\dot{2} \dot{3} \dot{9}$ & $\begin{array}{r}11.35 \\
9.50\end{array}$ & i.i. & $\begin{array}{r}10.20 \\
8.34\end{array}$ & 102 & 2.11 & 18.6 & 20.7 \\
\hline 1.5 amp.... & 1,969 & & 9.67 & & $\begin{array}{l}8.34 \\
8.51\end{array}$ & $\begin{array}{l}91 \\
88\end{array}$ & $\begin{array}{l}1.96 \\
1.91\end{array}$ & $\begin{array}{l}20.6 \\
19.8\end{array}$ & $\begin{array}{l}23.5 \\
22.4\end{array}$ \\
\hline Mar. $15,1912 \ldots$ & 1.967 & $1 \ddot{2} \dot{4} \dot{2}$ & 9.66 & 1.17 & 8.49 & 91 & 1.96 & 20.3 & 23.1 \\
\hline 1.5 amp...... & 1,946 & $\cdots$ & 9.58 & $\cdots$ & 8.41 & 91 & 1.96 & 20.5 & 23.3 \\
\hline & $\begin{array}{l}1,969 \\
1,948\end{array}$ & $\ldots$ & $\begin{array}{l}9.65 \\
9.54\end{array}$ & $\ldots$ & $\begin{array}{l}8.48 \\
8.37\end{array}$ & $\begin{array}{l}92 \\
90\end{array}$ & $\begin{array}{l}1.97 \\
1.94\end{array}$ & $\begin{array}{l}20.4 \\
20.3\end{array}$ & $\begin{array}{l}23.2 \\
23.2\end{array}$ \\
\hline & 2,003 & $\ldots$ & 10.01 & $\cdots$ & 8.84 & 89 & 1.92 & 19.2 & 21.7 \\
\hline & 1,899 & & 9.28 & & 8.11 & 78 & 1.73 & 18.6 & 21.3 \\
\hline & 2,342 & 242 & 11.19 & 1.16 & 10.03 & 100 & 2.08 & 18.6 & 20.7 \\
\hline 1.5 amp.......... & 2,073 & $\ddot{\theta}$ & 10.03 & & 8.87 & 92 & 1.97 & 19.6 & 22.2 \\
\hline & 2,206 & 233 & 10.91 & 1.14 & 9.77 & 98 & 2.07 & 19.0 & 21.2 \\
\hline & 2,368 & $\ddot{\theta}$ & 11.74 & & 10.60 & 101 & 2.09 & 17.8 & 19.7 \\
\hline $\begin{array}{r}\text { Mar. } 29,1912 \ldots \\
\quad 1.5 \text { amp..... }\end{array}$ & $\begin{array}{l}2,378 \\
2,227\end{array}$ & 278 & $\begin{array}{l}11.65 \\
10.89\end{array}$ & 1.33 & 10.32 & 100 & 2.09 & 17.9 & 20.3 \\
\hline Mar. $8,1912 . . .$. & 2,339 & $1 \ddot{2} \dot{4}$ & $\begin{array}{l}10.89 \\
11.43\end{array}$ & i.ji7 & 9.56 & 95 & 2.01 & 18.5 & 21.0 \\
\hline 1.5 amp... & 2,282 & $\ldots$ & 11.21 & 1... & $\begin{array}{l}10.26 \\
10.04\end{array}$ & $\begin{array}{l}99 \\
99\end{array}$ & 2.07 & 18.1 & \\
\hline & 2,365 & & 11.73 & $\ldots$ & 10.56 & $\begin{array}{r}99 \\
106\end{array}$ & 2.16 & 18.4 & $\begin{array}{l}20.6 \\
20.5\end{array}$ \\
\hline $\begin{array}{r}\text { Mar. } 18,1912 \ldots . . \\
\quad 1.5 \text { amp.... }\end{array}$ & 1,541 & 242 & 7.55 & 1.17 & 6.38 & 71 & 1.57 & 20.8 & 24.6 \\
\hline & 2,315 & $\cdots$ & 11.35 & $\cdots$ & 10.18 & 102 & 2.12 & 18.7 & 20.8 \\
\hline Mar. 27, 1912. & $\begin{array}{l}2,320 \\
2,258\end{array}$ & $1 \ddot{2} \dot{4}$ & $\begin{array}{l}11.39 \\
11.26\end{array}$ & ïiz & $\begin{array}{l}10.22 \\
10.09\end{array}$ & 102 & 2.11 & 18.5 & 20.6 \\
\hline 1.5 amp... & 2,327 & $\ldots$ & 11.63 & ... & 10.46 & 103 & $\begin{array}{l}2.10 \\
2.12\end{array}$ & $\begin{array}{l}18.0 \\
18.2\end{array}$ & $\begin{array}{l}20.8 \\
20.3\end{array}$ \\
\hline & 2,333 & & 11.43 & & 10.26 & 95 & 2.02 & 17.7 & $\begin{array}{l}20.3 \\
19.7\end{array}$ \\
\hline Mar. $19,1912 \ldots \ldots$ & 2,263 & 1242 & 11.15 & 1.17 & 9.98 & 102 & 2.11 & 18.9 & 21.1 \\
\hline 1.5 amp. . & 2,346 & $\cdots$ & 11.55 & $\cdots$ & $\begin{array}{r}10.38 \\
9.31\end{array}$ & 103 & 2.12 & 18.4 & 20.4 \\
\hline Mar. $11,1912 \ldots$ & 2,299 & $\ddot{2} \dot{4} \dot{7}$ & 11.29 & i.20 & $\begin{array}{r}8.01 \\
10.10\end{array}$ & 102 & $\begin{array}{l}2.03 \\
2.12\end{array}$ & $\begin{array}{l}19.4 \\
18.8\end{array}$ & 21.0 \\
\hline 1.5 amp...... & 2,220 & & 10.98 & & 9.78 & 101 & 2.09 & 19.0 & 21.4 \\
\hline Feb. $2,1912 \ldots \ldots$ & 2,433 & 246 & 11.83 & 1.19 & 10.64 & 104 & 2.16 & 18.3 & 20.3 \\
\hline $\begin{array}{r}1.5 \operatorname{amp} . \\
\text { Mar. } 4,1912\end{array}$ & 2,283 & & 11.30 & & 10.11 & 99 & 2.06 & 18.2 & 20.4 \\
\hline $\begin{array}{r}\text { Mar. } 4,1912 \ldots \ldots \\
1.5 \text { amp..... }\end{array}$ & 2,290 & 1242 & 11.33 & 1.17 & 10.16 & 104 & 2.15 & 19.0 & 21.2 \\
\hline 1.5 amp.... & 2,259 & $\ldots$ & 11.32 & $\cdots$ & 10.15 & 105 & 2.16 & 19.1 & 21.3 \\
\hline Jan. $24,1912, \ldots$ & 2,375 & $\ddot{\theta}$ & 11.72 & $i i 3$ & 10.55 & 103 & 2.12 & 18.1 & 20.1 \\
\hline $\begin{array}{r}J^{2}, 24,1912 \ldots \\
1.5 \text { amp. . . . }\end{array}$ & $\begin{array}{l}2,605 \\
2,040\end{array}$ & 232 & $\begin{array}{r}12.66 \\
9.97\end{array}$ & 1.13 & 11.53 & 106 & 2.16 & 17.1 & 18.7 \\
\hline Feb. $7,1912, \ldots$ & $\begin{array}{l}2,040 \\
2,488\end{array}$ & $\ddot{2} \dot{3} \dot{3}$ & $\begin{array}{r}9.97 \\
12.16\end{array}$ & 1.13 & $\begin{array}{r}8.84 \\
11.03\end{array}$ & $\begin{array}{r}90 \\
109\end{array}$ & $\begin{array}{l}1.94 \\
2.20\end{array}$ & $\begin{array}{l}19.5 \\
18.1\end{array}$ & $\begin{array}{l}21.9 \\
19.9\end{array}$ \\
\hline $1.5 \mathrm{amp} . \ldots \ldots$ & 1,976 & & 9.80 & & 8.67 & 90 & 1.94 & 19.8 & $\begin{array}{l}19.9 \\
22.4\end{array}$ \\
\hline Feb. $16,1912 \ldots$ & 2,286 & 222 & 11.23 & 1.08 & 10.15 & 107 & 2.17 & 19.3 & 21.4 \\
\hline 1.5 amp...... & 2,036 & $\cdots$ & 10.10 & $\ldots$ & 9.02 & 97 & 2.05 & 20.3 & 22.7 \\
\hline & 2,206 & & 10.59 & & 9.51 & 95 & 2.02 & 19.1 & 21.2 \\
\hline Feb. $29,1912 \ldots$ & 2,384 & 258 & 11.71 & 1.25 & 10.46 & 106 & 2.17 & 18.5 & 20.7 \\
\hline 1.5 amp.. & 2,248 & $\cdots$ & 11.13 & $\cdots$ & 9.88 & 102 & 2.11 & 19.0 & 21.4 \\
\hline Feb. $28,1912 \ldots$ & $\begin{array}{l}2,192 \\
2,356\end{array}$ & $\dot{2} \ddot{4} \dot{2}$ & 11.03 & iii & 9.78 & 102 & 2.12 & 19.2 & 21.7 \\
\hline $\begin{array}{r}1.5 \text { amp....... } \\
\end{array}$ & $\begin{array}{l}2,356 \\
2,101\end{array}$ & 1242 & $\begin{array}{l}11.77 \\
10.49\end{array}$ & 1.17 & $\begin{array}{r}10.60 \\
9.32\end{array}$ & $\begin{array}{r}108 \\
97\end{array}$ & 2.18 & $\begin{array}{l}18.5 \\
19.4\end{array}$ & 20.6 \\
\hline & 2,144 & $\ldots$ & 10.82 & $\ldots$ & $\begin{array}{l}9.32 \\
9.65\end{array}$ & 100 & $\begin{array}{l}2.04 \\
2.07\end{array}$ & 19.1 & $\begin{array}{l}21.9 \\
21.5\end{array}$ \\
\hline Feb. $14,1912 \ldots$ & 2,436 & 235 & 11.97 & 1.15 & 10.82 & 109 & 2.20 & 18.4 & 20.3 \\
\hline 1.5 amp........... & 2,009 & & 9.99 & & 8.84 & 95 & 2.02 & 20.2 & 22.9 \\
\hline Mar. 25, 1912... & 2,655 & 1242 & 13.08 & 1.17 & 11.91 & 110 & 2.21 & 16.9 & 18.6 \\
\hline 1.5 amp.... & 2,545 & $\cdots$ & 12.72 & $\cdots$ & 11.55 & 110 & 2.21 & 17.4 & 19.1 \\
\hline & 2,288 & $\ddot{2} \ddot{4} \dot{6}$ & 11.24 & ïi & 10.07 & 98 & 2.05 & 18.2 & 20.4 \\
\hline Apr $_{1.5} 16,1912 \ldots$ & 2,650 & 246 & 13.02 & 1.21 & 11.81 & $\begin{array}{l}108 \\
117\end{array}$ & $\begin{array}{l}2.20 \\
2.30\end{array}$ & 16.9 & 18.6 \\
\hline Feb. $15,1912 \ldots$ & 2,319 & $\ddot{2} 3 \dot{4}$ & $\begin{array}{l}14.25 \\
11.59\end{array}$ & 1.12 & $\begin{array}{l}13.04 \\
10.47\end{array}$ & $\begin{array}{l}117 \\
110\end{array}$ & $\begin{array}{l}2.30 \\
2.22\end{array}$ & $\begin{array}{l}16.1 \\
19.2\end{array}$ & $\begin{array}{l}17.6 \\
21.2\end{array}$ \\
\hline 1.5 amp...... & 2,004 & & 9.91 & 1.12 & 8.79 & 90 & 1.93 & 19.5 & $\begin{array}{l}21.2 \\
22.0\end{array}$ \\
\hline Feb. $8,1912, \ldots$ & 2,565 & 256 & 12.47 & 1.23 & 11.24 & 112 & 2.24 & 18.0 & $\begin{array}{l}22.0 \\
19.9\end{array}$ \\
\hline 1.5 amp...... & 2,146 & & 10.40 & & 9.17 & 94 & 1.99 & 19.1 & 21.7 \\
\hline Jan. $25,1912 \ldots \ldots$ & 2,452 & 249 & 12.17 & 1.20 & 10.97 & 112 & 2.24 & 18.4 & 20.4 \\
\hline $1.5 \mathrm{amp} . .$. & 2,303 & & 11.29 & & 10.09 & 102 & 2.12 & 18.8 & 21.0 \\
\hline Feb. 1, $1912 \ldots \ldots$ & 2,604 & 241 & 12.82 & 1.18 & 11.64 & 113 & 2.25 & 17.6 & 19.3 \\
\hline $1.5 \mathrm{amp} . \ldots \ldots$ & 2,010 & & 9.85 & & 8.67 & 90 & 1.94 & 19.7 & 22.4 \\
\hline Jan. 26, 1912 . . & 2,906 & 237 & 14.06 & 1.15 & 12.91 & 114 & 2.26 & 16.1 & 17.5 \\
\hline 1.5 amp...... & 2,167 & & 10.43 & & 9.28 & 91 & 1.95 & 18.7 & 21.0 \\
\hline Jan. $31,1912, \ldots$ & 2,784 & 240 & 13.81 & 1.19 & 12.62 & 118 & 2.30 & 16.7 & 18.2 \\
\hline 1.5 amp...... & 2,115 & & 10.29 & & 9.10 & 87 & 1.89 & 18.4 & 20.8 \\
\hline Mar. $6,1912 \ldots .$. & 2,976 & 259 & 14.72 & 1.27 & 13.45 & 128 & 2.40 & 16.3 & 17.8 \\
\hline 1.5 amp....... & 2,685 & ... & 13.36 & $\ldots$ & 12.09 & 113 & 2.25 & 16.8 & 18.6 \\
\hline
\end{tabular}

1 This figure is a general average of results obtained with this subject while lying on the couch before work. (See table 91.) 
The values for the net efficiency given in table 116 were computed by establishing the relationship between the heat equivalent of external muscular work and the increase in the metabolism during the work-period over that required for body maintenance when the subject lay quietly upon a couch. As will be seen later, the term "net efficiency" is not particularly felicitous in this connection as the value to be deducted from the total heat output may vary greatly with the conditions, but in computing the net efficiencies shown in table 116, the metabolism when the subject lay quietly upon a couch was selected as the base so that the results could be easily compared with those of earlier experiments. On inspection of the table it is seen from the data for the heat equivalent of external muscular work that the net efficiency also increased with the load.

While the great disparity in the number of experiments made with these different individuals prevents a strict comparison, such a comparison is not without interest, and accordingly in table 117 the highest efficiencies, both gross and net, are given for the six subjects. The difference between the gross and net maximum efficiencies with these individuals is approximately 3 per cent, the net efficiency being usually about 3 per cent higher than the gross efficiency. If we compare these maximum values it will be seen that those for the professional subject M. A. M. indicate a distinct advantage over those found with the untrained individuals. On the other hand, the advantage is not so great as would be expected when it is considered that these subjects were absolutely without training and, indeed, in some instances were unfamiliar with bicycle riding. Furthermore, since the value found for M. A. M. is a selected value out of several hundred obtained with this man, and those secured with the other subjects were few in number, it is obvious that such a comparison is not justifiable; this table is accordingly not particularly adapted for studying the difference in efficiency between trained and untrained men.

\section{TABLE 117.-Maximum gross and net efficiencies of subjects in respiration experiments with the bicycle ergometer.}

\begin{tabular}{|c|c|c|c|c|c|}
\hline Subject. & Gross. & Net. & Subject. & Gross. & Net. \\
\hline $\begin{array}{l}\text { E. P. C. } \\
\text { J. J. C. } \\
\text { H. L. H. }\end{array}$ & $\begin{array}{l}\text { p. } t .9 \\
19.9 \\
17.8 \\
18.6\end{array}$ & $\begin{array}{l}p . c t . \\
23.1 \\
20.4 \\
21.6\end{array}$ & $\begin{array}{l}\text { J. E. F. } \\
\text { K. H. A. } \\
\text { M. A. M. }\end{array}$ & $\begin{array}{l}p . c t . \\
19.8 \\
18.2 \\
21.2\end{array}$ & $\begin{array}{l}\text { p. ct. } \\
22.7 \\
20.8 \\
25.2\end{array}$ \\
\hline
\end{tabular}

While in general there is a tendency toward an increase in both gross and net efficiency with the increased load, nevertheless on inspection of the results, especially those for the subject M. A. M., we find certain inequalities that at first sight are difficult to explain. Making due allowance for abnormal figures which may be obtained in the individual periods, we find that there is at times a tendency towards a distinct falling off in the gross and net efficiency particularly when higher loads are used. That there may be variations in the efficiency even with the same amount of external muscular work is strikingly shown by a comparison of the experiment on April 8 with that of February 29. (See table 116.) In the first three periods of the experiment of April 8, the effective work averaged 1.35 calories per minute, the rate of 
revolution averaged 71 per minute, and the net efficiency was 23 per cent. On February 29, with the same effective work per minute but with a lower magnetization of the armature and a much higher rate of revolution, i. e., an average of 104 per minute, the net efficiency fell to approximately 16 to 18 per cent. It is interesting to note that the highest efficiencies found throughout the whole table are those of the group from March 12 to 14, in which the rate of revolution was approximately 70 , the efficiencies on these dates being practically 24 to 25 per cent. On days when the muscular work was excessive, $i . e ., 2.2$ calories or over, the rate of revolution was very high and the net efficiency almost invariably low. It is thus clear from an inspection of table 116 that some relationship exists between speed and efficiency, a relationship that will be subsequently considered. From this table, however, the general deduction may be made that the percentage of efficiency increases as a rule with the increased load, but that there are also definite indications of a marked influence of speed upon the efficiency.

The values here found for gross and net efficiency are wholly in line with those previously reported by Benedict and Carpenter ${ }^{a}$ save that the extraordinarily high maximum value of 25.2 per cent of net efficiency with the subject M. A. M. is not equaled by any of their subjects. On the other hand, the average net efficiency for all the experiments with M. A. M. in which the heat equivalent of muscular work was above 1.35 calories per minute was not far from 21 per cent, a net efficiency that compares very favorably with those found with the five other subjects as well as with the net efficiency in the experiments reported by Benedict and Carpenter. The results as a whole, therefore, indicate that the average net efficiency of the subjects used in this research, as computed by deducting the resting metabolism from that during work, is essentially 21 per cent; these later values thus confirm fully the experiments reported by Benedict and Carpenter in which ergometer I was used, and the heat was measured directly instead of being computed from the oxygen consumption and the respiratory quotient. While this substantiation of earlier results cannot be looked upon as a proof of the accuracy of indirect calorimetry as compared with direct calorimetry, nevertheless the uniformity in results furnishes strong support to the assumption that both the method of indirect calorimetry and the ergometer here employed give results that are not abnormal.

Efficiency in Work Experiments Based upon Valdes Obtained in Experiments with the SubJect Sitting on the Bicycle Ergometer.

While it may seem that the logical method of computation would be to deduct from the total energy output during work the values obtained in experiments with the subject sitting upon the bicycle ergometer, it was pointed out in a discussion of the results secured in such experiments, that in almost every instance the subjects complained of considerable strain, and found the experiments very trying and tiresome; the belief was therefore expressed that the values obtained were abnormal, particularly those for the professional subject M. A. M. To indicate the influence of deducting the sitting values from the total metabolism, we have computed the efficiency on this basis 
in a few specimen experiments with the subject M. A. M. and in one experiment with the subject E. P. C., these being compared in table 118 with the values for net efficiency taken from table 117. One objection to this form of comparison is shown instantly by the values for the oxygen consumption per minute in the sitting experiments with M. A. M., which range from 278 c.c. to 386 c.c.; this variation would not be expected, and can be explained only on the ground that the subject was extremely uncomfortable and disliked the experiments.

TABLE 118.-Efficiency in respiration experiments with the bicycle ergometer.

- [Basal values obtained with subject sitting on ergometer.]

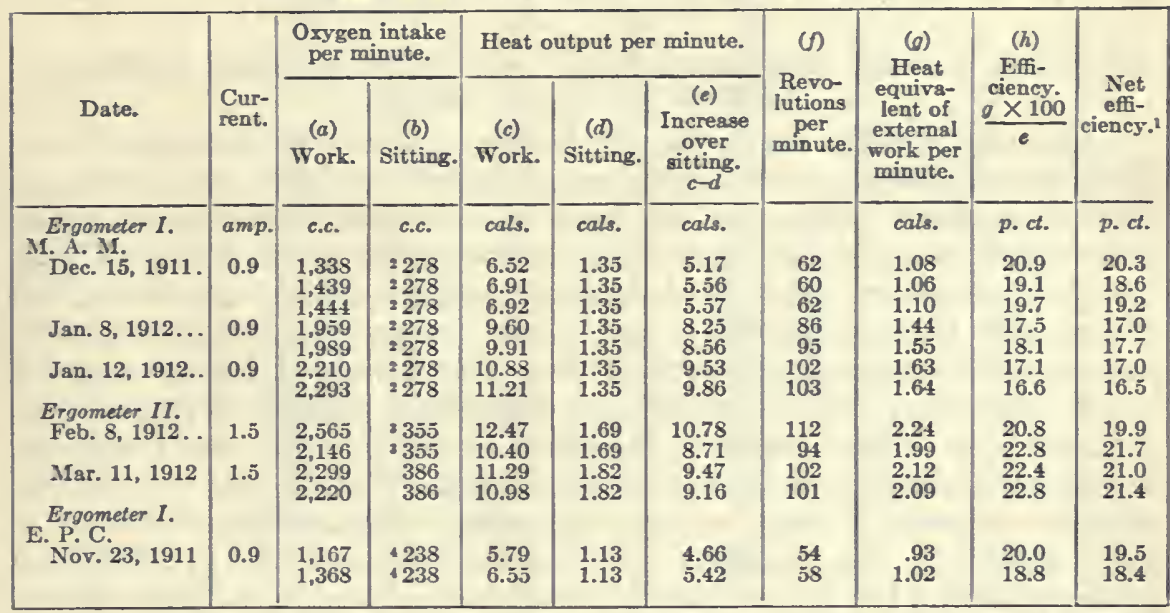

1 Drawn from table 116, in which the values obtained with the subject lying quietly on a couch were used as a base-line.

2 Average value obtained in sitting experiments of Dec. 7, 8, 11, and 12, 1911.

3 Average value obtained in sitting experiments of Jan. 23 and March 11, 1912.

- Value obtained in sitting experiment of Nov. 29, 1911.

Difficulty was found in selecting the proper sitting values to deduct from the results of the work experiments inasmuch as on relatively few days were the work experiments immediately preceded by sitting experiments. For the experiment of December 15, an average of 4 sitting experiments, i.e., those of December 7, 8, 11, and 12,1911, was used as a base-line, and likewise for the experiments of January 8 and 12. Since with this subject there was a marked difference in the sitting values when ergometer II was used, a change in the base-line was necessary for the experiment of February 8 , the average value for the sitting experiments of January 23 and March 11, 1912, being used. For the experiment of March 11 the base-line obtained on that particular day was employed. The influence of these different values as a base-line is apparent when one compares the efficiency as here computed with the net efficiency as drawn from table 116. For instance, in the first three experiments, with a base-line of 278 c.c. oxygen intake, the average increased efficiency by this method of computation over the net efficiency shown in the previous table amounts to approximately 0.5 per cent. On the other hand, with the base-line of 386 c.c. oxygen intake as used on March 11, 
the increase in efficiency as computed on this basis is 1.5 per cent greater than the net efficiency drawn from table 116. The experiment of November 23 with the subject E. P. C. is probably the least liable to adverse criticism, and here the increase is approximately 0.5 per cent. Since we believe that the values obtained during the sitting experiments were too high owing to abnormal conditions, we must consider that the efficiency computed on this basis will always be a little higher than that which would be obtained if the sitting values were not vitiated by the extraneous muscular movements and discomfort of the subject. In any event it can be seen that the increase in the efficiency due to using the sitting values as the basis varies only from 0.5 to 1.5 per cent.

\section{Efficiency in Work Experiments Based upon Values Obtained in No-Load EXPERIMENTS Without Motor.}

Although the increase in the metabolism incidental to changing from a lying position on the couch to sitting on the ergometer is large, when compared with the excessive heat-output during severe muscular work it plays a relatively slight rôle. On the other hand, the movement of the pedals with the feet, the involuntary throwing of the body from one side tothe other in balancing, and the unavoidable lateral motion of the head unquestionably produce extraneous muscular activity that is not measured directly upon the bicycle ergometer. Consequently it is desirable if possible to deduct from the total heat output the heat incidental to moving the pedals with the feet without the performance of external work. The no-load experiments (without the use of a motor to drive the pedals) were made in an attempt to secure such data. In discussing the no-load experiments (see p. 119) it was pointed out that the subject found himself uncomfortable, with a tendency either to "race" or else to "back pedal." Owing to this tendency, there was unquestionably considerable muscular activity, particularly noticeable in the alterations in the tension on the sprocket-chain. Notwithstanding the difficulty of using this base-line for a comparison, we have computed the results for a number of the experiments with the subject M. A. M., and give them in table 119.

Ergometer I was used in all experiments up to January 19, 1912, inclusive, ergometer II being used subsequent to that date. As in previous tables, the data are, in general, arranged in the order of increasing load. Here again it will be seen that even on this basis the efficiency has a tendency to increase as the load increases, the highest values being found with a current of 1.5 amperes when the heat equivalent of the external muscular work was 1.9 calories or above. The values fluctuate considerably, much more than in some of the earlier experiments, the lowest value being 22.4 per cent on January 19, and the highest value 41.0 per cent on February 26. The average efficiency for all of the experiments is 30 per cent. In considering this high efficiency, however, it is necessary to bear in mind that the values for riding the ergometer with no load are unquestionably higher than they should be. This we have pointed out clearly in the previous discussion of the results of these experiments. A further complication arises in that a change in speed produces a noticeable alteration in the oxygen consumption and consequently in the heat output. For this reason it has been difficult at times 
TABLE 119.-Efficiency of $M . A . M$. in respiration experiments with bicycle ergometer. ${ }^{1}$

[Basal values obtained in no-load experiments, without motor.]

\begin{tabular}{|c|c|c|c|c|c|c|c|c|c|}
\hline \multirow[b]{2}{*}{ Date. } & \multirow[b]{2}{*}{ Current. } & \multicolumn{2}{|c|}{$\begin{array}{l}\text { Oxygen intake per } \\
\text { minute. }\end{array}$} & \multicolumn{3}{|c|}{ Heat output per minute. } & \multirow{2}{*}{$\begin{array}{c}(f) \\
\text { Revolu- } \\
\text { tions } \\
\text { per } \\
\text { minute. }\end{array}$} & \multirow{2}{*}{$\begin{array}{c}\text { (o) } \\
\text { Heat } \\
\text { equivalent } \\
\text { of external } \\
\text { work per } \\
\text { minute. }\end{array}$} & \multirow{2}{*}{$\begin{array}{c}\begin{array}{c}(h) \\
\text { Effi- } \\
\text { ciency. } \\
g \times 100\end{array} \\
e\end{array}$} \\
\hline & & $\begin{array}{c}(a) \\
\text { Work. }\end{array}$ & $\begin{array}{c}\text { (b) } \\
\text { No load } \\
\text { without } \\
\text { motor. }\end{array}$ & $\begin{array}{c}\text { (c) } \\
\text { Work. }\end{array}$ & $\begin{array}{l}\quad(d) \\
\text { No load } \\
\text { without } \\
\text { motor. }\end{array}$ & $\begin{array}{l}\quad(e) \\
\text { Increase } \\
\text { over no } \\
\text { load } \\
\text { without } \\
\text { motor. } \\
(c-d)\end{array}$ & & & \\
\hline \multirow{5}{*}{$\begin{array}{l}\text { 1911. } \\
\text { Dec. if }\end{array}$} & $a m p$. & c.c. & c.c. & cals. & cals. & cals. & & cals. & p. ct. \\
\hline & 0.9 & 1,332 & 453 & 6.57 & 2.22 & 4.35 & 65 & 1.16 & 26.7 \\
\hline & 0.9 & $\begin{array}{l}1,150 \\
1,338\end{array}$ & $\begin{array}{l}453 \\
453\end{array}$ & $\begin{array}{l}5.74 \\
6.52\end{array}$ & $\begin{array}{l}2.22 \\
2.22\end{array}$ & 3.52 & 57 & .99 & 28.1 \\
\hline & & 1,439 & 453 & $\begin{array}{l}0.92 \\
6.91\end{array}$ & 2.22 & $\begin{array}{l}4.30 \\
4.69\end{array}$ & $\begin{array}{l}62 \\
60\end{array}$ & $\begin{array}{l}1.08 \\
1.06\end{array}$ & 25.1 \\
\hline & & $1,444^{\circ}$ & 453 & 6.92 & 2.22 & 4.70 & 62 & 1.10 & 23.4 \\
\hline 19 & 0.9 & 1,206 & 453 & 5.85 & 2.22 & 3.63 & 60 & 1.06 & 29.2 \\
\hline \multirow{3}{*}{20} & 0.9 & $\begin{array}{l}1,246 \\
1,316\end{array}$ & $\begin{array}{l}453 \\
453\end{array}$ & $\begin{array}{l}6.06 \\
6.39\end{array}$ & 2.22 & 3.84 & $\begin{array}{l}60 \\
60\end{array}$ & 1.06 & 27.6 \\
\hline & & 1,276 & 453 & 6.14 & 2.22 & 3.92 & $\begin{array}{l}60 \\
58\end{array}$ & $\begin{array}{l}1.06 \\
1.02\end{array}$ & $\begin{array}{l}25.4 \\
26.0\end{array}$ \\
\hline & & 1,344 & 453 & 6.48 & 2.22 & 4.26 & 59 & 1.04 & 24.4 \\
\hline 21 & 0.9 & 1,245 & 453 & 6.04 & 2.22 & 3.82 & 60 & 1.06 & 27.8 \\
\hline \multirow[t]{2}{*}{22} & 0.9 & $\begin{array}{l}1,256 \\
1,326\end{array}$ & $\begin{array}{l}453 \\
453\end{array}$ & $\begin{array}{l}5.97 \\
6.32\end{array}$ & $\begin{array}{l}2.22 \\
2.22\end{array}$ & $\begin{array}{l}3.75 \\
4.10\end{array}$ & 58 & $\begin{array}{l}1.06 \\
1.02\end{array}$ & $\begin{array}{l}28.3 \\
24.9\end{array}$ \\
\hline & & 1,355 & 453 & 6.49 & 2.22 & 4.27 & 58 & 1.02 & 23.9 \\
\hline \multirow{2}{*}{$\operatorname{Jan.}_{.}^{1912} 1$} & 0.9 & 1,160 & 453 & 5.71 & 2.22 & 3.49 & 60 & 1.06 & 30.4 \\
\hline & & 1,162 & 453 & 5.75 & 2.22 & 3.53 & 60 & 1.06 & $\begin{array}{l}30.4 \\
30.0\end{array}$ \\
\hline 2 & 0.9 & 1,254 & 453 & 6.05 & 2.22 & 3.83 & 60 & 1.06 & 27.7 \\
\hline \multirow[t]{3}{*}{3} & 0.9 & $\begin{array}{l}1,244 \\
1,356\end{array}$ & $\begin{array}{l}453 \\
453\end{array}$ & $\begin{array}{l}6.04 \\
6.37\end{array}$ & $\begin{array}{l}2.22 \\
2.22\end{array}$ & $\begin{array}{l}3.82 \\
4.15\end{array}$ & $\begin{array}{l}60 \\
60\end{array}$ & $\begin{array}{l}1.06 \\
1.06\end{array}$ & $\begin{array}{l}27.8 \\
25.5\end{array}$ \\
\hline & & 1,235 & 453 & 6.17 & 2.22 & 3.95 & 60 & 1.06 & 26.8 \\
\hline & 0.9 & 1,248 & 453 & 5.99 & 2.22 & 3.77 & 60 & 1.06 & 28.1 \\
\hline 8 & 0.9 & $\begin{array}{l}1,959 \\
1,959\end{array}$ & $\begin{array}{l}744 \\
904\end{array}$ & 9.60 & $\begin{array}{l}3.59 \\
4.34\end{array}$ & $\begin{array}{l}6.01 \\
5.57\end{array}$ & 86 & 1.44 & 24.0 \\
\hline 9 & 0.9 & 1.877 & 744 & 9.04 & $\begin{array}{l}4.54 \\
3.59\end{array}$ & 5.45 & 86 & $\begin{array}{l}1.35 \\
1.45\end{array}$ & $\begin{array}{l}27.8 \\
26.6\end{array}$ \\
\hline 10 & & 1,976 & 817 & 9.63 & 3.89 & 5.74 & 89 & 1.50 & 26.1 \\
\hline 10 & 0.9 & 2,092 & 904 & 10.18 & 4.34 & 5.84 & 96 & 1.56 & 26.7 \\
\hline 12 & 0.9 & 2,034 & 904 & 10.04 & 4.34 & 5.70 & 95 & 1.56 & 27.4 \\
\hline & & $\begin{array}{l}2,210 \\
2,293\end{array}$ & $\begin{array}{l}963 \\
963\end{array}$ & $\begin{array}{l}10.85 \\
11.21\end{array}$ & $\begin{array}{l}4.61 \\
4.61\end{array}$ & $\begin{array}{l}6.27 \\
6.60\end{array}$ & $\begin{array}{l}102 \\
103\end{array}$ & $\begin{array}{l}1.63 \\
1.64\end{array}$ & 26.0 \\
\hline 15 & 0.9 & 2,091 & 904 & 10.30 & 4.34 & 5.96 & 94 & 1.54 & $\begin{array}{l}24.9 \\
25.8\end{array}$ \\
\hline 16 & 0.9 & 2,131 & 817 & 10.32 & 3.89 & 6.43 & 91 & 1.52 & $\begin{array}{l}25.8 \\
23.6\end{array}$ \\
\hline 17 & 0.9 & 2,055 & 963 & 10.15 & 4.61 & 5.54 & 101 & 1.62 & 29.2 \\
\hline & & 2,143 & 817 & 10.32 & 3.89 & 6.43 & 91 & 1.52 & 23.6 \\
\hline $\begin{array}{r}18 \\
119\end{array}$ & 0.9 & 1,977 & 744 & 9.32 & 3.59 & 5.73 & 85 & 1.44 & 25.1 \\
\hline & 0.9 & 2,395 & 963 & 11.35 & 4.61 & 6.74 & 104 & 1.65 & 24.5 \\
\hline Feb. 23 & 0.95 & $\begin{array}{l}2,10 \pm \\
1,595\end{array}$ & 817 & $\begin{array}{r}10.14 \\
8.03\end{array}$ & $\begin{array}{l}3.59 \\
3.89\end{array}$ & $\begin{array}{l}6.55 \\
4.14\end{array}$ & $\begin{array}{l}88 \\
88\end{array}$ & $\begin{array}{l}1.47 \\
1.24\end{array}$ & $\begin{array}{l}22.4 \\
30.0\end{array}$ \\
\hline & 0.95 & 1,485 & 904 & 7.49 & 4.34 & 3.15 & 94 & 1.29 & 41.0 \\
\hline & & 1,589 & 817 & 7.61 & 3.89 & 3.72 & 93 & 1.28 & 34.4 \\
\hline 27 & 0.95 & $\begin{array}{l}1,535 \\
1,490\end{array}$ & $\begin{array}{l}744 \\
744\end{array}$ & 7.48 & $\begin{array}{l}3.59 \\
3.59\end{array}$ & $\begin{array}{l}3.89 \\
3.58\end{array}$ & 87 & 1.24 & 31.9 \\
\hline & & 1,418 & 744 & 6.86 & $\begin{array}{l}3.59 \\
3.59\end{array}$ & $\begin{array}{l}3.58 \\
3.27\end{array}$ & $\begin{array}{l}83 \\
82\end{array}$ & $\begin{array}{l}1.20 \\
1.18\end{array}$ & $\begin{array}{l}33.5 \\
36.1\end{array}$ \\
\hline & & 1,444 & 744 & 7.08 & 3.59 & 3.49 & 86 & 1.22 & 35.0 \\
\hline 29 & 0.95 & 1,785 & 963 & 8.72 & 4.61 & 4.11 & 102 & 1.35 & 32.8 \\
\hline Jan 24 & 15 & 1,907 & 963 & 9.20 & 4.61 & 4.59 & 104 & 1.35 & 29.4 \\
\hline & $\begin{array}{l}1.5 \\
1.5\end{array}$ & 2,040 & 817 & 9.97 & 3.89 & 6.08 & 90 & 1.94 & 31.9 \\
\hline & 1.5 & $\begin{array}{l}2,303 \\
2,167\end{array}$ & $\begin{array}{l}963 \\
817\end{array}$ & 11.29 & 4.61 & 6.68 & 102 & 2.12 & 31.7 \\
\hline 31 & $\begin{array}{l}1.5 \\
1.5\end{array}$ & $\begin{array}{l}2,167 \\
2,115\end{array}$ & $\begin{array}{l}817 \\
744\end{array}$ & $\begin{array}{l}10.43 \\
10.29\end{array}$ & $\begin{array}{l}3.89 \\
3.59\end{array}$ & $\begin{array}{l}6.54 \\
6.70\end{array}$ & $\begin{array}{l}91 \\
87\end{array}$ & $\begin{array}{l}1.95 \\
1.89\end{array}$ & $\begin{array}{l}29.8 \\
28.2\end{array}$ \\
\hline Feb. 1 & 1.5 & 2,010 & 817 & $\begin{array}{r}10.29 \\
9.85\end{array}$ & $\begin{array}{l}3.89 \\
3.89\end{array}$ & 5.96 & 87 & 1.94 & $\begin{array}{l}28.2 \\
32.6\end{array}$ \\
\hline & 1.5 & 2,433 & 963 & 11.83 & 4.61 & 7.22 & 104 & 2.16 & 29.9 \\
\hline 7 & & 2,233 & 963 & 11.30 & 4.61 & 6.69 & 99 & 2.06 & 30.8 \\
\hline 8 & 1.5 & 1,976 & 817 & 9.80 & 3.89 & 5.91 & 90 & 1.94 & 32.8 \\
\hline 9 & 1.5 & $\begin{array}{l}2,146 \\
2,342\end{array}$ & $\begin{array}{l}904 \\
963\end{array}$ & $\begin{array}{l}10.40 \\
11.19\end{array}$ & $\begin{array}{l}4.34 \\
4.61\end{array}$ & $\begin{array}{l}6.06 \\
6.58\end{array}$ & $\begin{array}{r}94 \\
100\end{array}$ & $\begin{array}{l}1.99 \\
2.08\end{array}$ & $\begin{array}{l}32.8 \\
31.6\end{array}$ \\
\hline & & 2,073 & 817 & 10.03 & 3.89 & 6.14 & 92 & 1.97 & 32.1 \\
\hline 14 & 1.5 & 2,009 & 904 & 9.99 & 4.34 & 5.65 & 95 & 2.02 & 35.8 \\
\hline 15 & 1.5 & 2,004 & 817 & 9.91 & 3.89 & 6.02 & 90 & 1.93 & 32.1 \\
\hline 16 & 1.5 & 2,036 & 963 & 10.10 & 4.61 & 5.49 & 97 & 2.05 & 37.3 \\
\hline 23 & 1.5 & & 904 & 10.59 & $\begin{array}{l}4.34 \\
3.89\end{array}$ & 6.25 & 95 & 2.02 & 32.3 \\
\hline 23 & 1.0 & $\begin{array}{l}1,955 \\
2,265\end{array}$ & $\begin{array}{l}817 \\
963\end{array}$ & $\begin{array}{r}9.43 \\
1.35\end{array}$ & $\begin{array}{l}3.89 \\
4.61\end{array}$ & $\begin{array}{l}5.54 \\
6.74\end{array}$ & $\begin{array}{r}88 \\
102\end{array}$ & 1.91 & $\begin{array}{l}34.5 \\
31.3\end{array}$ \\
\hline 26 & 1.5 & 1,917 & 817 & $\begin{array}{r}11.30 \\
9.50\end{array}$ & 3.89 & $\begin{array}{l}0.14 \\
5.61\end{array}$ & 102 & $\begin{array}{l}2.11 \\
1.96\end{array}$ & $\begin{array}{l}31.3 \\
34.9\end{array}$ \\
\hline & & 1,969 & 817 & 9.67 & 3.89 & 5.78 & 88 & 1.91 & 33.0 \\
\hline 27 & 1.5 & 1,828 & 817 & 9.13 & $\begin{array}{l}3.89 \\
3.59\end{array}$ & 5.24 & 88 & 1.91 & 36.5 \\
\hline & & $\begin{array}{l}1,855 \\
1,850\end{array}$ & $\begin{array}{l}744 \\
817\end{array}$ & $\begin{array}{l}9.20 \\
9.25\end{array}$ & $\begin{array}{l}3.59 \\
3.89\end{array}$ & $\begin{array}{l}5.61 \\
5.36\end{array}$ & $\begin{array}{l}87 \\
89\end{array}$ & $\begin{array}{l}1.89 \\
1.91\end{array}$ & $\begin{array}{l}33.7 \\
35.6\end{array}$ \\
\hline
\end{tabular}

1 Ergometer I was used for all experiments up to Jan. 19, 1912, inclusive; ergometer II was used for the experiments subsequent to that date. 
TaBle 119. - Continued.

[Basal values obtained in no-load experiments, without motor.]

\begin{tabular}{|c|c|c|c|c|c|c|c|c|c|}
\hline \multirow{3}{*}{ Date. } & \multirow{3}{*}{ Current. } & \multicolumn{2}{|c|}{$\begin{array}{l}\text { Oxygen intake per } \\
\text { minute. }\end{array}$} & \multicolumn{3}{|c|}{ Heat output per minute. } & \multirow{3}{*}{$\begin{array}{c}(f) \\
\text { Revolu- } \\
\text { tions } \\
\text { per } \\
\text { minute. }\end{array}$} & \multirow{3}{*}{$\begin{array}{l}\quad(g) \\
\text { Heat } \\
\text { equivalent } \\
\text { of external } \\
\text { work per } \\
\text { minute. }\end{array}$} & \multirow{3}{*}{$\begin{array}{c}(h) \\
\begin{array}{c}\text { Effi- } \\
\text { ciency }\end{array} \\
g \times 100 \\
e\end{array}$} \\
\hline & & (a) & & $(c)$ & $(d)$ & $\begin{array}{c}(e) \\
\text { Increase }\end{array}$ & & & \\
\hline & & Work. & $\begin{array}{l}\text { No load } \\
\text { without } \\
\text { motor. }\end{array}$ & Work. & $\begin{array}{l}\text { No load } \\
\text { without } \\
\text { motor. }\end{array}$ & $\begin{array}{c}\text { over no } \\
\text { load } \\
\text { without } \\
\text { motor. } \\
c-d\end{array}$ & & & \\
\hline \multirow{3}{*}{$\begin{array}{l}1912 . \\
\text { Feb. } 29\end{array}$} & \multirow{3}{*}{$\underset{1.5}{a m p}$} & c.c. & c.c. & cals. & cals. & cals. & & cals. & p. ct. \\
\hline & & 2,248 & 963 & 11.13 & 4.61 & 6.52 & 102 & 2.11 & 32.4 \\
\hline & & 2,192 & 963 & 11.03 & 4.61 & 6.42 & 102 & 2.12 & 33.0 \\
\hline 28 & 1.5 & 2,101 & 904 & 10.49 & 4.34 & 6.15 & 97 & 2.04 & 33.2 \\
\hline \multirow{3}{*}{ Mar. 4} & & 2,144 & 963 & 10.82 & 4.61 & 6.21 & 100 & 2.07 & 33.3 \\
\hline & 1.5 & 2,290 & 963 & 11.33 & 4.61 & 6.72 & 104 & 2.15 & 32.0 \\
\hline & & 2,375 & 963 & 11.72 & 4.61 & 7.11 & 103 & 2.12 & 29.8 \\
\hline \multirow[t]{2}{*}{8} & 1.5 & 2,339 & 963 & 11.43 & 4.61 & 6.82 & 99 & 2.07 & 30.4 \\
\hline & & 2,282 & 963 & 11.21 & 4.61 & 6.60 & 99 & 2.07 & 31.4 \\
\hline \multirow[t]{2}{*}{11} & 1.5 & 2,299 & 963 & 11.29 & 4.61 & 6.68 & 102 & 2.12 & 31.7 \\
\hline & & 2,220 & 963 & 10.98 & 4.61 & 6.37 & 101 & 2.09 & 32.8 \\
\hline \multirow[t]{5}{*}{15} & 1.5 & 1,967 & 817 & 9.66 & 3.89 & 5.77 & 91 & 1.96 & 34.0 \\
\hline & & 1,946 & 817 & 9.58 & 3.89 & 5.69 & 91 & 1.96 & 34.4 \\
\hline & & 1,969 & 817 & 9.65 & 3.89 & 5.76 & 92 & 1.97 & 34.2 \\
\hline & & 1,948 & 817 & 9.54 & 3.89 & 5.65 & 90 & 1.94 & 34.3 \\
\hline & & 2,003 & 817 & 10.01 & 3.89 & 6.12 & 89 & 1.92 & 31.4 \\
\hline \multirow[t]{2}{*}{18} & 1.5 & $\begin{array}{l}1,899 \\
2,315\end{array}$ & $\begin{array}{l}744 \\
963\end{array}$ & $\frac{9,28}{11.35}$ & $\begin{array}{l}3.59 \\
4.61\end{array}$ & $\begin{array}{l}5.69 \\
6.74\end{array}$ & $\begin{array}{l}78 \\
102\end{array}$ & $\begin{array}{l}1.73 \\
2.12\end{array}$ & $\begin{array}{l}30.4 \\
31.5\end{array}$ \\
\hline & & 2,320 & 963 & 11.39 & 4.61 & 6.78 & 102 & 2.11 & 31.1 \\
\hline \multirow[t]{3}{*}{19} & 1.5 & 2,263 & 963 & 11.15 & 4.61 & 6.54 & 102 & 2.11 & 32.3 \\
\hline & & 2,346 & 963 & 11.55 & 4.61 & 6.94 & 103 & 2.12 & 30.6 \\
\hline & & 2,146 & 904 & 10.48 & 4.34 & 6.14 & 96 & 2.03 & 33.1 \\
\hline 25 & 1.5 & 2,288 & 963 & 11.24 & 4.61 & 6.63 & 98 & 2.05 & 30.9 \\
\hline \multirow[t]{2}{*}{26} & 1.5 & 2,206 & 963 & 10.91 & 4.61 & 6.30 & 98 & 2.07 & 32.9 \\
\hline & & 2,368 & 963 & 11.74 & 4.61 & 7.13 & 101 & 2.09 & 29.3 \\
\hline \multirow[t]{3}{*}{27} & 1.5 & 2,258 & 963 & 11.26 & 4.61 & 6.65 & 102 & 2.10 & 31.6 \\
\hline & & 2,327 & 963 & 11.63 & 4.61 & 7.02 & 103 & 2.12 & 30.2 \\
\hline & & 2,333 & 904 & 11.43 & 4.34 & 7.09 & 95 & 2.02 & 28.5 \\
\hline \multirow[t]{3}{*}{28} & 1.5 & 1,861 & 744 & 8.94 & 3.59 & 5.35 & 80 & 1.75 & 32.7 \\
\hline & & 2,110 & 817 & 10.26 & 3.89 & 6.37 & 92 & 1.96 & 30.8 \\
\hline & & 1,909 & 744 & 9.31 & 3.59 & 5.72 & 84 & 1.83 & 32.0 \\
\hline \multirow[t]{2}{*}{29} & 1.5 & 2,378 & 963 & 11.65 & 4.61 & 7.04 & 100 & 2.09 & 29.7 \\
\hline & & 2,227 & 904 & 10.89 & 4.34 & 6.55 & 95 & 2.01 & 30.7 \\
\hline
\end{tabular}

to make the best selection of no-load experiments for comparison. While, therefore, it is necessary to disregard the individual periods, a general deduction can be made from the results as a whole that the percentage efficiency as computed on this basis gradually increases with the load, the average efficiency for the whole table being not far from 30 per cent. Disregarding individual periods with extraordinarily high values, the maximum efficiency was approximately 33 per cent. These values are unquestionably higher than they would have been had the subject been able to relax the muscles completely in the no-load periods. They should accordingly be taken with considerable reserve.

\section{Efficiency in Work Experiments Based on Values Obtained in No-Load Ex- PERIMENTS WITH A MOTOR-DRIVEN ERgometer.}

It would appear at first sight as if the energy required by the subject to drive a machine without resistance would be a suitable base-line to use in finding the increase in metabolism and measuring the efficiency of the subject when riding with load. If it were possible for the subject to rotate the pedals evenly and without undue strain this would be true, but unfortunately the subject M. A. M. found it extraordinarily difficult to ride without load, and complained continually of his inability to maintain an even pace, our obser- 
vations of the tension on the sprocket chain fully confirming his personal impression. Inasmuch as the values obtained were unquestionably higher than normal owing to this extraneous muscular activity, the attempt was made to obtain a more even revolution of the pedals by belting a motor to the rear wheel of the ergometer and driving the machine at varying rates of speed. In these experiments, which were made only with ergometer II, the subject endeavored to sit in a relaxed position, and allow the legs to move freely with the rotation of the pedals. The results are singularly indicative of an inability to relax completely, and show a continuous opposition to the work of the motor. Since the motor was used in relatively few no-load experiments and the rate of speed did not vary widely, the number of experiments which can be compared with the work experiments is much smaller than was used for the other comparisons. They have, however, been collected and presented in table 120.

In table 120 the values are given chronologically in order to compare the results obtained with the different rates of speed. On nearly every day the subject rode at two rates of speed, but unfortunately the rate was on some days so great as to make a comparison with the work experiments impossible, since no riding experiments at these speeds were available. On the other hand, the comparisons given are sufficient to show clearly, first, that the average efficiency for all the experiments is not far from 27 per cent; and second, that there is a marked difference in the results with a change in the rate of revolution, the efficiency almost invariably decreasing with the high rate of revolution.

Since it is believed that in the no-load experiments the values found were all too high, we must accept with considerable reserve the average value of 27 per cent for the efficiency as computed on this basis, and the fact should be clearly recognized that the percentage of efficiency was raised by many extraneous muscular movements, such as "back pedaling," which would have been absent in a work experiment. In this table, as in others, individual periods will be found that give abnormal results, but as before the results should be considered only as a general picture. Such a review of the results does not lead one to the conclusion so strikingly shown in the earlier tables, namely, that the efficiency increases with the load; on the contrary, the values appear to show the reverse. The values are, however, particularly significant in indicating the great variations due to alterations in the rate of speed. It will be noted that with one or two exceptions all the values of 29 per cent or above were obtained with the revolutions per minute not greater than 92. The method of determining the base-line is, however, open to such severe criticism that values computed in this way must be taken with great reserve.

Efficiency in Work Expernatens Based upon Values Obtained with a Current OF 0.5 AMPERE.

An inspection of the preceding tables shows at a glance the difficulties incidental to assuming a base-line other than lying, for the extraneous muscular activity incidental to sitting up or to riding with no load, either with or without motor, certainly calls for a greater metabolism than would be expected when no external muscular work is done. Our reasons for believing 
TABLE 120.-Efficiency of $M . A . M$. in respiration experiments with bicycle ergometer $I I$.

[Basal value obtained in no-load experiments, with motor-driven ergometer.]

\begin{tabular}{|c|c|c|c|c|c|c|c|c|c|}
\hline \multirow[b]{2}{*}{ Date } & \multirow[b]{2}{*}{ Current. } & \multicolumn{2}{|c|}{$\begin{array}{l}\text { Oxygen intake } \\
\text { per minute. }\end{array}$} & \multicolumn{3}{|c|}{ Heat output per minute. } & \multirow{2}{*}{$\begin{array}{c}(f) \\
\text { Revolu- } \\
\text { tions } \\
\text { per } \\
\text { minute. }\end{array}$} & \multirow{2}{*}{$\begin{array}{c}(g) \\
\text { Heat } \\
\text { equivalent } \\
\text { of external } \\
\text { work per } \\
\text { minute. }\end{array}$} & \multirow{2}{*}{ 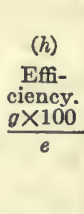 } \\
\hline & & $\begin{array}{c}(a) \\
\text { Work. }\end{array}$ & $\begin{array}{c}\text { (b) } \\
\text { No load } \\
\text { with } \\
\text { motor. }\end{array}$ & $\begin{array}{c}(c) \\
\text { Work. }\end{array}$ & $\begin{array}{c}(d) \\
\text { No load } \\
\text { with } \\
\text { motor. }\end{array}$ & $\begin{array}{c}(c) \\
\text { Increase } \\
\text { over no } \\
\text { load with } \\
\text { motor. } \\
c-d\end{array}$ & & & \\
\hline \multirow{2}{*}{$\begin{array}{c}1912 \\
\text { Jan. } 24\end{array}$} & $a m p$. & c.c. & c.c. & cals. & cals. & cals. & & cals. & per cent. \\
\hline & 1.5 & $\begin{array}{l}2,605 \\
2,040\end{array}$ & 743 & $\begin{array}{r}12.66 \\
9.97\end{array}$ & 3.61 & 9.05 & 106 & 2.16 & 23.9 \\
\hline & 1.5 & 2,303 & $\begin{array}{l}647 \\
743\end{array}$ & $\begin{array}{r}9.97 \\
11.29\end{array}$ & 3.09 & 6.88 & 90 & 1.94 & 28.2 \\
\hline & 1.5 & 2,167 & 647 & 10.43 & $\begin{array}{l}3.61 \\
3.09\end{array}$ & $\begin{array}{l}7.68 \\
7.34\end{array}$ & 102 & 2.12 & 27.6 \\
\hline & 1.5 & 2,115 & 625 & 10.29 & $\begin{array}{l}2.09 \\
2.99\end{array}$ & 7.30 & $\begin{array}{l}91 \\
87\end{array}$ & $\begin{array}{l}1.95 \\
1.89\end{array}$ & $\begin{array}{l}26.6 \\
25.9\end{array}$ \\
\hline \multirow{2}{*}{ Feb. } & 1.5 & 2,010 & 647 & 9.85 & 3.09 & 6.76 & 90 & 1.94 & 28.7 \\
\hline & 1.5 & $\begin{array}{l}2,433 \\
2,283\end{array}$ & 743 & 11.83 & 3.61 & 8.22 & 104 & 2.16 & 26.3 \\
\hline & 1.51 & 2,488 & $\begin{array}{l}672 \\
743\end{array}$ & $\begin{array}{l}11.30 \\
12.16\end{array}$ & $\begin{array}{l}3.25 \\
3.61\end{array}$ & $\begin{array}{l}8.05 \\
8.55\end{array}$ & $\begin{array}{r}99 \\
109\end{array}$ & $\begin{array}{l}2.06 \\
2.20\end{array}$ & 25.6 \\
\hline & & 1,976 & 647 & 9.80 & 3.09 & 6.71 & 90 & 1.94 & 28.9 \\
\hline \multirow{3}{*}{$\begin{array}{l}8 \\
9\end{array}$} & 1.5 & 2,146 & 647 & 10.40 & 3.09 & 7.31 & & 1.99 & 27.2 \\
\hline & 1.5 & 2,342 & 743 & 11.19 & 3.61 & 7.58 & 100 & 2.08 & 27.4 \\
\hline & 1.5 & $\begin{array}{l}2,073 \\
2,436\end{array}$ & 647 & 10.03 & 3.09 & 6.94 & 92 & 1.97 & 28.4 \\
\hline 14 & 1.0 & $\begin{array}{l}2,436 \\
2,009\end{array}$ & 743 & 11.97 & 3.61 & 8.36 & 109 & 2.20 & 26.3 \\
\hline 1 & 1.5 & $\begin{array}{l}2,009 \\
2,319\end{array}$ & $\begin{array}{l}672 \\
743\end{array}$ & 9.99 & 3.25 & 6.74 & 95 & 2.02 & 30.0 \\
\hline & & 2,004 & $\begin{array}{l}743 \\
625\end{array}$ & $\begin{array}{r}11.59 \\
9.91\end{array}$ & $\begin{array}{l}3.61 \\
2.99\end{array}$ & $\begin{array}{l}7.98 \\
6.92\end{array}$ & $\begin{array}{r}110 \\
90\end{array}$ & 2.22 & 27.8 \\
\hline 1 & 1.5 & 2,236 & 743 & 11.23 & $\begin{array}{l}2.99 \\
3.61\end{array}$ & $\begin{array}{l}6.92 \\
7.62\end{array}$ & 107 & $\begin{array}{l}1.93 \\
2.17\end{array}$ & 28.9 \\
\hline & & 2,036 & 672 & 10.10 & 3.25 & 6.85 & 97 & 2.05 & 29.9 \\
\hline 2 & 0.95 & $\begin{array}{l}2,206 \\
1,834\end{array}$ & 672 & 10.59 & 3.25 & 7.34 & 95 & 2.02 & 27.5 \\
\hline & & $\begin{array}{l}1,834 \\
1,595\end{array}$ & $\begin{array}{l}743 \\
625\end{array}$ & $\begin{array}{l}9.10 \\
8.03\end{array}$ & $\begin{array}{l}3.61 \\
2.99\end{array}$ & $\begin{array}{l}5.49 \\
5.04\end{array}$ & $\begin{array}{r}108 \\
88\end{array}$ & $\begin{array}{l}1.37 \\
1.24\end{array}$ & $\begin{array}{l}25.0 \\
24.6\end{array}$ \\
\hline & 1.5 & 1.955 & 625 & 9.43 & 2.99 & 6.44 & 88 & 1.91 & 29.7 \\
\hline & & 2,265 & 743 & 11.35 & 3.61 & 7.74 & 102 & 2.11 & 27.3 \\
\hline 2 & 0.95 & 1,485 & 647 & 7.49 & 3.09 & 4.40 & 94 & 1.29 & 29.3 \\
\hline & & 1,589 & 647 & 7.61 & $\begin{array}{l}3.09 \\
2.99\end{array}$ & 4.52 & 93 & 1.28 & 28.3 \\
\hline & 1.5 & $\begin{array}{l}1,535 \\
1,917\end{array}$ & $\begin{array}{l}625 \\
647\end{array}$ & $\begin{array}{l}7.48 \\
9.50\end{array}$ & $\begin{array}{l}2.99 \\
3.09\end{array}$ & 4.49 & 87 & 1.24 & 27.6 \\
\hline & & 1,969 & $\begin{array}{l}047 \\
625\end{array}$ & $\begin{array}{l}9.50 \\
9.67\end{array}$ & $\begin{array}{l}3.09 \\
2.99\end{array}$ & $\begin{array}{l}6.41 \\
6.68\end{array}$ & $\begin{array}{l}91 \\
88\end{array}$ & $\begin{array}{l}1.96 \\
1.91\end{array}$ & $\begin{array}{l}30.6 \\
28.6\end{array}$ \\
\hline 2 & 0.95 & 1,444 & 625 & 7.08 & 2.99 & 4.09 & 86 & 1.22 & $\begin{array}{l}29.0 \\
29.8\end{array}$ \\
\hline & 1.5 & 1,828 & 625 & 9.13 & 2.99 & 6.14 & 88 & 1.91 & 31.1 \\
\hline & & $\begin{array}{l}1.858 \\
1,850\end{array}$ & $\begin{array}{l}625 \\
625\end{array}$ & $\begin{array}{l}9.20 \\
9.25\end{array}$ & $\begin{array}{l}2.99 \\
2.99\end{array}$ & $\begin{array}{l}6.21 \\
6.26\end{array}$ & $\begin{array}{l}87 \\
89\end{array}$ & 1.89 & 30.4 \\
\hline 2 & 1.5 & 2,356 & 743 & 11.77 & 3.61 & 8.16 & 108 & $\begin{array}{l}1.91 \\
2.18\end{array}$ & $\begin{array}{l}30.5 \\
26.7\end{array}$ \\
\hline & & 2,101 & 672 & 10.49 & 3.25 & 7.24 & 97 & 2.04 & 28.2 \\
\hline 2 & & 2,144 & 743 & 10.82 & 3.61 & 7.21 & 100 & 2.07 & 28.7 \\
\hline & 1.5 & $\begin{array}{l}2,384 \\
2,248\end{array}$ & $\begin{array}{l}743 \\
743\end{array}$ & 11.71 & $\begin{array}{l}3.61 \\
3.61\end{array}$ & 8.10 & $\begin{array}{l}106 \\
102\end{array}$ & 2.17 & 26.8 \\
\hline & & 2,192 & 743 & 11.03 & $\begin{array}{l}3.61 \\
3.61\end{array}$ & 7.42 & 102 & $\begin{array}{l}2.11 \\
2.12\end{array}$ & $\begin{array}{l}28.1 \\
28.6\end{array}$ \\
\hline & 0.95 & 1,785 & 743 & 8.72 & 3.61 & 5.11 & 102 & 1.35 & 26.4 \\
\hline & & 2,028 & $\begin{array}{l}743 \\
743\end{array}$ & 9.78 & 3.61 & 6.17 & 107 & 1.35 & 21.9 \\
\hline Mar & 1.5 & 2,290 & $\begin{array}{l}743 \\
743\end{array}$ & $\begin{array}{r}9.20 \\
11.33\end{array}$ & $\begin{array}{l}3.61 \\
3.61\end{array}$ & $\begin{array}{l}5.59 \\
7.72\end{array}$ & 104 & 1.35 & 24.2 \\
\hline & & 2,259 & 743 & $\begin{array}{l}11.32 \\
\text {. }\end{array}$ & $\begin{array}{l}3.01 \\
3.61\end{array}$ & 7.71 & $\begin{array}{l}104 \\
105\end{array}$ & 2.16 & $\begin{array}{l}27.8 \\
28.0\end{array}$ \\
\hline & & 2,375 & 743 & 11.72 & 3.61 & 8.11 & 103 & 2.12 & 26.1 \\
\hline & 1.5 & 2,339 & 743 & 11.43 & 3.61 & 7.82 & 99 & 2.07 & 26.5 \\
\hline & & 2,282 & 743 & 11.21 & 3.61 & 7.60 & 99 & 2.07 & 27.2 \\
\hline 1 & 1.5 & 2,365 & 743 & 11.73 & 3.61 & 8.12 & 106 & 2.16 & 26.6 \\
\hline & & $\begin{array}{l}2,299 \\
2,220\end{array}$ & $\begin{array}{l}743 \\
743\end{array}$ & $\begin{array}{l}11.29 \\
10.98\end{array}$ & 3.61 & $\begin{array}{l}7.68 \\
7.37\end{array}$ & 102 & 2.12 & 27.6 \\
\hline Mar. 1 & 1.5 & 1,967 & 647 & $\begin{array}{r}10.98 \\
9.66\end{array}$ & $\begin{array}{l}3.61 \\
3.09\end{array}$ & $\begin{array}{l}7.37 \\
6.57\end{array}$ & $\begin{array}{r}101 \\
91\end{array}$ & $\begin{array}{l}2.09 \\
1.96\end{array}$ & $\begin{array}{l}28.4 \\
29.8\end{array}$ \\
\hline & & 1,946 & 647 & 9.58 & 3.09 & 6.49 & $\begin{array}{l}91 \\
91\end{array}$ & $\begin{array}{l}1.90 \\
1.96\end{array}$ & $\begin{array}{l}29.8 \\
30.2\end{array}$ \\
\hline & & 1,969 & 647 & 9.65 & 3.09 & 6.56 & 92 & 1.97 & 30.0 \\
\hline & & 1,948 & 647 & 9.54 & 3.09 & 6.45 & 90 & 1.94 & 30.1 \\
\hline 1 & 1.5 & $\begin{array}{l}2,003 \\
2,315\end{array}$ & $\begin{array}{l}625 \\
743\end{array}$ & $\begin{array}{l}10.01 \\
11.35\end{array}$ & $\begin{array}{l}2.99 \\
3.61\end{array}$ & $\begin{array}{l}7.02 \\
7.74\end{array}$ & $\begin{array}{r}89 \\
102\end{array}$ & $\begin{array}{l}1.92 \\
212\end{array}$ & 27.4 \\
\hline & & 2,320 & 743 & 11.39 & $\begin{array}{l}3.01 \\
3.61\end{array}$ & 7.78 & 102 & 2.11 & 27.1 \\
\hline 1 & 1.5 & 2,263 & 743 & 11.15 & 3.61 & 7.54 & 102 & 2.11 & 28.0 \\
\hline & & 2,346 & 743 & 11.55 & 3.61 & 7.94 & 103 & 2.12 & 20.7 \\
\hline 2 & 1.5 & $\begin{array}{l}2,146 \\
2,655\end{array}$ & $\begin{array}{r}672 \\
743\end{array}$ & 10.48 & $\begin{array}{l}3.25 \\
3.61\end{array}$ & 7.23 & 96 & 2.03 & 28.1 \\
\hline & & $\begin{array}{l}2,655 \\
2,545\end{array}$ & $\begin{array}{l}743 \\
743\end{array}$ & $\begin{array}{l}13.08 \\
12.72\end{array}$ & $\begin{array}{l}3.61 \\
3.61\end{array}$ & $\begin{array}{l}9.47 \\
9.11\end{array}$ & 110 & $\begin{array}{l}2.21 \\
2.21\end{array}$ & 23.3 \\
\hline & & 2,288 & 672 & 11.24 & $\begin{array}{l}3.01 \\
3.25\end{array}$ & 7.99 & 98 & 2.05 & 25.7 \\
\hline 2 & 15 & 2,206 & 672 & 10.91 & 3.25 & 7.66 & 98 & 2.07 & 27.0 \\
\hline & & 2,368 & 743 & 11.74 & 3.61 & 8.13 & 101 & 2.09 & 25.7 \\
\hline 2 & 1.5 & 2,258 & 743 & 11.26 & 3.61 & 7.65 & 102 & 2.10 & 27.5 \\
\hline & & $\begin{array}{l}2,327 \\
2,333\end{array}$ & $\begin{array}{l}743 \\
672\end{array}$ & 11.63 & 3.61 & $\begin{array}{l}8.02 \\
8.18\end{array}$ & 103 & $\begin{array}{l}2.12 \\
2.02\end{array}$ & 26.4 \\
\hline 2 & 1.5 & 2,110 & 647 & $\begin{array}{l}11.45 \\
10.26\end{array}$ & $\begin{array}{l}3.25 \\
3.09\end{array}$ & $\begin{array}{l}8.18 \\
7.17\end{array}$ & $\begin{array}{l}95 \\
92\end{array}$ & $\begin{array}{l}2.02 \\
1.96\end{array}$ & $\begin{array}{l}24.8 \\
27.3\end{array}$ \\
\hline 2 & 1.5 & 2,378 & 743 & 11.65 & 3.61 & 8.04 & 100 & 2.09 & 26.0 \\
\hline & & 2,227 & 672 & 10.89 & 3.25 & 7.64 & 95 & 2.01 & 26.3 \\
\hline Apr. & 1.25 & 2,343 & 743 & 11.53 & 3.61 & 7.92 & 105 & 1.83 & 23.1 \\
\hline & 1.1 & 2,252 & $\begin{array}{l}743 \\
743\end{array}$ & 11.29 & 3.61 & 7.68 & 108 & 1.58 & 20.6 \\
\hline & & 2,000 & 140 & 13.02 & 3.61 & 9.41 & 108 & 2.20 & 23.4 \\
\hline
\end{tabular}


this have already been freely mentioned in the previous discussions. It seemed desirable, therefore, that experiments should be made in which the subject should perform light work, sufficient in amount to insure a reasonably regular rotation of the pedals, and to eliminate all tendency to back pedal or to race. Accordingly a series of experiments was carried out in which the current through the armature was adjusted at 0.5 ampere. This was a very light load, and, indeed, somewhat lighter than the subject really preferred for comfort and complete muscular coôrdination; nevertheless there was considerably more resistance than with "no load" and the results furnish a reasonably constant base-line. In other experiments the subject rode with the resistance produced by a current of 1.5 amperes, and a comparison can logically be made of the results obtained in all experiments with these two resistances in which the revolutions per minute were essentially the same.

TABLE 121.-Efficiency of subjects in respiration experiments with bicycle ergometer with a current of 1.5 amperes.

[Basal values obtained in experiments with current of 0.5 ampere.]

\begin{tabular}{|c|c|c|c|c|c|c|c|c|c|c|c|c|}
\hline \multirow[b]{2}{*}{ Date. } & \multirow[b]{2}{*}{ Subject. } & \multicolumn{2}{|c|}{$\begin{array}{l}\text { Orygen in- } \\
\text { take per } \\
\text { minute dur- } \\
\text { ing work. }\end{array}$} & \multicolumn{3}{|c|}{$\begin{array}{l}\text { Heat output per } \\
\text { minute during work. }\end{array}$} & \multicolumn{2}{|c|}{$\begin{array}{l}\text { Revolutions } \\
\text { per minute. }\end{array}$} & \multicolumn{3}{|c|}{$\begin{array}{l}\text { Heat equivalent of } \\
\text { external work per } \\
\text { minute. }\end{array}$} & \multirow[b]{2}{*}{$\frac{\begin{array}{c}(k) \\
\text { Effici- } \\
\text { ency } \\
j \times 100\end{array}}{e}$} \\
\hline & & $\begin{array}{l}\text { (a) } \\
\text { Cur- } \\
\text { rent } \\
1.5 \\
\text { amp. }\end{array}$ & $\begin{array}{l}\text { (b) } \\
\text { Cur- } \\
\text { rent } \\
0.5 \\
\text { amp. }\end{array}$ & $\begin{array}{l}\text { (c) } \\
\text { Cur- } \\
\text { rent } \\
1.5 \\
\text { amp. }\end{array}$ & $\begin{array}{l}\text { (d) } \\
\text { Cur- } \\
\text { rent } \\
0.5 \\
\text { amp. }\end{array}$ & $\begin{array}{c}\text { (e) } \\
\text { Increase } \\
\text { over } \\
\text { work at } \\
0.5 \text { amp. } \\
c-d\end{array}$ & $\begin{array}{l}\text { (D) } \\
\text { Cur- } \\
\text { rent } \\
1.5 \\
\text { amp. }\end{array}$ & $\begin{array}{l}\text { (g) } \\
\text { Cur- } \\
\text { rent } \\
0.5 \\
\text { amp. }\end{array}$ & $\begin{array}{l}\text { (h) } \\
\text { Cur- } \\
\text { rent } \\
1.5 \\
\text { amp. }\end{array}$ & $\begin{array}{l}\text { (i) } \\
\text { Cur- } \\
\text { rent } \\
0.5 \\
\text { amp. }\end{array}$ & $\begin{array}{c}(j) \\
\text { Increase } \\
\text { over } \\
\text { work at } \\
0.5 \text { amp. } \\
h-i\end{array}$ & \\
\hline & & & & cals. & & & & & & & & p. $c$ \\
\hline & J. J. C. & & & & & & 72 & 71 & & & & 28.6 \\
\hline & & & 1,0 & 9.20 & $5.0>>>$ & & 72 & 71 & 1.6 & .4 & 1.1 & 27.0 \\
\hline Mar. 7 & K. H. A. & 2,060 & 1,076 & 10.02 & 5.19 & 4.8 & 79 & 79 & 1.74 & .52 & 1.22 & 25.3 \\
\hline & & & & 9.67 & & & & & & & & \\
\hline Apr. 3 & & 2,015 & 1,057 & 9.92 & 5.1 & 4. & 79 & 79 & 1.7 & .5 & 1.2 & 25.4 \\
\hline & & 2,14 & 1,057 & 10.41 & & & 79 & 79 & 1.7 & .52 & 1.2 & 23.2 \\
\hline Mar. 2 & J. E. F. & 1,648 & 876 & 8.10 & 4.3 & 3.7 & 72 & 75 & 1.59 & 1.50 & 1.09 & 29.0 \\
\hline Mar. 16 & & 1,801 & 87 & 8.82 & 4.3 & 4.4 & 79 & 75 & 1.7 & .5 & 1.2 & \\
\hline val. 00 & & & 87 & 8.84 & $\begin{array}{l}4.5 \\
4.3\end{array}$ & $\begin{array}{l}4.0 \\
4.5\end{array}$ & 71 & 75 & 1.5 & .5 & $\begin{array}{l}1.07 \\
1.08\end{array}$ & $\begin{array}{l}26.2 \\
24.0\end{array}$ \\
\hline Mar. 5 & E. P. C. & 1,495 & 8 & 7.40 & 3.9 & & 65 & 65 & & .4 & 1.0 & 28.6 \\
\hline$\pi$ & & & & 7.10 & & & 6 & 65 & & & .9 & 30.6 \\
\hline Feb. 28 & M. A. M. & 2,356 & 1,168 & 11.77 & 5.6 & 6.0 & 108 & 100 & 2.1 & .55 & 1.63 & 26.8 \\
\hline & & 2,101 & 1,168 & 10.49 & 5.6 & 4.8 & 97 & 100 & 2. & .5 & 1.4 & 31.0 \\
\hline Mar. & & 2,14 & $\begin{array}{l}1,168 \\
1,216\end{array}$ & 10.82 & 5.6 & $\begin{array}{l}5.14 \\
5.38\end{array}$ & 100 & $\begin{array}{l}100 \\
104\end{array}$ & & .5 & 1.5 & 29.6 \\
\hline & & 2,259 & 1,216 & 11.32 & 5.9 & 5.3 & 105 & 104 & 2 & .5 & 1.6 & $\begin{array}{l}29.7 \\
30.0\end{array}$ \\
\hline & & 2,375 & 1,216 & 11.72 & 5.9 & 5.7 & 103 & 104 & 2.1 & .5 & 1.5 & 27.2 \\
\hline Mar. 12 & & 1,564 & & 7.56 & & & 7 & 72 & & .4 & 1. & 30.2 \\
\hline & & 1,52 & & 7.4 & & & 7 & 7 & & .4 & 1.0 & 31.0 \\
\hline & & & & ... & 3.8 & 3.6 & 7 & & 1. & .4 & 1.0 & 30.1 \\
\hline Mar. 13 & & 1,513 & 86 & 7.44 & 4.2 & 3.2 & 7 & 7 & 1. & .4 & 1.0 & 33.2 \\
\hline & & 1,631 & 860 & & & 3. & 7 & $\pi$ & & & & \\
\hline & & 1,556 & 860 & & 4.22 & 3. & 7 & 7 & & .4 & 1.0 & \\
\hline Mar. 14 & & 1.550 & 818 & 7.5 & 3.95 & 3.6 & 71 & 7 & 1.5 & .4 & 1.1 & 30.2 \\
\hline & & 1,526 & 818 & 7.5 & 3.95 & 3.5 & 71 & 7 & & .4 & 1.1 & 30.7 \\
\hline & & 1,559 & 818 & 7.64 & 3.95 & 3.6 & 71 & 70 & 1. & .4 & 1.1 & 29.8 \\
\hline Mar. 18 & & & & & 3.9 & & & & & & & \\
\hline & & $\begin{array}{l}2,315 \\
2,320\end{array}$ & 1,168 & $\begin{array}{l}11.35 \\
11.39\end{array}$ & $\begin{array}{l}5.68^{2} \\
5.68\end{array}$ & $\begin{array}{l}5.67 \\
5.71\end{array}$ & $\begin{array}{l}102 \\
102\end{array}$ & 100 & 2.1 & 2.5 & 1.5 & 27.7 \\
\hline
\end{tabular}

1 Average of results obtained in the experiment of Mar. 16 with this subject.

2 Average of results obtained in the experiment of Feb. 28 with this subject.

In discussing the previous tables, it has been pointed out frequently that there appeared to be some intimate relationship between the speed and the total amount of work performed, and the results show that only experiments with constant speed should be compared. Accordingly in table 121 we have included only those experiments with the different subjects in which essen- 
tially the same rates of revolution were employed, a comparison being made of the work done with a current of 1.5 amperes with that done with a current of 0.5 ampere. By deducting from the total energy output when the subject rode at 1.5 amperes the heat given off when he rode at 0.5 ampere and comparing the difference with the difference in the external muscular work performed in the two cases, it is possible to compute an efficiency on a basis that is open to less objection than any other base-line that we have thus far proposed.

TABLE 122.-Efficiency in respiration experiments with bicycle ergometer II with currents of $0.95,1.1$, and 1.25 amperes. Subject, M.A.M.

[Basal values obtained in experiments with current of 0.5 ampere.]

\begin{tabular}{|c|c|c|c|c|c|c|c|c|c|c|c|}
\hline \multirow{3}{*}{ Date. } & \multicolumn{2}{|c|}{$\begin{array}{l}\text { Oxygen intake } \\
\text { per minute } \\
\text { during work. }\end{array}$} & \multicolumn{3}{|c|}{$\begin{array}{l}\text { Heat output per minute } \\
\text { during work. }\end{array}$} & \multicolumn{2}{|c|}{$\begin{array}{l}\text { Revolutions } \\
\text { per minute. }\end{array}$} & \multicolumn{3}{|c|}{$\begin{array}{l}\text { Heat equivalent of ex- } \\
\text { ternal work per minute. }\end{array}$} & \multirow{2}{*}{$\begin{array}{c}(k) \\
\text { Effi- } \\
\text { ciency. } \\
(j \times 100)\end{array}$} \\
\hline & \multirow{2}{*}{$\begin{array}{l}\text { (a) } \\
\text { Cur- } \\
\text { rent } \\
0.95 \\
\text { amp. }\end{array}$} & \multirow{2}{*}{$\begin{array}{c}(b) \\
\text { Cur- } \\
\text { rent } \\
0.5 \\
\text { amp. }\end{array}$} & \multirow{2}{*}{$\begin{array}{l}\text { (c) } \\
\text { Cur- } \\
\text { rent. } \\
0.95 \\
\text { amp. }\end{array}$} & \multirow{2}{*}{$\begin{array}{c}(d) \\
\text { Cur- } \\
\text { rent } \\
0.5 \\
\text { amp. }\end{array}$} & \multirow{2}{*}{$\begin{array}{c}(e) \\
\text { Increase } \\
\text { over } \\
\text { work at } \\
0.5 \text { amp. } \\
c-d\end{array}$} & \multirow{2}{*}{$\begin{array}{c}(f) \\
\text { Cur- } \\
\text { rent } \\
0.95 \\
\text { amp. }\end{array}$} & \multirow{2}{*}{$\begin{array}{c}(g) \\
\text { Cur- } \\
\text { rent } \\
0.5 \\
\text { amp. }\end{array}$} & \multirow{2}{*}{$\begin{array}{l}\text { (h) } \\
\text { Cur- } \\
\text { rent } \\
0.95 \\
\text { amp. }\end{array}$} & \multirow{2}{*}{$\begin{array}{c}\text { (i) } \\
\text { Cur- } \\
\text { rent } \\
0.5 \\
\text { amp. }\end{array}$} & \multirow{2}{*}{$\begin{array}{c}(j) \\
\text { Increase } \\
\text { over } \\
\text { work at } \\
0.5 \text { amp. } \\
h-i\end{array}$} & \\
\hline & & & & & & & & & & & $e$ \\
\hline \multirow{7}{*}{$\begin{array}{l}\text { 1912. } \\
\text { Feb. } 23 \\
\text { Feb. } 26 \\
\text { Feb. } 29\end{array}$} & C.c & & cals. & cals. & \multirow{7}{*}{$\begin{array}{l}\text { cals. } \\
2.40 \\
2.34 \\
2.46 \\
3.26 \\
3.08 \\
3.19\end{array}$} & & & cals. & cal. & cal. & p. ct. \\
\hline & 1,834 & 1,378 & 9.1 & 16.7 & & 108 & 108 & 1.37 & 10.5 & 0.8 & 34.2 \\
\hline & 1,485 & 1,070 & 7.49 & 5.15 & & 94 & $\begin{array}{l}96 \\
96\end{array}$ & 1.2 & 2.55 & & 31.6 \\
\hline & 1,785 & 1,116 & 8.72 & 35.46 & & 102 & 102 & 1.3 & 8.55 & 0.80 & 24.5 \\
\hline & 2,028 & 1,378 & 9.78 & 6.70 & & 107 & 108 & 1.3 & 1.55 & 0.8 & 26.0 \\
\hline & 1,907 & 1,254 & 9.20 & 46.01 & & 104 & 104 & 1.35 & . . .55 & 0.80 & 25.1 \\
\hline & $\begin{array}{c}\text { Cur- } \\
\text { rent } \\
1.1 \\
\text { amp. }\end{array}$ & $\begin{array}{c}\text { Cur- } \\
\text { rent } \\
0.5 \\
\text { amp. }\end{array}$ & $\begin{array}{c}\text { Cur- } \\
\text { rent } \\
1.1 \\
\text { amp. }\end{array}$ & $\begin{array}{c}\text { Cur- } \\
\text { rent } \\
0.5 \\
\text { amp. }\end{array}$ & & $\begin{array}{l}\text { Cur- } \\
\text { rent } \\
1.1 \\
\text { amp. }\end{array}$ & $\begin{array}{c}\text { Cur- } \\
\text { rent } \\
0.5 \\
\text { amp. }\end{array}$ & $\begin{array}{l}\text { Cur- } \\
\text { rent } \\
1.1 \\
\text { amp. }\end{array}$ & $\begin{array}{c}\text { Cur- } \\
\text { rent } \\
0.5 \\
\text { amp. }\end{array}$ & & \\
\hline \multirow{7}{*}{ Apr. 9} & & & 6.65 & 64.01 & \multirow{7}{*}{$\begin{array}{l}2.64 \\
2.72 \\
2.80 \\
4.59\end{array}$} & & 72 & 1.20 & 0.48 & 0.72 & \\
\hline & 1,378 & 822 & 6.73 & 4.01 & & 71 & 72 & 1.19 & .48 & 0.71 & 26.1 \\
\hline & $\begin{array}{l}1,387 \\
2,252\end{array}$ & $\begin{array}{r}822 \\
1,378\end{array}$ & $\begin{array}{r}6.81 \\
11.29\end{array}$ & $\begin{array}{l}4.01 \\
6.70\end{array}$ & & $\begin{array}{r}72 \\
108\end{array}$ & $\begin{array}{r}72 \\
108\end{array}$ & $\begin{array}{l}1.20 \\
1.58\end{array}$ & $\begin{array}{r}.48 \\
1.55\end{array}$ & $\begin{array}{l}0.72 \\
1.03\end{array}$ & $\begin{array}{l}25.7 \\
22.4\end{array}$ \\
\hline & & & & & & & & & & & \\
\hline & $\begin{array}{l}\text { Cur- } \\
\text { rent }\end{array}$ & $\begin{array}{l}\text { Cur- } \\
\text { rent }\end{array}$ & $\begin{array}{l}\text { Cur- } \\
\text { rent }\end{array}$ & $\begin{array}{l}\text { Cur- } \\
\text { rent }\end{array}$ & & $\begin{array}{l}\text { Cur- } \\
\text { rent }\end{array}$ & $\begin{array}{l}\text { Cur- } \\
\text { rent }\end{array}$ & $\begin{array}{l}\text { Cur- } \\
\text { rent }\end{array}$ & $\begin{array}{l}\text { Cur- } \\
\text { rent }\end{array}$ & & \\
\hline & 1.25 & & & & & 1.25 & חm & 1.25 & 0.5 & & \\
\hline & & & & & & amp. & amp. & & amp. & & \\
\hline \multirow[t]{3}{*}{ Apr. 8} & 1,422 & 802 & 6.97 & 3.88 & \multirow{3}{*}{$\begin{array}{l}3.09 \\
2.94 \\
3.07 \\
5.52\end{array}$} & 71 & 71 & 1.35 & ${ }^{6} 0.48$ & 0.87 & 28.2 \\
\hline & 1,425 & 833 & 6.95 & $\begin{array}{l}74.01 \\
5\end{array}$ & & 70 & $\begin{array}{l}70 \\
72\end{array}$ & 1.33 & 7.47 & 0.86 & $\begin{array}{r}29.3 \\
287\end{array}$ \\
\hline & $\begin{array}{l}1,431 \\
2,343\end{array}$ & $\begin{array}{r}1,254 \\
1,254\end{array}$ & $\begin{array}{r}11.53 \\
\end{array}$ & 26.01 & & 105 & 104 & $\begin{array}{l}1.00 \\
1.83\end{array}$ & 2.55 & $\begin{array}{l}0.00 \\
1.28\end{array}$ & 23.2 \\
\hline
\end{tabular}

1 Result obtained on Mar. 4.

2 Result obtained on Feb. 28. 3 Average of results obtained on Feb. 28 and Mar. 4, the oxygen being 1,170 and 1,061 c.c., respectively. 4 Result obtained on Feb. 28.

8 Average of results obtained on Mar. 12 and 13, the oxygen being 807 and 837 c.c., respectively.

- Average of results obtained on Mar. 12, 14, and 18, the oxygen being 797, 787, 823 c.c., respectively.

7 Average of two results obtained on Mar. 14.

Disregarding individual periods with exceptionally high or low values, it can be seen that with the professional subject the average efficiency on this basis is not far from 30 per cent. Essentially the same value is found for the untrained subject E. P. C., while the other untrained subjects J. E. F., K. H. A., and J. J. C. show somewhat lower percentages. The values for the subject M. A. M. are for the most part very regular, ranging in the 18 experiments from 26.8 per cent to 33.2 per cent, with practically all of the values between 29.7 and 31.0 per cent.

When the speed is taken into consideration in all the comparisons, however, we have for the first time the opportunity to study the effect of an 
increase in load without change in the speed. Since under these conditions the increase in the metabolism can be readily compared with the increase in effective muscular work, it would appear as though this was a most advantageous method of comparison.

In other experiments, when the subject was riding with a current through the armature of $0.95,1.1$, and 1.25 amperes, the rate of speed was such as to make the results comparable with similar experiments carried out with a current of 0.5 ampere. Hence comparisons can be made and deductions drawn from the differences in the metabolism and in the muscular work performed incidental to the change from a low to a higher resistance. This comparison has been made in table 122, the values with the 0.5 current being used as a base-line; the method of computation is exactly that used for the values given in table 121 . As would be expected, the experiments which can be used for this comparison are relatively few but fortunately they are all with the same individual, i.e., the professional subject, M. A. M. Here again the results show that the average efficiency on this basis of computation is not far from 27 per cent and with the exception of the single experiment on February 23, the highest efficiencies are found with the lowest rates of speed.

\section{Efficiency in Work Expertments Based upon Values Obtained with a CURRENT OF 0.95 AMPERE.}

Finally, although the data are insufficient for an exhaustive discussion, we have computed the efficiency using the values found with a current of 0.95 ampere as the base-line and determining the increase when the load was changed to 1.5 amperes without changing the speed. The results have been collected in table 123. Discarding the two high values of February 23 and February 29 which probably are abnormal, the results as a whole show a general average of 32 to 33 per cent efficiency, somewhat higher than that found with the comparison between 0.5 ampere and 1.5 amperes. It is quite possible that the light load of 0.5 ampere was hardly sufficient completely to eliminate extraneous muscular motions on the part of this subject, since there may have been at times an irregularity in the rate of speed or even back pedaling; while the values obtained with the 0.95 load indicate that this load required more constant work with much less liability of variations in speed. It would appear, therefore, as if with this particular subject the highest efficiency is obtained by using first a moderately severe load and then changing to a very severe load.

From observation of the subject while he was riding, particularly of the traction on the sprocket-chain, it appeared that with a resistance of 0.95 ampere, the extraneous muscular motions incidental to riding were the same as with the higher resistance, so that unquestionably the only two variable factors were the speed and the intensity of magnetization. For purposes of comparison, therefore, the results obtained with a moderate amount of work give the most logical base-line, since variability in the extraneous muscular motions is eliminated. Consequently, with this type of ergometer, when the speed is the same and the degree of magnetization is varied, the difference in work with this base-line may be consistently used for computing the efficiency. When it is considered that the values in table 123 were de- 
rived from individual periods and they are consequently liable to all the possible errors in individual experimentation, the agreement is on the whole remarkably satisfactory.

TABLE 123.-Efficiency in respiration experiments with bicycle ergometer with a current of 1.5 amperes. Subject, M.A.M.

[Basal values obtained in experiments with current of 0.95 ampere.]

\begin{tabular}{|c|c|c|c|c|c|c|c|c|c|c|c|}
\hline \multirow{3}{*}{ Date. } & \multicolumn{2}{|c|}{$\begin{array}{l}\text { Oxygen intake } \\
\text { per minute } \\
\text { during work. }\end{array}$} & \multicolumn{3}{|c|}{$\begin{array}{l}\text { Heat output per minute } \\
\text { during work. }\end{array}$} & \multicolumn{2}{|c|}{$\begin{array}{l}\text { Revolutions } \\
\text { per minute. }\end{array}$} & \multicolumn{3}{|c|}{$\begin{array}{l}\text { Heat equivalent of ex- } \\
\text { ternal work per minute. }\end{array}$} & \multirow[b]{2}{*}{$\begin{array}{c}(k) \\
\text { Effi- } \\
\text { ciency. } \\
j \times 100\end{array}$} \\
\hline & \multirow{2}{*}{$\begin{array}{c}\text { Cur- } \\
\text { rent } \\
1.5 \\
\text { amp. }\end{array}$} & \multirow{2}{*}{$\begin{array}{l}\text { (b) } \\
\text { Cur- } \\
\text { rent } \\
0.95 \\
\text { amp. }\end{array}$} & \multirow{2}{*}{$\begin{array}{c}(c) \\
\text { Cur- } \\
\text { rent } \\
1.5 \\
\text { amp. }\end{array}$} & \multirow{2}{*}{$\begin{array}{l}(d) \\
\text { Cur- } \\
\text { rent } \\
0.95 \\
\text { amp. }\end{array}$} & \multirow{2}{*}{$\begin{array}{c}(e) \\
\text { Increase } \\
\text { over } \\
\text { work at } \\
0.95 \\
\text { amp. } \\
c-d\end{array}$} & \multirow{2}{*}{$\begin{array}{l}(f) \\
\text { Cur- } \\
\text { rent } \\
1.5 \\
\text { amp. }\end{array}$} & \multirow{2}{*}{$\begin{array}{l}\text { (g) } \\
\text { Cur- } \\
\text { rent } \\
0.95 \\
\text { amp. }\end{array}$} & \multirow{2}{*}{$\begin{array}{l}(h) \\
\text { Cur- } \\
\text { rent } \\
1.5 \\
\text { amp. }\end{array}$} & \multirow{2}{*}{$\begin{array}{l}\text { (i) } \\
\text { Cur- } \\
\text { rent } \\
0.95 \\
\text { amp. }\end{array}$} & \multirow{2}{*}{$\begin{array}{c}(j) \\
\text { Increase } \\
\text { over } \\
\text { work at } \\
0.95 \\
\text { amp. } \\
h-i \\
\end{array}$} & \\
\hline & & & & & & & & & & & $e$ \\
\hline 1912. & c.c. & c.c. & cal & cal & cals. & & & cals. & cals. & cal. & p. ct. \\
\hline $\begin{array}{l}\text { Feb. } 23 \\
\text { Feb. } 26\end{array}$ & $\begin{array}{l}1,955 \\
1,917\end{array}$ & $\begin{array}{l}1,595 \\
1,589\end{array}$ & $\begin{array}{l}9.4 \\
9.5\end{array}$ & & 1.4 & $\begin{array}{l}88 \\
91\end{array}$ & $\begin{array}{l}88 \\
93\end{array}$ & 1. & & 0.6 & 47.9 \\
\hline Fon. & & & 9.6 & 7.4 & 2.1 & 8 & 87 & 1. & & .6 & 30.6 \\
\hline Feb. 27 & 1,82 & 1,44 & 9.1 & 7.0 & 2. & 8 & 8 & 1. & & & 33.7 \\
\hline & & & & & & & & & & & 31 \\
\hline \multirow{4}{*}{ Feb. 29} & & 1,44 & 9.25 & 7.0 & 2.1 & 89 & 86 & 1.9 & 1.2 & .6 & 31. \\
\hline & & & 11.71 & 9.7 & 1.8 & 106 & 10 & & & .8 & 42.5 \\
\hline & $\begin{array}{l}2,24 \\
2,19\end{array}$ & & & & & & 10 & & 1.5 & & 31.5 \\
\hline & & & 11.0. & 8.7 & 2.3 & 102 & 102 & 2.12 & 1.35 & & 33.3 \\
\hline
\end{tabular}

GENERAL CONSIDERATION OF THE EXPERIMENTAL DATA OBTAINED WITH THE PROFESSIONAL SUBJECT M. A. M.

With the professional subject M. A. M., such an extensive series of experiments was obtained at the magnetization of 1.5 amperes and with all possible speeds that it seemed practicable to establish a definite mathematical relationship between the muscular work performed and the total heat output. As frequently stated in the discussion of these tables, individual periods or experiments may give abnormal results, and the reader has been cautioned not to put undue confidence in these. We believe, however, that the best method of studying the research as a whole is to give all of the data careful scrutiny and, if possible, secure a series of curves from which the efficiency and the total heat output at any speed may be obtained. For this purpose we have used the results secured with M. A. M. at speeds ranging from 70 to 128 revolutions to plot a curve showing the probable value for the oxygen consumption at the different rates of speed. With a magnetization of 1.5 amperes, average values were secured at $70,80,90,95,102,110,113,117$, and 128 revolutions per minute respectively. The points for $70,90,95,102$, 110 , and 113 revolutions were obtained from an average of five or more periods at or about these speeds; for 80 revolutions the point was secured from the results of 3 periods; for 117 revolutions from 2 periods; and for 128 revolutions from only 1 period. In a similar manner the results obtained with magnetizations of $1.25,1.1,0.95$, and 0.5 amperes were used to plot curves for the oxygen consumption per minute for different speeds. These curves are all given in fig. 4.

It is seen that the form taken by the most probable curve is, in all degrees of magnetization, a straight line and consequently there is a regular agreement between the oxygen intake per minute and the rate of revolution, 
each revolution corresponding to a definite oxygen intake, i.e., 23.1 c.c. with a magnetization of 1.5 amperes.

Since the calibration curves for this ergometer show that the heat per revolution of the pedal decreases as the speed increases, ${ }^{a}$ this must in turn imply that there is a distinct alteration in the effciency of the body as a machine with an increase in speed. For a careful consideration of this point, however, another form of curve projection is necessary.

Leaving out of consideration the slight inequalities in the individual points found with the curve for the oxygen consumption at 1.5 amperes, the total heat production was computed from the oxygen consumption, making due allowance for the variations in the respiratory quotient found in the experiments. A curve was then plotted from a series of points representing the heat output per minute at varying speeds with a magnetization of 1.5 amperes. (See fig. 5.) As would be expected, this curve does not differ materially from that shown in fig. 4 for the oxygen consumption, both being straight lines. It is seen from the curve that the total heat given off from the body per revolution of the pedals was constant at all speeds. To accentuate the fact that the effective muscular work performed is not the same at all speeds we also give a curve representing the heat output per minute due to the effective work performed by rotating the pedals of the ergometer at the varying speeds. This shows clearly an increase in the work per minute but the increase per revolution is less and less as the speed increases. For example, in fig. 5

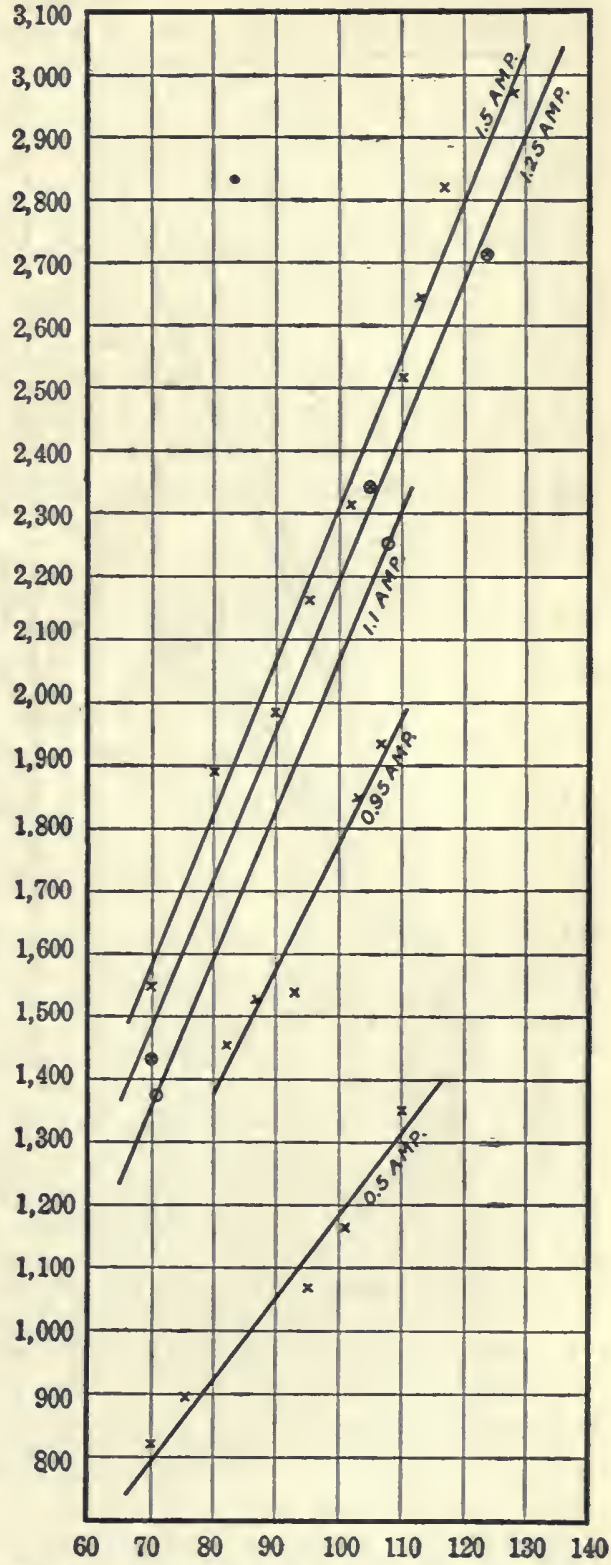

FIg. 4.-Curves showing oxygen consumption per minute with the subject riding at different speeds and with varying loads.

The revolutions per minute are given at the bottom of the figure and the oxygen consumption in cubic centimeters per minute at the left. 
the curve for the total heat output per minute with varying revolutions shows 7.61 calories at 70 revolutions per minute, and 15.04 calories at

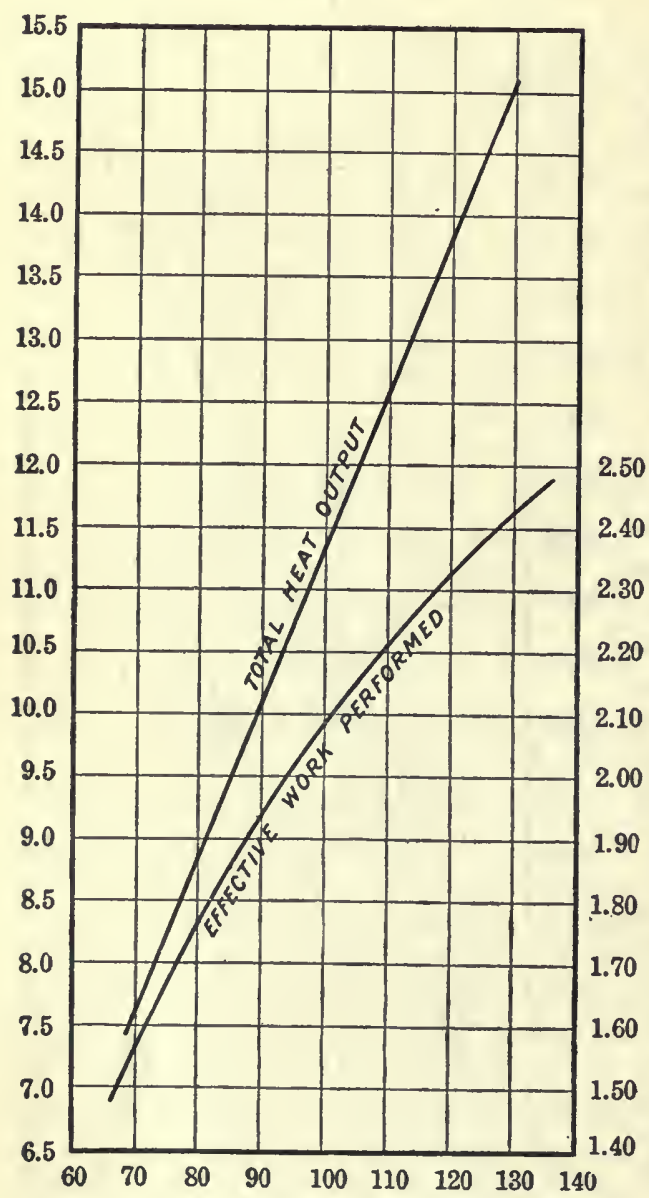

Fig. 5.-Curves showing the total heat output per minute and corresponding external muscular work per minute, expressed in calories, for subject riding with constant load- $-1.5 \mathrm{am}$ peres-at varying speeds.

The revolutions per minute are given at the bottom of the figure, the heat output per minute at the left, and the effective work performed per minute, expressed in calories, at the right.

fully into the discussion of the efficiency of the subject, using the data projected in these curves as the basis.

\section{Relationships between Speed and Efficienct.}

Under these circumstances we may now for the first time intelligently consider the relationship between speed and the gross efficiency. It was noted in the discussion of table 116 that while the efficiency increased in general 
with the load, with the heaviest loads there appeared definite indications of a decrease in efficiency. Since with practically all the heavy loads the rate of speed was high, the possible relationship between efficiency and load naturally becomes a relationship between efficiency and speed.

From the curves in fig. 5 it can be seen that to obtain 1.565 calories of effective muscular work at 70 revolutions per minute, it is necessary that the subject give off 7.61 calories of total heat, thus showing a gross efficiency of 20.6 per cent. Furthermore, in order to produce 2.425 calories of external muscular work at 130 revolutions, the subject must actually give off 15.04 calories of heat, corresponding to a gross efficiency of 16.1 per cent. The values for the gross efficiencies at the different speeds have been computed and are presented in table 124. Since in computing the net efficiency, the value used for the base-line, i.e., that obtained with the subject lying quietly on a couch, is constant and applicable to the whole curve irrespective of speed, it is obvious that the values for the net efficiency would be similarly affected by the speed.

TABLE 124.-Gross efficiency of subject M.A.M. at varying speeds with a current of 1.5 amperes. (See Fig. 5.)

\begin{tabular}{|c|c|c|c|}
\hline $\begin{array}{l}\text { Revolu- } \\
\text { tions per } \\
\text { minute. }\end{array}$ & $\begin{array}{l}\text { Gross } \\
\text { effi- } \\
\text { ciency. }\end{array}$ & $\begin{array}{l}\text { Revolu- } \\
\text { tions per } \\
\text { minute. }\end{array}$ & $\begin{array}{c}\text { Gross } \\
\text { effi- } \\
\text { ciency. }\end{array}$ \\
\hline $\begin{array}{r}70 \\
80 \\
90 \\
100\end{array}$ & $\begin{array}{l}p . c . \\
20.6 \\
20.0 \\
19.2 \\
18.4\end{array}$ & $\begin{array}{l}110 \\
120 \\
130\end{array}$ & $\begin{array}{l}\text { p.ct. } \\
17.6 \\
16.9 \\
16.1\end{array}$ \\
\hline
\end{tabular}

When we consider the variations in the output of work with increased speed, further relationships between the curve for the total heat output and that for the effective muscular work are found which indicate the influence of speed. From the upper curve it is seen that the output of heat is constant per 10 revolutions; on the other hand, the increase in the effective muscular work performed is not constant for each 10 revolutions, but there is a distinct falling off. If, therefore, we divide the increase in the external muscular work between any two points on the curve by the increase in the total heat output corresponding to the same two points, we get an efficiency based upon increasing speed, the degree of magnetization, i.e., the load, being the same. For instance, in changing from 70 to 80 revolutions per minute, there is an increase in the effective muscular work equivalent to 0.205 calories. Under these conditions there is an increase in the total heat output of 1.24 calories. Dividing the increase in the heat output due to the muscular work $(0.205$ calories) by the increase in the total heat output (1.24 calories), we find an efficiency for the increased amount of work performed of 16.53 per cent. Computations of a similar nature have been made for the various increases in speed and the results are given in table 125 .

It is thus evident that at the higher speeds with the same degree of magnetization there is a much larger heat output for the same amount of external muscular work performed, and consequently the efficiency decreases greatly as the speed increases, the optimum efficiency being at the lowest rates of speed, namely, about 70 revolutions. In perhaps no other table in connection 
with these experiments is this more strikingly brought out than here. Had it been possible to have this subject ride at a low rate of speed with this magnetization, an even greater efficiency than here noted might have been found, but as the rate of even 70 revolutions per minute was a little lower than he liked, since he usually preferred to ride at the rate of 80 or 90 revolutions per minute, the experimenting was not extended further in the direction of low speeds.

TABLe 125.-Efficiency of subject M.A.M. for increased amount of work due to increase of 10 revolutions in speed, with current of 1.5 amperes.

\begin{tabular}{|c|c|c|c|}
\hline $\begin{array}{l}\text { Increase in } \\
\text { revolutions } \\
\text { from- }\end{array}$ & $\begin{array}{c}\text { Effi- } \\
\text { ciency. } 1\end{array}$ & $\begin{array}{l}\text { Increase in } \\
\text { revolutions } \\
\text { from- }\end{array}$ & $\begin{array}{l}\text { Effi- } \\
\text { ciency.1 }\end{array}$ \\
\hline $\begin{array}{l}70 \text { to } 80 \\
80 \text { to } 90 \\
90 \text { to } 100\end{array}$ & $\begin{array}{l}p . c t . \\
16.53 \\
13.47 \\
11.94\end{array}$ & $\begin{array}{l}100 \text { to } 110 \\
110 \text { to } 120 \\
120 \text { to } 130\end{array}$ & $\begin{array}{r}\text { p. ct. } \\
10.48 \\
9.11 \\
7.82\end{array}$ \\
\hline
\end{tabular}

It is a striking coincidence that the decrease in the heat given off by the ergometer per revolution compensates almost exactly for the decrease in the efficiency of the subject, so that the total heat output per revolution of the pedal is exactly constant irrespective of speed.

Thus far in considering the results, the greatest emphasis has been laid upon variations in speed per se. The unavoidable variations in the amperage and consequently in the actual amount of work performed incidental to alterations in the speed evidently might affect the efficiency and this factor should also receive special consideration. Had it been possible to conduct experiments at 50 revolutions per minute and again at 111 revolutions per minute, it will be seen from the calibration curves of ergometer II that we would have had exactly the same heat equivalent of effective muscular work, and it is perhaps unfortunate that such a series of experiments was not attempted. Our experience in having the subject ride at a slow rate was, however, discouraging as he found it almost impossible to control his muscles so as to rotate the pedals less than once per second.

In considering these relationships, it is of more than ordinary interest to study the influence of speed on the net efficiency when the amount of effective muscular work remained constant. For this purpose we have collected such experiments as were comparable, and tabulated in table 126 the results according to the heat equivalent of muscular work performed at the different speeds.

The results given in table 126 show that with approximately the same heat equivalent of muscular work per minute but with different speeds, the net efficiency of the body was very considerably less with the higher speeds. For instance, when the heat equivalent of the muscular work per minute was approximately 1.95 calories per minute, the average of 18 periods with a speed of 90 revolutions showed a net efficiency of 22.6 per cent, while 2 periods with an increased speed of 124 revolutions per minute gave a net efficiency of 15.7 per cent. Similarly, when the heat equivalent of the muscular work was approximately 1.80 calories per minute, the net efficiency with 80 revo- 
lutions was 22.1 per cent and with 105 revolutions 17.7 per cent. With an average beat equivalent of the effective work of approximately 1.58 calories, the average of 10 periods in which the speed was 71 revolutions per minute showed a net efficiency of 24.5 per cent, while 1 period with the considerably greater speed of 108 revolutions gave a net efficiency of 15.6 per cent. Groups of experiments with an approximate heat equivalent of 1.35 calories are also compared, three periods with a speed of 71 revolutions per minute showing an average efficiency of 23.1 per cent; 1 period with a speed of 94 revolutions an efficiency of 20.4 per cent; and 4 periods with a speed of 105 revolutions an efficiency of 17.0 per cent. In still another group with a heat equivalent

TABLE 126.-Efficiency of subject M.A.M. compared at different speeds when the amount of effective muscular work per minute remained constant. (Ergometer II.)

[Basal values obtained with subject lying on couch.]

\begin{tabular}{|c|c|c|c|}
\hline Date. & $\begin{array}{l}\text { Revolu- } \\
\text { tions per } \\
\text { minute. }\end{array}$ & \begin{tabular}{|c|} 
Hest equiv- \\
alent of \\
external \\
work per \\
minute.
\end{tabular} & $\begin{array}{c}\text { Net } \\
\text { efficiency. }\end{array}$ \\
\hline & \multicolumn{3}{|c|}{ Effective work, 1.95 calories. } \\
\hline $\begin{array}{l}\quad 1912 . \\
\text { Feb. } 23 \ldots \ldots \\
\text { Feb. } 26 \ldots \ldots \\
\text { Feb. } 27 \ldots \ldots \\
\text { Mar. } 15 \ldots \ldots \\
\text { Feb. } 15 \ldots \ldots \\
\text { Feb. } 7 \ldots \ldots \\
\text { Feb. } 1 \ldots \ldots \\
\text { Jan. } 24 \ldots \ldots \\
\text { Mar. } 15 \ldots \ldots \\
\text { Jan. } 26 \ldots \ldots \\
\text { Feb. } 26 \ldots \ldots \\
\text { Mar. } 15 \ldots \ldots \\
\text { Mar. } 28 \ldots \ldots \\
\text { Mar. } 15 \ldots \ldots \\
\text { Feb. } 9 \ldots \ldots \ldots \\
\text { Feb. } 8 \ldots \ldots\end{array}$ & $\begin{array}{l}88 \\
88 \\
88 \\
89 \\
89 \\
90 \\
90 \\
90 \\
90 \\
90 \\
91 \\
91 \\
91 \\
91 \\
92 \\
92 \\
92 \\
91\end{array}$ & $\begin{array}{l}\text { cals. } \\
1.91 \\
1.91 \\
1.91 \\
1.91 \\
1.92 \\
1.93 \\
1.94 \\
1.94 \\
1.94 \\
1.94 \\
1.95 \\
1.96 \\
1.96 \\
1.96 \\
1.96 \\
1.97 \\
1.97 \\
1.99\end{array}$ & $\begin{array}{l}\text { p. ct. } \\
23.1 \\
22.4 \\
24.0 \\
23.4 \\
21.7 \\
22.0 \\
22.4 \\
22.4 \\
21.9 \\
23.2 \\
21.0 \\
23.5 \\
23.1 \\
23.3 \\
21.6 \\
23.2 \\
22.2 \\
21.7\end{array}$ \\
\hline \multirow{2}{*}{$\begin{array}{l}\text { Av. } 18 \text { periods } \\
\text { Apr. } 8 \ldots . .\end{array}$} & 90 & 1.94 & 22.6 \\
\hline & $\begin{array}{l}122 \\
126\end{array}$ & $\begin{array}{l}1.94 \\
1.98\end{array}$ & $\begin{array}{l}15.5 \\
15.8\end{array}$ \\
\hline \multirow[t]{2}{*}{ Av. 2 periods. } & 124 & 1.96 & 15.7 \\
\hline & \multicolumn{3}{|c|}{ Effective work, 1.80 calories. } \\
\hline $\begin{array}{l}\text { Mar. } 15 \ldots \ldots \\
\text { Mar. } 28 . \ldots \ldots\end{array}$ & $\begin{array}{l}78 \\
80 \\
84\end{array}$ & $\begin{array}{l}1.73 \\
1.75 \\
1.83\end{array}$ & $\begin{array}{l}21.3 \\
22.5 \\
22.5\end{array}$ \\
\hline \multirow{3}{*}{$\begin{array}{l}\text { Av. } 3 \text { periods } \\
\text { Apr. } 8 . . . . .\end{array}$} & 80 & 1.77 & 22.1 \\
\hline & 105 & 1.83 & 17.7 \\
\hline & \multicolumn{3}{|c|}{ Effective work, 1.58 calories. } \\
\hline $\begin{array}{l}\text { Mar. } 12 \ldots \ldots \\
\text { Mar. } 18 \ldots \ldots \\
\text { Mar. } 12 \ldots \ldots\end{array}$ & $\begin{array}{l}70 \\
70 \\
70 \\
71 \\
71 \\
71 \\
71 \\
71 \\
71 \\
72\end{array}$ & $\begin{array}{l}1.56 \\
1.56 \\
1.57 \\
1.57 \\
1.57 \\
1.57 \\
1.57 \\
1.57 \\
1.57 \\
1.59\end{array}$ & $\begin{array}{l}24.9 \\
24.0 \\
23.4 \\
25.2 \\
24.5 \\
24.7 \\
24.3 \\
24.8 \\
24.6 \\
24.9\end{array}$ \\
\hline Av. 10 periods & 71 & 1.57 & 24.5 \\
\hline Apr. $9 . \ldots .$. & 108 & 1.58 & 15.6 \\
\hline
\end{tabular}


TABLE 126. - Continued.

[Basal values obtained with subject lying on couch.]

\begin{tabular}{|c|c|c|c|}
\hline Date. & $\begin{array}{l}\text { Revolu- } \\
\text { tions per } \\
\text { minute. }\end{array}$ & $\begin{array}{c}\text { Heat equiv- } \\
\text { alent of } \\
\text { external } \\
\text { work per } \\
\text { minute. }\end{array}$ & $\begin{array}{c}\text { Net } \\
\text { efficiency. }\end{array}$ \\
\hline \multirow[b]{2}{*}{ Apr. $8 \ldots \ldots$} & \multicolumn{3}{|c|}{ Effective work, 1.35 calories. } \\
\hline & $\begin{array}{l}70 \\
71 \\
71 \\
\end{array}$ & $\begin{array}{l}1.33 \\
1.35 \\
1.36\end{array}$ & $\begin{array}{l}23.0 \\
23.3 \\
23.0\end{array}$ \\
\hline \multirow{2}{*}{$\begin{array}{l}\text { Av. } 3 \text { periods . } \\
\text { Feb. } 26 \ldots \ldots\end{array}$} & 71 & 1.34 & 23.1 \\
\hline & 94 & 1.29 & 20.4 \\
\hline \multirow{2}{*}{$\begin{array}{l}\text { Feb. } 29 \ldots \ldots \\
\text { Feb. } 23 \ldots \ldots \\
\text { Av. } 4 \text { periods. }\end{array}$} & $\begin{array}{l}102 \\
104 \\
107 \\
108\end{array}$ & $\begin{array}{l}1.35 \\
1.35 \\
1.35 \\
1.37\end{array}$ & $\begin{array}{l}18.1 \\
17.0 \\
15.8 \\
17.2\end{array}$ \\
\hline & 105 & 1.35 & 17.0 \\
\hline 1912 & \multicolumn{3}{|c|}{ Effective work, $1.20-1.25$ calories. } \\
\hline Apr. $9 \ldots \ldots$. & $\begin{array}{l}71 \\
71 \\
72\end{array}$ & $\begin{array}{l}1.20 \\
1.19 \\
1.20\end{array}$ & $\begin{array}{l}21.9 \\
21.4 \\
21.3\end{array}$ \\
\hline \multirow{2}{*}{$\begin{array}{l}\text { Av. } 3 \text { periods } \\
\text { Feb. } 27 \ldots \ldots\end{array}$} & 72 & 1.20 & 21.5 \\
\hline & $\begin{array}{l}82 \\
83 \\
\end{array}$ & $\begin{array}{l}1.18 \\
1.20\end{array}$ & $\begin{array}{l}20.7 \\
20.0\end{array}$ \\
\hline Av. 2 periods & 83 & 1.19 & 20.4 \\
\hline $\begin{array}{l}\text { Feb. } 27 \ldots \ldots \\
\text { Feb. } 26, \ldots \ldots \\
\text { Feb. } 23 \ldots \ldots \\
\text { Feb. } 26 \ldots \ldots\end{array}$ & $\begin{array}{l}86 \\
87 \\
88 \\
93\end{array}$ & $\begin{array}{l}1.22 \\
1.24 \\
1.24 \\
1.28\end{array}$ & $\begin{array}{l}20.6 \\
19.6 \\
18.0 \\
19.8\end{array}$ \\
\hline Av. 4 periods & 88 & 1.26 & 19.5 \\
\hline
\end{tabular}

of approximately 1.20 to 1.25 calories, the average net efficiency with 72 revolutions was 21.5 per cent; with 83 revolutions, 20.4 per cent; and with 88 revolutions, 19.5 per cent.

From a consideration of these various methods of computing the energy efficiency of the body, it is obvious that there are grave difficulties in the way of securing a base-line which will embrace only the extraneous muscular motions incidental to riding with load upon which could be superimposed a definite amount of muscular exertion productive of external muscular work. Certain it is that the various base-lines we have considered-lying, sitting, and riding no load with and without the motor-fail to meet this requirement. The comparisons previously made of the experiments with currents of 0.5 ampere and 1.5 amperes, and of 0.95 ampere and 1.5 amperes, indicate that experiments used for a base-line should be accompanied by an even greater amount of muscular work than would be required to overcome ordinary friction. With the best conditions it is possible to have the work done to such advantage that the increase in the effective muscular work may be as high as 33 per cent of the increase in the total heat output. On the other hand, we have to consider in this connection the various influences of speed upon the efficiency, since it has been clearly brought out in the previous discussion that the greater the speed the less is the efficiency, the greatest efficiency with the subject M. A. M. being obtained when he rode at the rate of 70 to 80 revolutions per minute. The ideal comparison, therefore, is found 
when experiments are made at the same speed, preferabiy from 70 to 80 revolutions per minute, and changing from moderately severe to severe muscular work.

\section{COMPARISON OF THE EFFICIENCY IN THE EARLIER AND LATER EXPERIMENTS WITH THE ERGOMETER.}

Since this is the second research carried out by means of this type of ergometer, a comparison of our results with those obtained earlier are of unusual interest. ${ }^{a}$ As has already been pointed out, ${ }^{b}$ the friction of these ergometers is so low that in calibrating them it was extremely difficult to measure the heat produced by means of the apparatus employed. In general the friction per revolution is not far from 1 to 2 per cent of the total heat produced. Under these conditions, it seemed to be entirely unjustifiable to utilize this figure in any of the computations, and hence in no experiment does the question of friction enter.

At this point the gross errors resulting from the use by Benedict and Carpenter ${ }^{c}$ of an erroneous value for the friction of the machine should be again pointed out. Their entire discussion of the mechanical efficiency based. on "coasting" or no-load experiments is vitiated by the fact that in deducting the "coasting" value from the total heat produced, they attempted to deduct the heat produced by friction from that produced by the external muscular work. Their values, which have been given in table $110,{ }^{d}$ have been recomputed by us and are given in table 127, in which it can be seen that the percentage efficiency based upon the so-called coasting values averages not far from 26 per cent as against the 24 per cent found and reported by them. Furthermore, their discussion of the internal friction of the legs ${ }^{6}$ is entirely unwarranted owing to this erroneous value for the friction of the apparatus. Our observations do, however, furnish interesting comparisons since the general thesis that the gross efficiency for bicycle riding is approximately 12 to 13 per cent and the net efficiency not far from 20 per cent confirms fully the values given for the previous research.

TABLE 127.-Mechanical efficiency based on coasting experiments of Benedict and Carpenter.

\begin{tabular}{|c|c|c|}
\hline \multirow[b]{2}{*}{ Subject. } & \multicolumn{2}{|c|}{ Efficiency. } \\
\hline & $\begin{array}{c}\text { Friction } \\
\text { value } \\
\text { deducted.1 }\end{array}$ & $\begin{array}{l}\text { Recomputed } \\
\text { without cor- } \\
\text { rection for } \\
\text { friction. }\end{array}$ \\
\hline $\begin{array}{l}\text { N. B... } \\
\text { N. } \\
\text { B. } \\
\text { N. B. } \\
\text { N. B. } \\
\text { A. L. } \\
\text { A. L. }\end{array}$ & $\begin{array}{l}\text { p. } d . \\
24.6 \\
23.7 \\
23.4 \\
24.6 \\
21.6\end{array}$ & $\begin{array}{l}\text { p. } c . \\
26.4 \\
26.0 \\
26.2 \\
28.4 \\
23.2\end{array}$ \\
\hline
\end{tabular}

1 The friction value used by Benedict and Carpenter in these computations ( 0.001547 per revolution) was erroneous.

One discrepancy between the earlier work and the more recent observations is in the computation of the effect on the efficiency of increasing the

\footnotetext{
a Benedict and Carpenter, U. S. Dept. Agr., Office Expt. Stas. Bull. 208, 1909.

Benediet and Cady, Carnegie Institution of Washington Publication No. 167, 1912, pp. 21 and 29.

c Benedict and Carpenter, loc cit., p. 39.

d See p. 110.

C Benedict and Carpenter, loc. cir., pp. 40 and 41.
} 
external work. According to the results reported by Benedict and Carpenter, the increase in load does not materially affect the efficiency of the body as a machine, all of the values with but one exception being approximately 21 per cent. ${ }^{a}$ The authors call attention to what may now be recognized as a very important fact that the speeds per minute were not uniform with all degrees of magnetization of the field and that the experiments were not made under ideal conditions for studying this particular point. Nevertheless the discrepancy between the 21 per cent found by them and the 27 per cent found by us (see table 122) is altogether too wide to be accounted for by any errors due to variations in speed. In order to show this more clearly, our results, computed on the basis of calories per hour, have been brought together in table 128 without regard to variations in speed. While these values confirm the inference drawn from their results by Benedict and Carpenter that increase in load does not materially affect the efficiency of the body, there is shown in general a slight tendency for the work to be done more efficiently in changing from a moderately heavy load to one still heavier than when changing from a light to a heavy load, that is, the percentage of effi-

TABLE 128.-Effect of increased load on body efficiency without regard to variations in speed.1

[Amounts per hour.]

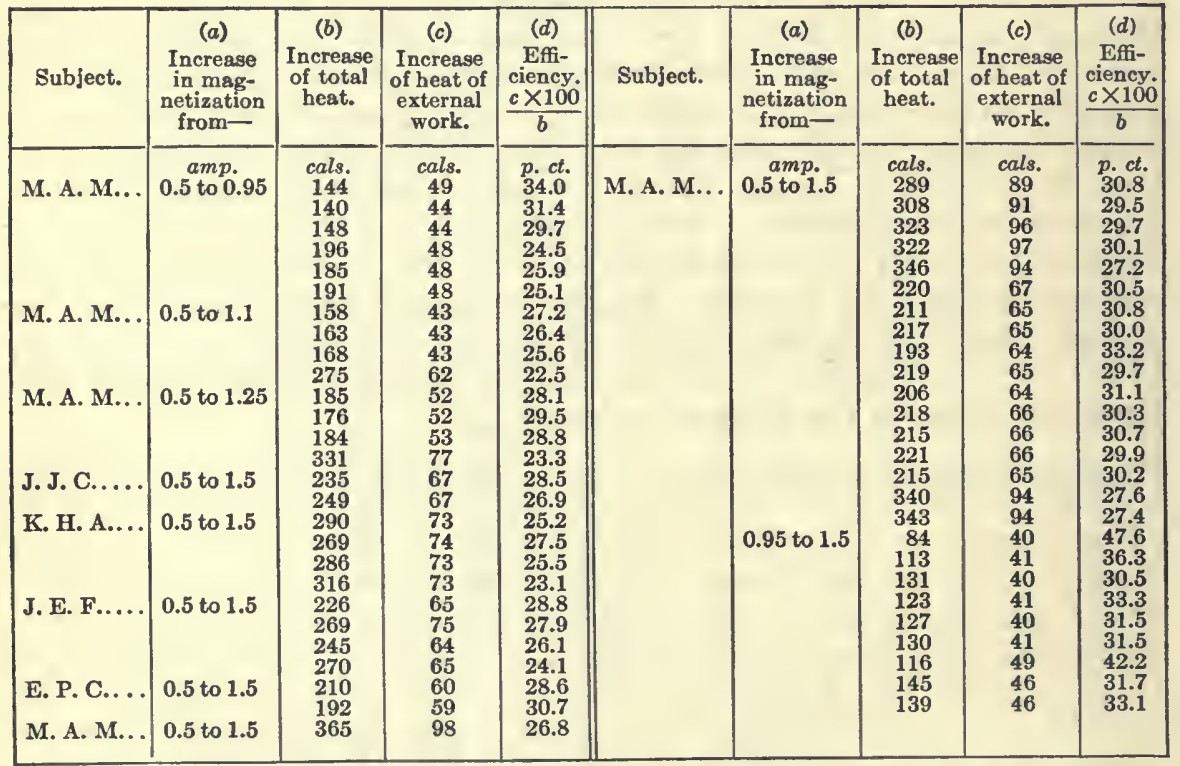

1 Values taken from columns $e$ and $j$ of tables 121, 122, and 123, and calculated to the per hour basis.

ciency in changing from 0.95 to 1.5 amperes was slightly higher than in changing from 0.5 to 0.95 ampere. ${ }^{b}$ The greatest discrepancy, however, is the fact that the percentages found by Benedict and Carpenter average about 21 per cent while ours average much nearer 28 to 30 per cent. Although the

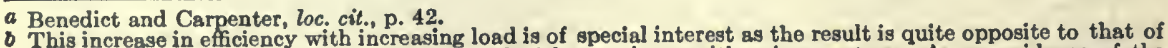
earlier workers and, indeed, not in accord with cxperience with prime motors. As an evidence of the flexibility of the human body, this observation is worthy of further study. 
later experiments were planned more particularly for studying this point and are hence much more complete and more numerous than the earlier experiments, we find it impossible to explain in any way the lower values found by Benedict and Carpenter with the ergometer I used by us in this research.

Finally, we should call attention to the fact that while the early observations with ergometer I implied a great discrepancy between the efficiency as determined by means of this apparatus and that obtained by Zuntz and his associates in their mountain-climbing and treadmill experiments, the later research gives results that agree with the best figures obtained by the Zuntz method, namely, 33 per cent.

\section{Relatioxship between Efficiency aNd the Character of the Diet.}

Several sets of experiments were planned to test the effect upon the efficiency of the character of the diet. While the evidence obtained is by no means conclusive, such results as are suitable for comparison have been gathered together in table 129 for examination and discussion.

TABLE 129.-Heat output in work experiments without food following diets carbohydrate-rich and carbohydrate-poor. Subject M.A.M.

\begin{tabular}{|c|c|c|c|c|c|c|c|}
\hline \multicolumn{4}{|c|}{ Carbohydrate-rich diet. } & \multicolumn{4}{|c|}{ Carbohydrate-poor diet. } \\
\hline Date. & $\begin{array}{l}\text { No. of } \\
\text { diet days } \\
\text { preceding } \\
\text { experi- } \\
\text { ment. }\end{array}$ & $\begin{array}{l}\text { Heat equiv- } \\
\text { alent of ex- } \\
\text { ternal work } \\
\text { per minute. }\end{array}$ & $\begin{array}{l}\text { Hest output } \\
\text { per calorie } \\
\text { of external } \\
\text { work per } \\
\text { minute } \\
\text { (calculated). }\end{array}$ & Date. & $\begin{array}{l}\text { No. of } \\
\text { diet days } \\
\text { preceding } \\
\text { experi- } \\
\text { ment. }\end{array}$ & $\begin{array}{l}\text { Heat equiv- } \\
\text { alent of ex- } \\
\text { ternal work } \\
\text { per minute. }\end{array}$ & $\begin{array}{c}\text { Heat output } \\
\text { per calorie } \\
\text { of external } \\
\text { work per } \\
\text { minute } \\
\text { (calculated). }\end{array}$ \\
\hline \multirow{2}{*}{$\begin{array}{l}\text { 1912. } \\
\text { Jan. } 24 \ldots . . . \\
\text { Jan. } 25 \ldots \ldots \\
\text { Jan. } 26 \ldots \ldots \\
\text { Feb. } 14 \ldots \ldots \\
\text { Feb. } 15 . \ldots \\
\text { Feb. } 16 . . .\end{array}$} & \multirow{2}{*}{$\begin{array}{l}1 \\
2 \\
3 \\
1 \\
2 \\
2 \\
3\end{array}$} & \multirow{2}{*}{$\begin{array}{l}\text { cals. } \\
2.05 \\
2.18 \\
2.11 \\
2.11 \\
2.08 \\
2.08\end{array}$} & \multirow{2}{*}{$\begin{array}{l}\text { cals. } \\
\mathbf{5 . 5 2} \\
\mathbf{5 . 3 8} \\
\mathbf{5 . 8 1} \\
\mathbf{5 . 2 0} \\
\mathbf{5 . 1 7} \\
\mathbf{5 . 1 2}\end{array}$} & \multirow{3}{*}{$\begin{array}{l}1912 . \\
\text { Feb. } 7 . . . \\
\text { Feb. } 8 . . . \\
\text { Feb. } 9 \\
\text { Aversge. }\end{array}$} & $\begin{array}{l}1 \\
2 \\
3 \\
\end{array}$ & $\begin{array}{l}\text { cals. } \\
2.07 \\
2.12 \\
2.03\end{array}$ & $\begin{array}{l}\text { cals. } \\
5.30 \\
5.40 \\
5.23\end{array}$ \\
\hline & & & & & \multirow[t]{2}{*}{ …...... } & \multirow[t]{2}{*}{$\ldots \ldots \ldots \ldots$} & \multirow[t]{2}{*}{5.31} \\
\hline Average. . & $\overline{\ldots \ldots \ldots}$ & $\ldots \ldots \ldots \ldots$ & 5.37 & & & & \\
\hline 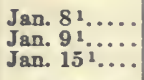 & $\therefore$ & $\begin{array}{l}1.50 \\
1.48 \\
1.64 \\
\end{array}$ & $\begin{array}{l}6.51 \\
6.31 \\
7.17 \\
\end{array}$ & \multirow{2}{*}{$\begin{array}{r}\text { Jan. } 17 . . . \\
\text { Jan. } 18 . . . \\
\text { Jan. } 19 . . . \\
\text { Average. }\end{array}$} & $\begin{array}{l}1 \\
2 \\
3 \\
\end{array}$ & $\begin{array}{l}1.57 \\
1.59 \\
1.56\end{array}$ & $\begin{array}{l}6.52 \\
6.62 \\
6.89\end{array}$ \\
\hline Average.. & $\ldots \ldots \ldots$ & .......... & 6.66 & & ….... & $\overline{\cdots \ldots \ldots \ldots}$ & 6.68 \\
\hline
\end{tabular}

1 The experiments made on Jan. 8, 9, and 15 followed days with ordinary or unrestricted diet. The average respiratory quotients for these days were respectively $0.88,0.85$, and 0.90 (lying before work).

As Zuntz has pointed out, if Chauveau's theory be correct, when fat is burned 30 per cent more energy per unit of work should be liberated than when carbohydrate or glycogen is burned, since Chauveau contends that fat must first be converted into glycogen, during which process heat is liberated which is not available for muscular activity. It would appear, therefore, that if there were so great a difference as 30 per cent between values obtained with diets which were carbohydrate-rich and diets which were carbohydrate-poor, such difference should be observed in these experiments. As already pointed out, the dietetic control was unfortunately not all that could be desired in the experiments in which this question was studied. The respiratory quotients show, however, that in general on the days when a carbohydrate-poor diet was being ingested, the average quotient the next morning was somewhat lower than with a carbohydrate-rich diet. (See table 94.) 
A further complication lies in the fact that in the experiments particularly planned for comparison purposes, a different amount of work was performed in one set than in the other; since this would materially affect the efficiency, it has been taken into consideration in making up the table. Three groups of experiments, each containing three individual experiments, have been selected for comparison in which the heat equivalent of the external muscular work was not far from 2 calories per minute. Six of these days were with a carbohydrate-rich diet and three with a carbohydrate-poor diet.

In three other experiments, namely, those of January 17, 18, and 19, the diet was carbohydrate-poor and the heat equivalent of the muscular work averaged only about 1.57 calories. Inasmuch as no experiments with a carbohydrate-rich diet were made with a comparable amount of work, the three experiments of January 8, 9, and 15 were selected for comparison. In these experiments, the heat equivalent of the muscular work was approximately 1.57 calories; the preceding diet was, however, unrestricted, but as the average respiratory quotients were respectively $0.88,0.88$, and 0.90 when the subject was lying upon a couch before work, it can be assumed that they are fairly indicative of a rich glycogen supply and hence suitable to be compared with the experiments of January 17, 18, and 19, in which the respiratory quotients of $0.77,0.77$, and 0.77 , respectively, indicated a relatively low glycogen storage.

The six experiments with a carbohydrate-rich diet in which the heat equivalent of muscular work was about 2 calories per minute gave an average output per calorie of external work per minute of 5.37 calories. On the three days with a carbohydrate-poor diet with which they are compared when essentially the same amount of work was performed, the average output per calorie of external muscular work per minute was 5.31 calories. On the days when less work per minute was performed, we have for the experiments with a diet presumably rich in carbohydrates an average of 6.66 calories per calorie of external muscular work per minute, while on the three days with a carbohydrate-poor diet, there were 6.68 calories per calorie of external muscular work per minute. It is thus seen that both the sets of experiments compared show approximately the same efficiency irrespective of the diet.

Making all allowance for the inadequate control of the diet, the evidence obtained from these experiments is strongly at variance with the conception that with a fat diet there will be an increase of 30 per cent in the energy output per calorie of external muscular work over that with a carbohydrate-rich diet. While it must be borne in mind that the carbohydrate-poor diet was not a carbohydrate-free diet, yet the fact that the experiments with the diet poor in carbohydrates showed not the slightest indication of an increase in the energy output per unit of work is strongly suggestive of the absence of the transformation during work of fat to glycogen with a consequent liberation of unavailable heat. 


\section{PHYSIOLOGICAL EFFECTS OF MUSCULAR WORK.}

\section{MECHANICS OF RESPIRATION.}

Since throughout this whole series of experiments much use is made of the respiratory quotient in determining the character of the katabolism, all the factors which could possibly affect this relationship between the carbon dioxide and the oxygen must be considered. Abnormal respiration has been shown by Zuntz and his associates to produce almost instantly abnormal respiratory quotients by virtue of a pumping out or excessive removal of carbon dioxide from the alveoli. In view of the very great ventilation of the lungs during the severe muscular work in these experiments, it became necessary to find whether or not there was an excessive pumping out of carbon dioxide which persisted throughout the entire experiment, since this removal of carbon dioxide would materially increase the output and thus abnormally raise the respiratory quotient. Furthermore, it is conceivable that after the work had ceased, there may have been a marked retention of carbon dioxide with a consequent lowering of the respiratory quotient, this low quotient implying the combustion of a relatively greater proportion of fat.

The professional subject, M. A. M., showed throughout all the resting experiments an irregularity in respiratory rhythm that at times made it difficult to carry out the experimental routine, as occasionally he inspired deeply and again the respiration would be shallow for a moment or two. Since the experimental data are obtained by connecting the subject with the respiration apparatus at the end of a normal expiration, great care was necessary with this irregularity in respiration to secure the right conditions for beginning an experiment. During the excessive ventilation of the lungs and the rapidity of respiration incidental to severe muscular work, it was possible to determine the moment for throwing the 3 -way valve at the end of an expiration either by the sound of the air rushing through the valve or by holding the hand in front of the open end. At the end of an experiment, the time for throwing the valve could be determined by noting the position of the rubber tension-equalizer. When the air was being expired from the lungs, the tension-equalizer rose; as soon as the tension-equalizer ceased rising, i.e., at the end of the expiration, the valve was thrown. Care was always taken to have the subject breathing through the mouthpiece and the 3-way valve for several minutes before the valve was thrown, to make sure that he had accustomed himself perfectly to the conditions of experimentation before the experiment began. Accordingly we have no reason to believe that there was any "pumping out" of carbon dioxide due to an altered respiratory type.

Following the excessive muscular work, there was again an altered respiration as the volume of respiration perceptibly decreased. A special study was therefore made of the ventilation of the lungs before, during, and after work; furthermore, in order to secure evidence regarding the possibility of the retention of carbon dioxide in post-work periods, a careful study was made of the carbon-dioxide tension of the alveolar air.

\section{Ventilution of the Lungs as Affected by Muscutar Work.}

Many experiments on animals and a few on men indicate that following muscular work there is an excessive ventilation of the lungs which continues for some time; in fact, the muscular work incidental to the large ventilation 
of the lungs has been used to explain in part the after-effects of muscular activity upon gross metabolism.

In three experiments with our professional subject, we determined the ventilation of the lungs by the spirometer recently devised in this laboratory ${ }^{a}$ and attached to the respiration apparatus. The results, which have been reduced to $0^{\circ} \mathrm{C}$. and 760 millimeters pressure, are given in table 130 which shows the ventilation of the lungs per minute, together with the carbon dioxide expired, and the respiration-rate. The table also gives the length of time between the end of the work and the beginning of the next experiment. The first period of the experiment following work invariably shows an increased ventilation, but with the exception of one experimentthat of March 29, 1912-the excessive ventilation had ceased 20 minutes after the work was over, and was no greater than it was before the work began. On March 29, the ventilation of the lungs continued somewhat above normal even 57 minutes after the work had ceased.

\section{TABLE 130--Ventilation of lungs in respiration experiments before and after work with subject M.A.M. lying on the couch.}

[Volumes at $0^{\circ} \mathrm{C}$. and $760 \mathrm{~mm}$.]

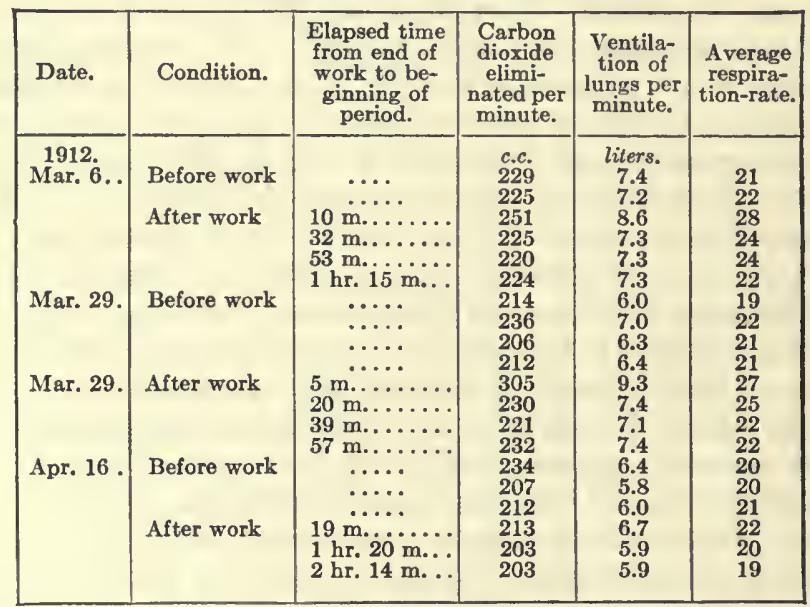

Unfortunately the observations are not sufficiently extensive to admit of comparisons between normal individuals and well-trained athletes. The experiments with this subject were all made within 5 weeks of the end of the training period and hence do not give us any information as to whether or not the return to normal ventilation in so short a time was due to training; observations of this nature should, however, be made. The important point shown by the results in table 130 is that the excess ventilation was usually noted immediately after the work ceased, but the ventilation again became normal in a short time in two out of three cases. Whatever the results may be with dogs, it is certain that with this man the prolonged increase in metabolism following work was not accompanied by an increased ventilation of the lungs.

a For a description of this spirometer and the method of obtaining the volume of respiration, see Benediet, Deutsch. Archiv f. klin. Med., 1912, 107, p. 172. 


\section{Carbon-dioxide Content of the Alveolar Air after Muscular Work.}

A possible explanation for the low respiratory quotients usually found in the rest periods immediately following the muscular work might be that they were due to a storage of carbon dioxide in the body instead of to a change in the character of the katabolism. Thus, if the residual carbon dioxide in the body were larger at the end than at the beginning of the period, the amount of the carbon dioxide expired would not indicate the amount produced, so that the respiratory quotient would not be a true index of the nature of the material burned in the body. It is possible that during work organic acids (especially lactic acid) in the blood might replace in part the carbon dioxide as a factor stimulating the respiratory center; this would cause a smaller carbon-dioxide content of the arterial blood. After cessation of work, such acids would doubtless soon disappear so that the carbon-dioxide content of the blood would gradually return to a normal value. If there were a larger residual amount of carbon dioxide in the body at one time than at another,

TABLE 131.-Determinations made on alveolar air with subject M. A. M. (without food).

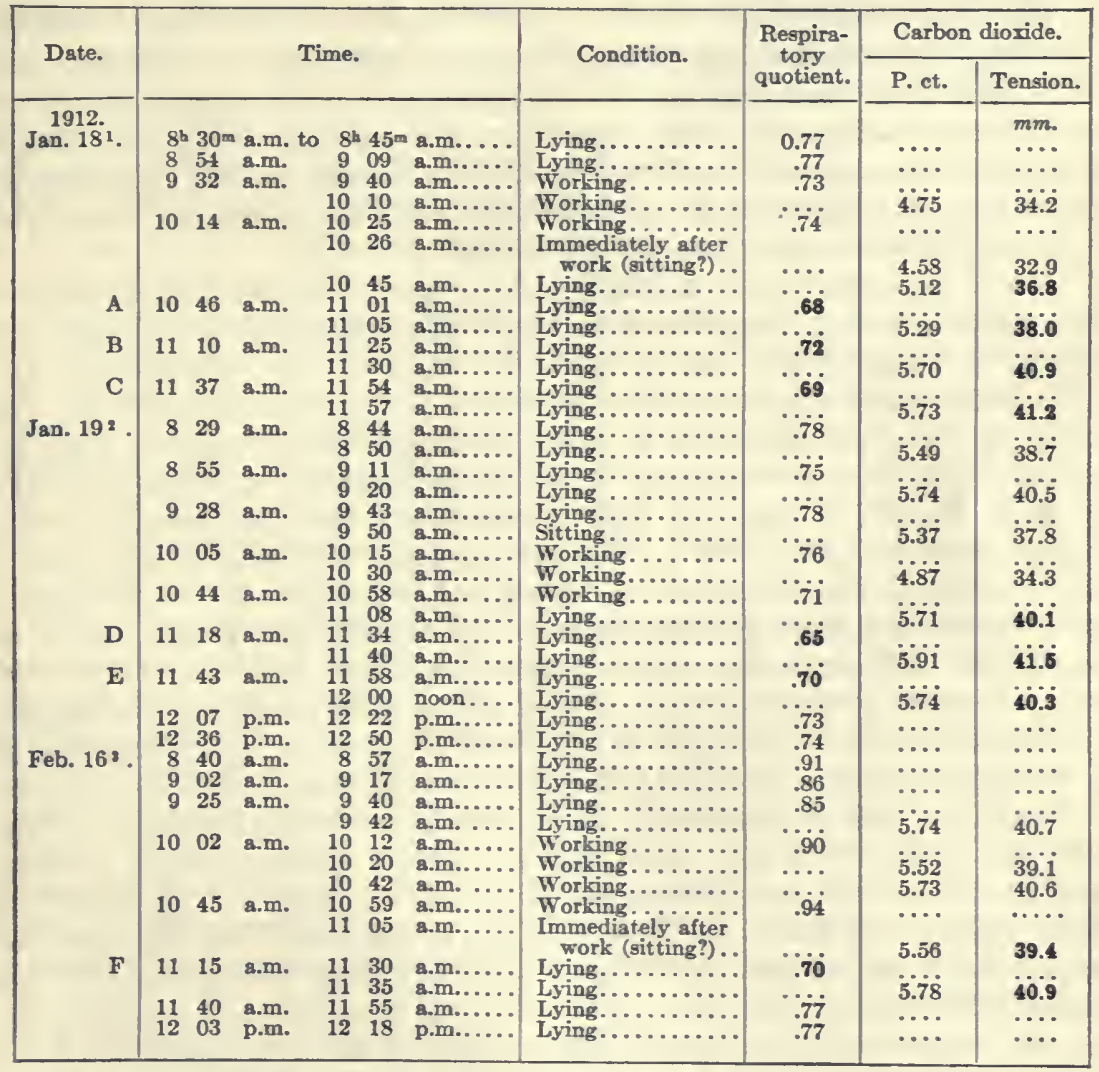
The results for this day are post-sbsorptive values as usual but following 2 days with carbohydrate-poor
diet ( 100 grams carbohydrates per day). 2 The results for this day are post-absorptive values as usual but following 3 days with carbohydrate-poor
diet (100 grams carbohydrates per day). 3 The results for this day are post-absorptive values as usual but following 3 days with carbohydrate-rich
diet ( 400 grams carbohydrates per day). 
it would be expected that the carbon dioxide in the alveolar air would also be relatively increased. Accordingly in a number of experiments with the subject M. A. M., samples of the alveolar air were taken at the beginning and end of some of the resting periods following the muscular work and analyzed by Mr. H. L. Higgins for carbon dioxide, the Haldane method being used. ${ }^{a}$ The results are summarized in table 131, together with the respiratory quotients which were obtained at approximately the same time.

By reference to the table, it will be seen that the data are given for six periods following work, these being lettered $\mathrm{A}$ to $\mathrm{F}$. The only period in which there is a marked difference shown between the alveolar carbon dioxide found at the beginning and that found at the end of the period is $\mathrm{B}$, but this difference is not seen in $\mathrm{A}$ or $\mathrm{C}$ for the same day, although the respiratory quotients for these two periods are much lower. The data for D and E, and especially $\mathrm{F}$, also show clearly that the low respiratory quotient following work was not due to a storage of carbon dioxide in the body. Consequently one must look elsewhere for an explanation of these low quotients after work.

\section{COLLAPSE FROM EXCESS OF CARBON DIOXIDE IN THE VENTILATING CURRENT.}

During the first few experiments with this apparatus, two or three subjects shortly after the beginning of the severe riding utterly collapsed. At first we were at a loss to account for this, but it was soon found to be due to an excessive accumulation of carbon dioxide in the system, and the rebreathing by the subject of the carbon-dioxide rich air; measures were therefore immediately taken to remedy this defect.

One of the experiments in which this collapse occurred was that of November 22, 1911, with the subject J. E. F. The first three rest periods were uneventful, the pulse-rate averaging 59 per minute. The subject then rode the bicycle ergometer for some 20 minutes before the pulse-rate became reasonably regular at 122 per minute. After the mouth was placed to the mouthpiece and the valve was turned, he collapsed within 2 minutes. His face became pallid, almost cyanotic; he broke out into a cold sweat, and the pulserate rose suddenly from 124 to 184 per minute. The subject was neither able to retain the mouthpiece in the mouth nor to keep his feet on the pedals, having completely lost muscular control. As quickly as possible he was removed from the ergometer, placed upon the couch and allowed to rest. Twenty minutes later, the pulse-rate had almost returned to the normal and he reported himself as being quite comfortable. Indeed, somewhat later he was ready for a work experiment which was carried out without inconvenience.

Two days later, November 24,1911 , the same subject attempted another experiment. As in the first experiment, the three resting-periods were uneventful. After 10 minutes of preliminary work upon the bicycle ergometer, with an average per minute of 59 revolutions, it was found that the pulse-rate was regular at about 124 . The first work experiment was then begun and lasted approximately 10 minutes, the work being done at the rate of 57 revolutions per minute. The pulse-rate rose to 146 and the respiration-rate to 24 , but no abnormalities were noted. Ten minutes after the conclusion of the first period, a second period was begun, but within 4 minutes the subject showed all the symptoms of collapse, including pallor, gasping, lack of muscular con-

a Haldane and Priestley, Journ. Physiol., 1905, 32, p. 225. 
trol of the hands, feet, and lips, cold sweat, giddiness, and rapid pulse-rate. The symptoms developed very suddenly, as the subject said before the beginning of the period that he felt perfectly well, this statement being corroborated by the fact that the pulse- and respiration-rates had both fallen in the intermission between the two working periods. He was immediately transferred to the couch and after 14 minutes was found to be in extremely good condition, the pulse-rate having fallen to 72 and the respiration-rate to 11 per minute. As it was thought that the subject might have a weak heart, an examination was made by E. P. C., who found no evidence of this. A confirmatory examination was made by Prof. D. L. Edsall who was at that time working in the Nutrition Laboratory, and his findings were also negative.

The experiment on December 13, 1911, with the professional subject M. A. M., likewise has an interest in this connection. The three restingperiods were without incident, as were also the three periods in which the subject rode without load. At $11^{\text {h }} 05^{\mathrm{m}}$ a.m., the current was passed through the magnet and the work period began at $11^{\mathrm{h}} 21^{\mathrm{m}}$ a.m. The subject reported that he found moving the wheel with resistance very hard work, the effort required being more like that necessary for hill-climbing than for track-racing. One record of the pulse-rate made during the work showed 116 beats per minute. Soon after the period began, the subject looked flushed; a few minutes afterwards he perspired freely, and at $11^{\mathrm{h}} 25^{\mathrm{m}}$ a.m. he was obliged to discontinue his efforts as he was on the point of collapse. In appearance he was wild and scared, his face was pallid, his mouth twitching, and he had lost the control of his muscles, being unable to grasp the handle bars or to speak when he stopped.

The subject said that although he had collapsed in races, yet he had never felt so ill as he did at this time. He was much chagrined at his failure to continue and in order to convince the observers that the apparatus and not he was at fault, he again commenced riding, assuming what he called his "racing position," in which he lay over the handle-bars with his arms well back. With apparent ease and certainly without signs of collapse, he made 138 to 140 revolutions of the wheel per minute. In this test he did not breathe through the mouthpiece.

On the next day (December 14), the amount of work performed in the experiment was controlled by using a metronome, so as to restrict the subject to but 60 revolutions per minute. Before the experimental period began, the subject rode for a preliminary period of 22 minutes. Throughout the working period, while breathing through the apparatus, he was bathed in perspiration and at the end of 10 minutes signalled that he could not continue; he began to sway in his seat, and the experiment was immediately stopped. The records of the pulse-rate for the working period are extremely interesting. The experimental period began at $10^{\mathrm{h}} 29^{\mathrm{m}}$ a.m.; at $10^{\mathrm{h}} 31^{\mathrm{m}}$ a.m., the pulserate was 124 per minute; at $10^{\mathrm{h}} 33^{\mathrm{m}}$ a.m., it was the same; at $10^{\mathrm{h}} 35^{\mathrm{m}}$ a.m., it had risen to 128 ; at $10^{\mathrm{h}} 37^{\mathrm{m}}$ a.m., to 134 ; at $10^{\mathrm{h}} 39^{\mathrm{m}}$ a.m., to 142 ; and at $10^{\mathrm{h}} 39^{\mathrm{m}} 30^{\mathrm{s}} \mathrm{a} . \mathrm{m}$. to 152 per minute, at which time he signalled for the experiment to be discontinued. The rapid rise in the pulse-rate is characteristic of impending collapse which was here present.

In a third experiment on December 15, the subject also showed signs of collapse in the third working-period, although the two preceding periods were 
uneventful. The pulse-rate in the third period rose rapidly, the records being: $10^{\mathrm{h}} 50^{\mathrm{m}}$ a.m., $124 ; 10^{\mathrm{h}} 52^{\mathrm{m}}$ a.m., $128 ; 10^{\mathrm{h}} 54^{\mathrm{m}}$ a.m., $130 ; 10^{\mathrm{h}} 56^{\mathrm{m}}$ a.m., 132 ; $10^{\mathrm{h}} 58^{\mathrm{m}}$ a.m., 136 ; at which time the experiment was discontinued.

As the result of a careful examination of the results of the experiments in which the indications of collapse appeared, it was decided that these symptoms were due to an accumulation of carbon dioxide in the ventilating system, caused either by using defective soda-lime or too slow a rate of ventilation. Furthermore, the possible discomfort and strain on the part of the subject in holding his head in the position required by the rigid brass pipe to which the mouthpiece was attached should if possible be avoided. Several modifications were therefore made in the apparatus and in the experimental routine. Since these have already been noted in the description of the apparatus (see p. 29), a brief description will suffice here.

To insure complete absorption of the carbon dioxide by the soda-lime, the composition of this absorbent was somewhat modified in accordance with the results of a series of experiments which had recently been made for testing it; furthermore, two soda-lime containers were used in series so that any carbon dioxide which might pass the first container would be completely absorbed in the second; finally, the efficiency of the soda-lime was tested in every experiment by deflecting a small part of the air-current after it passed the carbon-dioxide absorbers and sending it through a solution of barium hydroxide before returning it to the system, the presence of excess carbon dioxide being readily detected by this method. Since it was found that the rate of ventilation was not rapid enough to remove the expired air as fast as the subject breathed into the pipe, a larger pulley was placed upon the armature shaft of the motor by means of which the rate of ventilation was increased from 35 to 60 liters and later to 85 liters per minute, this being found amply sufficient. To give more freedom of movement for the head in riding, a flexible tube was attached to the valve-piece through which the subject breathed. As this addition increased the dead air-space, a supplementary piece of rubber tubing was attached and the air-current was deflected through this so that it passed directly by the mouthpiece, thus eliminating the possible effect on the respiration of so large a dead air-space. This modification of the apparatus is clearly shown in fig. 3, page 29. After these changes in the apparatus and in the experimental routine had been made, practically all of the experiments were performed without any indications of collapse except on one or two occasions when the subject suffered some distress owing to the use of a defective soda lime bottle.

In the so-called fatigue experiment with M. A. M. on March 15, a collapse seemed imminent, although not actually occurring; this, however, was not in any way due to the presence of excess carbon dioxide in the ventilating system or to deficient ventilation, for not only was the absence of carbon dioxide proved by the barium hydroxide test but the amount of oxygen in the air was determined and found to be 22.5 per cent. The impending collapse was unquestionably due to the excessive muscular activity and the onset of fatigue.

Possible criticism may be made that the collapse in the earlier experiments was due not to an accumulation of carbon dioxide in the system but to a lack of oxygen. This was not true, as an analysis of the air in the apparatus 
after each experiment showed that there was a sufficient supply of oxygen to meet the needs of the subject.

The observations of the pulse-rate in the experiments in which this collapse occurred are particularly noteworthy, the pulse rising in at least one experiment from 124 to 184 per minute inside of 2 minutes. Although the unusual conditions under which these pulse-rates were obtained do not make for the highest degree of accuracy, the records are not far from the actual values at the time the observations were made, as special care was taken to secure accurate records.

\section{PULSE-RATE.}

The intimate relationship between the pulse-rate and the muscular activity, or the degree of muscular rest, which has been observed so frequently in this laboratory not only with normal individuals but with pathological cases, with athletes and, indeed, with infants, emphasizes the importance of securing accurate records of the pulse-rate as an integral part of each experiment. When the subject is lying quietly on the couch, this may readily be done by means of a Bowles stethoscope lightly attached to the chest. During severe muscular work, however, these records were much more difficult to secure, and counts were therefore made of the radial pulse. When the subject rode at a high rate of speed with considerable lateral motion, accurate records even of the radial pulse were difficult to make so that only an experienced observer could be relied upon for these; accordingly, the records of the radial pulse were almost invariably taken by one of us (E. P. C.). Unfortunately, while the values obtained for the rest periods and subsequent to the work give admirable indications of the pulse-rate of the subject when at

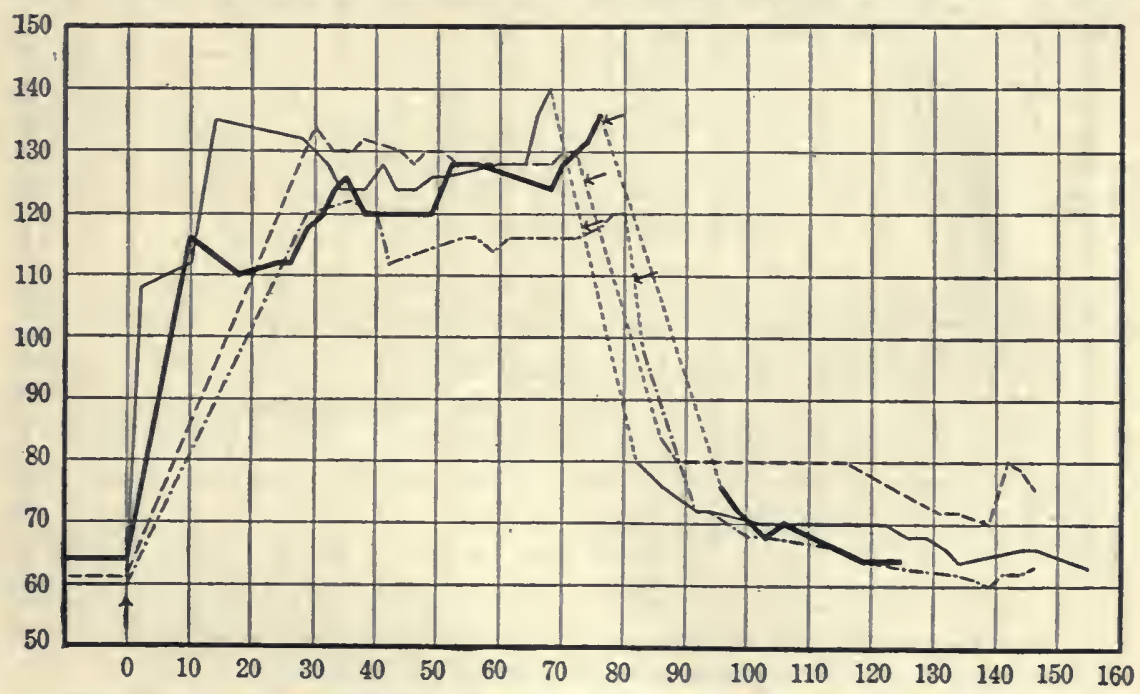

FIG. 6.-Curves showing the pulse-rate when the external muscular work was equivalent to 1.05 calories per minute.

rest, those taken during work, especially if the work were of a high intensity, were of necessity more intermittent and can only be looked upon as general indices of the rate of the heart-beat. It soon became apparent that the pulse- 
rate even during severe muscular work, very closely followed the amount of the energy output, an observation that is fully in accord with the values secured with normal resting subjects which show that the pulse-rate and the total metabolism are intimately related. Although innumerable observations of the pulse-rate were made in this study, it seems unnecessary to report these in detail, and we accordingly give only a few series of pulse-rate observations which were made before, during, and after the work with each of the intensities of muscular work performed.

The values for 4 experiments in which the subject was producing approximately 1.05 calories of external muscular work per minute are indicated by the curves in fig. 6. Before the experiments, when the subject was lying quietly, the pulse-rate was usually not far from 60 to 64 per minute, but after the work began there was a rapid ascent of the pulse-rate until it reached an average not far from 125 per minute with this degree of muscular activity. Immediately on the cessation of work, which is indicated on the chart by arrows, the pulse began to fall, the first observation being invariably many beats per minute less, although there was a distinct tendency for the pulserate after the work to become stationary at a higher level than it was before.

With an external work production of 1.5 calories per minute, the changes in the pulse-rate were even more strikingly marked, as shown by fig. 7 . Here again with an average rate during rest of approximately 64, there was inside of 20 minutes a rise in the pulse-rate to a level of approximately 160

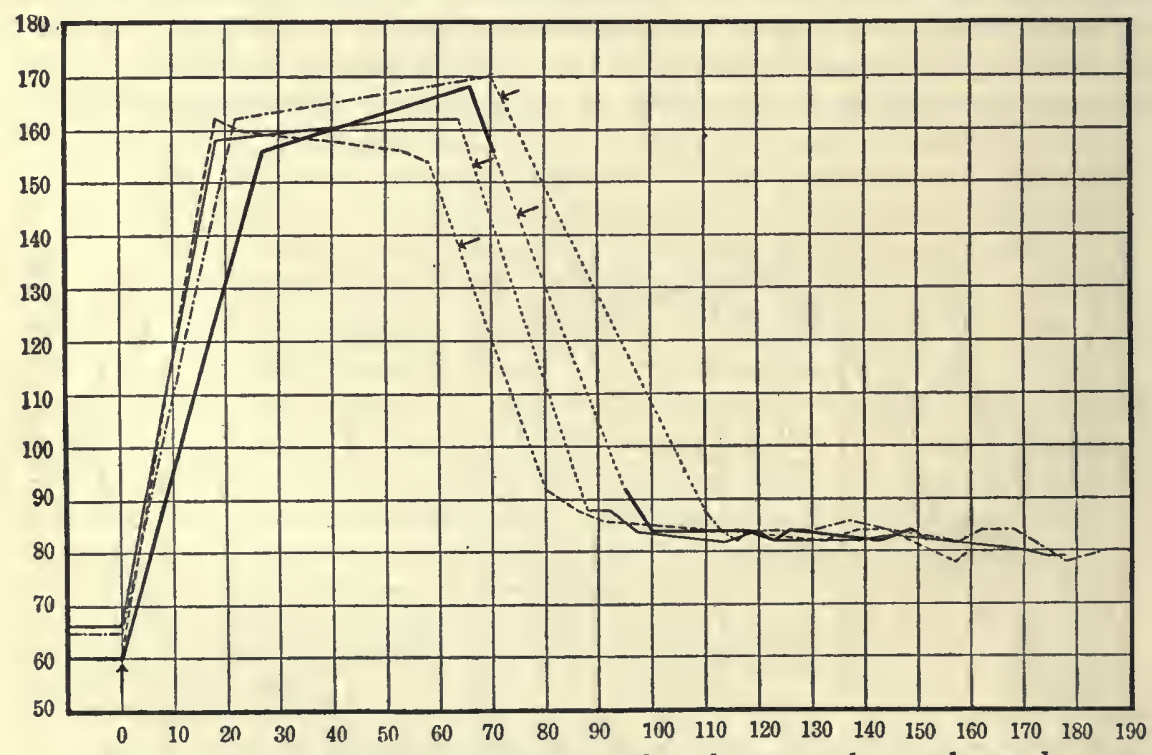

FIG. 7.-Curves showing the pulse-rate when the external muscular work was equivalent to 1.5 calories per minute.

per minute. With the cessation of work, the pulse fell rapidly, and the first values obtained in the rest-period after work were invariably much lower. The tendency for the pulse-rate to stop at a much higher level than before the experiment is even more clearly shown than in fig. 6 , the average level after work for these 4 experiments being not far from 83 beats per minute, as com- 
pared with an initial value before work of 64 per minute. With this intensity of work, therefore, which was nearly 50 per cent greater per minute than that in the experiments shown in fig. 6 , there was an average rise in the pulse-rate from 64 to 160 or approximately 35 beats per minute higher than when the muscular work was 1.05 calories per minute.

The curves for the pulse-rate in 5 experiments in which the external muscular work was 2.0 calories per minute are given in fig. 8 . These values show an average pulse-rate before work of about 60 per minute with an almost immediate rise inside of 15 or 20 minutes to a level of approximately 163,

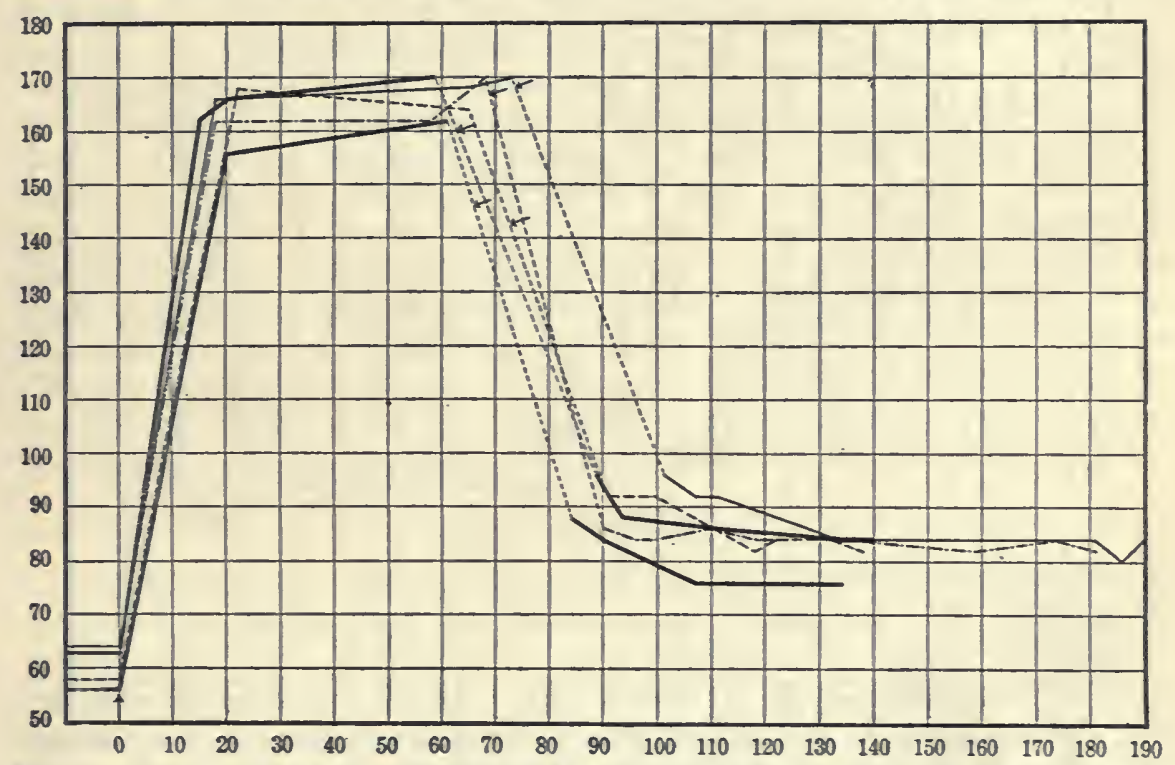

Fia. 8. Curves showing the pulse-rate when the external muscular work was equivalent to 2.0 calories per minute.

which continued throughout the work. After work the pulse-rate fell rapidly but became constant at a distinctly higher level than that before the work began. The average maximum rate, i.e., 163 per minute, is but a little higher than that with 1.5 calories of work.

The average values for the pulse-rate in two experiments in which the external muscular work was 2.25 calories per minute are plotted in fig. 9 . The initial pulse-rate before work averaged as usual about 63 , rising rapidly at the beginning of work, and seeking a level not far from 166, or essentially that with the work at 2 calories per minute. After the work ceased, there was again a rapid fall with a striking tendency for the pulse to remain above the initial level. In view of the single high observation of 180 per minute, it is to be regretted that more observations could not have been obtained during this severe muscular work.

As has already been pointed out, some method other than the radial pulse or the stethoscope must be used during muscular work in order to obtain satisfactory records of the pulse-rate, but these two methods were the only. ones available at the time, since we did not wish to hamper the subject 
with a chest pneumograph and a string galvanometer was not then at our disposal. It is evident, however, that there is here an interesting field for study in the relation between the pulse-rate and the intensity of muscular work.

One of the points clearly brought out in this study of the effect of muscular work on the pulse-rate is the distinct tendency for the pulse to settle

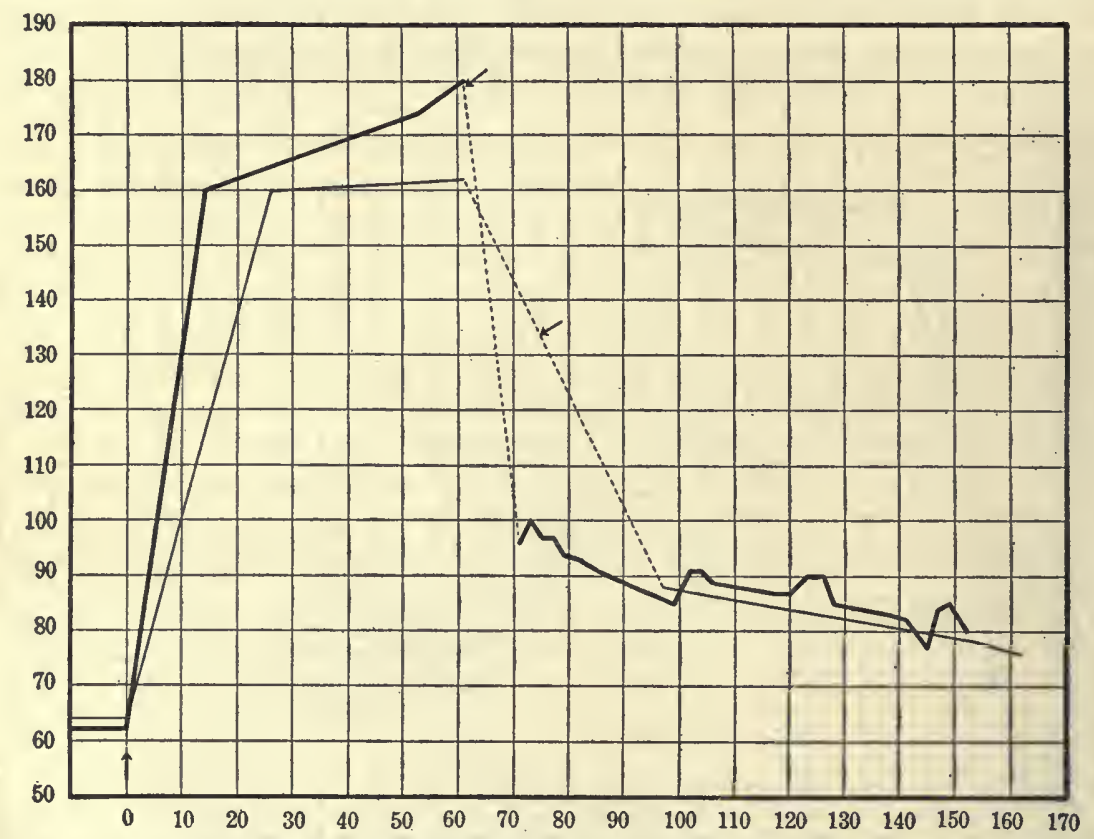

Fig. 9.-Curves showing the pulse-rate when the external muscular work was equivalent to 2.25 calories per minute.

to a much higher level than prior to work. In connection with fig. 8 , it should be noted that the pulse-rate continued on a level higher than the initial values so long as the observations were made, a record of 76 being obtained 361 minutes after the beginning of the work. Following one of the experiments shown on fig. 9 , the high pulse-rate of 70 or over continued up to the 400th minute when the observations were discontinued. This is in complete correlation with the higher metabolism found under these conditions which is discussed elsewhere in this report. ${ }^{a}$ Our results are strikingly at variance with the observations of Cook and Pembrey, ${ }^{b}$ who maintain that with welltrained persons the pulse-rate after a strenuous run rapidly returned not only to the earlier level but actually fell below. Only with poorly trained individuals did the pulse remain high after exercise. Our subject M. A. M. was admirably trained and usually very fit, as the amounts of work done without food amply testify. Inasmuch as in our experiments the pulse-rate showed an even greater tendency towards this persistency in maintaining a higher level after work than did the metabolism, a series of experiments definitely planned to study this interesting point should be made; in this research, 
the pulse-rate observations after work, as well as the body-temperature measurements, were wholly incidental to the major questions being studied, and both the nature of the experiments and the temperament of the subject made it impossible for us to hold him in the laboratory an undue length of time even for securing pulse-rate observations of such interest and value.

While there is a general tendency for the high level of the pulse-rate during severe muscular work to increase as the intensity of the work increases, the values being respectively 125 beats per minute for external muscular work of 1.05 calories, 160 per minute for 1.5 calories, 163 per minute for 2 calories, and 166 for 2.25 calories, the relationship is not so simple as would appear, for in the experiment of March 15, in which the work of about 2 calories per minute was so prolonged and continuous as to produce a condition of fatigue, the observations during the six experimental periods were as follows: At the 34th minute, 128 beats; 40th minute, 130; 78th minute, 128; 125 th minute, $136 ; 174$ th minute, 156 ; and 211 th minute, 160 . While general deductions are not warranted from this single series of observations during prolonged work, yet it is of interest to note that the work in the last three periods became more and more difficult, and in the last period it was necessary to stop work at the end of 7 minutes instead of the usual 10 minutes. The rise in the pulse-rate noted in the previous section as accompanying the condition of collapse is not here discussed since it would be obviously improper to consider in this connection values obtained under such abnormal conditions.

\section{BODY-TEMPERATURE.}

With the special equipment installed in this laboratory ${ }^{a}$ for the accurate measurement of the rectal body-temperature, it was hoped that during this research it would be possible to obtain many records of the body-temperature during severe muscular work. As a matter of fact, observations could be obtained only on three days, December 20,21, and 22, 1911, with subject M. A. M. At the end of this time the subject complained that the thermometer irritated him and rather than jeopardize the whole series of experiments by insisting upon the rectal temperature measurements, they were discontinued.

In but few instances have such measurements been obtained during the actual progress of muscular work, the most extensive series with which we are familiar being that of Benedict and Snell. ${ }^{b}$ In this series, two experiments are reported in which the subject, J. C. W., rode a bicycle ergometer. The results, which are presented in the form of curves, show that there was an immediate rise on beginning work until a maximum temperature was reached which remained essentially constant throughout the working period. After the work was discontinued, the temperature rapidly fell.

The thermometer with which the observations of Benedict and Snell were made was much larger than that employed in this research as in the earlier observations the resistance thermometer principle was used, while with the newer apparatus the records were made by means of the thermal junction only. In our thermal-junction thermometer the connections are covered for some 25 centimeters by a small flexible rubber tube, approximately 3.5

a Benedict and Slack, Carnegie Institution of Washington Publication No. 155, 1911.

$\checkmark$ Benedict and Snell, Pfügers Archiv f. d. ges. Physiol., 1902, 90, p. 33. 
millimeters in diameter. When the subject is at rest, the thermometer is tolerated for hours at a time without the slightest inconvenience; in fact after the thermometer has been inserted for 5 minutes, the subject is usually unconscious of its presence. On the other hand, when the subject is riding at high speed on the bicycle ergometer, more strain is naturally brought upon the sphincter, which increases the possibility of irritation, so that the objection of the subject to the thermometer could be easily understood.

The few observations made were, however, very accurate and representing as they do records obtained during the actual time of severe muscular work, they have a somewhat unusual interest. The results have been plotted in the form of curves shown in fig. 10. In the first experiment of which the curve is shown, that of December 20, the work began about $9^{\mathrm{h}} 30^{\mathrm{m}}$ a.m., the initial record being made at $9^{\mathrm{h}} 35^{\mathrm{m}}$ a.m. Unfortunately no records were taken before the work began. In 20 minutes the temperature steadily rose from $36.39^{\circ}$ C. to $37.08^{\circ}$ C., then gradually mounted until at $10^{\mathrm{h}} 17^{\mathrm{m}}$ a.m. the temperature had reached $37.22^{\circ} \mathrm{C}$. For a period of approximately 20 minutes, the measurements were lost and when resumed, the first observa-

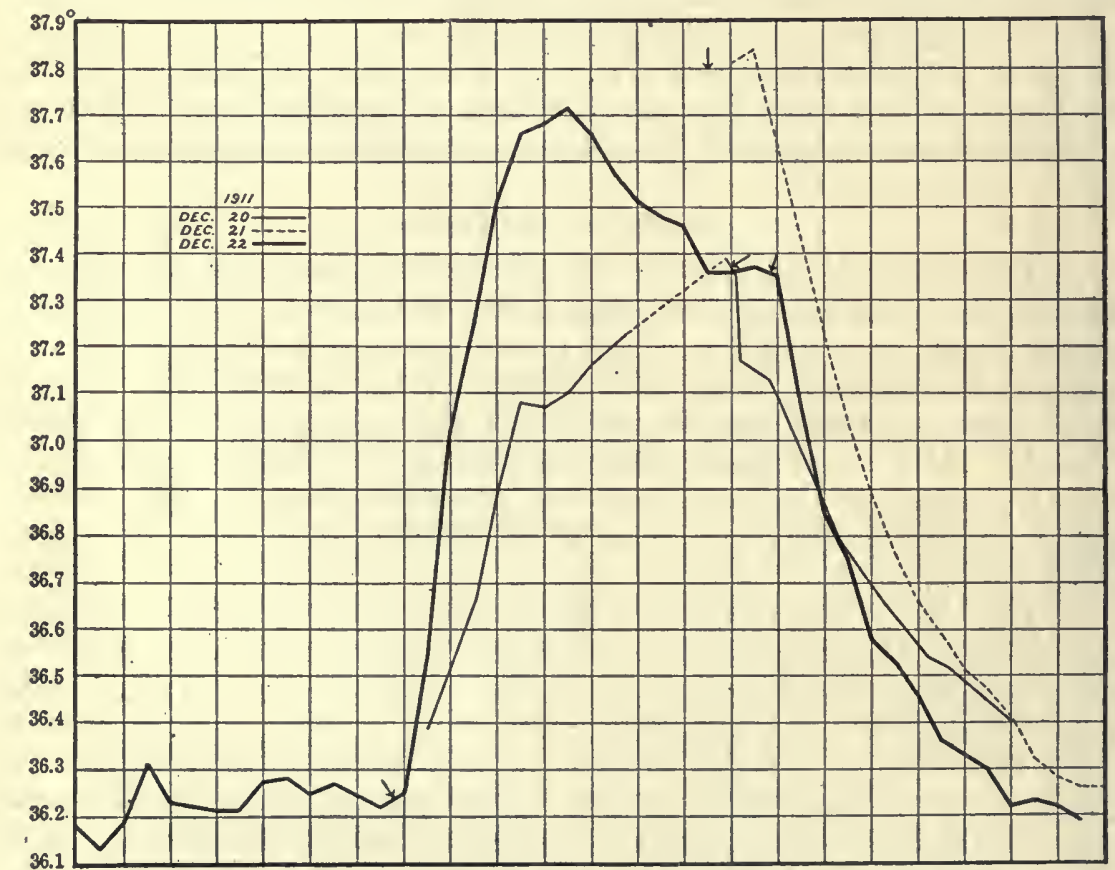

A.M.8.20 8.30 8.40 8.50 9.00 9.10 9.20 9.30 9.40 9.5010.0010.1010.2010.3010.40 10.5011.0011.1011.2011.3011.4011.5012.00

FIG. 10.-Continuous records of the rectal temperature obtained by thermal element during severe muscular work.

The work began about $9^{\mathrm{b}} 30^{\mathrm{m}}$ a.m. and ended as indicated by the group of arrows on the chart.

tion, which was taken just before the work ceased, gave a record of $37.39^{\circ} \mathrm{C}$. After the work there was an immediate rapid fall which persisted until the observations were discontinued at $11^{\mathrm{h}} 40^{\mathrm{m}}$ a.m., at which time the bodytemperature was still falling. Throughout these observations, the subject 
was performing effective muscular work corresponding to approximately 1 calorie per minute, or a total energy output of about 6 calories per minute. It is greatly to be regretted that temperature observations could not have been made at the time the amount of the external muscular work was double that when these records were made.

The observations for the experiment of December 21 include only the records for the body-temperature immediately following the cessation of work. The record obtained shortly after the work ended, i. e., $37.84^{\circ}$ C. at $10^{\mathrm{h}} 45^{\mathrm{m}}$ a.m., is the highest record secured for any of the experiments. The rapid persistent fall in temperature amounted to nearly $1.6^{\circ} \mathrm{C}$. inside of an hour. As will be seen by the curve, the body-temperature was assuming a constant level when the observations were discontinued.

The most complete-series of records obtained in the three experiments was that for December 22, which included observations before, during, and after work, the thermometer being kept in the rectum throughout the whole period of work. In the rest-periods when the subject lay upon the couch, the temperature in the rectum was reasonably constant at $36.25^{\circ} \mathrm{C}$. The work began at $9^{\mathrm{h}} 28^{\mathrm{m}}$ a.m., and in 7 minutes the temperature had risen rapidly, this rise continuing at almost the same rate until $9^{\mathrm{h}} 55^{\mathrm{m}}$ a.m., or 27 minutes after the work began, when the thermometer registered $37.66^{\circ} \mathrm{C}$., representing an increase in the body-temperature of $1.4^{\circ} \mathrm{C}$. This very high temperature was not maintained, however, for as the work progressed, there was a slight falling off, with a tendency to assume a level at $37.36^{\circ} \mathrm{C}$. The subject stopped working at $10^{\mathrm{h}} 50^{\mathrm{m}}$ a.m., and the characteristic rapid fall in temperature after work is again shown in this curve, the temperature ultimately reaching approximately the level shown for the observations prior to the work.

The laboratory protocols for the experiment of December 22 have a special interest in this connection. They show that when the subject began working at $9^{\mathrm{h}} 28^{\mathrm{m}}$ a.m., he worked very hard and as rapidly as possible until $9^{\mathrm{h}} 53^{\mathrm{m}}$ a.m. Unfortunately no record of the number of revolutions was obtained as the registering counter broke shortly after the work was begun. At $9^{\mathrm{b}} 53^{\mathrm{m}}$ a.m. the subject without stopping adjusted the rate of riding to 60 revolutions per minute. Singularly enough, this experiment is one in which the impending collapse appeared, so that at $10^{\mathrm{h}} 10^{\mathrm{m}}$ a.m. it was necessary for him to remove his mouth from the mouthpiece of the respiration apparatus. After an intermission of about 3 minutes, he resumed work, the rate throughout the rest of the experiment being essentially 58 to 60 revolutions per minute. It is thus seen that the rapid work at the beginning raised the body-temperature to the highest point, and that the falling off shown by the curve later was actually coincident with a considerable diminution in the amount of work done.

It will be noted that all of these values were taken deep in the rectum with a very sensitive thermometer, giving accurate measurements to $0.01^{\circ} \mathrm{C}$. The difficulties incidental to measuring the body-temperature of athletes during severe exercise have often been pointed out, and bicycle riding appears to offer the most ideal conditions for studying the influence of muscular activity on body-temperature. From the results obtained with two subjects in earlier observations, we have no reason to believe that a study of body- 
temperature by this method is not entirely practicable. On the other hand it did not seem wise to endanger the success of the research by attempting to overcome the idiosyncrasy of this individual subject in order to obtain observations which were at that time distinctly of secondary importance.

\section{THE MAXIMUM WORKING CAPACITY OF MAN.}

It is a well known fact that men are capable of intense muscular exertion for short periods, and that the intensity of the work is in general inversely proportional to the length of time through which it must be carried out. On this principle is based all the systems of training for short distances or long distances in running races. The results of our experiments throw an interesting light upon the possible maximum working capacity of man in periods ranging from one to four hours, and hence they are worthy of consideration from this point of view.

In discussing the maximum working capacity of man, R. C. Carpenter ${ }^{a}$ has tabulated the results of several computations regarding the average energy equivalent of the work of a man. Of these, the first four are particularly interesting in this connection since they give the energy equivalent of bicycle riding over periods of 10,15 , and 96 seconds, and 1 hour, respectively. These have been recomputed on the basis of calories per minute, and are given in table 132.

TABLE 132.-Energy equivalent of the work done on bicycle riding as reported by $R$. C. Carpenter. ${ }^{1}$

\begin{tabular}{|c|c|}
\hline Time. & $\begin{array}{c}\text { Effective } \\
\text { muscular } \\
\text { work per } \\
\text { minute. }\end{array}$ \\
\hline 10 seconds......... & cals. \\
15 seconds........ & 2.94 \\
96 seconds....... & 2.83 \\
1 hour........ & 1.94 \\
\hline
\end{tabular}

1 Recomputed by us from values given in foot pounds, 3,088 foot pounds being equal to 1 calorie.

In the data presented by Carpenter, we find that the professional subject C. W. M. in a 6-day bicycle race rode an average of 20.77 hours per day for 5 days, and accomplished, according to Carpenter's computations, 3,366 calories of external muscular work per day. This corresponds to 2.70 calories per minute, a value considerably better than that given in table 132 for 1 hour. It should be borne in mind that this value, as well as the values in table 132, are derived from computations of the effective muscular work performed, no direct measurements being possible. Our professional subject M. A. M., who had personally participated in 6-day races, agreed fully with the subject N. B., previously studied, ${ }^{b}$ that the resistance of the ergometer, which corresponded to an external effective work of approximately 1.6 calories per minute, represented quite closely that incidental to the air and track resistance in a 6-day bicycle race. From our experience in this research, therefore, we have every reason to believe that the values given by $\mathrm{R}$. C. Carpenter are very much too high, the error being due to the inadequate data for computing the amount of work done by the bicyclist. Making certain reservations,

a Atwater, Sherman, and Carpenter, U. S. Dept. Agr., Office Exp. Stas. Bul. 98, ${ }^{\circ 1901, ~ p . ~} 67$.

$b$ Benedict and Carpenter, U. S. Dept. Agr., Office Exp. Stas. Bul. 208, 1909. 
Magnus-Levy, ${ }^{a}$ on the basis of the research of L. Zuntz, ${ }^{b}$ has recomputed the total work performed by the bicycle rider in R. C. Carpenter's report, his results being 20 per cent higher than those computed by Carpenter.

Although for comparison with the results of this research, the data obtained in experiments with bicycle riders are of more value, nevertheless an interesting collection of calculations regarding the maximum work of man has been made by Blix. ${ }^{c}$ Using an ingenious crank dynamograph devised by Sandström, Blix obtained certain results which he compared with those obtained with other forms of severe muscular work. These data have been recomputed by Magnus-Levy on the basis of kilogrammeters, ${ }^{d}$ and for purposes of comparison, we have again recomputed them in terms of calories per minute of effective muscular work, and report them in table 133.

TABLE 133.-Effective muscular work in various forms of activity, as reported by Blix.1

\begin{tabular}{|c|c|c|c|}
\hline Kind of work. & Length of work. & $\begin{array}{r}\text { Effective m } \\
\text { per }\end{array}$ & $\begin{array}{l}\text { scular work } \\
\text { inute. }\end{array}$ \\
\hline 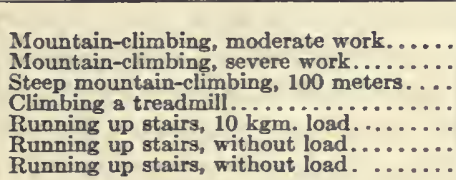 & $\begin{array}{l}\text { Many hours... } \\
1 \text { to } 2 \text { hours... } \\
33 \text { minutes.... } \\
30 \text { seconds..... } \\
15 \text { seconds..... } \\
30 \text { seconds...... } \\
4 \text { seconds..... }\end{array}$ & $\begin{array}{r}\text { kgm. } \\
500 \\
750-1,000 \\
2,000 \\
2,400-3,600 \\
3,700 \\
4,300 \\
5,700-6,000\end{array}$ & $\begin{array}{r}\text { cals. } \\
1.16 \\
1.74-2.33 \\
4.65 \\
5.58-8.37 \\
8.61 \\
10.00 \\
13.26-13.95\end{array}$ \\
\hline
\end{tabular}

1 Recomputed in kilogrammeters by Magnus-Levy, and by us in calories per minute.

While the subject M. A. M. occasionally sprinted for short periods at a speed as great as 198 revolutions per minute, our observations deal almost exclusively with periods in which he worked at a constant rate for not less than 10 minutes and usually for approximately an hour. In such experiments he repeatedly produced 2.3 calories per minute of external muscular work. In discussing the muscular work of mountain-climbing, Magnus-Levy ${ }^{d}$ states that he has often observed a herdsman in the Alps climb up in a direct ascent 800 meters in 1 hour, which he considers is equal to 60,000 kilogrammeters, or 1,000 kilogrammeters per minute, this corresponding to 2.3 calories per minute. It is thus seen that our subject M. A. M., when riding at the rate of 2.3 calories per minute, was performing work equal in amount to the severe work of the herdsman in the Alps; the experimental evidence shows that the subject M. A. M. on certain days maintained approximately this speed for an hour or more.

One of the most striking illustrations of the staying qualities and the endurance of our professional subject is shown in the experiment of March 15, in which the external work performed was at the rate of 2 calories per minute, this rate being kept up without cessation for $41 / 2$ hours. This is the greatest sustained muscular work that we have thus far seen reported, although essentially this amount of work was reported by Benedict and Carpenter ${ }^{e}$ as done by the professional bicycle rider N. B. On October 22, 1904, the subject N. B. rode from 2 p.m. to $4^{\text {h }} 58^{\mathrm{m}}$ p.m., with a preliminary riding period

a Magnus-Levy, Physiologie des Stoffwechsel, in von Noorden's Handbuch der Pathologie des Stoffwechsels, Berlin, 1906, 1, p. 248

b Leo Zuntz, Untersuchungen uber den Gaswechsel und Energieumsatz des Radfahren, Berlin, 1899.

c Blix, Skand. Archiv, 1901, 15, p. 122.

d Magnus-levy, loc. cit., p. 247.

e Benedict and Carpenter, loc. cit., pp. 30 and 31. 
of about 1 hour, the total period of muscular activity being approximately one hour less than that of the professional subject M. A. M. in the experiment of March 15 previously referred to. On the other hand, it should be stated that, in the case of N. B., the riding followed a substantial meal while all of the experiments with M. A. M. were made without food, the beginning of work in all cases being not less than 12 hours after the last meal. It is thus seen that in the experiment with M. A. M. on March 15, when the riding periods ended, the subject had been without food in the" stomach for at least 18 hours. As shown elsewhere in this report, ${ }^{a}$ the amount of work done during this time has been computed as probably being equivalent to not less than a 100-mile bicycle ride over ordinary roads, $i$. $e$. , a "century run" before breakfast.

As already noted, the mechanical efficiency does not vary greatly with different subjects; hence, instead of comparing the amount of work done, it is possible and quite logical to compare the amounts of oxygen consumed or the heat production computed indirectly for different individuals. Thus the great error due to the inability to calculate correctly the amount of external muscular work performed is eliminated in these comparisons. The oxygen consumption during severe muscular work has been determined in a number of instances and the results have been tabulated in table 134. All of these determinations were made by the Zuntz method and by Zuntz, or Durig, or their associates.

TABLE 134.-Comparison of the oxygen consumption during various forms of muscular work, as determined by the Zuntz method.

\begin{tabular}{|c|c|c|c|c|c|}
\hline Name of subject. & Kind of work. & $\begin{array}{l}\text { Oxygen } \\
\text { consump- } \\
\text { tion per } \\
\text { minute. }\end{array}$ & Name of subject. & Irind of work. & $\begin{array}{l}\text { Oxygen } \\
\text { consump- } \\
\text { tion per } \\
\text { minute. }\end{array}$ \\
\hline 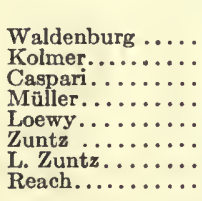 & 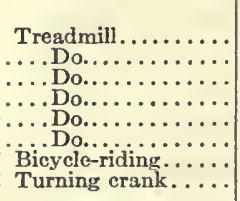 & $\begin{array}{c}\text { c.c. } \\
1,539 \\
2,280 \\
2,037 \\
2,194 \\
1,863 \\
1,542 \\
2,307 \\
1,197\end{array}$ & 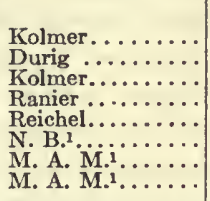 & 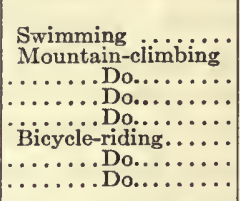 & $\begin{array}{r}c . c . \\
2,318 \\
2,245 \\
2,662 \\
2,584 \\
2,674 \\
\mathbf{2}, 130 \\
2,000 \\
\mathbf{2}, 850\end{array}$ \\
\hline
\end{tabular}

1 For comparison we give three values obtained on the bicycle ergometer.

2 For 15 minutes.

3 For 1 hour 10 minutes.

It is thus clear by every method of comparison that the subject M. A. M. performed an extraordinary amount of work and that his metabolism was elevated to an abnormally high degree. When it is considered that this high elevation persisted not simply for experimental periods of a few seconds or even 15 minutes, but for an hour or more, and that these long experiments were carried out by the subject without food in the stomach, it will be seen that this subject not only had great strength but very great endurance, and that the amount of work performed was considerably greater than that done in the most active mountain-climbing. 


\section{THE AFTER-EFFECTS OF MUSCULAR WORK.}

The long-continued rapidity of respiration and heart-beat after exercise, as, for instance, after running, is familiar evidence that the intense metabolism incidental to active muscular work does not instantly disappear with the cessation of the work. One of the earliest observers on this point is Vierordt ${ }^{a}$ who has said: "Es ist folglich die körperliche Bewegung von sehr grossem und nachhaltendem Einflusse auf die Ausscheidung der Kohlensäure." Later, Edward Smith, ${ }^{b}$ in his discussion of the after-effects of work on respiration, wrote: "It is evident that whilst there is, during the whole interval of rest, an increase in the respiratory changes over that of rest apart from this exertion, the great excess due to the exertion disappears after 5 minutes' rest."

The first accurate measurements of the increased metabolism following muscular work were reported by Speck, ${ }^{c}$ who, recognizing a definite relationship between pulse and metabolism, states in the report of one of his experiments that the pulse-rate, after muscular activity sufficient to bring it to 160 beats per minute, had only dropped to 96 beats per minute in a period of 24 minutes after the exercise had ceased. In discussing the fact that he always found increased carbon-dioxide production and oxygen consumption long after the cessation of work, Speck expressed the belief that the increase in the carbon dioxide expired cannot be due simply to the increased production during the few minutes of work, but that this increase in the formation of carbon dioxide must continue throughout the 20 or 25 minutes after work in which the greater output is observed.

In reporting the muscular-work experiments with the respiration chamber at Wesleyan University, Middletown, Connecticut, Atwater, Woods, and Benedict, ${ }^{,}$commenting upon the results following a work experiment, state that a rest-period of 6 hours was sufficient to bring the elimination of carbon dioxide again to the normal, even after a period of hard muscular work in which the production of carbon dioxide amounted at times to 500 grams in 6 hours. An examination of the results shows that the data are not so recorded as to permit this comparison, for the period preceding sleep included the whole time between 3 p.m. and 9 p.m., although the work unquestionably ended about 6 p.m. The first rest-period for comparison would thus be the period from 9 p.m. to $3 \mathrm{a} . \mathrm{m}$. whereas the work had actually ceased some 3 or 4 hours previous. The after-effect of the work would obviously have been greater between 6 p.m. and 9 p.m., but this would not be shown by the results since the data would be included in the values given for the work-period.

In subsequent publications from Wesleyan University, the after-effects of muscular activity were markedly shown; a summary of these results has been prepared and discussed by Benedict and Carpenter. ${ }^{e}$ Computing the heat production during sleep from 1 a.m. to 7 a.m. following different conditions of activity, they find the averages given in table 135. The work performed consisted of riding one of the various types of the bicycle ergometer used in that laboratory, the moderate work ranging from 130 to 280 calories

\footnotetext{
a Vierordt, Physiologie des Athmens, Karlsruhe, 1845, p. 100.

b Smith, Phil. Trans., 1859, 149, p. 711.

c Speck, Physiologie des menschlichen Athmens, Leipsic, 1892, p. 85. A summary is given of earlier papers.

d Atwater, Woods, and Benedict, U. S. Dept. Agr., Office Exp. Stas., Bul. 44, 1897, p. 52.

e Benedict and Carpenter, Carnegie Institution of Washington Publication No. 126, 1910, p. 193.
} 
for each day, and the severe work from 420 to 660 calories. In the very severe work experiment, the riding period began at $8^{\mathrm{h}} 01^{\mathrm{m}} \mathrm{a} . \mathrm{m}$. of the first day and ended at $3^{\mathrm{h}} 01^{\mathrm{m}}$ a.m. of the following. During this time the subject rode the bicycle ergometer approximately 11 hours in all, ${ }^{a}$ the heat equivalent of the muscular work being 957 calories. $^{b}$ When he stopped work at $3^{\mathrm{h}} 01^{\mathrm{m}}$ a.m., he changed his underclothes and lay down; the observer reported him to be asleep at $3^{\mathrm{h}} 20^{\mathrm{m}}$ a.m., the measurements of the metabolism after work given in table 135 beginning at 4 a.m. The influence of the preceding muscular activity on the metabolism is strikingly shown in these results.

TABLE 135.- Heat produced during sleep (1 a.m. to 7 a.m.) following different conditions of activity, as reported by Benedict and Carpenter. ${ }^{1}$

[Average per hour.]

\begin{tabular}{|c|c|c|c|c|}
\hline Subfect. & $\begin{array}{l}\text { Sleep } \\
\text { after } \\
\text { rest. }\end{array}$ & $\begin{array}{c}\text { Sleep } \\
\text { after } \\
\text { moderate } \\
\text { work. }\end{array}$ & $\begin{array}{l}\text { Sleep } \\
\text { after } \\
\text { severe } \\
\text { work. }\end{array}$ & $\begin{array}{l}\text { Sleep } \\
\text { after } \\
\text { very } \\
\text { severe } \\
\text { work. }\end{array}$ \\
\hline $\begin{array}{l}\text { E. O. } \cdots \\
\text { J F. S. } \\
\text { J. C. W... } \\
\text { B. F. D... } \\
\text { A. L. L... }\end{array}$ & $\begin{array}{l}\text { cals. } \\
69.3 \\
60.4 \\
77.2 \\
69.8 \\
78.3\end{array}$ & $\begin{array}{l}\text { cals. } \\
74.8 \\
65.3 \\
\ldots \ldots \\
\cdots \ldots\end{array}$ & \begin{tabular}{l} 
cals. \\
$\ldots \ldots$. \\
\hdashline 33.1 \\
83.3 \\
83.7
\end{tabular} & $\begin{array}{l}\text { cals. } \\
\ldots \ldots \\
\ldots \ldots \\
\dddot{97.9}\end{array}$ \\
\hline
\end{tabular}

1 All work ceased at least 7 hours before metabolism measurements began except in the case of the very_severe work in which work ceased but 1 hour before.

According to data presented for the subject J. C. W. by Benedict and Carpenter, ${ }^{c}$ the average heat production from 1 a.m. to 7 a.m. with food at rest was 449 calories. The data of the work experiments with this subject ${ }^{d}$ show that the amount of external muscular work was equivalent to approximately 586 calories per day, the calorie output in the 6 experiments from 1 a.m. to 7 a.m. being as follows: $528,527,534,475,503,487$, with an average for the 6 experiments of 509 calories. This represents an increment over the resting value of 60 calories or about 13 per cent, that is, during the period which began at least 7 or 8 hours after the muscular work had finished, the metabolism was still some 13 per cent above the normal. Aside from the experiment with A. L. L., none of these work experiments can be considered as a severe draft upon the subjects. The work was done easily, particularly by J. C. W., who was a college champion and an excellent amateur athlete. The muscular activity cannot therefore be considered as at all fatiguing or done under abnormal conditions.

In strong contrast with the results found in the Middletown respiration apparatus are those almost invariably ${ }^{e}$ reported by the investigators of the Zuntz school. The most recent and complete digest of the opinions of these workers is that which has been given by Loewy. Loewy ${ }^{f}$ contends that the increase in the oxygen consumption during the whole period following work is approximately equal to the total consumption during one minute of the work-

a Benedict and Milner, U. S. Dept. Agr., Office Exp. Stas. Bul, 175, 1907, p. 105.

- Benedict and Milner, loc. cit., p. 333 .

c Benedict and Carpenter, U. S. Dept. Agr., Office Exp. Stas., Bul. 208, 1909, p. 22.

a Benedict and Milner, U. S. Dept. Agr., Office Exp. Stas. Bul. 175, po. 332 and 307.

a Benedict and Milner, U. S. Dept. Agr., Office Exp. Stas. Bul. 175, pp. 332 and 307 . die Respiration in groesseren Hoehen. Skand. Archiv, 1913, 29, p. 133) in which they give more marked results than any that they have hitherto published.

foewy, in Oppenheimer's Handbuch der Biochemie, Jena, 1911, 4, (1), p. 263. 
ing-period, but points out that this holds true only when the work is done easily and without fatigue. Under conditions of fatigue, he maintains that the consumption of oxygen during the whole after-period following work may amount to the total oxygen consumption during 2 or 3 minutes of the workperiod, and concludes that the high values found by Speck were due to fatiguing work.

In experimenting on dogs, Porges and Pribram ${ }^{a}$ studied the gas-exchange following the cessation of work. After citing the after-effects of work on metabolism as found by Speck, Katzenstein, Loewy, Lehmann and Zuntz, Zuntz and Schumburg, Zuntz, Loewy, Müller and Caspari with men, and Zuntz and Lehmann as well as Zuntz and Hagemann with horses, they report the results secured with their dog and attempt to explain the increased metabolism on the basis of an increased ventilation of the lungs, assuming that each liter of lung ventilation requires an increase of 5 to 10 c.c. in the oxygen consumption. The authors computed the increase in the oxygen consumption incidental to the increase in the ventilation above the normal, and deducting this from the values actually found, they state that the total increase found with their animal corrected for the increase in the lung ventilation did not continue over 1 hour. Inasmuch as they were using a tracheotomized dog, which under conditions of work necessitated an artificial control of the temperature, it is obvious that these experiments were not best adapted for studying the after-effect of work. Undoubtedly there were temperature disturbances which even the artificial method for cooling the animal could not entirely prevent.

The question of the after-effects of muscular work upon metabolism is much more than simply an interesting physiological problem, since it has an important bearing upon the technique of studying metabolism in the bigher mountains. Jaquet ${ }^{b}$ maintains that there is a considerable after-effect of work and believes that until at least 24 hours has elapsed after reaching the high altitude, the subject is not in condition to be examined for the influence of high climate upon metabolism. Hence he recommends that localities should be selected for this kind of research to which the subjects can be carried by a mountain railway, thus eliminating the intense fatigue and excessive muscular strain incidental to climbing with baggage and apparatus to the point selected for the study. It is obvious that in studies of the influence of muscular work on the metabolism, there would be the least objection to the after-effects of the exercise of climbing inasmuch as usually large energy transformations are considered; on the other hand when a study is made of the influence of high altitude per se upon normal resting metabolism, it is a serious question as to whether or no the after-effects of muscular work are not such as to vitiate the results of many of the experiments made on this important point.

To secure definite evidence with regard to the after-effects of work upon metabolism, a large number of experiments were made in connection with this research in which the metabolism in the period following the severe muscular work was studied. The results of these studies have been brought together in table 136, in which are given the metabolism before the work began, the 
character and the amount of the work, and the metabolism measured at stated intervals after the work had ceased. The per minute total calorie output, the carbon-dioxide output, the oxygen consumption, and the respiratory quotient are included, together with the observations of the pulse- and respiration-rates. Naturally the measurements of the oxygen consumption have the greatest interest, since they form an admirable index of the total katabolism, and if corrections are made for the varying calorific equivalents of oxygen based upon the respiratory quotient as determined, the calorie production can be directly computed. One great difficulty with this type of experimenting is the fact that in order to determine accurately the respiratory quotient, exact determinations of the carbon dioxide are necessary, for if a resting period is begun immediately after the severe muscular work, abnormal results for carbon dioxide might be obtained as a result of retained carbon dioxide. ${ }^{a}$

TABLE 136. - Metabolism of subjects lying on the couch without food before and after work.

[The subject of the experiment of Nov. 21, 1911, was H. L. H.; of Nov. 23, 1911, E. P. C. and of the remaining experiments, M. A. M. Figures in italics represent duration of work, heat equivalent of work, and the oxygen consumption per minute during the last period of work.]

\begin{tabular}{|c|c|c|c|c|c|c|c|c|c|c|c|c|c|c|}
\hline \multirow{3}{*}{ Date. } & \multirow{3}{*}{$\begin{array}{l}\text { Elapsed } \\
\text { time } \\
\text { from } \\
\text { end of } \\
\text { work to } \\
\text { begin- } \\
\text { ning of } \\
\text { period. }\end{array}$} & \multicolumn{3}{|c|}{$\begin{array}{l}\text { Carbon dioxide } \\
\text { eliminated. }\end{array}$} & \multicolumn{3}{|c|}{$\begin{array}{l}\text { Oxygen } \\
\text { absorbed. }\end{array}$} & \multicolumn{2}{|c|}{$\begin{array}{c}\text { Heat } \\
\text { output } \\
\text { (computed). }\end{array}$} & \multirow{3}{*}{$\begin{array}{l}\text { Res- } \\
\text { pira- } \\
\text { tory } \\
\text { quo- } \\
\text { tient. }\end{array}$} & \multicolumn{3}{|c|}{ Pulse-rate. } & \multirow{3}{*}{$\begin{array}{l}\text { Res- } \\
\text { pira- } \\
\text { tion- } \\
\text { rate } \\
\text { per } \\
\text { min- } \\
\text { ute. }\end{array}$} \\
\hline & & \multirow{2}{*}{$\begin{array}{c}\text { Per } \\
\text { min. }\end{array}$} & \multicolumn{2}{|c|}{$\begin{array}{c}\text { Increase } \\
\text { after work. }\end{array}$} & \multirow{2}{*}{$\begin{array}{l}\text { Per } \\
\text { min. }\end{array}$} & \multicolumn{2}{|c|}{$\begin{array}{l}\text { Increase } \\
\text { after work. }\end{array}$} & \multirow{2}{*}{$\begin{array}{l}\text { Per } \\
\text { min. }\end{array}$} & \multirow{2}{*}{$\begin{array}{l}\text { In- } \\
\text { crease } \\
\text { after } \\
\text { work. }\end{array}$} & & \multirow{2}{*}{$\begin{array}{l}\text { Per } \\
\text { min. }\end{array}$} & \multicolumn{2}{|c|}{$\begin{array}{l}\text { Increase } \\
\text { after work. }\end{array}$} & \\
\hline & & & Amt. & P. ct. & & Amt. & P. ct. & & & & & Amt. & P. et. & \\
\hline \multirow[t]{2}{*}{$\begin{array}{l}\text { 1911. } \\
\text { Nov. } 21\end{array}$} & & $\begin{array}{l}\text { c.c. } \\
213\end{array}$ & $\begin{array}{l}\text { c.c. } \\
\cdots\end{array}$ & & c.c. & c.c. & & $\begin{array}{l}\text { cals. } \\
1.18\end{array}$ & $\begin{array}{l}p . c t . \\
\cdots\end{array}$ & 0.89 & 71 & .. & & 15 \\
\hline & $37 \mathrm{~min}$. & 198 & -15 & -7.0 & $\begin{array}{l}\text { Work: } \\
259\end{array}$ & $\begin{array}{l}65 \mathrm{~m} \\
19\end{array}$ & 7.9 & $\begin{array}{l}\text { cals. } \\
1.23\end{array}$ & $\begin{array}{r}1,754 \\
4.2\end{array}$ & $\begin{array}{l}\text { c.c. } \\
0.77\end{array}$ & 83 & 12 & 16.9 & 16 \\
\hline \multirow[t]{2}{*}{ Nov. 23} & & 169 & & & 211 & & & 1.01 & & .80 & 50 & .. & & 11 \\
\hline & $\begin{array}{l}15 \text { min. } \\
45 \text { min. }\end{array}$ & $\begin{array}{l}190 \\
159\end{array}$ & $\begin{array}{r}21 \\
-10\end{array}$ & $\begin{array}{l}12.4 \\
-5.9\end{array}$ & $\left|\begin{array}{l}249 \\
225\end{array}\right|$ & $\begin{array}{l}38 \\
14\end{array}$ & $\begin{array}{r}18.0 \\
6.6\end{array}$ & $\begin{array}{l}1.18 \\
1.05\end{array}$ & $\begin{array}{r}16.8 \\
4.0\end{array}$ & $\begin{array}{r}0.76 \\
.71\end{array}$ & $\begin{array}{l}58 \\
53\end{array}$ & $\begin{array}{l}8 \\
3\end{array}$ & $\begin{array}{r}16.0 \\
6.0\end{array}$ & $\because$ \\
\hline \multirow[t]{2}{*}{ Dec. 15} & & 200 & $\ldots$ & ... & 250 & $8=$ & & 1.20 & ii & .80 & 64 & .. & $\ldots$ & 23 \\
\hline & $\begin{array}{l}18 \text { min. } \\
42 \text { min. }\end{array}$ & $\begin{array}{l}215 \\
200\end{array}$ & $\begin{array}{l}15 \\
\cdots\end{array}$ & $\begin{array}{l}7.5 \\
\cdots\end{array}$ & $\begin{array}{l}255 \\
252\end{array} \mid$ & $\begin{array}{l}5 \\
2\end{array}$ & $\begin{array}{l}2.0 \\
0.8\end{array}$ & $\begin{array}{l}1.24 \\
1.21\end{array}$ & $\begin{array}{c}3.3 \\
.8\end{array}$ & $\begin{array}{r}0.84 \\
.80\end{array}$ & $\begin{array}{l}71 \\
64\end{array}$ & $\begin{array}{l}7 \\
\cdots\end{array}$ & $\begin{array}{c}10.9 \\
\ldots\end{array}$ & $\begin{array}{l}22 \\
19\end{array}$ \\
\hline \multirow[t]{2}{*}{ Dec. 20} & $\ldots$ & 194 & $\cdots$ & $\cdots$ & 226 & & & 1.10 & $\ddot{i i s}$ & .86 & 63 & ... & $\cdots$ & 19 \\
\hline & $\begin{array}{l}13 \text { min. } \\
34 \text { min. } \\
55 \text { min. }\end{array}$ & $\begin{array}{l}203 \\
192 \\
200\end{array}$ & $\begin{array}{r}9 \\
-2 \\
6\end{array}$ & $\begin{array}{r}4.6 \\
-1.0 \\
3.1\end{array}$ & $\left|\begin{array}{l}258 \\
247 \\
252\end{array}\right|$ & $\begin{array}{l}32 \\
21 \\
26\end{array}$ & $\begin{array}{r}14.2 \\
9.3 \\
11.5\end{array}$ & $\begin{array}{l}1.24 \\
1.18 \\
1.21\end{array}$ & $\begin{array}{l}12.7 \\
7.3 \\
10.0\end{array}$ & $\begin{array}{r}0.79 \\
.78 \\
.80\end{array}$ & $\begin{array}{l}68 \\
62 \\
63\end{array}$ & $\begin{array}{r}5 \\
-1 \\
\cdots\end{array}$ & $\begin{array}{r}7.9 \\
-1.6 \\
\cdots\end{array}$ & $\begin{array}{l}20 \\
20 \\
21\end{array}$ \\
\hline \multirow[t]{2}{*}{ Dec. 21} & & 199 & $\ldots$ & 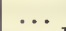 & 231 & & & 1.12 & & .86 & 60 & .. & ... & 18 \\
\hline & $\begin{array}{l}8 \mathrm{~min} . \\
27 \mathrm{~min} . \\
48 \mathrm{~min} \text {. } \\
1 \mathrm{~h} .9 \mathrm{~m} .\end{array}$ & $\begin{array}{l}217 \\
203 \\
196 \\
192\end{array}$ & $\begin{array}{r}18 \\
4 \\
-3 \\
-7\end{array}$ & $\begin{array}{r}9.0 \\
2.0 \\
-1.5 \\
-3.5\end{array}$ & $\begin{array}{l}259 \\
261 \\
247 \\
246\end{array}$ & $\begin{array}{l}2811 \\
30 \\
16 \\
15\end{array}$ & $\begin{array}{r}12.1 \\
13.0 \\
6.9 \\
6.5\end{array}$ & $\begin{array}{l}1.26 \\
1.25 \\
1.18 \\
1.17\end{array}$ & $\begin{array}{r}12.5 \\
11.6 \\
5.4 \\
4.5\end{array}$ & $\begin{array}{r}0.84 \\
.78 \\
.79 \\
.78\end{array}$ & $\begin{array}{l}75 \\
70 \\
67 \\
65\end{array}$ & $\begin{array}{r}15 \\
10 \\
7 \\
5\end{array}$ & \begin{tabular}{r|}
25.0 \\
16.7 \\
11.7 \\
8.3
\end{tabular} & $\begin{array}{l}23 \\
23 \\
20 \\
24\end{array}$ \\
\hline \multirow[t]{2}{*}{ Dec. 22} & ......... & 194 & $\cdots$ & $\ldots$ & 225 & & $\ldots$ & 1.09 & 1855 & .86 & 60 & .. & $\cdots$ & 20 \\
\hline & $\begin{array}{l}10 \text { min. } \\
32 \text { min. } \\
52 \text { min. }\end{array}$ & $\begin{array}{l}225 \\
197 \\
198\end{array}$ & $\begin{array}{r}31 \\
3 \\
4\end{array}$ & $\begin{array}{r}16.0 \\
1.5 \\
2.1\end{array}$ & $\begin{array}{l}253 \\
238 \\
228\end{array}$ & $\begin{array}{r}28 \\
13 \\
3\end{array}$ & $\begin{array}{r}12.4 \\
5.8 \\
1.3\end{array}$ & $\begin{array}{l}1.24 \\
1.15 \\
1.11\end{array}$ & $\begin{array}{r}13.8 \\
5.5 \\
1.8\end{array}$ & $\begin{array}{r}0.89 \\
.83 \\
.87\end{array}$ & $\begin{array}{l}70 \\
64 \\
62\end{array}$ & $\begin{array}{r}10 \\
4 \\
2\end{array}$ & $\begin{array}{r}16.7 \\
6.7 \\
3.3\end{array}$ & $\begin{array}{l}22 \\
20 \\
20\end{array}$ \\
\hline \multirow{2}{*}{$\begin{array}{l}1912 . \\
\text { Jan. } 1\end{array}$} & & 208 & $\ldots$ & & 233 & & & 1.14 & & .89 & 67 & .. & $\ldots$ & 20 \\
\hline & $\begin{array}{l}11 \text { min. } \\
37 \text { min. }\end{array}$ & $\begin{array}{l}224 \\
204\end{array}$ & $\begin{array}{l}16 \\
-4\end{array}$ & $\begin{array}{r}7.7 \\
-1.9\end{array}$ & $\begin{array}{r}268 \\
246\end{array}$ & $\begin{array}{l}35 \\
13\end{array}$ & $\begin{array}{r}15.0 \\
5.6\end{array}$ & $\begin{array}{l}1.30 \\
1.19\end{array}$ & $\begin{array}{r}14.0 \\
4.4\end{array}$ & $\begin{array}{r}0.84 \\
.83\end{array}$ & $\begin{array}{l}81 \\
68\end{array}$ & $\begin{array}{r}14 \\
1\end{array}$ & $\begin{array}{r}20.9 \\
1.5\end{array}$ & $\begin{array}{l}20 \\
20\end{array}$ \\
\hline
\end{tabular}

$a$ See discussion of this point, p. 148. 
TABLE 136. - Metabolism of subjects lying on the couch without food before and after work-Continued.

[Figures in italics represent duration of work, heat equivalent of work, and the oxygen consumption per minute during the last period of work.]

\begin{tabular}{|c|c|c|c|c|c|c|c|c|c|c|c|c|c|c|}
\hline \multirow{3}{*}{ Date. } & \multirow{3}{*}{$\begin{array}{l}\text { Elapsed } \\
\text { time } \\
\text { from } \\
\text { end of } \\
\text { work to } \\
\text { begin- } \\
\text { ning of } \\
\text { period. }\end{array}$} & \multicolumn{3}{|c|}{$\begin{array}{l}\text { Carbon dioxide } \\
\text { eliminated. }\end{array}$} & \multicolumn{3}{|c|}{$\begin{array}{l}\text { Oxygen } \\
\text { sbsorbed. }\end{array}$} & \multicolumn{2}{|c|}{$\begin{array}{c}\text { Heat } \\
\text { output } \\
\text { (computed). }\end{array}$} & \multirow{3}{*}{$\begin{array}{l}\text { Res- } \\
\text { pirs- } \\
\text { tory } \\
\text { quo- } \\
\text { tient. }\end{array}$} & \multicolumn{3}{|c|}{ Pulse-rate. } & \multirow{3}{*}{$\begin{array}{l}\text { Res- } \\
\text { pira- } \\
\text { tion- } \\
\text { rate } \\
\text { per } \\
\text { min- } \\
\text { ute. }\end{array}$} \\
\hline & & \multirow{2}{*}{$\begin{array}{c}\text { Per } \\
\text { min. }\end{array}$} & \multicolumn{2}{|c|}{$\begin{array}{c}\text { Increase } \\
\text { after work. }\end{array}$} & \multirow{2}{*}{ Per } & \multicolumn{2}{|c|}{$\begin{array}{c}\text { Increase } \\
\text { after work. }\end{array}$} & \multirow{2}{*}{$\begin{array}{c}\text { Per } \\
\text { min. }\end{array}$} & \multirow{2}{*}{$\begin{array}{c}\text { In- } \\
\text { crease } \\
\text { after } \\
\text { work. }\end{array}$} & & \multirow{2}{*}{$\begin{array}{l}\text { Per } \\
\text { min. }\end{array}$} & \multicolumn{2}{|c|}{$\begin{array}{l}\text { Increase } \\
\text { after work. }\end{array}$} & \\
\hline & & & Amt. & P. ct. & & Amt. & P. ct. & & & & & Amt. & P. ct. & \\
\hline \multirow[t]{3}{*}{$\begin{array}{l}1912 . \\
\text { Jan. } 2\end{array}$} &. & $\begin{array}{l}c . c . \\
199\end{array}$ & $\begin{array}{l}c . c . \\
\cdots\end{array}$ & - & c.c. & e.c. & & cals. & p.et. & 0.87 & 61 & .. & $\ldots$ & 17 \\
\hline & $10 \mathrm{~min}$. & 223 & 24 & 12.1 & 271 & $\begin{array}{l}732 t \\
39\end{array}$ & 16.8 & cals. & $\begin{array}{c}1,244 \\
15.9\end{array}$ & c.c. 33 & 81 & 20 & 32.8 & 24 \\
\hline & 34 min. & 208 & 9 & $4 . \overline{3}$ & 257 & 25 & 10.8 & 1.24 & 9.7 & .81 & 79 & 18 & 29.5 & 23 \\
\hline Jan. 3 & & 200 & $\cdots$ & ... & 233 & & & 1.13 & & .86 & 60 & .. & $\ldots$ & 19 \\
\hline & 13 min. & 219 & 19 & 9.5 & 257 & $\begin{array}{l}931 \\
54\end{array}$ & in. 11 & 6 csis. & $\begin{array}{l}1,2.48 \\
20.4\end{array}$ & $\begin{array}{l}\text { c.c. } \\
0.76\end{array}$ & 79 & 19 & 31.7 & 22 \\
\hline & 40 min. & 209 & 9 & 4.5 & 277 & 44 & 18.9 & 1.32 & 16.8 & .76 & 77 & 17 & 28.3 & 22 \\
\hline Jan. 4 & & 214 & $\cdots$ & ... & 235 & & & 1.16 & & .91 & 65 & $\cdots$ & $\ldots$ & 20 \\
\hline & 5 min. & 318 & 104 & 48.6 & 416 & 181 & 77.0 & 1.98 & $\begin{array}{l}1 \text { cals. } \\
70.7\end{array}$ & 0.77 & 100 & 35 & 53.8 & 28 \\
\hline - & $36 \mathrm{~min}$. & 215 & $\frac{1}{8}$ & 3.5 & 291 & 56 & 23.8 & 1.38 & 19.0 & .74 & 86 & 21 & 32.3 & 27 \\
\hline & 1h.19m. & 215 & 1 & .5 & 235 & $\begin{array}{l}49 \\
50\end{array}$ & $\begin{array}{l}20.9 \\
21.3\end{array}$ & $\begin{array}{l}1.36 \\
1.35\end{array}$ & $\begin{array}{l}17.2 \\
16.4\end{array}$ & $\begin{array}{l}.78 \\
.76\end{array}$ & 83 & $\begin{array}{l}19 \\
18\end{array}$ & 29.7 & $\begin{array}{l}26 \\
24\end{array}$ \\
\hline & lb. $35 \mathrm{~m}$. & 207 & -7 & -3.3 & 279 & 44 & 18.7 & 1.32 & 13.8 & .74 & 79 & 14 & 21.3 & 24 \\
\hline Jan. 5 & & 213 & $\ldots$ & ... & 233 & & & 1.15 & & .92 & 62 & .. & $\ldots$ & 20 \\
\hline & $5 \mathrm{~min}$. & $30 s$ & 95 & 44.6 & 407 & 174 & $60 \mathrm{mi}$ & a. 10 & 67.8 & 0.76 & 100 & 38 & 61.3 & 29 \\
\hline & $54 \mathrm{~min}$. & 209 & -4 & -1.9 & 311 & 78 & 33.5 & 1.46 & 27.0 & .68 & 88 & 26 & 41.9 & $\begin{array}{l}29 \\
23\end{array}$ \\
\hline & $1 \mathrm{~h} .18 \mathrm{~m}$. & 214 & 1 & .5 & 306 & 73 & 31.3 & 1.44 & 25.2 & .70 & 85 & 23 & 37.1 & 22 \\
\hline & 10.42010. & & & -1.9 & 293 & $\infty 0$ & 25.8 & 1.38 & 20.0 & .82 & sos & & 33.9 & 24 \\
\hline Jan. 8 & & 204 & $\cdots$ & 1 & 232 & $6 \ddot{8} \mathrm{mi}$ & $\cdots$ & 1.13 & 1980 & .88 & 59 & .. & $\cdots$ & 20 \\
\hline & $11 \mathrm{~min}$. & 241 & 37 & 18.1 & 238 & 56 & 24.1 & 1.40 & 23.9 & 0.81 & 89 & 30 & 50.8 & 22 \\
\hline & $37 \mathrm{~min}$. & 217 & 13 & 6.4 & 263 & 31 & 13.4 & 1.27 & 12.4 & .83 & os & 26 & 44.1 & 20 \\
\hline & $58 \mathrm{~min}$. & 220 & 16 & 7.8 & 263 & 31 & 13.4 & 1.28 & 13.3 & .81 & 83 & 24 & 40.7 & 20 \\
\hline Jan. 9 & ...... & 211 & $\ldots$ & ... & 241 & & & 1.18 & & .88 & 60 & $\cdots$ & $\ldots$ & 19 \\
\hline & $15 \mathrm{~min}$. & 229 & 18 & 8.5 & 329 & 88 & a. 36.5 & 1.54 & $\begin{array}{l}1,976 \\
30.5\end{array}$ & c.c. & 87 & 27 & 45.0 & 24 \\
\hline & $41 \mathrm{~min}$. & 207 & -4 & -1.9 & 299 & 58 & 24.1 & 1.41 & 19.5 & .70 & 83 & 23 & 38.3 & 24 \\
\hline & $1 \mathrm{h.6} \mathrm{m}$. & 213 & 2 & .9 & 285 & 44 & 18.3 & 1.35 & 14.4 & .75 & 83 & 23 & 38.3 & 24 \\
\hline Jan. 10 & & 208 & $\ldots$ & & 258 & & & 1.24 & & .80 & 65 & . & $\ldots$ & 20 \\
\hline & 13 min. & 247 & 39 & 18.7 & 333 & 75 & 29.1 & $\begin{array}{l}\text { cals. } \\
1.57\end{array}$ & $\begin{array}{l}2,034 \\
26.6\end{array}$ & 0.75 & 89 & 24 & 36.9 & 28 \\
\hline & in. & & 17 & 8.2 & & 50 & 19.4 & & 16 & .73 & & 24 & & 24 \\
\hline & $59 \mathrm{~min}$. & 228 & 20 & 9.6 & 316 & 58 & 22.5 & 1.49 & 20. & .73 & 86 & 21 & 32.3 & 22 \\
\hline & $1 \mathrm{~h} .18 \mathrm{~m}$. & 219 & 11 & 5.3 & 310 & 52 & 20.2 & 1.46 & 17.7 & .71 & 84 & 19 & 29.2 & 23 \\
\hline Jan. 12 & & 222 & $\ldots$ & $\cdots$ & 262 & & & 1.28 & & .85 & 63 & $\ldots$ & $\ldots$ & 21 \\
\hline & $21 \mathrm{~min}$. & 228 & & 2.7 & 321 & 59 & a. $\begin{array}{r}11 \\
22.5\end{array}$ & 6 cals. & $\begin{array}{l}2,293 \\
17.2\end{array}$ & 0.71 & 82 & 19 & 30.2 & 24 \\
\hline & $44 \mathrm{~min}$. & 212 & -10 & -4.5 & 289 & 27 & 10.3 & 1.37 & 7.0 & .74 & so & 17 & 27.0 & 20 \\
\hline & $1 \mathrm{h.7} \mathrm{m}$. & 210 & -12 & -5.4 & 288 & 26 & 9.9 & 1.36 & 6.2 & .73 & 81 & 18 & 28.6 & 24 \\
\hline Jan. 15 & $\cdots$ & 232 & & & 258 & & & 1.27 & & .90 & 65 & ... & $\ldots$ & 23 \\
\hline & 32 min. & 224 & -8 & -3.4 & 286 & 28 & 10.9 & $\begin{array}{l}\text { cals. } \\
1.37\end{array}$ & $\begin{array}{c}2,091 \\
7.9\end{array}$ & $\begin{array}{l}\text { c.c. } \\
0.79\end{array}$ & 84 & 19 & 29.2 & 20 \\
\hline & & & & & & 22 & 8.5 & 1. & 7. & .83 . & & 20 & & 24 \\
\hline & $1 \mathrm{~h} .23 \mathrm{~m}$. & 236 & 4 & 1.7 & 275 & 17 & 6.6 & 1.3 & 5. & .86 & 83 & 18 & 27.7 & 24 \\
\hline & $1 \mathrm{~h} .45 \mathrm{~m}$. & 220 & -12 & -5.2 & 266 & 8 & 3.1 & 1.29 & 1.6 & .83 & 79 & 14 & 21.5 & 20 \\
\hline Jan. 16 & & 211 & $\cdots$ & & 247 & & 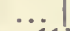 & 1.20 & & .85 & 82 & .. & $\ldots$ & 23 \\
\hline & $19 \mathrm{~min}$. & 226 & 15 & 7.1 & 293 & 46 & 18.6 & 5 cals. & $\begin{array}{l}2,191 \\
16.7\end{array}$ & 0.77 & 86 & 4 & 4.9 & 8 \\
\hline & n. & 217 & $\begin{array}{l}6 \\
8\end{array}$ & 2.8 & 275 & 28 & 11.3 & 1.32 & 10.0 & .79 & 83 & 1 & 1.2 & 28 \\
\hline & $1 \mathrm{~h} .10 \mathrm{~m}$. & 219 & 8 & 3.8 & 277 & 30 & 12.1 & 1.33 & 10.8 & .79 & 82 & $\cdots$ & .. & 24 \\
\hline Jan. 17 & ....... & 191 & ... & $\ldots$ & 251 & & & 1.20 & & .77 & 61 & .. & $\cdots$ & 20 \\
\hline & 13 min. & 233 & 42 & 22.0 & 335 & $64^{64}$ & n. & 1.5 & $\begin{array}{l}2,13.3 \\
30.0\end{array}$ & $\begin{array}{l}\text { c.c. } \\
0.70\end{array}$ & 89 & 28 & 45.9 & 28 \\
\hline & & & 14 & 7 & 2 & 45 & 17.9 & & & .70 & & & & 24 \\
\hline & $1 \mathrm{~h} .6 \mathrm{~m}$. & 216 & 25 & 13.1 & 283 & 32 & 12.7 & 1.35 & 12.5 & .76 & 83 & 22 & 36.1 & 24 \\
\hline & 1h. $27 \mathrm{~m}$. & 220 & 29 & 15.2 & 286 & 35 & 13.9 & 1.36 & 13.3 & .77 & 80 & 19 & 31.1 & 26 \\
\hline
\end{tabular}

1 The subject was not breathing in the circuit of the respiration apparatus. 
TABLE 136.-Metabolism of subjects lying on the couch without food before and after work-Continued.

[Figures in italics represent duration of work, heat equivalent of work, and the oxygen consumption per minute during the last period of work.]

\begin{tabular}{|c|c|c|c|c|c|c|c|c|c|c|c|c|c|c|}
\hline \multirow{3}{*}{ Date. } & \multirow{3}{*}{$\begin{array}{l}\text { Elapsed } \\
\text { time } \\
\text { from } \\
\text { end of } \\
\text { work to } \\
\text { begin- } \\
\text { ning of } \\
\text { period. }\end{array}$} & \multicolumn{3}{|c|}{$\begin{array}{l}\text { Carbon dioxide } \\
\text { eliminated. }\end{array}$} & \multicolumn{3}{|c|}{$\begin{array}{l}\text { Oxygen } \\
\text { absorbed. }\end{array}$} & \multicolumn{2}{|c|}{$\begin{array}{c}\text { Heat } \\
\text { output } \\
\text { (computed). }\end{array}$} & \multirow{3}{*}{$\begin{array}{l}\text { Res- } \\
\text { pira- } \\
\text { tory } \\
\text { quo- } \\
\text { tient. }\end{array}$} & \multicolumn{3}{|c|}{ Pulse-rate. } & \multirow{3}{*}{$\begin{array}{l}\text { Res } \\
\text { pira } \\
\text { tion } \\
\text { rate } \\
\text { per } \\
\text { min- } \\
\text { ute. }\end{array}$} \\
\hline & & \multirow{2}{*}{$\begin{array}{c}\text { Per } \\
\text { min. }\end{array}$} & \multicolumn{2}{|c|}{$\begin{array}{l}\text { Increase } \\
\text { after work. }\end{array}$} & \multirow{2}{*}{$\begin{array}{l}\text { Per } \\
\text { min. }\end{array}$} & \multicolumn{2}{|c|}{$\begin{array}{c}\text { Increase } \\
\text { after work. }\end{array}$} & \multirow{2}{*}{$\begin{array}{l}\text { Per } \\
\text { min. }\end{array}$} & \multirow{2}{*}{$\begin{array}{l}\text { In- } \\
\text { crease } \\
\text { after } \\
\text { work. }\end{array}$} & & \multirow{2}{*}{$\begin{array}{l}\text { Per } \\
\text { min. }\end{array}$} & \multicolumn{2}{|c|}{$\begin{array}{l}\text { Increase } \\
\text { after work. }\end{array}$} & \\
\hline & & & Amt. & P. ct. & & Amt. & P. ct. & & & & & Amt. & P. ct. & \\
\hline \multirow[t]{4}{*}{$\begin{array}{l}1912 . \\
\text { Jan. } 18\end{array}$} & & c.c. & c.c. & & $\begin{array}{c}c . c . \\
261\end{array}$ & c.c. & & $\begin{array}{l}\text { cals. } \\
1.24\end{array}$ & p.ct. & \begin{tabular}{|l|}
.77 \\
\end{tabular} & 63 & .. & & 24 \\
\hline & $21 \mathrm{~min}$ & 211 & 10 & 5.0 & Work: & $65 \mathrm{mi}$ & in 9 & 8 cals. & 1,977 & c.c. & & 24 & 381 & 26 \\
\hline & 45 min. & 222 & 21 & $\begin{array}{r}0.0 \\
10.4\end{array}$ & 309 & 48 & $\begin{array}{l}19.2 \\
18.4\end{array}$ & $\begin{array}{l}1.40 \\
1.45\end{array}$ & 16.9 & $\begin{array}{r}0.68 \\
.72\end{array}$ & $\begin{array}{l}87 \\
84\end{array}$ & $\begin{array}{l}24 \\
21\end{array}$ & $\begin{array}{l}38.1 \\
33.3\end{array}$ & $\begin{array}{l}26 \\
22\end{array}$ \\
\hline & $1 \mathrm{~h} .12 \mathrm{~m}$ & 203 & 2 & 1.0 & 297 & 36 & 13.8 & 1.40 & 12.9 & .69 & 84 & 21 & 33.3 & 24 \\
\hline Jan. 19 & & 199 & .. & & 260 & & & 1.24 & & .77 & 66 & .. & $\ldots$ & 21 \\
\hline & 19 min. & 205 & 6 & 3.0 & 316 & 56 & 21.5 & $\begin{array}{l}\text { cals. } \\
1.48\end{array}$ & $\begin{array}{l}2,164 \\
19.4\end{array}$ & $\begin{array}{c}c . c . \\
0.65\end{array}$ & 87 & 21 & 31.8 & 28 \\
\hline & $44 \mathrm{~min}$. & 210 & 11 & 5.5 & 300 & 40 & 15.4 & 1.41 & 13.7 & .70 & 82 & 16 & & 24 \\
\hline & $1 \mathrm{~h} .8 \mathrm{~m}$. & 214 & 15 & 7.5 & 294 & 34 & 13.1 & 1.39 & 12.1 & .73 & 82 & 16 & 24.2 & 20 \\
\hline & 1h. $37 \mathrm{~m}$. & 222 & 23 & 11.6 & 302 & 42 & 16.2 & 1.43 & 15.3 & .74 & 79 & 13 & 19.7 & 22 \\
\hline Jan. 24 & & 201 & .. & & 232 & & & 1.13 & & .87 & 63 & .. & 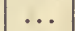 & 21 \\
\hline & 17 min. & 229 & 28 & 13.9 & 292 & 80 & n. 12 & 5 cals. & $\begin{array}{l}2,040 \\
23.9\end{array}$ & 0.78 & 92 & 29 & 460 & 20 \\
\hline & 43 min. & 211 & 10 & $\begin{array}{r}5.0 \\
\end{array}$ & 290 & 58 & 25.0 & $\begin{array}{l}1.40 \\
1.37\end{array}$ & 21.2 & $\begin{array}{r}0.78 \\
.73\end{array}$ & $\begin{array}{l}92 \\
86\end{array}$ & 29 & $\begin{array}{l}40.0 \\
36.5\end{array}$ & 24 \\
\hline & $1 \mathrm{~h} .10 \mathrm{~m}$. & 210 & 9 & 4.5 & $\cdots$ & .. & $\ldots$ & $\ldots$ & $\ldots$ & $\ldots$ & 84 & 21 & 33.3 & 22 \\
\hline Jan. 25 & & 199 & . & & 249 & & & 1.20 & & .80 & 63 & $\ldots$ & & 20 \\
\hline & 18 min. & 218 & 19 & 9.5 & 287 & 38 & 15.3 & $\begin{array}{l}9 \text { cals. } \\
1.36\end{array}$ & $\begin{array}{l}2,318 \\
13.3\end{array}$ & 0.76 & 89 & 26 & 41.3 & 22 \\
\hline & $42 \mathrm{~min}$. & 207 & 8 & 4.0 & 262 & 13 & 5.2 & 1.26 & 5.0 & .79 & 84 & 21 & 33.3 & \\
\hline & $1 \mathrm{~h} .9 \mathrm{~m}$. & 212 & 13 & 6.5 & 272 & 23 & 9.2 & 1.30 & 8.3 & .78 & 84 & 21 & 33.3 & $\ddot{2} \dot{4}$ \\
\hline Jan. 26 & & 202 & ... & & 237 & & & 1.15 & & .86 & 64 & 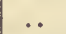 & 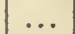 & 23 \\
\hline & 16 min. & 211 & 9 & 4.5 & 268 & 31 & a. 13 & $\begin{array}{l}5 \text { cals. } \\
1.28\end{array}$ & $\begin{array}{l}2,167 \\
11.3\end{array}$ & 0.79 & 85 & 21 & 32.8 & 24 \\
\hline & 41 min. & 214 & 12 & 5.9 & 266 & $\begin{array}{l}01 \\
29\end{array}$ & 12.2 & 1.28 & 11.3 & .81 & $\begin{array}{l}85 \\
82\end{array}$ & 18 & $\begin{array}{l}32.8 \\
28.1\end{array}$ & $\begin{array}{l}24 \\
24\end{array}$ \\
\hline & $1 \mathrm{~h} .7 \mathrm{~m}$. & 204 & 2 & 1.0 & 266 & 29 & 12.2 & 1.27 & 10.4 & .77 & 81 & 17 & 26.6 & 24 \\
\hline Jan. 31 & & 222 & .. & & 240 & & & 1.19 & & .93 & 66 & .. & $\cdots$ & 20 \\
\hline & $12 \mathrm{~min}$. & 229 & 7 & 3.2 & 285 & 45 & 18.7 & 1.37 & $\begin{array}{r}2,11 \\
15.1\end{array}$ & $\begin{array}{l}5 \text { c.c. } \\
0.80\end{array}$ & 93 & 27 & 40.9 & 28 \\
\hline & 35 min. & 216 & -6 & -2.7 & 262 & 22 & 9.2 & 1.27 & 6.7 & .83 & 85 & 19 & 28.8 & 22 \\
\hline & 59 min. & 220 & -2 & -.9 & 266 & 26 & 10.8 & 1.29 & 8.4 & .83 & 85 & 19 & 28.8 & 26 \\
\hline Feb. 1 & & 214 & .. & & 241 & & & 1.18 & & .89 & 68 & $i$ & $\cdots$ & 20 \\
\hline & $19 \mathrm{~min}$. & 217 & 3 & 1.4 & 280 & 39 & 16.2 & $\begin{array}{l}2 \text { cals. } \\
1.34\end{array}$ & $\begin{array}{l}2,010 \\
13.6\end{array}$ & c.c. & 91 & 23 & 33.8 & 24 \\
\hline & & 207 & -7 & -3.3 & 279 & 38 & 15.8 & 1.32 & 11.9 & .74 & 85 & & & 22 \\
\hline & $1 \mathrm{~h} .2 \mathrm{~m}$. & 218 & 4 & 1.9 & 280 & 39 & 16.2 & 1.34 & 13.6 & .78 & 84 & 16 & 23.5 & 20 \\
\hline Feb. 2 & & 204 & $\ldots$ & . & 246 & & & 1.19 & & .83 & 64 & .. & & 19 \\
\hline & $22 \mathrm{~min}$. & 220 & 16 & 7.8 & 284 & 38 & n. 15 & 2 cals. & $\begin{array}{l}2,285 \\
13.4\end{array}$ & $\begin{array}{l}\text { c.c. } \\
0.77\end{array}$ & 93 & 29 & 45.3 & 24 \\
\hline & $\mathrm{m}$. & 217 & 13 & 6.4 & 277 & 31 & 12.6 & 1.33 & 11.8 & .79 & 84 & 20 & 31.3 & 24 \\
\hline & & 21 & 12 & 5.9 & 282 & 3 & 14.6 & 1.3 & 12 & .77 & 83 & 19 & & 20 \\
\hline & & 22 & 20 & 9.8 & 277 & 31 & 12.6 & 1. & & .81 & 81 & & & \\
\hline & $2 \mathrm{~h} .54 \mathrm{~m}$. & 217 & 13 & 6.4 & 278 & 32 & 13.0 & 1.33 & 11.8 & .78 & 81 & 17 & & 24 \\
\hline & $3 \mathrm{~h} .29 \mathrm{~m}$. & 214 & 10 & 4.9 & 278 & 32 & 13.0 & 1.33 & 11.8 & .77 & 76 & & & 20 \\
\hline & 4h. $4 \mathrm{~m}$. & 226 & 22 & 10.8 & 282 & 36 & 14.6 & 1.35 & 13.4 & .80 & 79 & 15 & 23.4 & 20 \\
\hline & $4 \mathrm{~h} .32 \mathrm{~m}$ & 223 & 19 & 9.3 & 282 & 36 & 14.6 & 1.35 & 13.4 & .79 & 75 & 11 & 17.2 & 22 \\
\hline Feb. 7 & ...... & 195 & .. & & 233 & & .. & 1.13 & & .84 & 59 & .. & $\ldots$ & 20 \\
\hline & $15 \mathrm{~min}$. & 232 & 37 & $19.0^{\prime}$ & 278 & 45 & a. 19.3 & $1.35^{\circ}$ & $\begin{array}{l}1,976 \\
19.5\end{array}$ & $\begin{array}{l}\text { c.c. } \\
0.84\end{array}$ & 92 & 33 & 55.9 & 24 \\
\hline & & 216 & 21 & 10.8 & 262 & 29 & 12.4 & 1.27 & 12.4 & .82 & 83 & & & 24 \\
\hline & 58 min. & 217 & 22 & 11.3 & 268 & 35 & 15.0 & 1.29 & 14.2 & .81 & 83 & 24 & 40.7 & 24 \\
\hline Feb. 8 & ........ & 207 & .. & & 256 & & & 1.23 & & .81 & 66 & .. & $\cdots$ & 20 \\
\hline & 14 min. & & & 15.0 & 309 & 53 & 20.7 & $\begin{array}{l}7 \text { cals. } \\
1.47\end{array}$ & $\begin{array}{l}2,148 \\
19.5\end{array}$ & 0.77 & 96 & 30 & 45.5 & 22 \\
\hline & & 217 & 10 & 4.8 & 290 & 34 & 13.3 & 1.37 & 11.4 & .75 & 89 & 23 & 34.8 & 24 \\
\hline & $1 \mathrm{~h} .1 \mathrm{~m}$. & 218 & 11 & 5.3 & 293 & 37 & 14.5 & 1.39 & 13.0 & .75 & 86 & 20 & 30.3 & 22 \\
\hline
\end{tabular}

1 Owing to defects in the apparatus, the subject rode intermittently preceding the period here given. Of the 48 minutes so used he sat still for the last 20 minutes. The total time during which the subject actually rode was about 55 minutes, the heat equivalent of the work done being 120 calories. 
TABLE 136.-Metabolism of subjects lying on the couch without food before and after work-Continued.

[Figures in italics represent duration of work, heat equivalent of work, and the orygen consumption per minute during the last period of work.]

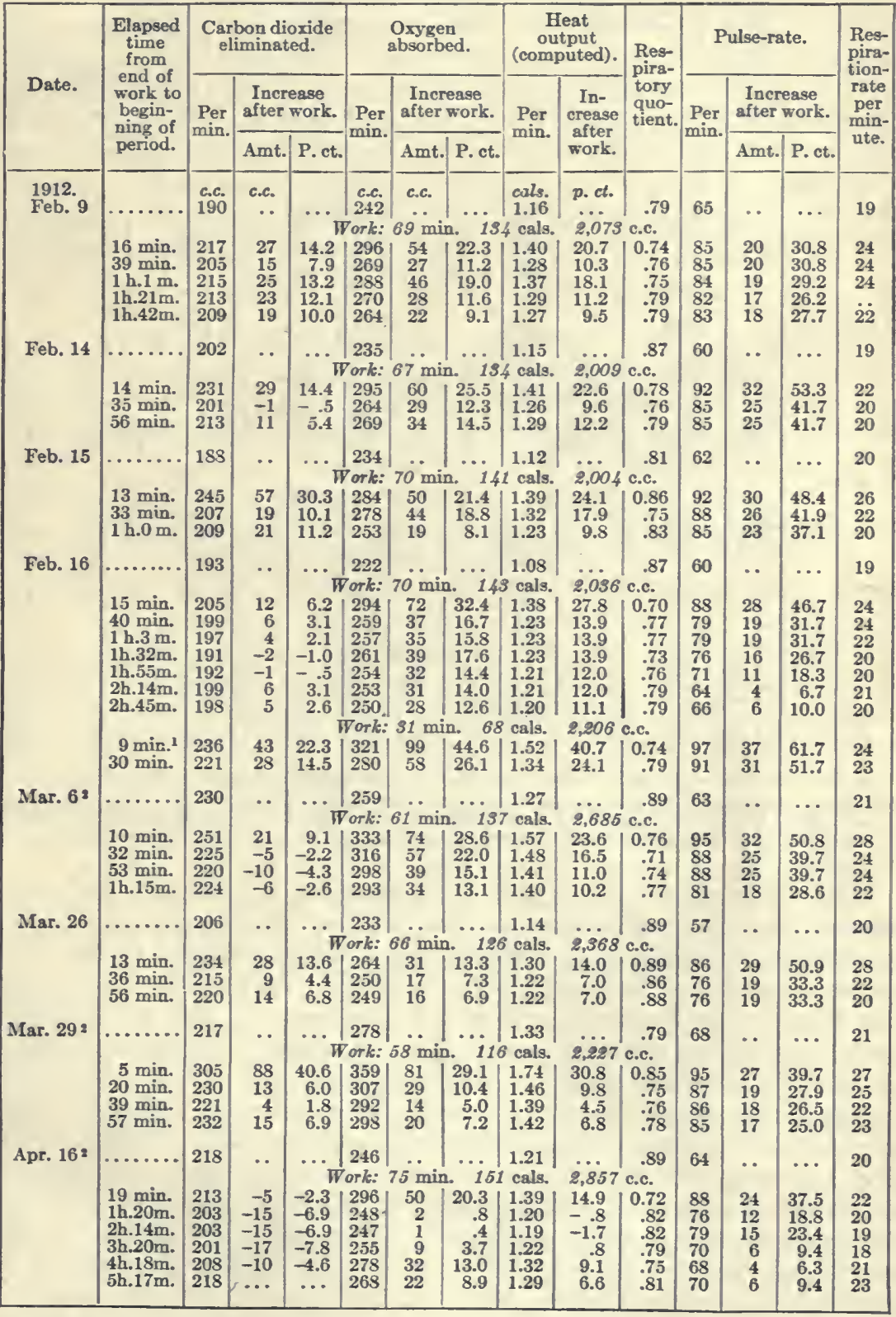

1 The resting value used in the second comparison on this day is the average obtained with the subject lying

2 In the experiments of Mar. 6, Mar. 29, and Apr. 16, the respiration of the subject while lying on the couch was recorded for the full time of each period. The ventilation of the lungs was also recorded. 
TABLE 136.-Metabolism of subjects lying on the couch without food before and after work-Continued.

[Figures in italics represent duration of work, heat equivalent of work, and the oxygen consumption per minute during the last period of work.]

\begin{tabular}{|c|c|c|c|c|c|c|c|c|c|c|c|c|c|c|}
\hline \multirow{3}{*}{ Date. } & \multirow{3}{*}{$\begin{array}{c}\text { Elapsed } \\
\text { time } \\
\text { from } \\
\text { end of } \\
\text { work to } \\
\text { begin- } \\
\text { ning of } \\
\text { period. }\end{array}$} & \multicolumn{3}{|c|}{$\begin{array}{l}\text { Carbon dioxide } \\
\text { eliminated. }\end{array}$} & \multicolumn{3}{|c|}{$\begin{array}{l}\text { Oxygen } \\
\text { absorbed. }\end{array}$} & \multicolumn{2}{|c|}{$\begin{array}{c}\text { Heat } \\
\text { output } \\
\text { (computed). }\end{array}$} & \multirow{3}{*}{$\begin{array}{l}\text { Res- } \\
\text { pira- } \\
\text { tory } \\
\text { quo- } \\
\text { tient. }\end{array}$} & \multicolumn{3}{|c|}{ Pulse-rate. } & \multirow{3}{*}{$\begin{array}{l}\text { Res- } \\
\text { pira- } \\
\text { tion- } \\
\text { rate } \\
\text { per } \\
\text { min- } \\
\text { ute. }\end{array}$} \\
\hline & & \multirow{2}{*}{ Per } & \multicolumn{2}{|c|}{$\begin{array}{l}\text { Increase } \\
\text { after work. }\end{array}$} & \multirow{2}{*}{$\begin{array}{l}\text { Per } \\
\text { min. }\end{array}$} & \multicolumn{2}{|c|}{$\begin{array}{c}\text { Increase } \\
\text { after work. }\end{array}$} & \multirow{2}{*}{$\begin{array}{l}\text { Per } \\
\text { min. }\end{array}$} & \multirow{2}{*}{$\begin{array}{c}\text { In- } \\
\text { crease } \\
\text { after } \\
\text { work. }\end{array}$} & & \multirow{2}{*}{$\begin{array}{l}\text { Per } \\
\text { min. }\end{array}$} & \multicolumn{2}{|c|}{$\begin{array}{l}\text { Increase } \\
\text { after work. }\end{array}$} & \\
\hline & & & Amt. & P. ct. & & Amt. & P. ct. & & & & & Amt. & P. ct. & \\
\hline \multirow[t]{3}{*}{$\begin{array}{l}1912 . \\
\text { Mar. } 19^{2}\end{array}$} & $\cdots \ldots \ldots$ & $\begin{array}{l}\text { c.c. } \\
205\end{array}$ & $\begin{array}{l}\text { c.c. } \\
\cdots\end{array}$ & & $\begin{array}{l}\text { c.c. } \\
242 \\
\text { ork: }\end{array}$ & 67 min & is & $\begin{array}{l}\text { cals. } \\
1.17 \\
8 \text { cals. }\end{array}$ & $\begin{array}{c}\text { p. ct. } \\
\dot{2}, \dot{2} 6 s\end{array}$ & $\begin{array}{l}.85 \\
\text { c.c. }\end{array}$ & 63 & . & . & 20 \\
\hline & $\begin{array}{l}16 \text { min. } \\
42 \text { min. } \\
1 \mathrm{~h} .4 \mathrm{~m} .\end{array}$ & $\begin{array}{l}240 \\
221 \\
220\end{array}$ & $\begin{array}{l}35 \\
16 \\
15\end{array}$ & $\begin{array}{r}17.1 \\
7.8 \\
7.3 \\
W\end{array}$ & $\begin{array}{l}260 \\
251 \\
254 \\
\text { ork: }\end{array}$ & $\begin{array}{r}18 \\
9 \\
12 \\
58 \mathrm{~min}\end{array}$ & $\begin{array}{l}7.4 \\
3.7 \\
5.0 \\
11\end{array}$ & $\mid \begin{array}{l}1.29 \\
1.23 \\
1.24 \\
2 \mathrm{cals}\end{array}$ & $\begin{array}{c}10.3 \\
5.1 \\
6.0 \\
2.146\end{array}$ & $\begin{array}{r}0.92 \\
.88 \\
.87 \\
\text { c. }\end{array}$ & $\begin{array}{l}72 \\
63 \\
64\end{array}$ & $\begin{array}{l}9 \\
\ddot{1}\end{array}$ & $\begin{array}{c}14.3 \\
\ddot{1.6}\end{array}$ & $\begin{array}{l}24 \\
24 \\
20\end{array}$ \\
\hline & $17 \mathrm{~min}$. & 222 & 17 & 8.3 & 276 & 34 & 14.0 & 1.33 & $13.7^{\circ}$ & 0.81 & 70 & 7 & 11.1 & 20 \\
\hline \multirow[t]{4}{*}{ Mar. 251} & .......... & 205 & . & & $\begin{array}{l}242 \\
\text { ork: }\end{array}$ & $58 \mathrm{~min}$ & n. $" 12$ & $\begin{array}{l}1.17 \\
6 \text { cals. }\end{array}$ & $\ddot{2}, \ddot{6} \dot{5} \bar{b}$ & c.c. .85 & 63 & & & 20 \\
\hline & $\begin{array}{l}10 \text { min. } \\
33 \text { min. } \\
58 \text { min. }\end{array}$ & $\begin{array}{l}277 \\
258 \\
261\end{array}$ & $\begin{array}{l}72 \\
53 \\
56\end{array}$ & $\begin{array}{l}35.1 \\
25.9 \\
27.3\end{array}$ & $\begin{array}{l}284 \\
271 \\
275\end{array}$ & $\begin{array}{l}42 \\
29 \\
33\end{array}$ & $\begin{array}{l}17.4 \\
12.0 \\
13.6\end{array}$ & $\begin{array}{l}1.42 \\
1.35 \\
1.37\end{array}$ & $\begin{array}{l}21.4 \\
15.4 \\
17.1\end{array}$ & $\begin{array}{r}0.97 \\
.95 \\
.95\end{array}$ & $\begin{array}{l}95 \\
89 \\
87\end{array}$ & $\begin{array}{l}32 \\
26 \\
24\end{array}$ & $\begin{array}{l}50.8 \\
41.3 \\
38.1\end{array}$ & $\begin{array}{l}26 \\
26 \\
24\end{array}$ \\
\hline & 11 min. & 271 & 66 & 32.2 & 281 & $\begin{array}{l}49 \mathrm{~m} \\
39\end{array}$ & n. 98 & $\begin{array}{l}\text { cals. } \\
1.41\end{array}$ & $\begin{array}{l}2,288 \\
20.5\end{array}$ & $\begin{array}{l}\text { c.c. } \\
0.97\end{array}$ & 101 & 38 & & 20 \\
\hline & 31 min. & 249 & 44 & 21.5 & 267 & 25 & 10.3 & 1.33 & 13.7 & .93 & 88 & 25 & 39.7 & 22 \\
\hline \multirow[t]{4}{*}{ Mar. 271} & & 205 & & & $\begin{array}{l}242 \\
\text { ork: }\end{array}$ & $2 \mathrm{mi}$ & $\cdots i 2$ & $\begin{array}{l}1.17 \\
\text { cals. }\end{array}$ & $\ddot{2} \ddot{257}$ & .85 & 63 & & $\cdots$ & 20 \\
\hline & $\begin{array}{l}11 \text { min. } \\
33 \text { min. } \\
57 \text { min. }\end{array}$ & $\begin{array}{l}261 \\
223 \\
214\end{array}$ & $\begin{array}{r}56 \\
18 \\
9\end{array}$ & $\begin{array}{r}27.3 \\
8.8 \\
4.4\end{array}$ & $\begin{array}{l}255 \\
256 \\
247\end{array}$ & $\begin{array}{l}13 \\
14\end{array}$ & $\begin{array}{l}5.4 \\
5.8 \\
2.1\end{array}$ & $\begin{array}{l}1.29 \\
1.25 \\
1.21\end{array}$ & $\begin{array}{r}10.3 \\
6.8 \\
3.4\end{array}$ & $\begin{array}{r}1.02 \\
.87 \\
.87\end{array}$ & $\begin{array}{l}88 \\
75 \\
78\end{array}$ & $\begin{array}{l}25 \\
12 \\
15\end{array}$ & $\begin{array}{l}39.7 \\
19.0 \\
23.8\end{array}$ & $\begin{array}{l}24 \\
20 \\
20\end{array}$ \\
\hline & $10 \mathrm{~min}$. & 255 & 50 & $24.4^{\prime}$ & 310 & 68 & 28.1 & $\begin{array}{l}\text { cals. } \\
1.49\end{array}$ & $\begin{array}{l}2,983 \\
27.4\end{array}$ & c.c. & 94 & 31 & & \\
\hline & $31 \mathrm{~min}$. & 221 & & 7.8 & 238 & $\mathbf{x}$ & -1.7 & 1.18 & .9 & .93 & 92 & $2 \overline{9}$ & 46.0 & 18 \\
\hline \multirow[t]{6}{*}{ Mar. 28} & & 205 & .. & $\cdots$ & 242 & & & 1.17 & & .85 & 63 & .. & $\ldots$ & 20 \\
\hline & 11 min. & 209 & 4 & $2.0^{\prime}$ & 298 & 56 & 23.1 & 1.40 & 19.7 & 0.71 & 69 & 6 & 9.5 & 24 \\
\hline & $35 \mathrm{~min}$. & $\begin{array}{l}201 \\
209\end{array}$ & $\begin{array}{r}-4 \\
4\end{array}$ & $\begin{array}{r}-2.0 \\
2.0\end{array}$ & $\begin{array}{l}262 \\
261\end{array}$ & $\begin{array}{l}20 \\
19\end{array}$ & $\begin{array}{l}8.3 \\
7.9\end{array}$ & 1.25 & $\begin{array}{l}6.8 \\
6.8\end{array}$ & $\begin{array}{l}.77 \\
80\end{array}$ & 63 & $\cdots$ & $\cdots$ & 20 \\
\hline & & & & & Vork: & $53 \mathrm{mir}$ & n. 96 & cals. & 1,909 & c.c. & 03 & .. & & 22 \\
\hline & 8 min. & 241 & $\begin{array}{l}36 \\
18\end{array}$ & 17.6 & 323 & $\begin{array}{l}81 \\
71\end{array}$ & 33.5 & 1.52 & 29.9 & 0.75 & 83 & 20 & 31.7 & 28 \\
\hline & $27 \mathrm{~min}$. & 223 & 18 & & 313 & 71 & 29.3 & 1.47 & 25.6 & .72 & 79 & 16 & 25.4 & 24 \\
\hline
\end{tabular}

1 The resting value used in the comparisons for Mar. 19, 25, 27 and 28 is a general average of results obtained with this subject while lying on the couch before work in respiration experiments without food. (See table 91.) The same resting value was used in the second comparison on each of these days.

Unfortunately for the oxygen measurements, which really are the best indices of the total metabolism, in relatively few experiments could a resting period be started inside of 10 minutes after the work ceased. Frequently the subject ended the experimental period covered with perspiration, especially after severe muscular work, and it was necessary for him to "rub himself down" before lying upon the couch. There was also a delay in beginning the rest period after work, since it was always considered advisable to have the mouthpiece in position for several minutes before throwing the valve; accordingly, actual experimenting could not begin much inside of 10 minutes. This delay is greatly to be regretted, as the values for the oxygen consumption per minute are in general very much higher for the first 10 minutes than subsequently, indicating a sharp gradient in the oxygen consumption beginning immediately with the cessation of work and falling off as time passes. The results given in table 136 show, both for the oxygen consumption and for the calories as computed indirectly, a persistent increase in metabolism following severe muscular activity. Owing to a change in the character of the katabolism, the carbon-dioxide output does not show corresponding increases. 
In very few instances was the oxygen consumption per minute less than 10 per cent above normal when the observations ceased each day; particularly is this true for experiments with M. A. M. after January 2, 1912. On some days, when these measurements were carried out for 2 to 4 hours, an increase in the metabolism of 14 or 15 per cent has been repeatedly noted at the end of the observations. The one exception to this is the experiment of April 16, 1912 , in which the metabolism apparently reached its normal level in 1 hour and 20 minutes after the work ceased, but in relatively few of the experiments does the oxygen consumption finally reach the base-line before the experiment terminates. Here again, however, since these observations were wholly subsidiary to the major problem studied, we could not hold the bicyclist in the laboratory an undue length of time to obtain further light on this minor question.

The values given in table 136 for the experiments with $\mathrm{H}$. L. H., and E. P. C., as well as for a few of the experiments with M. A. M., imply that the after-effect of muscular work is but little greater than that given by Loewy, namely, that the total excess oxygen consumption following work is approximately the same as for 1 minute of hard work. This general deduction does not hold true, however, for practically all of the experiments with the subject M. A. M. after January 2, 1912. That the results of our earlier experiments are not far from, although they actually do exceed Loewy's estimate, can be shown by the following computation: Using the low values given for January 2 , we find that the observations for the first period of rest began 10 minutes after the work ended and continued for the usual 15-minute period. Assuming the increase during the first 10 minutes after the work to be no greater than that found during the first period of rest, i. e., 39 c.c. per minute, there would be in the first 25 minutes after the work ceased an increased consumption of oxygen of 39 c.c. per minute, or a total excess amount of 975 c.c. An intermission of 9 minutes was followed by a second rest-period of 17 minutes; in this second rest-period the excess oxygen consumption was 25 c.c. per minute, and although during the intermission it was doubtless a little higher, we may assume that for the 26 minutes of intermission and rest-period the increase was constant, so that the total excess amount was 650 c.c. This added to the 975 c.c. computed for the first 25 minutes after the work ceased gives us 1,625 c.c. as the excess oxygen consumption in the 51 minutes following the cessation of work. On the assumption that no further increment in the oxygen consumption took place, it will be seen that this corresponds to a consumption of oxygen approximately 25 per cent larger than that during 1 minute of the last period of work, i. e., 1,244 c.c. (See table 136.) It should be remembered that this particular experiment was chosen as showing one of the lowest increases due to the muscular activity.

Bearing in mind the sharp gradient in the oxygen consumption which must take place immediately after the work ceased, it can be seen that in practically every experiment not only does the muscular work greatly increase the average oxygen consumption and heat output in the following periods, but this effect is long continued. Since it has been shown that the increase cannot be attributed to the mechanical work of an increase in the ventilation of the lungs, we have here unquestionably a sustained high metabolism due to the previous muscular exercise. How long this effect would continue, 
we have no means of knowing except that the results of the experiments which extended over considerable periods of time, with the single exception of the experiment of April 16, show that this influence persists for at least 5 or 6 hours. The results of experiments made in the respiration calorimeter at Middletown show that this increased metabolism continues even longer. We are distinctly inclined to sustain Jaquet's contention, therefore, that resting metabolism experiments should not be undertaken for a considerable period of time after the work of ascent has been accomplished.

While the carbon-dioxide excretion does not show such large increases as do the oxygen consumption and the calorie output, nevertheless the effect is noticeable, and we are therefore unable to agree with Higley and Bowen ${ }^{a}$ who came to the conclusion that after the cessation of work the output of carbon dioxide decreases to the normal amount inside of 2 minutes or less. These investigators, by means of an ingenious chemograph, studied the carbon-dioxide excretion during bicycling. Although the experiments were of short duration, from the one curve given by the investigators in their report, it can be computed that the work was sufficient to produce about 2,500 c.c. of carbon dioxide per minute. Of further significance is the fact that the puiserate fell inside of 1 minute after the work stopped and then remained at a point approximately 20 per cent above normal. While the apparatus was chiefly designed to study the effect of bicycling on the excretion of carbon dioxide, it is to be wished that the authors had continued their observations for a longer time after the working period ceased.

The intimate relationship between the pulse-rate and the metabolism is strikingly emphasized by the distinct tendency shown for the pulse-rate to assume a much higher level after work than before-a level that is roughly approximate to the increase in the total metabolism. The respiration-rate, on the other hand, does not alter greatly. Since they were reported primarily to show the influence of muscular activity on the pulse-rate, the observations of Pembrey ${ }^{b}$ are of interest here. One of his subjects before the test had a pulse-rate of 70; immediately after running 2 miles, the pulse-rate was found to be $164 ; 10$ minutes later, $128 ; 30$ minutes later, 100 ; and 60 minutes later, 82 . Another subject had a pulse-rate before running of 66 ; immediately after running the 2 miles, the pulse-rate was 140; after 2 minutes, 120; after 33 minutes, 106; after 77 minutes, 84; and 107 minutes afterwards, 74 . A second test with the same subject showed a pulse-rate before running of 56 ; immediately after the run, 136; 15 minutes afterwards, 104; 45 minutes afterwards, 88; and 75 minutes afterwards, 86 . In all of these observations, it will be seen that the pulse-rate remained at a considerably higher level after the exercise than the resting value obtained before the run.

We believe that our observations give convincing evidence that the increased pulse-rate noted as an after-effect of muscular work is accompanied by a distinctly higher metabolism-a metabolism which thus far has not been given due consideration in investigations on the metabolism following muscular work.

a Higley and Bowen, Am. Journ. Physiol., 1904, 12, p. 311 . 1909 , p. 208. 
AN ATTEMPTED ANALYSIS OF THE COMPONENTS OF THE TOTAL ENERGY TRANSFORMATIONS INCIDENTAL TO SEVERE MUSCULAR WORK.

Throughout the whole of this investigation it was apparent that during severe muscular work we had to deal with a number of complicated factors. Emphasis has already been laid upon the influence of the intensity of the magnetization of the field and the speed. Unfortunately the evidence as presented can throw but little light upon the effect of training, but the various methods of computing the efficiencies show that with different loads and with different speeds there were unquestionably different types of muscular action.

In the concluding paragraphs of this book an attempt will be made to analyze the various components of the energy transformations of the body incidental to severe muscular work.

The great differences between the efficiencies when the subject rode with a light load and those when he rode with a heavy load are clearly explainable only on the ground of extraneous exertion and inadequate adjustment of the muscles to the load, $i$. e., imperfect correlation. Aside from this irregularity in correlation, there must be an extra consumption of energy which is not directly productive of external muscular work.

An analysis of the results obtained when work with a light load preceded and followed work with a heavy load emphasizes the probability of a difference in the muscular activity under different conditions. The results of several experiments which give definite information upon this question are accordingly collected in table 137, the light work in all cases being done with a current of 0.5 ampere through the magnetizing field, and the severe work with a current of 1.5 amperes.

TABLE 137.-Comparison of oxygen intake in light work experiments before and after severe work.

\begin{tabular}{|c|c|c|c|c|}
\hline \multirow{2}{*}{ Subject and date. } & \multicolumn{2}{|c|}{$\begin{array}{l}\text { Light work ( } 0.5 \text { amp.) } \\
\text { before severe work. } 1\end{array}$} & \multicolumn{2}{|c|}{$\begin{array}{l}\text { Light work ( } 0.5 \text { amp.) } \\
\text { after severe work.1 }\end{array}$} \\
\hline & $\begin{array}{l}\text { Revolu- } \\
\text { tions per } \\
\text { minute. }\end{array}$ & $\begin{array}{c}\text { Oxygen } \\
\text { intake per } \\
\text { minute. }\end{array}$ & $\begin{array}{l}\text { Revolu- } \\
\text { tions per } \\
\text { minute. }\end{array}$ & $\begin{array}{l}\text { Oxygen } \\
\text { intake per } \\
\text { minute. }\end{array}$ \\
\hline 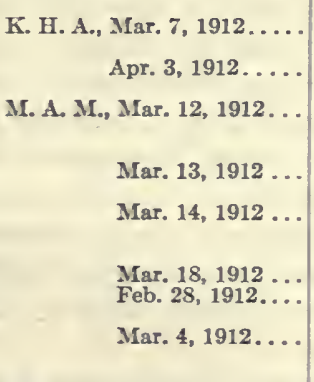 & $\begin{array}{l}\because \\
79 \\
79 \\
71 \\
72 \\
72 \\
72 \\
72 \\
\cdots \\
\cdots \\
102 \\
104 \\
102 \\
100\end{array}$ & $\begin{array}{c}c . c . \\
\ldots . \\
\ldots 90 \\
1,052 \\
1,061 \\
797 \\
807 \\
814 \\
837 \\
818 \\
\ldots \ldots \\
\ldots \ldots \\
\ldots 1,70 \\
1,254 \\
1,061 \\
1,148\end{array}$ & $\begin{array}{r}79 \\
79 \\
\cdots \\
\cdots \\
\cdots \\
\cdots \\
7 \\
71 \\
71 \\
71 \\
100 \\
99 \\
99 \\
\cdots\end{array}$ & $\begin{array}{c}c . c . \\
1,070 \\
1,082 \\
\ldots . \\
\ldots . \\
\ldots \\
\ldots \\
\ldots . \\
83 \\
833 \\
787 \\
833 \\
823 \\
1,134 \\
1,215 \\
1,173 \\
\ldots\end{array}$ \\
\hline
\end{tabular}

1 The severe work was done in all the experiments with a current of 1.5 amperes through the magnetizing field.

From the noticeable influence of severe muscular work upon the resting metabolism which is shown in the preceding section (see table 136) it would be reasonable to suppose that after the severe work-period, if the subject 
continued working but with a very much less load, the oxygen consumption would be considerably larger than when the light work preceded the severe work. The results given in table 137 do not, however, show this to be the case. With K.H. A. on March 7, when the light work followed severe work, the average oxygen consumption was 1,076 c.c. per minute with a rate of 79 revolutions per minute. On April 3, when the same amount of work was being performed prior to the severe muscular work, the average value shows a slightly less oxygen consumption of 1,057 c.c., a difference that must be considered within normal limits. A more satisfactory comparison, since the data were obtained on the same day, can be made of the results secured in two experiments with the subject M. A. M., in which records were obtained before and after the very severe work period. On February 28 , although the rate of revolution was approximately the same before and after the severe work, the oxygen consumption was a little less, if anything, in the after-period which may have been caused by the slightly lower rate of revolution. On March 4, the oxygen consumption was slightly greater after the severe work-period, the average before work being 1,105 c.c. and after work 1,173 c.c. The remaining comparisons can only be made with the values obtained on different days.

From the data given in this table, therefore, it will be seen that, contrary to expectation, the average oxygen consumption after the severe work is approximately the same as during the initial pericd of light work. In making this comparison no account is taken of the change in the character of the katabolism due to the lowering of the carbohydrate content of the body during the severe work, although, strictly speaking, this should be done, since the calorific equivalent of oxygen would be somewhat lower in the period after severe work. Obviously making such allowance the calorie output would be, on the average, slightly less in the periods following severe work.

It has been clearly demonstrated in previous comparisons of data that the metabolism is stimulated by severe muscular work, but the exact nature of this stimulus is at present unknown. That the effect of such stimulus persists even when light work follows the severe work is not an unreasonable supposition.

If we assume that there is a definite intensity of metabolism incidental to the "warming up," or adjustment of the body to a metabolism sufficient to make possible the work required, it will follow that as effective muscular work is performed, there must be superimposed upon the resting metabolism in addition to that required for effective work this stimulated metabolism, which may be designated as $S$. After the work has ceased, the stimulated metabolism, $S$, persists for a certain period but continually decreases in intensity, becoming zero only after several hours. Following work, then, we have the resting metabolism with a continually decreasing stimulated metabolism, $S$, superimposed upon it.

During work there is still another factor to be considered, $i$. e., the metabolism incidental to the extraneous and unnecessary motions which accompany riding, so that when work is performed we have the maintenance metabolism, plus the metabolism necessary for the extraneous activity, plus $S$, plus the metabolism especially involved in the production of effective work. 
From the several methods of computing the efficiency, it appeared that in the experiments with a load of $0.5,0.95$, and 1.5 amperes, varying amounts of extraneous muscular activity were present. Observations of the tension on the sprocket-chain and the general impressions of the subject led us to believe that with a load of 0.5 ampere, this extraneous activity played a large rôle, the maximum amount being obtained with this amperage. This was further emphasized by the results obtained in computing the efficiency. Since observations shomed that with a load of 0.95 and 1.5 amperes, there seemed to be a definite series of muscular movements for external work, we can assume, for purposes of comparison, that the extraneous unnecessary work disappears when these amperages are used. Under these circumstances, therefore, with moderately severe or severe work, the total metabolism is made up of maintenance metabolism, plus $S$, plus the metabolism which is involved in producing effective work.

In order to throw light upon the constancy of the metabolism for effective work, it thus becomes necessary to find whether or not the value $S$ is a constant. Since the values for the gross efficiencies obtained with a load of 0.5 ampere were essentially constant, we may assume that the total metabolism was likewise fairly constant. It has also been demonstrated that the resting metabolism remained approximately constant and from an inspection and careful consideration of the experimental technique, we can infer that the metabolism required for the extraneous work also remained constant. Apparently, therefore, the value $S$ was constant in the experiments in which a load of 0.5 ampere was used. The same may be said of any series of experiments with constant load.

An examination of table 136, however, shows that in general the aftereffects of work are greater when the rest-period follows severe work, than when it follows moderately severe work, $i$. e., the after-effects of work during which the subject consumed about 1,300 c.c. of oxygen per minute were considerably less than when the rest-period followed work of such an intensity as to require from 2,000 to 3,000 c.c. of oxygen per minute. If, therefore, the after-effects of work are due to the general stimulus to the higher metabolism required for the work, it is clear that we must infer that this stimulus is in a sense proportional to the intensity of the work, so that the value $S$ would not be constant under all conditions of load.

Having disproved the constancy of $S$ under varying load conditions, we then have the rather remarkable fact that the total metabolism in light work experiments was approximately constant both before and after severe work. Since the basal maintenance metabolism and the metabolism required for the extraneous activity were constant in both cases, and the stimulated metabolism, $S$, required for severe work persists after the severe work ceases, it is obvious that in the light work following severe work, the value $S$ must be greater than in the initial light work-periods. As the effective work remains the same, it follows that the metabolism involved in the production of effective work must be smaller, $i$.e., a larger proportion of the metabolism used directly for effective muscular work is converted into external muscular work.

We thus have different base-lines for the work preceding and following severe work, which may be represented by the following formulas: 
(1) For light work before severe work, $M+U+S_{1}$; and (2) for light work following severe work, $M+U+S_{2}$, in which $M$ equals maintenance metabolism, $U$ the metabolism for the unnecessary work due to the extraneous activity, $S_{1}$ the stimulated metabolism before severe work, and $S_{2}$ the stimulated metabolism following severe work. To these two base-lines is added the metabolism, $W$, directly involved in the production of external effective work, $E$, assuming that the value of $W$ is the same in both cases. The total energy output, $C$, is constant in both periods.

Under these conditions we have:

$$
C=M+U+\left(S_{1}+W\right)=M+U+\left(S_{2}+W\right)
$$

$M$ and $U$ are assumed equal in both cases, so that:

$$
S_{1}+W=S_{2}+W
$$

Since $S_{1}$ and $S_{2}$ are not equal, it follows that $W$ has a value changing with the conditions. Let $W_{1}$ represent the value before the severe work-period and $W_{2}$ the value after the severe work, then:

$$
W_{2}<W_{1}
$$

and as the effective muscular work remains the same in both periods,

$$
\frac{E}{W_{1}}<\frac{E}{W_{2}}
$$

This observation has its greatest value as a suggestion for further research. Our data at present permit of no mathematical estimates of the values of $S_{1}, S_{2}, W_{1}$, or $W_{2}$ but it is not beyond the bounds of reasonable speculation to believe that some accurate index of these values may later be found. It is evident from our experiments that the principles underlying the determination both of the external muscular work and the total work are sound. That being the case, an extension of this form of experimenting can but lead to fundamental information regarding the physiology of muscular work. ${ }^{a}$

a As this book goes to press, our attention has been called to the experiments of Boussaguet (Recherches expérimentales sur les conditions physiologiques du travail des mineurs, Paris, 1912), who used a bicycle fitted with a Prony brake. Although numerous measurements of the gaseous exchange are presented in a table, there is no discussion of the character or extent of the katabolism nor is the mechanical efficiency computed. 


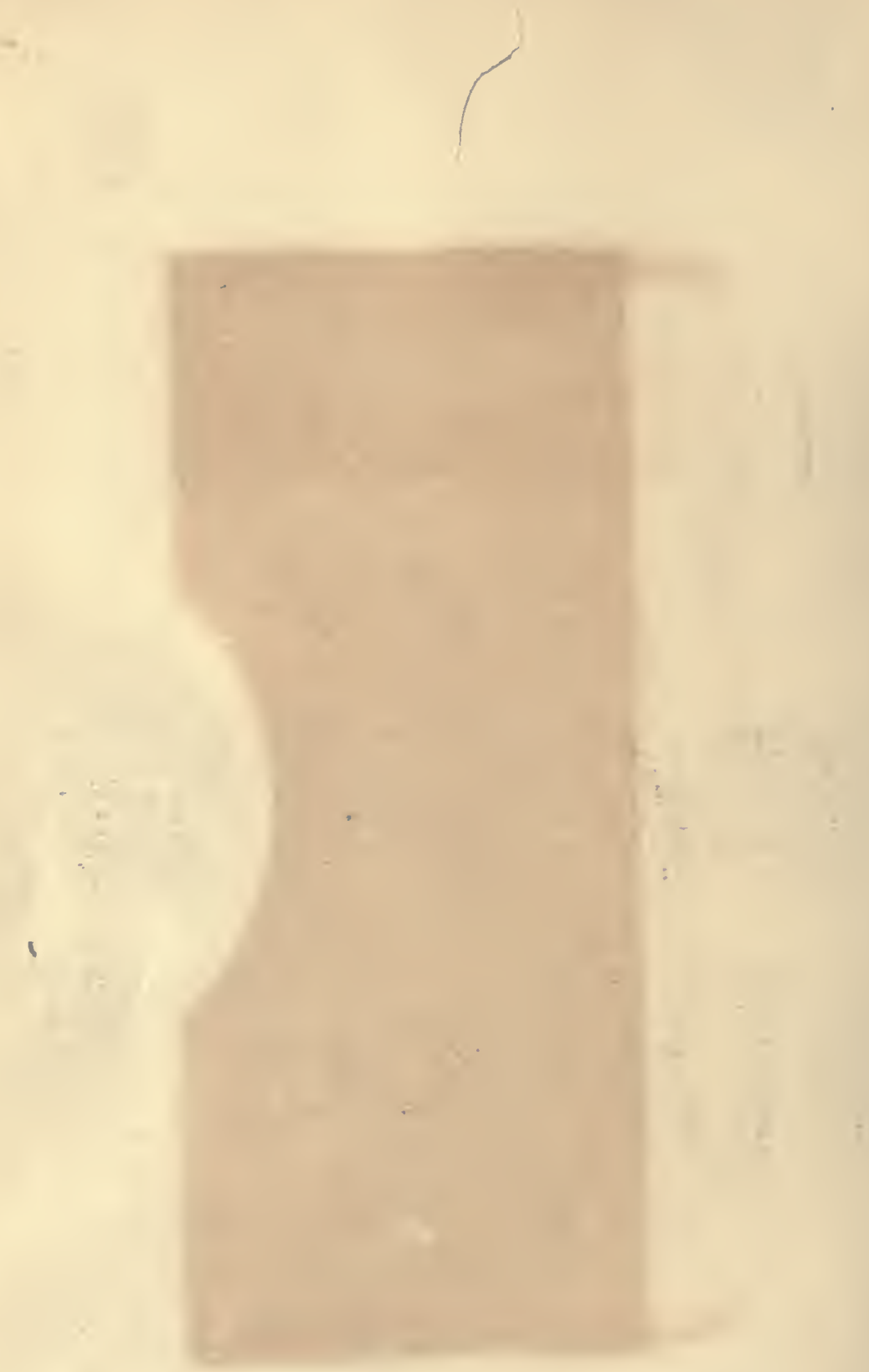


\section{IP Benedict, Francis Gano \\ 171 Muscular work \\ B463}

BioMed

PLEASE DO NOT REMOVE CARDS OR SLIPS FROM THIS POCKET

\section{UNIVERSITY OF TORONTO LIBRARY}




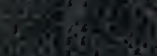

and

1ी

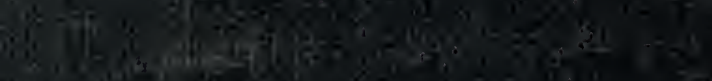

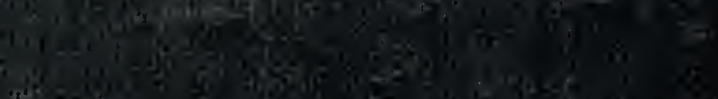

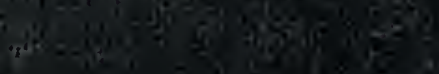

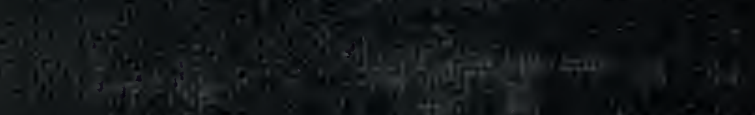

$$
3 \text { a }
$$

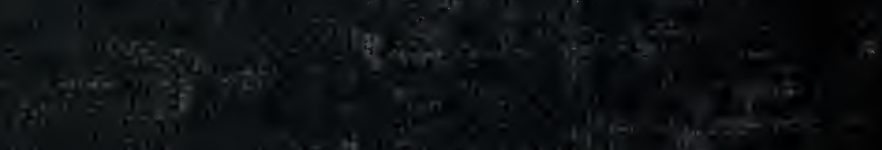

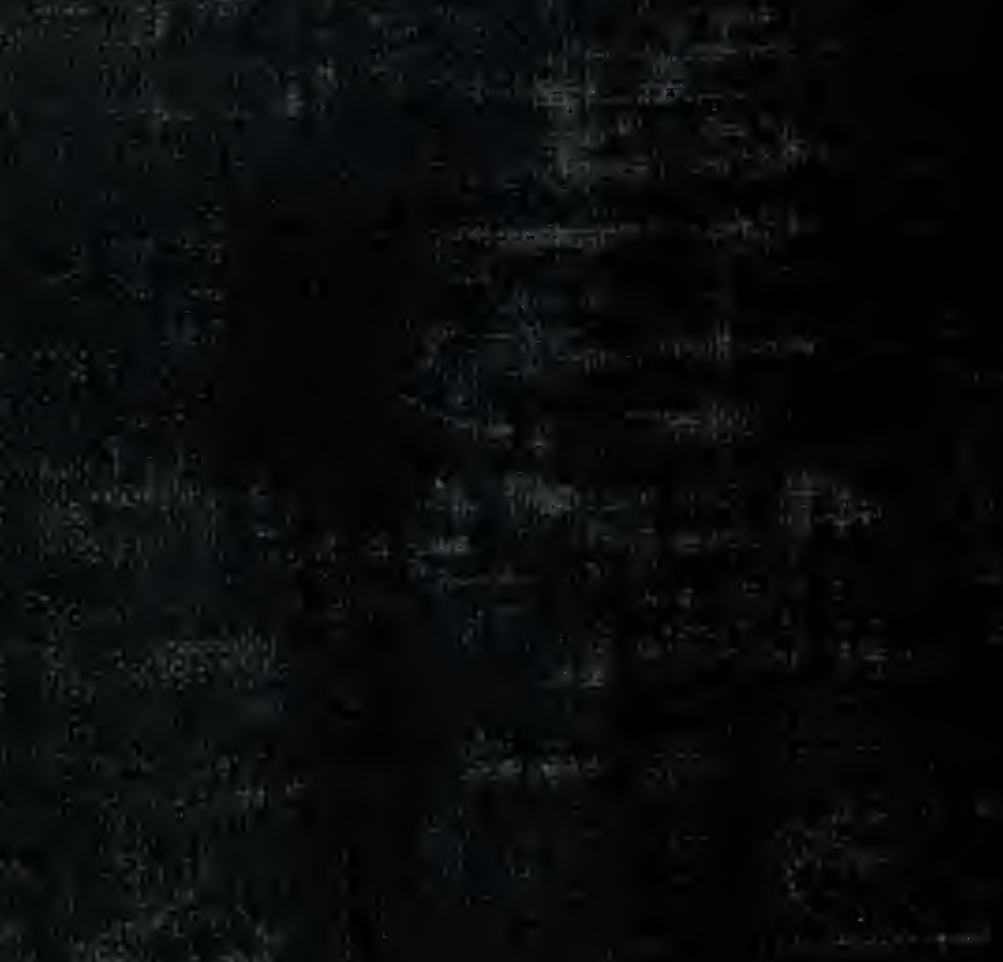

$408,2,230$

a.

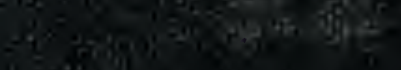

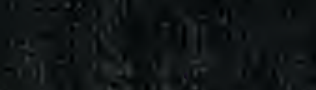

Sor. 